UNIVERSIDAD DE SALAMANCA

ESCUELA DE DOCTORADO

FACULTAD DE CIENCIAS SOCIALES

PROGRAMA DE DOCTORADO EN CIENCIAS SOCIALES

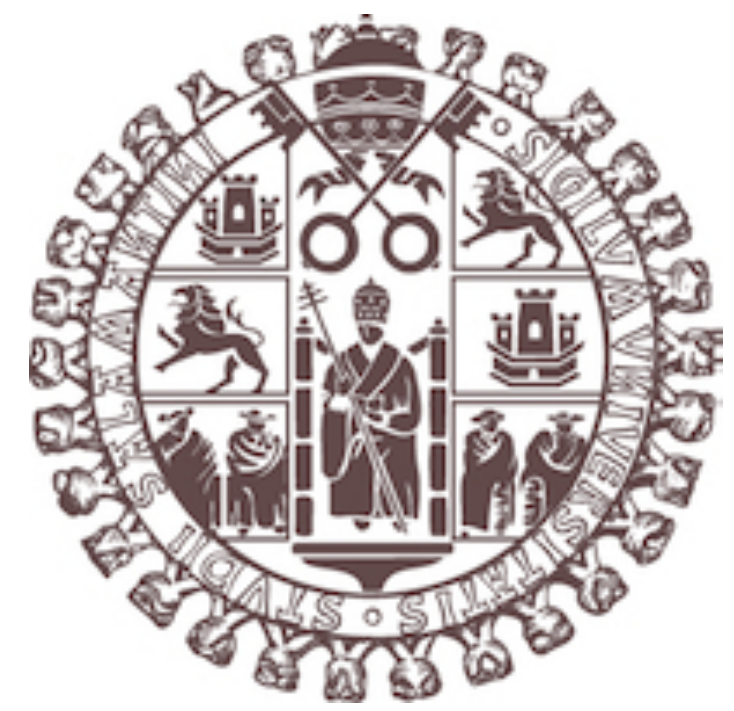

\title{
ANÁLISE JURÍDICO-ANTROPOLÓGICA DAS RELAÇÕES COLETIVAS DE TRABALHO NO BRASIL
}

\author{
TESIS DOCTORAL \\ D. ANTONIO AUGUSTO BONATTO BARCELLOS
}

DIRECTORES:

Dr. D. Emiliano González Díez

Dr. D. Ángel Baldomero Espina Barrio 
UNIVERSIDAD DE SALAMANCA

ESCUELA DE DOCTORADO

FACULTAD DE CIENCIAS SOCIALES

PROGRAMA DE DOCTORADO EN CIENCIAS SOCIALES

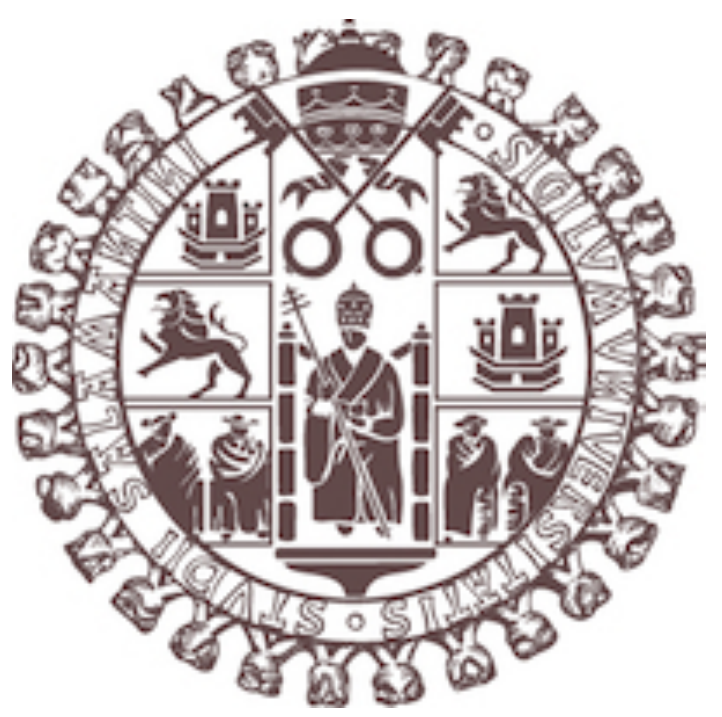

ANÁLISE JURÍDICO-ANTROPOLÓGICA DAS RELAÇÕES COLETIVAS DE TRABALHO NO BRASIL

\section{TESIS DOCTORAL}

D. ANTONIO AUGUSTO BONATTO BARCELLOS

DIRECTORES:

Dr. D. Emiliano González Díez

Dr. D. Ángel Baldomero Espina Barrio 
FICHA CATALOGRÁFICA

BONATTO BARCELLOS, Antonio Augusto. Análise jurídicoantropológica das relações coletivas de trabalho no Brasil. 2017. 430 p. Tese (Doutorado em Ciências Sociais) Facultad de Ciencias Sociales, Universidad de Salamanca, Salamanca, 2017. 


\section{ANTONIO AUGUSTO BONATTO BARCELLOS}

Tese apresentada como requisito parcial à obtenção do título de doutor pela Universidad de Salamanca.

Salamanca, de de 2017.

BANCA EXAMINADORA:

Firma

Dr. D.

Firma

Dr. D.

Firma

Dr. D.

Firma

Dr. D.

Firma

Dr. D. 


\section{DEDICATÓRIA}

Dedico este trabalho a todos aqueles que de alguma forma contribuíram para o seu andamento, principalmente aos amigos e familiares que sempre foram um baluarte de apoio em tão laboriosa e gratificante jornada.

Dedico também estas mal traçadas linhas aos meus diretores de tese, conhecidos em português pelo termo de orientadores, e na pessoa destes, a todos os profissionais da educação que se esforçam diuturnamente para elevar o conhecimento humano.

Salamanca, maio de 2017. 


\section{AGRADECIMENTOS}

Talvez outras tantas páginas, de igual número as que seguem, não fossem suficientes para deixar constância de minha gratidão a tantas pessoas que contribuíram em minha formação e nesta jornada iniciada há mais de três anos. Sinto-me verdadeiramente afortunado de desfrutar do convívio de tantas pessoas que muito por mim fizeram, de maneira desinteressada e sincera.

Aos meus pais, Otávio e Susana e minha irmã Ângela pela certeza de encontrar sempre ombros amigos e palavras de incentivo. Aos meus avós, primos e tios que mesmo com a distância souberam dar sua contribuição com carinho e afeto.

Aos meus amigos e companheiros de trabalho Bruno, Fernando Corrêa, Fernando Bonatto, Genito e Maria Elizabeth pela compreensão e força nos momentos de distância e ausência.

Aos meus amigos de coração desde a época do colégio Santo Antônio e amigos de infância como João, Andrew, Daniel e Rafael que muito fizeram, com sua amizade, para incentivar este autor.

Ao colega Dario Vignoli sem o qual grande parte do trabalho de campo não teria sido possível.

À Faculdade de Direito da Pontificia Universidade Católica do Rio Grande do Sul e à Scuola di Giurisprudenza da Universitá degli Studi di Salerno, por tornarem possíveis minhas estadias de estudos em seus departamentos.

A todos os companheiros, professores e colaboradores do Máster en Antropología de Iberoamérica e do Programa de Doctorado en Ciencias Sociales.

Aos orientadores Ángel Espina e Emiliano González bem como aos professores Alberto Monteiro e Eufemio Sánchez na pessoa dos quais busco referir a todos os docentes universitários brasileiros e espanhóis pelo esmero, paciência e dedicação com que apoiaram o presente trabalho.

Por fim, agradeço ao Banco Santander e à Universidad de Salamanca por terem tornado possível a realização de um projeto de vida atráves da bolsa de estudos que me foi concedida.

À todos, meu mais sincero, profundo e emocionado agradecimento.

Salamanca, maio de 2017.

Antonio Augusto Bonatto Barcellos 
"Procuremos más ser padres de nuestro porvenir que hijos de nuestro pasado." Miguel de Unamuno 


\section{RESUMO}

A presente tese trata sobre uma análise das relações coletivas de trabalho no Brasil sob um enfoque jurídico antropológico. A partir de uma análise da evolução da teoria antropológica e do sindicalismo procura-se desvendar as possíveis contribuições, principalmente do método antropológico, para análise da fundamentação sociocultural da norma e dos fenômenos jurídicos. Além disso, a própria comparação com os sistemas sindicais da Itália e da Espanha já induz a percepção sobre realidades culturais diferentes mas que tiveram em comum sistemas sindicais bastantes similares na primeira metade do século XX. Sendo o movimento sindical e a formação de grupos matéria especialmente relevante no âmbito das ciências sociais, entendemos que a antropologia e o direito devem ser conjugados na proposição de novas perspectivas para a regulamentação do sistema sindical brasileiro. Foi realizado de campo baseado na observação participante, com a realização de algumas entrevistas em profundidade e aplicação de alguns questionários buscando revelar a visão dos trabalhadores sobre as relações de trabalho brasileiras e sua adequação à legislação.

PALAVRAS-CHAVE: antropologia; direito; sindicatos; sindicalismo; relações e trabalho. 


\section{RESUMEN}

Esta tesis es un análisis de las relaciones colectivas de trabajo en Brasil, bajo un enfoque jurídico-antropológico. A partir de un análisis de la evolución de la teoría antropológica y del sindicalismo, busca desentrañar las posibles contribuciones, especialmente del método antropológico para el análisis de la base socio-cultural de los fenómenos normativos y legales. Por otra parte, la misma comparación con los sistemas sindicales de Italia y de España ya puede inducir la percepción de diferentes realidades culturales que tuvieran sistemas sindicales muy similares en la primera mitad del siglo XX. A medida que el movimiento sindical y la formación de grupos es un tema particularmente relevante en las ciencias sociales, entendemos que el derecho se debe mezclar con la antropología para encontrar una propuesta de nuevas perspectivas para la regulación del sistema sindical brasileño. Se llevó a cabo trabajo de campo basándose en la observación participante, con la realización de entrevistas y la aplicación de algunos cuestionarios que tratan de revelar la visión de los obreros en las relaciones laborales brasileñas y su adaptación a la legislación.

PALABRAS-CLAVE: antropologia; derecho; sindicatos; sindicalismo; relaciones y trabajo. 


\begin{abstract}
This thesis focus on an analysis of collective labor relations in Brazil under anthropological and legal approaches. From an analysis of the anthropological theory evolution and trade unionism, it is sought to unveil the possible contributions, mainly from the anthropological method, to analyze the norm's sociocultural basis and the legal phenomena. Moreover, the comparison between the union systems in Italy and Spain leads to the perception of different cultural realities, even though they had enough syndical systems in common during the first half of the 20th century. Being the trade union movement and the formation of groups especially relevant for the social sciences, it is understood that anthropology and law must be combined proposing new perspectives for the regulation of the Brazilian trade union system. The field research was carried out based on participant observation, applying indepth interviews and questionnaires seeking to reveal the workers' view on Brazilian labor relations and their adequacy to the legislation.
\end{abstract}

KEY WORDS: anthropology; law; trade unions; trade unionism; relations and work. 


\section{SUMÁRIO}

CAPÍTULO I - INTRODUÇÃO

1.2 Justificativa

1.2.1 Desenvolvimento da pesquisa

1.2.2 Da Delimitação do objeto de pesquisa

2.3 Definindo alguns conceitos importantes 43

CAPÍTULO III - TRABALHO/CULTURA/TRABALHO - O trabalho dos antropólogos e os caminhos da teoria antropológica

3.1 O corpo humano, veículo da cultura trabalho 
3.5 Os difusionismos britânico e alemão

3.6 O particularismo histórico

3.7 Cultura e Personalidade

3.8 A escola sociológica francesa

3.9 O funcionalismo

3.100 estruturalismo

$3.11 \mathrm{O}$ materialismo cultural

3.12 Antropologia Simbólica/Hermenêutica

CAPÍTULO IV - Encontros entre antropologia e direito -

Fundindo os horizontes jurídico-antropológicos

CAPÍTULO V - Profissões e divisão do trabalho

5.1 O trabalho pós-industrial

201

CAPÍTULO VI - SINDICALISMO

210

6.1 O surgimento da classe trabalhadora brasileira

6.1.1 Muitas terras e pouca mão-de-obra

6.1.2 Os imigrantes e a nova realidade

6.1.3 O brasileiro e seu traço ibérico 
6.3.2 Questões sobre liberdade e unicidade

6.3.3 Negociação Coletiva

6.3.4 Notas sobre greve

250

6.4 Sistema sindical italiano

251

6.4.1 Início do sindicalismo italiano

252

6.4.2 As corporações

253

6.4.3 Caminhos opostos

258

6.4.4 O novo modelo italiano

259

6.4.5 A liberdade sindical

260

6.4.6 Questões sobre a categoria

262

6.4.7 A abrangência dos contratos coletivos

265

6.4.8 Perspectivas

268

6.5 Sistema sindical espanhol

269

6.5.1 A evolução do sindicalismo

272

6.5.2 Os sujeitos coletivos

277

6.5.3 Liberdade sindical

279

6.5.4 Estrutura das organizações sindicais

280

6.5.5 Autonomia e negociação coletivas

281

6.5.6 Abrangência dos convênios coletivos

284

6.6 Sobre as diferenças entre os sistemas sindicais

286

6.7 Questões sobre a divisão do trabalho

290 
7.1 As classificações brasileira e internacionais de ocupações

7.2 O quadro de atividades e profissões da Consolidação das Leis do Trabalho

7.3 Alguns dados estatísticos

$7.4 \mathrm{O}$ trabalho de campo

$7.5 \mathrm{O}$ que pensam os trabalhadores 


\section{CAPÍTULO I - INTRODUÇÃO}

No Brasil, dada a estrutura sindical especial, herança do primeiro governo Vargas ${ }^{1}$, o conceito de categoria profissional, referido na Consolidação das Leis do Trabalho (CLT), assume fundamental importância. Explico. O Brasil, contrariando diversos tratados e acordos internacionais, entre os quais as convenções da Organização Internacional do Trabalho $^{2}$ e a Declaração Universal dos Direitos Humanos $^{3}$, ainda não houve por bem adotar um regime de liberdade sindical plena. No País, a liberdade sindical é chamada de pseudo-liberdade ou semi-liberdade ${ }^{4}$ já que, em alguns aspectos, o Estado segue impondo restrições.

A principal delas e a mais relevante para o assunto em comento é a unicidade sindical. Segundo tal regra, prevista no artigo 516 celetista $^{5}$, e reforçada no artigo $8^{\circ}$,

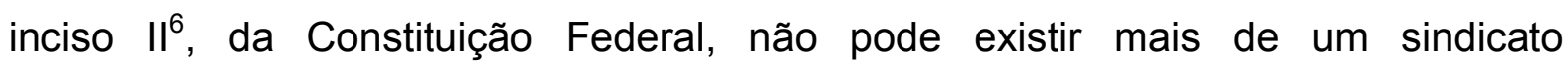
representativo da mesma categoria profissional ou econômica em dada base territorial. Em suma, em cada município, somente poderá haver um sindicato de determinada categoria profissional ou econômica.

Necessário aclarar o que seriam as categorias profissionais e econômicas. A categoria econômica é sempre a categoria dos empregadores. Os empregadores que exploram atividades econômicas idênticas, similares ou conexas podem formar a mesma categoria econômica para fins sindicais. A categoria profissional, em regra, forma-se a partir da categoria econômica para a qual trabalham determinado grupo de obreiros. Assim, por exemplo, os trabalhadores de empresas do setor de metalurgia serão metalúrgicos, independentemente da função que exerçam na

1A Consolidação das Leis do Trabalho (CLT) é o Decreto-lei 5.452 de $1^{\circ}$ de maio de 1943 . Nesse sentido 2 Principalmente a Convenção no 87 denominada "Liberdade Sindical e Proteção ao Direito de Sindicalização" de 1948 e ainda não ratificada pelo legislativo brasileiro, motivo pelo não qual não tem vigência formal no país. 3Liberdade de Sindicalização expressada no item 4 do artigo 23: "Toda a pessoa tem o direito de fundar com outras pessoas sindicatos e de se filiar em sindicatos para defesa dos seus interesses." Disponível em: $<$ http://www.ohchr.org/EN/UDHR/Documents/UDHR_Translations/por.pdf $>$ Acesso em: 03/01/2015.

4 Nesse sentido os autores SCHWARZ, Rodrigo Garcia. Direito do Trabalho. Rio de Janeiro: Elsevier, 2009. e PAULO, Vicente e ALEXANDRINO, Marcelo. Direito do Trabalho. Rio de Janeiro: Impetus, 2005. 5 BRASIL. Presidência da República. Consolidação das Leis do Trabalho. Decreto-lei 5.452/43. Art. 516 - Não será reconhecido mais de um Sindicato representativo da mesma categoria econômica ou profissional, ou profissão liberal, em uma dada base territorial. 6 BRASIL. Presidência da República. Constituição Federal.

Art. $8^{\circ}$ É livre a associação profissional ou sindical, observado o seguinte:

(...)

II - é vedada a criação de mais de uma organização sindical, em qualquer grau, representativa de categoria profissional ou econômica, na mesma base territorial, que será definida pelos trabalhadores ou empregadores interessados, não podendo ser inferior à área de um Município; (...) 
empresa. A exceção a essa regra é a Categoria Profissional Diferenciada, contemplada pelo parágrafo $3^{\circ}$ do artigo 511 da $\mathrm{CLT}^{7}$. A Categoria Profissional Diferenciada, por sua vez, é aquela que possui vicissitudes tais que são capazes de diferenciar o trabalhador dos companheiros de trabalho na mesma empresa. Destarte, uma secretária que trabalhe em tal empresa de metalurgia compartilhará o associativismo com outras secretárias e secretários de outras empresas tendo em vista a similitude de condições de vida, a formação comum e um estatuto profissional próprio.

A limitação à liberdade sindical, acontece, no Brasil, em função de dois fatores: categoria profissional e base territorial. O conceito de base territorial mínima foi, na Constituição atual, determinado como o município talvez como forma de adequar a estrutura piramidal sindical de sindicatos, federações e confederações à estrutura dos entes federativos estatais, seja, municípios, Estados e união, respectivamente.

Marx ${ }^{8}$, quando escreveu as "Formações Pré-capitalistas", em 1857, ainda que o texto tenha sido publicado somente no século $X X$, parecia vaticinar a sequência dos modos de produção pelos quais deveria passar a sociedade brasileira no caminho para o capitalismo. A sequência escravidão, feudalismo e capitalismo, de fato, ocorreu no Brasil nos séculos XIX e XX e, é claro, com suas especificidades próprias. O trabalho e a forma de relação do indivíduo com o espaço, ou a terra, para utilizar o mesmo termo que Marx $^{9}$, sempre exerceram protagonismo nas formas sócio-culturais de uma comunidade.

A partir da revolução de 1930 brasileira, onde a burguesia e a oposição cidade-campo tiveram um papel fundamental ${ }^{10}$, Getúlio Vargas precisou resolver várias questões em busca de uma maior industrialização brasileira. Entre elas

7 BRASIL. Presidência da República. Consolidação das Leis do Trabalho. Decreto-lei 5.452/43.

Art. 511. É lícita a associação para fins de estudo, defesa e coordenação dos seus interesses econômicos ou profissionais de todos os que, como empregadores, empregados, agentes ou trabalhadores autônomos ou profissionais liberais exerçam, respectivamente, a mesma atividade ou profissão ou atividades ou profissões similares ou conexas.

$\S 3^{\circ}$ Categoria profissional diferenciada é a que se forma dos empregados que exerçam profissões ou funções diferenciadas por força de estatuto profissional especial ou em consequência de condições de vida singulares. 8 MARX, Karl e HOBSBAWN, Eric. Formaciones Economicas Precapitalistas. México, D.F.: Siglo XXI, 2011.

9 Idem. p. 99 cujo título do capítulo é: Diferentes formas de relacionarse el indivíduo con la tierra.

10 FAUSTO, Boris. A revolução de 30: historiografia e história. São Paulo: Companhia das Letras, 1997. 
estava a criação de uma identidade nacional definida a partir de elementos selecionados de forma a promover a união e unidades nacionais ${ }^{11}$. Outra dessas dificuldades seria criar uma identificação profissional dos trabalhadores e possibilitar ao Estado controlar a crescente de massas de trabalhadores nas cidades. Assim, Getúlio Vargas, para criar entidades sindicais e uma identidade profissional nos trabalhadores teve que engessá-la ${ }^{12}$.

Desde então, a lei brasileira define o que, para o mundo jurídico, é uma categoria de fato e de direito. Contudo, resta por definir ou aclarar a própria definição legal. Para isto necessitamos da antropologia. As condições de vida singulares ou similares, capazes de tornar a associação entre determinados grupos de trabalhadores algo "natural" é um tema afeito ao método antropológico, fundamentalmente no campo da identidade.

Os sindicatos, que podem ser entendidos como organizações, são entidades com uma cultura e identidade próprias. Como toda organização, se define internamente e externamente, com fronteiras de inclusão e exclusão ${ }^{13}$. Estas questões, ao que parece, já tinham sido percebidas pelo renomado jurista brasileiro Mozart Victor Russomano ${ }^{14}$ quando aponta:

Se a sindicalização, necessariamente, se processa em função dos laços de solidariedade ou semelhança que aproximam certos empregados de outros empregados e certos empregadores de outros empregadores - a prévia especificação de quais sejam esses vínculos, de quais entidades sindicais que podem surgir neles baseados, é vital ao exercício prático das doutrinas sindicalistas; embora contrário, teoricamente, à idéia de plena liberdade sindical.

$\mathrm{Na}$ mesma linha estão os autores como Oliveira Vianna ${ }^{15}$ para quem o sindicato de ofício ou categoria é aquele que mais convém à sociedade justamente porque a homogeneidade da composição da categoria profissional, oriunda da identidade, similitude e conexidade das atividades exercidas entre seus membros têm condições de criar, de forma mais rápida entre os trabalhadores, a consciência

11 CARVALHO, José Murilo de. Nación Imaginada: memoria, mitos y héroes. in: GONZÁLEZ, E., MORENO, A. e SEVILLA, R. Reflexiones en torno a 500 años de historia de Brasil. Madrid: Catriel, 2000. 12 Analogia com a expressão de Jaime Guasp "el Derecho, para salvar la sociología, no tiene más remedio que matarla” em GUASP, Jaime. La pretensión procesal, II. Madrid: Civitas, 1981. p. 42

13 AGUIRRE BAZTAN, Silvio Ángel. La Cultura de las Organizaciones. Barcelona: Ariel, 2004.

14 RUSSOMANO, Mozart Victor. Comentários à Consolidação das Leis do Trabalho. Rio de Janeiro: Forense, 1997. p. 677/678

15 OliVeIRAVIANNA, Francisco José de. Problemas de direito sindical. Rio de Janeiro: M. Limonad, 1943. 
de unidade de grupo e fortalecer a militância pelos interesses coletivos. Também assim é a manifestação de Amauri Nascimento ${ }^{16}$ para quem a concepção de categoria é o prisma da organização sindical e para Campos Batalha ${ }^{17}$, o qual destaca que não se pode negar que a categoria, que poderia ser entendida como um critério de individualização de interesses afins de maneira que existe como fato social.

Nesse sentido, quando a lei aponta para conceitos que podem ser melhor traduzidos a partir do paradigma de outra ciência que não a pura hermenêutica do direito, é válido socorrer-se da antropologia para aclarar e delinear a definição legal.

\subsection{JUSTIFICATIVA}

\subsubsection{Desenvolvimento da Pesquisa}

A pesquisa será desenvolvida a partir da utilização do método antropológico como instrumento para interpretação do texto legal e da realidade social. Ainda assim, procurar-se-á desvendar quais são os laços fundamentais que determinam a associação entre trabalhadores. Tal associação deve ser "natural" segundo nossa legislação que, por seu turno, não explicita o que é uma associação natural, dando lugar a inúmeras interpretações. Seria necessário, portanto, ver a realidade através de um filtro multidisciplinar da realidade sócio-cultural ${ }^{18}$.

$\mathrm{Na}$ medida em que o ordenamento jurídico brasileiro somente permite um sindicato, por categoria, em determinada base territorial o conceito de categoria é fundamental para a formação dos sindicatos. A categoria, como um conceito abstrato, é passível de mudanças e releituras. Mesmo assim, a categoria é imprescindível, no atual sistema brasileiro, para legitimar a entidade sindical de primeiro grau. Já se fez analogia como a categoria sendo um "espírito e o sindicato o corpo que permite sua vida encarnada". Ressalte-se, que tal situação é peculiar do direito laboral brasileiro, por utilização do já citado regime de pseudo-liberdade sindical que vivemos.

16 NASCIMENTO, Amauri Mascaro. Direito Sindical. São Paulo: Saraiva, 1991.

17 CAMPOS BATALHA, Wilson de Souza. Sindicatos, sindicalismo. São Paulo: LTr, 1992.

18 HABERMAS, Jurgen. Direito e Democracia: entre facticidade e validade. Rio de Janeiro: Tempo

Brasileiro, 2003. 
O presidente Luiz Inácio Lula da Silva, em seu primeiro ano de mandato sinalizou com a necessidade de mudança no sistema sindical brasileiro ${ }^{19}$. Tal anseio foi parcialmente atendido a partir da inclusão e reconhecimento das Centrais Sindicais como parte integrante do Sistema Sindical brasileiro. O reconhecimento das Centrais Sindicais é mais um indício de que, para o trabalhador brasileiro, o limitado conceito de categoria expresso na Consolidação das Leis do Trabalho já não é suficiente.

Ademais, o contexto da economia globalizada da pós-modernidade reclama outras possibilidades de atuação sindical. Richard Sennet ${ }^{20}$ pontua a superação da profissão como fator determinante na formação da personalidade e na visão de mundo das pessoas. Por outro lado, também pontua o mencionado autor a crescente instabilidade das relações de emprego como resultado da revolução tecnológica, deslocalização (seja da empresa, de parte dela ou mesmo dos trabalhadores chegando a apontar que, no final do século $\mathrm{XX}$, um trabalhador normalmente mudava diversas vezes de emprego e de setor no qual trabalhava ao longo da vida. Tem-se, portanto, que o ofício desenvolvido não é necessariamente um fator indutor de semelhanças nos estilos de vida dos trabalhadores na pósmodernidade.

$\mathrm{E}$ as contradições da sociedade pós-industrial não param por aí. Tanto Habermas $^{21}$ como Horkheimer ${ }^{22}$ reconhecem as contradições formadas pela sociedade capitalista atual. O trabalhador é concorrente de seus companheiros de trabalho por uma vaga no mercado de trabalho e por maiores ganhos à vez que também necessitam produzir significados a partir de uma ação comunicativa em busca de melhores condições de trabalho e vida.

19 SUSSEKIND, 2004.

20 SENNET, Richard. La corrosión del carácter: las consecuencias personales del trabajo en el nuevo capitalismo. Barcelona: Anagrama, 2005.

21 HABERMAS, Jurgen. Teoría de la acción comunicativa, tomo I: Racionalidad de la acción y racionalización social. Madrid: Taurus, 1999.

22 HORKHEIMER, Max. Crítica de la razón instrumental. Trad. H. A. Murena y D. J. Vogelmann. Buenos Aires: Sur, 1973. 
Além disso, como ressaltado por Araújo ${ }^{23}$ e Sennet $^{24}$ os Estados nacionais vem perdendo força em comparação com os grandes conglomerados financeiros. Cada vez mais o Estado tem reduzida sua área de atuação na proteção do trabalhador indicando a necessidade de novas pautas sindicais de organização obreira.

Por outro lado, a legislação brasileira parece estar anacrônica. O direito, assim como outras áreas da ciência, soe andar a reboque das mudanças sociais. Um conjunto de normas jurídicas é pensado para atender uma realidade passada. Mesmo sendo praticamente impossível a criação de um sistema de normas plenamente adequado à realidade futura e incerta pode-se esperar um sistema jurídico ao menos mais atualizado.

Destarte, conjugando a legislação, a jurisprudência, os critérios de associativismo e as fronteiras identitárias de cada grupo/organização pretendemos propor critérios para completar a definição legal de categoria profissional inserta na CLT. Se propõe a pesquisa em quatro fases: bibliográfica, histórico-culturalgenealógica, etnográfica e interpretativa. Aliar teoria e prática, direito e antropologia, para chegar aos conceitos legais de identidade, similaridade e conexidade escritos pelo legislador.

Parece que a presente pesquisa, ao revelar a visão dos trabalhadores sobre as relações coletivas de trabalho pode contribuir como forma de sugerir novas pautas de organização sindical brasileira. A readequação da normativa legal, para ao menos tentar deixá-la mais próxima da realidade social se revela de utilidade no atual contexto. Além disso, pode auxiliar em um futuro projeto de emenda constitucional para a mudança do sistema sindical brasileiro. É bom lembrar que um dos grandes encontros entre antropologia e direito no Brasil se deu nas discussões da Assembleia Constituinte de 1988 onde os trabalhos antropológicos foram a base para as garantias dos direitos de muitas minorias na Constituição de 1988. Tal mudança pode evitar, também, a criação de sindicatos sem nenhuma representatividade ou sem nenhuma correspondente esfera de trabalhadores 
realmente significativa. Tal situação, como já dito, também é válida em um regime de liberdade sindical plena, como caminho e orientação aos trabalhadores na formação de entidades sindicais que realmente aportem aos envolvidos a necessária comunhão de interesses.

Como se sabe, na comparação reside um dos mais apreciados métodos antropológicos. A comparação com outros países que adotam regimes diferentes ao brasileiro, principalmente no tocante à formação dos sindicatos em sistema de liberdade plena. A Espanha ratificou a convenção da OIT em abril de $1977^{25}$ assim como garante a liberdade sindical plena na sua Constituição ${ }^{26}$, especificamente nos artigos 7 e 28 (respectivamente Sindicatos y asociaciones empresariales e Libertad de sindicación). Mesmo em um regime de liberdade sindical plena, onde não há restrições para formação de sindicatos, se pode notar que as entidades não são formadas sem um respeito mínimo ao conceito de categoria de trabalhadores, procurando congregar aqueles que possuem um mínimo de interesses comuns. Ainda assim, na Espanha também prosperam figuras como as centrais sindicais brasileiras, entidades sindicais de grande abrangência em termos nacionais e grande capacidade de mobilização de trabalhadores.

Por outro lado, temos também a Itália, que ratificou a convenção número 087 da OIT em março de $1958^{27}$, bem como garante na sua constituição ${ }^{28}$, desde 1947 , a liberdade sindical (artigo 39). É importante destacar que o direito brasileiro possui grandes semelhanças com os sistemas espanhol e italiano e a experiência sindical de ambos os países pode servir como um válido termo de comparação com o caso brasileiro. Cabe ressaltar que a nossa CLT teve inspiração na Carta del Lavoro de Mussolini e remonta ao ano de 1943 (elaborada sob a égide da Constituição de 1937, chamada de "polaca") ${ }^{29}$, durante o período conhecido como "Estado Novo" e presidência de Getúlio Vargas. Tanto a Carta del Lavoro ${ }^{30}$, quanto a Constituição Federal brasileira e a Consolidação das Leis do Trabalho começam seus tópicos

25 Dado do website oficial do Escritório da Organização Internacional do Trabalho na Espanha. Disponível em: $<$ http://www.ilo.org/madrid/españay-los-convenios/lang--es/index.htm> Acesso em: 22/12/13

26 ESPANHA. Presidencia del Gobierno. Constitución Española.

27 Dado do website oficial do Escritório da Organização Internacional do Trabalho na Itália. Disponível em: $<$ http://www.ilo.org/rome/ilo-italia/convenzioni-ratificate/lang--en/index.htm> Acesso em: 22/12/13

28 ITÁLIA. Governo Italiano. Costituzione Italiana.

29 BRASIL. Tribunal Superior do Trabalho. Exposição de Motivos da Consolidação das Leis do Trabalho. 30 ITALIA. Carta del Lavoro. 21 de abril de 1927. Disponível em:

$<$ http://www.historia.unimi.it/sezione/fonti/codificazione/cartalavoro.pdf $>$ Acesso em: 27 de outubro de 2014. 
acerca da organização sindical da mesma maneira: "É livre a associação sindical..."31; para, momento imediatamente posterior, apresentar restrições à liberdade sindical plena. O modelo implementado pelo General Francisco Franco na Espanha tampouco apresenta diferenças. Itens como o regime de sindicato único, de representatividade estendida a toda a categoria de trabalhadores, a capacidade para negociação coletiva (paliada em pouquíssimas exceções no caso brasileiro) e, finalmente, a capacidade de substituir o Estado na função de exigir contribuições compulsórias dos integrantes da categoria profissional ou econômica são comuns a todos os regimes totalitários originados no período entre guerras.

O período do Franquismo Espanhol foi bastante duradouro e nele o regime de sindicatos, similar ao caso brasileiro perdurou por mais quarenta anos ${ }^{32}$. No início da guerra civil houve repressão excessiva com a depuração de profissionais, principalmente professores, pelo simples fato de ostentar filiações sindicais, como aponta o historiador Eufemio Lorenzo ${ }^{33}$. Ademais, o movimento obreiro exerceu um forte papel na transição democrática, havendo exercido pressão sobre o regime franquista por quase duas décadas a partir da década de 1960 até o efetivo reconhecimento e ratificação da Convenção número 087 da Organização Internacional do Trabalho em $1977^{34}$. Bem assim, no caso espanhol, a transição para a democracia, que culminou com a Constituição de 1978, a qual também consagrou o direito à liberdade sindical, teve forte participação dos sindicatos como Comisiones Obreras y Unión Geral de Trabajadores, figuras assemelhadas às centrais sindicais brasileiras ${ }^{35}$.

Por tudo isso, acredita-se que desvendar a visão sobre a questão das categorias e grupos sindicalizáveis dos trabalhadores brasileiros possa contribuir para a implementação de mudanças efetivas no sistema sindical brasileiro. As

31 Pode-se comparar ambos com o texto constitucional da nota de rodapé número 7 e o excerto abaixo extraído da Carta del Lavoro: III. L'organizzazione sindacale o professionali è libera. Ma solo il sindacato legalmente riconosciuto e sottoposto al controllo dello stato, ha il diritto di rappresentare tutta la categoria di datori di lavoro o lavoratori, per cui è costituito; di tutelare di fronte allo stato e alle altri associazione professionali gli interessi; di stipulare contratti collettivi di lavoro obbligatori per tutti gli appartenenti alla categoria; di imporre loro contributi e de esercitare, rispetto a essi, funzioni delegati di interessi pubblico.

32 ALONSO OLEA, Manuel e CASAS BAAMONDE, Maria Emília. Derecho del Trabajo. Madrid:

Publicaciones Universidad de Madrid, 1995.

33 LORENZO SANZ, Eufemio. Represión y Depuración de los Maestros de la província de Palencia en la

Guerra Civil: de los anhelos republicanos a la resignación en el franquismo. Valladolid: IIACyL, 2014.

34 PALOMEQUE LÓPEZ, Manoel Carlos. Derecho del Trabajo. Madrid: Tecnos, 1994.

35 OJEDA AVILÉS, Antonio. Derecho Sindical. Madrid: Tecnos, 1984. 
mudanças, no contexto da atual sociedade, são bastante necessárias para ao menos tentar adequar a realidade dos trabalhadores à realidade legal.

\subsubsection{Da delimitação do objeto de pesquisa}

A delimitação do objeto de pesquisa perpassa as questões atinentes à formação da categoria de trabalhadores. Busca-se averiguar de acordo com a visão de trabalhadores urbanos brasileiros, qual conjunto ou grupo de pessoas é reputado por eles como integrantes ou passíveis de integrar a mesma categoria profissional/organização sindical.

O legislador, ao fazer constar as expressões identidade, conexidade e similaridade como necessárias para uma associação homogênea e natural de trabalhadores dá a entender que existem certas categorias válidas do ponto de vista sindical e outras não. Ou seja, para o legislador, pode ser que os garçons de um hotel e de um restaurante estejam próximos o suficiente para formar uma só categoria de trabalhadores, mas que esta categoria não poderia abarcar também os cozinheiros do restaurante ou as camareiras do hotel.

O próprio Arion Sayão Romita ${ }^{36}$, um dos principais autores brasileiros na área do direito do trabalho, já dizia que o conceito de grupo sindicalizável era dependente de diferentes fatores. Entre estes, citava que os mesmos estariam unidos entre si por uma rede ou sistema de relações sociais pautadas por normativas aceitas pelo grupo. Ademais, pontuava que os papéis e status interrelacionados nos quais se baseiam tais relações permitem estabelecer as fronteiras do grupo e diferenciar os membros e os não-membros.

A comparação entre o conceito de categoria sindical proporcionado pelos trabalhadores e o conceito legal, de um lado, e a comparação entre as realidades brasileira, italiana e espanhola, de outro, pode gerar suficiente tensão comparativa para a dedução de conceitos sobre a sindicalização. Assim, pretendemos ser capazes de apreender, a partir do método antropológico, quais as categorias de trabalhadores seriam legítimas desde uma perspectiva própria dos obreiros. Ou seja, estabelecer os limites/fronteiras sociais de pertencimento à determinada categoria de trabalhadores. 
Por fim, a definição da amostra será feita de maneira incidental de acordo com os a afluência dos informantes aos pontos de atendimento onde realizada a observação e concordândia destes em participar da pesquisa. Portanto, se buscarão diferentes trabalhadores sindicalizados com o propósito de comparar as duas visões. Como por exemplo, trabalhadores de uma planta montadora de automóveis, pois o próprio contexto das montadoras de automóveis (cujos trabalhadores, pela regra geral, pertencem à categoria dos metalúrgicos), símbolo do Fordismo e da sociedade industrial, pode proporcionar a observação de diversos aspectos. Um deles, é a relação entre os trabalhadores das empresas integrantes da planta industrial e não pertencentes à mesma categoria para fins sindicais.

\subsection{Objetivos}

O presente plano de estudos tem por objetivo:

\subsubsection{Objetivo Geral}

O objetivo geral consiste em analisar a visão dos trabalhadores brasileiros sobre o sistema relações coletivas de trabalho brasileiro.

\subsubsection{Objetivos Específicos}

Outros objetivos e questões emergem da abordagem da questão identitária e na busca da consecução do objetivo principal. Eles são os seguintes:

- Identificar as diferentes fronteiras identitárias dos diversos grupos de trabalhadores e o espaço de cada profissão e ofício na sociedade atual;

- Comparar o sistema sindical brasileiro com os sistemas espanhol e italiano, extraindo as peculiaridades, vantagens e desvantangens de cada um, sobretudo considerando-se que o último encontra-se em um regime de liberdade sindical;

- Apontar as deficiências e vantagens do sistema brasileiro no tocante às categorias de trabalhadores e representatividade sindical. 


\section{CAPÍTULO II - METODOLOGIA}

Para chegar às respostas sobre algum problema normalmente existem diversos caminhos possíveis. Em nosso entender, a partir de uma visão jurídico antropológica da lei e da realidade associada ao texto legal é possível avançar em ambos os campos. Conforme bem afirma $\operatorname{Streck}^{37}$, a pesquisa jurídica brasileira entrou em um círculo vicioso onde somente há revisão bibliográfica e análise jurisprudencial e um e outro se retroalimentam sem espaço para novidades. Entendemos que a lei e sua interpretação são elementos essenciais em nossa sociedade e, por isso, necessitamos de novas visões para compreendê-las de maneira mais adequada. Por outro lado, o sistema jurídico e as leis são destinados ao conjunto da sociedade e não somente aos juristas, motivo pelo qual é importante averiguar as impressões e as opiniões de outros destinatários da lei e não somente de juristas.

A questão do método em antropologia não é simples. Partimos do pressuposto, como sublinha Espina ${ }^{38}$, que a antropologia é uma ciência que trata do homem e de suas manifestações a partir de uma visão holística. Ao longo da história, muitas correntes teóricas, métodos e linhas de pensamento foram criados, testados, criticados e superados. Sentimo-nos impelidos a trazer à colação as linhas antropológicas, suas principais obras, principalmente naqueles aspectos que interessam ao presente tema, de maneira a justificar nossa escolha por este ou aquele paradigma teórico.

Os estudos de caso, ou o estudo de um pequeno grupo de determinada localidade ganhou importância somente em período muito recente das ciências sociais. No direito, mesmo quando se faz uma análise jurisprudencial e, portanto, casuística, normalmente opta-se por encontrar correntes jurisprudenciais dominantes ou discutir o matiz aplicado pelos julgadores ao caso. Por isso, principalmente com relação aos estudos antropológicos paira sempre a dúvida sobre a fiabilidade das conclusões do investigador e da relevância daquelas conclusões. No entanto, parece que a antropologia já fez diversas conclusões de valor para as

37 STRECK, Lênio Luiz. Hermenêutica jurídica e(m) crise: uma exploração hermenêutica da construção do direito. Porto Alegre: Livraria do Advogado, 2000.

38 ESPINA BARRIO, Ángel Baldomero. Manual de Antropologia Cultural. Tradução de Mário Hélio Gomes de Lima. Recife: Massangana, 2005. 
ciências sociais e já consolidou-se como um campo científico distinto das ciências da natureza e também distinto da arte, porque possui a propriedade de ser acumulativo ${ }^{39}$.

Segundo Gluckman é necessário sempre definir com cuidado o campo de estudo dentro de um espaço e em determinado tempo para analisar as relações sociais ocorridas naquele grupo. O que distingue o estudo antropológico do estudo de outro investigador social é a ênfase nos costumes ou, dizendo em outras palavras, a ênfase nas regras não escritas das relações sociais. Sempre, onde existir o costume e a tradição, haverá oportunidade para uma análise antropológica. Além disso, o autor afirma que é necessário armar-se de valor para tentar explicar aquilo que é evidente.

Para Streck, a pesquisa jurídica está restrita, ao menos no Brasil, somente à pesquisa bibliográfica com base na doutrina e jurisprudência "dominantes". Da mesma forma, as decisões judiciais são quase exclusivamente legalistas e bibliográficas, baseando-se na voz "autorizada" de poucos autores que avalizam, às vezes, todas as decisões em determinadas matérias. Formou-se assim um círculo vicioso repetitivo onde poucos doutrinadores pautam as decisões judiciais que, por sua vez, respaldam a opinião daqueles doutrinadores. Como bem destaca Streck, perdeu-se o interesse na discussão da matéria de fundo, no porquê das normas e sobre como queremos que seja nossa convivência social ${ }^{40}$.

A antropologia, por sua vez, teve uma primeira fase totalmente descritiva chamada comumente de pré-evolucionismo. Alguns autores, a exemplo de Lucy Mair ${ }^{41}$ sublinham que os primórdios da antropologia remontariam a Heródoto que descreveu muitas aldeias e povos mediterrâneos em suas viagens. Outros autores, como Espina, remontam esses primórdios da antropologia principalmente ao século $\mathrm{XVI}$, em razão da existência dos chamados Cronistas de Índias. Estes últimos eram os viajantes ou os exploradores que visitaram o novo mundo e contaram os detalhes de suas viagens como Hans Staden, Cabeza de Vaca e Bernardino de Sahagún, além, é claro, dos próprios Cristóvão Colombo e Pero Vaz de Caminha. Os missionários, padres e religiosos que estiveram no novo mundo durante os séculos

39 GLUCKMAN, Max. Política, derecho y ritual en la sociedad tribal. Madrid: Akal, 1978. 
XVII e XVIII também realizaram um importante labor no sentido de oferecer descrições sobre os costumes e gentes da América.

A primeira corrente teórica do pensamento antropológico foi efetivamente o evolucionismo. Seus principais representantes foram Herbert Spencer e Lewis H. Morgan com suas obras Princípios de Sociologia e Ancient Society (A sociedad Primitiva). O principal objetivo dos evolucionistas era classificar as sociedades e a cultura em etapas evolutivas levando-se em consideração que todos os grupos humanos possuem uma tendência intrínseca a evoluir em uma direção linear já predeterminada. Morgan utilizou uma divisão das etapas evolutivas com três principais: selvageria, barbárie e civilização. Em contraposição ao evolucionismo, no final do século XIX e início do século $X X$ surgiu o difusionismo. Segundo o difusionismo os humanos teriam a tendência de imitarem uns aos outros. Portanto, cada cultura seria um mosaico de elementos tomados de povos próximos ou distantes, mas que puderam ser observados. Algumas culturas funcionariam como centros difusores com relação a determinados rasgos culturais que seriam expandidos em círculos concêntricos de influência onde quanto mais próximo ao centro maior a similitude com o centro difusor ${ }^{42}$. (Harris, 1980)

Concomitantemente ao evolucionismo também passa a existir uma diferente corrente de pensamento, ainda que com muitas semelhanças em relação ao evolucionismo, mas que possui características próprias: a antropologia marxista ou materialismo histórico. Seus principais representantes seriam Karl Marx y Friedrich Engels. Marx acreditava que a teoria da luta pela sobrevivência das espécies era compatível com com sua teoria da luta de classes $^{43}$. Engels reputa a Marx a descoberta da lei da evolução cultural e ambos também sugerem a evolução cultural em estágios segundo o modo de produção principal: o primeiro deles seria a propriedade tribal, o segundo a propriedade escravagista e logo o terceiro a sociedade feudal. A partir de então a sociedade passaria ao modo de propriedade capitalista e daí evoluiria ao socialismo como fim (com sentido de finalidade) da história. No seu livro "Contribución a la Critica de la Economía Política 44" Marx oferece sua lista final de estágios da evolução da sociedade de classes, adaptando-

42 HARRIS, Marvin. EI desarrollo de la teoría antropologica. Historia de las teorias de la cultura. Madrid: Siglo XXI, 2003. 
a à realidade mundial: asiáticas, antigas, feudal e burguesa moderna ${ }^{45}$. Estas teorias foram de interesse para a etnologia, principalmente por enumerar e associar variáveis das mudanças culturais como as formas de propriedade, modos de produção e estrutura social ${ }^{46}$.

Já dissemos que outra importante orientação teórica no campo da antropologia foi o difusionismo. Esta corrente teórica tem como regra que as similaridades entre os povos devem-se a uma suposta unidade psíquica da humanidade, uma tendência do homem a possuir mitos e rituais semelhantes no afã de encontrar respostas para problemas também semelhantes ${ }^{47}$. Os autores do chamado difusionismo britânico, principalmente, Rivers, Perry y Smith, levaram este pensamento ao extremo, postulando que a base de todo o inventário cultural mundial teria uma única origem: Egito ${ }^{48}$. Devemos citar por outro lado, Franz Boas e seu particularismo cultural. Boas rechaçou as generalizações exageradas e propõe leis de difusão sempre que sejam fundamentadas numa antropologia mais empírica, indutiva e próxima às sociedades estudadas. Assim, seu método foi denominado análise de área e pretendia não separar os rasgos culturais da geografia em que estão inseridos ${ }^{49}$.

O particularismo de Boas abre caminho para uma visão mais específica e onde o estudo do aspecto mental do homem ganhava importância. Este enfoque da antropologia, chamado de "cultura e personalidade" teve também dois estágios: préfreudiano e freudiano. No período pré-freudiano a principal expoente foi Ruth Benedict que propôs uma antropologia do configuracionismo, da identificação das características culturais mais relevantes e sua posterior apresentação em um idioma psicológico familiar. Assim, fez uma aproximação entre o particularismo histórico e a psicanálise, dando vez a Freud no campo antropológico. No estágio freudiano, houve importantes contribuições para a explicação de diferenças e semelhanças culturais. Freud compara o homem selvagem a uma criança e a evolução infantil para a maturidade com os processos sociais de evolução cultural ${ }^{50}$.

45 HARRIS, 2003.

46 ESPINA BARRIO, 2005.

47 MAIR, 1980.

48 HARRIS, 2003

49 ESPINA BARRIO, 2005.

50 HARRIS, 2003. 
As orientações teóricas em antropologia podem ser descritas como um ciclo de êxito, críticas e contestações e cada uma das correntes teóricas goza de certo lapso temporal de validez, até ser substituída por outra. Não foi diferente com o funcionalismo e com o funcionalismo-estrutural (fase de transição entre o funcionalismo e o estruturalismo). Os principais representantes são, respectivamente, Bronislaw Malinowski e Alfred Reginald Radcliffe-Brown. O funcionalismo buscava explicar a função dos costumes e das instituições culturais. Segundo Malinowski, seria muito difícil e pouco científico compreender a origem de determinado ritual ou de determinado costume. Malinowski acreditava que, revelando a função de uma pauta cultural específica estaríamos já a caminho de descobrir suas origens ${ }^{51}$. Já Radcliffe-Brown, por sua parte, propõe uma visão funcional-estruturalista, que é ainda mais estreita que a visão de Malinowski concordando que a busca pelas origens de algum fenômeno é inútil e acientífica. Para o funcional-estruturalismo o bem-estar psicológico e biológico dos indivíduos tem valor em quanto importantes para a manutenção do sistema social. Tal função seria prioritária sobre todas as demais ${ }^{52}$.

Na metade do século $X X$, inaugura-se uma nova forma de pensamento em antropologia: o estruturalismo, cujo principal representante foi Claude Lévi-Strauss. Para ele, a sociologia, a etnografia e a linguística, possuíam métodos similares e que poderiam ser aproveitados entre si de maneira analógica, por isso seria razoável utilizar o método da linguística nas duas primeiras ${ }^{53}$. Lévi-Strauss analisa a cultura através da regra do incesto, com uma dupla leitura que o coloca como natural, mas, também como social. A regra do incesto tem papel central na teoria de Lévi-Strauss. A partir deste prisma o autor passa a definir as estruturas do parentesco, com algumas afirmações generalizáveis a toda sociedade e apoia-se na linguística para desvelar estruturas sociais e mitológicas ${ }^{54}$.

Uma distinção importante, que neste trabalho e em qualquer outro contexto onde se discuta a relevância sócio-cultural de um fenômeno, se faz necessária é entre relativismo cultural e etnocentrismo. O relativismo cultural é uma das bases do 
saber antropológico. Efetivamente, a cultura, tradições, costumes, comidas, jogos e atividades de determinado grupo humano não podem ser vistas nem julgadas como adequadas ou inadequadas. Cada povo possui sua própria forma de pensar e atuar, de maneira que suas tradições são válidas em quanto inseridas no seu contexto cultural. Não se pode ver desde outra perspectiva, a partir da visão de uma cultura exógena e avaliar a validade das condutas. Justamente o oposto é o conceito de etnocentrismo. A visão etnocêntrica é aquela que julga outros costumes e tradições desde o ponto de vista da própria cultura. Assim, a própria cultura será sempre "certa", "coerente" e "melhor". Por outro lado, o etnocentrismo, quando moderado, pode ser benéfico no sentido de atuar como agente de autopreservação das culturas, já que impede que certos costumes e tradições sejam esquecidas ou completamente transformadas ao entrar em contato com outros povos e/ou etnias ${ }^{55}$.

A distinção entre as visões etic y emic é também fundamental em trabalhos de cunho antropológico. Esta dicotomia, presente, como já dito, na relação necessária entre etnocentrismo e relativismo cultural, estará sempre a exigir do antropólogo que busque o equilíbrio entre ambas. As expressões etic e emic foram cunhadas por Pike $^{56}$ pela primeira vez na década de 50 do século $X X$. São uma analogia às expressões fonêmica e fonética ${ }^{57}$. Em antropologia, os termos adquirem outro significado, análogo, mas distinto. A visão emic faz com que o antropólogo explique e veja o mundo a partir da visão e da linguagem que poderia ser entendida pelo nativo da cultura à qual se refere. Tal visão seria aceita como adequada e significativa pelo próprio nativo. Para comunicar-se em linguagem emic o antropólogo teve que adquirir um conhecimento mínimo das categorias, características e regras dos nativos possibilitando uma visão da cultura desde "dentro". A seu turno, a perspectiva etic possui uma linguagem, categorias e regras derivadas da ciência (a teoria antropológica, estatísticas, demografia, economia, comparações). É uma visão técnica, científica e, portanto, estranha aos nativos, uma visão desde "fora" da cultura objeto de estudo.

No presente estudo parece ser possível combinar ambas as visões. Em um primeiro momento desde uma perspectiva mais etic, quando procurar-se-á desvelar 
alguns aspectos essenciais e histórico-culturais das relações de trabalho brasileiras. Sem embargo, adotar-se-á uma visão mais emic na etnografia e sua interpretação, de maneira que os nativos se sintam verdadeiramente representados e com "voz".

A questão da habilidade do antropólogo para observar o exótico e o familiar já foi abordada por um dos maiores antropólogos brasileiros: Roberto DaMatta ${ }^{58}$ (2011). Para ele, é necessário que o antropólogo tenha e exercite a habilidade de, no trabalho de campo, transformar o exótico em familiar para assim poder estudá-lo. Esta habilidade também pode ser exercitada de maneira inversa, a de transformar o familiar em exótico e desligar-se emocionalmente. $O$ autor faz analogia entre estômago e cabeça para representar os momentos do exótico e do familiar, para ele, o que possibilita essa separação, a familiarização com o estranho e o estranhamento do familiar são justamente as teorias antropológicas:

Isso significa que a apreensão no primeiro processo é realizada
primordialmente por um via intelectual (a transformação do exótico
em familiar é realizada fundamentalmente por meio de apreensões
cognitivas) ao passo que, no segundo caso, é necessário um
desligamento emocional, já que a familiaridade do costume não foi
obtida via intelecto, mas via coerção socializadora e, assim, veio do
estômago para a cabeça. Em ambos os casos, porém, a mediação é
realizada por um corpo de princípios-guia (as chamadas teorias
antropológicas) e conduzida num labirinto de conflitos dramáticos
que servem como pano de fundo para as anedotas antropológicas e
para acentuar o toque romântico de nossa disciplina. (DaMatta, 2011,
p. 186)

Este é o roteiro de que nos fala DaMatta realizando a mediação entre o exótico e o familiar, o diferente e o comum, ponto de convergência do relativismo cultural e do etnocentrismo e dos pontos de vista etic e emic, são as teorias e o método escolhidos pelo antropólogo.

Um trabalho antropológico, parece não poder prescindir da etnografia ao ponto que os termos etnografia e antropologia são por muitas vezes tratados como sinônimos, com o que não se concorda. De fato, esta situação foi causa de inúmeras confusões e incertezas. Kottak ${ }^{59}$ assim define tais termos:

La antropología cultural es el estudio de la sociedad humana y la cultura, el subcampo que describe, analiza, interpreta y explica las

58 DAMATTA, Roberto. Relativizando: uma introdução à antropología social. Rio de Janeiro: Rocco, 2011. P. 186

59 KOTTAK, Conrad Phillip. Antropología Cultural. México, D.F.: Macgraw Hill, 2011. 
similitudes y diferencias sociales y culturales. Para estudiar e interpretar la diversidad cultural, los antropólogos culturales se involucran en dos tipos de actividades: la etnografía (con base en el trabajo de campo) y la etnología (con base en la comparación transcultural). La etnografia proporciona una explicación de una comunidad sociedad o cultura particular. Durante el trabajo de campo etnográfico, el etnógrafo recopila datos que organiza, describe, analiza e interpreta para construir explicaciones, que puede presentar en forma de libro, artículo o película. De manera tradicional, los etnógrafos han vivido en pequeñas comunidades y estudiado el comportamiento, las creencias, las costumbres, la vida social, las actividades económicas, la política y la religión locales.(...) La etnologia examina, interpreta, analiza y compara los resultados de la etnografía: los datos recopilados en diferentes sociedades. Usa tales datos para comparar y contrastar, y para hacer generalizaciones acerca de la sociedad y la cultura. Al observar más allá de lo particular, hacia lo más general, los etnólogos tratan de identificar y explicar las diferencias y similitudes culturales, poner a prueba hipótesis, y construir teorías para mejorar nuestra comprensión de cómo funcionan los sistemas sociales y culturales. (Vea la sección "El método cientifico" al final de este capítulo.) La etnología obtiene sus datos por la comparación no sólo de la etnografía, sino también de los otros subcampos, en particular de la arqueología, que reconstruye los sistemas sociales del pasado.

É certo, por outro lado, que o trabalho de campo, e dentro dele, a observação participante, constituem uma parte central da antropologia e da etnografia. É o que diferencia esta disciplina das demais. O trabalho de campo, para Velasco y Díaz de $\operatorname{Rada}^{60}$ é "una situación metodológica y también en si mismo un proceso, una secuencia de acciones, de comportamientos y de acontecimientos, no todos controlados por el investigador (...)".

Mesmo não sendo possível, como em nosso caso, a realização de um trabalho de campo prolongado no tempo, devido às condições de distância (EuropaAmérica do Sul) e também temporais (devemos levar em consideração as diversas atividades exigidas pelo Programa de Doutorado, principalmente a exigência de publicação de artigos científicos em revistas de prestígio, trabalho quase tão árduo como a própria realização da tese doutoral, entre outras muitas atividades como, por exemplo, assistência a congressos e seminários), foi possível a realização de um trabalho de campo. Em tal trabalho, foram recolhidos diversos dados mediante 
observação participante, questionários e entrevistas em profundidade, documentos, e estatísticas.

Deve-se levar em consideração, também, o caráter reflexivo da investigação social. Como apontam Hammersley y Atkinson ${ }^{61}$ a investigação social, como parte do próprio mundo que estuda, é ao mesmo tempo observada e observadora, o que reflete não existir uma separação radical entre a ciência social e seu objeto.

Além do trabalho de campo, a antropologia tem outra grande referência enquanto método: a comparação. ${ }^{62}$ A comparação é, segundo Evans-Pritchard ${ }^{63}$ "uno de los procedimientos esenciales de todas las ciencias, y uno de los procesos elementales del pensamiento humano". Este autor também sublinha outro problema, seja, a dificuldade em escolher os objetos que serão comparados, os quais devem possuir características similares, a tornar possível a comparação. Não se pode comparar coisas incomparáveis e, no campo da antropologia, este cuidado é especialmente necessário já que são quase infinitas as unidades de comparação que podem ser escolhidas e utilizadas pelo observador de campo ou investigador em seus estudos. Em nosso caso, as comparações procurarão sempre utilizar as mesmas categorias mas em contextos históricos ou sócio-culturais distintos.

Para interpretar os dados recopilados, seja no trabalho de campo, seja de outras fontes como a pesquisa bibliográfica ou a estatística, utilizaremos, principalmente, a perspectiva de Clifford $\mathrm{Geertz}^{64}$, conjugada com aportes de DaMatta $^{65}$ e Gadamer ${ }^{66}$. Todos os três autores, tendo, acredita-se, o último influenciado os primeiros, têm ideias similares sobre a questão da interpretação. Seja no tocante à necessidade de estranhar o familiar e familiarizar o exótico, seja sobre a importância de fundir horizontes entre o autor e o intérprete e, finalmente, a centralidade da descrição densa em antropologia como elemento que fornece as chaves interpretativas, os três autores possuem ideias similares e complementares sobre a interpretação. Geertz destaca que devemos buscar as relações que existem

61 HAMMERSLEY, Martyn. e ATKINSON, Paul. Etnografía, métodos de investigación. Barcelona: Paidós, 1994.

62 VELASCO e DIAZ DE RADA,1997.

63 EVANS-PRITCHARD, Edward Evan. La mujer en las sociedades primitivas. Barcelona: Península, 1971.

64 GEERTZ, Clifford. Interpretação das Culturas. Rio de Janeiro: LTC, 2012.

65 DAMATTA, 2011.

66 GADAMER, Hans Georg. Verdad y método. Vol. I, Fundamentos de una hermenéutica filosófica.

Salamanca: Sígueme, 1996. 
entre os fatos, os discursos e os costumes e transferir de um a outro os juízos do investigador. A interpretação antropológica deve oferecer uma perspectiva daquilo que ocorre em uma sociedade, mas sem dissociar a interpretação dos fatos reais. Buscaremos contemplar as três principais características da etnografia, que seja interpretativa, que interprete o fluxo do discurso social e que o fixe no tempo e no espaço tornando-se analisável e questionável ${ }^{67}$. (Geertz, 2008)

Por isso, a hermenêutica será de fundamental importância para a interpretação dos dados obtidos no trabalho. A hermenêutica está entre dois mundos e jamais será uma verdade empírica e tampouco uma verdade absoluta. É apenas uma verdade limitada pela condição humana e pela linguagem. ${ }^{68}$

Desta forma, pretendemos utilizar perspectivas, métodos e orientações teóricas mistas para melhor atender ao objetivo da pesquisa. Seja na dualidade etnocentrismo/relativismo cultural, emic/etic, como também na mescla de técnicas de investigação como a pesquisa bibliográfica, a observação participante e a recopilação de dados estatísticos. Poderíamos resumir a antropologia e nosso labor no presente estudo, de maneira didática, como descrever, comparar e interpretar.

Trata-se de um estudo qualitativo dividido em três fases distintas. Na fase inicial da pesquisa, será utilizado o método bibliográfico, com a seleção, fichamento e recopilação da bibliografia atinente à temática ${ }^{69}$. Também, se fará a utilização do método histórico-cultural com a busca por taxonomias e classificações de profissões utilizadas pelos órgãos oficiais dos países de interesse, com mais atenção ao período posterior à revolução industrial e até os dias atuais. Também se buscará uma lista de sindicatos dos países mencionados, bem como sua evolução ao longo do tempo. Serão recolhidos dados através de pesquisas nos órgãos oficiais como, por exemplo, o Instituto Brasileiro de Geografía e Estatística (IBGE), o Cadastro Brasileiro de Ocupações (CBO), o Instituto Nacional de Estatística (INE/Portugal), o Instituto Nacional de Estadística (INE/Espanha).

Seguir-se-á na segunda fase com um trabalho de campo baseado na observação participante buscando averiguar as impressões e conhecimentos dos 
trabalhadores sobre seus ofícios. Além disso, pretende-se realizar entrevistas dirigidas indiretas com trabalhadores sindicalizados e não sindicalizados, bem como com dirigentes e profissionais especialistas no tema. Bem assim, seria possível observar a relação destes últimos com trabalhadores terceirizados e também as relações entre os trabalhadores filiados ao sindicato e não filiados. As visões de todos estes grupos podem conduzir ao melhor delineamento da visão de trabalhadores sobre as categorias profissionais, portanto, considera-se a eleição da amostra adequada. Ademais, as observações serão voltadas a descobrir qual é o núcleo mínimo de elementos que conduz à associação dos trabalhadores naquele determinado caso concreto.

Já na terceira fase os dados serão analisados e interpretados. A análise dos dados obtidos utilizará o método comparativo, buscando comparar categorias de dados equivalentes nos três países objeto do estudo. As fontes da pesquisa, portanto, serão principalmente os resultados obtidos nas fases aqui referidas. Poderse-ia resumi-los como a bibliografia gerada na primeira fase, na documentação e nas taxonomias geradas na segunda fase da pesquisa, nos resultados, observações e anotações colhidos no trabalho etnográfico e também no produto das comparações e interpretações de todos os elementos anteriormente referidos.

A cultura, objeto de estudo da antropologia, foi definida por Malinowski como os bens, ideias, hábitos e valores. A consideração de cultura também implicaria uma prolongação no tempo, a sobrevivência e manutenção em um determinado lapso de tempo. Outro aspecto da investigação antropológica desenvolvido por Malinowski foi a necessidade de contextualizar os objetos e as ações para entendê-los. Neste sentido, acabou mudando o próprio conceito dos museus de Antropologia onde passou a ser necessário colocar os objetos em seu contexto e não apenas coleções e listas de objetos.

As investigações antropológicas têm normalmente diversas etapas. Como já mencionado, neste caso particular, propomos quatro grandes etapas de investigação. A teoria antropológica, que em nosso entender, é o instrumento mais hábil para a consecução do objetivo de pesquisa e não deve servir a ela mesma, a auto-afirmar-se ou comprovar-se e sim servir a um propósito maior e possuir utilidade para um melhor conhecimento daquilo que nos propomos a investigar. 
A antropologia é uma ciência holística e historicamente interdisciplinar. De tal maneira, presta-se a uma profícua interrelação e complementaridade entre saberes que possibilita, muitas vezes, o avanço em todos os campos correlatos ${ }^{70}$. Para Firth $^{71}$ a Antropologia social tem por objeto a análise comparativa e razoável das formas do comportamento humano na sociedade. No entanto, o mesmo autor assevera que, para o antropólogo, a sociedade ocidental, e acrescentamos o adjetivo contemporânea, não é uma norma e sim apenas mais uma ou várias espécies de sociedades. ${ }^{72}$

Outra constatação que faz Firth é no sentido do desaparecimento gradual do valioso material de estudos da Antropologia. Uma das principais características do antropólogo sempre foi a de visitar culturas muito distintas oferecendo-nos um relato e uma interpretação das pautas culturais. Estabelece-se assim um ponto de comparação entre as diferentes culturas. Para Firth, virtualmente, já não existem os caçadores de cabeças, os sacrifícios rituais, o canibalismo e outras questões como o totemismo, a poligamia, a couvade sofreram muitas modificações. ${ }^{73}$

Assim, a antropologia se reproduz em um campo de estudos que se reduz como efeito da globalização e da homogeneização das pautas de conduta, principalmente no eixo ocidental Europeu-Americano. Por isso, é necessário encontrar novas pautas de estudo, voltadas para a sociedade atual, contemporânea, globalizada e pós-moderna, a qual não deixa de apresentar inúmeras incongruências, curiosidades e possíveis pautas de estudo. Ademais, mostrar as diferenças e vê-las sob outra perspectiva também pode contribuir para a preservação da diversidade cultural, um patrimônio da espécie tanto quanto ou maior que qualquer outro.

Para Firth, o antropólogo deve selecionar uma comunidade pequena ou uma amostra reduzida dentro de uma comunidade grande, pois assim a observação resultará muito mais exata. Desta forma, o antropólogo poderá obter pautas gerais e variações, bem como cotejar o que lhe é dito com as ações das pessoas da comunidade. Para o antropólogo, o principal material de trabalho é o comportamento 
social humano, seja ele verbal ou não verbal. Ademais, deve-se levar em consideração na investigação antropológica o critério subjetivo do pesquisar o que Firth chama de refração pessoal do observador. ${ }^{74}$

Firth também oferece os conceitos de sociedade e cultura. A sociedade é um conjunto de indivíduos e as vinculações que mantém entre si. Já a cultura seria:

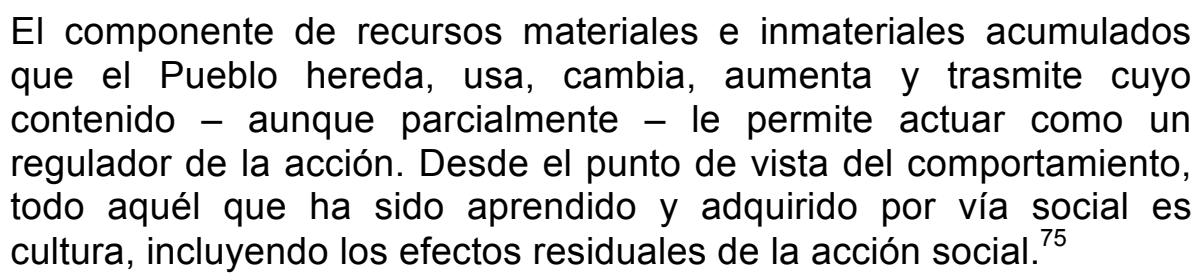

A antropologia cultural ou social nasce da constatação de que os aspectos da vida social, econômico, técnico, religioso, político, jurídico, estético formam um conjunto significativo, sendo impossível compreender algum deles quando tomado isoladamente. É característica do antropólogo, portanto, ir do todo para as partes e dar prioridade ao primeiro sobre as segundas ${ }^{76}$.

Para Lévi-Strauss, a etnologia (leríamos, no contexto atual, antropologia) se diferencia da sociologia por seu método filosófico. O sociólogo, para ele, objetiva por medo de enganar-se. Já o etnólogo não sente esta classe de temor, pois estuda sociedades longínquas e que nada tem a ver consigo. O observador, neste último caso, não corre o risco de estar implicado em nenhuma das conclusões ou observações efetuadas. ${ }^{77}$

Para Radcliffe-Brown ${ }^{78}$ por exemplo, a antropologia é uma ciência indutiva que observa fatos, formula hipóteses submetendo-as ao controle da experiência para descobrir leis gerais da natureza e da sociedade. Separa-se assim da etnologia que pretende reconstituir o passado de sociedades primitivas, mas com meios e métodos mais precários e em sua maior parte inúteis à antropologia.

74 FIRTH, 1971.

75 FIRTH, 1971. p. 46

76 LÉVI-STRAUSS, 2015

77 LÉVI-STRAUSS, Claude. Antropología Estructural: mito, sociedad y humanidades. Madrid: Siglo XXI, 2009.

78 RADCLIFFE-BROWN, Alfred Reginald. El método de la Antropología Social. Barcelona: Anagrama, 1975. 
Lévi-Strauss também atribui a Rousseau ${ }^{79}$ a origem da Antropologia. Segundo ele, Rousseau inaugura a reflexão sobre os problemas entre natureza e cultura onde Lévi-Strauss reconhece o primeiro tratado de etnologia geral. Destaca-se, ainda que Lévi-Strauss entende o pensamento de Rousseau como partindo de dois distintos postulados, quais sejam, a identificação com o outro, e quanto mais distinto, mais identificado e o rechace a identificar-se consigo mesmo. ${ }^{80}$

Lévi-Strauss é também um dos primeiros autores a abordar a necessidade do estranhamento em Antropologia. No Brasil o termo e suas implicações foram muito bem abordados por DaMatta ${ }^{81}$ na sua Introdução a Antropologia. Para DaMatta é necessário familiarizar-se com o alheio e estranhar o próprio para poder enxergar as diferenças e matizes invisíveis de outra forma.

É importante destacar as nuances da comunicação sublinhadas também por Lévi-Strauss. Para ele toda a emissão verbal do interlocutor existe para ser compreendida e, assim, a sua significação não é puramente intencional (desde o ponto de vista do emissor). A significação real e definitiva somente será obtida a partir do momento em que as emissões são vertidas no molde possuído pelo grupo social (representado pelo receptor) que é quem possui exclusivamente a segunda metade da significação.

O observador deve buscar as chamadas "categorias inconscientes ${ }^{82 " ~ a p o ́ s ~ a ~}$ análise racionalizada do discurso do indígena. $O$ termo indígena aqui é utilizado para designar o observado respeito ao observador. As categorias inconscientes são, em nosso entender, as categorias que nascem após a interpretação do discurso do informante e que completam esse sistema de significação composto por observado e observador.

Por outro lado, pontuam Hammersley y Atkinson ${ }^{83}$ que a etnografia consiste no recolhimento de todo o tipo de dados acessíveis para fornecer alguma luz sobre os temas que se escolheu estudar já que ao observar o comportamento alheio

79 ROUSSEAU, Jean Jacques. Discurso sobre el origen de la desigualdad entre los hombres. Barcelona: Península, 1970.

80 LÉVI-STRAUSS, 2009.

81 DAMATTA, 2011.

82 LÉVI-STRAUSS, 2009. p. 12

83 HAMMERSLEY e ATKINSON, 1994. 
geramos hipóteses do nosso próprio conhecimento cultural para descrever e explicar tais ações. Todavia com relação à etnografia é importante observar os princípios elencados por Velasco e Díaz de $\operatorname{Rada}^{84}$ segundo os quais a mente e emoção de outro ser humano são um dos melhores instrumentos para a compreensão de uma cultura, que uma cultura deve ser vista através dos olhos de quem a vive e que a cultura é um todo que dificilmente pode ser separada em partes para o estudo.

A comparação, para Evans-Pritchard ${ }^{85}$, é um dos "procedimientos esenciales de todas las ciencias, y uno de los procesos elementales del pensamiento humano". Ainda, Radcliffe-Brown ${ }^{86}$ também pontuou que sem estudos comparativos sistemáticos, a antropologia poderia ser chamada simplesmente de historiografia ou etnografia.

Sobre o etnocentrismo é importante destacar o que diz Lévi-Strauss no texto Raça e História onde destaca que em uma grande quantidade de povos, o próprio nome significa os homens, os verdadeiros homens ou algo do estilo. Ou seja, a humanidade cessa quando cessam as fronteiras do conhecido, chegando-se por vezes a privar o estrangeiro completamente do seu caráter humano e atribuindo-lhe características de uma aparição ou fantasma. Se a antropologia procura discriminar e separar culturas segundo seus rasgos específicos e idiossincrasias, tal atitude não é contrária ao relativismo cultural e tampouco nega a unidade da humanidade. No entanto, essa humanidade se realiza sob diferentes aspectos, diferentes costumes e em distintos lugares. ${ }^{87}$

Assim, Lévi-Strauss faz uma distinção das culturas que podem ser classificadas a partir do ponto de vista de qualquer outra. As culturas que são contemporâneas, mas se manifestam em outro espaço geográfico, as que se manifestam mais ou menos no mesmo espaço, mas que a precederam em tempo e, aquelas que existiram anteriormente e ademais em um lugar distinto. ${ }^{88}$

O progresso da humanidade é comparado metaforicamente por Lévi-Strauss ao progresso do cavalo do xadrez. São saltos quase sempre acompanhados de uma 
mudança de direção e que podem representar um retrocesso em outro campo. A humanidade, tal qual a peça do xadrez, sempre tem à sua disposição muitas possibilidades de movimento, mas nunca no mesmo sentido. Esse progresso está longe de ser representado como alguém que sobre uma escada e vai agregando altura à medida que adquire conhecimentos. ${ }^{89}$

No mesmo sentido, Lévi-Strauss destaca que a civilização ocidental que conhecemos é algo que ocupa uma porcentagem ínfima na história da humanidade. Neste sentido, o tempo necessário para que a humanidade chegasse onde está foi o necessário, segundo ele, para que se produzissem as condições adequadas e a combinação de fatores que possibilitou as mudanças. Mutatis mutandis, Lévi-Strauss a compara a um jogador de dados que pode obter uma determinada combinação na primeira ou na milésima jogada. ${ }^{90}$

Além de comparar os dados obtidos, por certo, será necessário interpretá-los, seja o resultado das comparações, seja aqueles dados não passíveis de comparação. Para isso, pretendemos adotar uma perspectiva pós-moderna de interpretação. Um dos expoentes desta perspectiva é sem dúvida Clifford Geertz ${ }^{91}$ para quem interpretar é dizer alguma coisa sobre algo, com apoio também da analogia. Ou seja, deve-se buscar por relações entre os fatos, discursos e costumes e transferir de um para o outro os juízos do pesquisador. A "descrição densa" de que também fala DaMatta ${ }^{92}$ seria, para Velasco e Díaz de Rada ${ }^{93}$ uma "composición hipotética de la cultura" tal como ela é vista pelo pesquisador. O antropólogo espanhol Carmelo Lisón Tolosana ${ }^{94}$ também advoga por uma antropologia que seja essencialmente interpretativa. Segundo ele, para "antropologizar" deve-se recolher dados etnográficos e descrevê-los de maneira sistemática para depois analisá-los de maneira semiológico-semântica e apropriar-se de seu significado através de uma interpretação hermenêutica.

Através de tal processo de interpretação pretendemos tornar compreensível as condutas humanas e, assim, descobrir as motivações, os interesses, as 
consequências e a efetividade da associação de grupos de trabalhadores. Em suma, desvendar os sistemas de símbolos e suas interrelações através da interpretação da ação social.

\subsection{Conceitos Fundamentais}

Os conceitos fundamentais a serem trabalhados e desenvolvidos na presente pesquisa tratam-se da: identidade coletiva, associações, categorias profissionais, fronteiras de exclusão/inclusão, trabalhadores, sindicatos e categoria profissional.

\subsection{Planificação Temporal}

Para a consecução dos objetivos da pesquisa o prazo previsto é de 48 (quarenta e oito meses) que serão divididos em diferentes fases. $O$ doutorado em Ciências Sociais da Universidad de Salamanca não exige a frequência em classes. Dito programa, doutorado em Ciências Sociais, apresenta algumas exigências aos doutorandos. Tais exigências dão-se conforme o ano do doutorado. De uma maneira geral, o candidato a doutor deve cumprir certos requisitos como seguimento de projetos (reuniões com o orientador), cursos de formação (seminários relacionados com a área do conhecimento na qual se desenvolve a tese doutoral), assistência/participação em congressos (dois congressos como assistente e dois como comunicante/palestrante, sendo ao menos uma das comunicações em algum evento de nível internacional, publicações científicas (uma publicação em periódico JCR ou duas em revistas indexadas), estadias em outras universidades (ao menos um mês de estadia em outra universidade) e mobilidade acadêmica (outro período de investigação em uma terceira universidade, trabalho de campo fora da localidade de Salamanca ou cursos universitários que perfaçam um total de 15 créditos/150 horas).

O trabalho será desenvolvido, em um primeiro plano, durante o período inicial de realização do período de investigações (curso 2014-2015) com a localização e identificação das fontes bibliográficas primárias e secundárias, sua compilação e fichamento. Neste período, está incluída também a localização e compilação das fontes relativas ao método antropólogico/etnográfico de maneira a preparar a pesquisa de campo. 
No segundo período de investigação, o curso 2015/2016 (de outubro de 2015 a setembro de 2016), prevê-se a realização de estágio de investigação (com trabalho de campo/etnografia), no Brasil (seis meses), que além de servir ao propósito da pesquisa, também cumprem os requisitos impostos pelo programa de doutorado. Ainda, no segundo semestre se dedicará à compilação e organização dos dados obtidos nos estágios de investigação. É de se destacar que durante todo o período do doutoramento serão mantidas as participações em seminários, apresentações de trabalhos e redação de artigos científicos como meio de implementar a capacidade investigadora. Ditos períodos de investigação também possibilitam a obtenção das menções "doctorado internacional" e "doctor europeus", de acordo com o regulamento da Universidade de Salamanca.

Finalmente, o último período de investigação, o curso 2017-2018 será dedicado à revisão final e redação da tese que tem previsão de defesa para o mês de outubro de 2017 e o retorno ao Brasil no prazo previsto de trinta dias após a leitura da tese. Para facilitar a leitura e compreensão o cronograma pode ser resumido no seguinte quadro sinótico:

\begin{tabular}{|l|l|}
\hline \multicolumn{1}{|c|}{ ATIVIDADES } & \multicolumn{1}{|c|}{ PERÍODO DE REALIZAÇÃO } \\
\hline $\begin{array}{l}\text { Identificação, localização, fichamento e } \\
\text { compilação de fontes primárias e } \\
\text { secundárias (em realização) }\end{array}$ & $\begin{array}{l}\text { Curso 2013-2014 (setembro de 2013 a } \\
\text { setembro de 2014) }\end{array}$ \\
Trabalho de Campo (Brasil) & $\begin{array}{l}\text { Curso 2014-2015 (fevereiro a julho de } \\
2015)\end{array}$ \\
\hline $\begin{array}{l}\text { Compilação dos Dados da Pesquisa e } \\
\text { Início da redação de tese doutoral. }\end{array}$ & $\begin{array}{l}\text { Curso 2014-2015 (julho a outubro de } \\
2017)\end{array}$ \\
\hline $\begin{array}{l}\text { Redação final, revisão e edição da Tese } \\
\text { Doutoral }\end{array}$ & $\begin{array}{l}\text { Curso 2015-2016 (outubro de 2016 a } \\
\text { setembro de 2016) } \\
\text { Entrega da Tese Doutoral }\end{array}$ \\
\hline Defesa da Tese & $\begin{array}{l}\text { Curso 2016-2017 (maio de 2017) } \\
\text { de 15 de setembro de 2017) }\end{array}$ \\
\hline
\end{tabular}


É importante destacar que optamos pela redação do trabalho em língua portuguesa, que tendo em vista a nacionalidade do autor, muito provavelmente deverá ser submetido a um processo de homologação/revalidação para adquirir validade legal no Brasil. Por outro lado, enquanto à formatação, escolhemos utilizar as normas da "Associação Brasileira de Normas Técnicas" (ABNT) em razão da familiaridade com tais normas e de um possível processo de convalidação. Contudo, adaptamos em alguns pontos a mencionada norma seja por recursos de estilo, seja por recursos gráficos, que entendemos podem tornar mais fácil a leitura.

\subsection{Definindo alguns conceitos importantes}

Para Marshall Sahlins ${ }^{95}$, uma sociedade primitiva é aquela onde não existe exploração do homem pelo homem. Já as sociedades camponesas seriam aquelas onde o a agricultura provê o abastecimento da sociedade assim como das classes dominantes, de maneira que os camponeses são uma classe explorada. Morgan ${ }^{96}$ nos facilita o conceito de Tribo que seria uma sociedade completamente organizada e capaz de reproduzir-se.

O termo primitivo deve ser entendido, neste trabalho e em antropologia não por seu sentido semântico estrito. Para Lévi-Strauss ${ }^{97}$ por exemplo:

Un Pueblo primitivo nos es un Pueblo atrasado, puede, en tal o cual
campo, revelar un espíritu de invención y realización que deja muy
por detrás los logros de los civilizados. Así, por ejemplo, esta
verdadera 'sociología planificada' que se revela en el estudio de la
organización familiar de las sociedades australianas, la integración
de la vida afectiva, en un complejo sistema de derechos y
obligaciones en Melanesia y, en casi todas partes, la utilización del
sentimiento religioso para fundar una síntesis viable, si no siempre
harmoniosa, entre las aspiraciones individuales y el orden social.

Assim que o termo primitivo não deve ser entendido como atrasado ou de forma etnocêntrica. Entretanto, por vezes se faz necessário diferenciar as sociedades que ocupam diferentes lugares no continuum do espaço-tempo cultural.

É importante, assim, livrar-nos do resíduo etnocêntrico e filosófico que tais termos trazem consigo ${ }^{98}$. Ler o contexto e entender os termos ali colocados é o 
primeiro passo para uma leitura e interpretação alinhadas com o estado da arte da antropologia.

Para Malinowski"9 , o vocábulo "selvagem", seja qual fosse sua conotação original, traz à tona imagens de liberdade e irregularidade. Assim, tem-se a impressão de selvagem em estado de natureza, quando as investigações antropológicas não cansam de demonstram sentido, organização e ordem nas comunidades primitivas que funcionam sob normas de parentesco bastante complexas.

Por outro lado, para o mesmo autor, a cultura é um conjunto etnográfico que apresenta, com relação a outro, variações significativas. Isto é, utilizamos o termo cultura para designar um conjunto de variações significativas cujos limites coincidem. Sempre que possuímos um conjunto etnográfico que não varia significativamente entre e si mas sim com respeito a outros, Lévi-Strauss designa este conjunto como uma cultura, neste sentido o termo cultura brasileira por exemplo ${ }^{100}$.

Lévi-Strauss também define os termos Etnografia, Etnologia e Antropologia. Para ele, a etnografia corresponde a uma primeira etapa da investigação, a observação e a descrição, o trabalho no campo em primeira mão. Já a etnologia seria um primeiro passo em direção à síntese, como uma espécie de prolongação da etnografia. Durante muito tempo estes dois termos foram suficientes para designar as atividades de descrição e recopilações de dados sobre culturas com algumas tímidas sínteses no sentido de determinar os centros de difusão e as origens de algum costume ${ }^{101}$. É importante destacar que, na França por exemplo, o termo antropologia nunca foi bem aceito e soe aplicar-se somente aos casos de antropologia física ${ }^{102}$.

A antropologia é, para Lévi-Strauss, aspirar a um conhecimento passível de ser extrapolado a todo o conjunto do desenvolvimento da humanidade desde seus primórdios. Já os termos social e cultural utilizados sobretudo para diferenciar a antropologia física ou biológica são bastante similares.

99 MALINOWSKI, Bronislaw. Los argonautas del Pacífico Occidental. Barcelona: Península, 1973. 
A noção de cultura neste contexto, distinto do contexto de cultura mencionado anteriormente provém de Tylor ${ }^{103}$ para quem a cultura é "esa totalidad compleja que incluye conocimiento, creencia, arte, moral, ley, costumbre y todas las demás capacidades y hábitos adquiridos por el hombre como miembro de la sociedad". O progresso, por sua vez, parece ser um estranho paradoxo. O progresso, ao menos do ponto de vista cultural, é uma coalisão de culturas a qual torna comuns as probabilidades de desenvolvimento de ambas. ${ }^{104}$

Com esses termos, pretendemos deixar claro o sentido de algumas expressões utilizadas no presente trabalho. Muitas delas, fogem do sentido comumente atribuído aos termos pelo que se faz necessário ler tais vocábulos tendo em mente a conceitualização efetuada anteriormente. 


\section{CAPÍTULO III - TRABALHO/CULTURA/TRABALHO - 0 trabalho dos antropólogos e os caminhos da teoria antropológica}

A história da espécie humana remonta já a alguns milhares de séculos. Contudo, quando comparada à história do universo ou mesmo à história do próprio planeta Terra tal história é bastante curta. O período do qual possuímos informações exatas e consciência dos fatos sucedidos é ainda menor. Mesmo assim, nesses aproximadamente duzentos mil anos da existência humana experimentamos uma constante mudança dos modos de vida, das interrelações e da interação com o ambiente.

Segundo aponta Lévi-Strauss ${ }^{105}$, os atualmente reputados como principais acontecimentos da humanidade ocupam um espaço de tempo ínfimo na sua história total. A agricultura ocupa apenas $2 \%$ da duração da humanidade, a metalurgia um 0,7\%, o alfabeto 0,35\%, a física de Galileu 0.035\% e o darwinismo 0,009\%. Ou seja, as revoluções científica e industrial estão inseridas em uma porcentagem ínfima do tempo de duração da humanidade.

Os termos civilização e trabalho, objetos deste capítulo, são bastante complexos e nem sempre tiveram o mesmo significado. A civilização, consiste em "uma maneira abreviada para designar um processo complexo"106". Não poderia existir, assim, nunca uma única "civilização mundial" homogênea, pois a própria expressão pressupõe a existência de diferentes culturas coexistentes.

Lado outro os termos estiveram sempre intimamente relacionados e com influência mútua. Engels, em um curto ensaio, abordou a importância do "trabalho para a transformação do macaco em homem." ${ }^{107}$ Tal visão parece bastante acertada na medida em que os componentes relacionados com o trabalho foram, de fato, decisivos para o caminhar da espécie humana.

Engels chega ao ponto de dizer que o trabalho é tão fundamental ao homem que o trabalho o teria criado. Além disso, destaca, também a grande probabilidade da linguagem haver nascido em razão da necessidade de comunicação para 
realização de tarefas comuns, nas quais seria necessária uma sincronização de tarefas ou ajuda entre os indivíduos ${ }^{108}$.

Tais afirmações servem de mote ao primeiro capítulo deste trabalho. Procuraremos desvendar até que ponto o trabalho formou o homem ou o homem criou o trabalho e as implicações de tal relação no estado de nossa sociedade atual.

A espécie humana passou por muitas mudanças desde o seu surgimento. Apontar as causas de tais mudanças e contextualizar as épocas em que ocorreram foi sempre uma preocupação dos antropólogos. Um dos autores clássicos da antropologia brasileira Darcy Ribeiro ${ }^{109}$ realizou a monumental tarefa de organizar e categorizar as etapas da evolução sociocultural dos mais diversos povos apontando os motores e as dificuldades de tais mudanças, da mesma maneira que já o haviam feito alguns antropólogos anteriores, principalmente Lewis H. Morgan.

Por outro lado, vários outros antropólogos, quiçá antes mesmo de que existira a antropologia como ciência organizada, escreveram sobre a evolução sociocultural e as fases/etapas que cumprimos enquanto espécie para chegar até os dias de hoje. Entre eles pode-se citar Lewis H. Morgan, Herbert Spencer, Henry Summer Maine, James Frazer, Edward B. Tylor, além de diversos outros. Quase todos parecem concordar com a existência de "revoluções tecnológicas", tal como apontado por Darcy Ribeiro, para quem:

a certas transformações prodigiosas no equipamento de ação humana sobre a natureza, ou de ação bélica, correspondem alterações qualitativas em todo o modo de ser das sociedades que nos obrigam a tratá-las como categorias novas dentro do continuum da evolução sócio-cultural ${ }^{110}$

Tais revoluções tecnológicas (que pode parecer um termo estranho ao considerar-se nosso atual uso do vocábulo) marcam a passagem de uma etapa à seguinte na organização das sociedades que as experimentam. Assim, seja Morgan, seja Ribeiro e mesmo Engels, apresentam um conjunto ordenado de etapas, 
revoluções tecnológicas e etapas subsequentes, buscando delinear o conjunto da evolução ${ }^{111}$ humana.

O autor Radcliffe-Brown ${ }^{112}$ emprega um conceito de evolução bastante similar ao que decidimos utilizar. Para ele, o termo alude à aparição de novas formas de estruturas sociais. Além disso, pontua ser a evolução social uma realidade merecedora do estudo de parte da antropologia social.

A maioria dos trabalhos parte do esquema proposto por L.H. Morgan ${ }^{113}$. As etapas da evolução sociocultural sugeridas pelos diversos autores coincidem. Procuraremos realizar um pequeno resumo de cada uma delas e organizar as opiniões com objetivo de apresentar uma sequência adequada de tais etapas e fases de evolução da cultura e sociedade humanas.

Ainda que o esquema proposto por Morgan seja objeto de muitas críticas ele foi um dos pioneiros em tentar delinear a evolução da espécie humana como um acontecimento uno e com uma esquematização bastante útil para o posterior desenvolvimento da ciência. Tais fases consistem em selvajaria, barbárie e civilização, cada uma com suas vicissitudes e com subdivisões próprias. Tentaremos resumir os aportes dos diferentes autores sobre cada um dos períodos e assim construir um esquema próprio da evolução da cultura. Lembremos, tal qual diz Engels, que o trabalho exerceu e exerce papel fundamental em tais mudanças e na transformação da estrutura social, daí a relevância e necessidade de termos bem claras as etapas da evolução social.

Aliás, do estudo de tal evolução ajudou a que tomasse forma a própria ciência antropológica. Tanto que os primeiros antropólogos modernos no atual uso do vocábulo podem ser situados dentro da linha evolucionista, ou seja, um grande grupo de antropólogos que se dedicou ao estudo da evolução da cultura. Procuraremos resumir as colaborações dos principais autores em tal sentido.

111 Ressalte-se que o termo evolução é empregado no sentido de uma mudança, nova fase, transformação pelo qual passaram as sociedades. Não se procura, com o termo, emitir juízo de valor sobre a qualidade da mudança se para um estágio melhor ou não. 


\subsection{0 corpo humano, veículo da cultura}

A história que costumamos estudar abarca um tempo ínfimo do tempo de existência do universo. Do mesmo modo, como veremos, as primeiras modificações culturais ocorreram há muito pouco tempo na história da humanidade. O próprio conceito de humanidade é algo que soe provocar a imagem de nossa espécie homo sapiens, e só. No entanto, existiram diferentes espécies de humanos com distintas formas corporais, capacidade cerebral e, inclusive, pautas culturais.

Não nos esqueçamos de que também existiram outras espécies de hominídeos com características entre humanos e símios. O autor Daniel Lieberman $^{114}$ fornece uma tabela ${ }^{115}$ para que tenhamos uma ideia das diferentes espécies de hominídeos e as datas de sua provável aparição:

\begin{tabular}{|c|c|c|}
\hline Espécie & $\begin{array}{c}\text { Datação (em milhões de } \\
\text { anos) }\end{array}$ & Lugar onde encontrado \\
\hline \multicolumn{3}{|c|}{ Primeiros hominídeos } \\
\hline Sahelanthropus tchadensis & $7,5-6$ & Chade \\
\hline Orrorin tugenensis & 6 & Quênia \\
\hline Ardipithecus kadabba & $5,8-4,3$ & Etiópia \\
\hline Ardipithecus ramidus & 4,4 & Etiópia \\
\hline \multicolumn{3}{|c|}{ Australopitecos gráceis } \\
\hline $\begin{array}{l}\text { Australopithecus } \\
\text { anamensis }\end{array}$ & $4,2-3,9$ & Quênia, Etiópia \\
\hline Australopithecus afarensis & $3,9-3,0$ & Tanzânia, Quênia, Etiópia \\
\hline Australopithecus africanus & $3,0-2,0$ & África do Sul \\
\hline
\end{tabular}

114 LIEBERMAN, Daniel. La historia del cuerpo humano. Evolución, salud y enfermedad. Barcelona: Pasado\&Presente, 2013.

115 Tabela adaptada de LIEBERMAN, 2013. p. 67 


\begin{tabular}{|l|c|c|}
\hline Australopithecus sediba & $2,0-1,8$ & África do Sul \\
\hline Australopithecus garhi & 2,5 & Etiópia \\
\hline Kenyantrhopus platyops & $3,5-3,2$ & Quênia \\
\hline \multicolumn{2}{|c|}{ Australopitecos robustos } \\
\hline $\begin{array}{l}\text { Australopithecus } \\
\text { aethiopicus }\end{array}$ & $2,7-2,3$ & Quênia, Etiópia \\
\hline Australopithecus boisei & $2,3-1,3$ & Tanzânia, Quênia, Etiópia \\
\hline Australopithecus robustus & $2,0-1,5$ & África do Sul \\
\hline
\end{tabular}

A aparição dos primeiros hominídeos, entre 7,5 e 6 milhões de anos atrás indica uma outra importante informação, quando existiu o último antepassado comum entre humanos e chimpanzés ${ }^{116}$. Por outro lado, vemos os primeiros da espécie homo somente surgiram a partir de aproximadamente 2 milhões de anos atrás. Sobre as espécies do gênero homo, Daniel Lieberman também proporciona uma tabela ${ }^{117}$ resumida sobre a aparição de cada uma das espécies:

\begin{tabular}{|c|c|c|}
\hline Espécie & $\begin{array}{c}\text { Datação (em milhões de } \\
\text { anos) }\end{array}$ & Lugar onde encontrado \\
\hline Homo habilis & $2,4-1,4$ & Tanzânia, Quênia \\
\hline Homo rudolfensis & $1,9-1,7$ & Quênia, Etiópia \\
\hline Homo Erectus & $1,9-0,2$ & África, Europa, Ásia \\
\hline Homo heidelbergensis & $0,7-0,2$ & África, Europa \\
\hline Homo neanderthalensis & $0,2-0,03$ & Europa, Ásia \\
\hline
\end{tabular}




\begin{tabular}{|c|c|c|}
\hline Homo floresisensis & $0,09-0,02$ & Indonésia \\
\hline Homo sapiens & $0,02-$ presente & Mundo inteiro \\
\hline
\end{tabular}

Os quadros acima dão uma pequena noção de como a espécie humana é nova no universo. Ademais, com a afirmação de nossa espécie ocorreu a extinção de todas as demais, de maneira que apenas sobrou uma espécie humana na face da terra. Disso se pode concluir a velocidade com que ocorre a evolução pautada pela seleção natural tal qual afirmava Darwin, são mudanças lentas e que levam diversas gerações para afirmar-se e confirmar-se como duradouras.

De fato, a evolução da anatomia humana nos propiciou as condições para o início de uma outra evolução, esta sim, muito mais rápida e muito mais impactante: a evolução cultural. Não é o momento de abordar os pormenores da evolução cultural, mas algumas circunstâncias deveriam ser mencionadas.

Segundo muitos autores a evolução cultural é um motor de mudanças bastante mais potente e mais rápido que a evolução biológica ${ }^{118}$. A evolução biológica trata de adaptar o corpo para melhor sobreviver ao ambiente em que vive. Por outro lado, a evolução cultural muda o próprio ambiente e inova em soluções para suprir necessidades biológicas mesmo em um ambiente adverso. Ou seja, desde o início da evolução cultural ocorre algo chamado de co-evolução ${ }^{119}$ onde biologia e cultura evoluem juntas, uma influenciando à outra.

Outra inevitável constatação é a da teoria do desajuste. A evolução biológica leva bastante mais tempo para se desenvolver, de fato, apresentamos pouquíssimas diferenças significativas com relação aos nossos primeiros antepassados Homo Sapiens. Os genes que herdamos foram polidos por milhares e milhares de anos, sob condições adversas e hostis para que chegassem ao ponto em que estamos hoje (lembremos, nossa espécie tem aproximadamente 200.000). Sem embargo, a evolução cultural, principalmente a partir do início da utilização da agricultura (entre

118 BOYD, Robert. \& RICHERSON, Peter. Culture and evolutionary Process. University of Chicago Press, 1985.

119 DURHAM, William. Co-evolution: Genes, Culture and Human Diversity. Stanford University Press, 1991. 
15.000 e 20.000 anos atrás) acelerou sobremaneira a evolução cultural. Por isso, muitas vezes se produz um desajuste entre os tipos de atividade e ambiente para os quais está adaptado nosso corpo e os ambientes e atividades que devemos enfrentar as quais, algumas vezes, podem causar enfermidades.

Olhar os gráficos populacionais pode nos dar indícios de quais foram os eventos importantes que assentaram nossa espécie no planeta. Além disso, podemos chegar à conclusão de que fomos, para as demais espécies humanas, extremamente prejudiciais ao ponto de nenhuma ter sobrevivido ao nosso levantar. Poucas espécies humanas sequer compartilharam o mundo conosco, diminuindo sempre conforme a nossa espécie prosperava.

A população mundial no início do neolítico era de aproximadamente 6 milhões de habitantes. Nos 11.800 anos que se seguiram (de 10.000 a.C. até 1.800 d.C) a população passou de 6 milhões para em torno de 1 bilhão de pessoas. Em outras palavras, levamos quase todo o tempo da existência da espécie para atingir a marca de 1 bilhão de pessoas. No entanto, somente nos 150 anos seguintes (de 1800 a 1950) chegamos à marca de 3 bilhões de pessoas e nos últimos sessenta anos mais que dobramos esta marca, atingindo mais de 7 bilhões de pessoas.

O início da agricultura e, em seguida, o início do período neolítico marcam importantes revoluções na cultura humana e mudam a forma de relação com o ambiente e de alimentar-se. E, é claro, o período do final do século XVIII marca o início da Revolução Industrial, sem dúvida um dos eventos mais importantes do ponto de vista evolutivo-cultural. Pois bem, analisemos um pouco como chegou a cultura humana até a revolução industrial.

\subsection{O evolucionismo unilinear do século XIX}

A maioria dos manuais de antropologia que trata sobre a etapa evolucionista, invariavelmente inicia os estudos a partir da obra de Lewis $\mathrm{H}$. Morgan ${ }^{120}$, Ancient Society, ou Sociedade Primitiva, na versão em português. Marvin Harris, Ángel Espina Barrio, Carmelo Lisón Tolosana, Lucy Mair, Phillip Kottak, entre outros, iniciam seus respectivos tópicos sobre o evolucionismo tendo como ponto de partida as ideias de Morgan. 
O autor começa seu livro declarando que seria lógica a evolução social, tanto no que se refere a achados e invenções como no que tange às instituições. Além disso, segundo ele, e o homem "labra su ascenso", isto é, trabalha para a ascender da selvajaria à civilização. Em seguida, propõe-nos um esquema evolutivo desde a pura subsistência até a existência da propriedade privada socialmente instituída. No caminho, desenvolvem-se os sistemas de governo, a linguagem, a família, a religião e a vida no lar.

Morgan pontua eventos específicos os quais, para ele, possibilitaram a evolução de uma etapa evolutiva para a posterior. Rechaça o autor, de pronto, as denominações sumamente utilizadas em arqueologia como idade da pedra, do bronze e do ferro alegando que as mesmas são insuficientes para denominar a evolução social.

Logo após, passa o autor a dar-nos a sua própria denominação a qual reputa correspondente às etapas de evolução. Seriam elas: selvajaria, barbárie e civilização, conforme já referido anteriormente. As duas primeiras divididas, por seu turno em estágios inferior, médio e inferior. Resumidamente, poderíamos oferecer um pequeno conceito de cada período baseando-nos nas próprias definições resumidas que aporta Morgan.

O estado inferior da selvajaria terminaria com o aprendizado do uso do fogo e o começo do uso da palavra. O período médio da selvajaria inicia com os acontecimentos que ocasionaram o final do período anterior e termina com a invenção e uso do arco e flecha. Por último, o período superior da selvajaria começa com o uso do arco e flecha e termina a partir da descoberta da olaria e do uso de utensílios de barro.

Segue-se o período de Barbárie que tem o seu período inferior iniciando-se com o uso dos utensílios de barro e final com a domesticação de animais (critério válido para o hemisfério oriental apenas) e com o cultivo do milho e outras plantas mediante o regadio e também uso da pedra e do adobe na construção de casas (critério válido para o hemisfério ocidental). O estágio médio inicia com os elementos que finalizaram o estágio anterior e termina com a descoberta do processo de fundição do ferro mineral. O estágio superior da barbárie inicia com o processo de 
fundição do ferro e vai até a invenção do alfabeto fonético e o uso da escrita. A partir do uso da escrita Morgan já estabelece a denominação de civilização na qual ainda nos encontramos.

É importante notar como o elemento da subsistência e as formas de lográ-la recebem especial atenção de Morgan para marcar a passagem de uma etapa evolutiva à outra. O que chama no decorrer de sua obra de "artes de subsistência" foram as condições que possibilitaram mudanças importantes no modo de vida humana.

No que interessa ao nosso trabalho, em especial, as ideias e conjecturas de Morgan são bastante interessantes. O conceito de mudança através de forma de subsistência que primeiro possibilitaram a vida longe de região particularmente provedora de fácil alimentação, do adensamento populacional em virtude de uma maior disponibilidade de alimentos e a consequente mudança na estrutura social para permitir tal estilo de vida.

Assim, pode-se dizer que o motor da evolução da sociedade é a necessidade de subsistência. Pode-se dizer, inclusive, que a formação dos grupos sociais que discute societas (grupo social baseado em clãs e gens com relações de caráter social e sem existência de Estado) e civitas (grupo social baseado na propriedade e no território, as relações se referem ao território e o Estado atua acima dos demais grupos) se dá principalmente pela necessidade de apoio mútuo em razão da sobrevivência.

Morgan teve o mérito de tentar organizar a evolução dos grupos e sociedades humanas e, de maneira inédita, tratar a evolução da espécie como una. Muitas críticas posteriores se fizeram ao seu trabalho e, ainda assim, a obra teve o condão de suscitar discussões e incentivar a proposição de teorias diversas. A obra de Morgan influenciou também a obra "O Capital", de Marx, provavelmente um dos textos que mais suscitou e suscita paixões e ódios na história ao lado dos textos religiosos como a bíblia e ao alcorão.

A atividade humana voltada para subsistência é imperativa e, como vimos, presente desde a aurora da espécie humana. A relação de toda a estrutura social tem a ver justamente com a necessidade de implementação de meios para a 
sobrevivência da espécie. A propriedade, o Estado, e a família monogâmica patriarcal são consequências felizes ou infelizes de tal processo evolutivo apresentado por Morgan e que serão discutidos também por Engels, como veremos a seguir.

Temos também, como um dos primeiros evolucionistas a Edward Burnett Tylor $^{121}$. As ideias de Tylor são inauguradoras da ciência antropológica inglesa tanto quanto são as de Morgan para a realidade estado-unidense. O livro de Tylor, ainda que bastante criticado depois de tantos anos, possui muitas qualidades. A sua convicção pelo desenvolvimento não ocasional de um estágio selvagem até um estágio superior é um dos pontos centrais de sua teoria.

Nesse sentido, Tylor afirma que "cuando los hombres no alcanzan a ver la línea de conexión de los hechos, se sienten inclinados a valerse de las nociones de impulsos arbitrarios, de infundados caprichos, de azar y de absurdo y de indefinida inexplicabilidad. ${ }^{122 "}$ Assim, Tylor afirma que a humanidade desenvolve uma espécie de caminho gradual desde o estado selvagem. Para isso, o homem responderia a uma necessidade natural e instintiva de criar novos métodos e meios de sobrevivência. Destarte, a evolução cultural também é, de certa forma, uma evolução nas capacidades de cognição da espécie.

Um dos pontos que podemos destacar em sua obra é a teoria da sobrevivência na cultura. Segundo ela, alguns costumes permanecem amplamente utilizados em algumas sociedades de estado "avançado" mesmo sendo oriundas de estágios anteriores menos avançados. Tais costumes muitas vezes sequer podem ser situados no tempo ou conhecida sua origem ou sua utilidade, são apenas praticados, constituindo um bastião de estágios anteriores dentro de uma nova cultura. As sobrevivências também poderiam atuar como fases de um estágio de transição entre culturas. Em nosso caso, centrando-nos em aspectos da evolução social do trabalho, o conceito de sobrevivência poderá ser útil e o retomaremos no momento oportuno.

Tylor apresenta um critério também bastante interessante ao nosso tema. Utiliza ele o critério do desenvolvimento das artes industriais que seriam a 
manufatura de instrumentos e utensílios, o manejo de metais, a agricultura, as formas de construção e etc. Tal desenvolvimento das "artes úteis" como chega a chamá-las em sua Introdução ao estudo do homem e da civilização ${ }^{123}$, é o que marca os avanços e retrocessos da civilização. Critério parecido é utilizado por Morgan e repetido por Engels ao falar sobre os finais de um estágio e início de outro a partir da invenção do arco e flecha, do uso de utensílios de barro entre outros.

Portanto, a obra de Tylor é uma das obras fundadoras da antropologia moderna. Suas ideias não são mais aplicáveis em sua maior parte, mas possibilitaram um grande avanço da ciência antropológica. Voltaremos a algumas delas em seguida.

O livro de Frazer $^{124}$ tem muitos méritos ainda que não toque, em nenhum momento, o assunto do trabalho e, para nosso estudo, revele menos relevância que outros. O texto é bastante agradável e a narrativa perpassa lugares, épocas e povos diferentes a partir de um estilo bastante particular do autor.

O livro se desenvolve a partir de duas perguntas sobre o ritual do sacerdote/rei do culto à Deusa Diana nos bosques e lago de Nemi na atual Itália (província de Roma). O ritual de troca de sacerdote apresentava duas especificidades intrigantes para Frazer. Primeiramente, qual seria o motivo de o sacerdote sucessor necessitar matar o antecessor para assumir o posto e, depois, porque antes de cometer o assassinato deveria quebrar uma rama de visco dourada que crescia na árvore sagrada do bosque.

Primeira pergunta: entre o céu e a terra. Como a vida da comunidade dependia da saúde e vitalidade da vida do rei/sacerdote. Assim, o rei deve morrer quando esteja em plena vitalidade dando forças ao seu sucessor numa continuidade de gerações em plena força, habilidade e destreza. O definhar de um rei e as agonias de uma morte natural seriam também sentidas pelo povo.

Segunda pergunta: O rei personificava a árvore em que crescia a rama dourada (visco - planta parasita - o "dourada" provavelmente se refere à rama

123 TYLOR, Edward Burnett. Antropología: introducción al estudio del hombre y de la civilización. Barcelona: Editorial Alta Fulla, 1987.

124 FRAZER, James George. La rama dorada: Magia y Religión. México, D.F.: Fondo de Cultura Economica, 1956. 
seca). Assim, arrancar e quebrar a rama dourada servia para debilitar as forças do rei e possibilitar sua morte.

A busca por essas respostas é o fio condutor da obra de Frazer. Por questões óbvias, não revelaremos aqui a resposta a tais questionamentos como forma de incentivar o leitor a empreender a descoberta juntamente com Frazer. O estilo, narrativa e fluidez de um texto denso encantaram e encantam muitos estudiosos ainda hoje. Por isso, é uma obra emblemática no campo da antropologia.

A análise que o autor faz da magia, da ciência e da religião assim como as distinções e classificações da magia simpática que divide em homeopática e contaminante. A magia simpática, segundo o autor, segue a lógica do pensamento científico. Se crê que o sistema da natureza segue uma ordem específica e que um determinado fato gera determinada consequência e assim será sempre que o mesmo fato for repetido. A crença do mago, portanto, é uma crença firme de que ao realizar determinado ato a natureza responderá sempre da mesma forma.

Frazer analisa a crença na magia como uma associação de ideias por semelhança (o que hoje chamaríamos de analogia) ou associação de ideias por contiguidade no tempo ou no espaço. Essa associação de ideias por semelhança produziria a magia homeopática ou imitativa e a associação de ideias antigas produz a magia contaminante. Esta mesma associação de ideias, quando empregada corretamente, para Frazer, produz ciência. Tais distinções são valiosas para o campo da antropologia e propiciaram diversas discussões e reanálises posteriores. Assim, a obra de Frazer, clássica para a Antropologia, termina, após mais de setecentas páginas com as respostas sobre o sacerdócio de Diana em Nemi.

Spencer, ao lado de Morgan, é um dos precursores da ciência antropológica. Escreveu sobre a evolução, tanto biológica, quanto cultural, antes de Darwin. Sua primeira obra: "O progresso, sua lei e sua causa" ${ }^{125}$ traz uma perspectiva evolucionista diferente daquela apontada por Darwin dois anos depois, ainda que Spencer já tenha referido sobre a sobrevivência dos mais dotados. A obra utiliza um método comparativo entre as estruturas do Universo e dos seres vivos para explicar o progresso social. Também se lhe pode apontar como o precursor das palavras 
estrutura, função e sistema com viés antropológico, termos até hoje discutidos em muitas obras posteriores.

No seu livro, Spencer procura primeiramente definir o que é o progresso. Para ele a concepção de progresso não pode ser analisada apenas sob o prisma da felicidade ou da facilitação da vida humana na Terra, esta não seria a definição mesma do progresso e sim suas consequências. Spencer pontua que o progresso atende a uma lei natural, derivada das observações biológicas em organismos vivos, trata-se da passagem de algo homogêneo para algo heterogêneo. Esta é a lei fundamental do progresso, seja ele orgânico, seja cultural ou seja social.

Justificando sua teoria, seguem-se os capítulos da obra, no progresso da matéria dá o exemplo da geologia, citando o próprio planeta Terra, homogêneo em seu início como uma massa incandescente e progressivamente mais heterogêneo, com a solidificação de algumas camadas e a liquidificação de outras, até atingir o estado atual. O mesmo raciocínio se aplica aos animais, os quais seriam de uma heterogeneidade constante, ainda que o autor se atenha somente ao grupo dos mamíferos já que, por exemplo, no caso dos répteis, quiçá não seria possível comprovar sua hipótese. No caso dos humanos, argumenta ser inegável a grande heterogeneidade de fenótipos oriundos de um tronco comum.

Chega um momento em que Spencer trata do progresso na vida em sociedade. Este aspecto, por óbvio, nos interessa especialmente. A lei do progresso segue, no tocante à sociedade a mesma máxima, passa de composições mais homogêneas para outras mais homogêneas. A primeira divisão que aponta é a cisão entre governantes e governados, passa-se de uma situação de igualdade entre os membros dos grupos (sem embargo da divisão existente entre os sexos), para uma divisão entre aqueles que exercem o poder civil e religioso. Também, destaca, em um primeiro momento, não há divisão entre o poder secular e o poder religioso, concentrando-se ambos na mesma pessoa. No seio de cada um desses poderes, civil e religioso, também ocorrem subdivisões posteriores, com a fragmentação e escalonamento do poder. Tal é o silogismo do progresso da classe governante.

No caso dos governados, já em tempos de revolução industrial, fala-se em massa de trabalhadores e na divisão do trabalho vigente na época. Parece claro, 
aponta, que em um primeiro momento cada homem executava todos os trabalhos que necessitava para sobreviver, cuidava da própria alimentação, fabricava armas, construía ferramentas, construía sua moradia entre outras atividades. Pela lei já enunciada, o progresso traz a heterogeneidade do trabalho onde cada homem passa a executar um trabalho específico, não mais para si, mas para os outros. Criase assim, uma rede imbricada de relações entre produtores, compradores, fornecedores e vendedores. Spencer aponta como causa do progresso a multiplicidade de resultados que decorre de uma força aplicada, de uma ação. Assim, uma causa única, gera uma infinidade de efeitos causadores da futura passagem do homogêneo para o heterogêneo.

Seguindo a linha de raciocínio acima exposta, temos que a divisão do trabalho, por exemplo, se dá a partir da demonstração, por um indivíduo, de especial aptidão para a realização de determinada tarefa. Assim, aquele indivíduo passa a dedicar-se exclusivamente a tal tarefa e deve, portanto, ser servido pelos demais das diferentes coisas que necessita para sobreviver. Enquanto um se aperfeiçoa cada vez mais na execução de algum trabalho, os outros, via de consequência, acabam por perder as aptidões para o exercício daquela tarefa, necessitando, assim, produzir alguma outra espécie de utilidade para comunidade. Inaugura-se assim, para Spencer, o período de necessidade de trocas, precursor da atual organização industrial. Estaria explicada assim, a origem da divisão do trabalho que inegavelmente aumentou em complexidade com a evolução da vida em sociedade. O simples fato do fim da vida nômade, do estabelecimento de grupos em determinados locais tende a aumentar a demanda e perpetuar formas de fabricação de produtos.

A teoria de Spencer, simples em princípio, já que se cinge à premissa de o progresso se rege pela lei universal da passagem de uma condição homogênea para condições progressivamente mais heterogêneas. O autor não explica o caso das modernas religiões como o islamismo, o catolicismo, o judaísmo, todas regiões monoteístas que foram precedidas por religiões politeístas. Fala-se em aumento da complexidade do poder religioso através das estruturas de controle e administração e os diferentes níveis de sacerdotes. No entanto, do ponto de vista da doutrina 
religiosa, é impossível comentar, por exemplo, que houve mudança de uma estrutura mais homogênea para outra mais heterogênea.

Por outro lado, poder-se-ia dizer que as religiões citadas viveram justamente o processo contrário, condensaram, em um único Deus, as adorações antes devidas a muitos deuses de igual ou muito parecido status. Ainda que as religiões tenham mantido uma estrutura polissêmica, como no caso do catolicismo com os santos, virgens, anjos e arcanjos, o Deus considerado verdadeiro é apenas um.

No caso da divisão do trabalho tampouco se pode dizer que Spencer tenha acertado em cheio. A hipótese da divisão do trabalho entre mais pessoas não significa exatamente que as funções antes não eram exercidas, no entanto, pela mesma pessoa. A complexidade das teias comerciais, sem dúvida, aumenta, mas as funções executadas pelo homem consideradas individualmente se tornaram e se tornam cada vez mais simples. Além disso, a fabricação de qualquer material se tornou um processo dividido em muitas etapas, cada uma delas extremamente especializada e homogênea quando considerada em si mesma.

A fabricação de móvel para a casa, antes realizada inteiramente pelo carpinteiro que em certas épocas era também responsável pela extração da madeira agora se tornou um processo em que, quiçá, o trabalhador final só tenha o trabalho de montar e encaixar as peças do móvel, cada uma delas produzidas por uma indústria diferente. Este último trabalho é bastante mais homogêneo quando considerado em si mesmo que o anterior, com diversos processos e conhecimentos diferentes.

Desta feita, a teoria de Spencer, mesmo com muitas inconsistências e incongruências, foi um assoalho sobre o qual pisaram muitos antropólogos posteriores. A discussão de suas ideias possibilitou grandes avanços para a teoria antropológica e sociológica.

A obra de Maine ${ }^{126}$ pode ser apontada como uma das primeiras que faz a necessária correspondência e aproximação entre o direito e a antropologia. O livro começa apontando questões sobre o direito na Índia, uma questão bastante 
presente em razão da colonização britânica na região. Na Índia, até os dias atuais, as regras religiosas confundem-se com as regras de direito e são um campo especialmente fértil para estudos no campo jurídico/sociocultural. Aliás, o autor aponta um período histórico de necessária confusão entre o jurista e o clérigo, onde os segundos exerceram enorme influência sobre as regras de direito.

No mesmo sentido é a obra de Fustel de Coulanges ${ }^{127}$ que bem retrata as religiões grega e romana da antiguidade e suas influências para o estabelecimento de costumes até hoje existentes. De fato, ambos os autores, Maine e Coulanges, colocam em posição de destaque, para o desenvolvimento do direito, a questão do culto aos antepassados ou conforme o caso, da religião familiar. Tal questão é fundamental, seja na antiga tradição romana, seja na indiana, para definir os contornos do direito de sucessão, do direito de família e também do direito de propriedade.

A família, sob a autoridade suprema do pai (pater familiae), é a unidade básica que estrutura a sociedade. O indivíduo, fora da família, não representa quase nada para a organização político-social da época.

A religião familiar é descrita como o culto aos antepassados comuns. O culto é devido por toda a família sendo que o pai é o chefe do culto, só ele pode recitar certas orações, somente ele conhece todo o ritual e é o único que tem a permissão de ensiná-lo aos seus sucessores. O culto aos antepassados é o fator que une a família, um grupo de pessoas que professa o mesmo culto.

Os irmãos, neste contexto, são parentes, pois praticam o mesmo culto, adorando os mesmos antepassados masculinos. A esposa, quando casada, entra para a religião do marido e retira-se do culto de sua família de nascimento. O culto dos antepassados, seja em Roma ou na Índia, é responsável pela criação e desenvolvimento de várias regras de direito sucessório e familiar assim como ficções jurídicas como a adoção.

Maine destaca que o código de Visnú, na Índia, detalha perfeitamente os ritos e sacrifícios devidos pelos descendentes no culto aos seus antepassados. Segundo 
Maine ${ }^{128}$ "un hombre puede obtener perdón por haber descuidado todos sus deberes sociales, pero estará por siempre maldito si deja de celebrar las exequias y de presentar las ofrendas que son debidas a sus padres". Tal afirmação deixa bem clara a importância do culto aos antepassados para os indianos.

Está clara a importância do sistema de culto para o direito até os dias de hoje. Tanto Maine quanto Coulanges o reconhecem. Também parece bastante certo que a sacralidade do pai como futura divindade a ser adorada e também como sacerdote supremo do culto familiar tenha aumentado o poder patriarcal até um extremo inconcebível mesmo para a época e incompreensível nos dias de hoje. Do culto familiar surgem outras muitas consequências interessantes, as quais ainda hoje experimentamos. As palavras pai e padre em muitos idiomas são exatamente as mesmas, para designar duas coisas diferentes. No italiano, padre (progenitor) e padre (sacerdote da igreja católica apostólica romana), igualmente no espanhol padre para as duas designações e também no inglês (father). Não é pura coincidência. O pai exercia as duas funções e arriscamo-nos a afirmar que a de sacerdote era bastante proeminente.

Outras questões como a palavra que designa a casa, o domicílio da família, era o nome pelo qual se denominavam os espíritos dos antepassados lares em Roma ou manes na Índia. Também o costume de pegar a noiva nos braços ao entrar no recinto nupcial tem a ver com a complementação do ritual de passagem da esposa para a religião do marido sem a qual esta última não poderia cruzar/tocar o umbral da casa deste por ser sagrado e sob pena de profanar o culto familiar. Enfim, a questão do culto dos antepassados traz diversas e importantes questões interessantes para a antropologia do direito e para esclarecer alguns costumes em geral.

Maine tenta, através da observação possível dos costumes antigos, compor uma teoria para o desenvolvimento da sociedade em geral. Segundo ele, a família patriarcal, governada pelo ascendente masculino mais velho é o antecedente mais próximo da família tal qual conhecemos hoje. Em tal ponto, coincidem, para Maine, os direitos indiano, eslavo, grego e romano. Aliás, faz-se a ressalva, como na filologia que supõe a descendência de uma mesma língua comum para várias 
línguas, sem, no entanto, conhecer exatamente aquela língua antecedente. $O$ mesmo poder-se-ia dizer dos modelos familiares das sociedades e povos já citados.

É importante destacar as ideias de outros autores, como, por exemplo, Lewis Henry Morgan, sobre quem já comentamos e que, ao contrário de Maine, atribui à sociedade matriarcal a condição de precedente do modelo atual. Em nosso ver, as teorias não são exatamente incompatíveis. Morgan se refere a tempos bastante anteriores ao que pudemos conhecer através das sociedades indiana e romana mais atuais. Desta feita, pode ser que apenas os autores se refiram a períodos diferentes da história. Maine resolve a situação entendendo que ambas as teorias, quando tomadas com pretensões de universalidade, apresentam sérios problemas e grandes dificuldades. É bastante interessante a discussão proposta por Maine na discussão das teorias de Mac Lennan e de Morgan.

Maine, contudo, traz diversas visões interessantes para o campo do direito, extraídas da observação da evolução social. Declara que a fonte de todas as novas (na segunda metade do século XIX) formas de parentesco é o poder. Assim, foi o poder que criou o vínculo que hoje conhecemos como nacionalidade, permitindo distinguir um conjunto de nacionais de outro.

Outra das concepções importantes e digna de destaque relaciona-se também com o parentesco e com os Radjputas ${ }^{129}$ da Índia. Nesta sociedade, existem múltiplos círculos de afinidade e sua reconstrução, dá a ideia de famílias geradas a partir de um mesmo ascendente comum. Reputa-se um dos enigmas que se impõe sobre a mente humana responder qual o motivo que leva à simpatia e relações com determinados outros humanos, mas não com todos. A resposta para essa pergunta Maine resume como o parentesco. Para os Radjputas, a associação, de igual para igual, com alguém com quem não se possui laços de fidelidade (nas diversas acepções e formas que o termo pode assumir) é antinatural e inconcebível.

Um trecho da obra de Maine, o qual pretendemos retomar futuramente, pois tem nítida relação como nosso tema de estudo, trata sobre o domínio e resguardo de determinada parcela de terra para uso exclusivo de um grupo autorizado. Isto é,

129 Una etnia indiana que, segundo Maine, após um período de conquistas e forte militarismo, foi obrigada, pela invasão muçulmana, a refugiar-se na fortaleza natural (um imenso platô onde hoje se encontra a região indiana do Rajasthan) chamada Radjputana onde puderam resistir longo tempo à submeter-se aos mongóis. 
num primeiro momento, os grupos humanos reservavam para si uma área de terra da qual retiravam seu sustento através, nos tempos mais remotos, da caça, pesca e recoleção. Em um momento posterior, talvez reservassem a terra para o pasto dos animais, o certo é que tal reserva e defesa se davam por um instinto econômico e de sobrevivência básicos.

Uma das principais contribuições de Maine foi diferenciar as sociedades em razão da proeminência do parentesco como sistema de posições sociais e de status sociais. Segundo o autor, nas sociedades onde o parentesco é o sistema primordial, as relações são regidas pelo status fornecido pelo parentesco. Naquelas sociedades onde o parentesco perde importância as posições e relações sociais ocorrem pelos contratos celebrados. Aliás, hoje em dia, o contrato de trabalho, e, de maneira mais ampla, o trabalho executado, é um dos principais meios de saber que posição social cada um ocupa.

Está clara a importância da obra de Maine ao analisar as questões sobre as estruturas sociais e jurídicas antigas. Além disso, Maine foi um daqueles, juntamente com Morgan, Tylor e MacLennan, que influenciou as teorias de Marx, as quais revolucionaram o papel do trabalho e dos trabalhadores na sociedade. ${ }^{130}$

\subsection{Marxismo, antropologia e trabalho}

\subsubsection{Hegel, o precursor da contradições do mundo do trabalho}

Georg Wilhelm Friedrich Hegel foi, com toda a certeza um dos filósofos com mais influência para uma percepção global da filosofia da história com pretensões universais. Hegel aproveitou o novo momento criado pela recente e atuante revolução industrial (e também pela revolução francesa) para estabelecer explicações sobre como haveria chegado a humanidade ao estágio no qual se encontrava.

Hegel tentou estabelecer uma lógica evolutiva, leis da evolução social, as quais seriam inexoráveis e obrigatórias. Tais leis não dependeriam dos indivíduos que, aliás, seriam apenas objetos do espírito. 
Outra das aportações de Hegel ${ }^{131}$ é a noção de fim da história. Aqui o fim assume o sentido de finalidade e não de final, como soe acontecer em teogonias ou cosmogonias, as quais sempre trazem um momento de "juízo final". Hegel declara, que o fim da história seria a plena consciência sobre si mesmo e a liberdade. No mesmo livro, Hegel concebe a história como um processo racional e dependente da política econômica onde o espírito se autorrealiza a partir da superação de sua alienação. Portanto, o fim da história seria a busca de um fim absoluto e não de questões privadas e subjetivas ${ }^{132}$.

Além disso, o espírito de que devemos nos ocupar na história, para Hegel, é o espírito do povo, ou seja, o espírito de um indivíduo em geral. Os povos seriam o conceito que o espírito tem de si mesmo. Essa consciência universal contém todos os fins e interesses de determinado povo atuando como uma atmosfera que pesa sobre os indivíduos e que atua sobre ele. Assim, a história universal seria, para Hegel, a exposição de como o espírito obra para chegar a saber o que é em si mesmo $^{133}$. Portanto o fim da história ou a finalidade do mundo, seria a plena consciência de sua liberdade pelo espírito, de modo a realizar tal liberdade.

O fim último, a natureza, aquilo que o espírito é em si mesmo é algo universal e abstrato, segundo o próprio Hege ${ }^{134}$. Para passar da interioridade à existência é necessário um segundo momento: o momento da atuação, da realização, da atividade do homem no mundo e sobre ele. Para a plena liberdade, seria necessário que o homem encontrasse sua própria satisfação em uma atividade ou trabalho. Então, diz Hegel se "los hombres exigen que, si han de laborar por una causa, esta se les agrade; quieren estar en ella con su opinión y convicción de la bondad de la cosa, de su legitimidad, de su utilidad, de la ventaja que representa para ellos... ${ }^{135}$..

Hegel também afirma que a atividade é sempre individual, cada um é o que é na ação. Sem embargo, a partir da ação individual é que se realiza o universal. Essa

131 HEGEL, Georg Wilhelm Friedrich. Lecciones sobre la filosofía de la historia universal. Madrid: Alianza, 1982. p. $59-63$

132 SANMARTÍN BARROS, Israel. EI fin de la historia en Hegel y Marx. in: História da Historiografia, Ouro Preto, $\mathrm{n}^{\mathrm{o}} 12$, ago/2013. p. 100-118

133 HEGEL, 1982. p. 67

134 HEGEL, 1982.

135 HEGEL, 1982. p. 81 
ação individual, a atividade produtora do homem, cobrará bastante importância para o desenvolvimento de uma cultura do trabalho.

Outra das interessantes contribuições de Hegel é o conceito de história lógica, onde cabe aos indivíduos e sociedades somente executar os desígnios de uma razão lógica que guiaria a história. Ou seja, a evolução teria um sentido determinado, o qual não poderia ser mudado pelos homens. A simbiose entre o contingente e o empírico (aquilo que é realmente histórico) e a racionalidade pode ser interpretada como uma das visões hegelianas. Prescindir de fatos aleatórios ou fortuitos e elevar os dogmas da razão para desvelar leis imutáveis da evolução histórica pode ser uma das consequências da primazia da razão sobre os fatos ${ }^{136}$.

Se a história universal é regida por leis obrigatórias, rígidas e imutáveis, pouco espaço sobra para o desenvolvimento e manifestação das decisões humanas, retirando a culpa ou responsabilidade pelos acontecimentos históricos. Desta forma, é fácil justificar qualquer momento histórico a partir das leis racionais que regem a evolução. Sob este teto, qualquer regime, medida ou tragédia é encarada como inevitável e justificável. Sem travas críticas, éticas e morais, o inevitável pode acontecer das mais diversas formas, justificando absurdos e relacionando o real com o lógico-histórico. Desta forma, é possível avalizar qualquer regime político que seria, conveniente segundo a evolução histórica ${ }^{137}$.

Outra obra de Hegel, talvez a mais aclamada e controvertida, produz até hoje releituras e interpretações, A Fenomenologia do Espírito ${ }^{138}$, estabelece as bases da definição de autoconsciência em oposição e em jogo com a vida. Qual delas determinaria a outra, vida e autoconsciência, é uma das questões principais da obra de Hegel. Essa descoberta da autoconsciência em que o indivíduo torna-se consciente de si mesmo, é parte de um processo. A descoberta da autoconsciência exige um caminho a ser percorrido pelo individuo e é somente a partir desta descoberta que é possível a emancipação do ser humano.

Para o mundo do trabalho e também para a política, as ideias de Hegel forneceram um amplo arcabouço de argumentos que, aliados à revolução francesa 
(definida por Hegel como a reconciliação do divino com o mundo ${ }^{139}$ ) e revolução industrial, começaram a pautar o ideário político-ideológico de muitos, aí incluídos Marx e Engels. A dialética entre mestre e escravo, ou dominação e escravidão é o ponto mais comentado da obra e vem precedida da necessária distinção entre conhecer e autoconhecer-se ou entre um ser consciente e autoconsciente.

Para Hegel a "autoconciencia sólo alcanza su satisfacción en una autoconciencia distinta, en otra autoconciencia ${ }^{140 " . ~ E n t a ̃ o, ~ s e ~ p o d e ~ c o n c l u i r ~ q u e ~ a ~}$ verdade sobre a autoconsciência seria a autoconsciência da autoconsciência, uma condição necessária para a existência da autoconsciência ${ }^{141}$. Isto é, a autoconsciência não pode ser alcançada antes de que o indivíduo conheça essa autoconsciência.

A distinção, portanto, entre vida e autoconsciência fica mais clara quando utilizamos um objeto do conhecimento para mediar a relação. Um objeto de desejo, uma refeição que desejemos comer é objeto da autoconsciência enquanto desejo de viver, objeto de desejo, mas não autoconsciência da autoconsciência, ou seja, autoconhecimento. A vida, não é em si mesma, portanto, suficiente para a autoconsciência enquanto autoconhecimento ${ }^{142}$.

A diferença entre vida e autoconsciência é bastante útil para a antropologia pois afasta do ser humano apenas seu caráter biológico, carnal, de instintos e desejos. A autoconsciência produz algo sumamente humano, diferente da vida biológica mesma, que é a consciência de si mesmo.

As contribuições de Hegel foram, sem dúvida, bastante novas no campo da filosofia e viriam, no futuro, a influenciar a antropologia de várias formas. Hegel admite um dilema entre determinismo e liberdade. Por um lado temos as leis naturais, inexoráveis e passíveis de aferição através da lógica e, de outro, a liberdade da autoconsciência alcançada. Para ele, este conflito traz em si mesmo as

139 HEGEL, 1982.

140 HEGEL, 2006. p. 285

141 WARMINSKI, Andrzej. Hegel/Marx: Consciousness and life. in: Yale French Studies, $n^{\circ}$ 88, New Haven, 1995. pp. 118-141

142 WARMINSKI, 1995. 
condições de sua superação e é na dicotomia que se encontram as relações de oposição $^{143}$.

Tais aportes são extremamente válidas do ponto de vista das identidades. A autoconsciência é definida/alcançada através das relações de oposição entre a autoconsciência e aquilo que não é autoconsciência. O conhecimento dessa separação, daquilo que não sou, ajuda a definir aquilo que sou.

Hegel sem dúvida foi um dos principais defensores da lógica dialética em oposição à lógica formal. Esta última, muito bem representada por Aristóteles está fundada na identidade e não contradição. Sem embargo, na lógica dialética, a contradição é vista como parte do processo de pensamento. Hegel busca confirmar a existência de uma razão efetiva no mundo. Ser e pensamento não são, para Hegel, necessariamente opostos. No pensamento o objeto encontra-se de maneira concreta, unem-se assim, espírito objetivo e subjetivo para sintetizar o espírito absoluto de Hegel. E a filosofia, assim, adquire o caráter de ciência do universal, do absoluto mostrada aos homens através da consciência. O absoluto seria uma forma de determinação da história, efetivada através do Estado. Este seria o papel da filosofia, de identidade cultural de caráter nacional, no caso, principalmente o espírito germânico o qual procura autoconhecer-se ${ }^{144}$. Nesse sentido, o próprio Hegel ${ }^{145}$, faz algumas considerações sobre essa dialética:

La voluntad es la unidad de estos dos momentos, la particularidad reflejada en sí misma y por ello reconducida a la universalidad: la individualidad. Ella es la autodeterminación del yo de ponerse en lo uno como lo negativo de sí mismo, es decir, de ponerse como determinado, limitado, y al mismo tempo permanecer consigo, o sea, en su identidad consigo y universalidad, y, en la determinación, unirse sólo consigo mismo.

Das ideias de Hegel, podem-se extrair muitas conclusões para o mundo do direito e para o mundo do trabalho. Cabe destacar que os conflitos laborais e as contradições entre trabalhadores e empregadores eram ainda bastante incipientes quando escrevia Hegel. Isso não impediu que sua filosofia fosse aplicada aos

143 NUNES DA COSTA, Marta. O que Marx nos pode ensinar sobre a nova "classe perigosa" - crítica, neoliberalismo e o futuro da emancipação humana. in: Revista Novos Estudos, nº 101, São Paulo, mar/2015, pp. 97-114.

144 TROTTA, Wellington. O pensamento político de Hegel à luz de sua filosofia do direito. in: Revista de Sociologia e Política, v. 17, $\mathrm{n}^{\circ}$ 32, Curitiba, fev/2009, pp. 9-31

145 HEGEL, Georg Wilhelm Friedrich. Principios de la Filosofia del Derecho. Buenos Aires: Sudamericana, 1975. 
acontecimentos e influenciasse, até hoje, as dinâmicas sociais através das apropriações de suas ideias feitas por outros filósofos, juristas e cientistas sociais.

O autor Eduardo Vazquéz, em sua obra Dialectica y Derecho en Hegel ${ }^{146}$, faz diversas considerações e aproximações entre o pensamento de Hegel e o direito. Afirma o autor que Marx, ao expor seu método, deixa clara sua dívida com Hegel. Consiste tal método em elevar-se do abstrato ao concreto, de momentos isolados e abstraídos, citando como exemplo o trabalho, divisão do trabalho, necessidade, valor de troca, por exemplo, até momentos mais concretos expressados pelo Estado, trocas entre nações e mercado mundial.

Para Vásquez, a autoconsciência é o elemento que estabelece a igualdade entre os homens. A autoconsciência abstrata estabelece a igualdade abstrata entre os homens. A igualdade verdadeira só existiria no plano abstrato das autoconsciências e da razão universal comum.

O autor também busca interpretar aspectos da filosofia do direito de Hegel, estes fundamentais à noção e natureza jurídica dos modernos contratos de trabalho. Tal questão é sobre o caráter das aptidões pessoais, espirituais, conhecimentos, talentos de cada pessoa que, segundo ele, não podem ser objetos de contrato. Os objetos internos (assim chamados pelo autor) só se coisificam a partir da manifestação externa de tais habilidades e aptidões e essa manifestação externa sim que poderia objeto de contrato. Nisso está a natureza do contrato de trabalho que inicialmente foi concebido como locação da pessoa pelo direito romano e, atualmente, está sentada a separação da pessoa e da personalidade do contrato de trabalho.

Vásquez também menciona aspectos interessantes sobre o direito à propriedade e as desigualdades sociais. Para ele, interpretando Hegel, o direito só existe em uma sociedade onde a pessoa possa ser proprietária, o desrespeito à propriedade é um estado natural de violência e de não-direito. A divisão do trabalho e a divisão de indivíduos que realizam diversos tipos de atividades laborais provoca a desigualdade entre os homens e a desigualdade de capital. A desigualdade é, portanto, elemento necessário da sociedade civil. A única igualdade possível é, 
portanto, manifestada pela igualdade ao direito de propriedade, uma igualdade abstrata produzida pela abstração de todas as desigualdades que imperam.

Tal questão segue discutida pelo autor mais adiante, com o contraponto necessário sobre a impossibilidade de que os homens sejam iguais na lei em aspectos nos quais são desiguais fora da lei (quer dizer, fora da abstração do mundo do direito). O autor cita como exemplo que a todos pode ser reconhecido igual direito a escrever um livro ou frequentar hotéis luxuosos, no entanto, tal direito abstrato esbarraria na falta de meios para concretizar a vontade. É importante destacar a centralidade da oposição entre igualdade e propriedade privada destacada por Vásquez na obra de Hegel. A igualdade ou autoconsciência geral seria o "princípio racional criador do direito ${ }^{147 "}$ e também o fundamento da propriedade privada. Sem embargo, a mesma propriedade privada é a criadora de desigualdades e aqui está implícita a negação da igualdade pela propriedade.

A questão sobre a existência de uma razão universal que de alguma forma rege o mundo também se aplica, em menor escala às razões de cada povo, conduzem a uma força popular interior e silenciosa a condicionar o direito e as relações de cada povo. O direito de cada povo, seria assim, construído segundo sua razão histórica ${ }^{148}$.

A dialética, a visão do conflito como salutar e profícuo para a evolução e o desenvolvimento encontrariam, também, eco posterior nas ideias de Marx. No caso da classe obreira, existem muitas contradições, sobretudo na ação sindical, que são apoiadas, de alguma maneira na dialética hegeliana. A identidade profissional, ao definir-se precisa do outro, de outra autoconsciência para chegar ao núcleo essencial do que seria uma determinada profissão ou uma consciência obreira/profissional motora da ação sindical.

Outra das evidentes contradições é a relação de oposição/independência entre patrões e empregados. Ambos necessitam um ao outro e contribuem para o desvelar mútuo das autoconsciências. No entanto, os interesses são nitidamente contrapostos, pois, em teoria, quanto menos ganhar o empregado, mais ganhará o patrão embora este último necessite dos primeiros para funcionar e para definir-se 
como tal. O contrário também é válido no caso dos trabalhadores que dependem do patrão para definir-se como trabalhadores e também o necessitam enquanto objeto de interesse oposto e para enquanto provedor do posto de trabalho.

Ademais, os trabalhadores enfrentam ainda outro problema, outra contradição no seio da ação coletiva. Os companheiros de profissão que, segundo a lógica hegeliana aplicada a mesma escala, compartilham de uma razão ou espírito comum que os provê com uma similar visão do mundo. Os companheiros, necessários para oposição ao patrão são também concorrentes no mercado de trabalho. Assim, ao mesmo tempo em que se quer eliminar ou prejudicar o objeto da rivalidade, também se necessita do mesmo, por vários motivos e de várias formas.

Curiosamente, as noções de espírito do povo e de uma razão histórica determinante das relações sociais e também do direito (fundamentos da soberania estatal) são utilizados justamente para dificultar a circulação da classe obreira. A consciência de distintos povos serve de fundamento para as fronteiras estatais e justifica a tão difícil circulação de trabalhadores pelo mundo. Do contrário, existe uma livre circulação do capital financeiro o que ajuda na diminuição dos salários, na guerra das moedas e na busca por locais com mão de obra menos organizada e menos custosa.

Talvez uma das melhores interpretações sobre a fenomenologia do espírito tenha sido a do Professor Ramón Valls Plana ${ }^{149}$, bastante recomendada e que se revelou uma obra acessível e valente, no sentido de possibilitar uma melhor compreensão do texto de Hegel. É verdade que o mencionado livro apresenta a opinião e o entendimento do autor sobre a obra de Hegel e, nem por isso perde importância ou valor, já que a argumentação é sólida e bem fundamentada.

Logo na introdução, o autor deixa transparecer a importância que reputa à obra de Hegel, principalmente como "gran antepasado" dos estudos marxistas. O autor refere ter querido Marx utilizar a linha de interpretação da dialética da existência humana sobre a terra proposta por Hegel. A conexão entre a fenomenologia e o marxismo é inegável e o autor bem pontua essa 
interdependência em uma frase que reproduzimos, por entender ser uma ótima reflexão:

Se puede incluso decir que en la fenomenología late un cierto espíritu marxista avant la lettre: sentido dramático de la historia y de su movimiento ascensional, el intento de construir una escatología inmanente y el deseo apasionado de, por tanto, de trasplantar el cielo a la tierra mediante la comunidad universal. ${ }^{150}$

Valls Plana também faz algumas considerações sobre a obra de Hegel em sua introdução. Por um lado, entende que Hegel não pretende diluir o singular no universal, mas nem por isso pretende deixá-lo isolado, postulando pera necessária compreensão do singular (indivíduo) inserido na sua comunidade. Ainda, o caminho ascendente da consciência não seria apenas um caminho individual mesmo que trilhado pelo indivíduo. Este último, o percorrê-lo, incorporaria a história coletiva.

Como não poderia ser diferente, Valls Plana também faz importantes considerações sobre o capítulo quarto da fenomenologia, geralmente o capítulo mais discutido e comentado da obra. Para nosso trabalho, que recorre aspectos sobre a evolução das pautas de trabalho humano, formação dos ofícios e a visão de mundo gerada a partir da realização de um mesmo tipo de trabalho.

Para Valls Plana, o reconhecimento mútuo é o que relaciona as consciências entre si e possibilita a unidade do espírito. Cada um busca superar-se consigo mesmo superando ao outro, busca-se no outro a restituição da própria consciência que se encontra nele. Esse reconhecimento mútuo assegura a liberdade e independência do espírito no seio da comunidade espiritual. Há, no entanto, imperfeições inerentes à dialética do senhor e do servo. O senhor tem subordinados à si o servo e a natureza (na forma do objeto manipulado/trabalhado pelo servo) e, por isso, se realiza em grau limitado. Já o servo não consegue se realizar perfeitamente como homem, pois não encontra o reconhecimento do senhor como tal. A coisa (objeto) não pertence ao servo, que a transfere ao senhor depois de manipulada (humanizada). Já para o senhor a coisa é somente objeto de gozo. Por isso, o senhor necessita do servo para se reconhecer como homem e assim, inverter-se-ia a ordem e o senhor ficaria submetido ao servo já que dependente 
deste para alcançar o autoreconhecimento como homem. Se um dos aspectos fundamentais da humanidade é vencer o mundo e transformá-lo ao senhor faltaria justamente esta superação do mundo que lhe é entregue através do servo. A subjetividade somente alcançaria sua plenitude ao ser formulada e expressada através do trabalho.

A profundidade e grandeza da concepção de trabalho proposta por Hegel põe de relevo, segundo Valls Plana, o caráter espiritual e humano da ação de transformar a natureza. Certamente, as considerações de Hegel sobre o trabalho informa toda uma plêiade de teorias posteriores e que chegam até os dias atuais, destacando o trabalho como um elemento de dignidade e não somente como um elemento de sobrevivência.

A obra de Hegel é pródiga em ensinamentos e sugestões de tal natureza, que nos mostram muitas aplicações atuais de suas teorias. Embora a obra de Hegel tenha sido inovadora para a época, talvez a razão maior de seu reconhecimento seja haver despertado a crítica e o respeito de Marx, um dos autores que mais causou e causa polêmicas, ódios e paixões, como se disse.

\subsubsection{A Antropologia Marxista}

Não por acaso, deixamos de referir as obras de Karl Marx e Friedrich Engels entre os evolucionistas. De fato, as obras de Marx e Engels podem ser apontadas como aquelas que mais influenciaram os trabalhadores mundiais e que seguem, até os dias de hoje, provocando as emoções mais diversas e os mais acirrados enfrentamentos.

Ambos tiveram também suas ideias encampadas por uma multidão de outros autores os quais não poderemos referir a todos, mas trataremos de enfrentar os principais e discutir as teorias centrais do marxismo. Trataremos aqui principalmente de duas obras, que acabaram sentando as bases de todo o pensamento Marxista posterior e por apropriar-se das ideias do evolucionismo de Morgan para adaptá-lo ao materialismo histórico. 
A primeira obra de que trataremos é "Formaciones económicas precapitalistas $^{151 "}$ " na qual Marx realiza um esboço da evolução da humanidade até a entrada na era capitalista, detalhando as condições que tornaram possível as formações capitalistas originárias. O texto faz parte de um manuscrito de Marx, preparatório à redação da Contribuição à Crítica da Economia Política e do Capital. O texto não foi publicado durante a vida de Marx e esta seção ganhou o apelido de Formen devido ao título em alemão "Formen die der kapitalistischen produktion vorhergehen". Em nossa opinião, é o texto mais antropológico de Marx e onde restam claras as influências recebidas dos evolucionistas do século XIX, sobretudo Spencer.

Marx parte do pressuposto de que o trabalho assalariado e livre é um dos requisitos do sistema de produção capitalista. Para isso, seria necessário separar o trabalhador de seu local de trabalho natural, a terra. A propriedade da terra, e, portanto, dos meios materiais para o trabalho pode ser individual ou comunitária e, em ambos casos, o trabalhador pode manter uma relação objetiva com sua existência, independentemente do trabalho. O objetivo do trabalho nestes casos não é criar valor e sim propiciar a subsistência do indivíduo, de sua entidade familiar ou mesmo da comunidade. Nestes casos, pode até existir um sobretrabalho com objetivo de criar excedentes que são destinados à trocas. Essas trocas fazem parte do sistema social e auxiliam na manutenção da comunidade enquanto grupo como se poderá ver claramente em Malinoswski.

Segundo Marx, esse trabalhador despido (no sentido de propriedades) é um produto histórico da humanidade. Passa-se então, a discutir as diferentes formas de relação com a terra durante os séculos. A primeira forma analisada por Marx são as comunidades nômades. Neste caso, a comunidade tribal é o requisito básico para uma apropriação temporária e utilização do solo. A terra, nestes casos, é tratada como propriedade comunitária e o indivíduo somente adquire direitos a ela enquanto pertencente àquela determinada comunidade. Os excedentes do trabalho produzidos, em tais casos, pertencem à unidade suprema que é a comunidade.

A segunda das formas analisadas por Marx também coloca a comunidade como principal fundamento. A principal distinção é o caráter sedentário onde a aldeia 
transforma-se no centro da comunidade e a terra como elemento secundário, meio de sobrevivência e trabalho. A partir de então a guerra e a conquista tornam-se a grande atividade comunitária ao redor da qual organiza-se a comunidade.

Logo após, paulatinamente a propriedade do indivíduo deixa de ganhar valor somente através do trabalho em comum. A comunidade passa a adquirir o status de garantidora das propriedades individuais face às ameaças externas. A comunidade passa a ser o vínculo entre esses indivíduos iguais e livres, garantindo-os contra o exterior. Um dos requisitos para que este tipo de comunidade perdure é essa igualdade entre indivíduos livres e autossuficientes. Neste tipo de comunidade, o excedente de produção segue pertencendo à comunidade sob a forma de trabalho guerreiro. A propriedade dos produtos do próprio trabalho é consequência da propriedade dos meios de trabalho (terra e ferramental) garantidos pela existência da comunidade.

A terceira forma de propriedade referida por Marx é a forma Germânica. Neste tipo de organização a propriedade é sempre coletiva e os indivíduos são apenas possuidores de uma fração da propriedade enquanto membros ativos das comunidades.

Já com relação à antiguidade clássica, Marx aponta que a agricultura era altamente respeitada enquanto o comércio e ofícios urbanos eram pouco apreciados. $\mathrm{Na}$ idade média teria ocorrido o inverso com a valorização do comércio e dos ofícios urbanos. Na antiguidade o trabalho da terra era tido como a ocupação própria do homem livre em razão da própria formação da comunidade, inicialmente a partir de livres proprietários de terra. $\mathrm{O}$ artesanato era originalmente um trabalho de escravos libertos e estrangeiros. Não existia, para Marx, a ideia de uma corporação como entidade autônoma e com identidade própria. Na antiguidade, por exemplo em Roma, Marx refere não ter existido preocupação sobre qual forma de propriedade era mais lucrativa e sim qual forma de propriedade seria capaz de criar melhores cidadãos.

Em todas as mencionadas formas, onde a propriedade da terra e a agricultura são a base da ordem econômica o objetivo é a produção de valores de uso e a reprodução dos indivíduos. A propriedade vem através do trabalho, e é um 
pressuposto da existência, a possibilidade de acessar a terra e laborar enquanto membro da comunidade. O individuo isolado não poderia ter propriedade do solo.

Marx acredita que a história pré-burguesa possuiu sempre um fundamento econômico como razão de seu movimento evolutivo. As relações econômicas existiram, para o autor, desde sempre, com distintas roupagens. O objetivo de todas as comunidades seria a sua reprodução, reprodução dos seus modos de existência. No entanto, para Marx, a própria reprodução encerra uma nova produção e a destruição das pautas anteriores. Se cada um dos indivíduos é proprietário ou possuidor de uma parcela de terras, o simples aumento da população exigirá que a comunidade conquiste novas terras. A propriedade, é, portanto, relacionar-se com as condições de produção e reprodução como algo seu.

A formação das modernas relações capitalistas são, para Marx, o resultado de um processo histórico com diversas fases. Para que ocorram as relações do capitalismo é necessária uma conjugação de fatores, alguns enumerados por Marx como por exemplo: a dissolução das relações com a terra como pressuposto inato e inerente à condição de homem; desaparecimento da propriedade dos instrumentos de trabalho; impossibilidade de sobreviver durante o processo de produção; desaparecimento do trabalhador como incluído nas condições de trabalho, ou seja, o próprio trabalhador não importa à realização do trabalho que poderá ser realizado por máquinas, animais ou humanos, o componente principal é a capacidade de trabalho. Estes, são os principais requisitos enumerados por Marx como fios condutores do aparecimento de trabalhadores livres e que não possuem propriedade alguma. Esta carência de propriedades obriga os indivíduos a que se tornem vendedores de trabalho, em outras palavras, trabalhadores assalariados.

Marx ressalta que, para a formação do mercado de trabalho, é necessário que exista uma massa de trabalhadores livres de relações de escravidão, servidão ou clientela e livres de posses. Sua única forma de sobrevivência é a vender sua capacidade de trabalho ou optar pelo ócio na mendicância e na vagabundagem ou até mesmo pela criminalidade. Segundo Marx, as massas optaram pelas últimas vias mas foram empurradas ao trabalho assalariado pela forca e pelo chicote através do poder estatal. 
Por outro lado, sentimos necessidade de ao menos tecer algumas considerações sobre a obra mais famosa de Marx, "El Capital ${ }^{152 "}$. Por óbvio, não se pretende de maneira alguma esgotar o tema. Aliás, sobre O Capital, inclusive hoje em dia estão a surgir novas interpretações sobre a obra de Marx a exemplo de David Harvey e sua obra "Para entender O Capital".

Em O Capital, Marx procura explicar como se dá a formação e o movimento da produção no seio do capitalismo. O aspecto comum de todas as mercadorias, para Marx, é que são produtos do trabalho. Sua primeira definição é sobre o trabalho humano que seria "el empleo de esa simple fuerza de trabajo que todo hombre posee en su cuerpo, sin necesidad de especial educación. ${ }^{153 "}$ Marx ainda acrescenta que em cada sociedade e tempo determinados existe um trabalho médio, isto é, uma capacidade de trabalho comum à maior parte da população. Também está presente o conceito de força de trabalho entendida por Marx como um conjunto de capacidades físicas e intelectuais do ser humano as quais ele coloca em atividade para a realização de trabalho.

Inicialmente, destaca-se que a função do dinheiro era somente servir de parâmetro de valor para expressar os valores das mercadorias. O dinheiro e a mercadoria estão envolvidos em dois ciclos de movimentos: mercadoria-dinheiromercadoria e dinheiro-mercadoria-dinheiro. O possuidor do dinheiro como impulsor deste movimento converte-se em capitalista cujo objetivo é seguir criando a plusvalia e aumentando seu lucro.

Marx também divide o processo de trabalho em três elementos simples. $O$ primeiro é a atividade pessoal do homem. Já o segundo é o objeto sobre o qual se trabalha e o terceiro é o meio pelo qual se exerce o trabalho. Para Marx, o que importa para a criação de valor é o tempo de trabalho necessário nas condições ordinárias de produção.

Segundo o autor, as diferentes formas de produção que as sociedades adotaram ao longo dos séculos, a exemplo da escravidão e do trabalho assalariado, somente são distintas na forma de impor o trabalho e usurpar o sobre-trabalho do trabalhador. O sobre-trabalho é o tempo que o trabalhador atua de graça, segundo 
Marx, para o empregador. A remuneração pelo trabalho tem relação direta com o custo da sobrevivência do trabalhador e as possibilidades de que possa reproduzirse (sustento de sua família). Portanto, o trabalho necessário é aquele que o trabalhador deve trabalhar para garantir o próprio sustento. Além deste tempo, a jornada é normalmente estendida e o trabalhador produz um ganho não remunerado para o empregador.

A jornada de trabalho é, portanto, o elemento central de um cabo-de-guerra entre empregador e trabalhador. A jornada está limitada, ao início, pelas forças do trabalhador que necessita descansar e recuperar forças para produzir outro dia. A duração da jornada de trabalho será, portanto, objeto de luta entre trabalhadores e empregadores, a luta de classes.

A jornada de trabalho (o termo jornada obviamente refere-se ao dia de trabalho, 24 horas) para o empregador durará 24h completas excetuando-se somente os tempos absolutamente necessários para alimentação e descanso. Assim, não sobra tempo para desenvolvimento físico e intelectual do trabalhador. $\mathrm{Na}$ prática, a limitação da jornada de trabalho teve de ser limitada pelos Estados, o próprio Marx refere o Congresso Obreiro Internacional de Genebra, em 1866, como uma das primeiras iniciativas no sentido de limitar a jornada de trabalho a 8 horas (8h) diárias.

Marx também adverte que quanto maior o número de trabalhadores explorados, maior é a sua capacidade de resistência contra o capitalista. No entanto, segundo o autor, o capitalista também se aproveita dessa coletividade, da força de trabalho coletiva, a qual não remunera. A força de trabalho coletiva seria aquela produzida pelo conjunto de trabalhadores em comunhão de esforços para um objetivo comum.

Esse tipo de manufatura, que emprega um conjunto de trabalhadores como parte de um conjunto e partes de organismo, também retira do trabalhador habilidades e a visão do todo. Ademais, o trabalhador passa a executar somente uma ínfima parte do processo total, atomizando as funções de cada ofício envolvido e simplificando o processo. Essa simplificação retira valor das habilidades especiais 
necessárias à construção de um produto completo, tal qual o artesão, e torna o trabalhador facilmente substituível por outro.

Marx também refere a existência da divisão do trabalho social na manufatura e na sociedade como base do processo de produção de mercadorias. A divisão social do trabalho requer a dispersão dos meios de trabalho entre diversos produtores.

A revolução tecnológica também provocou mudanças na sociedade. Enquanto indisponíveis máquinas para a realização de trabalhos de força, emprestando trabalho mecânico às atividades fabris, era muito difícil que mulheres e crianças pudessem trabalhar. A partir do momento em que a força bruta não é mais necessária, mulheres e crianças podem fazer parte do mercado de trabalho. Tal circunstância diminui o valor da força de trabalho seja pela maior oferta, seja porque a remuneração do chefe da família deveria ser suficiente para sustentar toda a sua família e, a partir de então, esse valor é repartido entre os membros da família. As máquinas também induzem uma prolongação da jornada de trabalho. Como a máquina diminui o número de trabalhadores para determinado capital é necessário prolongar o máximo possível a jornada daqueles que restam, até mesmo para aproveitar o maquinário durante a maior parte do tempo possível, inclusive em turnos ininterruptos de revezamento.

Segundo Marx, a relação econômica salarial, serve para ocultar o trabalho não pago realizado pelo obreiro. O preço do trabalho parece ser mais barato para Marx nos países pobres onde os insumos para sobrevivência são mais baratos. A destruição dos privilégios feudais e das regras de reserva de mercado dos grêmios de ofício foram essenciais para a criação do mercado de trabalho livre.

A opção por comentar a obra de Engels ${ }^{154}$ logo após a de Marx parece a mais lógica, ainda que esta obra tenha íntima relação com a obra de Morgan. Quiçá o próprio Engels não soubesse ou esperasse que sua obra seria um dia incluída entre as obras de antropologia marxista. À época, a antropologia apenas engatinhava como campo autônomo do saber e a obra de Engels possuía, ao que se depreende 
de sua leitura, intuito de reforçar as bases da teoria comunista e do manifesto comunista que foi publicado em (1848).

Engels debruça-se sobre as descobertas de Morgan e as analisa sob o prisma das formas de família (das diversas formas existentes até a predominância da família monogâmica patriarcal) e organização até o advento do Estado e da propriedade privada. A crítica é latente e denota sua opinião de que a evolução dos sistemas sociais se dá às custas de hipocrisia e exploração de uma classe pela outra. Assim é quando chega à conclusão de que a família monogâmica patriarcal somente pode sobreviver às custas da prostituição como serviço instituído e aceito socialmente, como também do adultério (esse ferrenhamente proibido quando perpetrado pela mulher).

As constatações de Engels sobre o aspecto evolutivo do trabalho são de extrema utilidade ao nosso estudo. O mencionado autor coloca as relações sob um prisma pragmático-materialista e contribui nas discussões sobre o trabalho. Segundo ele, na época da barbárie inferior (recordemos das classificações de Morgan), o escravo capturado não tinha nenhum valor para o captor. Pudera, naquela época um homem podia produzir o justo para sua sobrevivência ou talvez pouco mais. Assim, a praxe entre as comunidades era matar o escravo ou incorporá-lo ao grupo como um igual.

Ainda, segundo Engels, as divisões do trabalho operaram mudanças sociais, primeiro na contradição entre a agricultura e outros ofícios e depois na dualidade campo versus cidade. O que aponta como a primeira grande divisão social do trabalho é o início da criação de animais e a atividade pastoril. O aumento da produtividade e a extensão da atividade no campo produzem duas grandes mudanças: uma delas é o início da escravidão já que o trabalho passa a ser cobiçado e pode ser fonte de maior riqueza e a outra é a mudança de posição no interior do lar.

Destarte, a primeira divisão social do trabalho, segundo Engels, necessariamente divide o mundo em duas classes: escravos e senhores, explorados e exploradores. No seio dos lares não foi diferente. O excedente da produção, muito escasso no período de simples caça e recoleção, agora começa a ser mais farto e 
tal excedente pertence ao homem. A situação muda o panorama das relações de família. Onde antes os utensílios e o comando do lar eram o mais valioso e importante para sobrevivência, deixa de ser com o advento da produtividade incrementada pela posse e criação de animais.

Outro ponto de especial de interesse para a presente investigação é o que Engels aponta como a segunda grande divisão do trabalho consubstanciada na divisão entre os ofícios e a agricultura. A constante complexidade da realização de tarefas como, por exemplo, a produção de azeite, vinho, o trabalho com metais e o trabalho de tecer tornaram impossível que o mesmo indivíduo ou a mesma família dessem conta de produzir tudo que necessitavam. Em tal estágio, segundo Engels, a humanidade encontra-se já no final do período da barbárie superior e nos umbrais da civilização.

Nesse contexto, a produção começa a gerar demasiados excedentes. O homem deixa de produzir para a própria subsistência e passa a produzir intencionalmente excedentes para troca. Estas circunstâncias criam o que Engels chama de terceira grande divisão social do trabalho. Cria-se uma nova classe que não interfere na produção e sim se ocupa somente da troca: os mercadores.

O autor faz questão de destacar que as divisões na sociedade aconteceram primeiro a partir da escravidão, depois com a servidão e, por último, com o trabalho assalariado que não deixa de ser a forma moderna de exploração da força de trabalho. O texto serve para o desenvolvimento e sustentação da teoria comunista e da luta de classes, localizando-a e apontando-a como um dos males da sociedade. As diversas divisões sociais do trabalho a que se refere operaram-se em diversos contextos e, ao que se depreende, foram as causas determinantes das mudanças na família, na propriedade e na forma de Estado.

Além disso, todas as mudanças ocorridas, para Engels, se prestam somente a um único e determinado fim: manutenção da propriedade e da exploração de uma classe pela outra. O livro, ainda hoje, é capaz de suscitar diversas críticas e paixões. O trabalho tem o mérito de colocar as observações de Morgan sob um olhar mais pragmático e que procura explicar a razão dos conflitos da época. 
Somente por haver suscitado tantas discussões a obra tem seus méritos. Cobra muita importância, também, a obra de Morgan, a qual sustenta, em grande parte, as teses de Engels. Contudo, destacamos apenas alguns dos aspectos mais importante para nossa investigação. Não se trata de esquadrinhar a obra de Engels e sim de ressaltar a importância da mesma para o paradigma evolucionista e para as discussões em torno do trabalho.

\subsection{0 evolucionismo do século $X X$}

O livro de Gordon Childe, Social Evolution ${ }^{155}$, publicado pela primeira vez em 1950, traz um olhar diferente sobre a teoria evolutiva. Além de tratar a evolução e os períodos pelos quais passou a humanidade sob o ponto de vista da arqueologia, Childe propõe novas ideias para a teoria evolutiva que depois serão discutidas e criticadas por autores posteriores.

Childe começa com uma crítica à teoria evolucionista anterior, principalmente a de Spencer, que reputa como causadora de um vício posterior, ou, poder-se-ia ler, a inauguração de uma tendência em descrever a evolução em etapas préassinaladas apoiando-se em alguns exemplos etnográficos. Segundo Childe, a obra dos evolucionistas como Spencer, Tylor, Maine e outros desconsiderava vários fatores como a herança recebida, o meio e questões históricas para poder comparar todas as sociedades isolando certos aspectos de cada uma e nunca no todo.

Com relação a Morgan, afirma que este acerta em tentar analisar a evolução social como um conjunto e não apenas de aspectos isolados. Entretanto, Morgan segue as mesmas abstrações quanto a diferenças do meio e históricas para considerar o uso de diferentes tecnologias e instrumentos como as linhas divisórias para os seus estágios evolutivos.

Assim, diz Childe, pensou-se que a utilização de critérios mais objetivos para a fixação dos períodos evolutivos acabaria com o subjetivismo das teorias anteriores. Claro, para ele, o que deixavam implícito os autores anteriores era que consideravam mais evoluída a sociedade quanto mais se aproximava esta do modelo europeu vigente à época. No entanto, em termos tecnológicos, a utilidade ou 
não de um instrumento para determinada sociedade é, segundo Childe, bastante relativa, para cada grupo uma inovação tecnológica pode ter mais ou menos valor, ser mais ou menos necessária, conforme o contexto da época. Exemplifica ele com a questão do automóvel e se um caçador de renas de 30.000 a.C. ou um egípcio de 3.000 a.C. necessitavam percorrer 300 quilômetros a $90 \mathrm{~km} / \mathrm{h}$. Utilizando tal exemplo conclui que a hierarquia da evolução sob o prisma de tecnologias só pode ser medida através da arqueologia. Reconhece, entretanto, a importância de Morgan dada a circunstância de que Marx e Engels adotaram seu esquema não por acidente e sim por adequar-se à sua concepção materialista da história anunciada em 1859 sobre a qual já discorremos anteriormente. Childe reputa a Morgan a melhor tentativa de organizar a evolução em estágios ainda que já seria insustentável àquelas alturas.

Childe reputa o termo evolução, bem como a teoria de Darwin como um ataque direto aos dogmas religiosos que pregavam a queda do homem e a criação de todas as espécies por uma intervenção da providência. No que tange à evolução do homem o dogma atacado era o da queda do homem do paraíso e sua degeneração. Cita Tylor, que, efetivamente, dedica bastantes páginas para explicar que os grupos humanos, na verdade, estão em um caminho para a evolução e que a degeneração poderia ser uma exceção e não a regra.

Childe coloca de manifesto o papel do evolucionismo que não é contrário ao difusionismo. Para ele ${ }^{156}$ :

... el conflicto entre evolución y difusión es enteramente ficticio. La
difusión es un hecho. La transferencia de materiales desde un
territorio a otro está demostrada arqueológicamente desde la Edad
de la Piedra Antigua en adelante. Pero si los objetos materiales
pueden difundirse así, igual pueden hacerlo las ideas: inventos,
mitos, arte, instituciones. Los evolucionistas nunca negaron este
hecho, puesto que la 'evolución' no pretende describir el mecanismo
del cambio cultural. No es una explicación de por qué cambian las
culturas - esto es asunto de la historia -, sino de cómo cambian.

Importante também assinalar a definição de cultura de Childe, para quem esta é uma expressão material duradoura da adaptação a um meio que permite a uma sociedade sobreviver e desenvolver-se. A partir daí, Childe passa a apresentar sua 
proposta de esquema evolutivo, baseando-se principalmente em dados arqueológicos.

Uma das principais ideias do autor, ele enuncia no segundo capítulo de sua obra. Na verdade, é uma constatação bastante útil e que acaba com as generalizações de grandes períodos aplicáveis ao conjunto da humanidade. Sua principal contribuição, em nosso ponto de vista, foi deixar claro que as diferentes etapas evolutivas não aconteceram ao mesmo tempo em todos os locais. Ou seja, a cronologia das “idades", termo que Childe desejava ver preterido por "estágios", é sempre relativa e não absoluta. Não existe, para ele, uma Idade da Pedra somente. Existe uma Idade da Pedra para cada local e grupo, dependendo de qual analisamos. A vantagem, no entanto, de cada uma destas idades é que todas representam o mesmo. Assim, a denominação de cada idade obedecerá os mesmos critérios não importando onde esteja e nem em que época. A sequência e os critérios de definição de cada idade permitem comparar as idades de cada uma das zonas e sociedades que se deseja analisar. No entanto, para comparar as culturas, a classificação em idades, é, segundo o próprio Childe, inútil.

Por isso, Childe tenta fazer coincidir as "idades do arqueólogo" com os "estágios do etnológo", isto é, encontrar, por exemplo, a idade neolítica com o estágio de barbárie proposto por Morgan. Entretanto, apesar de algumas idades e estágios apresentarem congruências, no geral, não se pode adotar os mesmos critérios e obter uma total paridade entre as classificações.

Ao tratar sobre a as mudanças nos tamanhos das cidades e povoados, verificados, pela arqueologia através do aumento do número de tumbas, Childe nos dá pistas importantes do início da especialização em matéria de trabalho. Sobre, isso, é importante frisar que a questão dos instrumentos utilizados no trabalho ocupa um lugar central para a definição dos contextos e das idades arqueológicas.

O autor aponta a idade do Bronze como a de possível início da especialização do trabalho e cita Engels, para quem se trata, tal fato, da separação entre agricultura e artesanato. Se depreende que o conceito de especialização aqui é concebido como aquele trabalhador que não produz, nem coleta os próprios alimentos e sobrevive, assim, da troca ou venda dos produtos que possui para poder alimentar- 
se. Outra das conclusões a que chega Childe é a de que os indivíduos que possuem algum tipo de habilidade especial, como a fabricação de vasos ou de armas, podem ser encontrados em todos os níveis sociais, exceto nos inferiores.

Após resumir as sequências culturais na selvajaria e na barbárie (novamente adotando a classificação de Morgan) Childe aponta, já nas conclusões, a chegada ao período da civilização. Ressalta que não se chegou à civilização da mesma forma e ao mesmo tempo em todos os lugares, mas que algumas características são comuns àquelas sociedades que alcançaram tal estágio. Tais características são apontadas por ele como os aglomerados urbanos e a acentuação das divisões no âmbito do trabalho.

Finalmente, Childe chega a algumas conclusões interessantes sobre 0 processo evolutivo. Primeiro que, a par das diferenças no desenvolvimento das sociedades, principalmente no velho mundo, o termo evolução não perde validade, pois significa justamente um processo de variação e diferenciação, tal e qual significava para Lamarck e Darwin. Childe não exclui a difusão da evolução. Aponta o autor a difusão como um processo cultural de adaptação social além de que, nunca se poderia excluir, a priori, a possibilidade de progresso (em um mesmo sentido) de maneira independente. Ademais, conclui ele que a analogia entre a evolução cultural e biológica é falha sem, contudo, admitir que seja impossível pensar na evolução cultural como um processo racional e ordenado capaz de ser explicado e compreendido.

A obra de White ${ }^{157}$, publicada pela primeira vez em 1949, explica os fundamentos de uma ciência voltada para elucidar os enigmas e problemas da cultura. Um dos grandes debates, pelo qual o leitor é conduzido durante a obra é sobre a validade da existência e independência de uma ciência que trate exclusivamente sobre a cultura.

Um dos primeiros argumentos de White é de que a ciência é feita empregando o método científico. A subdivisão das ciências seria, portanto, apenas um reflexo da divisão de tarefas na sociedade em geral. Ou seja, a ciência na verdade é una e suas subdivisões são maneiras de realizar o trabalho científico, de 
tal maneira que não se poderia conceber ciência em compartimentos estanques e incomunicáveis. Se cremos no contrário, exemplifica White, um astrônomo, ao escrever sobre a história do sistema solar, não faria ciência, pois não estaria utilizando o método científico próprio da astronomia.

White realiza também uma distinção entre planos ou categorias de fenômenos, os quais podem ser culturais, biológicos ou físicos e, por sua vez, manifestar-se-iam nos planos espacial, temporal ou espaço-temporal. Reproduzimos o quadro sinótico apresentado pelo próprio autor ${ }^{158}$ :

\begin{tabular}{|c|c|c|c|}
\hline & TEMPORAL & $\begin{array}{l}\text { ESPAÇO- } \\
\text { TEMPORAL }\end{array}$ & ESPACIAL \\
\hline CULTURAL & $\begin{array}{l}\text { História, História da } \\
\text { Cultura ou História } \\
\text { da Civilização }\end{array}$ & Evolução Cultural & $\begin{array}{l}\text { Processos não- } \\
\text { temporais e de } \\
\text { repetição próprios da } \\
\text { sociedade humana e } \\
\text { determinados } \\
\text { culturalmente }\end{array}$ \\
\hline BIOLÓGICO & $\begin{array}{l}\text { História racial do } \\
\text { homem. História de } \\
\text { espécies e gêneros } \\
\text { animais e vegetais }\end{array}$ & $\begin{array}{l}\text { Evolução biológica; } \\
\text { Crescimento dos } \\
\text { indivíduos. }\end{array}$ & $\begin{array}{l}\text { Processos não- } \\
\text { temporais e de } \\
\text { repetição na conduta }\end{array}$ \\
\hline Físıco & $\begin{array}{c}\text { História do sistema } \\
\text { solar, da Terra, de } \\
\text { um continente, } \\
\text { sistema de } \\
\text { montanhas, rio, gota } \\
\text { d'água, um grão de } \\
\text { areia }\end{array}$ & $\begin{array}{l}\text { Evolução cósmica, } \\
\text { solar, estelar, } \\
\text { galáctica. } \\
\text { Desintegração de } \\
\text { substâncias } \\
\text { radioativas }\end{array}$ & $\begin{array}{l}\text { Processos não } \\
\text { temporais e de } \\
\text { repetição na física, } \\
\text { química, astronomia }\end{array}$ \\
\hline
\end{tabular}

Seu esquema também serve para, na introdução, realizar uma defesa daquilo que depois virá a ser conhecido como neoevolucionismo. White reconhece a grande contribuição de Morgan, Tylor e Spencer, todos já comentados anteriormente, reconhecendo, também, as críticas e imperfeições dos esquemas apresentados por estes. 
Seu capítulo seguinte, e talvez o fundamental, trata sobre o símbolo. White reputa a capacidade de simbolização como a base da conduta e da cultura humanas. O autor usa o exemplo da menina Hellen Keller, a qual perdeu muito cedo a visão e a audição e vivia, portanto, alheia ao mundo de símbolos humano, em estado praticamente animal. A senhora Sullivan, contratada pelos pais da menina para ser sua tutora, começou desenhando palavras em uma das mãos da menina. As palavras, no entanto, eram apenas signos, ausentes de significado. A menina confundia os signos "jarra" e "água", pois ambos, para ela, estavam relacionados ao ato de beber. Contudo, em um passeio pelo jardim, a tutora colocou uma das mãos da menina debaixo de um jorro de água de uma mangueira enquanto desenhava a palavra água na outra. A partir de então, os signos passaram a adquirir significado e a menina passou a realizar um progresso espantoso rumo ao mundo simbólico.

White também é um dos primeiros e fundamentais defensores do vocábulo "culturologia" para designar a ciência que estuda a cultura. Assombra vislumbrar a paixão e dedicação com a qual White defende a cultura e sua importância, afirmando, inclusive, importar mais ao futuro da humanidade aquilo que se passa nas mentes e corações humanos do que aquilo que acontece nos laboratórios e centros de produção. Outra de suas afirmações é também categórica: a cultura possui mais o homem do que o homem a cultura.

Em aspecto especialmente interessante para nossa investigação, White aborda a questão do surgimento da escravidão e seu declínio. O autor não concorda com apontar a origem e supressão do sistema escravista a partir de mudanças na mentalidade ou psique humanas, admitindo primeiro e rechaçando em seguida as ideias escravistas. White aborda a questão do ponto de vista da cultura e materialista, isto é, a escravidão surge quando um homem é capaz de produzir mais do que o necessário para o próprio sustento. Por outro lado, o declínio do sistema de escravidão aconteceu em virtude do menor custo e maior eficiência do trabalhador livre. Além disso, o patrão e dono de escravos possuía obrigações com o sustento e cuidado de suas "propriedades", os escravos, enquanto o empregador de trabalhadores assalariados poderia livrar-se dos mesmos no caso de diminuição de suas ganâncias. Destarte, White explica a escravidão através de mudanças 
tecnológicas e dos mecanismos sócio-culturais e não a partir de mudanças de mentalidade ou psique humanas.

A obra também traz importantes considerações sobre a importância dos sistemas energéticos para a evolução da cultura. Este, talvez seja o traço mais importante e difundido das teorias de White, a centralidade dos sistemas energéticos e do desenvolvimento tecnológico para a cultura humana.

O autor divide o sistema cultural em três aspectos: tecnológico, sociológico e ideológico. O aspecto tecnológico é apontado como o conjunto de instrumentos materiais, mecânicos, físicos e químicos bem como suas técnicas de uso através dos quais o homem se relaciona com seu habitat. Já o aspecto sociológico seria composto das relações interpessoais e pautas de conduta. E por fim, o aspecto ideológico estaria composto pelas ideias, crenças e conhecimentos.

Para White, o sistema principal, primário e básico é o tecnológico, sobre o qual se apoia a vida e cultura humanas. Os demais sistemas viriam conformados sempre a reboque do sistema tecnológico que marca as mudanças sociológicas e ideológicas. Para medir o grau de desenvolvimento da cultura, White propõe que sejam levados em conta três fatores: a quantidade de energia aproveitada anualmente per capita, a eficiência dos meios tecnológicos de aproveitamento de energia e a quantidade de bens e serviços capazes de satisfazer necessidades humanas. Por isso, a fórmula que expressa o grau de desenvolvimento cultural seria resumida por $\mathrm{E} \times \mathrm{T} \rightarrow \mathrm{C}$. "C" é a expressão do desenvolvimento cultural, "E" é a quantidade de energia aproveitada anualmente per capita e "T" a qualidade das ferramentas empregadas no consumo de energia. Desta fórmula, White retira sua lei básica da evolução cultural: "la cultura evoluciona a medida que aumenta la cantidad de energía aprovechada anualmente per cápita, o a medida que aumenta la eficiencia de los medios instrumentales usados para poner a trabajar la energía. ${ }^{159 ",}$

Pelo mecanismo das mudanças tecnológicas, foi possível produzir alimentos para todos com a ocupação de apenas de alguns poucos. Tal situação possibilitou a dedicação da mão de obra excedente às outras atividades, acarretando a divisão de 
funções. Sem dúvida, a obra de White traz aportações novas ao evolucionismo, relendo alguns aspectos da linha teórica a atualizando-a na metade do século XX.

A obra de Steward faz parte da tendência antropológica a que pertencem também os já citados Leslie White e, em menor grau, também Gordon Childe. $O$ movimento buscava recuperar o conceito de evolução, desacreditado e despreciado desde a escola boasiana. Afinal, o conceito de evolução segue, até os dias atuais, possuindo centralidade e importância vital para a as ciências biológicas. O principal livro de Steward ${ }^{160}$, Theory of cultural change, sobre o qual trataremos de maneira resumida inaugura um novo paradigma antropológico, ou quiçá dois: a evolução multilinear e a ecologia cultural.

Para Steward a antropologia se distingue no campo das ciências sociais em razão de sua aproximação histórica e comparativa à cultura. As explicações históricas e comparativas em general possuem três distintas formas: a primeira delas é o "evolucionismo unilinear" onde se acredita que todas as sociedades passam pelos mesmos estágios de desenvolvimento; a segunda delas, em evidente contraste com o evolucionismo estão os relativistas culturais, para quem o desenvolvimento das culturas é divergente e, portanto, o antropólogo deveria buscar divergências nas culturas; e, por fim, o evolucionismo multilinear, defendido pelo próprio Steward e resumido como a crença de que tipos similares de cultura, sob as mesmas condições, mas alguns aspectos da cultura irão desenvolver-se da mesma maneira e em uma sequência regular em toda humanidade.

No último parágrafo de sua introdução, Steward faz uma crítica à Leslie White, a quem chama de "culturologista descompromissado", que se preocupa em falar de cultura de um modo general e não de culturas delimitadas e particulares. Steward atribui esta vontade de desvelar aspectos da cultura em general como uma pulsão sentida por muitos cientistas sociais para os quais a verdadeira explicação científica deveria explicar todos os comportamentos. Steward, por outro lado, afirma não possuir tal pretensão generalizadora, e sim formular hipóteses e formulações em um universo limitado já que, para ele, nenhum fenômeno cultural é universal.

160 STEWARD, Julian H. Theory of culture change: the methodology of cultural evolution. Champaign, IL: University of Illinois Press, 1990. 
O autor, ao começar a explicar seus métodos, ressalta as distinções evidentes entre os processos de evolução cultural e evolução biológica. Ainda que exista relação entre ambos, principalmente pelo fato de que a evolução biológica foi condição necessária para o progresso da cultura. No entanto, não se pode pretender igualar as evoluções culturais e biológicas, Steward resume tal distinção citando uma asserção de Kroeber: "o processo de desenvolvimento cultural é aditivo e acumulativo ao passo de que a evolução biológica é substitutivo ${ }^{161}$."

A evolução multilinear, segundo Steward, assume que regularidades significativas ocorrem nas mudanças culturais e estão relacionadas com a determinação de leis culturais. O método multilinear é definido como mais empírico que dedutivo o que certamente fará perder em universalidade e, sem embargo, ganhar em especificidade e concretude. Steward ainda faz um aviso de que metodologia do evolucionismo multilinear não irá contentar àqueles interessados em leis e formulações gerais já que a grande promessa é a análise e comparação de paralelos e similaridades de maneira limitada.

A seguir, o autor passa a explicar os conceitos da ecologia cultural, outros dos conceitos por ele desenvolvidos e dados a conhecer. Para Steward, o conceito de ecologia é "adaptação ao ambiente ${ }^{162 ", ~ o ~ t e r m o, ~ s e g u n d o ~ e l e, ~ s e m p r e ~ f o i ~ u s a d o ~}$ como forma de explicar a origem de novos genótipos e variações fenotípicas evolutivas geradas pela interação da interação adaptativa com o ambiente.

O autor acredita que o progresso do Homo sapiens enquanto espécie provavelmente se deve muito mais a causas culturais que físicas. Segundo ele, os grupos sociais determinados por sistemas de parentesco ou por atividades econômicas em determinado ambiente particular são cruciais na diferenciação da emergência de variantes do homem. A tendência, aponta Steward, é conceber as comunidades humanas desde pontos de vista biológicos e conceitos como competição, sucessão, organização territorial, migrações, gradientes etc. Contudo, na biologia, as leis da evolução e os conceitos da ecologia podem ser aplicados a todas as espécies e ambientes envolvidos. O mesmo não ocorre no caso das

161 Tradução livre da frase originalmente em inglês de Kroeber: "The process of cultural development is an additive and accumulative one, whereas the process of organic evolution is a substitutive one." in: KROEBER, Alfred Louis. Anthropology. New York: H.B.C., 1948.

162 STEWARD, 1990. p. 30 - A expressão exata utilizada pelo autor é "adaptation to environment". 
ciências sociais. O problema das ciências sociais, de explicar as mudanças em padrões culturais em contextos distintos, não pode ser resolvido utilizando-se os métodos da biologia e tampouco leis universais.

Levando em consideração tais diferenças entre a biologia e as ciências sociais, Steward propõe o método da ecologia cultural, como forma de tentar explicar as diferenças culturais entre diferentes áreas. O problema da ecologia cultural, segundo o autor, é pontuar como os ajustes entre as sociedades humanas e o ambiente requerem modos particulares de atuar ou como permitiriam um determinado escopo de atuações possíveis. O autor pretende deixar clara a diferença entre a ecologia cultural e o determinismo ambiental ou o determinismo econômico.

O autor defende um conceito importante e que, em nosso entender, poderia ser extrapolado para outras investigações, ao menos como forma de detalhar aspectos imprescindíveis da vida das comunidades. Tal conceito é o de núcleo cultural $^{163}$, o qual define um conjunto de fatores mais estreitamente relacionados com a subsistência e arranjos econômicos. Tal núcleo incluiria as atividades mais intimamente ligadas ao núcleo, sejam de ordem política, religiosa ou social. Quanto mais ligada ao núcleo, menor o potencial de variação de uma pauta cultural, segundo Steward. As atividades mais distantes do núcleo seriam mais propensas a variações e estariam sujeitas aos fatores histórico-culturais propiciadas por invenções independentes e aleatórias ou pela difusão. Como exemplo de circunstâncias determinadas pelo núcleo cultural o autor cita o exemplo dos esquimós, onde a caça é escassa e, portanto, caçar em grupos é pouco rentável já que a presa teria de ser muito dividida, não recompensando o esforço empregado na caça. Tal fator também levaria a que os esquimós estejam divididos pelo território em grupos pequenos.

Steward também faz algumas considerações sobre como encontrar o núcleo cultural, que pode ser distinto a depender do tipo de sociedade analisada. No caso de sociedades primitivas, o núcleo estaria próximo às atividades de subsistência, tais como armas e instrumentos de caça e pesca, modos de armazenamento de comida, fontes de água e combustível e sistemas de proteção ao calor ou ao frio 
excessivos. Se passamos a análise de sociedades mais desenvolvidas, o núcleo estaria mais próximo às tecnologias da agricultura e pecuária e à manufatura de objetos essenciais. Em um mundo industrial, mais importantes e próximos ao núcleo seriam os sistemas de capital e crédito e os sistemas comerciais.

O autor faz algumas ressalvas apontando que a estrutura e funções do sistema bancário, o qual utiliza de exemplo, representa um aspecto supra-individual da cultura e, apesar de estar introjetado nas mentes dos homens, o método etnográfico seria de pouca valia para desvendar questões sobre sua operação. Além disso, a questão sobre um sistema bancário não pode ser apartada de outras questões que nela influem direta ou indiretamente, como o nível de industrialização, o sistema de leis, a propaganda etc. Neste sentido, Steward divide os componentes mais significativos das sociedades modernas em dois grupos e indica aqueles que, para ele, são suscetíveis de análise a partir do método etnográfico. O primeiro grupo se refere aos componentes que deveriam ser estudados em nível nacional e o segundo trata de grupos de subculturas ou segmentos da população. Para o autor, somente no segundo caso a análise a partir de métodos de observação direta usados pela etnologia poderiam ser úteis. Steward refere uma ação contínua de crescimento das culturas onde existiria uma sucessão de tipos de organização mais complexos e novas formas emergentes de organização social. Os tipos de organização anteriores não deixariam de existir e sim se tornariam novas partes de um novo todo mais complexo.

Finalmente cumpre-nos referir algumas considerações que faz Steward e que são de especial interesse para nosso trabalho. Retomando o pontuado acima, o autor menciona que a aproximação etnográfica à instituições do primeiro grupo (instituições nacionais) poderia ser útil somente na medida de desvelar um comportamento estereotipado e formal esperado dos indivíduos enquanto membros de uma instituição (comportamento institucional). Cita Steward que os trabalhadores, vendedores, agentes, gerentes e proprietários que trabalham juntos em determinada fábrica se adaptam a certas pautas de comportamento relacionadas à situação de trabalho comum de todos. Sem embargo, o status e comportamento de cada um, apesar de fornecer pistas sobre sua vida fora da fábrica, não chega a oferecer um panorama completo sobre a vida dos indivíduos, tais como religião e vida familiar. 
Tal afirmação, contida acima, conforma exatamente uma das hipóteses do presente trabalho, já anteriormente citada, segundo a qual a visão de mundo dos trabalhadores não deriva necessariamente de uma mesma profissão ou trabalho similar. Segundo Steward, as pautas comportamentais da fábrica, ou em outras palavras, do trabalho comum, formam apenas uma parte da subcultura de cada indivíduo, que será complementada segundo sua religião, vida familiar, atividades de lazer entre muitas outras.

A teoria de Steward, como se nota, agregou importantes conceitos ao complexo arcabouço conceitual da antropologia moderna. Suas ideias pretenderam sentar uma nova teoria que rechaça o evolucionismo unilinear, o difusionismo e o particularismo histórico, ainda que aproveite conceitos de cada um deles. Além disso, Steward já oferece notas de materialismo cultural ao relacionar pautas culturais com as condições do ambiente, principalmente, com as condições de sobrevivência proporcionadas pelo ambiente (comida, alojamento e combustível fundamentalmente).

\subsection{Os difusionismos Britânico e Alemão}

A corrente teórica difusionista surgiu em resposta às generalizações evolucionistas do século XIX. A teoria difusionista é talvez uma das partes da contribuição de Boas e seus discípulos, bem como caminha lado a lado com a ideia particularista histórica.

O difusionismo encerra uma contrariedade intrínseca com relação ao evolucionismo. Neste último, defendia-se a unidade psíquica da humanidade, ou seja, face a problemas semelhantes, os grupos humanos tenderiam a encontrar semelhantes soluções. Alguns importantes avanços da humanidade, que para Morgan representavam a passagem de um estágio para outro em seu esquema, teriam sido inventados diversas vezes, por diferentes grupos humanos em distintos lugares. Sem embargo, os difusionistas, ainda que não neguem a importância e possibilidade da invenção independente, atribuem maior importância ao contato entre culturas com a difusão e empréstimo de matizes culturais. Não se pode supor que os difusionistas acreditassem cegamente somente na difusão como meio de modificação da cultura. Em algum momento e em algum lugar foram criadas novas 
pautas culturais que seriam passadas adiante por difusão. Como é impossível a redução ao infinito, supõe-se, acreditariam os difusionistas no gênesis bíblico, momento no qual foram "inventadas" as tradições culturais da humanidade, modificando-se e avançando pela difusão a partir de tal centro difusor. Está claro ser uma teoria de pronto rechaçada por grande parte da comunidade científica. $O$ difusionismo, tal qual o inimigo que deseja veemente combater, o evolucionismo, viu-se mergulhado em um poço de críticas e provações. Os difusionistas utilizaram algumas unidades conceituais para analisar os padrões de difusão: rasgos culturais, padrão dos rasgos culturais e área cultural. Explica Phillip Kottak ${ }^{164}$ que o rasgo cultural seria algo como o arco e flecha, o padrão do rasgo cultural seria a maneira com que diferentes grupos utilizam o arco e flecha para caçar. Por fim, a área cultural seria uma região onde tais rasgos e padrão seriam compartilhados como uma determinada planície, o sudoeste dos Estados Unidos entre outros. A área cultural teria o condão de limitar a dispersão dos rasgos culturais para fora de tal área devido, principalmente, a fatores ambientais.

O conceito de área cultural, segundo Marvin Harris ${ }^{165}$, emergiu das necessidades práticas da antropologia norte-americana para representar de maneira cartográfica os grupos de índios americanos. Pode-se reputar a difusão do termo a Otis Mason ${ }^{166}$ o qual utilizou por primeira vez o conceito de área cultural para agrupar os índios americanos em dezoito "entornos ou áreas culturais". Outro americano, Wissler ${ }^{167}$, 1926, tentou elaborar uma lei geral da difusão, segundo a qual haveria sempre um centro difusor e a difusão aconteceria do centro para a periferia. Portanto, os rasgos culturais mais distantes do centro seriam os mais antigos.

O difusionismo começou na Europa, com os Britânicos e Alemães, até chegar na América do Norte não sem algumas modificações que o transmutaram no particularismo histórico da escola boasiana e as derivações das quais foram responsáveis os discípulos de Boas.

164 KOTTAK, 2011.

165 HARRIS, 2003.

166 MASON, Otis. Similarities in culture. in: American Anthropologist. N. 8, 1895. pp. 101-117

167 WISSLER, Clark. The relation of nature to man in aboriginal America. New York: Oxford University

Press, 1926. 
A escola Britânica, da qual são expoentes maiores Elliot Smith, J. Perry e W.H.R. Rivers. A escola britânica foi chamada, por muito tempo, de escola hiperdifusionista, já que reputava um só foco cultural para toda civilização avançada, o Egito. Segundo a teoria hiperdifusionista, as invenções e inovações produzidas no Egito há cerca de 4.000 anos, muito pelas condições favoráveis apresentadas pela região com relação ao desenvolvimento da agricultura, teriam se expandido pelo mundo através da difusão. A teoria de Elliot Smith se apoia em uma série de verdades inamovíveis (na opinião dos autores): que a cultura surge só sob circunstâncias excepcionalmente favoráveis tendo em vista que o homem é pouco criativo e por isso seria quase impossível que surjam culturas distintas de modo independente; por outro lado, a cultura de outras regiões, deve-se ao resultado da difusão desta superior civilização e, por fim, o grau de civilização vai se diluindo na propagação para as zonas marginais, sendo que a decadência é um fato importante na história humana ${ }^{168}$. Além disso, Elliot Smith era contra o paralelismo cultural pois acreditava ser um dos diferenciais da cultura humana a dificuldade de prever a conduta adotada ante as mais diferentes situações. Desta forma, jamais poderia concordar com as invenções independentes e com a ideia evolucionista da unidade psíquica da humanidade ${ }^{169}$. Já Rivers, ao tentar explicar os contrastes entre as culturas melanésias e polinésias, reputou-os a sucessivas ondas de imigração que teriam provocado a difusão dos rasgos culturais. Além disso, aqueles aspectos não explicados pela sua teoria da difusão foram creditados à desaparição acidental ou a pequenas populações de imigrantes já desaparecidas.

A seu turno, os difusionistas alemães, representados por Fritz Graebner, defendem a expansão de conjuntos de traços culturais partindo de diversos focos. $O$ difusionismo alemão sentou suas bases sobre as teorias de Friedrich Ratzel, o qual criticava seus contemporâneos por atribuir demasiadas circunstâncias à unidade psíquica e invenção independente. Para este último, a invenção independente poderia ser uma opção apenas após descartadas outras hipóteses como as migrações ou contato entre povos distintos ${ }^{170}$. Esta série de focos cria uma subsequente série de círculos culturais que aumentam por difusão, sobrepondo-se ou mesmo destruindo uns aos outros. Após Graebner, Wilhelm Schimdt passou a 
comparar as origens dos empréstimos e da difusão dos traços culturais sendo considerado um evolucionista multilinear ${ }^{171}$.

Ambos, Graebner e Schimdt, concordavam em dois critérios para a aferição das afinidades entre as culturas e determinar a cronologia de cada uma delas. $O$ primeiro de tais critérios, chamado de critério de forma ou qualidade, aduz serem as semelhanças entre dois elementos culturais não provenientes da própria natureza do objeto, do material do qual estão feitos ou da função que cumprem, deve ser resultado da difusão sem que a distância que os separa seja excludente de tal hipótese. O outro critério recebe o nome de critério de quantidade e versa sobre a quantidade de semelhanças apontadas entre dois elementos culturais, o que aumentaria a possibilidade de uma relação histórica entre os elementos. Ao utilizar tais critérios, Graebner e Schimidt foram capazes de recriar alguns poucos círculos culturais originais e, a partir daí, toda a história humana poderia entender-se como a simples difusão de pautas culturais desde os círculos originais ${ }^{172}$.

O certo é que a tendência difusionista esteve muito ligada à escola americana de sua época e influenciou no desenvolvimento de outra corrente antropológica. A corrente particularista histórica capitaneada por Franz Boas e seus discípulos, principalmente, inaugura alguns novos paradigmas na antropologia moderna.

\subsection{O particularismo histórico}

Em resposta a toda teoria evolucionista do século XIX, surge o particularismo histórico. Esta visão da antropologia teve como maior expoente e principal defensor Franz Boas que se voltou contra as aspirações de revelar leis gerais para a humanidade. Boas advogava por uma antropologia mais voltada aos fatos, ao trabalho de campo e que ressaltasse as particularidades de cada cultura a partir dos processos históricos de desenvolvimento de cada rasgo cultural. Ao contrário dos evolucionistas, os quais pressupunham unicidade de pensamento na humanidade, Boas reputava as diferentes culturas ao conjunto de fatos ocorridos ao longo da história e rejeitava a ideia de que semelhantes causas sempre produzam semelhantes consequências. 
O particularismo histórico não se conformava com as conclusões alcançadas pelo método comparativo, até então dominante. $O$ fato de que duas culturas distantes apresentassem semelhantes rituais funerários ou uso dos mesmos tipos de armas não era, para Boas, suficiente para supor uma evolução paralela e uniforme de dois povos que nunca haviam se encontrado. Recolher dados ao azar e, principalmente, de fontes secundárias, comparando-os em seguida, foi um método duramente criticado a partir do particularismo histórico. Ao que parece, Boas não foi um antievolucionista, buscava, entretanto, um método próprio da antropologia o qual a afastaria cada vez mais das chamadas "hard sciences" ${ }^{173}$. Ele não refutou em nenhum momento a possibilidade de invenções independentes, evolução paralela ou convergente, embora tenha acreditado que a difusão é mais frequente que as demais hipóteses. ${ }^{174}$

Em seu texto sobre as limitações do método comparativo em antropologia, publicado em 1896, Boas explicita algumas de suas ideias para estabelecer as bases de sua crítica ao método e às concepções evolucionistas. Uma destas é a de que não basta ao antropólogo conhecer algumas concepções de caráter universal, mas também averiguar sua origem e aplicação em cada cultura. Como exemplo, cita o uso de máscaras por alguns povos. As máscaras, que pretendem enganar espíritos, comemorar fatos ou lembrar defuntos. Cada um dos costumes de usar máscara pode ter se desenvolvido de maneira distinta. Não se pode reduzir o fato ao simples uso de máscaras e concluir que, sob determinadas causas, a mente humana atua sempre buscando os mesmos resultados. Sobretudo, Boas propõe o estudo dos processos pelos quais se desenvolveu cada costume em cada local distinto. Para isso defende um estudo detalhado do costume sobre o qual se deseja saber dentro da cultura total do povo e conectada com uma investigação geográfica com povos vizinhos. Em resumo, Boas rejeita afirmações a priori sobre o desenvolvimento de determinado costume, sobretudo a formulações de leis gerais sobre o desenvolvimento da humanidade. ${ }^{175}$

Boas aplica às concepções universais o conceito de entorno e de variações individuais, em outras palavras, variações geográficas e psicológicas. A formação de 
Boas como geógrafo provavelmente tem a ver com a formulação de um conceito tal qual o de área cultural. A área cultural consiste em um pequeno entorno geográfico sobre o qual se deve debruçar o pesquisador ao tentar entender determinado aspecto cultural. Deve estudar e comparar dentro da área cultural e, após ter feito isso, pode procurar a extensão dos limites da área cultural além dos iniciais. $\mathrm{O}$ autor não reputa o entorno geográfico como fundamental na formação das culturas embora defenda uma conhecida tendência de contato entre povos próximos e a grande probabilidade de intercâmbio de conhecimentos.

Em outro texto posterior, titulado "Os métodos da etnologia"176, Boas novamente critica autores como Morgan e Spencer, dizendo-os "enfeitiçados" pela ideia de um desenvolvimento uniforme e geral da cultura em toda a humanidade. Toda a teoria evolucionista parte do pressuposto de que alguns paralelismos encontrados ao redor do globo, entre populações distantes, somente podem ser creditadas à tendência da humanidade de encontrar semelhantes soluções para semelhantes problemas. Contudo, como bem afirma Boas, esta é somente uma hipótese e não pode ser generalizada como lei universal.

À hipótese evolucionista, Boas afirma estar afirmada radicalmente a hipótese difusionista segundo a qual rasgos semelhantes sempre se devem à migração e à difusão. No entanto, para que seja verdadeira, seria preciso conectar de alguma forma áreas extremamente grandes e, por vezes, bastante distantes.

Ao estabelecer as fraquezas de ambos os métodos, levados radicalmente ao extremo, Boas começa sua defesa de um terceiro método. Para ele, investigar os detalhes de cada rasgo cultural (utilizando, para isto, o exemplo do desenho de formas decorativas) e acompanhar uma sequência histórica de suas mudanças contribui para descobrir melhor a forma da evolução daquele determinado aspecto cultural. Ou seja, Boas caracteriza o problema da cultura como um problema histórico e afirma ser necessário conhecer não só como são as coisas, mas como chegaram a ser como são.

A partir destas constatações, inclusive as sociedades mais primitivas perderiam sua aparente imobilidade e simplicidade já que o processo histórico de 
mudança é contínuo e inexorável. Assim também surge outra questão fundamental, o desenvolvimento de cada rasgo pode ser influenciado pelos indivíduos que compõem cada sociedade e existe mútua influência do indivíduo na sociedade e desta no indivíduo. Assim, Boas reafirma sua ideia de que cada grupo cultural tem sua evolução marcada por peculiaridades internas, pelas influências externas e pelas relações particulares entre umas e outras. Por isto o desenvolvimento de cada grupo é particular, particularidade esta a ser definida através da análise do processo histórico de mudanças enfrentadas ${ }^{177}$.

\subsection{Cultura e Personalidade}

A corrente antropológica da cultura e personalidade também foi influenciada por Boas já que muitos dos representantes desta escola foram seus discípulos. Contudo, talvez a principal influência sobre os pensadores da cultura e personalidade tenha sido exercida por Freud. Ainda que à primeira vista pareça que os dois autores não compactuam das mesmas ideias, o que em parte é verdade, os arcabouços teóricos desenvolvidos por um e por outro foram complementares, possibilitando o surgimento de uma nova maneira de pensar as mudanças culturais.

De fato, a teoria evolucionista do século XIX é repleta de generalizações em diversos aspectos. Morgan, por exemplo, constrói uma sequência de estágios evolutivos onde a organização do parentesco progride em direção à família monogâmica. Ou seja, os grupos humanos teriam uma orientação mais promíscua no início e mais reprimida com o passar do tempo. Para Freud, a ideia de uma progressiva repressão sexual servia especialmente ao desenrolar de suas teorias.

Freud defende que uma progressiva repressão dos impulsos libidinais leva a criança à enculturação facilitando, posteriormente, a formação de grupos sociais e a sua coesão. O conflito edípico, cuja universalidade foi defendida por Freud, baseiase nas renúncias aos impulsos e repressões aos instintos que gera nos infantes sentimentos hostis com relação aos pais e a um sentimento de culpa ${ }^{178}$.

Muitos autores se destacaram nesta corrente de pensamento. Entre eles podemos citar Margaret Mead, Ruth Benedict, Abram Kardiner, Géza Roheim, Ralph 
Linton e Robert Levine. Claro que não nos cabe analisar exatamente as contribuições de cada um deles. Contudo, é conveniente ao menos citar as principais contribuições de cada um dos autores à teoria antropológica.

Ruth Benedict $^{179}$, por exemplo, a despeito de muitas vezes duvidar da teoria psicanalítica colocavam a mesma em enfoque ao afirmar a enculturação a partir de certos ideais ou pautas de conduta como os apolíneos Zuñi (sudoeste norteamericano) ou os dionisíacos Kwakiutl (nordeste norte-americano). Melhor que os evolucionistas do século XIX, até mesmo por se tratar de uma comparação mais restrita e sem pretensões de generalização universal.

Benedict realizou a comparação de diversas pautas dos zuñi e dos kwautiutl para defender sua teoria de que a cultura particular é integrada por um ou dois temas psicológicos dominantes os quais influenciam os demais aspectos culturais e mantém, naquela determinada comunidade, algum grau de coesão. Pretendia, assim, etiquetar as culturas de acordo com os atributos psicológicos de cada uma delas. As comparações procedidas por Benedict são ricas em detalhes e abarcam um grande espectro de pautas culturais dos grupos estudados.

Os kwautiutl foram classificados por Benedict como um povo esforçado em superar os próprios limites, cometer excessos e não esmorecer diante de limitações. Por isso, os kwautiutl valorizavam as drogas, o álcool e o transe como formas de ingressar em outra ordem da experiência e foram tomados por dionisíacos. Já os zuñi eram um povo mais tranquilo e pacífico que desconfiava dos excessos e dos extremismos. Destarte, os zuñi receberam a classificação de apolíneos em referência a Apolo, Deus grego do fogo e da luz.

A corrente defendida por Benedict ficou conhecida como configuracionismo, pois entendia que as culturas estavam integradas e que todas eram únicas e singulares. Ademais, chegou-se a entender terem as culturas uma tendência normal para a consistência. Benedict preferiu comparar padrões gerais de conduta de 
determinados grupos humanos do que selecionar determinadas pautas e comparálas de maneira transcultural ${ }^{180}$.

Posteriormente, a análise de Benedict recebeu muitas críticas. Por exemplo, acreditar que uma cultura integrada e fundada em determinados rasgos culturais era, na verdade, um fato raro como, aliás, havia de certo previsto a própria autora ao afirmar que muito poucas culturas poderiam encaixar-se na dualidade apolíneodionisíaca. Outra das críticas recebidas foi no sentido de que os princípios ou rasgos culturais integradores defendidos por Benedict acabavam por estereotipar culturas com base em apenas algumas poucas pautas culturais.

Margareth Mead ${ }^{181}$, escreveu sua obra influenciada pelo paradigma configuracionista e também por Boas. Uma das principais aportações de Boas ao esquema de Mead é a grande influência da cultura sobre a biologia. No caso do livro sobre a adolescência em Samoa, onde Mead compara tal fase da vida das samoanas com suas homólogas norte-americanas, pretende demonstrar que adolescência não necessariamente é uma fase atribulada ou complicada como parece ser na cultura ocidental. Ou seja, Mead também defendia que existiam condicionantes culturais capazes de influenciar outras pautas da cultura como a fase da adolescência.

O trabalho de Mead tentava decifrar os sentimentos e emoções das meninas samoanas desde o início da puberdade até o casamento. Mead foi uma das defensoras das diferenças presentes no estudo da cultura e das ciências físicas. Comparava-se ela mesma ao médico e ao psiquiatra que diagnosticavam com base em cada caso e história de vida, servindo este caso, com todas suas vicissitudes, como base para uma futura tese. Mead também foi uma das primeiras a escrever claramente sobre o papel da cultura na atribuição de papéis aos gêneros. Comparando três culturas buscou verificar como variava o comportamento em função do sexo em cada uma delas. ${ }^{182}$ A mencionada obra, Sex and temperament in three primitive societies ${ }^{183}$ foi uma das primeiras a ressonar no público defensor dos direitos das mulheres. Ao demonstrar a total diferença de papéis exercidos por 180 KOTTAK, Conrad Phillip. Antropología. Una exploración de la diversidad humana con temas de cultura hispana. Madrid: Mcgraw-Hill, 1995.

181 MEAD, Margaret. Adoescencia, sexo y cultura en Samoa. Barcelona : Planeta-Agostini, 1985 182 HARRIS, 2003.

183 MEAD, Margaret. Sexo y temperamento en las sociedades primitivas. Barcelona: Laia, 1973. 
homens e mulheres nos três diferentes grupos estudados, Mead cumpre com a agenda Boasiana para reforçar o papel da cultura na atribuição de papéis aos sexos. $^{184}$

Uma das conclusões a que chegou é que o conhecimento de uma ampla gama de possibilidades de enculturação poderia levar a que as sociedades produzissem mudanças culturais modificativas das pautas até então estabelecidas. Ademais, Mead via tal possibilidade como uma solução ao determinismo cultural.

A afirmação das teorias de Sigmund Freud provocou uma grande mudança nos estudos de Antropologia Cultural, principalmente com relação aos integrantes e simpatizantes da corrente de pensamento da cultura e personalidade. Algumas obras de Freud influenciariam por muitos anos a muitos antropólogos como, por exemplo: Totem e Tabú, O porvenir de uma ilusão e o Mal-estar da Cultura ${ }^{185}$. Destaque-se, também, a grande quantidade de autores (Kroeber) para os quais a obra de Freud provocou críticas o que, nem por isso, deixa de ser importante para a teoria antropológica.

Outros autores também influenciaram e compuseram o espectro teórico de Cultura e Personalidade como, por exemplo, Abram Kardiner ${ }^{186}$. Este autor foi uma das figuras centrais das investigações antropológico-psicológicas. Kardiner desenvolveu um esquema que buscava a identificação das reações humanas a algumas realidades da vida. Defendia Kardiner ser os fatores possíveis de condicionar a personalidade bastante mais numerosos e, também distintos, daqueles outrora elencados por Freud.

Kardiner faz uma intepretação da religião como sistema projetivo o qual poderia ser utilizado para integrar outras atitudes individuais dentro de um maior panorama social. Além disso, defende, também, de maneira bastante similar a Benedict, o conceito de personalidade básica de cada sociedade, sobre a qual se construiriam e desenvolveriam as personalidades individuais com uma ampla variedade de formas e, até mesmo, casos de inadaptação. A ideia da personalidade

184 CALVO BUEZAS, Tomás y BARBOLla CAMARERO, Domingo. Antropología: Teorías de la Cultura, métodos y técnicas. Badajoz: Abecedario, 2006.

185 CALVO BUEZAS, 2006.

186 KARDINER, Abram. El individuo y su sociedad : la psicodinámica de la organización social primitiva.

México: Fondo de Cultura Economica, 1945. 
básica é deveras semelhante ao conceito, proposto por Benedict, de pautas de culturas estruturantes de determinada cultura como os apolíneos e dionisíacos.

Ademais, Kardiner também apresentou o conceito de instituições primárias e secundárias. As instituições primárias seriam aquelas mais estáveis e menos suscetíveis a variações, sejam em razão do ambiente, seja em razão do clima. Poder-se-ia apontar como instituições primárias na visão de Kardiner a família, por exemplo. As instituições secundárias, a seu turno, seriam aquelas destinadas a mitigar as tensões criadas pelas instituições primárias como, por exemplo, a religião e a ideologia.

A importância da contribuição de Kardiner está no fato de que provavelmente é o intento mais sério e profícuo de explicar as questões mágico-religiosas. A partir da consideração da relação do indivíduo com as instituições primárias e secundárias seria possível prever sua personalidade. No entanto, um dos grandes problemas de Kardiner é jamais haver determinado de alguma maneira como nascem e tomam forma a instituições primárias, deixando a cargo apenas da história tal tarefa ${ }^{187}$.

Por fim, ainda que restem muitos outros antropólogos com interessantes contribuições no campo da cultura e personalidade, caberia citar Ralph Linton. Talvez Linton tenha sido um dos que, junto com Kardiner, ampliou as fronteiras do campo da cultura e personalidade, criando novos paradigmas. Linton conceituou a cultura como a "herencia social íntegra de la humanidad"188", ou seja, um comportamento que é acumulado e transmitido. Linton também foi pioneiro no que toca à interdisciplinariedade ou multidisciplinariedade das ciências sociais, integrando estudos de psicologia, sociologia e antropologia.

Linton também defendeu a noção de comportamento base de um determinado grupo humano. No entanto, Linton não é tão radical como Ruth Benedict, cedendo mais espaço às variações possíveis nas personalidades dos indivíduos, ainda que no bojo de determinado comportamento base. Embora exista a influência de um comportamento modal este não condiciona exatamente as personalidades que serão formadas em determinado contexto já que as 
possibilidades de interação e retroalimentação entre comportamento base e personalidade são praticamente ilimitadas.

\subsection{A escola sociológica francesa}

A escola sociológica francesa tem Emile Durkheim como seu principal expoente. Durkheim acaba por influenciar, através de seu sobrinho e discípulo Marcel Mauss, várias gerações de cientistas sociais franceses. Cabe destacar, Marvin Harris sinaliza, e não sem razão, que os franceses sempre entenderam por antropologia somente a antropologia física ${ }^{189}$. Ou seja, ainda que com o nome de escola sociológica, a devemos entender como escola das ciências sociais.

Um dos pilares da escola sociológica francesa e também um dos bastiões de Durkheim é fugir do reducionismo biológico ou psicológico para explicar os fenômenos sociais. Deve-se entender os fenômenos sociais como "fatos sociais" e explicá-los através de uma ciência própria, a sociologia. Os "fatos sociais" seriam sempre externos ao indivíduo e possuem capacidade de influência e coerção sobre ele $^{190}$.

Tal inclinação de Durkheim o faz negar o racismo e as explicações dos fatos sociais a partir de certa espécie de determinismo racial. Concordar com o determinismo racial tornaria inútil uma ciência sociológica e, para Durkheim, pressupunha uma evasão aos problemas sociais ${ }^{191}$.

Para Espina Barrio ${ }^{192}$, o trabalho de Durkheim e Mauss é uma importante fonte de influência para Lévi-Strauss e a construção de sua teoria. Para o mencionado autor, é clara a influência do ponto de vista sociológico na obra de LéviStrauss o qual escreveu, inclusive, um artigo para destacar a importância de Durkheim para a etnologia.

Em dito artigo, Lévi-Strauss ${ }^{193}$ ressalta os serviços prestados por Durkheim à etnologia. Ainda que Durkheim tenha começado a tratar a etnografia com certo desdém e desconfiança, aos poucos, estudando grandes autores que realizaram 
trabalhos de campo, passou a respeitá-la e utilizá-la como apoio em suas pesquisas. Durkheim também rechaçou o uso dos dados etnográficos como valiosos pela estranheza ou raridades dos comportamentos ou sociedades descritas. Tampouco concordava com a existência de um "banco de dados" de descrições etnográficas para serem astutamente pinçadas conforme o interesse em apoiar alguma especulação sobre a evolução humana. Durkheim valorava cada experiência etnográfica em si mesma e capaz de desvendar algum tipo de verdade geral. Segundo Lévi-Strauss, no livro "Las formas elementales de la vida religiosa", Durkheim utilizou com critério e cuidado as observações etnográficas trazendo-as, assim, ao miolo da sociedade científica ${ }^{194}$.

Durkheim chegou a atribuir aos fatos sociais uma existência autônoma e os reconhecia a partir de seu poder coercitivo, isto é, a prova definitiva sobre a natureza de algo como fato social seria sua capacidade de coerção. Para Harris ${ }^{195}$, essa concepção metafísica dos fatos sociais é exagerada e o próprio Durkheim admitiria a existência de algumas pautas de condutas aprendidas e não captada dos fenômenos sociais. Durkheim também acreditava na existência de uma "alma coletiva" que encarnaria nos indivíduos, uma clara alusão à Hegel e Comte ${ }^{196}$.

Essa consciência coletiva é distinta da consciência dos indivíduos pelos quais está composta. Tampouco se trata de uma soma pura e simples das consciências. Os indivíduos são assim estudados como elementos de algo superior, um sistema mais amplo, com papéis sociais e status, perpetuados através da enculturação. Esse seria, para Durkheim, o objeto de estudo dos antropólogos ${ }^{197}$.

Durkheim teve diversas obras importantes para a sociologia e a antropologia. Por razões óbvias, "A divisão do trabalho social" é fundamental para o presente estudo, bem como as "Lecciones de Sociología: física de las costumbres y derecho". Tais textos serão analisados em momento posterior, pois tratam especificamente do tema da divisão do trabalho e da formação de grupos sociais, bem como sua importância para as mudanças sociais. De fato, as "Lecciones de Sociología" começam com seus três primeiros capítulos destacando a moral profissional e 
algumas questões sobre a organização social a partir de ofícios. Portanto, para ilustrar as perspectivas da Escola Sociológica Francesa analisaremos outro fundamental texto de Durkheim: "As regras do método sociológico". E, não podemos deixar de analisar o sobrinho e discípulo de Durkheim, Marcel Mauss e seu texto "Dones y Devolución", também importante para a influência exercida pela escola sociológica francesa.

Nas "Reglas del Método Sociológico ${ }^{198 " ~ D u r k h e i m ~ p r o c u r a ~ r e s u m i r ~ s u a s ~ o b r a s ~}$ anteriores e estabelecer os parâmetros para a ciência sociológica. O autor procura destacar como se deve buscar a explicação para a existência de pautas sociais. Durkheim ressalta, na esteira de Tylor, existirem costumes sobreviventes, isto é, que existem sem um fim específico, como mera reminiscência de tempos anteriores e que permanece em razão da inércia dos hábitos. Ainda, ressalta serem os órgãos independentes da função que exercem, sendo possível o mesmo órgão (seja ele social ou biológico) realizar funções distintas.

Neste sentido, afirma o autor que, para explicar um fato social, é necessário investigar separadamente a causa que o produz e o efeito por ele cumprido. Mesmo assim, afirma ser a existência dos fatos sociais independente dos resultados que por ele são produzidos. Por isso, um fato social não é "criado" a partir da antecipação feita de seu resultado esperado e sim como forma de manter a causa da qual deriva. Parece estar claro para Durkheim ser necessária a utilidade de um fato social para a manutenção deste. Do contrário, se gerasse mais esforços que benefícios, seria eliminado ou tornaria muito difícil a vida social.

Durkheim advoga pela eliminação do componente individual na explicação dos fatos sociais. A própria natureza da sociedade deve ser capaz de fornecer elementos explicativos para os fatos sociais. A pressão exercida sobre os indivíduos, em maior ou menor grau, é o signo distintivo da sociedade. Conclui-se então, ser a sociedade algo mais que a simples soma dos indivíduos dos quais está formada. Forma-se, a partir daí, uma nova realidade psicológica, de cunho coletivo, uma verdadeira "individualidade coletiva" onde se deve buscar a explicação dos fatos sociais.

198 DURKHEIM, Emile. Las reglas del método sociológico. Madrid: Akal, 1987. 
A "individualidade coletiva" a que se refere Durkheim não é contraditória ou sem sentido. Por individualidade coletiva devemos entender a consciência única formada por uma coletividade determinada. Essa consciência é, a sua vez, distinta dos indivíduos que a compõem e diferente de outras consciências coletivas formadas por outros agregados de indivíduos. Essa "individualidade coletiva" é, portanto, uma consciência coletiva perfeitamente possível de individuar e distinguir das demais.

Ainda, Durkheim repisa a questão de não associar os fatos sociais com fatores psicológicos. Para ele, não se pode explicar a família e o matrimônio, por exemplo, por uma tendência natural de afeição presente no ser humano. Para o autor, o segundo é consequência dos primeiros e não ao revés. Para corroborar seu argumento, ressalta a imensa variedade de distintas formas de parentesco e organização familiar existentes.

O autor também foi importante no seu rechaço ao racismo. Durkheim foi peremptório ao dizer que nenhum fenômeno social poderia ser creditado às diferenças raciais. $E$, acrescenta que, em sociedades de mesma raça se podem encontrar diferentes tipos de costumes e organizações enquanto que o contrário também é verdadeiro para raças distintas.

A partir de tais premissas, Durkheim formula duas proposições para o estudo sociológico. A primeira delas é que as causas determinantes dos fatos sociais devem ser buscadas nos fatos sociais antecedentes e não nas consciências individuais. A seguinte é de que a função de um fato social deve ser buscada na relação com seu fim social.

Por outro lado, a condição primeira dos fatos sociais, para Durkheim, é a forma de associação das partes que compõem esse grupo maior denominado sociedade. Desta feita, para o sociólogo, incumbiria a tarefa de descobrir, no meio social, formados por indivíduos, coletivos e coisas, os processos capazes de alterar a ordem dos fatos sociais.

Durkheim cita especificamente o caso das corporações profissionais para ilustrar a importância exercida por tais coletivos com relação ao todo social. No caso das corporações profissionais, estas podem ter sua importância mais ou menos 
estendida conforme a profissão está mais ou menos regulada. A força da constituição de cada corporação profissional (circunstância que, ao que se depreende, poderia ser extrapolada a outros grupos sociais como a família, por exemplo) determinará a intensidade de sua influência no conjunto total e também a quantidade de influências recebidas deste.

Para o autor, a pressão e o controle sociais exercidos sobre o indivíduo não podem ser consideradas como fatos naturais e criados pelo mesmo indivíduo. A sociedade está destinada a exercer coações sobre o indivíduo e impedir-lhe de produzir ações antissociais. O indivíduo viveria em um estado natural de dependência e inferioridade mitigado pela vida em sociedade. Por isso, tem interesse na vida social e realizará pequenos sacrifícios diários da vontade individual para poder seguir vivendo em sociedade.

Durkheim, como já mencionado, possui diversas outras obras de relevo, duas das quais serão abordadas posteriormente neste trabalho dada a sua especificidade com relação ao tema do trabalho. São notáveis, no entanto, as influências recebidas de Durkheim, principalmente de Spencer e Comte. Ambos recebem diversas críticas e discordâncias de Durkheim. Contudo, acredita-se ser este o caminho correto para o progresso da ciência, a tese, a antítese e a síntese e assim sucessivamente. Para ilustrar a Escola Sociológica Francesa mencionaremos um dos seguidores de Durkheim, Marcel Mauss.

Marcel Mauss teve o valor de escrever sobre um tema cotidiano e sobre o qual muitos de nós já provavelmente já refletimos. Trata-se da questão dos presentes e da obrigação de recebê-los e devolvê-los, além de toda uma série de costumes sociais originadas de tal prática. Aliás, a prática de dar e devolver presentes acaba por gerar ao redor de si uma série de outros costumes ou práticas sociais acessórias. Por vezes, o dar e devolver presentes é apenas o início ou a desculpa para outras atividades como o comércio ou a política.

O texto em comento é o "Ensayo sobre los dones. Razón y forma del cambio en las sociedades primitivas ${ }^{199 ",}$, de Marcel Mauss, publicado pela primeira vez em 1923, na Anné Sociologique. Mauss começa com a constatação de que, na cultura 
escandinava, sob a aparente forma livre e desinteressada, esconde-se uma verdadeira obrigatoriedade de dar e devolver presentes para tornar efetivos os contratos e as trocas. Há, para ele, obrigação e interesse econômico em tais prestações.

Por outro lado, o autor ressalta ser comum nas sociedades primitivas a assunção de obrigações e a satisfação das mesmas de forma coletiva. Não são os indivíduos que intercambiam bens ou celebram contratos e sim as coletividades, representadas pelo chefe de ditas coletividades. Neste sistema, chamado por Mauss de sistema de prestações totais, há um intercambio não só de bens ou riquezas, mas também de matrimônios, festas, rituais, serviços militares, feiras e são rigorosamente obrigatórias. Nesta categoria de prestações totais também se inclui o potlach onde toda a tribo ou clã celebra o potlach por tudo que possui buscando eclipsar a tribo ou clã vizinha e associada na troca de bens.

Mauss diz que os primeiros contratos e obrigações de reciprocidade da humanidade foram com os espíritos dos mortos e os deuses. Os sacrifícios e doações realizadas aos deuses são uma forma de presente que deverá ser necessariamente devolvido respeitando a regra da reciprocidade.

Mauss faz muitas referências às experiências de outros antropólogos, a exemplo de Malinowsky e sua descrição sobre os sistemas avançado de intercambio de bens encontrado em Trobriand. Para Mauss, é a "más neta, completa y consciente y por otro lado más fácil de entender para el observador que la que Malinowski ha encontrado en Trobriand. ${ }^{200 " ~ S e g u n d o ~ e l e, ~ t o d o ~ o ~ e n t o r n o ~ d a s ~}$ sociedades praticantes do kula é invadido pela prática nos aspectos econômico, tribal e moral dos habitantes de Trobriand.

Em outra passagem de seu texto, Mauss atribui aos bens trocados um caráter mítico e imaginário, assemelhando-se às considerações de Frazer quando fala da magia de contato ou homeopática. Acredita Mauss que os bens trocados não se desprendem de seus antigos donos e de certa maneira exercem influência sobre o novo proprietário, criando a obrigação do recebedor para com o doador. 
O sistema de doações e devoluções revela, também notável interesse jurídico. Mauss constata algo bastante verdadeiro: a pouca preocupação dos juristas com práticas como a de dar presentes e os reflexos de tal prática na sociedade e no mundo jurídico. Para o mencionado autor o doar um presente introduz duas noções jurídicas importantes. A primeira delas é a noção de crédito, isto é, ao dar um presente e este ser aceito o doador credita-se por algo semelhante. A segunda noção é a de prazo diferido para o pagamento. O crédito será satisfeito quando exista a oportunidade.

O sistema de intercambio de presentes supõe a dilação no tempo e a ausência de uma ambição imediata em satisfazer o crédito sob pena da desonra daquele ambicioso imediatista. Para Mauss, inclusive, os contratos evoluíram apenas para encurtar o espaço temporal entre o dar e receber, a compra e venda torna imediata e mais materialista uma prática outrora bastante ritualizada.

Citando os Kwakiutl, Mauss fala das três obrigações daqueles envolvidos nas práticas de intercambio de presentes ou nos rituais de potlach, são elas: dar, receber e devolver. A obrigação de receber pode parecer a de mais fácil cumprimento mas não é tão simples. Não há a possibilidade de rechaçar o presente recebido. $O$ rechaço é quase como a não devolução. Entenderiam os Kwakiutl que a negativa em receber deve-se ao medo da obrigação de devolução. Por isso, aquele que nega-se a receber é tão vergonhoso como não devolver o presente recebido ou não devolvê-lo à altura.

Após haver analisado diversas formas de intercambio de bens e rituais em sociedades consideradas por ele como primitivas são uma fase intermediária entre outra duas. A sociedade que prática o sistema de intercambio, já teria superado a fase de prestações totais (obrigação de todo um clã ou toda uma tribo para com outro clã ou outra tribo determinada). De outro lado, tal sociedade ainda não chegou ao sistema de contratos individuais e de circulação pura e simples de dinheiro e mercadorias.

Mauss também analisa o direito romano (em uma fase que denomina antiquíssimo) para verificar como era a tradição do intercambio de presentes e rituais entre estes. $\mathrm{O}$ autor refere que as coisas dadas se revestem de um caráter 
espiritual e assim seria a origem das arras, algo mais que uma simples antecipação do preço, estabelecem uma ligação entre as partes. Da mesma maneira, o conceito romano de família o qual compreende as coisas (res) e as pessoas da casa.

É bastante interessante a proposta de origem da palavra réu feita por Mauss. O reus é o que contrata, o que recebeu a res de outro e, por isso, fica vinculado à ela (em outro sentido, possuído por ela). A derivação da palavra caminharia no sentido de que o reus é aquele individuo implicado no negócio causado pela coisa e, mais modernamente, o culpável ou responsável. Ao receber alguma coisa, o indivíduo que a recebe torna-se um quase culpado, inferior espiritualmente com relação ao que a deu e dependerá do pagamento para liberar-se da obrigação e da culpabilidade.

Já ingressando nas conclusões, Mauss sente-se aliviado ao constatar que, felizmente, nem tudo está por nós classificado em termos de valores monetários. Persistem, todavia nas sociedades modernas, algumas coisas com valores sentimentais e a moral que orienta os costumes. Segundo, também, a própria caridade de hoje, fere aquele que a aceita e a sua moral concentra esforços em evitar a injuriosa esmola ${ }^{201}$. Há uma moral distinta, segundo o autor, no caso dos industriais e comerciantes no intuito de seguir as coisas que produziram e de ver que o resultado de seu trabalho é revendido sem nenhum benefício para eles.

Mauss aponta especialmente as profissões liberais como guardiãs de uma moral elevada e de um alto grau de solidariedade corporativa que são também favoráveis às necessidades do trabalho. Ao mesmo estilo que Durkheim, as questões dos trabalhadores, ocupavam a pauta de Mauss. Ao referir-se aos sindicatos, o autor comenta que tais entidades pregam advogar pelo interesse geral tanto quanto pelo interesse individual dos seus associados, no entanto, parece que são belas metáforas e que, na verdade, as entidades possuem preocupações mais simples como o recebimento regular do pagamento pelo trabalho.

O autor reputa como fato central para a evolução a estabilização das relações no seio dos grupos sociais. O dar, receber e devolver foi crucial no aprendizado de intercambio de bens e satisfação de interesses sem o necessário recurso às armas. 
Por fim, Mauss argumenta que a Antropologia Social, a Sociologia e a História ensinam como "caminha" o pensamento humano. Conhecer-nos a nós mesmos é uma das formas de melhorar.

Cabe destacar que Mauss foi autor de outros inúmeros textos que ajudaram a conformar a Escola Sociológica Francesa e a influenciar muitos pesquisadores contemporâneos e posteriores. Está clara a importância desta escola no desenvolvimento da teoria antropológica, principalmente defendendo a validade de experiências únicas provenientes do trabalho de campo bem como mudanças de paradigmas com relação a observações de fatos totais. De fatos que não possuem um só aspecto, são ao mesmo tempo importantes no público e no privado, são à vez econômicos e religiosos, políticos e domésticos. Tudo isso afasta nosso afã de tentar reduzir os fatos para estudá-los, podendo existir grande valor na compreensão destes tipos de fatos totais, dos quais um dos exemplos é o potlach. Precisamente aqui reside um dos logros de Mauss, aprofundar a análise de fatos como o kula com um olhar distinto, podendo retirar da bem sucedida experiência de Malinowski mais proveitos para a ciência antropológica.

\subsection{O funcionalismo}

A explicação dos fatos de interesse antropológico não pode ser definida apenas pelo papel desempenhado, mas sim pela sua relação e importância dentro do sistema social considerado como um todo. Malinowski teve o valor de buscar a função desempenhada por aparentes extravagantes ou tradições sem sentido que eram chamadas simplesmente de "costumes selvagens". A visão de que os mais complexos rituais ou estranhos costumes cumprem, ainda assim, um papel relevante naquele sistema social tornou-se lugar-comum da antropologia após as contribuições de Malinowski. A covada ${ }^{202}$, por exemplo, deixava de ser uma excentricidade para ser um ato que destacava as obrigações do pai para com o filho.

A obra de Malinowski é cheia de bons exemplos e valiosas contribuições para a Antropologia. No entanto, neste ponto, utilizaremos sua obra-prima, em nosso entender, como exemplo do funcionalismo e do trabalho de campo etnográfico. Em

202 Costume no qual, logo após dar a luz, a mãe retoma suas atividades normais e o pai se queda no leito com o recém-nascido sendo atendido pela esposa que acaba de dar à luz. Tal costume é associado com algumas regiões da Provincia de León, como a Maragatería. 
outras partes do texto utilizaremos outras obras suas já que Malinowski também foi um dos antropólogos preocupados com o estudo da lei e do direito de outros povos, bem como nas definições sobre estes aspectos oferecidas por outras culturas. $O$ livro "Os Argonautas do Pacífico Ocidental ${ }^{203 "}$ descreve a vida do autor na Melanésia, nas ilhas Trobriand, um arquipélago a norte da ponta mais oriental do que hoje conhecemos como Papua-Nova Guiné.

$\mathrm{Na}$ introdução da obra, Malinowski parece descrever um tratado de metodologia etnográfica. De fato, o autor explicita os princípios e métodos que, para ele são fundamentais para a realização do trabalho de campo em antropologia. Uma das primeiras afirmações do autor é sobre a necessidade de especificar com detalhe as condições do trabalho de campo. Compara, o autor, o trabalho de campo etnográfico com trabalhos experimentais no campo das ciências exatas onde é necessário descrever minuciosamente as condições do experimento levado à cabo. Além disso, Malinowski ressalta a necessidade de que se possa diferenciar, no relato, as descrições, os aportes do indígena e as deduções do autor do texto. Diminuir a distância entre os dados concretos e as teorizações e deduções é a principal missão do etnólogo, de acordo com Malinowski.

Para Malinowski, depois de descrever alguns princípios básicos do trabalho de campo, semelhantes aos que propõe Espina Barrio ${ }^{204}$, no seu decálogo do investigador de campo, existe um ideal fundamental do trabalho de campo. Tal ideal é "dar un esquema claro y coerente de la estructura social y destacar, de entre el cúmulo de hechos irrelevantes, las leyes y normas que todo fenómeno cultural conlleva. ${ }^{205 "}$

Malinowski também afirma existirem diversos fenômenos que não podem ser apreendidos com interrogatórios ou análise de documentos, para esta classe de fenômenos, e que somente a observação direta pode revelar seus aspectos mais interessantes. Cita como exemplo as sobrevivências, conceito consagrado por Tylor $^{206}$ e já por nós referido anteriormente. As sobrevivências, para Malinowski, residem principalmente nos aspectos acessórios de cada comportamento. Assim, o 
etnólogo deve empenhar-se em fazer com que os fatos falem por si mesmos. Quando acompanha uma cerimônia, por exemplo, tão importante quanto a cerimônia em si são as ações dos atores e dos espectadores. Para este tipo de trabalho, Malinowski anuncia a necessidade do que depois ficou conhecido como observação participante, ou seja, que o pesquisador abandone a câmera, o caderno e o lápis para intervir no acontecimento.

Por outro lado, Malinowski define que captar os pensamentos, impressões e experiências pessoais dos indivíduos somente interessa para antropologia sobre o que sentem e pensam tais indivíduos enquanto membros daquela comunidade estudada. Além disso, o autor anuncia as dificuldades da tradução de expressões para dar uma ideia fiel daquilo que foi dito. Para ele, as declarações de importância devem ser sempre citadas ipsis litteris, justamente pelas dificuldades encontradas na tradução para expressar esses momentos de importância. Seguir os postulados enumerados pelo autor, para ele, possibilita captar o mundo segundo o ponto de vista do indígena, sua posição e sua visão de mundo.

A partir de então, a obra passa a dedicar-se ao trabalho monumental, um dos mais significativos do século $X X$, que foi a descrição e "descoberta" do Kula enquanto sistema ritual de intercâmbios. Para chegar a uma descrição fiel do Kula, Malinowski descreve vários aspectos secundários (com relação ao Kula) e que tocam pontos importantes da vida indígena. A descrição, segundo destaca o próprio autor, apresenta-se desde o ponto de vista trobriandês. O distrito do Kula compreende várias ilhas e cobre uma área bastante extensa. Malinowski refere alguns distritos e desde logo não limita o Kula a estes. O Kula se dava nas ilhas Trobriand, nas Amphlett, nas Woodlark (Murua), nas Samarai, na Ilha de Dobu e também na costa sul da Nova Guiné. As comunidades do Kula são assim divididas entre aquelas que realizam expedições independentes e possuem limites máximos de associação para todos seus membros.

O Kula, para o autor, parece ser uma nova classe de fato etnológico até então desconhecido, daí a justificativa do termo descoberta utilizado no parágrafo anterior. O intercâmbio do Kula é algo novo na medida em que é um intercâmbio de objetos capaz de provocar um desejo competitivo e conceder prestígio e distinção social. Os objetos valiosos integrantes do Kula (vaygu'a) nunca são utilizados como moeda de 
troca para transações comerciais. Possuir um vaygu'a é em si mesmo um objetivo que reconforta e concede prestígio ao possuidor.

Malinowski define o Kula como um tipo de intercambio tribal de grande envergadura executado por comunidades que ocupam um amplo círculo de ilhas e constituem um circuito fechado. Neste circuito circulam, com exclusividade, dois produtos, sem cessar e em sentidos contrários. No sentido horário circulam longos colares de conchas vermelhas chamados de soulava. No sentido anti-horário circulam braceletes de conchas brancas chamados mwali. Todos os movimentos e as transações são determinados por uma série de normas, convenções e tradições. Uma destas normas é a de que "uma vez no Kula, sempre no Kula", seja com respeito aos participantes, seja com relação aos próprios objetos. A associação entre indivíduos que intercambiam os artefatos permanece por toda a vida.

Em conjunto com as cerimônias e intercâmbios do Kula uma série de outras transações é efetuada, em momentos distintos e sem a mesma grandeza ritual, mas aproveitando a viagem e a visita, são negociados, importados e exportados produtos de uma comunidade à outra. Segundo Malinowski, os próprios indígenas não têm noção do Kula como instituição, de maneira que somente podem apreciar uma parte dele e são incapazes de ver o todo. Trata-se, o Kula, de uma ampla rede de relações intertribais impulsionada por um interesse comum no intercâmbio de braceletes e com diversas outras relações secundárias. Malinowski adverte que o Kula é realmente é o centro da atuação dos indígenas, por ele se fixam as datas das festividades e se realizam expedições. O comércio intertribal é apenas secundário com relação ao Kula.

A relação entre dois associados no Kula é como a de dois amigos que se devem respeito e reciprocidade. O tipo de presente que deve ser dado por um a outro vem determinado pelas posições geográficas da residência de cada um. Assim, cada artigo somente anda em uma mesma direção e demora aproximadamente dez anos em dar um volta completa. Nenhum dos presentes recebidos pode ser retido por muito tempo e deve retornar ao círculo. As conversas sobre a origem do artigo recebido e as intenções sobre para quem doar-lhe são um dos temas preferidos de conversação, segundo Malinowski. 
Outro dos princípios do Kula é o equilíbrio e equitatividade nas relações. Em outras palavras, um presente de colar deve ser retribuído com um bracelete equivalente. A competição é sobre quem é o doador mais generoso. Quem recebe um presente notavelmente inferior ao doado anteriormente se vangloria de sua grande generosidade face à mesquinhez do associado. A generosidade no Kula atrai um grande número de proposições comerciais e de associação.

Importante destacar que no Kula não pode existir nenhuma espécie de pechincha sobre os objetos. Quem determina o que dará é o doador e toda oferta exige ser correspondida após algum tempo por outra similar. Aquele que recebe um presente valioso (vaygu'a) e não tem condições de retribuir de maneira equivalente em um futuro próximo faz doações de presentes intermediários conhecidos como basi.

Malinowski dedicou também várias linhas ao tema da organização e divisão social do trabalho entre os trobriandeses. Os esforços são organizados e dirigidos por algum tipo de autoridade, principalmente nas atividades mais complexas, como a construção de canoas. A organização do trabalho está fundamentada em dois fatos principais, a diferenciação de funções e a regulamentação mágica do trabalho.

De outra banda, Malinowski afirma que a ganância imediata nunca é motivação suficiente para o trabalho dos indígenas. A divisão de tarefas está enraizada na própria estrutura social, existem os proprietários da canoa, outros tomavam parte no trabalho como serviço ao chefe local, outros iriam obter benefícios posteriores com o uso da canoa e outros deveriam ser remunerados. Segundo Malinowski o que impele os indivíduos a cumprir com seu dever é a tradição, segundo sua posição e para manutenção de seu status quo. A simplista afirmação de que o "direito é a força" não teria aplicação para a sociedade trobriandesa.

Um dos aspectos observados por Malinowski é a divisão do trabalho entre homens e mulheres. As mulheres possuem parte do trabalho de agricultura sob seu controle e este controle é considerado mais um privilégio que um dever. Destaquese que os indígenas, segundo a descrição de Malinowski, dedicam a metade do tempo laboral ao cultivo horticultor e muito dos seus interesses e ambições giram em torno a tal atividade. Além disso, os indígenas trobriandeses levam o orgulho 
profissional muito a sério e são realizadas muitas tarefas pouco úteis, com finalidade puramente ornamental nas hortas e campos de cultivo.

Antes de que sejam iniciados os trabalhos da horticultura os campos são consagrados em um ritual mágico levado a cabo pelo "mago das hortas", um personagem de poder e prestígio que realiza rituais prévios a cada nova fase de trabalho e de desenvolvimento das plantas. O mago também é responsável pelo controle do trabalho, marcando o ritmo através dos rituais mágicos. As considerações sobre o trabalho indígenas nas hortas, principalmente sobre sua preocupação com o aspecto ornamental e com a magia, foram utilizadas por Malinowski para refutar a concepção materialista da história que aponta o homem primitivo como movido por motivos puramente econômicos e visando a benefícios imediatos. Os exemplos trobriandeses, para Malinowski, entre muitos outros, servem para refutar tão falaz teoria.

O horticultor trobriandês obtém prestígio em razão de sua capacidade de trabalho e recebe o título de tokwaybagula, com significado de "bom/eficiente horticultor". Ademais, quase todo o fruto do trabalho pessoal se destina não ao próprio horticultor ou a sua família (aqui entendida como sua esposa e seus filhos), mas sim aos seus aliados políticos, aproximadamente três quartos da produção são destinados ao chefe tribal e à família da irmã. Para Malinowski, todas estas evidências denotam a enorme diferença entre o homem primitivo de carne e osso e o "homem econômico" das deduções escolásticas de economia abstrata ${ }^{207}$.

Malinowski oferece também uma distinção entre trabalho organizado e trabalho comunitário. O primeiro trata-se de um trabalho feito a partir da cooperação entre diversos fatores sociais e econômicos. Já o segundo se trata apenas de diversas pessoas trabalhando conjuntamente em um esforço comum sem diferenciação hierárquica ou de funções. Nas hortas, por sua vez, existem diversas formas de trabalho comum segundo quem convoca a realização do trabalho e quem toma parte no mesmo.

$\mathrm{Na}$ realidade trobriandesa, alguns trabalhadores sempre são remunerados pelo seu trabalho, seja, os experts, técnicos na construção das canoas que dirigem o 
trabalho braçal dos demais. O especialista recebe uma oferenda inicial de alimentos e é alimentado com manjares durante todo o processo, se necessitar viver fora de sua casa durante a construção. Se mantém sua residência, o futuro proprietário da canoa realiza visitas periódicas com ofertas de alimentos e já fiscaliza a evolução do trabalho.

O autor Óscar Fernández ${ }^{208}$, em sua obra sobre Malinowski, a antropologia e o funcionalismo, destaca diversas contribuições originais daquele autor para as ciências sociais. Uma destas contribuições é no sentido de desprezar as relações entre o indivíduo e sua descendência, pois, para Malinowski, a ligação entre pais e filhos descansa principalmente sobre afetividade e emotividade e, por isso, o papel do indivíduo e suas características psicológicas ganham importância. Segundo Óscar Fernández, Malinowski buscava desvincular a família nuclear das superestruturas, principalmente as de natureza jurídica.

A obra de Fernández também nos ajuda na compreensão de alguns conceitos desenvolvidos por Malinowski e que acabaram tornando-se lugar-comum das ciências sociais, explicadas muitas vezes sem a profundidade e o conhecimento como faz o professor Fernández. Um exemplo é a diferenciação entre baloma e kosi para os nativos de trobriand. Baloma seria a forma principal e mais perene da alma do defunto e Kosi é uma classe de alma mais complexa e não tão bem definida. Kosi é uma espécie de alma do defunto que soe vagar pelos lugares frequentados pelo morto nos dias que seguem à defunção. Sendo assim, Baloma é associada ao reflexo do indivíduo no espelho e Kosi associada a sua sombra. Outra das crenças sobrenaturais dos trobriandeses é sobre a fecundação. Para eles, a gravidez é sempre consequência de um espírito que abandonou o mundo dos mortos para voltar ao mundo dos vivos e alojou-se no útero materno. Esse novo ser tem participação direta e fundamental de algum antepassado da mãe, o qual lhe trará a necessária força vital ${ }^{209}$.

É importante destacar, como já dedicamos algumas linhas, as questões apontadas por Malinowski com relação à antropologia econômica. Reforça-se a proibição do regateio no Kula como uma das suas principais características. 
Malinowski também chegou a conclusões sobre o papel de cerimônias e festas na organização do trabalho. O trabalho com importância econômica, para Malinowski, deve ser sustentado, repetido e planejado racionalmente. O autor também destacou a importância do totemismo como indutor de uma incipiente divisão do trabalho. As cerimônias e festas tinha um importante papel em propiciar um árduo trabalho dividido e organizado. Essas e outras conclusões de Malinowski hoje parecem simplórias e óbvias, mas contribuíram enormemente na relativização das teorias evolucionistas $^{210}$.

Em sua análise econômica dos aspectos da família trobriandesa, Malinowski relacionava a divisão do trabalho no seio da família para estabelecer a unidade do grupo social. Tinha importância fundamental para o trabalho trobriandês a função do mago das hortas, que controlava os tempos de início do trabalho, fixava controles de qualidade e impunha tabus que acabavam por determinar formas de execução do trabalho. A atuação do mago das hortas contribuía grandemente para a efetividade e produtividade do trabalho horticultor. Malinowski também foi responsável pela análise dos valores de troca dos objetos e por distinguir os objetos valiosos por seu uso ritual e os valiosos por seu valor prático ${ }^{211}$.

Malinowski também destacou os problemas da tradução de expressões indígenas pelo uso distinto da língua que faziam os naturais de Trobriand. $O$ autor se dá conta da ineficácia de uma tradução literal, palavra por palavra, para alcançar ao leitor inglês o mesmo significado pretendido pelos trobriandeses ${ }^{212}$. Malinowski adianta, também, um conceito que será recuperado na teoria antropológica décadas depois, como a interpretação fenomenológica, ou seja, a importância do contexto de fundo para a produção do significado linguístico.

Malinowski define uma teoria das necessidades que, segundo ele, conduzem ao desenvolvimento da cultura. As necessidades orgânicas, obrigam a comunidade a realizar atividades organizadas. Nesse sentido, as regularidades das culturas como a religião e a lei podem ser concluídas como resultado de necessidades profundas. Por isso, a definição de função pode ser dada como a satisfação de necessidades por meio de uma atividade na qual os seres humanos cooperam. 
Neste aspecto, um dos tipos de instituições referidos por Malinowski são as ocupações e profissões. Refere o autor que nas sociedades civilizadas existem diversos grupos organizados em torno a um interesse econômico e também associações profissionais no campo da medicina, do direito, ensino, sacerdócio etc $^{213}$.

Assim, é possível destacar alguns eixos centrais do funcionalismo de Malinowski. Primeiramente, destaca o caráter de patrimônio instrumental da cultura como forma de solucionar problemas para satisfazer necessidades; em segundo lugar, as atividades e objetos estão organizados ao redor de instituições sociais como a família, equipes organizadas para cooperação econômica e para atividades políticas, judiciais e educativas. Fernández assim conclui sobre a importância de Malinowski: "aún cuando hoy la ciencia se incline por la segmentación en disciplinas especializadas ávidas de autonomia, la noción de totalidad sigue inspirando las obras más importantes de la época moderna $(. . .)^{214 "}$.

Optamos por também mencionar, entre os funcionalistas, a Alfred Reginald Radcliffe-Brown, autor que exerceu a um papel transitório entre funcionalismo e estruturalismo. A transição e a identificação dos autores com escolas determinadas não é tarefa fácil e, invariavelmente, recolhe componentes subjetivos daquele que realiza a classificação. A obra de Radcliffe-Brown que comentaremos se chama "Estructura y función en la sociedad primitiva ${ }^{215 " . ~ N a ~ v e r d a d e, ~ a ~ o b r a ~ c o m p o ̂ e-s e ~ d e ~}$ uma coleção de ensaios de Radcliffe-Brown, reunidos em sua homenagem por Evans-Pritchard e Fred Eggan, respectivamente, professores de Oxford e Chicago.

Uma das primeiras advertências do autor consiste em diferenciar a explicação histórica de uma instituição da sua compreensão teórica. Se a pergunta é por que existe determinada instituição, o autor aponta que o correto seria uma exposição histórica da sua origem, demonstrando a cadeia fática que conduziu àquela formação. Ao estudarmos povos sobre os quais não dispomos de informes históricos, muitas vezes realizamos conjeturas e hipóteses no sentido de explicar certas instituições. No entanto, essa segunda atividade é substancialmente diferente da primeira. 
Para Radcliffe-Brown o material de estudo dedica-se à observação, descrição, comparação e classificação, não de uma entidade ou instituição, mas do processo social como um todo. $E$ tal processo social deve ser limitado a determinado lugar e a determinado tempo. Ao observar o processo, poderá identificar certas regularidades de maneira a reconstruir, ao leitor posterior, os rasgos gerais daquela sociedade. Radcliffe-Brown concebe a antropologia como o estudo teórico comparativo entre os povos primitivos.

O sentido de processo adotado por Radcliffe-Brown também aplicado aos termos cultura e tradição cultural. Segundo o autor, a cultura é uma forma de vida social transmitida mediante alguns processos de tradição cultural de uma geração à outra. Essa transmissão de formas de pensar, sentir e atuar é considerada pelo autor como um processo cultural e diferencia a espécie humana das demais espécies do planeta.

Radcliffe-Brown também revela suas influências, principalmente de Montesquieu e de Comte. O autor destaca o conceito de sistema social proposto por Montesquieu segundo o qual existem relações de interdependência e interconexão entre as diversas partes e rasgos sociais. Essa mesma interconexão foi chamada por Comte de relações de solidariedade entre os rasgos sociais. E, acrescentamos, também foi utilizada por Durkheim na explicação das solidariedades mecânica e orgânica. O autor também se reporta a Spencer para dizer que o conceito de adaptação estará presente na sua análise ao considerar que o sistema social só funcionará se estiver adaptado interna e externamente de maneira eficaz.

Em seguida, Radcliffe-Brown, nos proporciona seu conceito de estrutura que seria "una disposición ordenada de partes o componentes ${ }^{216 " . ~ O ~ a u t o r ~ t a m b e ́ m ~ d i z ~}$ que a continuidade social, ou seja, a perpetuação de determinada estrutura é um dos principais problemas sociológicos. Segundo ele, as interações entre indivíduos e grupos sociais está determinada pela estrutura social.

Os três elementos de análise, processo, estrutura e função, seriam componentes de uma mesma teoria para possibilitar a compreensão dos sistemas 
sociais. O termo função, é, para o autor, utilizado para designar a relação entre processo e estrutura.

Outra importante constatação de Radcliffe-Brown, a qual nos filiamos, é de que a crítica puramente negativa não serve ao progresso da ciência. $O$ único modo de rechaçar uma hipótese insatisfatória é encontrar outra melhor. O autor realiza esta constatação ao início de um ensaio sobre o irmão da mãe. Para o autor, também é impossível estudar determinada instituição sem estudar as demais instituições com as quais se relaciona e coexiste.

A função da ciência da cultura, para o autor, consiste em reduzir um complexo número de dados em um número limitado de leis e princípios gerais. A par disso, Radcliffe-Brown incorpora algumas influências de Durkheim para reconhecer que cada grupo tem uma relação com determinado totem como maneira de manter viva a solidariedade do grupo. Cada grupo necessita um símbolo que para representar seu segmento social.

O autor também faz considerações sobre o caráter bilateral das relações de parentesco. Isto é, os indivíduos se relacionam com certas pessoas através do seu pai e com outras através da sua mãe. Além disso, mesmo nas sociedades mais profundamente patriarcais, é possível vislumbrar sempre alguma importância no papel da mãe e de seus parentes. A principal característica das sociedades chamadas primitivas é a regulação das condutas através das relações de parentesco segundo regras já fixadas de atuação de acordo com cada grupo familiar.

O sistema social possui um componente chamado de inconsistência funcional. Como é muito difícil lograr uma perfeita harmonia entre as partes do todo, a inconsistência provoca um conflito entre as partes e produz uma mudança no sistema. Esse fenômeno é recorrente e provoca contínuas mudanças nos sistemas sociais. Por isso, o autor aponta duas leis sociológicas que justificam a sucessão unilinear (matriarcal ou patriarcal): a necessidade de direitos precisos e claros para que exista um reconhecimento geral e impeça conflito insolúveis; e, a necessidade de continuidade do sistema social através de relações definidas de direitos e deveres. 
Em seus estudos de parentesco, Radcliffe-Brown já adverte que, ao referir-se a sistema de parentesco, também inclui as demais relações do sistema como as de afinidade. O autor também já refere a família elementar formada pelo pai, a mãe e seus filhos. Em qualquer sociedade se reconhece um determinado número de relações entre os membros desta família elementar e uma série de direitos e deveres relacionados a posição ocupada por qualquer um dos membros. Assim, o sistema de parentesco, para o autor, é "una red de relaciones sociales de tipo definido que constituyen parte de toda la red de relaciones sociales que llamo estructura social. ${ }^{217 "}$ Para o autor, a nomenclatura das relações de parentesco, causadoras de tantas controvérsias entre antropólogos, são partes do sistema de parentesco e também do sistema da linguagem. Não seria possível compreender a nomenclatura sem compreender as demais relações.

O autor realiza uma análise também sobre o tabu, derivado da palavra polinésia tabu que significa proibição de qualquer gênero. Uma sociedade necessita, minimamente, de uma rede de relações sociais que una os indivíduos. Outra condição necessária é que os membros desta sociedade coincidam nos valores que reconhecem. Além disso, existem, também, diferenças entre os membros e uma das tarefas do antropólogo é descobrir uniformidades profundas debaixo de superficiais diferenças.

O autor também concorda com Maine e Fustel de Coulanges sobre o papel fundamental da religião na constituição das sociedades grega e romana. Por isso, defende a estreita correspondência entre a forma religiosa e a forma da estrutura social. Para corroborar esta explicação o autor utiliza exemplos de Grécia e de Roma e também do sistema de totemismo australiano.

Finalmente, chegamos ao ensaio onde Radcliffe-Brown detalha seus conceitos de função em ciências sociais. O conceito e a importância da função nasceram de analogia com as partes do corpo humano. A função de qualquer elemento social é o papel que desempenha em prol da continuidade social, ou seja, a sua contribuição para a manutenção da estrutura social. Dito de outra forma, a função é a contribuição que uma atividade ou um grupo parcial oferece ao todo do qual faz parte. Ademais, para o autor, não devemos partir da premissa de que todas 
as pautas sociais possuem uma função, mas sim aceitar a hipótese de que pode existir uma função e que é válido e razoável tentar descobri-la.

A estrutura social, por outro lado, é a complexa rede de relações entre os indivíduos. Cada ser humano, quando está inserto em uma determinada sociedade é à vez indivíduo e pessoa na acepção de Radcliffe-Brown. Ao utilizar o termo individuo o autor refere-se ao componente biológico de cada ser humano enquanto o termo pessoa serve para designar a personalidade social do ser humano como pai, marido, trabalhador, designa seu lugar na estrutura social. Esse papel na estrutura social também encontra a divisão do trabalho social reputada como componente importante da estrutura social.

Radcliffe-Brown faz uma importante advertência sobre a frequente habilidade dos juristas em abstrair a sociedade do estudo das leis. Certamente é conveniente abstrair a realidade para o estudo do direito. No entanto, adverte o autor, o direito é apenas uma parte mediante a qual se mantém a estrutura social. Para entender o sistema jurídico de uma sociedade, necessário estudá-la em seus outros aspectos ao mesmo tempo em que o sistema jurídico será um componente importante para o estudo de uma estrutura social.

O termo lei vem incluindo de numerosas formas de controle social, especialmente quando há a aplicação sistemática da força da sociedade. Nas sociedades primitivas, o autor aponta a distinção entre direito dos delitos públicos e direito dos delitos privados. Quando ocorre um fato que ofende a todo o grupo social e este, de maneira organizada reage contra o ofensor, caracteriza o delito público, o qual depois passa a chamar-se direito penal. Estes fatos normalmente contém um forte componente moral capaz de provocar uma ação de disforia social. Já o delito privado é aquele no qual a violação se dá em relação a uma determinada pessoa ou a uma grupo de pessoas. Os ofendidos buscarão uma compensação ou indenização pelo dano sofrido. A natureza daquilo que se considera delitos públicos ou privados muda conforme cada realidade social. O autor dá diversos exemplos onde o assassinato não é considerado um delito público, mas sim o é o incesto.

Radcliffe-Brown possui outras diversas obras ainda que Evans-Pritchard, no prólogo da obra aqui comentada, diga que o autor escreveu pouco, levando-se em 
conta sua extensa e profícua carreira acadêmica. Além disso, o próprio RadcliffeBrown não aceitava o título de inventor da escola funcional de antropologia. Aliás, o autor também repudiava as escolas em que passou-se a dividir a antropologia, para ele o cientista sempre parte do trabalho de seus antecessores e procura aportar contribuições ao corpo teórico da ciência.

\subsection{0 estruturalismo}

O estruturalismo não chega a ser uma escola propriamente dita. Na verdade, assemelha-se mais a uma orientação conectada com a linguística estrutural de Saussure ${ }^{218}$. Busca-se, na visão estruturalista, captar estruturas subjacentes ao pensamento, a linguagem e a cultura ${ }^{219}$. O principal expoente desta corrente de pensamento é Claude Lévi-Strauss o qual preparou o terreno para o florescimento e afirmação das chamadas teorias antropológicas pós-modernas. Por este motivo, o autor Espina Barrio ${ }^{220}$ apontou Lévi-Strauss como o antropólogo entre os dois mundos, moderno e pós-moderno. Na obra de Lévi-Strauss, pode-se vislumbrar alguns rasgos pós-modernos que serão depois trabalhados por autores como Geertz, Turner e Douglas.

A obra de Lévi-Strauss é bastante ampla e aqui somente nos limitaremos a comentar algumas de suas principais obras, principalmente com relação ao enfoque estruturalista e os pontos de sua obra que podem ser relacionados com 0 materialismo cultural e como prenúncio da teoria pós-moderna. Entre as obras em destaque estão as coleções de textos chamadas ambas de Antropologia Estrutural, as Estruturas Elementares de Parentesco, Tristes Trópicos e as Mitológicas.

Nas coleções de textos chamadas de Antropologia Estrutural temos o primeiro dos livros ${ }^{221}$, mais antigo, onde o autor trata questões sobre linguagem, parentesco, organização social. As estruturas, ressalta Lévi-Strauss, logo na introdução, não devem ser consideradas como a simples ordenação das partes de um todos. Para que essa ordenação de partes seja verdadeiramente estruturada é necessário que

218 SAUSSURE, Ferdinand de. Curso de linguística general. Tres Cantos (Madrid): Akal, 2006.

219 ESPINA BARRIO, 2005.

220 ESPINA BARRIO, Ángel Baldomero. Lévi-Strauss: ¿El último moderno y el primer postmoderno? in: ESPINA BARRIO, Ángel Baldomero; DE LA FUENTE, Iñigo González. Antropología de Iberoamérica: Estudios Socioculturales en Brasil, España, México y Portugal. Recife: Massangana, 2010. pp. 23-40 221 LÉVI-STRAUSS, 2015. 
atenda a pelo menos dois requisitos essenciais: que seja um sistema regulado por alguma forma de coesão interna; e, que esta coesão esteja inacessível à observação de um sistema isolado e sim revelada a partir da observação de sistema aparentemente distintos.

O autor explica neste livro, como faz em outros textos, a estreita relação entre linguística e sociologia (lembremo-nos, segundo Harris ${ }^{222}$, na França, o termo antropologia demorou muito a firmar-se). Para ele, a linguística pode revelar a persistência de relações desaparecidas, hipótese a qual poderá ser confirmada com a ajuda do sociólogo.

O sistema de parentesco, para Lévi-Strauss, comporta duas realidades completamente diferentes. A primeira é a nomenclatura utilizada para designar as relações familiares. A segunda é como os indivíduos designados por tais nomenclaturas assimilam tais nomes. Desde logo, parece restar claro para o mencionado autor que os indivíduos se sentem impelidos a determinadas condutas diretamente relacionadas com o nome dado à relação entre ele e outro, como por exemplo o dever, a hostilidade, a familiaridade ou a afeição.

O elemento de parentesco para Lévi-Strauss é resultado direto da existência universal da proibição do incesto. Registre-se, em outro ponto da mesma obra, o autor ressalta a existência da proibição do incesto como um dos caráteres da unidade do pensamento humano. Com isso o autor afirma que somente é possível obter uma mulher das mãos de outro homem, seja ela filha ou irmã. O tio materno, portanto, não surgiu com o termo avunculado, mas já existia previamente e quiçá com diferentes acepções. O avunculado é parte integrante da estrutura elementar de parentesco e integrante do átomo de parentesco.

Segundo Lévi-Strauss, o parentesco só pode estabelecer-se e perpetuar-se a partir das alianças formadas entre indivíduos e grupos. O autor critica RadcliffeBrown por tomar a família como entidade elementar quando, em verdade, o elementar são as relações entre as famílias, as quais determinam as relações de aliança e respeitam a proibição do incesto na qual a relação avuncular é uma consequência, às vezes implícita e outras explícita. 
Lévi-Strauss vai inclusive mais além, compara a linguagem com a estrutura de parentesco em que ambos são sistemas complexos e que servem para comunicar. As palavras são os signos da linguagem e as mulheres, para LéviStrauss, são os signos do sistema de parentesco. Da mesma forma, a pulsão inicial que compeliu os homens a intercambiarem palavras também pode ter influenciado a função simbólica de outros intercâmbios, entre eles o de mulheres.

Lévi-Strauss divide o globo em diversas áreas e de alguma forma estabelece a correlação entre a matriz linguística e os sistemas de parentesco. São cinco as áreas consideradas pelo autor: área indo-europeia, área sino-tibetana, área africana, área oceânica e área norte-americana. Como exemplo, utilizaremos para comentar a área indo-europeia a qual possui uma densidade tal que é suficiente para proporcionar um sistema de intercâmbios generalizados a partir de um pequeno número de proibições matrimoniais. Para propor uma analogia Lévi-Strauss ressalta que o sistema linguístico da área deveria estar formado por línguas de estrutura simples, mas que empregam uma quantidade de elementos, assim como a língua deveria possuir uma grande diversidade de elementos capazes de ocupar o mesmo espaço (mesma posição na estrutura).

Lévi-Strauss também explica porque o átomo de parentesco não pode ser considerado como uma família consanguínea isolada. Para a representação do átomo de parentesco é sempre necessário que esteja presente um elemento da família que cede a mulher. Assim, o átomo de parentesco estará formado por um marido, uma mulher, uma criança e um elemento da família que cedeu esta mulher. Desta feita, as relações entre os integrantes do átomo de parentesco determinarão o tipo de atitudes, positivas ou negativas, entre cada um dos membros. Lévi-Strauss representa os tipos de atitudes entre os membros do átomo de parentesco com os sinais + (positivo) e - (negativo) a depender de como se verificam tais relações.

É importante deixar claro o quê, para Lévi-Strauss, significa uma organização dualista. Segundo o mencionado autor, uma organização dualista é aquela dividida claramente em dois grupos menores que intercambiam direitos e deveres opostos e complementares como, por exemplo, a obrigação de casar-se com um membro do outro grupo. Lévi-Strauss ainda aponta as diferenças entre um dualismo diametral e um dualismo concêntrico. Se imaginarmos as disposições de casas e construções 
de determinado grupo em uma forma circular, na primeira hipótese entende-se existir uma divisão pela metade em que os dois lados da metade assume obrigações mútuas para com o outro grupo. No caso do dualismo concêntrico este é mais dinâmico e, como sugere o próprio nome, é formado por dois círculos concêntricos.

No entanto, a despeito de tentar entender e explicar as sociedades organizadas em forma aparentemente dualistas Lévi-Strauss não se deixa convencer pela simplicidade da explicação dualista. Para ele, na verdade, uma organização dualista revela muitas contradições e anomalias, de modo que é melhor reinventá-la, encontrar outro tipo de nomenclatura já que em seu entender a organização dualista é apenas superficial e as estruturas são bastante mais complicadas do que demonstram a simples vista.

No âmbito da magia e da religião, Lévi-Strauss também fez muitas considerações importantes. Neste sentido, diz o autor que o universo não significa nunca o bastante para o homem já que este dispõe sempre de um excesso de significações com relação aos elementos disponíveis para as relacionar. Desta forma, necessário criar um novo sistema de referência, como o sistema mágico para que este excesso de significações possa ser integrado.

A cura realizada pelos xãmas é outro exemplo em que Lévi-Strauss a compara com a psicanálise, por serem ambos métodos para trazer à consciência conflitos e resistências que permanecem no inconsciente. $O$ xamã, tal qual o psicanalista, estabelece um primeiro papel de orador (de ouvinte no caso do psicanalista) estabelecendo relações mediatas e imediatas, respectivamente, com o inconsciente e consciente do enfermo.

Ainda, no que tange a aspectos do inconsciente e subconsciente, este último seria o léxico onde cada um acumula o vocabulário de sua história pessoal. No entanto, tal vocabulário só é possível de ser inteligível se o inconsciente se encarrega de organizá-lo de forma possível a construir um discurso coerente. As estruturas do mundo simbólico são, portanto, bastante limitadas em suas leis, mas o que não impede uma imensa diversidade de conteúdo.

Estas considerações preliminares, bastante resumidas, são necessárias para que se entre em contato com as propostas de explicação da estrutura dos mitos 
propostas por Lévi-Strauss. Uma das primeiras considerações a levar-se em consideração para analisar os mitos é seu caráter contraditório e livre, onde em teoria tudo é possível. O mito está na linguagem, mas vai além da linguagem. $E$ no campo linguístico é possível situar o mito como oposto a poesia. A poesia é de muito difícil tradução de forma que preserve o sentido e a forma tal e qual o autor, no idioma original, a construiu. Já o mito, a despeito de traduções sofríveis, segue preservando o seu valor e seu significado. No mito importa muito mais a história relatada que a forma ou o estilo do relato.

Por isso, Lévi-Strauss conclui que a maneira como as partes do mito estão colocadas e combinadas é o fator de maior relevo para que o mito adquira sentido. As verdadeiras propriedades do mito devem ser buscadas em um nível superior ao da linguagem, pois são de natureza mais complexa que esta. O mito está, para ele, formado por unidades constitutivas formadas também por fonemas, morfemas e semantemas. Contudo, como o mito opera em um nível superior, é necessário encontrar essa unidade a qual o autor chamou de mitema. Ou seja, buscou resumir as sequências de acontecimentos nas frases mais curtas possíveis e agrupá-las em feixes relacionados de maneira a possibilitar uma releitura e reconstrução sequencial do mito.

O pensamento mítico, para o autor, opera com a mesma lógica do pensamento científico e isso comprova que o homem sempre pensou igualmente bem. Na verdade, as mudanças ocorreram no mundo ao seu redor e não na sua consciência. Cada vez mais o homem não se conforma com conhecer e necessita reconhecer-se como conhecedor. A humanidade muda e com ela muda significativamente o mundo tornando-se o homem cada vez mais o objeto de sua investigação.

Um exemplo dado pelo próprio autor é como a tabela seguinte ${ }^{223}$ :

\begin{tabular}{|lr|}
\hline Cadmo & busca \\
irmã & Europa \\
raptada & por Zeus
\end{tabular}




\begin{tabular}{|c|c|c|c|}
\hline & & $\begin{array}{lll}\text { Cadmo mata } & 0 \\
\text { dragão } & & \end{array}$ & \\
\hline & $\begin{array}{l}\text { Os Espartanos } \\
\text { eliminam-se } \\
\text { mutuamente }\end{array}$ & & \\
\hline & & & $\begin{array}{l}\text { Lábdaco (pai de } \\
\text { Layo) = coxo (?) }\end{array}$ \\
\hline & $\begin{array}{l}\text { Édipo mata seu pai } \\
\text { Layo }\end{array}$ & $\begin{array}{l}\text { Édipo imola a } \\
\text { Esfinge }\end{array}$ & $\begin{array}{l}\text { Layo (pai de Édipo) } \\
=\text { torcido (?) }\end{array}$ \\
\hline $\begin{array}{l}\text { Édipo se casa com } \\
\text { sua mãe Jocasta }\end{array}$ & & & Édipo = pé-inchado \\
\hline & $\begin{array}{l}\text { Etíocles mata a } \\
\text { seu irmão Polinices }\end{array}$ & & \\
\hline $\begin{array}{l}\text { Antígona enterra a } \\
\text { Polinices, seu } \\
\text { irmão, violando a } \\
\text { proibição }\end{array}$ & & & \\
\hline
\end{tabular}

As colunas verticais, em número de quatro, agrupam relações pertencentes ao mesmo feixe. Para o relato do mito seria necessário esquecer a disposição em colunas e simplesmente ler da esquerda para direita e de cima para baixo. No entanto, para superar o plano da linguagem e verdadeiramente compreender o mito seria necessário ler cada coluna como um todo.

Como se pode notar, cada coluna agrupa uma série de relações representativas de um mesmo rasgo comum (e por isso estão agrupadas de tal maneira). Na primeira coluna da esquerda estão elencadas relações entre parentes consanguíneos, que são exageradas, e há um tratamento mais íntimo entre os parentes que o recomendado ou permitido pelas regras sociais. Na segunda coluna 
produz-se o mesmo tipo de relações, mas com o sentido inverso, e as relações entre os parentes estão subestimadas. Na terceira coluna estão relacionados os monstros e sua destruição, neste caso o dragão e a esfinge. Já na quarta coluna Lévi-Strauss avança sobre uma hipótese mais elaborada, obtida a partir da comparação dos três nomes e que os três de uma mesma linha sucessória masculina representem alguma dificuldade para "andar erguido". O mito opera como um sistema de metalinguagem formando uma hiperestrutura capaz de operar em diversos níveis da linguagem. A união da linguagem e da metalinguagem constrói os mitos e contos que adquirem significado a partir da combinação entre diferentes elementos. A estruturação do vocabulário, dá-se, para o autor a posteriori e não a priori. De outro lado, os mitemas possuem uma significação já carregada a priori, pois são "palavras de palavras ${ }^{224 "}$ e funcionam simultaneamente em dois planos, o da linguagem e o da metalinguagem.

Segundo Lévi-Strauss, para os índios Pueblo, por exemplo, é frequente a representação do homem nascido na terra como com alguma dificuldade para andar erguido. A partir desta constatação Lévi-Strauss relaciona a primeira e segunda coluna como apresentado fatos contraditórios da mesma maneira como a terceira e quarta colunas. Esta contradição, para o autor, está presente no mito e faz parte de sua característica. Ademais, não é necessário empreender uma busca pela primeira ou autêntica versão do mito, o mito é composto pelo conjunto de suas variações.

As incursões iniciais no terreno da mitologia são importantes para oferecer uma introdução ao tema da estrutura em antropologia. Para Lévi-Strauss, descobrir a estrutura pode ser um método valioso a ser aplicado com relação a diversos problemas sociais, ainda que tenha sido utilizado (até o momento em que escrito o livro a que nos referimos) quase sempre com relação as estruturas de parentesco. Para que uma estrutura possa ser considerada como tal, necessita ser um sistema integrado e ordenado onde a modificação em alguma das partes acabe por provocar modificação ou alteração nos demais.

As estruturas devem ter uma determinada natureza que se lhes permita traduzir em modelos comparáveis inclusive na forma de partes isoladas. Além disso, 
para o autor, a principal tarefa do estruturalista é identificar os níveis de realidade que permitem a estruturação dos mencionados modelos.

Para Marx $^{225}$ e Engels ${ }^{226}$, por exemplo, parece ser que as sociedades chamadas primitivas são regidas por laços de consanguinidade e, as sociedades posteriores, por relações de produção. Em outras palavras, para os mencionados autores, nas sociedades pré-capitalistas, as relações de parentesco desempenhavam um papel bastante mais importante que as relações entre classes.

Outro livro de Lévi-Strauss, Tristes Trópicos ${ }^{227}$, também traz algumas considerações de interesse para nosso estudo, sobretudo no capítulo sobre os homens, mulheres e chefes dos nambiquaras. Tristes Trópicos é um livro de trabalho de campo e sobre ele. Reúne diversas passagens que podem ser objeto de uma mais profunda reflexão e aprofundamento. Aproveitamos apenas alguns deles que entendemos ser de especial interesse para nosso estudo.

No primeiro de tais trechos, o autor comenta sobre a circunstância da diminuição do grupo e a necessidade de o chefe buscar aliança em outro grupo maior, deixando, assim, de exercer a chefia:

Llegará un día en que el jefe se encontrará a la cabeza de un grupo
demasiado pequeño para hacer frente a las dificultades cotidianas o
para proteger sus mujeres contra la codicia de los extranjeros. En
ese caso no le quedará más remedio que abandonar su mandato y
unirse, con sus últimos compañeros, a una facción más feliz. Se ve
entonces que la estructura nambiquara está en estado fluido. La
banda se forma y se desorganiza, crece y desaparece. En el
intervalo de pocos meses, su composición, sus efectivos y su
distribución se hacen a veces irreconocibles. Intrigas políticas en el
interior de la misma banda y conflitos entre bandas vecinas imponen
su ritmo a estas variaciones, y la grandeza y la decadencia de los
individuos y de los grupos se suceden de manera a veces
sorpreendente.

Esta organização fluída em muito lembra aspectos da vida moderna e também é comparável ao sistema de alianças dos $\mathrm{Nuer}^{229}$. Na descrição efetuada

225 MARX, Karl. El capital: critica de la economia política. México: Fondo de Cultura Económica, 1984 226 ENGELS, 2008.

227 LÉVI-STRAUSS, Claude. Tristes Trópicos. Barcelona: Paidós, 2002.

228 LÉVI-STRAUSS, 2002. p. 331.

229 EVANS-PRITCHARD, Edward Evan. Los Nuer. Barcelona: Anagrama, 1977. 
por Evans-Pritchard, o autor nos mostra que os Nuer mudam de aliados e inimigos conforme o interesse momentâneo.

Por outro lado, a questão sobre o chefe exercer muitas vezes de maneira concomitante o papel de xamã também se nota a influência de Spencer ${ }^{230}$. A teoria de Spencer em Princípios de Sociologia é a de que toda a divisão de tarefas começou a partir do sacerdote ou xamã como primeira diferenciação com relação aos demais. Lévi-Strauss parece concordar com Spencer ao asseverar: "Estas funciones parecerían llevar fácilmente al chamanismo, y ciertos jefes son al mismo tempo curanderos y brujos. ${ }^{231 "}$

Por fim, quanto a Tristes trópicos, cabe destacar as constatações acerca da obra de Rousseau e do apoio prestado pela antropologia, especialmente por LéviStrauss às teorias daquele. O chefe (Uilikandé) significa para os nambiquara aquele que une ou que ata juntos, sugerindo que o chefe é uma criação do grupo para reforçar sua unidade e não uma entidade de poder central necessária. Para LéviStrauss há uma relação quase contratual entre o chefe e seus companheiros baseada em prestações e contraprestações entre o chefe e seus seguidores fazendo da reciprocidade um dos elementos centrais das relações de poder. Contrato, consentimento e reciprocidade, seriam para Lévi-Strauss as matérias primas da vida social e sem elas não há edifício social que se sustente ${ }^{232}$.

Atualmente, para Lévi-Strauss, e isso dizia o autor na década de 50 do século passado, mesmo os biólogos e os físicos já tem consciência das significações antropológicas de suas descobertas. As ciências todas, afinal, são humanas e as ciências sociais já redundam em ser humanas e sociais ao mesmo tempo. (antropologia estructural 2) As behavioral sciences seriam, para o autor, algo intermédio entre as ciências humanas e as exatas, exigindo um tratamento rigoroso dos fatos humanos.

Lévi-Strauss comenta, também o marxismo, do qual certamente recebeu importantes influências. Para ele a questão central do marxismo é descobrir porque e como o trabalho produz a plusvalia. Para o autor, a própria resposta de Marx a tal 
problema oferece questões de caráter etnográfico. A primeira delas é que a humanidade, em grupos reduzidos, buscava estabelecer-se em locais onde fosse possível obter um valor positivo pelo seu trabalho. Além disso, Lévi-Strauss reputa como propriedade intrínseca da cultura a necessidade de obter uma plusvalia pelo trabalho executado. Assim, para Lévi-Strauss o trabalho produz sempre e necessariamente uma plusvalia.

Lévi-Strauss aponta que entre as sociedades chamadas hoje de subdesenvolvidas e as desenvolvidas existe uma relação de complementariedade. Para o autor, no que concorda com $\mathrm{Marx}^{233}$, as relações entre trabalhador e capitalista são outra forma de relação entre colonizador e colonizado onde a partir da violência, saque e extermínio produziu-se uma acumulação originária capaz de instituir as diferenças sociais hoje existentes. ${ }^{234}$

Segundo Lévi-Strauss a origem da divisão sexual do trabalho entre homens e mulheres tem a ver com as relações que fazem muitos povos entre natureza e cultura. A existência, em ditos povos chamados de "primitivos", de um componente sobrenatural relacionado a natureza opera como mediador entre o mundo natural e cultural. A despeito da primazia quase sempre concedida aos elementos da cultura, a natureza possui esse aspecto de divindade, local onde pode-se entrar em contato com os deuses, os antepassados, os espíritos. Este componente está em um plano superior (em termos de importância) à cultura e inferior em relação à natureza, mas depende desta. Destas diversificações entre natureza e cultura surge também a dualidade homem/mulher onde a mulher identifica-se com o componente natural e o homem com o componente cultural. Por isso, à mulher restariam as tarefas mais relacionadas com a natureza (o autor dá como exemplo a jardinaria) e ao homem aquelas relacionadas com a ordem cultural (sendo exemplo aquelas atividades que demandam a utilização de instrumentos elaborados).

$\mathrm{Na}$ questão do parentesco certamente foi a maior contribuição de LéviStrauss e de seu enfoque estruturalista. O incesto, para Lévi-Strauss, exerce a função de estimular as alianças sociais. Ao projetar irmãs e filhas para fora do grupo sanguíneo o incesto inaugura alianças entre grupos consanguíneos distintos e funda 
a sociedade. Para Lévi-Strauss o incesto é a sociedade, a qual depende de uma rede instável e complicada de alianças entre famílias consanguíneas. A existência desta rede faz com que surjam questões que o autor reputa como centrais para a antropologia como, por exemplo, se esta estrutura seria homogênea em todos os lugares ou variável segundo cada local. ${ }^{235}$

Para Lévi-Strauss o sistema de parentesco, as regras de filiação e de matrimônio constituem um conjunto coordenado para possibilitar a permanência do grupo social. A permanência é conseguida de maneira mais fácil ao entrecruzar-se os atores social na forma de relações consanguíneas e relações de aliança.

Para o autor, não se pode encontrar na humanidade traços de comportamento pré-culturais. Pergunta-se o autor se seria possível obter, em níveis limítrofes da vida animal, comportamentos predecessores da cultura. A oposição entre o comportamento humano e animal parece ser, para ele, o exemplo maior da oposição entre natureza e cultura ${ }^{236}$.

Lévi-Strauss não se cansa de assinalar a importância da proibição do incesto como a única regra social que possui um caráter universal ${ }^{237}$. Para o autor, ao procurar um grupo que não proíba o matrimônio de nenhuma maneira este não pode ser encontrado, pois mesmo naqueles grupos mais flexíveis quanto às regras matrimoniais, existe sempre algum grupo com cujos membros é defeso casar-se.

A proibição do incesto, portanto, "se encuentra en el umbral de la cultura, en la cultura y, en cierto sentido, como trataremos de mostrarlo, es la cultura misma ${ }^{238 "}$ Por outro lado, segundo o autor, é necessário rechaçar a explicação que oferecem autores como Morgan e Maine sobre a dupla origem da proibição dos incestos às vezes natural, às vezes social, pois seria uma regra social derivada de uma questão biológica, qual seja, preservar a espécie das supostas desvantagens das uniões consanguíneas. Sobre isso, o autor enfatiza que em uma comunidade pequena, de aproximadamente 80 pessoas, a proibição de casamento entre parentes próximos, nestes incluídos os primos de primeiro grau, não diminuiria o número de portadores de gens recessivos raros mais que um $10 \%$ ou $15 \%$. 
Outra das explicações comuns costuma dizer que a proibição do incesto não é mais que um reflexo, sobre o plano social, de tendências intrínsecas à natureza do homem. Para Lévi-Strauss, a tendência do homem não é repugnar o incesto e sim buscá-lo, daí o sentido da proibição como regra universal. Desta forma, Lévi-Strauss afirma ser a proibição do incesto natural e cultural, sendo que a proibição do incesto constitui o vínculo entre natureza e cultura. De forma geral se poderia dizer, para o autor, que a proibição do incesto opera a passagem do fato natural da consanguinidade para o fato natural da aliança ${ }^{239}$.

$\mathrm{Na}$ verdade, segundo Espina Barrio ${ }^{240}$, Lévi-Strauss procurou defender uma postura intermédia na explicação do tema do incesto ficando entre as explicações puramente biológicas e aquelas puramente sociais. De plano, contudo, destaca-se que Lévi-Strauss rechaçou desde o princípio as explicações de cunho exclusivamente biológicos, tais como aquelas propostas por Maine e Morgan segundo quem a regra do incesta era resultado de uma reflexão social sobre um fato biológico.

A cultura, a partir da existência de um grupo, opera para a continuidade de tal grupo. Com o advento da regra do incesto, a cultura tem o papel de organizar a aplicação da regra e impor uma ordem onde antes havia a desorganização. Além disso, para muitos povos indígenas, os sistemas de intercâmbios matrimoniais e econômicos formam parte de um mais amplo sistema de reciprocidade. Como um exemplo deste sistema, refere a situação de carnear um boi no centro de um povoado tonga onde cada parte corresponde a um parente ou integrante da comunidade segundo um intrincado sistema de relações.

Citando aos nambikwara, Lévi-Strauss também afirma que a regra da monogamia não é absoluta já que eles permitem a poligamia para os chefes e xamãs. O fato de que os chefes e xamãs possam ter várias mulheres em comunidades pequenas obriga os demais a ter a virtude de, por vezes, não terem uma mulher disponível para casamento. 
Os chefes por exemplo, adquirem o direito à poligamia em troca da segurança coletiva proporcionada pela organização de uma comunidade presidida por alguém. Ou seja, o grupo renuncia a parte de sua segurança individual (direito e possibilidade de desposar alguma mulher) em favor de um ganho coletivo, ainda que ambas as situações sejam etéreas e, às vezes, apenas hipotéticas.

O sistema adéqua-se com a homossexualidade em alguns casos e a poliandria em outros. Por estes motivos, mesmo em sociedades onde exista equilíbrio entre homens e mulheres, o fato de umas serem mais desejáveis que outras faz com que a demanda de mulheres sempre esteja desequilibrada ou sob tensão.

A questão dos desequilíbrios entre os sexos serve para ilustrar outra das considerações de Lévi-Strauss: a de que o matrimônio nas sociedades primitivas tinha uma importância que transcendia ao aspecto sexual. Nestas comunidades, a satisfação econômica e da subsistência descansa sobre a divisão sexual do trabalho. Por isso, o matrimônio reveste-se de muito mais importância que apenas o aspecto erótico.

Lévi-Strauss traz algumas estruturas mentais as quais recorremos constantemente e que ele julga universais: "la exigencia de la regla como regla; la noción de reciprocidad como la forma más inmediata en que puede integrarse la oposición entre el yo y el otro; por fin, el carácter sintético de la donación, vale decir, el hecho de que la transferencia consentida de un valor de un individuo a otro transforma a estos en partenaires y agrega una nueva calidad al valor transferido. ${ }^{241 "}$ O intercâmbio, para Lévi-Strauss é apenas um dos aspectos de um sistema global de reciprocidade.

Cabe diferenciar, de maneira resumida, os sistemas de organização dualista e de intercâmbio generalizado. No caso das organizações dualistas, de maneira muito simplória, existe no seio do grupo uma divisão que instaura obrigações mútuas e pares matrimoniais restringidos. Ou seja, neste sistema, os indivíduos do mesmo grupo não poderão casar entre si e terão, necessariamente, de casar-se com membros do outro grupo. Podem existir, ainda, grupos com os quais o matrimônio 
seja aconselhável ou fortemente indicado dentro do grupo de parceiros não proscritos. Já o intercâmbio generalizado baseia-se na crença e na confiança de que o sistema funcionará e aquilo que foi dado será em algum momento recebido. Não há uma reciprocidade imediata e palpável entre dois grupos senão uma reciprocidade instalada e generalizada no grupo social. O pai cede a filha em matrimônio com a confiança de que, quando chegue a idade de casamento de seu filho mais novo, outra família cederá sua filha. Este tipo de sistema, para LéviStrauss, inaugura as operações à prazo. A crença funda o crédito e a confiança o concede ${ }^{242}$.

O que determina o matrimônio não é a relação de parentesco e sim o fato de que a relação de parentesco transforma-se em aliança e instaura uma estrutura de reciprocidade. Esta estrutura pode expressar-se de duas formas diferentes, ou com todos os matrimônios sendo realizados na mesma geração (paralela) ou com os matrimônios realizados em gerações distintas (oblíqua). A perspectiva paralela funciona de forma diferida, pois a compensação não é obtida pelos mesmos indivíduos que suportaram o peso do sacrifício, ainda que crie uma melhor regularidade e afetividade. Pelo contrário, a perspectiva oblíqua responde a um caráter mais individualista e imediatista onde aquele que realiza o sacrifício exige uma compensação imediata. Lévi-Strauss associa estes tipos de estruturas matrimoniais com as sociedades que realizam intercâmbios imediatos (compras em dinheiro) e aquelas que realizam os intercâmbios a prazo ${ }^{243}$.

Para o autor, portanto, uma estrutura de parentesco complexa corresponde a uma estrutura que não implica a indicação de cônjuge preferencial e apresenta apenas um pequeno grupo de restrições. A proibição do incesto realiza uma arbitragem entre aliança e parentesco como não se cansa de repetir Lévi-Strauss. Esta proibição é menos uma proibição e mais uma obrigação de fazer, isto é, pretende mais instigar que a mãe, a irmã e a filha sejam entregues do que proibir o casamento no seio da família. Três são os caracteres que foram adotados para conformar o matrimônio da sociedade europeia moderna: a liberdade de escolha do parceiro respeitando o grupo proibido; a igualdade dos sexos frente aos votos conjugais; e, a emancipação dos parentes a partir do matrimônio, com o caráter 
individual do contrato. O matrimônio não se esgota, entretanto, no limite do casal, pois faz parte de um sistema mais amplo de reciprocidade e intercâmbio.

Nas conclusões, Lévi-Strauss dá um célebre exemplo, frequentemente citado pelo autor Espina Barrio onde o caçador indígena é perguntado sobre por qual motivo não se casava com sua irmã. A resposta deste é no sentido de que seria uma loucura casar-se com a própria irmã porque, ao casar-se com a irmã de outro e outro casar-se com a sua, ele adquiria dois cunhados, companheiros de caça por excelência, fato que aumentaria muito suas probabilidades de êxito e sobrevivência ${ }^{244}$.

Contrariando, como assinala o próprio Lévi-Strauss, algumas das asserções de Radcliffe-Brown, uma família biológica implica sempre uma relação de aliança entre dois famílias. Por tal motivo, o átomo de parentesco deve ser formado sempre pelo marido, a esposa, os filhos e um representante do grupo que cedeu a mulher, seja o irmão materno ou pai da esposa. Tal tipo de estrutura básica mostra um sistema quadrangular de relações possíveis representada pelas relações entre marido e mulher, pai e filho, irmã e irmão e tio materno e sobrinho. ${ }^{245}$

Para o estudo dos mitos Lévi-Strauss ainda nos ofereceu a tetralogia "mitológicas" onde aborda uma infindável série de mitos e os analisa de maneira profunda buscando revelar os significados ocultos, as contradições e a importância do mito em relação com a forma de vida da sociedade que os adota e os conta. Um dos primeiros problemas referidos por Lévi-Strauss é a dificuldade de adotar-se o pensamento cartesiano com relação ao mitos. Não existe uma unidade secreta isolável do mito. Quando se crê tê-lo separado, as partes voltam a fundir-se por afinidades imprevistas. ${ }^{246}$

O autor refere que realizou uma sintaxe da mitologia Sul-americana. E, por outro lado, afirma que não é exigível a apresentação de um discurso mítico total, já que tal solicitação carece de sentido, como visto antes. O autor também se pergunta, em determinado ponto, se as mitológicas não são uma distração 
desnecessária ao antropólogo que deveria estudar sociedades concretas e seus problemas políticos, sociais e econômicos.

A família biológica não está sozinha e deve recorrer à aliança com outras famílias para perpetuar-se. Por isso, todo matrimônio é, para Lévi-Strauss, um "encuentro dramático entre la naturaleza y la cultura, la alianza y el parentesco.247"

$\mathrm{Na}$ cultura, para o autor, são distintos o canto e a língua falada assim como a cultura difere da natureza e o discurso sagrado do mito é diferente do profano. Estas oposições são a base para análise dos mitos. O jaguar e o homem são uma oposição duplamente formada pela linguagem ordinária. Um come o cru e o outro come o cozido, o jaguar come o homem, mas o homem não come ao jaguar. Esta contradição representa uma relação de reciprocidade nula.

Nas mitológicas também há a referência ao parentesco onde o autor constata que a união de um homem e uma mulher abala o equilíbrio do grupo social enquanto estes não tenham filhos. O matrimônio retira dois possíveis consortes do jogo matrimonial e não devolve nenhum até o nascimento da prole. O nascimento da descendência representa a reinserção da família nos intercâmbios e alianças matrimoniais.

A contradição entre o cru e o cozido, utilizada durante toda a tetralogia nada mais é do que uma metáfora da contradição entre natureza e cultura. O cru representando a natureza e o cozido a cultura. Neste sentido, são colocados para cozinhar indivíduos recêm entregues a um processo fisiológico intenso como recém nascido e a moça púbere. O fogo de cozinha é o elemento que realiza a mediação entre o cru e o cozido representado pela cocção do produto cru para o consumo humano. Lévi-Strauss ainda destaca que, para os Tarahumara, somente é alimento verdadeiro aquele que foi cozido previamente. ${ }^{248}$ Alguns indígenas também pensam que a agricultura é uma das formas de cozer os alimentos. Os alimentos cultivados já sofreram a influência da cultura e não necessariamente precisam ser cozinhados para virar alimentos. ${ }^{249}$

249 LÉVI-STRAUSS, Claude. Mitológicas II: De la miel a las cenizas. México: Fondo de Cultura Económica, 1972-B. 
No segundo volume das mitológicas, Lévi-Strauss comenta a relação entre o mel e o tabaco ambos produtos autóctones da América do Sul e que possuem papéis ambíguos e em constante transformação. Ambos os produtos podem variar do alimento supremo ao veneno mais mortal. Além disso, existem diversas formas intermediárias a depender do momento da colheita, do processo de fabricação, da qualidade do produto. A oposição também poderiam expressar-se como cru e cozido, molhado e queimado e infraculinário e supraculinário. Contudo, as relações entre mel e tabaco são muito mais complexas que tais contradições. ${ }^{250}$

De igual maneira o cru e o cozido representam as relações da cozinha, ou seja, do interior do lar. Por seu turno, mel e tabaco representam dimensões exteriores à cozinha, a festa, a coletividade e também a sazonalidade. O mel está aquém da cozinha, pois o homem o busca na natureza já pronto e o mel, por sua vez, está também além da cozinha por necessitar ser mais que cozinhado, necessita ser queimado. 251

Outro dos autores reputados frequentemente como um dos principais do estruturalismo, ainda que um pouco eclipsado ante o volume a transcendência da obra de Lévi-Strauss é Raymond Firth. Firth ocupou a mesma cátedra que Malinowski na London School of Economics e foi um dos fundadores da Antropologia Econômica. $\mathrm{O}$ autor defendeu a importância das crenças culturais para a estruturação da vida econômica. ${ }^{252}$ Analisaremos de maneira sucinta alguns aspectos de sua obra principalmente aqueles que mais interessam ao presente estudo.

Ao destacar um fato aparentemente sem maior importância, Firth traz alguns assuntos interessantes para reflexão. Segundo o autor, em Tikopia, homens e mulheres mudam de nome ao casar-se. $O$ nome de solteiro a partir de então somente é utilizado por parentes íntimos. Normalmente o homem adota o pré-nome $\mathrm{Pa}$, algo similar ao "Senhor" ou "Seu" do português, "Don" do espanhol e mais um nome de um dos antepassados. Se o casal não tem filhos, vai-se investigar como foi a prole do antepassado e se esta foi escassa, o insucesso é atribuído ao nome que é imediatamente trocado. Essa questão, Firth atribui à importância do nome para 
colocar o indivíduo dentro de pautas sociais fundamentais como a identidade e posição no grupo.

Firth também traz algumas noções sobre o conceito de estrutura em antropologia. Para ele, a estrutura social deve cumprir determinadas condições para que possa receber verdadeiramente o nome de estrutura: a primeira delas é que deve abarcar relações ordenadas das partes com o todo, essas relações deverão ser superpostas em diversos níveis de complexidade, bem como sua ocorrência apresenta um grau mínimo de continuidade, não sendo admitidas relações efêmeras. Destarte, Firth pressupõe que cada ação social tem uma ou mais funções sociais a qual ele define como a relação entre uma ação e o sistema do qual forma parte.

Outra importante distinção que realiza o autor é a diferenciação entre os termos estrutura e organização social. Para Firth, ao definir-se a estrutura em termos abstratos é mister definir a organização em termos concretos. A organização social, seria, portanto, dispor a ação em sequências concretas para atender a objetivos eleitos anteriormente. Ou seja, a organização social implica a reunião de elementos diferentes em uma relação comum. A organização social se encarrega de ordenar sistematicamente as relações através de atos de eleição e decisão. Toda organização, por outro lado, rege-se por um sistema de valores e normas que sejam capazes de influir nas decisões dos membros ${ }^{253}$.

Em outro artigo, Firth destaca novamente a diferença entre estrutura e organização social. Esta última seria a ação ordenada em busca de um objetivo, a organização social seria o ajuste funcional de uma sociedade. Quanto à estrutura, Firth diferencia a estrutura manifesta, composta de grupos de filiação, relações de parentesco básicas e hierarquia formal da estrutura latente, composta de características igualmente fundamentais numa sociedade, mas que não são observáveis senão depois de uma profunda sistematização. Existe distinção também entre a mudança social, onde são modificados elementos básicos da sociedade e 
mudanças em detalhe onde a ação social, mesmo repetida, não muda as formas sociais básicas ${ }^{254}$.

Firth também destaca que o ordenamento social, de alguma forma, numa acepção mais restringida da estrutura, compreende não só os grupos baseados no sexo, na idade e no parentesco, mas também outras formas de associação constituídas com um fim comum como o trabalho. Também são necessários alguns sistemas de crenças e procedimentos para orientar as atividades das pessoas. Tais métodos de controle social compreendem um conjunto de conhecimentos técnicos e empíricos que permitem ao individuo atuar no ambiente em que se insere. Firth também destaca a importância de alguns grupos, chamados por ele de primários, onde os integrantes de tais grupos mantém um contato íntimo e pessoal na sua vida diária. Citando tais grupos, o autor coloca como exemplo a família, o grupo de trabalho, a vizinhança e grupos de jogo.

Para Firth a existência de tais grupos primários é fundamental. Os mesmos proporcionam o sentimento de pertencimento ao indivíduo, lhe dão segurança e oportunidade de aumentar sua autoestima e obter gratificações morais. Sobre o cimento de tais grupos primários é que erigem-se outros grupos mais complexos e formais. A cooperação, também destaca o autor, é fundamental e os indivíduos deverão superar as diferenças pessoais para lograr a consecução de objetivos comuns. Ainda que em alguns pontos exista incompatibilidade entre os desejos do grupo e os do indivíduo, tal contradição faz parte da natureza da sociedade e é muito mais profundo, para o autor, que o conflito de classes o qual seria somente uma das manifestações de tal conflito.

O tamanho da sociedade ou do grupo influi diretamente na quantidade e qualidade dos vínculos sociais. Em comunidades pequenas, os grupos primários soem coincidir em vários pontos. Por exemplo, membros de uma mesma família que exercem o mesmo trabalho, o que acaba por mitigar as diferenças entre os valores e realidades de casa e do trabalho, por exemplo. Firth faz ainda uma diferenciação entre comunidades pequenas integrais e parciais. A primeira delas, integral, é uma estrutura completa onde seus aspectos não dependem para nada de grupos 
externos. Assim que o sistema religioso, o sistema de clãs, o de parentesco, o sistema político são constituídos com total independência do elemento externo. Já a comunidade parcial depende, de alguma forma, de elementos exteriores, como o pertencimento a um mesmo clã ou está subordinada a um chefe em comum com outras comunidades.

Portanto, nas comunidades pequenas e pobres, é bastante provável que acabe-se por mesclar os aspectos pessoal e econômico. As trocas e intercâmbios se darão muito mais por razões de parentesco ou obrigações que propriamente pelo valor econômico. E assim, aplicar-se-ia ao caso a máxima de Maine ${ }^{255}$, segundo o qual as relações tendem a estabelecer-se mais pelo status que por contrato.

O autor entende por comunidade humana um grupo de pessoas que compartilha atividades comuns, ligada de tal maneira que os indivíduos, para lograr seus objetivos pessoais, necessitam obrigatoriamente colaborar com outros. Esta comunidade, para Firth, soe ocupar um local determinado onde convivem em comum e mantém um contato regular.

Outra das interessantes definições de Firth é sobre as mudanças estruturais. Sempre que existe uma mudança estrutural é porque, certamente, no quadro anterior havia alguma falha capaz de gerar dificuldades para uma parte significativa do grupo social. A mudança pode ocasionar dois efeitos: a convexão social ou a transmissão social. O processo de convexão se dá quando alguns integrantes do grupo mudam suas pautas sociais, sendo possível que outros indivíduos sigam a tendência por estarem de acordo, por imitação ou por ressentimento. Já a transmissão é quando alguns integrantes adotaram alguma inovação cujas consequências são imprevisíveis e às quais deverão se acostumar. Tais processos de mudanças podem ser desencadeados desde dentro da comunidade ou ser estimulados desde fora.

Firth, por sua formação e interesses, acabou sempre dando extremado valor aos aspectos econômicos e utilizou por diversas vezes o termo "antropologia econômica". Neste sentido, assevera o autor que ao antropólogo cabe interessar-se pela estrutura e organização da atividade econômica e a maneira como influem nas 
pautas sociais e culturais. Aliás, para o autor o antropólogo se depara com sistemas econômicos dos mais distintos, desde os mais simples até os mais complexos onde as pautas culturais e econômicas apresentam relações de dependência. Além disso, o antropólogo também enfrenta a dificuldade de lidar, por vezes, com sistemas econômicos onde ausente o dinheiro e ausente a quantificação de valores. Para Firth, a maioria das relações sociais revela uma faceta econômica, ainda que representada pela simples opção em acudir ou não a uma celebração social quando se estaria economizando tempo e energia.

Analisando sociedades fundadas no campesinato, Firth comenta que o trabalho pode ser executado não por um salário, mas, quiçá, somente pela participação nas ganâncias, pelo parentesco ou pela lealdade devida a um chefe determinado. A produção é somente uma das muitas facetas da relação social. Portanto, nestas comunidades, as relações econômicas dependem sobretudo do status e das relações sociais do indivíduo e os meios econômicos tendem a ser traduzidos em fins sociais. O contraste com a sociedade ocidental é total já que o campo econômico e o social-afetivo não deveriam mesclar-se.

No sistema de uma sociedade camponesa, cada um deverá atuar segundo impõe seu status social naquela comunidade. Para não perder os benefícios que o mesmo status lhe reserva, o indivíduo deve executar com diligência as obrigações que lhe incumbem. O pertencimento ao grupo aporta incentivos para que queira trabalhar. Tal circunstância, para Firth, revela o imperativo moral que possui a atividade econômica, já que por trás das tarefas que o indivíduo realiza está um sistema de regras morais que the impelem a realizar ditas atividades. Assim que o trabalho realizado e a paga recebida trazem implícita uma relação de justiça e de equilíbrio não importando apenas o aspecto econômico. No mesmo sentido, algumas atividades, classificadas pelo autor como "serviços pessoais ${ }^{256 " ~ m e r e c e m ~}$ um pagamento extra, não porque a pessoa que paga espere receber um melhor tratamento ou porque entenda moralmente correto e sim para satisfazer a opinião alheia, inclusive daqueles que recebem a "gorjeta". Para o autor, as relações econômicas descansam sobre cimentos morais muito mais do que soemos acreditar. 
O autor também faz uma longa consideração sobre as proibições, sobre a usura e a diferenciação entre o dinheiro que se investe e cujo investidor ganhará ou perderá conforme o sucesso da empresa e a certeza dos ganhos praticada na usura. A melhor maneira de empregar o capital é quando este coopera com o trabalho na forma de sociedades mercantis. O autor também cita as festas de potlach, para ele, em princípio, irracionais, mas que também pretendem obter benefícios materiais e imateriais futuros. Se a atividade econômica está subordinada aos ideais sociais, é através destes últimos que se poderá chegar ao âmago dos primeiros.

Ao contar aspectos de seu trabalho de campo em Tikopia o autor detalha a forma com que os habitantes insulares tratavam a amizade com o observador estrangeiro. Para eles, a base natural para a amizade com o forasteiro era o interesse material. Desta forma, esperavam e exigiam recompensas materiais do autor sempre que possível.

Em relação a ação coletiva, o autor pontua que os diferentes critérios de valor para os comportamentos ajudam a demarcar um grupo e servir de base para a atuação conjunta. Por isso, o sistema moral está conectado com a organização social. O grupo ou clã segundo Firth, utiliza-se de totens ou símbolos, pois é assim que seus integrantes conseguem construir uma imagem mental do grupo. O símbolo ou totem torna-se assim a própria imagem do grupo, representando-o para seus integrantes e para a comunidade externa. Tal conceito é aplicável também a questão da categoria profissional que se personifica através de um sindicato. A categoria profissional necessita de uma nomenclatura e de algumas pautas de conduta, de linguagem e de atuação para que possa fazer uma ideia de si mesma e transmitir tal ideia aos elementos externos.

Firth também conceitua a estrutura social como o conjunto de relações necessárias para manutenção da sociedade. Além disso, pontua serem importantes as relações ideais em qualquer formulação sobre a estrutura social, contudo tais relações não são a estrutura social. O autor também contempla a noção de estrutura social como modelo. O modelo, e o autor adota as concepções de modelo oriundas 
dos economistas, é uma reconstrução deliberada, simplificada e desviada da realidade para contemplar um ou vários fenômenos ${ }^{257}$.

\subsection{0 materialismo cultural}

Para realizarmos uma aproximação ao materialismo cultural utilizaremos dois dos principais autores desta corrente do pensamento antropológico e duas das principais obras condutoras desta linha do pensar. Trata-se de Maurice Godelier e sua obra "Economia, Fetichismo y Religión en las Sociedades Primitivas" e Marvin Harris e sua obra "Materialismo Cultural ${ }^{258 " . ~}$

Poder-se-ia resumir o materialismo cultural como uma espécie de amálgama entre o materialismo histórico de cunho marxista, a antropologia ecológica e o evolucionismo social. Fez-se necessário, ao menos para Harris, distinguir os pontos de vista emic e etic no desenvolvimento de sua teoria, bem como ressaltar a importância e equivalência entre os termos ${ }^{259}$.

Começaremos pela obra de Harris para tentar explicar o materialismo cultural. Para Marvin Harris, o materialismo cultural é uma estratégia de investigação, um modo distinto de abordar o problema de estudo. Harris se posiciona contrariamente à simples recopilação de dados sobre o objeto de estudo como forma de gerar axiomas válidos e úteis cientificamente. Para o autor, é necessário, também, uma teoria que guie a interpretação dos dados obtidos. Além disso, Harris ressalta que a ciência sempre consistiu em um equilíbrio entre empirismo e racionalismo, entre indução e dedução, tentar exacerbar o protagonismo de um ou de outro e tentar separá-los, desvirtuaria o trabalho científico. Neste mesmo sentido está Comte ${ }^{260}$, ao dizer que, para a observação de quaisquer classes de fenômenos, necessária a guia inicial e final de alguma teoria.

É nos primeiros capítulos que Marvin Harris faz a distinção entre Emic e Etic. O primeiro autor a introduzir tais termos foi o linguista Kenneth Pike ${ }^{261}$ e a distinção provém efetivamente da linguística. O termo phonetic é utilizado pelos filólogos para 
descrever os sons baseados em uma lista de movimentos e órgãos que produzem as ondas sonoras. Por outro lado, phonemic, utiliza-se para designar as distinções entre os sons realizadas pelos nativos de maneira quase inconsciente e não científica.

Harris nos oferece a concepção dos termos adequada ao estudo antropológico. A visão emic, derivada do inglês phonemic, é aquela que coloca o nativo como principal julgador das descrições e análises feitas sobre fatos culturais. Os enunciados de tipo emic podem ser entendidos, ter sentido e ser apropriados na visão do próprio nativo. Já a visão etic, também do inglês phonetic, é aquela própria do observador e não do nativo, os enunciados soem ser adequados para a formulação de teorias. Nesta visão provavelmente o nativo não concordará ou entenderá o significado das expressões e interpretações.

Trabalhemos agora na descrição de princípios teóricos do materialismo cultural explicados por Harris. O materialismo cultural rege-se por razões de "índole práctica y terrenal ${ }^{262 " ~ e ~ p r o c u r a ~ r o m p e r ~ c o m ~ a s ~ a b s t r a c ̧ o ̃ e s ~ d e ~ o r i g e m ~ h e g e l i a n a . ~ A ~}$ teoria de Harris divide os rasgos culturais em infraestrutura, estrutura e superestrutura.

A infraestrutura, formada pelos modos de produção e reprodução é o aspecto predominante e que orienta os demais aspectos da estrutura e superestrutura. A grande ameaça de desordem para o materialista cultura provém de aspectos econômicos que impactam na distribuição do trabalho e seus produtos entre os indivíduos.

Harris $^{263}$ nos oferece uma lista para exemplificar as estruturas sociais: 


\begin{tabular}{|c|c|c|c|c|c|}
\hline \multicolumn{5}{|c|}{ Modo de produção } & \multirow{4}{*}{ 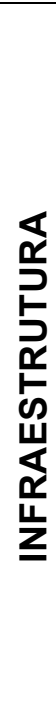 } \\
\hline $\begin{array}{l}\text { Tecnologia } \\
\text { de } \\
\text { subsistencia }\end{array}$ & $\begin{array}{l}\text { Relações } \\
\text { técnico- } \\
\text { ambientais }\end{array}$ & Ecossistemas & $\begin{array}{ll}\text { Pautas } & \text { de } \\
\text { trabalho } & \end{array}$ & & \\
\hline \multicolumn{5}{|c|}{ Modo de reprodução } & \\
\hline Demografia & $\begin{array}{l}\text { Pautas de } \\
\text { pareamento }\end{array}$ & $\begin{array}{l}\text { Fecundidade, } \\
\text { Natalidade e } \\
\text { Mortalidade }\end{array}$ & $\begin{array}{l}\text { Controle } \\
\text { médico das } \\
\text { pautas } \\
\text { demográficas }\end{array}$ & $\begin{array}{l}\text { Anticoncepção, } \\
\text { aborto } \\
\text { infanticídio }\end{array}$ & \\
\hline \multicolumn{5}{|c|}{ Economia Doméstica } & \multirow{6}{*}{ 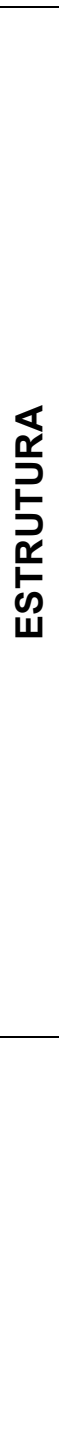 } \\
\hline $\begin{array}{l}\text { Estrutura } \\
\text { familiar }\end{array}$ & $\begin{array}{l}\text { Divisão do } \\
\text { trabalho } \\
\text { doméstico }\end{array}$ & $\begin{array}{l}\text { Socialização, } \\
\text { enculturação e } \\
\text { educação } \\
\text { domésticas }\end{array}$ & $\begin{array}{l}\text { Papéis sexuais } \\
\text { e geracionais }\end{array}$ & $\begin{array}{l}\text { Disciplina, } \\
\text { hierarquia } \\
\text { sanções } \\
\text { domésticas }\end{array}$ & \\
\hline & & Economia Polí & ica & & \\
\hline $\begin{array}{l}\text { Organização } \\
\text { política, } \\
\text { facções, } \\
\text { clubes, } \\
\text { associações } \\
\text { e } \\
\text { corporações }\end{array}$ & $\begin{array}{l}\text { Divisão do } \\
\text { trabalho, } \\
\text { esquemas } \\
\text { fiscais e } \\
\text { tributários }\end{array}$ & $\begin{array}{l}\text { Socialização, } \\
\text { enculturação e } \\
\text { educação } \\
\text { políticas }\end{array}$ & $\begin{array}{l}\text { Classes, } \\
\text { castas, } \\
\text { hierarquias } \\
\text { urbanas } \\
\text { rurais }\end{array}$ & $\begin{array}{l}\text { Disciplina, } \\
\text { controle policial- } \\
\text { militar e guerra }\end{array}$ & \\
\hline \multicolumn{4}{|c|}{ Superestrutura de Conduta } & \multirow{2}{*}{ 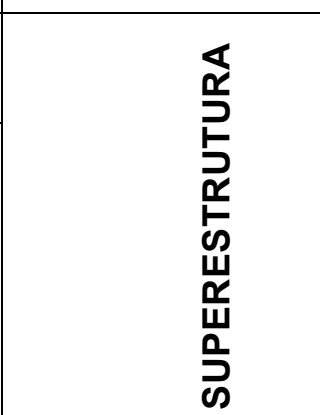 } & \\
\hline $\begin{array}{l}\text { Arte, música, } \\
\text { dança, } \\
\text { literatura e } \\
\text { propaganda }\end{array}$ & Rituais & $\begin{array}{l}\text { Esportes, } \\
\text { jogos, } \\
\text { passatempos }\end{array}$ & Ciência & & \\
\hline
\end{tabular}


O núcleo principiológico do materialismo cultural, segundo Harris, já havia sido antecipado por Marx, na medida em que acredita não ser a consciência dos homens que determina seu ser e sim seu ser social que determina sua consciência. Em outras palavras, o modo de produção determina outros aspectos da vida social, política e espiritual. O conceito proposto por Harris é o seguinte: "Los modos de producción y reproducción conductuales etic determinan probabilísticamente, las economías domésticas y política conductuales etic, que a su vez determinan las superestructuras conductual y mental emic. ${ }^{264 "} \mathrm{O}$ próprio autor resume tal princípio chamando-o de determinismo infraestrutural.

E por quê a infraestrutura? Harris responde a questão a partir das leis que regem a sobrevivência e reprodução humanas. Segundo ele, os seres humanos necessitam consumir energia para obter energia e possuem uma capacidade maior de produzir crianças que capacidade para obter energia para elas. Estas leis são imutáveis e, por isso, os seres humanos estão obrigados a buscar um equilíbrio entre reprodução e produção/consumo de energia. A infraestrutura, é a zona que representa a interrelação entre natureza e cultura e as pautas socioculturais adotadas buscam superar ou modificar as restrições ecológicas, químicas e físicas.

Para Harris, três fatores foram determinantes para a evolução cultural: o aumento da oferta de energia; incremento da produção; e, crescimento demográfico. Para explicar a ausência de um crescimento demográfico importante no neolítico, por exemplo, Harris sugere que uma das forças determinantes da pré-história foi o controle de natalidade a partir de métodos como a agressão à gestante com métodos abortivos traumáticos, o infanticídio (especialmente o feminino) e o descuido nutricional seletivo para com as meninas e adolescentes do sexo feminino. Para o autor, o aspecto da produção mais importante é o da reprodução, o qual também pode ser chamado de produção de seres humanos.

Harris não descuida de afirmar a interdependência entre infraestrutura, estrutura e superestrutura. Reconhece o autor que uma mudança em qualquer um deles pode modificar os demais, mas não abre mão da prevalência da infraestrutura como motor indutor de tais mudanças. Não seria incorreto dizer que a estrutura e 
superestrutura representam o resultado final de uma contínua alimentação e retroalimentação com predomínio da infraestrutura.

A passagem quase generalizada e simultânea em diversos locais do globo, da caça/recolecção para a agricultura deveu-se, provavelmente, ao melhor custobenefício desta última com relação à primeira. Some-se a isso as mudanças climáticas que marcaram o início do atual período interglacial. Harris aponta o florescimento da arte em sítios arqueológicos como Çatal Huyuk e Jericó como sugestão da eficiência obtida pelas sociedades quando empregavam agricultura e pecuária, muito superior à dos caçadores-recoletores.

Harris também atribui ao maior benefício material a criação de chefaturas, precursoras dos Estados. A existência de um chefe influencia a produção de três maneiras: intensificam a produção; servem para promover uma redistribuição dos excedentes agrícolas e das mercadorias; e, por último, serve também para, em torno do chefe, organizarem-se expedições comerciais e militares.

O surgimento do Estado segue uma lógica parecida a partir da tríade intensificação-redistribuição-guerreiros até uma clara diferenciação entre a classe dirigente e a classe dirigida. Essa diferenciação foi aceita e inclusive desejada pela classe dirigida que não se importava, segundo Harris, em perder sua independência em troca de participar nas redistribuições das aldeias mais opulentas. Assim, uma vez instalado tal sistema, forma-se um ciclo vitorioso de amplificação onde o poder da classe governante lhe dá mais capacidade para intensificar a produção, para redistribuir e para ir à guerra. Aos vizinhos só resta sucumbir pela dependência ou pela guerra ou formar o próprio Estado.

Harris destaca também a preponderância da infraestrutura no caso das maiores religiões mundiais. Para o autor, o triunfo do confucionismo, taoísmo, budismo, cristianismo e islamismo deve-se à glorificação da pobreza que livrou a classe dominante de proporcionar meios materiais suficientes aos pobres. No mesmo sentido, Harris contraria os postulados da antropologia biológica ao afirmar que o motor da evolução é a luta por aumentar o poder político-econômico e não na luta por alcançar o êxito reprodutor. 
Lado outro, Harris destaca as contradições propostas por Hegel e Marx. Para Hegel a contradição não produz um retorno ao status quo anterior. A negação da negação forma parte de um grande processo de desenvolvimento que conduz ao encontro da consciência humana com o "espírito mundial". Para Marx, a contradição do capitalismo consiste em que na busca incessante por benefícios que leva o empresário a substituir o trabalho humano por máquinas, o que acaba por diminuir os níveis de lucros, já que o lucro se obtém a partir da exploração de pessoas e não de máquinas. Ou, por outro lado, para aumentar a rentabilidade, explora-se mais a mão de obra e diminui-se o poder de compra da classe trabalhadora retraindo o mercado consumidor. Para Harris, tais sugestões do materialismo dialético são insuficientes para explicar a realidade.

O idealismo, do qual apropriou-se Lênin, servia para justificar sua visão de mundo. Se o capitalismo cria o proletariado este estaria destinado a expropriar os expropriadores e a criar um novo modelo de sociedade sem classes. A negação da negação teria de acontecer. Harris rechaça a dialética ao preferir uma ciência objetiva do social em oposição às formas de misticismo político e religioso. Neste sentido, Harris destaca que a eliminação da exploração nunca será alcançada em uma sociedade que subverte a lógica empírica e operacional por razões de conveniência política. Neste contexto, é impossível saber o que soemos chamar de democracia é uma forma de liberdade ou apenas uma nova forma de exploração.

Pelos mesmos motivos já elencados, Harris repudia o idealismo psicológico, próprio da escola, cultura e personalidade. Se a psique individual prima sobre a infraestrutura, jamais seremos capazes de formulações nomotéticas da evolução sociocultural. Portanto, a personalidade não pode ser o fator determinante das mudanças socioculturais, segundo Harris. O mesmo vale para a fenomenologia que prega a subjetividade dos significados que exigiria uma incursão subjetiva no pensamento nativo e, portanto, distinta em cada caso particular.

Para encerrar este breve resumo do materialismo cultural, segundo Harris, subscrevemos a sua crítica do sistema estabelecido. Segundo o autor, a verdade é aquilo que consegue persuadir as pessoas a acreditar. Fazer com que acreditem é então o requisito básico para submeter. Para o autor, quando a verdade não pode 
ser induzida ela é imposta e, portanto, as verdades criam-se e recriam-se várias vezes durante o embate.

O materialismo cultura também encontra outro forte expoente na figura de Maurice Godelier $^{265}$. O autor realiza, logo de início, uma análise crítica das contribuições de Marx e Engels. Para ele, segundo Marx e Engels em "La ideologia Alemana ${ }^{266 ", ~ h a ́ ~ o ~ d e s c o b r i m e n t o ~ d e ~ u m a ~ l e i ~ s o c i a l, ~ q u a l ~ s e j a, ~ o ~ f u n d a m e n t o ~ u ́ l t i m o ~}$ da vida em sociedade repousa sobre as formas e estruturas dos diversos modos de produção. A partir de então os povos que realizam trabalhos em comum e que em comum possuem a terra passam a ser o ponto de partida da evolução das sociedades. Este tipo de sociedade tem o parentesco como fio condutor das relações entre seus membros.

Godelier afirma que a grande capacidade de teorizar de Marx e Engels Ihes permitiu incorporar as teorias de Morgan já no último quartel do século XIX. O oferecimento de várias vias de evolução, desde o comunismo primitivo até o Estado, fizeram de "El orígen de la família, la propiedad privada y el Estado" um dogma até hoje por muitos reivindicado.

Outro ponto que faz cair por terra as teorias de Morgan e Engels diz sobre a evolução dos sistemas de parentesco. Para os dois mencionados autores, a evolução dos sistemas de parentesco seria pautada pela seleção natural onde atuaria com força o componente biológico, favorecendo aqueles grupos que mantiveram relações exógamas. No entanto, pontua Godelier que os sistemas de parentesco são de ordem principalmente social e não biológica. Como já vimos em Lévi-Strauss, o sistema de parentesco baseia-se em formas de proibição sexual e conjugal e não em regras biológicas, até hoje não comprovadas pelas ciências da saúde.

Era impossível, quando escrevia Godelier, e segue sendo hoje, retomar os postulados Marxistas do século XIX porque fundados em teorias evolucionistas que

265 GODELIER, Maurice. Economía, Fetichismo y Religión en las Sociedades Primitivas. Madrid: Siglo XXI, 1978.

266 MARX, Karl e ENGELS, Friedrich. La ideología Alemana: crítica de la novísima filosofía alemana en las personas de sus representantes Feuerbach, B. Bauer y Stirner y del socialismo alemán en las de sus diferentes profetas. Barcelona: Grijalbo, 1972. 
também já caíram em desuso. Parece lógico que, ao ruir a base, todo o edifício desmorone.

De outra banda, Godelier aponta que a moderna Antropologia confirmou não existir uma relação mecânica entre o desenvolvimento das forças produtivas e o desenvolvimento das desigualdades sociais. Entretanto, a competição social nas sociedades primitivas e nas sociedades de classes, oferece um grande incentivo para o aumento da produção e para a existência de excedentes.

A desigualdade social, comenta Godelier, somente é justificada pelos serviços prestados à comunidade por aquele que exerce um papel central. Falando em sociedades primitivas o chefe presta um serviço à comunidade, incentiva a produção, redistribui os excedentes e, portanto, recebe uma maior fatia da produção. Essa desigualdade, é, portanto, benéfica para a comunidade. Para Godelier, a afirmação de Marx e Engels de que na base de toda supremacia política está o exercício de funções sociais relevantes é atual e serve para propor uma teoria sobre o surgimento da desigualdade e o surgimento do Estado. Ou seja, para Marx segundo Godelier, a desigualdade protege os interesses das comunidades primitivas e constitui um fator essencial do progresso.

Resta assinalar a característica do "modo de produção asiático", que seria a transição entre uma sociedade sem classes e as sociedades de classes. Este modo de produção combina e une relações de produção e organização social das sociedades de classes e sem classes. No entanto, tal transição é específica já que a exploração de classes ocorre sobre a forma de propriedades comunitárias da terra e dos meios de produção.

Ainda detalhando o pensamento de Marx e Engels, Godelier afirma que a competição, no seio de comunidades primitivas, começa para além da esfera da produção e acesso aos bens básicos de subsistência. Ou seja, a competição, nas comunidades primitivas, não ameaça a sobrevivência. No entanto, promove-se a competição ao redor de determinados bens escassos que dão acesso às mulheres e à autoridade. Tal competição, assegura o respeito e observância de diversas pautas sociais que conformam aquela sociedade em especial, assegurando a sobrevivência do modo de vida daquele grupo. 
Por isso, para Godelier, deve-se refutar a tese de que a economia das sociedades primitivas era somente uma economia de subsistência já que havia a produção de algum tipo de excedente destinado a regular as pautas sociais. Por outro lado, a produção do excedente não conduz automaticamente ao aumento das forças produtivas.

É necessário investigar a origem das classes sociais através da análise das sociedades sem classes e das primeiras sociedades de classes. Somente assim seria possível descobrir a lógica oculta das relações sociais e entender alguns comportamentos que nos parecem absurdos. Nas sociedades primitivas, Godelier afirma que o parentesco exerce o papel simultâneo de infraestrutura e superestrutura, pois pauta as relações de produção, reprodução, esquema político e ideológico.

Godelier também realiza algumas afirmações de antropologia econômica, uma delas é responsável por derrubar o mito de que, nas sociedades primitivas, os indivíduos viviam para prover sua subsistência. Segundo o autor:

parece ser que el desarrollo de la agricultura condujo a la prolongación de la jornada de trabajo y la cantidad de trabajo anual necesário para la producción y reproducción de las condiciones materiales de existencia de la sociedad. ${ }^{267}$

Godelier também faz anotações interessantes sobre algumas contribuições de Polanyi ${ }^{268}$. Estas são sobre os mecanismos de integração social, capazes de garantir a produção e reprodução de bens materiais, apontados como de três tipos. O primeiro deles corresponde às sociedades onde o parentesco representa um papel dominante e onde a reciprocidade é o principal mecanismo de integração. $O$ segundo é o mecanismo de redistribuição, que ocupa um papel central naquelas sociedades regidas por um forte poder central onde há uma concentração dos bens para depois redistribuí-los. Por fim, está o princípio de mercado, base da integração nas sociedades capitalistas onde, para adquirir algo, deve-se vender algo.

Ainda assim, Godelier fala de outra distinção, na qual concorda com Polanyi, sobre os sistemas embutidos e livres. Os sistemas econômicos podem estar 
embutidos no funcionamento de estruturas sociais de base não econômica como as relações de parentesco ou político-religiosas. Já o sistema mercantil é considerado como independente e livre das amarras das demais relações sociais regulando-se a si mesmo. Godelier também nos oferece seu próprio conceito de modo de produção:

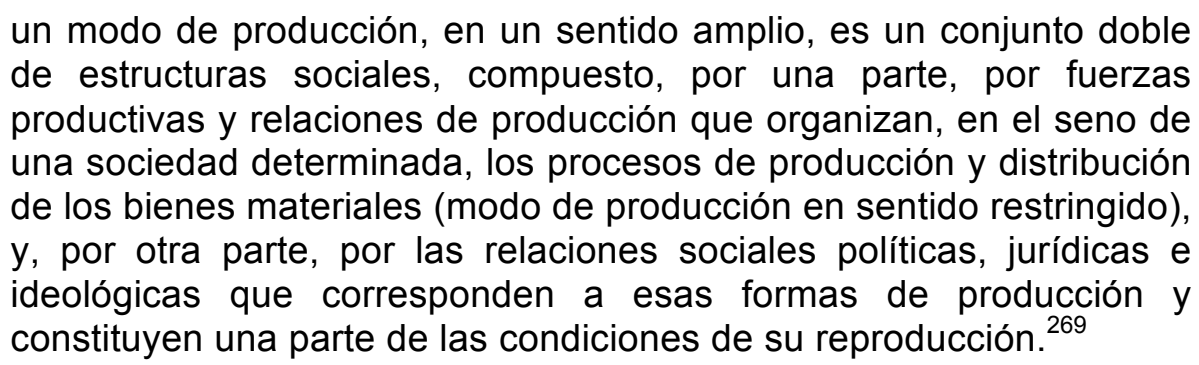

Todo processo de produção, para Godelier, é um ato de apropriação da natureza pelo homem o qual necessita combinar três espécies de atividades. A primeira delas é o objeto de trabalho que entra em transformação, seja ele a própria terra ou outra matéria prima. A segunda, são os meios de trabalho consubstanciados nas ferramentas ou utensílios utilizados. A terceira é a espécie de trabalho realizado pelo homem. O trabalho pode ser individual ou coletivo e em todos os casos é realizado dentro de uma divisão social do trabalho que poderá estar baseada na existência de classes ou castas de produtores especializados. Todas as formas de divisão do trabalho implicam, para Godelier e falando sobre as sociedades primitivas, alguma forma de divisão sexual e geracional do trabalho. Quando se nota a especialização de uma sociedade em determinada atividade, tal especialização sinaliza a existência de uma divisão interétnica, intertribal ou internacional do trabalho.

Godelier também insiste no primado da infraestrutura para a conformação social. Para ele, o modo de produção limita e exige a compatibilidade das estruturas sociais. No entanto, essa adaptação das estruturas sociais ao modo de produção pode ser conseguida de diversas maneiras. Como apontava Malinowski, entre os habitantes de Trobriand, os recursos naturais eram propriedade comum, enquanto alguns instrumentos, como por exemplo as canoas, eram propriedade individual. Godelier afirma que o fundamento do direito do homem ao uso dos recursos naturais (e não sua propriedade) se dá enquanto membro daquele grupo. Contrapõe-se essa 
ideia ao postulado geral de que o trabalho sobre algo, nesse caso, a terra, dá direitos aquele que lá trabalhou.

Sobre o parentesco, Godelier afirma que o mesmo deixa de ser importante para o processo de produção. O casal passa a ser somente uma unidade de consumo e a produção acontece em locais separados completamente da organização familiar. Além disso, o fato de que a força de trabalho tornou-se uma mercadoria é responsável pela circulação dos fatores de produção em um mercado único e objeto de quantificação monetária.

Godelier opõe-se ao que chama de materialismo vulgar e contesta a explicação de Marvin Harris sobre a sacralização das vacas na Índia. Para Godelier, este tipo de explicação tende a reduzir todas as relações sociais a meros acessórios das relações econômicas que, por sua vez, seriam apenas a adaptação ao meio natural. O autor pontua que, com uma sociedade que existe e funciona, é fácil encontrar, mediante tautologias, vantagens econômicas para determinadas pautas sociais.

Segundo o autor, existem relações de ordem entre os diversos níveis estruturais da sociedade e essas relações de ordem fazem com que a base material da sociedade esteja influenciada pelas propriedades de outros níveis. A relação entre as características do modo de produção deveria ser representada da seguinte maneira, para Godelier ${ }^{270}$ :

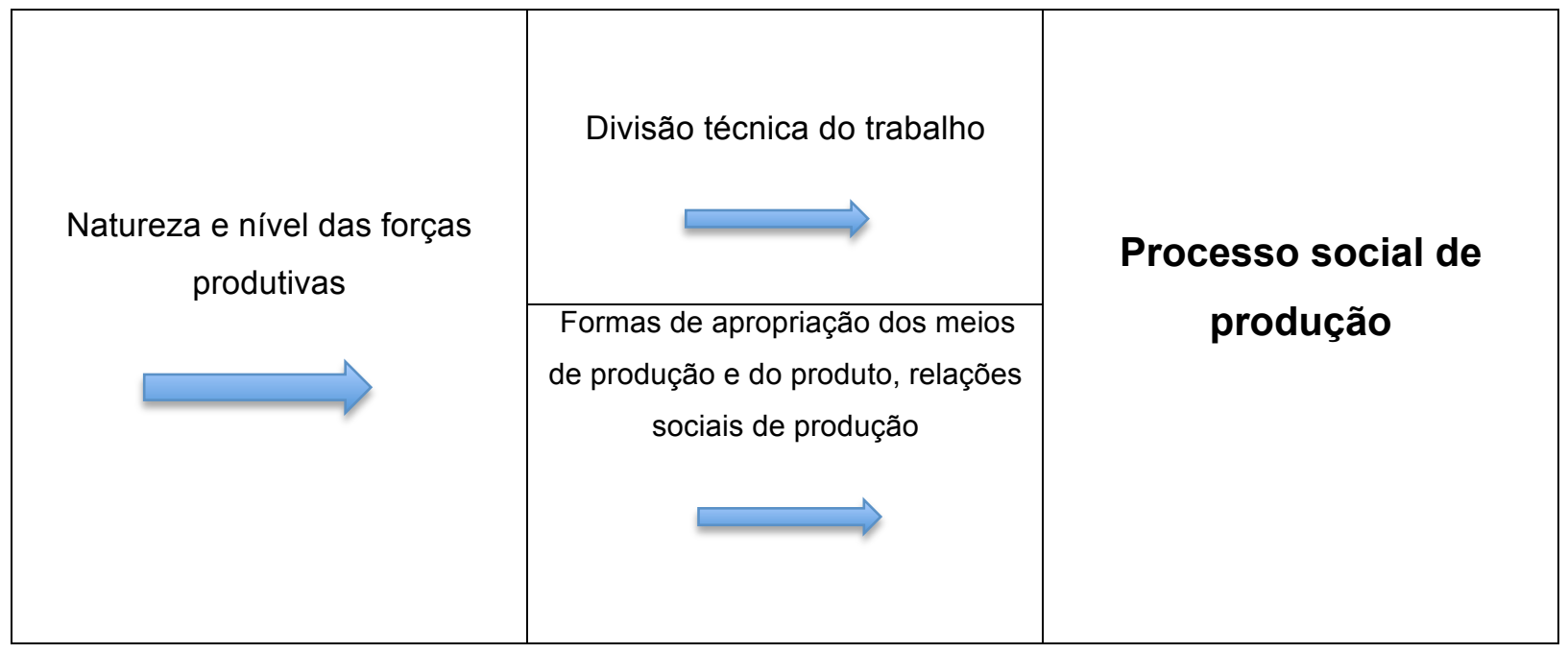

270Adaptado de GODELIER, 1978. p. 248. 
Godelier também dá uma definição de trabalho não especializado que seria aquele onde o trabalhador pode ser substituído por qualquer outro dentro dos limites da divisão sexual. A magia do dinheiro consiste em ser a medida para equivalência de todas as coisas e principalmente, por ser a encarnação de todo o trabalho humano existente. O dinheiro na forma de capital seria um mediador da relação social entre pessoas.

Como se pode notar, a questão do modo de produção está intimamente relacionada com aspectos da divisão do trabalho. A existência de profissões, de conselhos profissionais, de largos cursos de formação e de associações dedicadas exclusivamente à defesa e representação das classes profissionais revelam a grande importância deste aspecto na organização social moderna e pós-moderna. A análise materialista cultural coloca o trabalho e suas divisões como eixo central da vida social.

\subsection{Antropologia simbólica/hermenêutica}

A antropologia simbólica/hermenêutica, apesar de já remontar aos anos 70 , é uma das recentes escolas consolidadas de antropologia. $\mathrm{Na}$ verdade, os autores produziram, em nosso entender, uma mudança nos paradigmas antropológicos. De outro lado, talvez a antropologia hermenêutica (a partir de agora a chamaremos apenas assim) seja aquela corrente que mais pode contribuir para uma melhor aproximação entre direito e antropologia. Os últimos anos, o Brasil tem demonstrado a utilização da hermenêutica jurídica como técnica de exercício de poder e do ativismo judicial que passou a reger a vida nacional brasileira em detrimento dos poderes legislativo e executivo.

A análise do livro começa melhor se iniciamos pelo segundo capítulo e depois voltamos ao primeiro. Naquele capítulo, Geertz faz a contribuição para a organização dos conceitos e da posição da cultura na evolução da espécie humana, adotando conceitos diferentes daquelas classificações evolucionistas próprias do século XIX. O pensamento científico da cultura sempre procurou o que é o homem, bem como ordenar a complexidade existente. Até hoje não se chegou a um consenso sobre onde estaria a linha divisória entre o que é universal e constante no homem e aquilo que é local e variável. O embate entre o relativismo cultural e o 
evolucionismo continua presente. Por um lado, corre-se o risco de desprezar as diferenças culturais como apenas estágios e, por outro, como produtos do acaso, tendo o homem como moldado exclusivamente pelo determinismo ambiental e histórico.

Segundo Geertz, várias foram as tentativas de localizar o homem no conjunto dos seus costumes. O autor afirma que todas elas adotaram uma estratégia que divide o homem em níveis: biológico, psicológico, social e cultural. Cada um desses níveis seria completo em si mesmo e reforçaria aquele superposto. Assim, seria possível despir o homem em camadas dos diversos níveis ressaltando a cultura como o único aspecto exclusivo dos homens. A partir de então, começou uma procura por constantes culturais presentes nos costumes mundiais como forma de apontar certos traços essenciais e comuns a toda humanidade. Segundo Geertz, sempre que se pretende generalizar algum aspecto é necessário defini-lo de maneira tão ampla que a força se perde completamente. Ainda, não se pode afirmar que as instituições servem apenas para um propósito biológico ou psicológico como, por exemplo, o casamento não é mero reflexo da necessidade de reprodução.

Geertz propõe, acertadamente a nosso ver, um conjunto de mecanismos de controle para governar o comportamento. Para o autor, o homem é o animal mais necessitado e dependente de tais mecanismos de controle extragenéticos/extrapele para coordenar seu comportamento. O fato de o homem ser extremamente adaptável ao ambiente e possuir uma plasticidade de condutas bastante elevada significa também dizer que o homem não possui mecanismos de resposta e de apoio gravados em seu material genético. As orientações emanadas pelo sistema genético são difusas e permitem ao homem aprender e viver milhares de possíveis combinações. No entanto, a cultura nos conduz a que vivamos apenas uma dessas milhares de possibilidades. A cultura é, portanto, não apenas o que ordena a existência humana, mas uma condição para a mesma e sua principal distinção com relação às demais espécies.

Com base em tal perspectiva, Geertz realiza uma crítica à forma como tradicionalmente tem-se abordado a relação entre biologia e cultura. Para ele, faz-se necessário assumir três premissas básicas dessa relação. Primeiro, é necessário refutar a afirmação de que o desenvolvimento da cultura começou apenas com o 
surgimento da espécie homo sapiens, em outras palavras, que há uma relação sequencial entre o desenvolvimento biológico e cultural, o primeiro como pressuposto do segundo. Em segundo lugar, que a maior parte das mudanças que diferenciam o homem moderno dos seus antepassados imediatos ocorreram no cérebro e no sistema nervoso central e, em terceiro lugar, que o homem é, em termos físicos, um animal inacabado pois necessita aprender uma grande quantidade de coisas antes de poder funcionar em sua plenitude.

No que tange ao primeiro argumento relatado por Geertz, o autor afirma parecer nunca ter existido, efetivamente, um momento mágico no qual o homo sapiens passou a produzir e transmitir padrões culturais. Tal momento foi resultado de uma longa e ordenada sequência que envolveu, inclusive, outras espécies do gênero homo além do sapiens. Geertz afirma que houve uma superposição de aproximadamente um milhão de anos entre o início da evolução cultural e o aparecimento do gênero homo (a partir da constatação de ferramentas junto aos Australopitecíneos). Tal fato, indica, para o autor, que a cultura foi parte fundamental da evolução biológica do gênero que culminou com nossa espécie e não foi um ingrediente acrescentado a uma espécie já acabada. O crescimento lento da cultura na era glacial gradualmente foi trazendo vantagens adaptativas aos indivíduos mais capazes. Ou seja, para o autor, a relação entre cultura, corpo e cérebro era (e continua sendo) um sistema de feedback positivo no qual um modelava o progresso do outro. Para Geertz, em resumo, o homem criou-se a si mesmo, ou, ao menos, contribuiu substancialmente para sua evolução biológica e cerebral.

Tal constatação também leva a uma segunda: a de que não existem homens fora da cultura. Não existe a natureza humana sem cultura, o homem necessita de padrões culturais para sua existência. Nosso cérebro é incapaz de guiar nossa existência sem o apoio de símbolos significantes, existe um hiato entre o que diz nosso corpo e o que devemos saber para funcionar e esse hiato deve ser preenchido com as informações preenchidas por nossa cultura. Os homens são, segundo o autor, artefatos culturais.

No entanto, as afirmações produzem o paradoxo de ter de defender a relação entre desenvolvimento cultural e capacidade psíquica no período prévio ao Homo Sapiens com a necessidade de afirmar a unidade psíquica da humanidade no 
período atual. O autor resolve o problema defendendo a ideia de que o tempo das análises da progressão da cultura deve ser reduzido. Como por exemplo quando comparamos os chimpanzés com os homens. Os chimpanzés não são verdadeiros antepassados do homem, tivemos com tal espécie um último antepassado comum há vários milhões de anos e, por isso, não podemos presumir que saltamos da condição de chimpanzés à condição de humanos como um passe de mágica evolutivo. Lado outro, desde o surgimento da espécie Homo Sapiens, os limites em que a espécie varia em todos os cantos do globo são muito estreitos o que permite reafirmar a unidade científica da humanidade.

A conclusão do autor é a de que os recursos culturais são ingredientes e não acessórios do pensamento humano. Efetivamente, mesmo aquilo que chamamos de emoções são efetivamente artefatos culturais. Para saber como nos sentimos com relação às coisas necessitamos de imagens públicas de sentimentos que são regularmente fornecidas pelo ritual, o mito e a arte.

Como já mencionado em outros tópicos relativos a outras escolas antropológicas, é impossível, e seria despropositado, analisar todos os autores de determinado assunto. Optamos, no presente tópico, por tratar de três autores por nós considerados como fundamentais desta corrente de pensamento: Clifford Geertz, Mary Douglas e Victor Turner. Começaremos com uma breve análise das contribuições de Geertz ${ }^{271}$ em sua obra "A interpretação das culturas".

O primeiro capítulo da obra é talvez um dos textos antropológicos de maior influência das últimas décadas e trata do modo de descrever e interpretar antropológico. A “descrição" densa proposta por Geertz foi encampada também por DaMatta $^{272}$ que a exalta:

Uma dedução possível, entre muitas outras, é a de que, em antropologia, é preciso recuperar esse lado extraordinário e estático das relações entre pesquisador/nativo. Se este é o lado menos rotineiro e o mais difícil de ser apanhado da situação antropológica, é certamente porque ele se constituí no aspecto mais humano da nossa rotina. É o que realmente permite escrever a boa etnografia. Porque sem ele, como coloca Geertz (1978), manipulando habilmente um exemplo do filósofo inglês Ryle, não se distingue um piscar de olhos de uma piscadela marota. E é isso, precisamente, 
que distingue a "descrição densa" - tipicamente antropológica - da descrição inversa, fotográfica ou mecânica, do viajante ou do missionário.

Geertz também exalta a necessária de contenção do conceito de cultura para que o mesmo adquira uma dimensão justa e não se perda difuso como aquilo que é tudo e ao mesmo tempo não é nada. O conceito de cultura defendido por Geertz é o de "teias de significados e sua análise. ${ }^{273 "}$

A piscadela, acima referida por DaMatta, é o exemplo utilizado por Geertz para explicar o que seria a "descrição densa". O ato onde, em um grupo de pessoas, alguém pisca para a outra, pode ser explicado de várias formas. No entender de Geertz, do ponto de vista do corpo humano, o movimento é um só, a contração de músculos de algum dos olhos que ocasiona o cerre da pálpebra. No entanto, a piscadela pode ser oriunda de um tique nervoso ou uma piscadela conspiratória, daquelas que indicam a presença de uma trama secreta entre o piscador e aquele ou aqueles para quem piscou. Segundo o autor, a diferença entre ambas as coisas é enorme e, no entanto, não pode ser entendida sem uma descrição densa, que capte e interprete a simbologia envolvida no ato do piscar de olhos. Geertz ressalta que o que piscou, além de contrair a pálpebra, também piscou, ou seja, realizou um ato deliberado, destinado a alguém em particular para transmitir uma mensagem específica segundo um código socialmente estabelecido e sem o conhecimento dos demais. Por isso, aquele que realiza a piscadela, além de contrair as pálpebras, também piscou, diferentemente do que possui um tique nervoso que somente contraiu a pálpebra sem outro significado especial.

$\mathrm{Na}$ diferença entre uma descrição superficial e a descrição densa, entre a contração da pálpebra e a piscadela conspiratória está o objeto da etnografia. Esse contínuo de estruturas significantes, uma descrição interpretativa e uma interpretação descritiva, permite perceber e interpretar as ações humanas. 0 antropólogo observa e explica, às vezes, explica explicações e interpreta outras interpretações. O texto antropológico necessariamente será uma obra de ficção, interpretações da realidade obtidas de segunda ou terceira mão (a interpretação nativa seria a de primeira mão). Para Geertz a análise cultural deveria ser uma 
adivinhação dos significados, com avaliação das conjeturas e conclusões traçadas a partir das melhores conjeturas.

A etnografia, tem como pressuposto ser microscópica, refere-se a determinado grupo, a determinado lugar, a certa época e circunstâncias específicas. Tal circunstância torna as interpretações resistentes a modos de avaliação sistemáticos. A abordagem semiótica da cultura auxilia no acesso do pesquisador ao mundo simbólico e conceitual no qual vivem os sujeitos da pesquisa de forma a poder dialogar com eles. Por outro lado, o autor afirma como necessário manter a análise das formas simbólicas o mais estritamente ligadas aos acontecimentos sociais quanto possível. Na interpretação é necessário sempre resistir ao subjetivismo ainda que seja impossível eliminá-lo por completo. ${ }^{274}$

Outra das autoras que consideramos como fundamental para a compreensão da antropologia hermenêutica é Mary Douglas. Analisaremos sua obra Natural Symbols ${ }^{275}$ cujo título já encerra uma contradição, como admitido pela própria autora.

Como vimos a sociedade vive em um equilíbrio entre natureza e cultura (aqui representada pelo símbolo), por outro lado, o próprio homem têm, há milhares de anos influenciado a natureza através das adaptações culturais. Na visão anterior de Geertz, este é convicto sobre a atuação do homem na seleção genética e tal tendência parece consolidar-se cada vez mais. Além disso, o homem tem influenciado o ambiente de todas as formas, também influenciando circunstâncias naturais. Por fim, o paradoxo natureza cultura também pode conter a afirmação de que se a cultura é o complemento necessário da ação humana esta, por sua vez, também seria "natural". Para a própria autora, os símbolos naturais também podem se dever ao fato de que a psique humana, única, produz similares soluções simbólicas para problemas parecidos. Contudo, admite Mary Douglas, uma simbologia panumana e funcional no mundo todo parece ser uma impossibilidade. Para autora, cada entorno social fixa os limites para suas expressões simbólicas e, justamente por tal motivo, algumas comparações cruzadas podem se revelar totalmente despropositadas. 
A obra da autora busca analisar as distintas maneiras de relação entre a comunidade e os símbolos. O livro foi publicado pela primeira vez na década de 60 , auge do movimento hippie e dos milenianistas. Para Douglas, viviam-se tempos de movimentos de contracultura, de revolta contra o formalismo, de contestação dos valores tradicionais, da sociedade e das instituições em geral. O culto ao corpo era uma forma de simbolizar o único "sistema" conhecido que realmente funcionava em detrimento da sociedade, tida como algo ineficiente e inoperante.

Douglas considera o ritual como uma forma de comunicação e o define como uma série de atos roteirizados que adquirem diferente significado de seu uso corrente. O ritual normalmente é utilizado em antropologia como uma forma de comunicação que refletem as crenças comuns do grupo a despeito das opiniões pessoais ou a ideologia daqueles que praticam o ritual. A razão é que em pequenas sociedades, no universo microscópico da etnografia, o espaço entre os significados privados e públicos não é muito grande e tende a não aumentar tendo em vista a proximidade dos sujeitos.

Ainda, na jurisprudência das sociedades tradicionais, há uma aparente confusão entre lei e moralidade. Não existe lei, nem tampouco precedentes escritos, assim, é possível realizar pequenas mudanças nas regras legais para adaptá-las às novas situações morais experimentadas. Para essas sociedades não há contradição, na prática, entre a existência de uma lei divina imutável e pequenas mudanças na lei mundana. A religião cumpre a função de preencher problemas de adaptação e mau-funcionamento psicológicos. Ao passo que os problemas de adaptação tornam-se menos proeminentes o ritual e as rotinas deixam de ser observados. As formas públicas de expressão simbólica, entretanto, não podem ser desprezadas, principalmente pelos antropólogos.

A autora utiliza diversas comparações entre sociedades para tentar definir os rasgos gerais de relação com o mundo conforme a visão cosmológica e ritual de cada grupo. Neste caso, em sociedades onde o simbolismo e o ritualismo são fortes a ideia de pecado envolve atos específicos que não devem ser praticados. Por outro lado, em sociedades onde o ritualismo é débil, o pecado está mais associado a estados internos de consciência do que com atos externos. Para a autora, a percepção e interpretação dos símbolos são determinadas socialmente. 
Segundo Douglas as experiências mais intensas de ritualismo são percebidas em grupos sociais fechados e restritos. A autora rejeita a ideia de que a secularização seja uma tendência moderna atribuível ao crescimento das cidades e progresso da ciência. Para ela, diferentes graus de secularização e ritualismo são encontrados nas sociedades tradicionais pelo que se deve rejeitar a ideia préconcebida de que o homem primitivo sempre é profundamente religioso.

O anti-ritualismo extremo seria uma tentativa de erradicar a comunicação através de sistemas de símbolos complexos. A autora apoia-se na obra de Basil Bernstein para discorrer sobre suas impressões sobre os tipos de comunicação (discursos) existentes. São apresentados dois tipos básicos de discursos: o primeiro é aquele proferido em pequena escala dentro de um grupo onde todos possuem as mesmas acepções iniciais fundamentais. Neste caso o discurso funciona como reafirmação social e promotor da solidariedade do grupo. Também pode funcionar como forma de controle além de forma de comunicação. O segundo tipo é aquele onde os interlocutores não possuem ou assimilam as mesmas percepções iniciais. Nesta hipótese o discurso funciona como forma de expor as percepções individuais e construir pontes para a compreensão mútua.

Existe, também, um código de comunicação (discurso) super-elaborado que acaba por desvincular-se da estrutura social normal e a exigir que esta passe a ser estruturada conforme o discurso elaborado como é o caso da linguagem científica. Tal tipo de discurso, para Douglas, é produto da divisão do trabalho que exige a especialização e diferenciação social. As conferências dos antropólogos (ou de qualquer outro corpo de profissionais), as normas de publicação e de citação são formas pré-codificadas de interação. Assim, Douglas faz uma crítica a Bernstein ${ }^{276}$, que, com sua dicotomia entre códigos de comunicação restritos ou elaborados estaria no mesmo nível de Durkheim ${ }^{277}$ e as solidariedades orgânica e mecânica ou de Maine ${ }^{278}$ entre o status e o contrato. Bernstein procurava refletir os efeitos da divisão do trabalho no discurso e nas formas de controle. Segundo o autor, onde os efeitos da divisão do trabalho são mínimos, as formas de discurso e controle fundamentam uma diferente versão de relações familiares.

276 BERNSTEIN, Basil. Clases, códigos y control. Estudios teóricos para una sociología del lenguaje. Torrejon de Ardóz: Akal, 1989. 
Com isso a autora afirma que diferentes estruturas sociais geram diferentes tipos de discurso. Além disso, as palavras e o discurso têm perdido importância enquanto forma de comunicação imediata para ser utilizadas em estruturas mais amplas as quais exigem elaboração e complexa codificação.

Os símbolos, para Douglas, são os únicos significantes da comunicação. São as maneiras de expressar valorações, instrumentos do pensamento e reguladores da experiência. No entanto, para funcionar, os símbolos necessitam estar devidamente estruturados e ordenados. Da mesma maneira, um sistema de classificações necessita de um controle estável para manter sua coerência. A existência de uma estrutura faz com que, em determinada situação, exista um pequeno abanico de soluções possíveis, causando pouca confusão psicológica sobre a atitude a tomar.

A cosmologia de caça às bruxas normalmente surge em sistemas com limites estreitos e raramente em sociedades nômades e caçadoras-recoletoras. Tal situação pode ser aplicada aos casos de associação e representação compulsória, pouca mobilidade social, elevada burocracia onde, frequentemente, é necessário encontrar culpados para o insucesso ou para as crises cíclicas.

No entanto, a autora alerta para a maneira como as cosmologias nos aprisionam em seus sistemas simbólicos. A autora, no entanto, refuta a teoria da sociedade como infraestrutura e a cultura como superestrutura. Para ela, os códigos elaborados devem incitar os indivíduos a permanentemente questionar seus valores e desenvolver modos pessoais de controle e comunicação. Insistir na superioridade do espírito sobre a matéria é afirmar a liberdade dos indivíduos e procurar libertá-lo de constrangimentos indevidos. Já o contrário, afirmar a prevalência da matéria e a necessidade do espírito realizar-se através dela, é dizer que o indivíduo é subordinado à sociedade e só encontrará a liberdade nas formas por ela previstas.

Por fim, analisaremos a obra de Victor Turner ${ }^{279}$, O Processo Ritual, para completar essa "vista aérea" do que seria a antropologia hermenêutica. O livro de Turner, como soe acontecer, começa com o autor declinando suas percepções sobre os temas mais inquietantes da antropologia como, por exemplo, a questão da 
unidade psíquica da humanidade. Neste sentido, Turner assevera que a "vida imaginativa y emotiva del hombre es, en todo lugar y ocasión, rica y compleja. ${ }^{280 \text { " }}$ Por outro lado, deve-se ter em conta, segundo o autor, que uma mesma estrutura cognitiva presente em nossas mentes é capaz de articular experiências culturais muito diversas.

Turner realizou estudos junto aos Ndembu da África Central os quais possuem um importante desenvolvimento do simbolismo ritual segundo definições do próprio autor. De maneira prudente, o autor diz que não se pode atalhar o caminho pelos mitos e cosmologias para evidenciar a estrutura. Deve-se proceder de maneira gradual pelo caminho simbólico para tentar compreender o modo de pensar indígena.

O autor identifica, em partes dos rituais Ndembu, a disposição e classificação de objetos de maneira similar ao que fez Lévi-Strauss na Mitológicas, a partir de classificações binárias e opostas. $\mathrm{O}$ autor, explica e interpreta um dos rituais que é relacionado à fertilidade da mulher. Bem assim, o autor aborda o paradoxo dos gêmeos que causam instabilidade na estrutura social ao não se poder atribuir aos dois o papel que seria destinado ao filho, seja na ordem de nascimento entre os irmão, seja com relação à comunidade em geral. Para Turner os gêmeos cumprem uma função mediadora entre divindade e humanidade, são mais que humanos e menos que humanos à vez. Cabe recordar que a expressão "humano" envolve a definição presente no nome da maioria dos povos que se autoclassificam como os verdadeiros e únicos "homens".

Turner também destaca que o anormal pode ser sacralizado citando 0 exemplo das pessoas com retardos mentais em certos pontos da Europa Oriental onde consideravam-nos como sagrados e a comunidade era obrigada a alimentá-los e protegê-los. O mesmo ocorre com o caso dos gêmeos, algo que em princípio é beneficioso e até necessário, o filho, torna-se um pesado fardo para a família e para a lactância materna em especial. Desta feita, toda a comunidade vê-se obrigada a contribuir com o sustento dos gêmeos. $O$ autor ressalta que, para sociedades organizadas com base no parentesco, o nascimento de gêmeos pode abalar a estrutura social e duas soluções são possíveis: ignorar o fato e seguir atuando como 
se não existisse ou aceitá-lo e tentar com que adquira coerência com o restante do arcabouço cultural. Nesse sentido os gêmeos podem tornar-se exemplos da pluralidade, da oposição ao único ou bem da divisão da unidade, no caso Ndembu, a opção adotada foi ressaltar os aspectos de oposição e complementariedade.

O autor contribui para aproximar a sociedade Ndembu da realidade das sociedades ocidentais modernas e pós-modernas ao apresentar a convivência de ideais antitéticos naquela sociedade, similar ao que podemos verificar com relação às oposições norte $x$ sul e socialismo $x$ capitalismo (esta última especialmente relevante na época em que escrito o livro). O ritual dos gêmeos, segundo o autor, serve para colocar em evidência as contradições reconhecidas pelos Ndembu como a separação entre homens/mulheres, sentimentos privados/públicos e esterilidade/fecundidade. Para Turner, uma das funções do ritual é utilizar as forças da desordem em prol da estrutura social ativando uma série ordenada de símbolos que atuam como mediadores e comunicadores entre biologia e estrutura.

Naquele que reputamos como o principal capítulo de sua obra, o que trata sobre a liminariedade e communitas, Turner discorre sobre elementos dos rituais de passagem, principalmente, e apoia-se na obra de Arnold Van Gennep ${ }^{281}$. Os rituais de passagem são aqueles que marcam mudanças de lugar, posição social e idade, por exemplo. Todos os rituais, segundo Van Gennep e Turner possuem necessariamente três fases: "separación, margen o limen (que en latín quiere decir 'umbral') y agregación. ${ }^{282 " ~ N a ~ p r i m e i r a ~ f a s e ~ o ~ i n d i v i ́ d u o ~ e ́ ~ s e p a r a d o ~ d o ~ g r u p o, ~ n a ~}$ segunda, apresenta características ambíguas, que não são compatíveis nem com o estado anterior e nem posterior, por fim, na terceira fase o indivíduo empregado é reincluído no grupo já com o novo status.

Os atributos da liminariedade são ambíguos. As pessoas nesta condição fogem ao sistema de classificações e características esperadas vigente na sociedade. A conduta das pessoas em situação liminar é normalmente passiva e submissa. Estes fenômenos interessaram a Turner também pelas oposições que apresentam entre o simples e o sagrado e a homogeneidade e o companheirismo. Para o autor, os momentos liminares têm o condão de fazer ressaltar os vínculos 
sociais existentes entre os presentes que reconhecem a necessidade e sacralidade das posições sociais que estruturam a comunidade e, por isso, o autor utiliza o termo communitas para diferenciar essa comunhão evidenciada pelos momentos liminares, daquela comunidade utilizada para designar algum aspecto de vida em comum. Para Turner a vida social é dialética e compreende tensões entre diversos aspectos como, por exemplo, homogeneidade/diferenciação ou alto/baixo(referindose às posições sociais).

Turner faz ainda afirmações interessantes sobre a questão da liminariedade na sociedade pós-moderna. Para o autor, a partir, principalmente, da complexidade social fomentada pela divisão social do trabalho, aquilo que nas sociedades tradicionais eram estados de liminariedade que permeavam outros estados/posições perfeitamente definidos tendem a tornar-se agora sempre liminares. $\mathrm{Na}$ sociedade atual, a liminariedade ou, em outras palavras, a pertença a diversos status, transitando entre eles, tornou-se a regra. Vários personagens de romances e mitos são marginais ao grupo e, portanto, podem apresentar atitudes morais distintas daquela apresentada pelo grupo maior e restrito.

Destaque-se, por outro lado, o perigo dos estados de liminariedade. Tudo aquilo que não pode ser classificado tende a ser apontado como perigoso ou contagioso. Portanto, manifestações prolongadas de communitas podem ser perigosas e anárquicas. A communitas é a manifestação do presente, em contraposição à estrutura que se projeta e é projetada pelo futuro e pelo passado através da tradição, da lei, do costume e da linguagem. Essa oposição entre communitas e estrutura expressa a relação entre a sociedade considerada como uma totalidade homogênea e como uma série de partes justapostas e hierarquizadas.

O autor parte também de uma das definições de Spencer ${ }^{283}$ sobre estrutura social definida como a ordenação mais ou menos diferenciada de instituições especializadas e mutuamente dependentes que interatuam entre si e tentam adaptar-se ao seu entorno físico. Turner diz que quase todas as definições da estrutura social implicam em uma série de posições ordenadas e instituições que se 
prolongam no tempo. As partes acabam por traduzir-se também em conflitos entre elas por maior status e proeminência.

Turner ressalta que a communitas possui uma natureza espontânea, concreta e imediata, no que se opõe à natureza abstrata e institucionalizada da estrutura social. Sem embargo, a communitas só consegue manifestar-se a partir da utilização de elementos da estrutura social justapondo-se ou hibridando-se com esses elementos. Para explicar a communitas o autor utiliza a metáfora de uma roda de carreta onde os raios e a circunferência exterior de nada valeriam se não fosse o buraco do centro que permite encaixar a roda na carreta. A communitas seria esse vazio central da estrutura social como se pode advogar pela similitude do sindicato com esse vazio na estrutura da organização e da divisão do trabalho.

Para Turner a communitas pode surgir nos interstícios da estrutura social, pelas suas margens ou mesmo por debaixo desta quando se trate, respectivamente, da liminariedade, marginalidade ou inferioridade. Essas condições estruturais seriam aquelas mais propícias ao surgimento dos mitos, dos rituais e dos símbolos. Nos ritos de passagem os homens são momentaneamente liberados da estrutura social para viver a communitas e, após, retornam a uma estrutura renovada pela experiência da communitas. O exagero na manifestação da communitas poderá causar, inclusive, manifestações contra ou à margem da lei.

Para Turner, autores como Morgan, Marx e Rousseau estiveram equivocados ao confundir manifestações da communitas como exclusivas das sociedades primitivas. A communitas, segundo Turner, é uma manifestação presente em todas as sociedades e não é monopólio daquelas mais arcaicas.

O autor também critica o modelo da antropologia tradicional britânica, chamada por ele de "ortodoxa", que classifica a sociedade como um ordenamento de posições sociais podendo apresentar estrutura segmentada, hierárquica ou ambas. Para Turner as unidades da estrutura social estão compostas das relações entre status, papéis e funções.

Contudo, o caráter espontâneo e livre da communitas raramente poderá sustentar-se por muito tempo. A própria communitas acaba por desenvolver normas para reger o comportamento dos indivíduos. Assim, nasce uma diferenciação entre 
três tipos básicos de communitas definidas por Turner: a communitas existencial, aquela em que à época da redação dos textos os hippies chamariam de happening e que hoje poderia ser comparada às manifestações sociais inexplicáveis ou a flashmobs, nascidos sem interesse comercial; a communitas normativa é aquela onde, pela passagem do tempo surge a necessidade de organizar os recursos e regular a ação dos indivíduos; e, por fim, a communitas ideológica que se pode chamar aquelas comunidades utópicas nascidas da communitas existencial. As duas últimas já são permeadas pela estrutura social e perdem muito de sua espontaneidade e liberdade, experimentando uma queda quando aproximadas da estrutura.

Segundo Turner, toda utopia necessita, em algum momento, organizar as pessoas para produzir as condições necessárias para a sobrevivência e então passa a exigir a existência de relações estruturadas entre os homens. Assim, para o autor, todo o sistema de produção e distribuição de recursos encerra em si a segmentação e diferenciação social. Dessa maneira, ao adotarmos perfeita igualdade em algum aspecto da vida social significa provocar uma perfeita desigualdade em outro aspecto desta mesma vida social.

A communitas e o êxtase por ela provocado são formas, principalmente nas sociedades tradicionais, de possibilitar uma participação mais plena na enorme gama de papéis sociais existentes. A estrutura social, por outro lado, relaciona-se principalmente com a história, pois possibilita a perpetuação do grupo social e de suas formas de vida.

O autor passa a analisar os rituais de elevação e inversão de status, ressaltando as três fases descritas por Van Gennep ${ }^{284}$, seja, separação, margem e reagregação e que também podem ser chamadas de pré-liminar, liminar e pósliminar. O autor define a estrutura social como: "una disposición más o menos característica de instituciones especializadas mutuamente dependientes y la organización social de posiciones y/o de los actores que las mismas implican. ${ }^{285 ",}$

A liminariedade, nas sociedades industriais e pós-industriais, devido ao estágio da divisão do trabalho, converteu-se em um estado religioso ou quase 
religioso tendendo a adquirir características estruturais. O autor diferencia dois tipos de liminariedade, os rituais de elevação de status e os rituais de inversão de status. Os rituais de elevação de status são aqueles onde um noviço é transferido irreversivelmente de um status inferior a um status superior. A seu turno, os rituais de inversão de status são normalmente cíclicos ou sazonais onde aqueles que normalmente ocupam status inferiores podem exercer autoridade ou proeminência sobre aqueles normalmente de status superior. O ritual de inversão de status reúne aspectos de uma conduta ilícita, extravagante e permitida temporariamente.

Para Turner, todas as sociedades humanas são remitidas a dois modelos sociais em franca oposição. Um deles é a sociedade estruturada em posições jurídicas, econômicas e políticas e o outro é a communitas que reúne indivíduos com idiossincrasias e que compartilham a mesma condição humana. O primeiro modelo é fragmentado e segmentado enquanto o segundo é homogêneo e global.

A inversão ritual de status tem o condão de produzir a liberação momentânea do indivíduo de seu status habitual conduzindo os indivíduos a uma experiência extática no sentido etimológico de "estar fora" de sua posição habitual e das obrigações a ela inerentes. Para Turner a necessidade dos rituais de inversão de status estão intimamente ligadas a uma permanente inferioridade estrutural de alguns membros do grupo social.

Sobre a sociedade atual diz Turner ${ }^{286}$ :

Indudablemente, en las sociedades complejas a gran escala, con un alto grado de especialización y división del trabajo y con muchos lazos asociacionales de interés único y un debilitamiento general de los estrechos vínculos corporativos, la situación será muy distinta.

A flexibilidade e mobilidade da sociedade industrial e pós-industrial podem, para Turner, favorecer o surgimento da communitas existencial através de encontros efêmeros. Para o autor, nossa existência social é um processo dialético entre estrutura e communitas já que há a necessidade humana de participar em ambas.

A antropologia, portanto, mudou seus enfoques e suas aspirações durante os séculos XIX e XX. Embora, a tendência maior dos séculos anteriores fosse a separação das ciências e a necessidade de afirmação de cada uma como campo 
autônomo do conhecimento humano já é hora de seguir o caminho inverso. A antropologia, como área que estuda a cultura, deve servir para fundamentar os aspectos socioculturais de tantas outras áreas e atividades humanas. É justamente isso que pensamos com relação ao direito, a antropologia poderá servir para explicar o surgimento e o objetivo das normas bem como atuar de maneira preventiva nos conflitos, identificando suas causas, enquanto o direito ocupar-se-á do conflito quando este já existe. 


\section{CAPÍTULO IV - ENCONTROS ${ }^{287}$ ENTRE ANTROPOLOGIA E DIREITO -} Fundindo os horizontes jurídico-antropológicos

O direito, como parece ser consenso, faz parte da cultura humana e por ela foi instituído como forma de possibilitar e facilitar a convivência em sociedade ${ }^{288}$. No estudo do direito, a partir de quando o direito passou a ser a forma predominante, principalmente nos Estados ocidentais, tornou-se bastante corriqueira a comparação entre leis e institutos jurídicos entre nações. Os Estados considerados mais desenvolvidos foram tomados como parâmetro para a inserção ou supressão de normas consideradas necessárias ou ultrapassadas.

A comparação é também um elemento central nos estudos antropológicos e está presente quase sempre, ainda que de maneira inconsciente quando o observador estranha aqueles comportamentos a que não está acostumado. René David diz que a função moderna do direito comparado é: "la de hacernos comprender los puntos de vista ajenos y la de hacer comprender a los otros nuestros propios puntos de vista, es decir, la de organizar, en la esfera jurídica, la coexistência pacífica y, si es posible, armónica que constituye conditio sine qua non para el mantenimiento y el progreso de nuestra civilización. ${ }^{289,}$

A frase do doutrinador francês bem poderia estar estampada em qualquer manual de antropologia falando sobre a necessidade de relativizar os costumes alheios e procurar compreender as pautas culturais segundo a visão do nativo. $O$ mesmo princípio aplica-se com relação ao direito. $O$ direito comparado não deixa de ser uma forma de fazer antropologia com um objeto cultural bastante restrito que são os aspectos jurídicos de determinados povos. Além disso, como pano de fundo do direito positivado na lei ou construído pela jurisprudência, estão as concepções jurídicas, o papel atribuído à lei e ao direito, a estrutura econômica, o idioma e todo o arcabouço de costumes de cada país ${ }^{290}$.

287 Expressão utilizada pela Dra ${ }^{\mathrm{a}}$. Ana Lúcia Pastore nas aulas do Máster en Estudios Brasileños da Universidad de Salamanca, Curso 14-15 a qual me parece apropriada para designar os pontos de interseção entre Antropologia e Direito.

288 REALE, Miguel. Lições preliminares de direito. São Paulo: Saraiva, 2001.

289 DAVID, René. Los grandes sistemas jurídicos contemporáneos. Madrid: Aguilar, 1968. p. 8

290 DAVID, 1968. 
É importante lembrar que o direito surgiu como forma de regular as relações entre as pessoas. Portanto, o direito civil é o primeiro e mais antigo ramo do direito. As demais partições do direito em administrativo, constitucional, tributário, laboral, penal etc., são ramos posteriores e nos quais o direito civil segue exercendo influência, por vezes indevida. Existem diversas grandes famílias de direitos reconhecidas pelos juristas ao redor do mundo, citamos algumas das principais: romano-germânica, common law e direitos religiosos e tradicionais dentre os quais destacam-se o direito dos países muçulmanos, da Índia, da China e do Japão.

Em nosso estudo, interessar-nos especialmente a família romano-germânica irradiada desde o continente europeu e aplicada principalmente na América Latina devido à colonização. $O$ direito romano tornou-se foco de estudos nas Universidades da Idade Média que passam a entender o direito como um modelo de organização social. De fato, o direito romano foi a base do direito ensinado nas universidades, com proeminência face aos direitos nacionais, até o século XIX. No entanto, nos séculos XVII e XVIII notabilizou-se a Escola do Direito Natural que preconizava a existência de um direito naturalmente comum a todos os povos e todos os tempos. Esta escola contribuiu para criar no âmbito europeu uma comunidade de princípios filosóficos e morais comuns. A escola do direito natural também favoreceu a que o direito fosse expandido para outras relações como a relação entre o Estado e particulares na forma de direito público e principalmente no direito penal ao consagrar regras mínimas de humanidade e dignidade no trato dos processados e condenados. ${ }^{291}$

O direito germânico que compõe a grande família romano-germânica, na verdade, é uma abstração com elementos de vários locais e povos que insertaram elementos não romanos nos direitos nacionais. Na península ibérica resta a dúvida sobre se e os elementos germânicos do direito peninsular são realmente germanos ou são locais, provenientes de uma tradição ibérica. ${ }^{292}$

O costume desempenha um importante papel também na família romanogermânica. Os juristas são guiados pelas opiniões dominantes e pelas próprias ideias pré-concebidas com relação ao costume de determinado local. Para René 
David o costume atua como as condições de produção da teoria marxista, os costumes são a infra-estrutura do direito ${ }^{293}$.

A norma jurídica na família romano-germânica está a meio caminho entre a decisão do litígio concreto e os princípios que a informam. A norma deve deixar certa margem de ação ao juiz e, quando certas situações soem repetir-se, procurase adequar fato e norma como forma de proporcionar um guia aos cidadãos sobre como proceder. A lei e o direito não se confundem, ainda que a lei tenha alcançado um grande protagonismo. No entanto, o direito somente será encontrado com o cotejo de diversos elementos e atuação dos juristas.

René David ${ }^{294}$ aponta duas tendências legislativas no seio da família romanogermânica. Uma delas tende a expressar as normas da forma mais inteligível possível para a população e a outra procura utilizar uma linguagem técnica o mais precisa possível. A distinção entre as tendências é a mesma daquela já comum em antropologia entre a linguagem e pontos de vista emic e etic já explicados neste trabalho.

$\mathrm{Na}$ atual situação em que se encontram os Estados Democráticos de Direito parece ser uma insanidade a elaboração de leis com linguagem técnica e jurídica. Aliás, tal situação passa a ser causadora de enorme insegurança jurídica e provavelmente de interpretações que subverterão os motivos pelos quais foi criada a lei. A lei, ao menos em Estados Democráticos, é elaborada e aprovada por representantes eleitos do povo e é destinada ao conjunto da população. A lei, embora normalmente seja objeto de discussão pelos juristas é destinada ao total da população e a esta deve ser acessível. Os cidadãos necessitam entender a lei e saber como proceder.

A incompetência, a lentidão e a influência de interesses não legítimos no processo legislativo têm cada vez mais diminuído a qualidade das normas emanadas pelos parlamentos nacionais. A tendência a partir de então é que se abra a possibilidade e necessidade de interpretações que muitas vezes contrariem as leis para que se possa atender efetivamente os interesses da população e não de 
determinados grupos normalmente dominados por grandes investidores, bancos e grandes empresas de construção.

A jurisprudência passa então a exercitar atividade criadora de leis, principalmente através das cortes supremas, ainda que haja sempre a natural propensão a mascarar a atividade criadora sob o pano de fundo de revelação da verdadeira vontade do legislador ou do espírito da lei. Não é à toa que a interpretação das leis tem recebido cada vez mais atenção, mais teorias e clama pela imposição de limites, sob pena do direito perder-se no emaranhado interpretativo e ficar sujeita, sempre, ao casuísmo e subjetivismo. Não é por nada que uma das últimas escolas consolidadas de antropologia é a hermenêutica/simbólica, também no sentido de fornecer interpretações validas sobre costumes e tradições buscando modos de que o leitor entenda e possa respaldar ou criticar a interpretação feita pelo autor.

O problema da hermenêutica de fato aproxima o direito das demais ciências humanas colocando ao jurista o problema de interpretar os textos e símbolos do mundo da cultura. A justificativa racional e antropológica do direito somente se dará a partir de uma interpretação de acordo com a razão humana. Neste sentido, o direito deve ser sempre estudado e compreendido na perspectiva do dever ser e nunca somente daquilo que está posto. Ainda, é necessário ver o direito desde uma perspectiva histórica e evolutiva rechaçando a existência de um direito válido para sempre como alguns dogmas religiosos. O desenvolvimento do direito normalmente acompanha a evolução dos demais aspectos culturais de um povo. ${ }^{295}$

O direito sempre esteve dividido entre as leis positivas de determinado povo em determinado tempo e as condições sociais que criaram aquele direito, assim como sua legitimidade. Neste sentido lhering teve o mérito de voltar a ciência jurídica para a sociedade como forma de privilegiar os comportamentos sociais e as finalidades do direito. ${ }^{296} \mathrm{O}$ autor também foi um daqueles que procurou compreender a sociedade romana como um todo e não apenas o direito romano de maneira isolada. Para ele, o direito romano era um dos componentes que adquiria coerência dentro do arcabouço de costumes e instituições romanas e é esta coerência que 
devemos buscar ao utilizar os elementos do direito romano atualmente. ${ }^{297}$ Tal tipo de forma de encarar o direito causou uma inovação sem precedentes na forma de aplicar a lei, fugindo-se do formalismo e legalismo extremos para considerar a ponderação de cada caso com as complexidades que normalmente se apresentam.

Uma contradição, desde então, passará a estar sempre presente no direito e possibilitará duas formas possíveis de enxergar a prática jurídica: uma delas que entende o direito como fator cultural inserido na história e na cultura de um povo como mais um dos seus elementos; a outra é a visão do direito como uma soma de significados extraídos das normas existentes. ${ }^{298}$

Em contraposição a tais teorias surgiu uma concepção positivista do direito plasmada na obra de Hans Kelsen o qual advogava por uma teoria do direito positivo, apenas. Kelsen pretendia fugir da subjetividade e do caráter de ciência humana do direito ao pretender que o estudo e a aplicação do direito acontecesse somente com base nas leis existentes, sem críticas ou justificativas. Pretendia o autor conceder ao direito o status de uma ciência empírica e palpável, capaz de afrontar as demais ciências como a química ou a física. A corrente teórica defendida por Kelsen foi chamada de teoria pura do direito e, de fato, era uma teoria do direito positivado. $^{299}$

Para Norberto Bobbio o direito deveria ser uma ciência que aproveitasse a cientificidade das ciências sociais e estudasse as correlações entre os fatos sociais e as normas jurídicas. O direito seria como uma ciência comportamental que estuda a incessante mudança das normas jurídicas para adaptar-se às novas realidades sociais. Esta seria a necessidade das modernas sociedades que são abertas e mutáveis em oposição às sociedades estáticas e fechadas. O autor também é responsável por promover o embate entre o jusnaturalismo e o positivismo jurídico, embate este que promove outro dos encontros ou aproximações entre antropologia e direito. Bobbio define o jusnaturalismo como um feixe de princípios éticos e de primados da razão que servem de sustento e base para a atividade legislativa. A seu turno, o direito positivo é aquele direito expresso pela legislação existente e em vigor

297 JHERING, Rudolf Von. El espíritu del derecho romano en las diversas fases de su desarrollo. Granada: Comares, 1998.

298 LASK, Emil. Filosofía Jurídica. Buenos Aires: Depalma, 1946.

299 KELSEN, Hans. Teoría Pura del Derecho. México: Porrúa, 2005. 
em determinada nação. Para os positivistas ${ }^{300}$ aquilo que não foi transformado em legislação não é direito e sequer merece consideração. Para os jusnaturalistas o direito natural fundamenta e prevalece sobre o direito positivo, mas não o exclui da esfera de existência. ${ }^{301}$

O embate entre direito natural e positivo é daqueles paradoxos tão próprios da sociedade humana e também do clássico embate entre relativismo cultural e etnocentrismo. A aceitação de costumes alheios é sempre difícil quando tais costumes envolvem práticas que, para nós, incluem princípios irrenunciáveis como o direito à vida, à existência digna e à não discriminação. Falar em direito à vida poderia ser um enunciado de direito natural a pressupor que todo humano tem direito a desfrutar de sua vida e não ser dela privado por outro humano. No entanto, tal direito é constantemente relativizado, a depender da situação autorizadora (guerras e penas de morte por exemplo) e geralmente com base no direito positivo.

Assim, o que buscamos é um direito que insira a legislação e sua aplicação num contexto dos comportamentos sociais dos cidadãos e não um direito que encontre sua validade apenas no plano formal das normas em vigor. A norma deve possuir uma justificação emanada desde a realidade histórica, cultural, ética e social onde vige. $O$ trabalho de interpretação do direito deve ter em consideração o conhecimento das normas para alcançar seu significado, mas também uma base antropológica que empreste razão às normas. O significado da norma deve aflorar depois de estar oculto e esse tipo de interpretação supera uma pretensão de absoluta cientificidade da dogmática jurídica. ${ }^{302}$

Nas últimas décadas, muitos juristas têm aceitado e loado a teoria hermenêutica de Gadamer $^{303}$ que a propõe como uma teoria do pensar em geral e reduz diferenças, inclusive entre as ditas ciências da natureza e do espírito. Isso sem abrir mão da condição sempre histórica e necessária do compreender. A história não se soma àquilo que sabemos, mas é condição prévia do compreender. Em lugar de propor uma visão hermenêutica que seja capaz de se colocar no lugar

300 Aqui não nos referimos a "positivistas" ou "jusnaturalistas" em concreto mas utilizamos a figura de linguagem para demonstrar a oposição de ideias.

301 BOBBIO, Norberto. Giusnaturalismo e positivismo giuridico. Lecce: Laterza, 2011.

302 OSUNA FERNÁNDEZ-LARGO, 1992.

303 GADAMER, Hans Georg. Verdad y método. Vol. I, Fundamentos de una hermenéutica filosófica.

Salamanca: Sígueme, 1996. 
do outro, criam-se novos conceitos como a fusão de horizontes. Esse conceito de fusão de horizontes é a nova função das ciências do espírito, fundir o horizonte do presente com o horizonte do passado. ${ }^{304}$

O sentido de um texto (e aqui acrescentamos o de qualquer símbolo legível/acessível aos sentidos) transborda sempre o primeiro entendimento que dele se tem e retorna em cada interpretação que dele é feita. A compreensão não é uma atividade passiva e reprodutiva, mas sim ativa e criativa. Para uma correta compreensão de qualquer texto é necessária a mediação dos fatores tempo e tradição para possibilitar o acesso correto à realidade. Aliás, Gadamer propõe que somente através da distância seria possível apreender o sentido completo das coisas. $^{305}$ Essa distância pode manifestar-se como distância temporal ou como estranheza cultural como soe acontecer em antropologia. A partir da distância do observador, a observação adquire completude.

O compreender passa por um momento circular em dois pontos distintos chamados de momento adivinhatório onde tentamos captar situações individuais em sua singularidade e o momento comparativo onde partimos do conjunto geral para a compreensão de aspectos particulares. Para Gadamer, este círculo vai da précompreensão que temos à coisa possibilitando um contraste entre nossa ideia préconcebida e o objeto da interpretação. Por isso seria necessário abordar o texto com a mente aberta e propensa a entender a opinião alheia e outras possibilidades além daquela já pré-concebida. No entanto, como bem destaca o autor, o pré-juízo é inerente à atividade interpretativa e existem certos aspectos de pré-compreensão que são legítimos, pois compatíveis com o intérprete e com a sua condição históricoexistencial. ${ }^{306}$ Tal situação é bastante similar a estranhar o familiar e familiarizar o estranho de que fala DaMatta ${ }^{307}$ como exercício necessário para a atividade antropológica.

Gadamer sugere-nos a ideia de um diálogo interpretativo entre o intérprete e o texto. Há uma retroalimentação circular entre ambos e para isso o intérprete deve estar disposto a perguntar e a escutar o que diz o texto. A cada nova interpretação 
de uma norma esta é atualizada e adquire nova vida dentro da perspectiva criadora da interpretação. A tensão entre texto e intérprete é a situação ideal da compreensão que foi definida por Gadamer como dialéctica da familiaridadeestranheza, tal e qual DaMatta adaptou, posteriormente, à antropologia. ${ }^{308}$

Somente a partir da atividade interpretativa é que seria possível encontrar o direito. Devemos abolir a já ultrapassada intenção de encontrar a vontade do legislador e sim tentar diminuir a distância entre a generalidade da lei e a especificidade das situações concretas. Para Gadamer é inviável um conhecimento científico do direito como das ciências da natureza, o conhecimento do direito é de tipo hermenêutico, mais arte que técnica. ${ }^{309}$

Existiria uma tradição hermenêutica do direito que representa as expectativas de sentido impostas pela tradição jurídica e evitam uma ruptura total com os sentidos do texto legal. A formação jurídica deveria ser no sentido de transmitir essa tradição hermenêutica. O saber anterior necessário a proposição de indagações é o grande diferencial das ciências como o direito, inseparáveis de alguns valores históricos e das finalidades humanas. ${ }^{310}$

De acordo com Gadamer devemos prestar mais atenção à realidade cultural no momento da interpretação. A linguagem aparece como mediadora do ser e é impossível fugir de uma ontologia da linguagem no momento de pretender uma ontologia hermenêutica. A linguagem é a condição de transcendência da hermenêutica e esta não trata de descobrir sentidos ocultos na norma e sim o significado e o sentido para aquele intérprete naquela condição histórico-existencial. 311 Uma aplicação do direito restrita às possibilidades objetivas e positivas, na verdade, o que faz é afastar o direito da práxis dos cidadãos e isolá-lo. ${ }^{312}$

Para muitos autores, há uma crise na dogmática jurídica atual. O modelo de direito herdado do império romano buscava tratar conflitos interindividuais entre cidadãos romanos de possibilidades muito similares. Tal crise teria dois fatores fundamentais: o individualismo, ao colocar-se os problemas e direitos de pessoas 
físicas e jurídicas individuais com primazia em relação aos direitos da comunidade; e o formalismo que leva todas as discussões para o campo processual esvaziando a discussão do mérito das ações. Lênio Streck advoga em prol de um modelo substancialista onde o poder judiciário deveria fazer prevalecer a vontade geral implícita no texto constitucional e nos princípios considerados como fundamentais na cultura local e ocidental. ${ }^{313}$

Nas constituições dos Estados sociais do pós-guerra foram inseridos diversos princípios entendidos como comuns e não negociáveis, ao menos na sociedade moderna ocidental. No entanto, no Brasil, as diversas normas programáticas assentadas na Constituição Federal, não são cumpridas pelos poderes da República fazendo com que os prejudicados tentem fazer valer alguns direitos através do Poder Judiciário. Nesse sentido o Lênio Streck pontua o absurdo da despedida arbitrária e sem justa causa vedada pela Constituição brasileira e até hoje não regulamentada e tampouco aplicada. ${ }^{314}$

Por isso, na imensa maioria dos países ocidentais, de tradição no direito romano-germânico, a despedida, de um funcionário singular ou de vários, já não se admite sem uma causa que a justifique. Em outras palavras, a Constituição brasileira, a exemplo de outros países, veda a dispensa arbitrária ou sem justa causa. A vedação já está presente no sistema brasileiro há mais de um quarto de século sem haver cobrado um patamar mínimo de efetividade. Aliás, a baixa multa/compensação para o caso de uma despedida sem justa causa traz a impressão de que esta é permitida, bastando depositar algumas migalhas para o trabalhador. Mutatis mutandis, seria como acreditar ser permitido trafegar em excesso de velocidade, bastando, para isso, o depósito de uma multa em favor do Estado.

A dispensa arbitrária, sem qualquer razão além da discricionariedade do empregador, ou a sem justa causa, aquela fundada em uma causa, mas não justa o suficiente para embasar o despedimento, são ambas vedadas pela Constituição brasileira. Se a sanção posta é inexistente ou não atende minimamente aos requisitos de uma sanção a ponto de coibir a prática da conduta vedada, a norma 
carece de efetividade. Afinal, é o que se passa em nosso sistema, ao ponto de muitos acreditarem ser permitida a dispensa sem justa causa, fato arraigado, inclusive, no próprio ideário dos trabalhadores. Somadas, estas circunstâncias induzem a incrível rotatividade dos postos de trabalho brasileiros e os pesados gastos com subvenções aos desempregados ${ }^{315}$.

O exemplo citado por Lênio Streck é adequado e demonstra como o Estado descumpre as normas programáticas fixadas por todos como fundamentais. Neste sentido, aquela pré-compreensão de que fala Gadamer e que devem possuir os juristas sempre ocorre do ponto de vista do sujeito isolado. A reviravolta linguística significa que o sentido nunca é produzido individualmente e para si mesmo, mas para uma comunicação recíproca dentro de uma tradição determinada e de uma comunidade linguística. O autor adota a denominação de sentido comum teórico para designar esse complexo de saberes acumulados e comunidade de significados compartilhada pelos juristas como uma para-linguagem que atua além dos significados e significantes dominantes na comunidade extra-jurídica. ${ }^{316}$

Essa existência de uma tradição de significados existentes de e para os juristas causa uma verdadeira separação entre o mundo e o mundo jurídico. Lembremos que a lei não é destinada somente aos juristas e sim ao conjunto da população e como condição limitadora do Poder do próprio Estado. Essa postura torna a atividade jurídica dissociada dos verdadeiros problemas postos em tela e facilita o trabalho jurídico ao favorecer a aplicação desse sentido comum teórico sem grandes reflexões sobre a tarefa judicial e sobre a questão de mérito. Assim, o imenso escopo de possibilidades interpretativas de cada texto resta reduzido sensivelmente à vertente interpretativa "oficial" e "vinculante". A realidade deixa de importar ao mundo jurídico que se perdeu no plano formalista-oficialista. ${ }^{317}$

A interpretação, por óbvio, representa um processo criativo e não meramente reprodutivo ou adivinhatório. O que rege uma interpretação são as condições sob as

315 BONATTO BARCELlOS, Antonio Augusto e LEAL DA SILVA, Elizabet. A despedida coletiva no Brasil: uma análise da possível aplicação da experiencia europeia. in: STURMER, Gilberto. (Coord.) Revista de Processo do Trabalho e Sindicalismo, n 7, Porto Alegre, 2016.

316 STRECK, 2000.

317 STRECK, 2000. 
quais foi levada a cabo. A condição histórico-existencial do intérprete e seus interesses políticos e teóricos são parte do processo interpretativo. ${ }^{318}$

Neste ponto, cabe fazer um parênteses para destacar outro dos pontos de encontro entre o direito e a antropologia. Já tratamos aqui sobre Geertz e seu conceito de descrição densa como aquela útil à antropologia por revelar diversos aspectos que uma descrição superficial poderia não revelar. O exemplo da piscadela poderia ser descrita apenas como a contração de tecido muscular ou como uma conspiração entre duas pessoas para enganar uma terceira. A diferença nas conclusões sobre a piscadela reside justamente na qualidade da descrição efetuada pelo observador/intérprete. Por isso, o intérprete jurídico, tal qual o observador/intérprete antropológico têm obrigação de realizar uma descrição densa e completa dos fatos que motivaram tal interpretação. $O$ intérprete jurídico, principalmente os julgadores, mas também outros profissionais da área, devem esclarecer os pormenores que levaram a optar por esta ou por aquela interpretação da lei naquele caso concreto. Note-se que tais pormenores não podem ser limitados à citação de precedentes ou correntes doutrinárias.

Aqui a antropologia tem muito a ensinar com relação ao direito. Imaginemos uma interpretação de antropólogo sobre a famosa piscadela dizendo que, em determinado contexto, a piscadela também é sinal de uma trama conspiratória porque assim já disse Geertz. Os antropólogos (e também a humanidade) aprenderam a duras penas sobre a imensa variabilidade da conduta humana. A interpretação de um fato (ou de uma norma) acontecida em um caso pode até ser aplicável a outra similar, mas não é sempre assim. O desejo por julgar casos e responder a estatísticas é tão grande que provoca paradoxos inconciliáveis, tais como o paradoxo da similitude de fato. Em outras palavras, para adequar um precedente anterior ao caso concreto os fatos são sempre muito similares, mas, para admitir um recurso com base em divergência jurisprudencial, os fatos nunca são suficientemente semelhantes.

Defendemos, portanto, que o observador/intérprete, sempre realize uma descrição densa e completa dos motivos que embasaram aquela interpretação entre tantas possíveis. Só assim, o intérprete poderá estar sujeito ao crivo dos demais que 
poderão avaliar a razoabilidade da interpretação naquele contexto e aceitá-la ou criticá-la. A descrição densa, deveria ser também aplicada ao direito.

Lênio Streck ${ }^{319}$ também pontua sobre outro paradoxo do direito: - O direito é mais importante como instrumento de justiça ou como elemento que organiza a convivência social resolvendo problemas não necessariamente da maneira justa? Para alguns autores, a exemplo de Dworkin, o juiz sempre dá uma boa resposta ao problema ao resolvê-lo. ${ }^{320}$

A compreensão de qualquer texto, segundo Gadamer, deve ser precedida da pré-disposição a que o texto Ihe diga algo. Essa compreensão acontecerá sempre dentro da tradição linguística do tempo e do autor com o intérprete projetando-a. Essa abertura à opinião do outro (neste caso o autor do texto) coloca o outro em relação com o intérprete e sua condição histórico-existencial. Como é impossível nos situarmos no lugar do outro, o que prega Gadamer é a fusão de horizontes do autor e do intérprete. ${ }^{321}$

É necessário também discutir as relações entre o direito e a cultura. O homem sempre procurou controlar os elementos da natureza e prever as relações entre os indivíduos. O pseudocontrole sobre os elementos naturais dava-se por meio de magias e encantamentos como tão bem detalhou Frazer.

Em povos sem uma tradição jurídica de direito positivo e sem um Estado organizado tal e qual as nações modernas também havia formas de exercício de direitos. Com relação ao direito de propriedade sobre a terra, por exemplo, Gluckman $^{322}$ ressalta que quando se diz que determinado grupo possuía a terra isso quer dizer que todos os membros daquele grupo poderiam reclamar certos direitos sobre aquela fração de terra. Os direitos de cada um sobre a terra poderiam variar em razão do status daquele membro particular.

Já com relação a alimentos e bens móveis Gluckman afirma que o direito de propriedade era apenas relativo já que seus parentes e inclusive estranhos poderiam 
exercitar direitos sobre aqueles bens móveis sem que o "proprietário" pudesse exercer oposição. O autor exemplifica com o instituto do "kufunda" entre os Lozi da África Central (atual Zambia). Tal expressão foi traduzida como "roubo legal" que consistia no direito de qualquer parente do falecido a apropriar-se dos bens do de cujus. Inclusive, quando o Rei Lozi tratou o compromisso de amparo com a Companhia Britânica Sul-Africana fizeram constar que o "kufunda" não seria criminalizado e tampouco sujeito a processos judiciais. Por isso, para Gluckman o sistema de propriedade está intimamente ligado ao sistema de status daquele povo e não é possível entender o primeiro sem estudar o segundo. ${ }^{323}$

Uma das consequências a que chega o autor é a de que a propriedade, naquele contexto, jamais é absoluta, pois o mais importante é o papel que a propriedade exerce no contexto das relações sociais. Os objetos materiais produzidos pelo homem podem ser utilizados como laços de união entre as pessoas que vinculam a cultura material e as relações. O autor utiliza um exemplo de uma espada que passa de pai para filho simbolizando a continuidade hereditária e sucessão geracional através da entrega do objeto. Da mesma maneira os contratos vinculam as partes por mais tempo com relação às coisas por mais tempo inclusive para garantir de vícios ocultos ou até roubos praticados por terceiros. ${ }^{324}$

Gluckman, assim como já fizemos, pontua que a afirmação do movimento descrito por Maine "do status ao contrato" é uma das definições mais acertadas e que fala sobre um movimento crucial da história humana. As pessoas intercambiavam bens e serviços somente enquanto membros de uma mesma hierarquia política e grupo social de parentesco e confundem-se as relações de status e de propriedade. No caso de instituições, o posto ocupado pelo indivíduo e o ofício que exerce são considerados "entidades" distintas do indivíduo que o ocupa. Assim, permite-se que haja uma continuidade das instituições independentemente do indivíduo que ali está naquele momento ocupando determinados cargos. ${ }^{325}$

Segundo Gluckman, mesmo nas sociedades tradicionais, os sistemas políticos apresentam duas estruturas que são comuns a todos os sistemas desta natureza: um sistema administrativo e um sistema de competição pelo poder. $\mathrm{O}$ 
sistema administrativo é aquele onde se tomam as decisões e impõem obrigações. Os cargos administrativos são os prêmios entregue ao vencedor do sistema de competição de poder. No caso das sociedades tradicionais, os chefes não poderiam, nem deveriam, legislar, mas devem tomar decisões administrativas na regulação da vida do grupo. A maioria das leis aprovadas por chefes africanos após a chegada dos europeus foi no sentido de enfrentar as mudanças introduzidas por aqueles. ${ }^{326}$

Para Gluckman os antropólogos descuidaram incrivelmente os detalhes do processo político/legislativo das sociedades tradicionais bem como a motivação para as alterações legislativas e políticas. Está sempre posto o problema de discutir a lei das sociedades tradicionais a partir de nossos conceitos jurídicos sem uma adequada fusão de horizontes. Para Radcliffe-Brown ${ }^{327}$, por exemplo, a lei é o controle social exercido através da aplicação sistemática da força em uma sociedade organizada o que poderia sugerir não existir lei em sociedades que não possuem uma organização política formal. Já Gluckman pontuou que a finalidade da lei é dirigir e canalizar o uso da força e que a lei e costume seriam diferentes justamente porque a primeira é imposta enquanto o segundo não. Essa tendência de definir como lei aquilo que é imposto pelos tribunais pode ter trazido dificuldades ao falar-se de lei em sociedades onde ausente uma estrutura organizada de tribunais. ${ }^{328}$ Malinowski, como veremos a seguir, apresentará um conceito um pouco distinto sobre a lei.

Gluckman $^{329}$ destaca que, em inglês, somente existe uma mesma palavra para designar direito e lei: law; a seu turno as línguas latinas fazem distinção entre jus e lex, já sugerindo, acrescentamos, que nem sempre a lei e o direito caminham juntos. O costume participa de uma forma importante como fonte de direito e, nas sociedades tradicionais, verifica-se uma hipertrofia de normas, ainda que não exista a estrutura de tribunais.

A lei das sociedades tradicionais (e o mesmo aplica-se atualmente) só poderá ser apreciada a partir de uma visão do conjunto da cultura daquele povo e dentro de 
um marco comparativo com as outras culturas ${ }^{330}$. A lei surge de um acumulado das condições ambientais, psicológicas e sócio-econômicas e, poder-se-ia dizer que, onde tais condições sejam similares, a lei também será similar. ${ }^{331}$

Nas sociedades tradicionais também existiam mecanismos "auxiliares" de controle e ajuste das condutas e opiniões coletivas. As crenças místicas, bruxarias e vontade de divindades são maneiras de ajustar-se a conduta popular conforme seja necessário. A possibilidade de manejo das pressões sociais depende em grande parte, também, do sentido de justiça e da lei presentes na comunidade. ${ }^{332}$ Esse papel é exercido atualmente pela imprensa e pelas redes sociais com imensa importância.

Neste ponto, acreditamos ter ficado claro que o direito é apenas uma parte da cultura de um povo e a lei e o direito nem sempre significam o mesmo, principalmente nos países de tradição romano-germânica. A lei dos povos foi criada para proteger o núcleo essencial da cultura, aquelas infrações que mais abalam a ordem social. Bem assim, o direito é variável segundo as condições históricoexistenciais de cada sociedade. A ideia de um direito natural é verdadeiramente contrária à existência da imensa variabilidade cultural presente nas comunidades humanas. Aquilo que será considerado de acordo com o direito estará sempre em constante movimento e evolução, a depender do momento pelo qual passa cada cultura. Um exemplo é o direito à vida, entendido, ao menos na sociedade ocidental como um direito indiscutível e inerente à espécie. Esse mesmo direito é relativizado em diversas situações como, por exemplo, a declaração de guerra, onde passa a ser lícito matar certas pessoas.

Malinowski, ademais de ter sido um dos mais importantes autores das ciências sociais do século $X X$, também foi um dos que compreendeu a importância do sistema legal no estudo das sociedades. No decorrer de sua obra, o autor modificou seu próprio conceito de lei. Em sua obra sobre a família australiana Malinowski definia a lei como uma norma social que possui uma sanção social ativa. Ainda em seus estudos australianos, Malinowski fez distinção entre três classes de

330 ASSIS, Olney Queiroz e KUMPEL, Vitor Frederico. Manual de Antropologia Jurídica. São Paulo: Saraiva, 2011. 
normas: religiosas, de costume e legais. A sanção de cada uma delas difere, também, com relação ao conteúdo. As normas religiosas normalmente possuem uma sanção somente no plano sobrenatural, já as normas do costume possuem uma sanção em forma de ridículo e desprezo social. Por fim, as normas legais possuem sanções decididas pelo conjunto da comunidade e com observância obrigatória $^{333}$. A sanção da lei penal, por exemplo, é para Malinowski o castigo provocado pela reação raivosa de toda a comunidade. ${ }^{334}$

Malinowski também definiu a lei sob seu aspecto de reciprocidade. Ou seja, apontava que o individuo cumpriria a lei por esperar as recompensas que tal cumprimento Ihe proporcionaria. Este, para Malinowski, é um dos aspectos funcionais da lei que para ele também era uma necessidade instrumental da vida em sociedade. ${ }^{335}$

Em sua obra mais tardia, Malinowski procurou clarificar o estudo da lei a partir de sua definição precisa em vários aspectos. Concretamente, o autor identificou quatro diferentes acepções da lei. A primeira delas é a lei do determinismo cultural com o mesmo sentido de lei natural ou lei da ciência. Os indivíduos normalmente desconhecem tais leis, mas as seguem de maneira inata. A segunda é a lei enquanto norma de conduta englobando aspectos como conhecimento, tecnologia, cooperação e vida em comum. A sanção deste segundo tipo de lei é automática pela própria existência do sistema, ou seja, o descumprimento torna-se pouco proveitoso e o convencionalismo se vê afetado. O terceiro tipo de matiz da lei é a que toca questões como ordem e preservação, as relações de propriedade, contratuais e também as formas e direito das relações sexuais entre os indivíduos. O quarto aspecto é a lei enquanto mecanismo retribuidor e restituidor da sociedade a partir de uma infração cometida. ${ }^{336}$

Malinowski foi um dos autores que mais prontamente reconheceu a capacidade da antropologia para influenciar a lei e a jurisprudência. Além disso, reconhecia que o sistema legal formal é apenas uma parte de um sistema normativo

333 MALINOWSKI, Bronislaw. The Family Among the Australian Aborigenes. Londres: University of London Press, 1913.

334 MALINOWSKI, Bronislaw. Crimen y Costumbre en la sociedad salvaje. Barcelona: Ariel, 1971 335 SCHAPERA, ISAAC. Malinowski y la teoría de la ley. in: Hombre y Cultura: La obra de Bronislaw Malinowski. Madrid: Siglo XXI, 1974

336 SCHAPERA, 1974. 
e social muito mais amplo e essa noção é fundamental para o campo das ciências sociais. As pautas convencionais, as modas, a etiqueta, o costume e preceitos morais também governam as ações humanas ${ }^{337}$. Entre estas normas também destaque-se aquelas que regem o trabalho, muitas delas não escritas e apenas derivadas da experiência e do costume. ${ }^{338}$

Malinowski recebe a concordância consciente ou inconsciente de Hans Kelsen ${ }^{339}$. Este último afirma que o temor à vingança no plano sobrenatural é o principal fator de controle social nas sociedades primitivas. Algumas sociedades primitivas possuem, inclusive, algum tipo de instituições e cargos especializados e dedicados ao cumprimento da lei. Sem embargo, existem diversas outras sociedades primitivas que não possuem tal tipo de instituições e tal fator não pode significar a ausência de lei. A contribuição mais importante de Malinowski ao estudo da lei e da cultura foi reconhecer que a lei é apenas uma parte do sistema social e cultural e o formalismo exacerbado, sobretudo quando discrepante da realidade social perde completamente o sentido. ${ }^{340}$ Já para Santos ${ }^{341}$, o que sugere Malinowski é a existência de regras práticas as quais não podem integrar o plano religioso e muito importantes para que seu cumprimento seja deixado ao bel-prazer dos cidadãos. Estas normas são aquelas que integram o domínio do direito nas sociedades primitivas.

Ainda, é importante destacar que o conhecimento do direito, ao menos do direito de tradição romano-germânica começa invariavelmente pelo estudo do direito romano. A história do direito formal começa pelo contato com outra cultura, com outro povo e com uma civilização de mais de dois milênios atrás. Pode ser que os estudantes e professores não se deem conta, mas no estudo do direito romano e de direitos de outros povos pretéritos há necessariamente o estudo de aspectos culturais daqueles povos para possibilitar o entendimento das instituições jurídicas. Isto é o que faz, por exemplo, Emiliano González ${ }^{342}$ ao comentar aspectos sobre

339 KELSEN, Hans. General Theory of Law and State. Cambridge: Harvard University Press, 1949. 340 SCHAPERA, 1974.

341 SANTOS, Boaventura de Sousa. Sociología jurídica crítica : para un nuevo sentido común en el derecho. Madrid: Trotta, 2009. 
naturalização e direitos dos estrangeiros no novo mundo, onde é necessário apresentar e aplicar a conjugação das realidades castelhana e americana, aliadas aos postulados do direito romano-canônico para entender tais aspectos.

Por outro lado, persiste a dúvida, mais que dúvida, um confronto de posições sobre a existência de direito nas sociedades primitivas, inclusive aquelas sem escrita. O debate oscila entre aqueles que buscam transportar uma visão moderna e ocidental do direito aos povos primitivos para concluir que não havia, de fato, a existência de um sistema legal. Em posição contrária estão os que compreendem direito, cultura e sociedade como um conjunto indissociável e interdependente, de maneira que o direito também exerce uma função estrutural e simbólica na sociedade. Inclusive, nas sociedades mais simples, o direito deveria cumprir apenas algumas funções básicas como: a) definição das relações entre os membros da sociedade; b) organizar as forças de manutenção da ordem e encarregadas de executar a coerção física; c) resolver os conflitos; d) manutenção da adaptabilidade com a redefinição das relações entre grupos e indivíduos ${ }^{343}$.

Os próprios estudos de Malinowski ou de Radcliffe-Brown ocorreram em um contexto colonial onde as administrações locais inglesas deveriam realizar uma simbiose entre o direito inglês (baseado, obviamente, na realidade e no costume ingleses) e o direito local. Para levar a cabo tal tarefa, seria necessário selecionar quais costumes locais poderiam ser incorporados ao direito inglês para aplicação local $^{344}$. Em alguns casos, como já mencionado, ainda que se proibissem formalmente alguns costumes, na prática, não havia sanções judiciais em razão dos costumes proibidos.

Houve, durante muito tempo, a ideia, propagada principalmente pela teoria marxista, de que o direito é apenas um instrumento de dominação e submissão da classe obreira. Sem embargo, o direito, sabe-se já, pode ser um instrumento de resistência em favor dos direitos e garantias fundamentais, bem como uma ferramenta de transformação da realidade. Ainda, não se pode mais estudar ou pretender realizar a interpretação de normas, análise de constitucionalidade ou 
integração sistemática sem um amplo enfoque social, econômico e político. O direito contemporâneo se tornou a linguagem da tradução dos conflitos sociais ${ }^{345}$.

O direito não pode existir como fundamento próprio à maneira positivista radical que apenas analisa a formalidade das normas. E não é diferente no que tange aos conflitos sindicais e sua complexidade. Buscaremos aprofundar a seguir em alguns temas de relevo no estudo dos sindicatos. 


\section{CAPÍTULO V - PROFISSÕES E DIVISÃO DO TRABALHO}

A temática da divisão do trabalho sempre ocupou aqueles preocupados em explicar as razões das mudanças na sociedade. Em verdade, jamais se logrou uma explicação definitiva para a constante e sempre crescente divisão do trabalho, existem muitas conjecturas e muitas hipóteses, sem, entretanto, como soe acontecer em ciências sociais, haver consenso sobre o assunto. Destaque-se que o tema da divisão do trabalho está em pauta desde a antiguidade clássica envolvendo célebres pensadores como Aristóteles ${ }^{346}$. No mesmo sentido, o assunto recebeu teorias de Adam Smith, Herbert Spencer e Emile Durkheim, sendo esta última talvez a mais completa obra sobre o tema. Discutiremos, no ponto, algumas das mais famosas e célebres teorias sobre a divisão do trabalho começando por Spencer.

Herbert Spencer, como já mencionamos anteriormente, foi um dos primeiros a intuir sobre a teoria da evolução e aplicá-la aos fatos sociais, ideia que foi posteriormente encampada por Darwin no plano biológico e que acabou por revolucionar as ciências. Alguns autores, a exemplo de Marvin Harris ${ }^{347}$, chegam a sugerir que o apelido recebido pelas ideias de Spencer no plano social - darwinismo social - é uma injustiça. Para Harris, a contribuição de Darwin deveria se chamar spencerismo biológico, já que Spencer foi o precursor da ideia da evolução.

Spencer, seguindo seu raciocínio geral de adaptação evolutiva e progressão do simples ao complexo também delineou o surgimento de diversas profissões. Tal tese de Spencer encontra-se na sua principal obra "Princípios de Sociologia ${ }^{348 "}$ onde há um capítulo especialmente dedicado às "professional institutions". O capítulo chegou a ser traduzido e publicado em separado na Espanha onde recebeu o nome de "Orígen de las profesiones ${ }^{349 "}$ ". Outras diversas obras de Spencer foram traduzidas para o espanhol por Miguel de Unamuno ${ }^{350}$, demonstrando o relevo de Spencer.

346 ARISTÓTELES. Ética a Nicómaco. Introducción, traducción y notas de José Luis Calvo Martínez. Madrid: Alianza, 2001.

347 HARRIS, 2003.

348 SPENCER, 2013.

349 SPENCER, Herbert. Orígen de las Profesiones. Barcelona: Ediciones populares Iberia, 1932.

350 Como por exemplo a obra de SPENCER, Herbert. Organismo Social. Madrid: La España moderna, 1894. 
Com relação às profissões, a pergunta que move Spencer é similar àquela que nos move: o que diferencia as profissões das demais instituições existentes na sociedade? Partindo da premissa evolucionista, Spencer deseja descobrir de qual tecido social derivam as profissões por especialização e diferenciação. $O$ autor segue sua premissa, defendida durante toda a obra, de que as instituições sociais derivam de especializações provenientes de uma massa relativamente homogênea.

Para Spencer, a vida em sociedade constitui uma relação de mútua dependência com seus membros. O viver em sociedade tem como objetivo a preservação da vida dos indivíduos que a compõem. Para conseguir tal objetivo é necessária uma certa dose de regulamentação da vida em sociedade como, por exemplo, na guerra onde é necessário que os subordinados executem as ordens de um chefe para atuarem com mais chances de sobrevivência. São necessárias, portanto, certas restrições no plano individual para a consecução dos objetivos sociais. A vida em sociedade também implica em intercâmbios e trocas que mudam a realidade do princípio onde cada um deveria procurar a própria comida, vestimentas e abrigo.

Spencer se pergunta se a evolução social é estancada no momento em que está garantida a proteção e sobrevivência dos indivíduos que a compõem. O próprio autor conclui que não, que a partir do momento em que está garantida a sobrevivência do grupo, a função da sociedade passa a aumentar o tempo e a qualidade da vida dos indivíduos.

Segundo o autor, as profissões originam-se da primitiva organização política e eclesiástica. Esta última, para Spencer, contém o embrião das demais profissões. As funções de chefe e sacerdote foram, para o autor, as primeiras divisões funcionais presentes na sociedade, sendo que a função sacerdotal seria mais ampla e abrangente por servir à divindade e possuir caráter atemporal.

A tese principal de Spencer com relação às profissões é que todas derivam do sacerdócio. Em primeiro lugar, a classe sacerdotal necessita ser sustentada pelos demais e, por isso, tem tempo ocioso suficiente para dedicar-se ao aprimoramento intelectual. 
Os dotes intelectuais dos sacerdotes levaram a que estes passassem também a executar outras funções na sociedade como a de curandeiro ou responsável pelos rituais de cura. O exercício de tais funções, no início exercida pelo sacerdote eventualmente, conduziu a uma gradual separação entre as funções até o surgimento dos atuais médicos e cirurgiões. O mesmo se pode dizer do sacerdote enquanto intérprete da vontade divina ou enquanto mediador entre as vontades do chefe e a vontade divina. Para Spencer, o exercício de tais funções, também pelo sacerdote, conduziu à gradual separação em direção ao que atualmente se conhece como profissões jurídicas, especialmente a de advogado e juiz.

Com este mesmo método, Spencer detalha o surgimento de diversas profissões, como a de professor, de músico, de escritor etc. Não cabe aqui detalhar o surgimento de cada uma de tais profissões, o que é apoiado por Spencer com uma grande quantidade de exemplos etnográficos obtidos de fontes secundárias. $O$ importante é deixar claro o modo de raciocínio de Spencer ${ }^{351}$, bem como reconhecer seu pioneirismo ao abordar um tema tão complexo ainda no século XIX.

Sobre a divisão do trabalho, Durkheim ${ }^{352}$ escreveu a obra "La división del Trabajo Social", a qual é o resultado de tese doutoral e segue até hoje como obra importante no campo da sociologia e da antropologia. O próprio autor reconhece ser a divisão do trabalho um tema bastante importante e que, sem embargo, passou a ganhar espaço em trabalhos acadêmicos somente a partir da revolução industrial.

As indústrias, segundo ele, tendem cada vez mais a uma divisão extrema do trabalho e, cada uma delas, já é por si própria um elemento de divisão, pois se propõe a uma atividade específica, dentro da qual subdividem-se outras tarefas necessárias ao desenvolvimento da tarefa industrial. Durkheim encampa de certo modo as teorias de Spencer acerca da semelhança entre os organismos biológicos e sociais. Por isso afirma serem os organismos mais desenvolvidos quanto mais individualizadas sejam as suas funções, inferindo passar o mesmo com as sociedades. Para Durkheim, acabou o tempo do homem que pretendia ser completo, interessando-se e compreendendo tudo que oferecia a humanidade. Para o autor: 
Han pasado los tiempos en que parecíanos ser el hombre perfecto aquel que, interesándose por todo sin comprometerse exclusivamente por nada, y siendo capaz de gustarlo y comprenderlo todo, encontraba el medio de reunir y de condensar en él lo que había de más exquisito en la civilización. ${ }^{353}$

Para o autor, a divisão do trabalho, pela sua importância e caráter de lei natural, deixa de ser uma opção e passa a ser uma obrigação aos indivíduos. De fato, o imperativo moral é que cada indivíduo esteja em condições de preencher uma determinada função na sociedade.

Após sua introdução Durkheim propõe-se a desvendar a função social da divisão do trabalho. Fala-se em função para não tratar o assunto em razão de suas consequências. Para ele, a divisão do trabalho está naquela categoria de coisas dadas por óbvias e sem necessidade de maiores aprofundamentos. Ou seja, como a divisão do trabalho aumenta a produtividade, a habilidade e desenvolve as sociedades, parece ser incontestável a função exercida pela divisão do trabalho.

O autor faz importantes considerações sobre uma visão pragmática e utilitária normalmente empregada para analisar fatos sociais. Falando da atividade industrial, sem dúvida o grande catalisador da divisão do trabalho, esta responde a necessidades sociais e não morais. Neste contexto, se a divisão do trabalho não respondesse a outras necessidades que não as puramente utilitárias e físicas, não faria mais que atenuar os efeitos produzidos por ela mesma. Explica-se Durkheim que as vicissitudes do trabalho na sociedade industrial demandam bens e serviços os quais não seriam necessários não fosse a própria sociedade industrial. Portanto, Durkheim intui que a divisão do trabalho não pode responder unicamente a necessidades materiais, e que a mesma deve possuir também outra função na sociedade.

A partir deste ponto de seu trabalho, Durkheim passa a tentar descobrir e justificar outras funções da divisão do trabalho que não aquelas baseadas simplesmente no aspecto prático e material da vida. Segundo o autor, o próprio ser humano tende a sentir falta daquilo que não possui, mesmo aqueles considerados melhores e mais completos seres humanos, compartilham sempre tal sensação de insuficiência. Por tal motivo, é inerente ao homem buscar em outros seres humanos 
qualidades e características sentidas por ele como faltantes. Essa especial característica dos seres humanos induz a associações entre os seres humanos onde cada um realiza uma função em apoio e solidariedade ao próximo.

No caso da divisão do trabalho, a sua função precípua, seguindo a linha de raciocínio de Durkheim, seria a de criar solidariedade social entre os indivíduos e entre grupos sociais distintos. A própria solidariedade crescente e formação de famílias, se deve à crescente divisão sexual do trabalho entre homens e mulheres. $O$ fato de homens e mulheres dividirem o trabalho melhora as possibilidades de ambos, que passam a compartilhar melhores condições de sobrevivência e de progresso de sua descendência. Aliás, o fato de prosperar a descendência, é tido por autores de antropologia física como o principal fator de sucesso e evolução das espécies e dos indivíduos ${ }^{354}$. Estariam mais evoluídas e exitosas as espécies e indivíduos/animais que mais conseguem fazer prosperar a sua descendência. Acrescenta Durkheim que a divisão do trabalho, além de aumentar o rendimento das atividades ao dividi-las, torna-as mais solidárias.

Em outro ponto interessante para o presente trabalho, Durkheim assevera ser o direito apenas uma parte da realidade social e nem sempre reflete a totalidade dos costumes e das relações sociais. Neste sentido, o costume é causa de relaxamento das regras e correção dos excessos de formalidade. Embora o direito reflita as principais formas de solidariedade social, não bastaria elencar as categorias traçadas pelos juristas para encontrar aquela correspondente à solidariedade causada pela divisão do trabalho.

Durkheim, fundando-se também nas subdivisões do direito nos ramos público e privado para refletir as relações do indivíduo com o Estado e destes entre si, respectivamente, propõe divisões para a análise de espécies de solidariedade social. O autor as divide em mecânica ou por semelhança e oriunda da divisão do trabalho ou orgânica. A solidariedade mecânica consiste naquela determinada pelas normas de direito repressivo cuja desobediência acarreta uma punição. A solidariedade orgânica, a seu turno seria aquela induzida pela divisão do trabalho e representada, como um dos exemplos utilizados pelo autor, pelo direito de família, 
que estabelece o rol de cada membro familiar cuja união é determinada justamente pelo papel que deve ser desempenhado pelos indivíduos dentro da família.

O autor também destaca a íntima relação do direito contratual com a divisão do trabalho. Para ele, o contrato é a expressão jurídica da cooperação social e cooperar é dividir entre si uma tarefa comum. De fato, o contrato representaria as trocas sociais como ocorre também para Spencer ${ }^{355}$ com os órgãos do corpo humano onde existem trocas tituladas pelo autor de contrato fisiológico. O próprio processo judicial seria também uma das expressões de cooperação já que concorrem diversos agentes com distintas tarefas para levar a cabo o procedimento.

A solidariedade por semelhança, na visão de Durkheim, induz a que todos os indivíduos sejam parecidos, havendo o predomínio de uma consciência coletiva ou comum, sobre as consciências individuais. Quanto mais semelhante sejam os integrantes de uma sociedade maior é a solidariedade mecânica ou por semelhança. Contudo, como bem afirma Durkheim, a solidariedade que nasce da divisão do trabalho é aquela que emana das diferenças e das personalidades distintas individuais. Assim, cada pessoa depende mais da sociedade quanto mais dividido está o trabalho. O comunismo, bastante frequente em sociedades antigas, para o autor, é mais uma das expressões da solidariedade mecânica. Neste tipo de organização, o indivíduo é absorvido pelo grupo, perdendo importância nas suas idiossincrasias.

Enquanto a estrutura das sociedades orgânicas, Durkheim aponta sensíveis distinções com relação a forma das sociedades preponderantemente mecânicas. As relações da sociedade fundada na solidariedade orgânica abandonam as posições sociais derivadas da descendência/parentesco para as posições sociais derivadas da atividade a que cada indivíduo se consagra. Há uma mudança do "meio natal para o profissional ${ }^{356 " . ~ D a ~ m e s m a ~ m a n e i r a, ~ a s ~ d i v i s o ̃ e s ~ q u e ~ p a s s a m ~ a ~ p r e p o n d e r a r ~}$ são aquelas de ordem territorial e não social/familiar.

Para Durkheim, entretanto, a maneira com que se agrupam os indivíduos de acordo com seu meio profissional não necessariamente coincide com a agrupação 
ocasionada pela família ou pelo território. É um novo tipo de agrupação que demanda, inclusive, a regulação jurídica das relações entre as funções divididas. Cada profissão acaba por constituir uma moral profissional a qual é imperativa e demanda sacrifícios diários do indivíduo em prol do grupo. A escolha da profissão e também das funções domésticas, para Durkheim uma decisão individual a despeito de todas as críticas que se possa fazer a tal posicionamento, traz consigo consequências e obrigações.

Na segunda parte do seu trabalho, Durkheim pretende detalhar as causas da divisão social do trabalho, após ter delineado anteriormente suas funções. A divisão do trabalho progrediria conforme exista mais contato entre os indivíduos e permite interatuarem e produzirem novas combinações. Então, a divisão do trabalho é incrementada pela condensação da população, havendo uma relação diretamente proporcional entre condensação e divisão do trabalho. Para Durkheim, o número de relações sociais é aumentado pelo maior número de indivíduos, levando-o a formular a seguinte proposição:

La división del trabajo varía en razón directa al volumen y a la densidad de las sociedades, y, si progresa de una manera continua en el transcurso del desenvolvimiento social, es que las sociedades, de una manera regular, se hacen más densas, $y$, por general, más voluminosas. ${ }^{357}$

Face à lei formulada, é possível concluir pela possibilidade de convivência entre as várias profissões em determinado local. Sempre e quando exista um equilíbrio entre as necessidades ou entre o campo de atuação de determinada profissão e o número de profissionais existentes, a divisão do trabalho será mantida constante. Quando exista um deficit de áreas de atuação, os profissionais excedentes serão obrigados a desaparecer ou a transformar-se, incidindo aí a divisão do trabalho na criação de novas profissões. Durkheim vaticina ser a divisão do trabalho o resultado da luta pela vida. E, esta luta é a solução para os problemas de sobrevivência, uma solução mais "doce" já que permite a luta pela vida com a coexistência dos indivíduos.

A divisão do trabalho, por outro lado, somente pode se realizar no seio de uma sociedade já constituída. Algumas sociedades, possuindo já um laço de união 
pela semelhança e comunidade de sentimentos e crenças (solidariedade mecânica) avançam no sentido da divisão do trabalho a qual contribui para manter e aumentar a união previamente existente.

Na sequência de seu trabalho, Durkheim toca em um ponto extremamente importante para o nosso estudo. A divisão do trabalho, tal qual o surgimento de uma nova religião, sofre resistências e dificuldades. Durkheim refere que na Grécia e em Roma, assim como em algumas religiões, existem atividades pré-determinadas para cada classe social. Tais preconceitos e dificuldades criadas em oposição a divisão do trabalho dificultam seu progresso natural e induzem a sociedade a encontrar outras soluções para um problema que poderia se resolver mediante a divisão do trabalho. O autor aponta outras soluções na luta pela sobrevivência como a imigração, a colonização, a resignação ou a simples eliminação dos mais débeis, seja através do suicídio, seja de outra maneira.

A divisão do trabalho proporciona às sociedades maior flexibilidade e elasticidade. Cada profissão constituiu um próprio corpo com moral e regras próprias. O próprio contexto social que permissivo a divisão do trabalho também possui menor coerção sobre os indivíduos, sendo mais fácil que ocorram inovações e diferenciações, mesmo dentro do grupo profissional.

Outro ponto fundamental do trabalho de Durkheim é a análise e o reconhecimento da solidariedade social gerada pela divisão do trabalho como um tipo sui generis de solidariedade social. Este tipo de solidariedade não suprime a competição e tampouco a luta pela vida, a solidariedade modera a competição servindo como pano de fundo e limitadora das disputas, para que não exista o rompimento da unidade básica. Aqui, para ele, é precisamente onde reside o valor moral da divisão do trabalho, na aquisição, pelo indivíduo, da consciência de sua dependência dos demais.

O autor reclama de anomia no sistema social com relação aos fatos causadores e causados pela divisão do trabalho. Cita o autor a questão do contrato de trabalho, à época ainda conhecido como contrato de arrendamento de serviços o qual carecia da mais mínima regulamentação mesmo face à clara especificidade e complexidade das relações patrão-empregados. 


\subsection{Trabalho pós-industrial}

O trabalho, tal qual conhecemos hoje, é um fenômeno muito recente na história da humanidade. Trabalhar por conta alheia, vendendo a força de trabalho em troca de uma retribuição econômica é um fenômeno praticado em larga escala há pouco mais de dois séculos. Entender as mudanças nas perspectivas do trabalho humano ao longo dos milênios é importantíssimo para interpretar os dilemas atuais sobre o assunto, de interesse praticamente universal.

As grandes revoluções, citadas por Lévi-Strauss como a neolítica e a industrial foram acompanhadas não somente de uma diferenciação do corpo social, mas também da inauguração de estatutos diferenciais do ponto de vista econômico. Estas transformações quase sempre são entendidas como consequências do progresso técnico. No entanto, o autor aponta que os dois fenômenos estão ligados não por uma relação de causalidade e sim por uma relação funcional. Que o progresso técnico tenha revolucionado as formas de exploração do homem pelo homem já parece, para o autor, apoiar a hipótese de ausência de relação causal entre os fenômenos ${ }^{358}$.

Como já apontamos anteriormente, a antropologia tentou reconstruir, principalmente a partir do paradigma evolucionista, as etapas ou estágios distintos pelos quais passaram os grupos humanos. Embora a imensa quantidade de críticas ao método e resultados da linha evolucionista, muitas delas coerentes e procedentes, os esquemas propostos pelos evolucionistas, sobretudo Morgan, ajudam a compreender as etapas anteriores de organização social. É conveniente destacar terem algumas classificações propostas por Morgan, encontrado respaldo até hoje, mesmo após mais de um século de intensas pesquisas, com mais meios disponíveis.

As greves são tão antigas quanto a própria história. Alguns historiadores apontam a revolta dos ladrilheiros judeus do Egito em 1490 a.C. como um protesto contra a ordem de fabricar ladrilhos sem palha, ou seja, pela falta de materiais adequados para o trabalho. No entanto, apontam os autores, é impossível que 
manifestações de tal natureza sejam consideradas como precedentes análogos do sistema sindical contemporâneo ${ }^{359}$.

Em geral soemos apontar o século XVII como século da revolução social na Europa Ocidental. Diversos Estados encontraram no absolutismo uma forma de resolver alguns problemas básicos. Pela primeira vez tais Estados conseguiam que as ordens governamentais fossem obedecidas, que houvesse suficientes recursos para sua manutenção e que os exércitos pudessem ser manejados com mais liberdade.

Dando-se por estabelecido que o capitalismo deveria triunfar, então também podemos estabelecer que a sociedade agrária e feudal deveria ruir. A divisão social do trabalho desempenha um papel fundamental neste processo e no aumento da produtividade bem como na redistribuição das forças de trabalho entre as atividades, isto é, a agricultura e a indústria. O crescimento do capitalismo também necessitava mercados de expansão, nem que fosse através da criação de novos mercados. A revolução inglesa é, para Hobsbawn, o produto mais decisivo de uma crise que assolou a Europa no século XVII.

Essa mesma crise, eliminou completamente as barreiras ao desenvolvimento do capitalismo. Segundo Hobsbawn ${ }^{360}$, até 1780, a economia mundial esteve taxiando na pista do aeroporto e, desde então, tem estado voando sem descontinuidades. Para o autor, o desenvolvimento do capitalismo industrial abarcou ao menos oito séculos do ano 1000 ao ano 1800 com duas descontinuidades que o impediu de iniciar, pelas crises dos séculos XIV e XVI e da crise do século XVII. Segundo o autor as crises que debilitavam mais as empresas de tipo feudal que as progressistas, que a economia europeia e a das colônias formavam uma realidade única e a revolução burguesa são fatores gerados pela crise e que favoreceram o avanço à etapa posterior. A revolução industrial também é vista pelo autor como uma "combustão espontânea" cada vez que se encontram os ingredientes necessários: crescimento da população, expansão do comércio, acumulação de capitais, progresso econômico e clima social propício

359 WEBB, Sidney e WEBB, Beatrice. Historia del Sindicalismo: 1666-1920. Madrid: Ministerio de Trabajo y Seguridad Social, 1990.

360 HOBSBAWN, Eric. En torno a los orígenes de la revolución industrial. Madrid, Siglo XXI, 1988. 
A Inglaterra certamente foi a precursora do movimento industrial e, consequentemente, da transformação das relações de trabalho em razão do novo sistema. Já no século XVII a Inglaterra deixou de lado o absolutismo para consagrar uma democracia sustentada pela burguesia e por um sistema de liberdades individuais. Por outro lado, os velhos grêmios ou corporações da idade média começam a agonizar e a ser substituídos por clubes que são reuniões das elites de cada profissão. Pouco a pouco, a livre concorrência e estipulação das condições de trabalho começam a deixar suas marcas nos trabalhadores que iniciam uma mudança nas suas associações, posicionando-as em contraposição aos empregadores. O sindicalismo, durante o século XVIII, também mostra suas facetas políticas e usa a importância e relevância social para lutar por sufrágio universal e liberdade de associação ${ }^{361}$.

A partir da segunda metade do século XIX o capitalismo começa a desenvolver-se na maioria das nações. Na Inglaterra, principalmente, já 1860, inauguram-se comissões mistas de empresários e trabalhadores para resolver conflitos laborais. A década de 1870 traz a Comuna de Paris, amplamente apoiada pela classe obreira. A reação à Comuna traz em seu seio o preconceito contra os sindicatos e contra a Internacional que são culpados por todas as desgraças. $O$ governo francês também proíbe o associativismo internacional de trabalhadores e os grandes sindicatos franceses acabam por retirar seu apoio à AIT (Primeira Internacional de Trabalhadores) ${ }^{362}$.

$\mathrm{Na}$ década seguinte, surge, também na Inglaterra, um novo tipo de sindicalismo, movimento que ficou conhecido como New Unionism. Este novo sindicalismo preconizava a possibilidade de congregar toda a classe obreira em prol de reivindicações comuns. O sindicalismo por ofícios acabava por separar a classe obreira, criando pequenos grupos, principalmente dos trabalhadores mais qualificados e estáveis em detrimento dos obreiros sem qualificação e com empregos precários ${ }^{363}$. A tática utilizada foi centrar-se em determinado ofício e agrupar consigo outros ofícios similares e sem tanta representatividade ou 
estabilidade ou, por outro lado, a de estabelecer sindicalismos por ramos industriais, abarcando verticalmente todos os trabalhadores, independentemente do ofício ${ }^{364}$.

O sistema de relações industriais foi certamente e em maior medida o responsável pelo florescimento das questões sindicais. A capacidade e importância política da classe trabalhadora e dos sindicatos como força potencial capaz de melhorar as condições de trabalho e analisar a importância do fator trabalho humano na economia. No caso dos sindicatos europeus, a partir da primeira metade do século XX, começaram a aglutinar em seu entorno economistas, juristas e sociólogos que também começaram a realizar investigações na linha das relações industriais. Utilizar o conceito de relações industriais coloca as relações coletivas no centro da discussão sobre o trabalho e a partir daí analisa-se a conexão da relação coletiva com o contrato de trabalho (para baixo) e com a lei (para cima) ${ }^{365}$.

Ojeda Avilés traz sua opinião sobre a nomenclatura do ramo do Direito do Trabalho que estuda os sindicatos. Para o mencionado autor a nomenclatura Direito Sindical, corresponde ao ramo jurídico da macrodisciplina das relações industriais. Ademais, a nomenclatura não dá a ideia de uma parte acessória ou secundária após o estudo do direito individual como faz a nomenclatura utilizada em muitos países: direito coletivo do trabalho. Essa mudança de paradigma anunciada pelo autor responde a novos enfoques sobre o assunto que são resumidos em quatro pontos. O primeiro deles é o protagonismo dos sujeitos coletivos em detrimento do Estado que reconhece ser incapaz de cobrir satisfatoriamente um campo normativo tão diversificado e extenso. O segundo é a constatação sobre a necessidade de tratamento multidisciplinar das relações de trabalho, o Direito Sindical utiliza sistemática e instrumentalmente os achados de outras disciplinas. Já o terceiro ponto é a prevalência das relações coletivas de trabalho sobre as relações individuais. As relações coletivas transformam-se em fundamental predecessora dos pactos individuais já que conformam as normas deste último. Por fim, o quarto ponto que representa a mudança no enfoque é o caráter totalizante das relações coletivas 
que passam a imiscuir-se nas relações individuais reguladas através dos instrumentos coletivos ${ }^{366}$.

É impossível falar de espaços de atuação sindical sem citar o quanto, principalmente no último século, mudaram as relações entre Estados, trabalhadores e empregadores. É comum ouvir dizer que a globalização acaba por prejudicar os interesses dos trabalhadores quando deveria ser o contrário. Efetivamente, as questões sobre mercado de trabalho, comércio de bens e serviços e circulação de pessoas formam um dos eixos centrais do assunto da globalização. Socorro-me, neste ponto, das ideias de Manuel Castells ${ }^{367}$ e Thomas Friedman ${ }^{368}$, dois notáveis autores que, com diferentes visões, escreveram sobre a globalização nos últimos tempos.

Comecemos por este último, por facilitar o silogismo a ser desenvolvido. Friedman estrutura seu livro, principalmente, em cima de dez razões de teriam "achatado" o mundo. Não há espaço para que as contemos todas e, em muitas delas, tanto Castells quanto Friedman coincidem nas razões das mudanças mundiais. Entretanto, é importante sublinhar as mudanças concretas que o autor aponta, principalmente aquelas com reflexos no mundo do trabalho.

Uma das datas cruciais que aponta Friedman é o ano de 1989 com a queda do muro de Berlim e, simbolicamente, a prevalência do sistema capitalista como o caminho a seguir por países até então fechados em suas economias. Também é importante citar a questão da criação de possibilidades de compartilhamento de conteúdo online e também dos softwares de fluxo de trabalho, permitindo a criação de conteúdo através da rede. Sem embargo, duas das forças que o autor aponta como determinantes para o achatamento do mundo também o são em relação ao simples trabalhador: a terceirização e o off-shoring. ${ }^{369}$

Expliquemos e diferenciemos os dois fenômenos de uma maneira rápida e resumida. A terceirização de que tratamos não é justamente aquela simples terceirização já tão conhecida ou, nem tampouco, o conceito de terceirização que 
deriva da lei brasileira, mas aquela onde contratamos uma empresa de limpeza para que se encarregue de tal serviço dentro da nossa própria ou uma cadeia de outras empresas que prestam serviços, tudo isso porque é mais barato terceirizar do que centralizar todas as fases do processo de produção. A terceirização, atualmente, vai além. A partir da informatização, da abertura dos mercados e de uma certa estabilidade nas regras do comércio internacional muitos atividades puderam ser terceirizadas, literalmente, para qualquer lugar do mundo. E este lugar será certamente onde for mais rentável.

O off-shoring, por seu turno, é bastante similar. Contudo, enquanto na terceirização a empresa transfere a outra (empresa) parte de sua atividade, no offshoring a empresa transfere toda uma fábrica, centro de vendas ou polo de atividades para outro país. Normalmente, no país de destino, oferecem-se mão de obra barata, incentivos fiscais e subsídios governamentais. Tal situação, é claro, gera uma competição atroz entre os países para oferecer tais condições às empresas. E a mão de obra é um dos fatores primordiais para decidir o destino do off-shoring. Claro, além de tudo isso, as empresas necessitam de outras condições a depender de suas atividades como, por exemplo, um melhor nível de formação da mão de obra e condições mínimas de infra-estrutura e estabilidade. Um bom exemplo, citado pelo autor, é a empresa de informática Dell que possui seis fábricas no mundo, todas em lugares estratégicos: Estados Unidos (duas fábricas, incluída a própria matriz), Irlanda, Malásia, China e Brasil. Claro, também importam questões estratégicas de localização e mercado interno, por exemplo, mas se pode notar que as grandes empresas são hábeis em selecionar seus locais de produção e o fazem de uma maneira lógica para os tempos atuais. O trabalhador, nesse processo, é só mais um elemento na conta e já falaremos sobre ele.

Castells, a bem da verdade, já vai mais além da globalização. O autor fala de uma era da informação e de uma sociedade em rede. Para construir seus conceitos, traz uma série de fatos e dados que, para ele, têm mudado mercado, Estado e relações sociais, principalmente a partir da década de 70 do século passado. ${ }^{370}$ 
Há um capítulo, na obra de Castells ${ }^{371}$, especialmente relevante para o nosso tema de investigação: o capítulo quarto do primeiro volume, que trata das transformações do trabalho e emprego. Comecemos por uma afirmação com a qual concordamos, o trabalho e o emprego estão no núcleo da estrutura social. As transformações destas estruturas podem ser analisadas a partir de uma visão histórica do trabalho. O principal motor das mudanças econômicas e sociais entre a primeira e segunda metades do século $X X$ é a revolução das tecnologias da informação. Tais tecnologias também abriram caminho para a integração dos mercados mundiais e unificação da economia global. Não seria de todo verdade, por outro lado, que a economia estaria mudando totalmente de uma atividade industrial para o setor de serviços. Ainda que a tendência é de aumento da atividade no setor de serviços ou informacional, o que tem ocorrido é a mudança de lugar da produção industrial, produzindo um aumento da atividade em países em desenvolvimento e diminuição nos países já desenvolvidos. Ressalte-se que a própria divisão entre tais categorias de trabalho também não é de todo fiável já que os setores de serviços e de informação muitas vezes produzem calcados no apoio à atividade industrial sem a qual não poderiam se expandir.

As teorias apontam, ao menos entre as décadas de 1970 e 1990, uma tendência de aumento dos empregos vinculados à informação e também daqueles que exigem baixas qualificações, ao menos nos países desenvolvidos. Tal circunstância produziu a polarização das atividades com crescimento maior nas extremidades, ou seja, nos empregos que exigem uma alta qualificação e nos que praticamente não exigem qualificação alguma ${ }^{372}$.

Já para o século XXI, parece estar claro que estamos enfrentando, também, mudanças substanciais na estrutura de trabalho e emprego. A previsão de Castells para o informacionismo engloba algumas categorias e, claro, devemos sempre supor que se baseia no modelo estado-unidense, de maneira que, no caso brasileiro, é preciso considerar as vicissitudes locais. Ainda assim, as tendências de mudanças apresentam coerência lógica e, na pior das hipóteses, contribuem para a construção de hipóteses teóricas do caso brasileiro. 
As projeções do autor apontam a uma desaparição progressiva do emprego agrícola, diga-se, uma constante diminuição das taxas de emprego rural assim como daqueles postos gerados pela indústria de transformação tradicional. Por outro lado, crescem os serviços prestados às empresas e os serviços de saúde. Os serviços também tendem a diversificar-se cada vez mais e a criar mais empregos assim como os empregos para executivos, profissionais e técnicos especializados. Por fim, Castells prevê uma estabilidade nas taxas de crescimento do comércio minorista e a polarização do aumento dos empregos entre trabalhadores muito e pouco qualificados com ligeiro aumento daquelas profissões que exigem formação superior.

Cabe ainda, uma pequena consideração do termo mão de obra global, empregado pelo autor e também por Johnston $^{373}$, que parece possuir significação importante para o assunto que tratamos. Aliás, seria lógico dizer que se existe uma economia global, empresas globais e um mercado mundial, também deveria existir uma mão de obra global. Mas a lógica não é tão simples. Na verdade, as barreiras impostas pelos Estados continuam bloqueando a circulação efetiva da mão de obra. Como vimos, a mão de obra mais barata é um fator que impulsiona a circulação de capitais, a terceirização e o off-shoring produzindo a contradição de uma mão de obra local em uma economia global. Destaque-se que a imigração e a mão de obra gerada pelas ondas de imigração cobra cada vez mais importância, principalmente nos países desenvolvidos sem, contudo, representar uma verdadeira e fácil mobilidade de mão de obra. Mesmo não existindo um mercado de trabalho global é inegável que a situação dos trabalhadores de determinado país possui uma relação direta com as condições de trabalho em outros países. Atualmente, as condições de trabalho mais flexíveis e favoráveis às empresas forçam a adaptação dos demais países no mesmo sentido, para competir no mercado global.

A análise dos autores acima leva à inevitável conclusão de que o mercado mundial e as pautas de emprego e trabalho mudaram profundamente, principalmente em relação à primeira metade do século XX. No entanto, no Brasil, persistimos com um modelo sindical de 1943, baseado numa realidade completamente diferente da atual. Os sindicatos são uma parte importe do imbricado 
sistema mundial de relação comércio, capitais e trabalho. Será que os sindicatos não poderiam atuar de maneira diferente e participar mais ativamente no processo? Veremos como isso poderia acontecer. 


\section{CAPÍTULO VI - SINDICALISMO}

O sindicalismo, historicamente, acompanha os demais movimentos sociais e também tem se traduzido em um braço da política. A economia, as relações de trabalho e as lutas de classes são elementos que orientam o movimento sindical. A história e conformação do sindicalismo, certamente, seriam suficientes para muitas monografias, teses e dissertações. Tentar-se-á, dentro do possível, abordar a evolução do Sindicalismo

Alguns autores apontam a origem das associações antigas e modernas a partir de um sentimento inato do homem de se unir para enfrentar perigos comuns. Por outro lado, pode-se conceituar a classe social como um conjunto de pessoas que exercem atividades análogas, vivem de modo semelhante, possuem um nível similar de formação intelectual e possuem ideias e sentimentos semelhantes. A classe social origina-se do conjunto de todos os elementos elencados, do contrário, seja, na existência de apenas um ou alguns deles, não estaremos diante de uma mesma classe social. As profissões seriam um conjunto de pessoas que exercem uma série coerente de atividades dirigidas a satisfazer uma determinada categoria de necessidades. A profissão nasce com a divisão do trabalho e pode ser descrita como uma sociedade natural formada pelas pessoas que se dedicam a atividades iguais ou afins. Não há hierarquia nem subordinação entre os integrantes de uma mesma profissão. A profissão seria uma potência que gravita entre o indivíduo isolado e a entidade sindical ${ }^{374}$.

Ao comentar sobre a formação da classe obreira na Inglaterra Thompson destaca que já por volta de 1776 os trabalhadores ingleses reivindicavam alguns direitos mínimos, bem como a participação no processo legislativo, ao menos com relação às leis que Ihes interessavam. As leis e a Constituição inglesas eram consideradas boas somente para a nobreza e altos cargos públicos, a nação seria dividida entre aqueles que pagam impostos e aqueles que vivem dos impostos pagos pelos demais. ${ }^{375}$

374 FIGUEROLA, Francisco José. Sindicalismo: síntesis histórica. Buenos Aires: Perrot, 1958. 375 THOMPSON, Edward Palmer. La formación de la clase obrera en Inglaterra. Tomo I. Barcelona: Editorial Crítica, 1989. 
Chega-se a afirmar que o espírito da classe obreira está intimamente relacionado com a forma da produção fabril. O conjunto de equipamentos industriais, o vapor e o tear, criavam novas instituições, relações sociais e pautas culturais. Contudo, Thompson nega uma relação direta, ao modo dos materialistas, entre a dinâmica do progresso econômico e as dinâmicas sócio-culturais. Como exemplo desta negação, Thompson destaca que as agitações obreiras do princípio da revolução industrial deveram-se principalmente à ação dos trabalhadores fabris. Trabalhadores a domicílios, pequenos artesãos (os artífices do ludismo), trabalhadores da construção civil, sapateiros, impressores etc., formaram, em muitos locais, o núcleo dos movimentos obreiros. Por isso, é preferível falar em classes trabalhadoras, ante a enorme variabilidade de interesses, de qualificações e de circunstâncias que envolvem os trabalhadores. É possível sustentar que o trabalhador típico, no início do século XIX, não era o obreiro das fábricas e sim os que trabalhavam em pequenas oficinas ou em sua própria e o trabalhador eventual portuário ou da construção. ${ }^{376}$

Segundo Thompson, o fato mais destacado ocorrido entre 1790 e 1830 foi a formação de uma classe obreira, o que ocorreu a partir da formação de uma identidade de interesses entre os trabalhadores e opostos às demais classes sociais. Por outro lado, desenvolveram-se também, neste período, formas organizadas de ação político-social da classe trabalhadora como os sindicatos, sociedades de socorro mútuo, publicações periódicas e pautas de comportamento coletivo. A classe obreira surgiu em razão de uma conjuntura política, social, cultural e econômica. Não foi um uma criação espontânea do sistema fabril ou da "revolução industrial" como forças externas que moldaram um novo tipo humano. Para Thompson a revolução industrial nunca foi uma situação consolidada e sim uma fase de transição entre diferentes modos de vida. Durante esta transição nem a pobreza e nem a doença foram os principais problema e sim o trabalho e suas condições. Essa formação deu-se, também, no seio das ideias de um inglês livre de nascimento e da igualdade ante a lei. ${ }^{377}$ 
De outra banda, é importante destacar que devemos ter a noção do processo histórico completo e não escolher alguns fatos isolados, tendo em conta alguns pressupostos para concluir que o nascimento da classe obreira era algo que deveria acontecer, algo inevitável. Neste mesmo sentido, é possível que as estatísticas e a realidade humana caminhem em sentidos opostos. A renda per capita pode aumentar, bem como aumentar o consumo, mas, ainda assim, existir um transtorno na qualidade de vida, no lazer e nas relações sociais. ${ }^{378}$

$\mathrm{Na}$ Inglaterra as Combination Acts acabaram por proibir toda associação (nestas incluídas também as de caráter obreiro) e também extinguiram a legislação de caráter paternalista em relação aos trabalhadores. A proibição das associações obreiras ocasionou que algumas sociedades se formassem e adquirissem o caráter parecido com a maçonaria e outras sociedades secretas, com ritos de iniciação, juramentos e uma estrutura fragmentada que não permitisse identificar as principais lideranças. Tal movimento culminou com as ações violentas do ludismo e de outras trade unions até a revogação das Combination Acts. ${ }^{379}$

Para Thompson, a legislação paternalista foi em grande parte restritiva e punitiva para o trabalhador. No entanto, mostrava uma faceta de um Estado corporativo benevolente e censor dos industriais sem escrúpulos. O movimento ludista foi quase insurrecional e violento, onde foram destruídas máquinas e aparatos sob comando do "General" Ludd. O movimento ludista foi complexo e abarcou objetivos de cunho trabalhista, mas também político, já que o movimento era apoiada pelas classes baixas em geral contra os negociantes, o exército e os magistrados. ${ }^{380}$

Thompson revela que a consciência de classe formou-se através de intelectuais autodidatas que entendiam o mundo a partir da sua perspectiva de vida. Assim criaram-se basicamente dois pontos de vista sobre a identidade de classe: a primeira era a identidade de interesses entre a classe trabalhadora dos mais diversos tipos de ocupação e que foi expressada pelo sindicalismo geral da década 
de 1830; a segunda era uma aspiração velada ou ao menos não exposta claramente a um sistema político e social alternativo ${ }^{381}$.

Os sujeitos coletivos das relações de trabalho passaram por uma luta atroz para conseguir conquistar seu lugar entre o direito público e direito privado. A doutrina francesa consagrou três fases fundamentais dos sujeitos coletivos nesta luta: a primeira de proibição, a segunda de tolerância e finalmente a terceira onde conquistam o reconhecimento jurídico ${ }^{382}$.

As três fases correspondem a períodos com diversos acontecimentos. A Lei Le Chapelier é uma delas. Tal lei proibia a associação obreira e a reunião de trabalhadores de um mesmo ofício ou profissão. Os artigos primeiro e quarto são especialmente significativos em tal sentido:

Art. 1. L'anéantissement de toutes espèces de corporations des citoyens du même état ou profession étant une des bases fondamentales de la constitution française, il est défendu de les rétablir de fait, sous quelque prétexte et quelque forme que ce soit.

Art. 4. Si, contre les principes de la liberté et de la constitution, des citoyens attachés aux mêmes professions, arts et métiers, prenaient des délibérations, ou faisaient entre eux des conventions tendant à n'accorder qu'à un prix déterminé le secours de leur industrie ou de leurs travaux, lesdites délibérations et conventions, accompagnées ou non du serment, sont déclarées inconstitutionnelles, attentatoires à la liberté et à la déclaration des droits de l'homme, et de nul effet ; les corps administratifs et municipaux seront tenus de les déclarer telles. Les auteurs, chefs et instigateurs, qui les auront provoquées, rédigées ou présidées, seront cités devant le tribunal de police, à la requête du procureur de la commune, condamnés chacun en cinq cent livres d'amende, et suspendus pendant un an de l'exercice de tous droits de citoyen actif, et de l'entrée dans toutes les assemblées primaires. $^{383}$

O artigo primeiro refere ser uma das bases fundamentais da constituição a abolição de todas as espécies de corporações de cidadãos de mesmo estado ou profissão. Além disso, preconiza que as reuniões ou confabulações dos cidadãos mencionados no artigo primeiro com objetivo de não exercer seu trabalho ou

381 THOMPSON, Tomo 2, 1989.

382 VERDIER, Jean-Maurice. Syndicats et droit syndical. Vol. I, Liberté, structures, action. Paris: Dalloz, 1987.

383 FRANÇA. Lei Le Chapelier de 14 de junho de 1791. Disponível em: www.vie-publique.fr/documentsvp/loiChapelier.pdf Acesso em: 21 jun 2016. 
somente exercê-lo mediante uma paga determinada. Tais determinações serão consideradas como inconstitucionais e atentatórias às liberdades do homem. Ou seja, em claro resquício de temor das velhas corporações de ofício medievais a França, em consonância com o período de proibição do associaciativismo e de exaltação das liberdades individuais proíbe toda forma de ação sindical.

Já no período de reconhecimento, pode-se destacar a lei britânica. Tal dispositivo é de 1871 (Trade Union Act) e reconhece as associações sindicais e também a eficácia jurídica dos acordos sindicais ${ }^{384}$.

O movimento sindical, em nosso entender, sofreu e sofre até os dias atuais de preconceitos ligados a fatos concretos e errôneos, consagrados como uma espécie de senso comum através da história. O primeiro deles é entender os sindicatos como sucessores das corporações de ofício medievais. Tal concepção não poderia ser mais equivocada. De fato, as corporações de ofício não pretendiam oferecer oposição aos empregadores e bem eram uma entidade que regulava o mercado, a oferta, a demanda, a qualidade e os preços dos produtos a encargo de um ofício determinado. Os conflitos, no caso das corporações de ofício, eram muito mais entre a corporação e a população e entre mestres e aprendizes. As corporações também eram conhecidas pela prática do cartel de preços em produtos muitas vezes essenciais aos cidadãos e, daí vem, em grande parte a ojeriza contrária a tais entidades.

Lado outro, o preconceito que associa imediatamente os sindicatos ao movimento comunista e à revolução socialista alimenta em grande parte o desconhecimento e o temor sobre os sindicatos. Neste ponto, também em nosso entender, o preconceito carece de fundamento. Os sindicatos e associações obreiras foram entidades com força política utilizadas pelos partidos ou pelo partido para tentativas de implantação de uma ditadura do proletariado. No entanto, a gênese e o desenvolvimento do movimento sindical não guardam relação essencial com o comunismo ou socialismo, mais bem foram veículos de sua expansão e promoção. Por óbvio que os institutos têm relação, no entanto, esta é a mesma que 
possui qualquer outro elemento político em um jogo de interesses e oposições políticas.

De outra banda, muitos países já se deram conta da importantíssima função reguladora e filtrante do sindicato com relação às queixas dos trabalhadores e insatisfação geral. A ausência do sindicato e de um meio negociado de solução dos conflitos faz com que os trabalhadores estado-unidenses busquem os tribunais onde, quase invariavelmente, jurados identificados com a condição do trabalhador condenam as empresas a pagar vultosas quantias. Neste contexto, o próprio empresariado passa a fomentar as associações obreiras ${ }^{385}$.

\subsection{O surgimento da classe trabalhadora brasileira}

Quando se pretende falar de Brasil, quase sempre surge um temor reverencial, às vezes um receio sincero de abordar um tema complexo e sem consenso. Afinal, o Brasil não é para principiantes, sentença atribuída a Antônio Carlos Jobim e que revela um pouco dessa autoridade mínima necessária para falar de Brasil. A frase também revela um algo de autoritarismo do tipo "sabe com quem tá falando?", sentença explicada por DaMatta ${ }^{386}$. Em outra interpretação, entenderão alguns pela humildade do reconhecimento da incapacidade que muitos de nós, ainda que brasileiros, temos para explicar coisas do Brasil. Mesmo assim, decidimos escolher esse caminho e tentar aprofundar um pouco o estudo sobre a questão da formação da classe obreira no Brasil.

O complicado adquire aqui um caráter mais positivo do que negativo. Essas vicissitudes brasileiras mostram suas facetas em quase todos os campos e na temática jurídico-cultural não seria diferente. A vasta extensão do território e sua recente, em termos históricos, consolidação, certamente é um dos fatores a ter-se em consideração. O regime escravista, motivo atual de vergonha e disputas aliado à intensa chegada de imigrantes de várias partes do mundo, construíram um cenário bastante único, mas passível de analogias, inferências e deduções. 
Cabe lembrar, a legislação trabalhista ainda vigente no Brasil é a Consolidação das Leis do Trabalho ${ }^{387}$, publicada em 1943 por Getúlio Vargas, durante o regime conhecido como "Estado Novo". Tal lei, a qual, por certo, já recebeu inúmeros artigos, revisões e adendos, buscou compilar, organizar e consolidar uma série de leis trabalhistas esparsas do princípio do século $X X$.

A natureza do assunto clama por uma análise interdisciplinar baseada, principalmente, na revisão de literatura e interpretação de dados, fatos e leis. Buscaremos analisar uma razoável quantidade de obras, algumas delas fundamentais para a fundação ou refundação da identidade brasileira. Entendemos que o estudo da formação da classe obreira, no Brasil, pode contribuir para a sociedade brasileira no sentido de fornecer alguns bastiões de apoio quando da análise do estado atual de coisas.

\subsubsection{Muitas terras e pouca mão-de-obra}

Ao considerarmos a imensa quantidade de terras da América Portuguesa é possível ter uma noção do quanto seria difícil colonizar o novo mundo. Essa dificuldade é acentuada pelo motivo de Portugal estar bastante mais ocupado com as Índias e o lucrativo comércio que lá acabava de estabelecer. Somente a partir do declínio do comércio com as Índias, algumas décadas depois da chegada dos portugueses à ilha de Vera Cruz é que as novas terras começaram a parecer interessantes e uma alternativa viável de comércio e expansão territorial ${ }^{388}$.

A empresa colonizadora é uma relação necessária entre sociedade e espaço. Colonizar é expandir seu território, adir terras ao seu patrimônio, dominar meios econômicos e populações, ter controle sobre determinada área. A capacidade do colonizador em adaptar-se e enfrentar a realidade imposta pelas condições das terras a colonizar determinará o êxito da atividade colonial $^{389}$.

Apesar da experiência portuguesa, havia uma necessidade urgente de ocupar o Brasil para conciliar os motivos comerciais e os políticos. No entanto, a ocupação 
deveria tornar economicamente viável e rentável a colônia, não interessando que fosse uma iniciativa antieconômica sob nenhum aspecto ${ }^{390}$.

A densidade demográfica das terras americanas abaixo do equador era bastante distinta daquela encontrada no Império Azteca ou Inca. A capital Azteca, possuía aproximadamente o triplo de habitantes existentes na maior cidade espanhola da época, Sevilha. Enquanto isso, nas terras mais ao sul da américa, a densidade demográfica era extremamente baixa, em média 2 (dois) habitantes por $\mathrm{km}^{2}$ e agrupados em apenas algumas áreas ${ }^{391}$.

Então, Moraes aponta dois vetores da colonização portuguesa. O primeiro deles é justamente o quadro populacional e a densidade demográfica e o segundo são os recursos naturais. No Brasil, os portugueses, de início, não encontraram nem uma coisa nem outra. Destaca-se, como bem ressalta Moraes, que Brasil é uma invenção luso-européia, não existia uma unidade territorial ou cultural antes da chegada dos portugueses $^{392}$.

Ou seja, a tarefa de colonizar, envolvia custos e trabalho. Estes custos foram em grande parte repassados a particulares a partir da doação das capitanias hereditárias a indivíduos que teriam a responsabilidade de explorar a terra e pagar impostos ao governo central ${ }^{393}$. Cabe destacar, a maioria das capitanias tinha uma área equivalente ao que hoje são Estados brasileiros. Muitas maiores que alguns países europeus, doadas a uma única pessoa. Nessas circunstâncias, tornava-se também bastante difícil aos donatários cumprir com a obrigação de explorar a terra.

Quase todos os livros referem-se ao "Problema da mão-de-obra", isto é, como amealhar braços suficientes para laborar na empresa econômica de exploração da colônia. O início da importação de escravos africanos deveu-se, segundo Fausto, a um conjunto de fatores e não a esta ou aquela causa isolada. ${ }^{394}$

390 FENELON, Dea Ribeiro. 50 textos de história do Brasil. São Paulo: Hucitec, 1986.

391 MORAES, Antonio Carlos Robert de. Bases da Formação Territorial do Brasil. in: Revista Geografares, Vitória, $\mathrm{n}^{\mathrm{o}} 2$, jun $/ 2001$.

392 MORAES, 2001

393 FAUSTO, Boris. História do Brasil. São Paulo: Editora da Universidade de São Paulo, 1995.

394 FAUSTO, 1995. 
Muitos foram, portanto, os fatores determinantes do início da escravidão africana no Brasil. Enumeramos alguns deles à guisa de rol exemplificativo e não taxativo dos motivos indutores da escravidão africana no Brasil colonial.

O índio, apesar das diversas tentativas de utilizá-lo como mão de obra revelou não servir ao propósito indicado. A imensa distância cultural do índio e sua cultura nômade e de subsistência dificultavam sua adaptação. Além disso, houve, de parte dos religiosos, principalmente da Escola de Salamanca, uma defesa candente dos direitos do índio considerada por alguns autores ${ }^{395}$ como a gênese dos direitos humanos.

Note-se que o tema do índio, nativo da terra como acabou consagrado pelos dicionários, oferecia um excelente campo para argumentação jurídica baseada nos direitos de conquista e dominação. Ademais, o índio era tido como selvagem e sem cultura, o que oferecia um vasto número de almas a evangelizar. Não parece ser que os postulados da Escola de Salamanca foram feitos em detrimento do africano mais que com intenção de proteção ao índio. A questão é bastante mais complexa e também envolve aspectos econômicos que possibilitariam a exploração das novas terras pela Coroa de Castela. Ainda, a possibilidade de uma imigração portuguesa ou do restante da Europa para o Brasil era pouco factível dadas as condições precárias da infraestrutura e o custo de dita mão de obra, os salários teriam de ser atraentes ao imigrante.

Tais fatores, aliados ao modo de exploração dos engenhos de açúcar, os quais, pela natureza própria da atividade, consistiam em enormes propriedades monocultoras. $O$ trabalho do engenho necessitava de abundante mão de obra e de um trabalho árduo. Ao que consta, a quase totalidade das propriedades produtoras do período colonial era praticamente autossuficiente, seja por necessidade (ausência de comércio na colônia), seja por razões práticas, para manter a mão de obra próxima ao trabalho e constantemente ocupada. Neste contexto, acabou por prevalecer a alternativa da importação de escravos como a mais viável economicamente para a exploração da colônia. 
A "indústria" do açúcar criou outra lucrativa atividade: a do comércio de escravos. Muitos comerciantes passaram a dedicar-se à atividade do comércio de escravos para a Europa e a América. Existem muitos estudos dedicados a investigar estatísticas e documentos sobre as cifras do comércio negreiro e seu consequente impacto sobre o território e as sociedades da então colônia estabelecida no Brasil.

Fausto $^{396}$ estima em 4 (quatro) milhões o número de escravos chegados aos portos da América Portuguesa entre 1550 e 1855. Outros diversos autores chegam a cifras parecidas. Eltis e Richardson ${ }^{397}$ estimam em aproximadamente 12 (doze) milhões os escravos foram retirados forçosamente da África em 366 anos de duração do comércio negreiro. Destes, apontam que uns 11 (onze) milhões de escravos vieram para a América, entre os quais quase a metade para o Brasil. Outro estudo $^{398}$ aponta que somente entre 1750 e 1808 foi de quase um milhão o número de escravos desembarcados no Brasil. Face aos estudos citados, parece bastante acertado supor entre 4 (quatro) e 5 (cinco) milhões de escravos.

A magnitude desta imigração forçada foi tal que seus efeitos são sentidos até hoje na sociedade brasileira. De fato, considerando as capitanias existentes em 1590, como, por exemplo, Salvador, Rio de Janeiro, Espírito Santo, entre outras, chegamos ao total de aproximadamente 42.000 escravos, 5.500 portugueses (e seus descendentes) e 28.000 índios cristianizados ${ }^{399}$. Ou seja, os escravos superavam com grande vantagem os outros dois estamentos somados. Poder-se-ia discutir a fiabilidade das fontes e também a inclusão ou não de determinados grupos populacionais. Entretanto, é possível vislumbrar a realidade da época colonial.

Mesmo no Rio Grande do Sul, uma das províncias que mais tardiamente foi povoada e adotou a política escravocrata, em 1814, eram mais de 20.000 escravos para aproximadamente 32.000 brancos. E, no contexto rio-grandense, os escravos

396 FAUSTO, 1995.

397 ELTIS, David e RICHARDSON, David. Atlas of the transatlatic slave trade. New Heaven \& London: Yale University Press, 2010.

398 XIMENES, Cristiana Ferreira Lírio. Bahia e Angola: redes comerciais e o tráfico de escravos (17501808). Tese (Doutorado) - Universidade Federal Fluminense, Instituto de Ciências Humanas e Filosofia, Departamento de História, 2012.

399 CARRARA, Angelo Alves. A população do Brasil, 1570-1700: uma revisão historiográfica. in: Revista Tempo, Niterói, vol 20, 2014. 
participavam efetivamente de atividades mais complexas, sendo muitos deles artífice de algum ofício como a carpintaria ou a construção ${ }^{400}$.

Para Caio Prado Jr. ${ }^{401}$ a sociedade colonial era reflexo de sua base material. O poder político e econômico concentrado nas mãos dos senhores de engenho, em torno dos quais gravitava um pequeno número de trabalhadores livres e uma grande massa de escravos. Era esta, praticamente, a composição social presente na colônia.

A grande massa de escravos foi, até o início do século XIX, praticamente o único grupo de trabalhadores existente na Colônia. Com a transferência da família real para o Brasil, em 1808, incorpora-se à massa de trabalhadores uma plêiade considerável de funcionários da administração real e dos serviços de Estado. Embora considerável, seu número era infinitamente menor e estavam restritos a poucos locais, como a sede da Corte e outros de relevância administrativa. O trabalhador escravo estava, sem embargo, espalhado de Norte a Sul e em número bastante superior.

Muitos fatores contribuíram para o declínio e ocaso do modo de produção escravista durante o século XIX. Parece acertado dizer, a exemplo de Cardoso, ser uma questão complexa e de difícil resposta. Se os tratados internacionais proibiram o comércio de escravos, tornando a compra e venda mais difícil e onerosa, a inserção do Brasil já independente em um mercado global de importação e exportação demandava um aproveitamento mais racional dos recursos e uma melhor divisão do trabalho. Manter um escravo "ocupado" ainda que sem trabalho útil acaba revelando-se uma empresa custosa e irracional. ${ }^{402}$

Assim, ao elevar-se no horizonte a perspectiva abolicionista, volta a surgir o "dilema" da mão de obra. A questão dos braços para trabalhar nas grandes propriedades rurais passa a apontar para os imigrantes, a solução encontrada para resolver o premido problema do trabalho.

400 CARDOSO, Fernando Henrique. Capitalismo e Escravidão no Brasil Meridional: o negro na sociedade escravocrata do Rio Grande do Sul. Rio de Janeiro: Paz e Terra, 1997.

401 PRADO JÚNIOR, Caio. A evolução política do Brasil e outros estudos. São Paulo: Companhia das Letras, 2012.

402 CARDOSO, 1997. 


\subsubsection{Os imigrantes e a "nova" realidade}

O "nova" assim, entre aspas, deve-se ao fato de os imigrantes terem encontrado um modo de produção semelhante àquele utilizado com os escravos. A diferença estava na utilização de mão de obra livre em lugar de cativos. Continuava a exploração na base latifúndios, quase sempre autossuficientes e monocultores. A produção cresceu para o Sul, com Minas Gerais e São Paulo, principalmente, liderando a produção cafeeira.

Neste sentido, falar de imigração é quase sempre falar de São Paulo, o Estado que mais viu imigrantes chegar e que mais se transformou a partir da política migratória adotada pelo Estado Nacional. A chegada de imigrantes, tal e qual a de escravos no seu período, foi em números expressivos e contundentes, capazes de alterar o panorama das relações de trabalho brasileiras em poucas décadas.

Segundo o $\mathrm{IBGE}^{403}$, entre 1884 e 1939, chegaram ao Brasil quase quatro milhões e duzentos mil imigrantes de várias nacionalidades, com os italianos representando mais de um terço do total. É digno de nota que em aproximadamente três séculos de regime escravista, o número de escravos trazidos ao território brasileiro é, segundo o já discutido, bastante próximo ao de imigrantes. Está clara a diferença entre o Brasil (e aqui sim já falamos efetivamente de Brasil) de finais do século XIX, em relação a incipiente colônia do século XVII. Mesmo assim, os números não deixam de impressionar e sugerir o grande impacto da imigração nas mais diversas áreas do país, entre elas na questão das relações de trabalho, tema do qual nos ocupamos.

Para Oliveira ${ }^{404}$, o imigrante desejado era aquele com perfil de colono agricultor, o qual aceitaria povoar e viver nos "vazios" demográficos, principalmente do interior. A estratégia de atrair imigrantes nasce concomitantemente às questões que acabariam por provocar o final do regime escravocrata. A derrocada da escravidão, para Fenelon ${ }^{405}$, ocorreu no momento de maior expansão da economia brasileira onde principiavam o êxito das fazendas de café e algumas esparsas 
atividades industriais de manufatura. Continuava, portanto, a necessidade de braços para a realização do trabalho.

Por certo, importante destacar que a mentalidade escravocrata não pode ser apagada dos corações e mentes ao promulgar uma lei. A "conversão" de escravos em trabalhadores livres, respondia à necessidade de lucro e nem por isso deixava de ser desvantajosa para o trabalhador. Acostumados ao regime da escravidão, poucos trabalhadores nacionais tinham condições de ocupar os postos de trabalho vacantes, e entre aqueles habilitados, poucos eram os desejosos de sujeitar-se ao trabalho em tais condições.

A escravidão também criou inúmeros preconceitos com relação aos trabalhadores nacionais e aos escravos libertos. Como aponta Cardoso ${ }^{406}$, ao escravo liberto restava a opção de seguir trabalhando para seu "senhor" e receber apenas o suficiente para não morrer de fome, com condições de trabalho bastante precárias ou optar por uma miséria "livre" do trabalho. A associação da ideia do exercício do trabalho como algo degradante e destinado ao escravo é esperada e natural em uma sociedade que conviveu com tal fato durante séculos. Por isso, o trabalhador nacional sentia e, ao que parece, ainda sente, certa repulsa pelo trabalho manual, similar ao outrora destinado aos escravos.

E foi neste contexto que desembarcaram os imigrantes. Em um território dividido entre senhores e escravos e com pouquíssimos ocupando o "limbo", isto é, os postos de trabalho assalariados e livres. Assim surgiu também uma imagem préconcebida dos imigrantes com relação ao trabalhador nacional, segundo Oliveira ${ }^{407}$ os imigrantes viam os brasileiros como preguiçosos e incapazes. Tal visão também era partilhada pela elite nacional e era reforçada pela relativa capacidade dos imigrantes, principalmente naqueles trabalhos que exigiam alguma preparação como os artífices de diversos tipos.

A maioria dos historiados cita diversos fatores para e expansão do mercado de trabalho e evolução da economia nacional no final do século XIX. A exemplo de Fenelon ${ }^{408}$, o rol de motivos parece ser próximo a este: repercussões da guerra do 
Paraguai na sociedade nacional; maior importância do Exército na política nacional; a expansão da cafeicultura; início da produção artesanal e fabril; abolição da escravatura; a necessidade de braços para a lavoura; e, o movimento republicano. Todos os fatores enumerados fazem parte de um contexto estruturado, no qual os imigrantes desempenham um papel importante.

A diferenciação das atividades e expansão da economia também causa uma maior divisão do trabalho. Surgem e são demandadas novas ocupações e trabalhadores com maiores e melhores qualificações. Em tais postos de trabalho destacam-se os imigrantes, com maiores e melhores qualificações.

Para Mota e Lopez ${ }^{409}$ o início do crescimento vertiginoso da cidade de São Paulo deu-se justamente no final do século XIX, onde começaram grandes obras de saneamento e eletrificação, assim como o aumento populacional. Para Fausto os imigrantes tiveram papel crucial na ocupação de postos de trabalhos que exigiam qualificação e no pequeno comércio. Nas profissões liberais, também houve relativo sucesso dos imigrantes, e este fato provocou, já no século $X X$, um crescente preconceito com relação aos imigrantes e à criação, inclusive, de leis restritivas do acesso ao mercado de trabalho e de revalidação de diplomas estrangeiros. Ademais, pode-se destacar a participação dos imigrantes no início de manifestações por melhores condições de trabalho e a germinação de alguns núcleos de consciência de classe. ${ }^{410}$

Para Prado Jr. ${ }^{411}$, o povoamento do Brasil está diretamente relacionado com a necessidade de mão de obra, ora para uma atividade, ora para outra. As mudanças e a sazonalidade de cada ciclo produtor provocaram, também, a desordem na ocupação do território brasileiro, problema persistente até a atualidade. Nota-se, assim, que o destino brasileiro sempre esteve ligado à questão do trabalho e a resolução do "problema" da mão de obra, orientou o povoamento e a evolução do Brasil. A chegada dos imigrantes, de alguma maneira, "forçou" o desenvolvimento de um mercado de trabalho nacional a partir da existência de uma mão de obra mais

409 MOTA, Carlos Guilherme e LOPEZ, Adriana. Historia de Brasil: una interpretación. Traducción de José Manuel Santos Pérez. Salamanca: Ediciones Universidad de Salamanca, 2009.

410 FAUSTO, Boris. Historiografia da Imigração para São Paulo. São Paulo: Ed. Sumaré-FAPESP, 1991.

411 PRADO JÚNIOR, 2012. 
qualificada e disposta, obrigando os nacionais e também os escravos libertos a igualar a disputa em vontade e qualificações.

Finalmente, para possibilitar o avanço ao tema seguinte, destacamos dados sobre as nacionalidades dos imigrantes chegados ao Brasil nos anos de ouro da imigração. Segundo o IBGE, mais de um terço dos imigrantes eram italianos, aproximadamente um milhão e quatrocentos mil. As outras duas nacionalidades com maior número de imigrantes são, portugueses e espanhóis. O número de portugueses é apenas duzentas mil almas menor que o de italianos e chegaram mais de quinhentos mil espanhóis. Essas três nacionalidades superam e quase dobram a soma de todas as demais. ${ }^{412}$

Tal contexto ajuda a corroborar as conclusões dos autores daqueles livros que são considerados como inauguradores de uma identidade nacional verdadeiramente brasileira. Até tal momento, que se soe fixar como a década de $1930^{413}$, o Brasil era apenas um amontoado desordenado de pessoas provenientes de diversos locais do planeta. Nessa identidade brasileira restou marcado um rasgo identificativo muito forte: o caráter ibérico. Sobre ele, discutiremos no tópico seguinte.

\subsubsection{O brasileiro e seu traço ibérico}

Cabe-nos tocar em um ponto controvertido, por vezes "esquecido", tendo em vista as paixões que desperta e a dificuldade de sua análise e interpretação. De maneira oposta, aqueles grandes livros considerados como fundadores de uma identidade nacional brasileira da talha de Casa Grande \& Senzala, Raízes do Brasil ou a Formação do Brasil Contemporâneo todos tratam de alguma forma sobre as influências ibéricas na formação do caráter brasileiro. E tais obras são aquelas consideradas como fundadoras de uma identidade nacional nascida em meados da década de 1930 e amplamente apoiada pela propaganda oficial. Claro está, existem outros importantes autores que escreveram sobre o assunto a exemplo de Darcy Ribeiro, sem, no entanto, a ampla difusão e aceitação dada aos três livros já citados, muito quiçá, pela própria ausência do apoio oficial. 
Falar sobre o caráter ibérico impresso nos brasileiros parece ser bastante óbvio, afinal, por mais de três séculos, apenas portugueses e espanhóis circulavam oficialmente pela América do Sul, em que pese existirem algumas tentativas de penetração francesa, inglesa e holandesa, por exemplo. No entanto, parece ser que atribuímos todos nossos males à colonização e costumamos negar um pouco nossas origens com relação aos diversos matizes que compõem a sociedade brasileira.

Em Casa Grande \& Senzala, Freyre destaca muitos traços do caráter português, os quais possibilitaram que um país pequeno e de reduzida população, pudesse empreender a façanha de estabelecer colônias ao redor do mundo. Tais características do português e, de alguma maneira, ibéricas nas inúmeras semelhanças existentes entre os dois países moldaram os fatos da colonização e da aurora de uma "civilização europeia nos trópicos". 414

A bem da verdade, a colonização, como assim se convencionou chamá-la, não é mais do que uma ínfima parte da imensa empresa européia pela expansão do comércio. O progresso da engenharia marítima e os novos barcos, permitiram deslocar o centro europeu do mediterrâneo para as áreas voltadas para o Atlântico onde a península ibérica ocupava posição privilegiada. ${ }^{415}$

Da mesma maneira, Buarque de Holanda também ressalta o caráter ibérico de alguma maneira incorporado pelo brasileiro. Para o autor, Portugal, Espanha e Rússia são espécies de territórios-ponte através dos quais a Europa se comunica com outros mundos. A região ibérica funcionou, de fato e durante muitos séculos, como zona de transição entre o mundo árabe e a Europa. Ademais, Portugal sempre viveu aberto e próximo da África, seja no clima, seja na proximidade física. ${ }^{416}$

O caráter do português é definido por Freyre como uma sorte de equilíbrio de antagonismos provocados pela indecisão cultural entre Europa e África, existente, também, em outras zonas da península ibérica como, por exemplo, acrescentamos, a Andaluzia. Esse equilíbrio de antagonismos gerou as condições especiais em que

414 FREYRE, Gilberto. Casa Grande \& Senzala: formação da família brasileira sob o regime da economia patriarcal. São Paulo: Global 2003.

415 PRADO JÚNIOR, Caio. A formação do Brasil contemporâneo: colônia. São Paulo: Companhia das Letras, 2011.

416 BUARQUE DE HOLANDA, Sérgio. Raízes do Brasil. São Paulo: Companhia das Letras, 1995. 
desenvolvida a colonização portuguesa na América e perdura até hoje expressada pela mesma sociedade brasileira a qual segue equilibrando-se em antagonismos. ${ }^{417}$

Para Ribeiro (1995), Portugal já era, ao tempo da expansão ultramarina, uma sociedade dividida entre o campo e a cidade, estratificada e integrada em uma sorte de economia internacional. Ao implantar um sistema de exploração econômica colonial com a chancela papal, justificada pela empresa catequizadora, Portugal e Espanha, em verdade, buscavam outras riquezas, além da espiritual. Isso explica que todos os habitantes da então colônia passaram a ser dominados e transfigurados a serviço dos interesses da metrópole ${ }^{418}$.

A empresa colonial-escravistas Ibérica nas Américas foi extremamente semelhante ao modo adotado pelos impérios da antiguidade clássica (Grécia, Roma, Cartago) em seu sistema de dominação e expansão. ${ }^{419}$ Tal processo é parte de um sistema de atualização histórica ${ }^{420}$ pelo qual passou o território americano a partir da chegada dos europeus. Se para Ortega e Gasset ${ }^{421}$, a Europa é, de certa forma, o legado romano, este processo constituiu o elo de ligação entre o Brasil e a Europa, o Brasil e o Império Romano, imprimindo no brasileiro marcas indeléveis de caráter ibérico.

Dentre estas características, apontadas pelos livros fundacionais da identidade brasileira, várias podem ser apontadas. Várias delas nos interessam como por exemplo, a verdadeira aversão do culto ao trabalho. As nações ibéricas preferem o ócio ao negócio, e consideram uma digna ociosidade menos aviltante que a luta desenfreada pelo pão de cada dia. ${ }^{422}$

Além disso, Freyre aponta como característica dos portugueses a fácil mudança de profissão e de residência, componentes de outras duas características mais generalizantes referidas pelo autor: a adaptabilidade e a miscibilidade.

417 FREYRE, 2003.

418 RIBEIRO, Darcy. O povo brasileiro: a formação e o sentido do Brasil. São Paulo: Companhia das Letras, 1995.

419 RIBEIRO, 1979.

420 A atualização histórica é um dos conceitos trabalhados por Darcy Ribeiro e significa, grosso modo, o ato de trasladar, para outro Estado ou território, conceitos e/ou pautas culturais já existentes em outro Estado ou Território. Este conceito, bem como o de aceleração evolutiva, também trabalhado pelo autor mereceria bem um capítulo ou dissertação de modo que nos é impossível detalha-lo no presente trabalho.

421 ORTEGA Y GASSET, José. La Rebelión de las Masas. Madrid: Tecnos, 2003.

422 BUARQUE DE HOLANDA, 1995. 
Outrossim, o maior antagonismo, aquele que produz efeitos até hoje, é o do senhor e do escravo. ${ }^{423}$

A questão do senhor e do escravo permeou as relações brasileiras de uma mescla entre profissional e pessoal. Ganhar o afeto e amizade dos clientes, dos empregados, do patrão, passa a ser mais importante que a efetividade das relações mercantis ou laborais, mergulhando o mundo do trabalho em uma profusão de emoções, tornando-o ainda mais complexo e singular. ${ }^{424}$

Todas estas situações criaram uma sociedade sui generis e repleta do legado daqueles que aportaram no território hoje brasileiro. A especificidade e complexidade da sociedade brasileira são um fato e outro é ser o Brasil Ibérico, em certa medida.

\subsubsection{A equação resolvida por Vargas}

Como se nota, no início do século XX, o Brasil possuía uma massa disforme de trabalhadores oriundos de muitos lugares distintos. De fato, imigrantes e escravos libertos constituíam o núcleo da classe obreira brasileira. Esse núcleo era, de certa forma, estrangeiro, imigrante e descendente de imigrantes ou escravo e descendentes de escravos.

Assim, longe de coexistirem apenas as três raças (brancos, negros e índios), referidas pelos autores clássicos convivendo harmonicamente, havia em verdade uma enorme multiplicidade de variações de origens, aspirações e papéis sociais. Esta complexidade, faz-nos rechaçar, de plano, tal qual DaMatta ${ }^{425}$ (2011), a simplicidade do mito das três raças, cada qual com sua aportação à mestiçagem brasileira e com seu lugar já previamente determinado na hierarquia social.

Além disso, o período de convulsão social do início do século $X X$, com 0 crescimento das cidades, demandas por melhores condições de trabalho coincidiu com o período revolucionário europeu, sobretudo a revolução do outubro vermelho, a qual abria o precedente das reivindicações operárias. Começa, então, um período 
de protestos de trabalhadores, formações de sindicatos e greves, buscando, na maior parte das vezes, contraprestações imediatas e pontuais como melhores salários ou menor jornada de trabalho ${ }^{426}$.

A partir de então, os trabalhadores passaram a postular novas chances de ascensão social, bem como participação na decisão dos rumos da nação, algo inédito até então na vida política brasileira. O declínio do poder das oligarquias rurais era evidente e a convulsão social causada por inúmeros fatores dividia o País e dificultava sua governabilidade.

O mundo, na década de 20 do século XX, vivia dois interessantes momentos, geralmente proporcionados pelo final da guerra e o ressurgimento e fortalecimento dos vencedores. O capitalismo cobrava força e se desenvolvia em sua forma mais liberal assim como a Revolução Socialista produzia novas ideias captando a simpatia de intelectuais em todo o mundo ${ }^{427}$. O contexto de crise econômica de 1929 e a oligarquia instalada e levada a efeito com a República do Café com Leite levam à revolução de 1930. Vargas pregava o atendimento às necessidades dos trabalhadores e uma regeneração da nação e assim chega ao poder através de um golpe militar ${ }^{428}$.

Ao assumir, Vargas dá início aos seus projetos para o país. E assim, uma das primeiras medidas foi a criação do Ministério do Trabalho e a discussão de leis trabalhistas. O enigma de Vargas, que, até sua declaração formal de guerra ao eixo nazi-fascista, não deixava transparecer de qual lado estava, foi facilitado pelas enormes contradições do Brasil e do mundo no período anterior.

Os confrontos entre os aliados do imperialismo, representados pelos grandes latifundiários e os apoiadores de um emergente nacionalismo nascido no seio da pequena burguesia e das classes trabalhadoras tomavam conta do País. A burguesia, segundo alguns, buscava tomar o controle estatal das mãos da oligarquia rural e propiciar a expansão do capitalismo no Brasil. Para muitos autores citados por Boris Fausto $^{429}$, existe uma conexão entre a industrialização brasileira e a Revolução de 30 , não porque o movimento tenha redundado em benefício da 
burguesia nacional e sim pelo surgimento e participação desta como fração de classe.

É claro que não se pode estabelecer uma data exata onde tem fim um modo de produção e se dá início a outro. Normalmente, por razões didáticas, assim como fez Morgan $^{430}$, em seu esquema evolutivo, dividindo as sociedades em níveis de barbárie, selvajaria e civilização, com subdivisões em inferior, médio e superior de cada um dos dois primeiros. Parece-nos correto apontar o predomínio do feudalismo ou semi-feudalismo a partir da proclamação da República e o predomínio do capitalismo a partir da Revolução de 30, mesmo, como já dito, que apenas para fins de argumentação e como forma de situar mais facilmente o leitor nos tempos históricos.

O contexto da Revolução de 30 não pode ser resumido de maneira maniqueísta em conflitos cidade-campo, indústria-agricultura ou burguesiaoligarquia. Por outro lado, também não se pode negar o papel desempenhado por ditos conflitos no resultado final. Se a Aliança Liberal não apresentava um programa essencialmente voltado para a indústria, tampouco poder-se-ia negar que seu programa diferia do programa de Júlio Prestes, especialmente elaborado para a elite agrária $^{431}$.

Frente ao liberalismo desenfreado dos anos anteriores, o governo necessitava instalar e praticar políticas de intervenção estatal na economia, o que certamente contribuiria, depois, para deslocar o pêndulo da preferência de Vargas pelos regimes fascistas. Bem assim, é importante destacar que, no mesmo momento, crescia em importância e reconhecimento a revolução socialista onde os trabalhadores e entidades sindicais instalavam a ditadura do proletariado a partir do movimento sindical.

Vargas dá início ao plano de substituição de importações a partir de um forte controle estatal. As fases de implantação do programa podem ser resumidas em implementar primeiro 0 atendimento às necessidades básicas (alimentação, segurança, vestuário, moradia etc.) da população em busca do aumento do mercado consumidor interno. Logo após, parte-se para o a indústria de bens primários, 
secundários e, finalmente de base (como, por exemplo, maquinário para a própria indústria). Neste contexto também entra a matéria-prima (minério, energia) para o aumento da produção. Tais fases estão perfeitamente descritas e resumidas por Mota e Lopez ${ }^{432}$ no subitem chamado "Uma economia dirigida pelo Estado".

Então, a equação de Vargas na questão trabalhista era melhorar e regulamentar a situação dos trabalhadores urbanos sem possibilitar o surgimento da mentalidade e lideranças socialistas. Além disso, Vargas necessitava de um sistema que criasse certos laços de coesão da classe trabalhadora, o mesmo que foi feito em maior escala com a seleção e valorização de elementos identitários específicos atribuídos aos brasileiros em geral. Até aquele período, a semelhança dos brasileiros de Norte a Sul e de Leste a Oeste resumia-se ao idioma, a lei e à partilha do vasto território. A resposta foi encontrada no sistema sindical fascista e Vargas, para criar a identidade dos trabalhadores não teve mais remédio que a limitar.

Os debates e aprovação do texto final da Consolidação das Leis do Trabalho aconteceram no delicado contexto já explicitado. De fato, a ideia inicial era a de compilar e consolidar (daí o famoso nome) as diversas legislações esparsas sobre a temática trabalhista surgidas nas décadas posteriores ao final da escravidão. É de se destacar que somente quatro décadas separam o final da escravidão e o início da vigência da legislação trabalhista brasileira atual.

A Consolidação das Leis do Trabalho foi gestada e concebida, em sua maior parte, sob a égide da Constituição de 1937, apelidada de "a polaca" por seu alinhamento com os regimes totalitários e autoritários europeus da época. O então Ministro da Justiça de Vargas, Francisco Campos, procura justificar a severidade da Constituição, como sempre, pela imperativa necessidade de salvação nacional. A Constituição de 1937 foi a primeira que dispensou o poder constituinte. Nem a Constituição do império foi outorgada da mesma forma, já que o texto adotado foi, quase na íntegra, aquele debatido pela Assembleia Constituinte dissolvida pelo Imperador. ${ }^{433}$

Antes de 1937, na verdade, Getúlio Vargas já havia dado início à publicação de leis reguladoras do trabalho. Com a criação do Ministério do Trabalho e a 
atuação de seu então Ministro Lindolfo Collor, um dos decretos legislativos do período foi 19.770 que regulava a forma de associação em sindicatos. O ministro recebeu a missão de organizar os trabalhadores como segmento de cooperação com o Estado. ${ }^{434}$ Tal decreto já estabelecia a unicidade sindical compulsória. Arnaldo Sussekind ${ }^{435}$ afirma não se poder dizer que a legislação trabalhista copiava a Carta del Lavoro italiana de 1927, para ele as mesmas ideias já haviam sido defendidas bastante antes por Lênin e Maxime Leroy.

No entanto, mesmo que muitos defensores da Consolidação das Leis do Trabalho se ofendam com a indicação de inspirações fascistas presentes no texto consolidado, é impossível negar tais influências. Tal fato é acentuado no que se refere à estrutura sindical. O texto da Carta del Lavoro ${ }^{436}$ (ITALIA, 1927) é, no ponto específico, o seguinte:

III. L'organizzazione sindacale o professionali è libera. Ma solo il sindacato legalmente riconosciuto e sottoposto al controllo dello stato, ha il diritto di rappresentare tutta la categoria di datori di lavoro o lavoratori, per cui è costituito; di tutelare di fronte allo stato e alle altri associazione professionali gli interessi; di stipulare contratti collettivi di lavoro obbligatori per tutti gli appartenenti alla categoria; di imporre loro contributi e de esercitare, rispetto a essi, funzioni delegati di interessi pubblico.

A semelhança com o sistema sindical brasileiro atual é total. Todos os institutos acima definidos continuam vigentes no Direito Coletivo do Trabalho brasileiro ainda hoje. O excerto acima, extraído da Carta del Lavoro, disciplina o regime de sindicato único, de representatividade estendida a toda a categoria de trabalhadores, a capacidade para negociação coletiva (paliada em pouquíssimas exceções no caso brasileiro) e, finalmente, a capacidade de substituir o Estado na função de exigir contribuições compulsórias dos integrantes da categoria profissional ou econômica.

A estrutura era perfeita para estabelecer o controle estatal sobre os sindicatos e sobre a grande massa de trabalhadores. Vale lembrar que a Carta del Lavoro, nos

434 BRITO PEREIRA, João Batista. O sindicalismo no Brasil. Uma proposta para o seu fortalecimento. in: VIDOTTI, T. J. E GIORDANI, F.A. (Coord.) Direito Coletivo do Trabalho em uma sociedade pós-industrial.

São Paulo: LTr, 2003.

435 SUSSEKIND, 2004.

436 ITALIA. Carta del Lavoro. 21 de abril de 1927. Disponível em:

$<$ http://www.historia.unimi.it/sezione/fonti/codificazione/cartalavoro.pdf $>$ Acesso em: 27 de novembro de 2015. 
mesmos moldes da CLT, alcança aos trabalhadores alguns direitos mínimos como repouso semanal, férias remuneradas etc.

Ao redigir a CLT, o trabalho de reforma da legislação sindical levado a efeito entre os anos de 1939 e 1942 por Oliveira Vianna e Luiz Augusto de Rego Monteiro, teve de forçosamente ser incluído no texto. Desta forma, os preceitos de intervenção e controle estatal na legislação sindical entraram no bojo da CLT e, desde então, nunca deixaram de viger. As seguintes constituições, de 1946 e 1967, não alteraram o panorama. Por fim, a Constituição de $1988^{437}$, na qual se esperava por fim a liberação do sistema sindical, regulou especificamente a matéria, com redação inclusive parecida à carta italiana de seis décadas antes. ${ }^{438}$

Como se pode ver, tanto a Carta del Lavoro quanto Consolidação das Leis do Trabalho $^{439}$ e a Constituição Federal de $1988^{440}$ começam o tópico da mesma maneira: é livre a associação sindical. Ambas, no entanto, adicionam condicionantes importantes à liberdade, de forma totalmente contraditória, ao melhor estilo de "dar com uma mão e retirar com a outra". A CLT regula a formação de entidades sindicais em diversos artigos (entre os artigos 511 e 521 fundamentalmente) os quais, se cotejados e comparados, traduzem as mesmas limitações expressas pela Carta de Mussolini.

No mesmo sentido é a afirmação de Buarque de Holanda ${ }^{441}$, para quem no "fascismo, a variedade brasileira ainda trouxe a agravante de poder passar por uma teoria meramente conservadora...". E com efeito, a manobra utilizada por Vargas, não só acalmava as classes trabalhadoras com a garantia de direitos mínimos, como também estabelecia as bases para o controle operário a partir do Estado via sindicatos e imposto sindical.

Embora no período anterior a Vargas se possa apontar o surgimento de coalisões obreiras e incipientes formações sindicais, todavia a classe obreira não parecia representar uma fração social importante na vida política do País. A partir da

437 BRASIL, 1988.

438 SUSSEKIND, 2004.

439 BRASIL, 1943.

440 BRASIL, 1988.

441 BUARQUE DE HOLANDA, 1995. p. 187 
legislação trabalhista, criou-se, primeiro de direito e depois de fato, uma classe obreira no Brasil.

\subsection{0 começo do Sindicalismo}

O termo sindicato, etimologicamente, deriva do latim sindicus que por sua vez deriva do grego syndikayos e pode ser traduzido como aquele que representa uma coletividade, a mesma acepção de síndico, popularmente conhecido nos condomínios residenciais e comerciais. Uma grande parte dos autores aponta as corporações de ofício da idade média como a origem do sindicalismo contemporâneo. No mesmo sentido são apontados os remotos tipos de associações das civilizações antigas como grega, romana, egípcia e chinesa.

Para outros autores como Arion Sayão Romita e José Marthins Catharino a origem do movimento sindical contemporâneo tem suas raízes na revolução industrial e nas alterações que esta provocou no seio social e nas relações de trabalho. Já Orlando Gomes e Elson Gottschalk assinalam que ainda que existam semelhanças estruturais e alguns interesses coincidentes entre as corporações de ofício e os sindicatos atuais, as entidades são fundamentalmente diferentes. Registre-se que as corporações de ofício defendiam os interesses coletivos da categoria dos mestres frente ao consumidor, regulando preços, oferta de produtos e modos de produção. O sindicato, atualmente, é um instrumento de oposição da classe de trabalhadores face ao patrão, ou daqueles em relação a estes, mesmo que os interesses patronais continuem a se opor aos interesses do consumidor de maneira genérica.

O sindicalismo pode ser definido como um corpo de ideias, elaborações teóricas, estratégias e ações de luta levadas a cabo por sindicatos e associações de resistência. É um dos eixos centrais daquilo que soe chamar-se movimento obreiro junto aos partidos políticos e outras entidades de classe. O sindicalismo, principalmente no âmbito europeu, passou claramente por três fases bastante definidas: uma primeira fase de proibição; uma segunda fase de tolerância; e, a 
terceira fase de reconhecimento jurídico, inclusive através das constituições dos Estados modernos ${ }^{442}$.

Contudo, na Grécia antiga, em Roma e mesmo no Egito é possível vislumbrar traços de um remoto tipo de associativismo. O próprio Aristóteles eternizou a expressão de que o homem é um "animal social" e, por isso, precisa sempre estar inserto em algum tipo de comunidade ou grupo. Em Roma, por sua vez temos o instituto dos "colégios" que reuniam os homens segundo suas artes e ofícios por determinação legal, o que, segundo alguns autores, teria surgido ainda na Grécia.

Segundo Segadas Vianna, em Roma vislumbramos verdadeiramente uma divisão da população segundo as artes e ofícios. No entanto, os colégios romanos eram criados por lei e se regiam por estatutos próprios livremente criados, desde que não contrariassem a ordem pública.

Após o advento do sistema greco-romano de associativismo, pode-se destacar o surgimento das guildas na Idade Média. As guildas surgiram fundamentalmente entre os povos germânicos e saxônicos e possuíam, de início, finalidades de reunião, companheirismo, lealdade e assistência mútua. Entretanto, a partir do século $X$, passaram a apresentar fins políticos dando margem ao aparecimento das guildas mercantis e guildas de ofícios. Essas corporações (guildas) obtiveram intenso poder político e econômico durante a Idade Média com vultosos pagamentos de impostos ao Estado e a obtenção do monopólio do mercado, em contrapartida, regulando os preços, a produção e a concorrência mediante autorização para que alguém pudesse exercer a profissão.

Esse sistema vigorou, de maneira mais ou menos intensa, até o advento da Revolução Francesa. O liberalismo exacerbado que insuflou a revolução não podia aceitar a subordinação do homem a nenhum organismo político que intermediasse a relação indivíduo/Estado. A associação, fosse ela qual fosse, não podia estar acima do homem como condição fundamental de liberdade. Nesse contexto, foram extintas as corporações medievais e, logo após, sedimentava-se a revolução industrial ${ }^{443}$. 
A revolução industrial, em período contíguo às revoluções francesa e americana trouxe profundas e diferentes mudanças na ordem social. O trabalho humano passa a ter importante valor e é necessário para a manutenção da ordem vigente.

A resistência obreira espontânea ou pré-consciente teve um dos primeiros movimentos, exatamente aquele conhecido como antimaquinismo ou ludismo (nome dado em referência ao trabalhador inglês Nelson Ludd que protagonizou por primeira vez a destruição de máquinas). Parece evidente o equívoco em reputar às máquinas a causa das péssimas condições de trabalho.

Assim, em oposição ao regime escravagista ou corporativo vigentes até então, as revoluções e declarações de direitos humanos que se seguiram pregavam uma total e incondicional liberdade do homem, inclusive no aspecto do trabalho. Destarte, patrão e empregado possuíam a liberdade de pactuar livremente as condições de trabalho, horários, salários, folgas e etc. Como se soube, a liberdade excessiva conduziu a abusos de toda ordem, mormente por aqueles que detinham o capital, sobre os trabalhadores e que eram obrigados a "vender" sua força de trabalho para sobreviver.

A intensa exploração do trabalho humano, sem nenhum limite palpável senão as próprias forças dos trabalhadores produz duas reações. A primeira é a necessidade, vislumbrada pelos trabalhadores de se unir em prol dos interesses comuns, mormente, reivindicar melhores condições de trabalho. E a segunda é a reação estatal, interferindo na autonomia privada no que tange à estipulação do contrato de trabalho.

Os Estados nacionais viram-se na contingência de interferir nas relações para garantir um mínimo de direitos aos trabalhadores, acobertando-os por um manto de proteção estatal, ainda que mínimo. Pelo mesmo motivo, os trabalhadores deram-se conta de que sua união e organização poderia colocá-los em condições de reivindicar em posição não tão desfavorável frente aos patrões e detentores do capital. Se por um lado os trabalhadores necessitavam do trabalho para a sobrevivência os empregadores também o tinham como imprescindível para o 
sucesso do empreendimento. Assim, inaugura-se um período de profunda confusão dos deveres estatais e sindicais e uma relativa promiscuidade entre uns e outros.

A situação culmina, no período pós Segunda Guerra Mundial com diversas e diferentes orientações dos organismos internacionais pregando a liberdade de associação e a liberdade sindical. Nesse sentido destacam-se a Convenção $n^{\circ} 87$ da Organização Internacional do Trabalho (OIT) e a Declaração Universal dos Direitos do Homem, ambas de 1948, e rezando pela plena liberdade sindical e de associação. A liberdade de associação, modernamente, é um dos pilares de qualquer democracia, sendo uma das primeiras medidas de qualquer estado de exceção a cassação dos direitos de associação da população.

Em resumo, a definição de Russomano sobre a origem do sindicalismo nos parece a mais apropriada:

Nesse sentido, podemos afirmar que o nascimento do sindicalismo é
a culminação de um longo processo histórico, cheio de antecedentes
numerosos e importantes, que tinha por desaguadouro o ideal
comum de valorização do homem como pessoa e de reconhecimento
dos direitos essenciais à defesa de seus interesses e à expansão de
sua personalidade.

Assim, resta óbvio que o nascimento de um fenômeno tão complexo e com tantas variáveis como o sindicalismo não poderia ter sua origem em um ou outro fato histórico isolado. A compreensão da conformação histórica das relações de trabalho e do sindicalismo é fundamental para nosso estudo.

\subsection{O Sistema Sindical Brasileiro}

O tema sindical é um tema complexo e que já esteve, inclusive, na pauta de assuntos mundiais em épocas de guerra fria. A participação dos trabalhadores em uma entidade associativa provoca diversas questões para o debate. Nacionalmente, o tema parece que foi relegado para um segundo plano e não se nota vontade em estabelecer novos rumos de atuação e participação sindical, seja na vida econômica, seja na vida política do país. Alguns autores, a exemplo do Professor Gilberto Sturmer ${ }^{444}$, veem na questão sindical um importante meio de efetivação de direitos fundamentais e também um mecanismo fundamental para aprimorar as 
relações de trabalho. Veremos algumas questões importantes, que traçam o rumo das discussões em torno da questão sindical, qual seja, por exemplo, a principal delas, a unicidade sindical.

O Brasil, contrariando todas as convenções da Organização Internacional do Trabalho $^{445}$, ainda não houve por bem adotar um regime de liberdade sindical plena. No País, a liberdade sindical é chamada de pseudo-liberdade ou semi-liberdade já que, em alguns aspectos, o Estado segue impondo restrições. Dada essa estrutura sindical especial, herança de inspiração fascista do primeiro governo $\operatorname{Vargas}^{446}$, o conceito de categoria profissional, referido na Consolidação das Leis do Trabalho (CLT), assume fundamental importância. As regras definidas na consolidação são contraditórias e conduzem ao que o doutrinador Homero Batista Mateus da Silva ${ }^{447}$ chama de "artifício da categoria".

Segundo a regra da unicidade sindical, prevista no artigo 516 celetista $^{448}$, e reforçada no artigo $8^{\circ}$, inciso ${ }^{449}$, da Constituição Federal, não pode existir mais de um sindicato representativo da mesma categoria profissional ou econômica em dada base territorial. Em suma, em cada município, somente poderá haver um sindicato de determinada categoria profissional ou econômica.

Necessário aclarar o que seriam as categorias profissionais e econômicas. A categoria econômica é sempre a categoria dos empregadores. Os empregadores que exploram atividades econômicas idênticas, similares ou conexas podem formar a mesma categoria econômica para fins sindicais. A categoria profissional, em regra, forma-se a partir da categoria econômica para a qual trabalham determinado grupo de obreiros. Assim, por exemplo, os trabalhadores de empresas do setor têxtil formarão uma categoria correspondente à categoria do empregador, independentemente da função que exerçam na empresa. A exceção a essa regra é a Categoria Profissional Diferenciada, contemplada pelo parágrafo $3^{\circ}$ do artigo 511

445 Principalmente a Convenção no 87 denominada "Liberdade Sindical e Proteção ao Direito de Sindicalização" de 1948 e ainda não ratificada pelo legislativo brasileiro, motivo pelo não qual não tem vigência formal no país.

446 Nesse sentido posicionam-se, por exemplo, GIGLIO, 2005. E SUSSEKIND, 2004.

447 SILVA, Homero Batista Mateus da. Curso de Direito do Trabalho Aplicado, vol. 7: Direito Coletivo do Trabalho. Rio de Janeiro: Elsevier, 2010.

448 BRASIL, 1943.

449 BRASIL, 1988. 
da $\mathrm{CLT}^{450}$. A Categoria Profissional Diferenciada, por sua vez, é aquela que possui vicissitudes tais que são capazes de diferenciar o trabalhador dos companheiros de trabalho na mesma empresa. Destarte, uma secretária que trabalhe em tal empresa têxtil compartilhará o associativismo com outras secretárias e secretários de outras empresas, tendo em vista a similitude de condições de vida, a formação comum e um estatuto profissional próprio.

Por tudo isso, a Categoria Profissional Diferenciada tem sido a solução encontrada pela sociedade face à regra da unicidade sindical. Como somente se permite um sindicato por categoria e por base territorial, cada vez mais são criadas novas categorias para que se possa ter um novo sindicato. Esse é o artifício da categoria a que se refere Homero Batista Mateus da Silva ${ }^{451}$.

Estas questões, parecem já ter sido percebidas pelo renomado jurista brasileiro Mozart Victor Russomano ${ }^{452}$ quando aponta:

Se a sindicalização, necessariamente, se processa em função dos laços de solidariedade ou semelhança que aproximam certos empregados de outros empregados e certos empregadores de outros empregadores - a prévia especificação de quais sejam esses vínculos, de quais entidades sindicais que podem surgir neles baseados, é vital ao exercício prático das doutrinas sindicalistas; embora contrário, teoricamente, à idéia de plena liberdade sindical.

$\mathrm{Na}$ mesma linha estão os autores como Oliveira Vianna ${ }^{453}$ para quem o sindicato de ofício ou categoria é aquele que mais convém à sociedade justamente porque a homogeneidade da composição da categoria profissional, oriunda da identidade, similitude e conexidade das atividades exercidas entre seus membros têm condições de criar, de forma mais rápida entre os trabalhadores, a consciência de unidade de grupo e fortalecer a militância pelos interesses coletivos. Também assim é a manifestação de Amauri Nascimento ${ }^{454}$ para quem a concepção de categoria é o prisma da organização sindical.

450 BRASIL. Presidência da República. Consolidação das Leis do Trabalho. Decreto-Lei 5.452 de $1^{\circ}$ de maio de 1943.

451 SILVA, 2010.

452 RUSSOMANO, Mozart Victor. Comentários à Consolidação das Leis do Trabalho. Rio de Janeiro:

Forense, 1997. p. 677/678

453 OLIVEIRA VIANNA, Francisco José de. Problemas de direito sindical. Rio de Janeiro: M. Limonad, 1943.

454 NASCIMENTO, 1991. 
Muitos autores, a exemplo de Santos $^{455}$, apontam como origens do sistema sindical os grêmios e corporações de ofício surgidos na Idade Média. Ainda que não concordemos de todo com tal afirmação é importante registrar que, já naquela época, trabalhadores de um mesmo ofício sentiram necessidade de unir-se e possuir uma pauta de assuntos comuns e assim enfrentar suas possibilidades dentro do restrito mercado da época.

Se a Europa tem uma longa tradição em reunião de trabalhadores e a Revolução Industrial, no Velho continente, deu-se de forma mais gradual e os trabalhadores tiveram que se adaptar, primeiro a um mercado totalmente liberal e depois ao Estado controlando as relações, até se darem conta da importância dos sindicatos como meio de resolução dos conflitos e canalização da vontade obreira.

Já na América Latina em geral, e, no Brasil, especialmente, não foi bem assim. A importância de questões culturais no tema é fundamental. O Brasil passou de um regime escravocrata a uma incipiente economia industrial em poucas décadas. Para exemplificar, a nossa legislação trabalhista ainda vigente foi promulgada apenas meio século depois da abolição da escravatura, sendo que várias das leis que a integram, já tinham vigência nas décadas anteriores.

Assim, a lógica cultural brasileira, até um passado muito recente, operava de maneira totalmente diferente. Freyre ${ }^{456}$, no seu clássico, Casa Grande \& Senzala, explica um pouco dos matizes da relação dono/escravos. O trabalho foi visto, por muito tempo, como reservado para uma classe secundária de pessoas, para gente menos importante. Ademais, o dono, o patrão além de responsável pelo trabalho do escravo, também era seu responsável moral. Ambos conviviam na mesma propriedade, mantinham, muitas vezes, relações bastante próximas. As relações pessoais interferiam na relação de trabalho e o trabalho nas relações interpessoais. Um pouco desta lógica persiste ainda hoje e dificulta a reinvindicação obreira e os embates patrão/empregado.

Reside em todos esses motivos, seja na defasagem do sistema sindical brasileiro, seja nas diferenças culturais, seja na necessidade de dar significado ao

455 SANTOS, Luiz Alberto Matos dos. A liberdade sindical como direito fundamental. São Paulo: LTr, 2009.

456 FREYRE, 2003. 
que a lei chama de laços de identidade, conexidade e similaridade, a proposição de novas pautas e espaços para a ação sindical. Sobre esse ponto trabalharemos na continuidade desta investigação.

No Brasil o movimento sindical, seu surgimento e evolução não foi muito diferente do resto do mundo, guardadas as devidas proporções. Há registros de que, no Brasil, também existiram corporações de ofício, ao menos semelhantes às medievais $^{457}$.

Contudo, seguindo a tendência liberal mundial, nossa primeira constituição, em 1824, proibia a reunião dos trabalhadores em corporações de ofício. No início do Século XX, a lgreja Católica, no Brasil, manifestou profundo interesse pela união dos trabalhadores, na esteira da Encíclica Rerum Novarum ${ }^{458}$ do Papa Leão XIII, que incentivava a mutualidade operária ${ }^{459}$. Também nessa época, começaram a surgir diferentes tipos de associações com fins também diversos e alguma semelhança com os sindicatos de hoje. É o caso da Liga de Resistência dos Trabalhadores em Madeira (1901), a Liga dos Operários em Couro (1901) e a Liga das Costureiras $(1906)^{460}$.

Em 1907, foi promulgado o Decreto $n^{\circ} 1637$, que possibilitou a formação de sindicatos por todos os trabalhadores. Os sindicatos que surgiram, no entanto, tinham pouco ou nenhum poder de pressão. Segundo consta, os primeiros líderes sindicais foram perseguidos pelo governo e pelos empregadores, tornando extremamente difícil a tarefa de defender os interesses dos trabalhadores. É desse período que surgiu a célebre frase: "No Brasil, a questão social é uma questão de polícia." A frase foi atribuída ao Presidente Washington Luiz e nunca foi dita por ele $^{461}$. Seguindo essa ideologia, a Aliança Liberal, vencedora da Revolução de 1930, criou o Ministério do Trabalho, Indústria e Comércio, nomeando para a pasta Lindolfo Collor. Destarte, em 1931, foi lançado o Decreto $n^{\circ} 19.770$, que efetivamente organizava o trabalho e as instituições sindicais brasileiras. No bojo da

457 NASCIMENTO, 1991.

458 PAPA LEÃO XIII. Encíclica Rerum Novarum: sobre a condição dos operários. Disponível em: < http://www.vatican.va/holy_father/leo_xiii/encyclicals/documents/hf_l-xiii_enc_15051891_rerumnovarum_po.html > Acesso em: 04/06/2014.

459 GOMES E GOTTSCHALK, 2002.

460 NASCIMENTO, Amauri Mascaro. Compêndio de Direito Sindical. São Paulo: LTr, 2008.

461 RUSSOMANO, 1998. 
legislação estavam insertas uma profunda dependência e controle dos sindicatos pelo Estado e a regra do sindicato único ${ }^{462}$.

A Carta Magna de 1934, concebida sob ideais liberais, anulou a unicidade sindical, estabelecendo marcos de autonomia e pluralidade. Contudo, a Carta de 1937, ditatorial, vinculou novamente os sindicatos ao governo. Tal situação, mesmo após diversas constituições e após o advento da Convenção 87 da OIT, permanece até hoje $\mathrm{H}^{463}$.

A atual Consolidação das Leis do Trabalho, que estabelece as bases da organização sindical até hoje, também pertence ao mesmo período. Foi promulgada em 1943, justamente durante a segunda guerra mundial e teve inspiração na Carta del Lavoro de Mussolini ${ }^{464}$, como já se disse.

\subsubsection{A organização sindical brasileira}

O presente tópico é de extrema importância para que se possa entender como são formados os sindicatos no Brasil e para que o leitor, principalmente aqueles não habituados às discussões do direito laboral, possa sedimentar as bases das discussões que serão propostas. A simbiose que se formou no Brasil entre a Consolidação das Leis do Trabalho, de 1943, e a Constituição Federal de 1988, que não recepcionou alguns dos dispositivos sobre a organização sindical presentes na Consolidação, criou uma formatação de direito sindical quase única e com muitas vicissitudes.

O sistema de organização sindical está previsto no art. 511 e seguintes (até o art. 577) da Consolidação das Leis do Trabalho e no art. $8^{\circ}$ da Constituição Federal. Ao invés de adotar a sistemática de comentar os artigos na sequência em que aparecem, tendo em vista a natureza deste trabalho, serão comentados somente os postulados estabelecidos em cada um deles, na ordem em que aparecem na legislação.

Por primeiro, fundamental referir que a Constituição consagrou o princípio da não intervenção estatal nos sindicatos. Assim, ao Estado é vedado impedir a 
fundação de um sindicato e, desde que cumpridos os requisitos legais, ao mesmo deve ser concedido o registro ${ }^{465}$. O postulado da não intervenção estatal acabou por revogar, de maneira tácita, os artigos 512 e 515 da Consolidação, principalmente, que tratavam de condições para o reconhecimento e investidura sindical. Da mesma maneira, qualquer diploma legal que estabeleça exigências para o registro sindical ou qualquer modo de intervenção é de ser considerado revogado tacitamente pela Constituição Federal de $1988^{466}$.

Seguindo, temos a polêmica regra da unicidade sindical. Segundo essa regra, só pode haver uma entidade sindical por categoria e por base territorial. Assim, a liberdade de sindicalização encontra limite na regra da unicidade que impede que existam duas entidades representativas da mesma categoria em determinada base territorial $^{467}$. A discussão acerca da unicidade será retomada, sendo satisfativo esse conceito para o momento.

A propósito, já que feita a referência, o Brasil adota o sistema confederativo. Nesse sentido possuímos uma estrutura sindical vertical e piramidal onde, na base da pirâmide, temos os sindicatos com bases territoriais municipais, intermunicipais ou estaduais. No meio da pirâmide temos as Federações com bases territoriais que podem ser estaduais ou regionais. Por fim, no topo da pirâmide temos as Confederações que são as entidades representativas da categoria em nível nacional $^{468}$. Destaque-se que são necessários ao menos 05 (cinco) sindicatos para a criação de uma Federação e ao menos 03 (três) Federações para a criação de uma Confederação. Assim, pelo gênero "entidade sindical" entendam-se compreendidas as diversas espécies de entidade, nos diferentes níveis hierárquicos: sindicatos, federações e confederações ${ }^{469}$.

Outro importante fator presente na organização sindical brasileira é que, como regra, os sindicatos são formados de acordo com a categoria econômica do 
empregador, de modo que haja uma paridade entre o sindicato patronal e o sindicato dos empregados. Nesse sentido destaca Homero da Silva ${ }^{470}$ :

Assim, por exemplo, integram o sindicato dos metalúrgicos quase todos os trabalhadores da indústria metalúrgica, ainda que ali não exerçam atividade de metalurgia, mas de compras, vendas, divulgação de produtos, limpeza, assessoria e assim por diante, ressalvadas as categorias ditas diferenciadas (...).

$\mathrm{O}$ art. $511^{471}$ da Consolidação, em seu parágrafo segundo, traz duas grandes hipóteses de reunião de trabalhadores para a formação de uma entidade sindical. A primeira delas diz com trabalhadores que apresentam similitude de condições de vida oriundas da profissão ou trabalho em comum. Já a segunda refere-se a trabalhadores com condições de emprego na mesma atividade econômica ou em atividades econômicas similares ou conexas. No Brasil parece sempre ter prevalecido a segunda hipótese ${ }^{472}$.

Contudo, a questão da categoria é justamente um dos cernes do presente estudo e será analisada de maneira pormenorizada adiante, de modo que, neste momento, os conceitos até aqui apresentados são suficientes para a compreensão inicial do tema. Persistem muitas e muitas questões interessantes no âmbito sindical.

O tema da organização sindical, por si só, também poderia render diversas laudas. Parece-nos importante esclarecer as funções e prerrogativas das entidades sindicais que representam um verdadeiro binômio direito/dever de todas essas entidades.

A primeira função reconhecida dos sindicatos diz respeito à representatividade. Essa função consubstancia-se em falar e agir em nome da categoria, seja junto aos empregadores, ao Poder Judiciário, a órgãos governamentais ou mesmo junto à sociedade, propondo debates de interesse da categoria e da comunidade em geral $^{473}$. 
Em segundo lugar, tem-se a função negocial que se caracteriza na busca do diálogo com empregadores ou sindicatos de empregadores para a celebração de instrumentos coletivos. A função negocial é prerrogativa exclusiva dos sindicatos, no Brasil, no que tange aos trabalhadores. Assim, só haverá possibilidade de celebração de acordos ou convenções coletivas quando os trabalhadores estiverem representados por um sindicato ${ }^{474}$.

A derradeira e terceira função sindical reconhecida em nossa ordem jurídica e modo de organização sindical é a função assistencial. À entidade sindical cabe a adoção de medidas para melhorar e facilitar a vida de seus associados ou até, de toda a categoria. É o caso de convênios médicos, educacionais, cooperativas de crédito entre muitos outros ${ }^{475}$.

Ainda, uma distinção é necessária. Essa diferenciação trata do caráter público ou privado dos sindicatos no Brasil. Em que pese as diversas críticas que sofre a divisão entre o direito público e privado, a bem da verdade, não se trata aqui dessa distinção pura em simples. O caráter de órgão estatal ou privado das entidades sindicais sempre esteve fortemente ligado ao modelo político do Estado. Nos regimes autoritários e ditatoriais é comum que o os sindicatos sejam subordinados ao governo e insertos no rol de entes públicos, atuando, de fato, como longa manus do regime vigente. Por outro lado, é postulado de Estados Democráticos que as associações e sindicatos possam funcionar sem a intervenção estatal e segundo o que determinarem seus membros. Ainda importante destacar que as entidades sindicais no Brasil são de caráter privado ${ }^{476}$. Importante não confundir a expressão "privado" com "individual", pois as entidades sindicais podem representar individualmente seus membros, mas o mais comum é que o façam no interesse coletivo daquela categoria. Em suma, os sindicatos são pessoas jurídicas de direito privado que representam interesses coletivos e são de interesse público devido ao relevante papel social que desempenham ${ }^{477}$. 
Outros muitos aspectos da organização sindical brasileira poderiam ser debatidos a exemplo da contribuição sindical, o caso das centrais sindicais, garantias de emprego dos dirigentes sindicais, enfim, vários temas interessantes. Ademais, não há tempo nem espaço para tantas discussões, sob pena de dispersão do ponto nodal da investigação, devemos nos ater aos conceitos necessários em nosso objeto de pesquisa.

\subsubsection{Questões sobre liberdade e unicidade}

A liberdade sindical e a unicidade imposta no regime brasileiro também são assuntos interessantíssimos que não poderiam deixar de ser abordados. A ordem também é proposital. Primeiro comentaremos os aspectos da liberdade para depois situarmos a unicidade dentro do mesmo plano, já que, para a maioria dos autores a pluralidade sindical é um dos aspectos da liberdade.

A liberdade, na maior parte da doutrina nacional, é elevada à condição de princípio ${ }^{478}$. Efetivamente, tal postulado parece o mais correto, na medida em que as condições de liberdade deveriam informar todas as demais normas que regulamentam o sistema sindical. Também parecem corretos aqueles que enumeram a liberdade sindical como direito fundamental do qual são titulares trabalhadores e empregadores, discutindo-se apenas o grau de intensidade e proteção necessário a cada um deles ${ }^{479}$.

Nascimento ${ }^{480}$ traz o enfoque da liberdade sob os prismas metodológico e conceitual. No plano metodológico a liberdade serve inclusive como um filtro epistemológico de interpretação e leitura de todas as normas jurídicas de um sistema de organização sindical. $O$ plano conceitual seriam as diversas manifestações da liberdade e suas dimensões, justamente como destaca Russomano acima.

A liberdade sindical é tratada como uma liberdade complexa envolvendo três institutos distintos que se interpenetram, dando a idéia de um triângulo equilátero.

478 Nesse sentido DELGADO, CASSAR, RUSSOMANO, SÜSSEKIND e NASCIMENTO. 
Destarte, a liberdade sindical passa pela efetivação dos direitos à sindicalização livre; à autonomia sindical; e, à pluralidade sindical ${ }^{481}$.

A liberdade de associação, uma das pontas do triângulo, não pode ser vista simplesmente como a permissão para que existam sindicatos ou associações. A liberdade de associação plena engloba o direito à livre criação e extinção de sindicatos bem como o direito de os indivíduos filiarem-se ou desligarem-se das entidades sindicais a qualquer momento ${ }^{482}$.

A autonomia sindical, outra das pontas do triângulo tem a ver com a liberdade de autorregulação das entidades sindicais. Nesta ótica, trata-se da plena e "livre estruturação interna do sindicato, sua livre atuação externa, sua sustentação econômico-financeira e sua desvinculação de controles administrativos estatais ou em face do empregador" ${ }^{\prime 43}$.

Completando o triângulo das liberdades sindicais temos justamente o tema, de longe, mais polêmico na questão da liberdade sindical: a pluralidade. Em oposição ao sistema da unicidade que vige no Brasil, a liberdade efetiva passaria pela permissão da pluralidade de sindicatos. No regime da unicidade, em vigor no Brasil, a liberdade do trabalhador ou mesmo do empregador limita-se à singela opção, ingressar ou não no sindicato de sua categoria. Isso porque, como já vimos, é permitido somente um sindicato por categoria e por base territorial. Assim, não há a possibilidade de escolha por parte do trabalhador do sindicato que mais lhe convém ou aquele que julga mais representativo ou combativo. $E$ isto porque existe somente um sindicato representativo da categoria em determinada base territorial e não podem ser criados outros ${ }^{484}$.

Alguns autores como Nascimento ${ }^{485}$ referem a liberdade sindical brasileira. Mas a liberdade deveria ser igual em todo o mundo, ou não? O próprio autor reconhece o paradoxo da expressão, justificando-a no sentido de que o sistema brasileiro não pode ser enquadrado como de liberdade plena, pois apresenta a regra do sindicato único. 
Outro paradoxo causado pela legislação brasileira em termos sindicais tratase do caso da Organização Internacional do Trabalho - OIT. O Brasil é membro fundador e signatário da Organização Internacional do Trabalho. Em 1948, houve a aprovação pela Assembléia da Organização da já aludida Convenção 87 . 0 art. $2^{\circ}$ da convenção ${ }^{486}$ dispõe que trabalhadores e empregadores têm direito a fundar organizações de sua escolha bem como de se filiar àquelas que bem entenderem, sem qualquer restrição ${ }^{487}$. Desde então, o Brasil vive um "processo de transição" (65 anos!) para implantação da pluralidade sindical. Até 1998, contudo, havia uma justificativa, o argumento de que a Convenção 87 era um tratado internacional como qualquer outro e que, enquanto não ratificado na forma da lei brasileira, não poderia vigorar em território nacional. Entretanto, em 1998, a Organização Internacional do Trabalho aprovou uma Declaração sobre Princípios e Direitos Fundamentais no Trabalho. Tal declaração estabelece o compromisso a todos os países membros, que ainda não tenham ratificado as convenções, para que o façam, como obrigação por integrarem a organização. A liberdade sindical foi elevada, assim, de maneira oficial, à condição de direito fundamental na seara trabalhista. Então, desde 1998, o Brasil descumpre as determinações da Organização Internacional do Trabalho, entidade com a qual se comprometeu a colaborar e difundir, através da filiação. Não se pode imaginar que o Brasil abandone os quadros da Organização Internacional do Trabalho nesta altura dos tempos e da globalização. Por isso, medidas são necessárias no sentido da implantação de condições efetivamente garantidoras da liberdade plena ${ }^{488}$.

É claro que a implementação de uma pluralidade plena também encontra óbices de ordem prática e alguns de ordem dogmática. Na Espanha, por exemplo, existe a pluralidade sindical com a proibição, de outro lado, da filiação do trabalhador ou empregador a mais de uma entidade. Tal limitação deixa de estar no campo da unicidade para cercear a liberdade no campo do direito de associação ${ }^{489}$.

As questões sobre a liberdade sindical e a unicidade terão reflexos em quase todos os demais pontos da organização sindical nacional. As influências vão desde o

486 ORGANIZAÇÃO INTERNACIONAL DO TRABALHO. Convenção n⿳0 87 de 1948: Liberdade Sindical e Proteção ao Direito de Sindicalização. San Francisco: 1948.

487 SÜSSEKIND et al, 2005.

488 SILVA, 2010.

489 RUSSOMANO, 1998. 
próprio reconhecimento sindical ao sistema de custeio sindical através de contribuições compulsórias refletindo na capacidade para a celebração de normas coletivas.

\subsubsection{Negociação Coletiva}

Importante também, esclarecermos alguns pontos sobre uma das principais funções sindicais: a negociação coletiva. Para alguns a negociação coletiva é a essência do direito do trabalho ${ }^{490}$, para outros, uma saliente atuação das partes na negociação coletiva favorece uma estruturação mais democrática do contexto social $^{491}$. Incontestavelmente, a negociação coletiva é importantíssima quando se fala em direito coletivo do trabalho e sindicatos.

A origem da negociação coletiva remonta a período anterior ao sindicalismo tal qual conhecemos hoje. Alguns situam sua origem nos antigos estatutos das corporações de ofício medievais já que os mesmos estabeleciam condições e normas de trabalho. Outros fazem um paralelo situando a origem das negociações coletivas com os primeiros movimentos grevistas onde a negociação teria sido a solução encontrada para pôr um fim ao movimento paredista ${ }^{492}$. É digno de nota que a negociação coletiva e seus instrumentos principalmente utilizados no Brasil como a convenção e o acordo coletivo têm sido objeto de muitas e muitas pesquisas de diferentes áreas que encontram nesse objeto um ponto de convergência para filósofos, sociólogos, economistas, estudiosos de direito civil, direito do trabalho, direito administrativo e direito constitucional ${ }^{493}$.

A negociação é efetivamente um fato social complexo que caminha, também, lado a lado com o grau de industrialização e democratização de uma sociedade. $O$ contrato individual de trabalho antecede as convenções coletivas e estas últimas são uma evolução natural dos primeiros no sentido de suprir as lacunas existentes naquele ${ }^{494}$. 
Convenção coletiva e acordo coletivo diferenciam-se em razão da parte que ocupa o lugar destinado aos empregadores. Sempre que dois ou mais sindicatos representativos de categorias econômicas e profissionais (empregadores e trabalhadores) celebrarem um acordo de caráter normativo, tratar-se-á de uma convenção coletiva. Quando, os sindicatos de categorias profissionais celebram acordos de caráter normativo com uma ou mais empresas da correspondente categoria econômica, estaremos falando de acordo coletivo de trabalho ${ }^{495}$. A diferenciação está tipificada no art. 611 da Consolidação das Leis do Trabalho ${ }^{496}$.

Apesar da interminável discussão que se estabeleceu sobre a natureza jurídica dos instrumentos coletivos. Essa definição motiva diversas teorias como a civilista, a normativa e as teorias mistas. No intuito de simplificar, é válida a "célebre frase de Carnelluti que define o acordo coletivo como híbrido, com corpo de contrato e alma de lei" ${ }^{497}$. Com efeito, a teoria que mais tem encontrado adeptos é a teoria mista, que estabelece ser o instrumento coletivo um "contrato" em sua elaboração, por se traduzir na expressão da vontade das partes que o celebram e uma "lei" quanto aos seus efeitos, já que determina verdadeiras normas que extrapolam os limites das partes que o celebraram, estendendo-se a toda a categoria representada ${ }^{498}$.

Novamente, a situação brasileira é paradoxal no tocante à negociação coletiva no âmbito internacional. A Organização Internacional do Trabalho, que possui uma convenção (Convenção $n^{\circ}$ 98), a qual versa sobre a negociação coletiva, entende como indissociáveis a liberdade sindical e a efetiva evolução e desenvolvimento da negociação coletiva. É notável o exemplo dos servidores públicos no Brasil, permitiu-se-Ihes a sindicalização, mas Ihes foi vedada a negociação coletiva. Nesse aspecto, a sindicalização dos servidores públicos é "sofrível", já que tem tolhido um dos seus principais modos de solução dos conflitos $^{499}$. Resta, nesse caso, aos servidores públicos brasileiros, um único instrumento de mobilização, talvez um dos primeiros e mais controvertidos: a greve. 


\subsubsection{Notas sobre greve}

Os historiadores situam a origem da greve com o nascimento da grande indústria e após a Revolução Francesa, onde se estabeleceu definitivamente condições de trabalho livre ${ }^{500}$. Lado outro, inicialmente, a greve foi vista como um instrumento de desordem e foi proibida, inclusive através de normas penais, por diversos regimes autoritários desde a Revolução Francesa. Nos países democráticos e desenvolvidos, entretanto, a greve se afirmou como um direito dos trabalhadores ${ }^{501}$.

No Brasil, a greve é um direito constitucionalmente assegurado desde $1946^{502}$. A greve desempenhou, inclusive, um papel fundamental para que se firmasse a autonomia do direito do trabalho em oposição a outros ramos do direito. A greve é uma manifestação dos trabalhadores destinada única e exclusivamente a causar prejuízos ao empregador, com o amparo da lei e da constituição, no caso do Brasil. Não é por menos que a greve se presta a grandes polêmicas e muitos estudos $^{503}$.

A greve é um direito, como conceituada pela maior parte da doutrina ${ }^{504}$. Este direito é híbrido. É um direito individual de cada trabalhador (que pode escolher participar ou não do movimento), mas que só pode ser exercitado coletivamente (através do sindicato da categoria) e com o cumprimento de alguns requisitos ${ }^{505}$.

O conceito de greve, ainda que controvertido, pode ser definido como "a cessação coletiva e voluntária do trabalho, decidida por sindicatos de trabalhadores assalariados de modo a obter ou manter benefícios ou para protestar contra algo. ${ }^{506 ", ~}$ Conceito parecido está transcrito no art. $2^{\circ}$ da Lei $n^{\circ} 7.783$ de $1989^{507}$ que regula o exercício do direito de greve.

Muitas teorias gravitam em torno da greve, sua natureza jurídica, o momento em que deixa de ser legal e passa a ser abusiva. Não há possibilidade de 
analisarmos amiúde tantas posições doutrinárias. É suficiente que se perceba a multiplicidade de institutos importantes derivados de um mesmo postulado: a sindicalização dos trabalhadores.

Pôde-se perceber que a sindicalização no Brasil é um fato social deveras complexo e que ainda não alcançou seu nível mais elevado de evolução. Lado outro, as proposições se imbricam de maneira que não podemos falar de liberdade sindical sem tratar do tema da unicidade. Para falar de unicidade devemos tocar no assunto das categorias. Da mesma maneira ocorre quando falamos em negociação coletiva e greve, onde não podemos fugir do tema da liberdade e das categorias que se aglutinam em sindicatos.

\subsection{Sistema sindical italiano}

Não é segredo que o regime sindical brasileiro é bastante semelhante (para não dizer uma cópia exata) do Sistema Sindical Italiano da era Mussolini. Na Itália, tal sistema é chamado comumente pelos doutrinadores de corporativo ou fascista, prevalecendo a primeira denominação. Tal sistema se caracteriza pelo regime de sindicatos oficiais e únicos no âmbito de cada categoria. Os sindicatos são utilizados assim, como longa manus do Estado para controlar a massa de trabalhadores.

É importante destacar, que a palavra evolução é utilizada aqui com o sentido que possui de mudança, transformação, nova fase. O evolucionismo, principalmente aquele do século XIX, representado por Morgan, Tylor, Spencer entre tantos outros, acabou por relegar à palavra um significado oculto, eurocêntrico e etnocêntrico já que os autores afirmavam ser sociedades superiores aquelas mais próximas à realidade europeia, principalmente inglesa, daquele tempo.

O Brasil vive um momento de especial tensão entre os atores sociais, muitos deles contra as políticas governamentais. No entanto, parece não haver consenso entre um dos grupos, justamente o dos trabalhadores, o mais frágil e necessitado de coesão. Os trabalhadores estão divididos entre o sindicalismo "oficial", na maior parte das vezes alinhado com o governo, e as próprias pautas dos trabalhadores não militantes ou participantes do sindicalismo oficial. 
A Itália, que na década de 40 tinha em comum com o Brasil uma legislação trabalhista e sindical de cunho fascista, hoje, passou por muitas transformações. Ainda que o sistema corporativo tenha durado aproximadamente duas décadas na Itália, o mesmo foi suprimido e deixou um legado de dúvidas e questões a resolver.

As discussões travadas ao redor das novas conformações do sistema sindical italiano têm muito a ensinar. Afinal, já são mais de 60 anos de experiência e evolução de um sistema que pode ser considerado hoje como um dos mais avançados dos países latinos.

\subsubsection{Início do Sindicalismo Italiano}

O direito sindical italiano só poderá, de fato, receber tal denominação no início do século XX. Nos anos 1800, havia uma grande lacuna legislativa sobre as questões das relações de trabalho. O código civil italiano de 1865 simplesmente ignorava a revolução industrial e todas as suas consequências sociais. As regulações existentes, buscando colmar a imensa lacuna legislativa, davam-se entre particulares e eram irrelevantes com relação ao direito formal estatal ${ }^{508}$.

É inegável que Direito Sindical nasce e se desenvolve a partir das condições sociais proporcionadas pela Revolução Industrial. Os trabalhadores que laboram ombro a ombro na fábrica de estilo fordista, exemplo maior do "progresso" industrial, não tardam em unir-se buscando melhores contraprestações pelo trabalho. 0 conflito industrial é aquele instaurado entre capital e trabalho, uma dicotomia própria do século XIX e que até hoje traz consequências ao mundo moderno.

Durante os anos 1800, os trabalhadores formavam uniões ocasionais buscando melhores condições de trabalho. Um dos resultados foi a celebração de alguns acordos de tarifa (concordati di tariffa) onde se estabelecia a remuneração mínima a ser alcançada a determinado grupo de trabalhadores. Tal remuneração, no prazo do acordo, não poderia ser reduzida.

A última década do século XIX, já começa a dar sinais das mudanças em relação ao sindicalismo italiano. No ano de 1891, é publicada a bula Rerum Novarum, do papa Leão XIII, a qual trata especificamente sobre a questão obreira, 
recomendando que o trabalho deve ser prestado em condições mínimas de dignidade e que a contraprestação alcançada deve ser suficiente para atender às necessidades básicas dos trabalhadores. Em 1892 nasce a primeira central sindical italiana a CGIL, de inspiração socialista. Ainda no mesmo ano é fundado o partido comunista italiano ${ }^{509}$.

No final do século XIX e início do século $X X$ as questões envolvendo negociações coletivas e associações obreiras eram inovadoras e vistas por muitos com reservas. Autores da época, a exemplo de Messina ${ }^{510}$, falam sobre a necessidade de regular os contratos coletivos, talvez maior e mais premente que a regulação das associações. O próprio Messina foi um dos primeiros a dar-se conta da disparidade de forças na relação contratual típica do direito do trabalho. Por isso, incentivava a contratação coletiva como forma de compensar o desequilíbrio de forças na estipulação das prestações e contraprestações devidas na relação de trabalho.

A verdade é que o período de mais de um século entre o início da revolução industrial, na Itália, e uma relativa aquisição de importância de parte dos sindicatos, transcorreu de forma mais gradual e sem tantos sobressaltos como no Brasil. Todo este período normalmente é tratado pelos autores em poucas páginas a exemplo do que faz Giugni ${ }^{511}$. Este período recebeu o nome de pré-corporativo, por anteceder ao período criado pelo regime fascista. Curiosamente, foi no regime sindical fascista que se encontraram os sistemas sindicais brasileiro e italiano. Tal encontro produz consequências na atualidade, onde muito do sistema fascista persiste no sistema brasileiro mesmo sob a égide de uma constituição apelidada de "cidadã". Conheçamos um pouco o regime corporativista italiano.

\subsubsection{As corporações}

É importante destacar, apesar de o nome corporação trazer à memória as corporações da idade média, não se tratam de instituições parecidas. Talvez a única similitude que se possa apontar é a delegação, aos coletivos reconhecidos pelo Estado, de algumas atribuições estatais como o recolhimento de impostos. Esta 
mescla de público e privado é uma das principais características do sistema corporativo.

Existem muitos autores que não aceitam a ideia de que nossa CLT, tão aclamada e saudada pelos trabalhadores, seja fascista. Alguns relutam em aceitar o óbvio. De fato, ao menos no que tange à organização sindical o sistema adotado pela Consolidação é quase exatamente igual ao do preconizado no item III da Carta del Lavoro. Por certo que não se trata de uma cópia literal já que nem o idioma permitiria, mas cotejando ambos os diplomas, a semelhança salta aos olhos.

O regime fascista italiano, ante as ameaças da revolução russa e o crescente interesse e apoio de intelectuais à causa comunista, necessitava controlar de maneira forte os movimentos obreiros. A solução é sufocar os conflitos e controlar com mão de ferro os sindicatos sem os proibir, já que esta última opção provavelmente acabaria por incitar os revolucionários.

Em 1925, no chamado acordo do Palacio Vidoni, a Confindustria, central sindical que agregava os industriais, reconhece como única representante dos trabalhadores a Confederação representante dos sindicatos fascistas. No mesmo acordo, ficou estabelecida a eliminação das comissões internas de representação dos trabalhadores nas indústrias ${ }^{512}$.

A lei número 563, de abril de 1926, assim como a Carta del Lavoro de 1927, passou a admitir como legítimos somente os sindicatos reconhecidos pelo Estado. Tais sindicatos recebiam o direito de celebrar contratos coletivos, de cobrar contribuições e de representar a categoria profissional como um todo, representando mesmo aqueles não filiados. Os demais sindicatos, ainda que não proibidos ou dissolvidos, passaram a uma existência formal e sem nenhuma função ou relevância prática $^{513}$.

Outra das características do regime corporativo foi a criação de uma representação artificial dos trabalhadores através do sindicato único. Por isso, os contratos coletivos celebrados pelo sindicato único, adquiriam eficácia erga omnes, 
isto é, todos os representados pelas categorias dos sindicatos convenentes estavam obrigados ao cumprimento das cláusulas do contrato coletivo.

O contrato coletivo deveria perseguir interesses públicos e estava sob a tutela do Estado de diversas formas. O Estado poderia destituir os diretivos dos sindicatos bem como exercer vigilância e tutela sobre as atividades sindicais. Além disso, os conflitos coletivos estavam sujeitos à tutela jurisdicional que podiam inclusive sancionar penalmente as partes. A deflagração de greve ou de lock-out poderiam ser consideradas atentatórias ao interesse público e à ordem econômica e seus promotores sancionados penalmente ${ }^{514}$.

Como se vê, as semelhanças com o sistema brasileiro são muitas. Para ajudar na comparação, colacionamos uma tabela onde se podem cotejar os artigos da Consolidação das Leis do Trabalho ${ }^{515}$ e aqueles correspondentes do regime corporativo italiano:

\begin{tabular}{|c|c|}
\hline CLT Brasil (1943) & Carta del Lavoro Itália (1927) \\
\hline $\begin{array}{l}\text { Art. } 512 \text { - Somente as associações } \\
\text { profissionais constituídas para os fins e na forma } \\
\text { do artigo anterior e registradas de acordo com o } \\
\text { art. } 558 \text { poderão ser reconhecidas como } \\
\text { Sindicatos e investidas nas prerrogativas } \\
\text { definidas nesta Lei. } \\
\text { Art. } 513 \text {. São prerrogativas dos } \\
\text { sindicatos: } \\
\text { a) representar, perante as autoridades } \\
\text { administrativas e judiciárias os interesses gerais } \\
\text { da respectiva categoria ou profissão liberal ou } \\
\text { interesses individuais dos associados relativos à } \\
\text { atividade ou profissão exercida; } \\
\text { b) celebrar contratos coletivos de } \\
\text { trabalho; } \\
\text { c) eleger ou designar os representantes } \\
\text { da respectiva categoria ou profissão liberal; } \\
\text { d) colaborar com o Estado, como orgãos } \\
\text { técnicos e consultivos, no estudo e solução dos } \\
\text { problemas que se relacionam com a respectiva }\end{array}$ & $\begin{array}{l}\text { III. L'organizzazione sindacale o } \\
\text { professionale è libera. Ma solo il sindacato } \\
\text { legalmente riconosciuto e sottoposto al controllo } \\
\text { dello Stato, ha il diritto di rappresentate } \\
\text { legalmente tutta la categoria di datori di lavoro o } \\
\text { di lavoratori, per cui è costituito: di tutelarne, di } \\
\text { fronte allo Stato e alle altre associazioni } \\
\text { professionali, gli interessi; di stipulare contratti } \\
\text { collettivi di lavoro obbligatori per tutti gli } \\
\text { appartenenti alla categoria, di imporre loro } \\
\text { contributi e di esercitare, rispetto ad essi, } \\
\text { funzioni delegate di interesse pubblico. }\end{array}$ \\
\hline
\end{tabular}

514 PERSIANI, Mattia. Diritto Sindacale. Padova: Cedam, 2012.

515 BRASIL, 1943. 
categoria ou profissão liberal;

e) impor contribuições a todos aqueles que participam das categorias econômicas ou profissionais ou das profissões liberais representadas.

Parágrafo Único. Os sindicatos de empregados terão, outrossim, a prerrogativa de fundar e manter agências de colocação.

Art. 578 - As contribuições devidas aos Sindicatos pelos que participem das categorias econômicas ou profissionais ou das profissões liberais representadas pelas referidas entidades serão, sob a denominação do "imposto sindical", pagas, recolhidas e aplicadas na forma estabelecida neste Capítulo.

Art. 516 - Não será reconhecido mais de um Sindicato representativo da mesma categoria econômica ou profissional, ou profissão liberal, em uma dada base territorial.

Art. 525 - É vedada a pessoas físicas ou jurídicas, estranhas ao Sindicato, qualquer interferência na sua administração ou nos seus serviços. proibição:

Parágrafo único - Estão excluídos dessa

a) os delegados do Ministério do Trabalho, Indústria e Comércio, especialmente designados pelo ministro ou por quem o represente;

b) os que, como empregados, exerçam cargos no Sindicato mediante autorização da Assembléia Geral.

Art. 611 - Convenção Coletiva de Trabalho é o acordo de caráter normativo, pelo qual dois ou mais Sindicatos representativos de categorias econômicas e profissionais estipulam condições de trabalho aplicáveis, no âmbito das respectivas representações, às relações
IV. (...) Le corporazioni costituiscono l'organizzazione unitaria delle forze della produzione e ne rappresentano integralmente gli interessi.

In virtù di questa integrale rappresentanza, essendo gli interessi della produzione interessi nazionali, le corporazioni sono riconosciute come organi di Stato.

Quali rappresentanti degli interessi unitari della produzione le corporazioni possono dettare norme obbligatorie sulla disciplina dei rapporti di lavoro e anche sul coordinamento della produzione tutte le volte che ne abbiano avuto i necessari poteri dalle associazioni collegate.

l'azione giudiziaria non può essere intentata se
l'organo corporativo non ha prima esperito il
tentativo di conciliazione.
Nelle controversie individuali
concernenti l'interpretazione e l'applicazione dei

l'organo corporativo non ha prima esperito corporativo non ha prima esperito it tentativo di conciliazione. concernenti l'interpretazione e l'applicazione dei 
individuais de trabalho.

Art. 616 - Os Sindicatos representativos de categorias econômicas ou profissionais e as empresas, inclusive as que não tenham representação sindical, quando provocados, não podem recusar-se à negociação coletiva. contratti collettivi di lavoro, le associazioni professionali hanno facoltà di interporre i loro uffici per la conciliazione. La competenza per tali controversie è devoluta alla magistratura ordinaria, con l'aggiunta di assessori designati dalle associazioni professionali interessate.

Como facilmente se nota nos exemplos colacionados acima, as semelhanças são muitas. Os sindicatos, em ambos os diplomas, são únicos, ou seja, jamais haverá uma categoria profissional ou econômica representada por dois sindicatos distintos. A representatividade do sindicato é extensiva a toda a categoria de trabalhadores, filiados e não filiados. O sindicato assume atribuições do Estado como a cobrança de impostos e há a nítida permissão para que o Estado possa intervir nos assuntos sindicais. Finalmente, as entidades são obrigadas a tentar a negociação coletiva como requisito de acesso ao poder judiciário.

No Brasil, as diversas vicissitudes do contexto nacional, fizeram que o Governo Getúlio Vargas adotasse o método italiano para o controle da massa trabalhadora no Brasil. A convergência da legislação trabalhista culminou com a promulgação da Consolidação das Leis do Trabalho, em 1943, e durou pouco, somente até o final da segunda guerra mundial. A partir de então, as legislações tomam caminhos muito distintos.

Ambos os modelos foram pensados como paliativos em razão das ameaças de convulsão nacional e a partir dos temores criados pela Revolução Russa. Os Estados brasileiro e italiano, ainda que em contextos distintos, resolveram tomar as rédeas da questão sindical como forma de dar estabilidade ao mercado e às relações sociais.

Carnellutti ${ }^{516}$ apontava que a legislação corporativa era nada mais que uma bengala estendida aos trabalhadores. Mesmo oferecendo esse apoio aos trabalhadores, o Estado deveria seguir buscando a cura do paciente, aqui entendida como a consciência da relevância e importância do movimento sindical e da 
negociação coletiva de modo que a bengala pudesse ser gradualmente retirada. De fato foi o que acabou por acontecer, mas não por vontade do Estado e sim pela queda do regime fascista.

\subsubsection{Caminhos opostos}

Uma circunstância foi fundamental para determinar a separação dos caminhos dos direitos sindicais brasileiro e italiano, o final da segunda guerra. Ao acabar o conflito, o Brasil havia lutado no lado vencedor, enquanto a Itália havia sido derrotada. É normal que quando um regime é derrotado, suas instituições e métodos sejam com ele também derrotados. Lado outro, com os vencedores, cresce a legitimidade e popularidade do líder bem como a impressão de que tudo vai bem.

A partir da queda do regime fascista começam a ser aprovadas leis que vão provocando a derrocada do regime de sindicalismo corporativista. Em 1943 há a publicação da Lei 721, de 23 de novembro, a qual acaba com os sindicatos corporativos, os quais são extintos ${ }^{517}$. Em 1944, outra lei aprova a existência e representatividade das comissões internas nas empresas, órgão não sindical de representação dos trabalhadores ${ }^{518}$.

Em 1948, é promulgada uma nova constituição italiana que rompe completamente com as tradições do liberalismo extremo e com o modelo fascista. Restaram consagrados os artigos 39 e 40 onde, respectivamente, o sindicato é libertado das amarras estatais e é reconhecido o direito de greve. Inaugura-se, então, uma fase que nada tem a ver com as anteriores, o modelo é de regulação estatal no plano individual e abstenção total no plano sindical. Neste período, a ausência normativa em questões sindicais deixou à doutrina e à jurisprudência a tarefa de sistematizar e racionalizar a questão sindical, influenciando as futuras produções legislativas ${ }^{519}$.

Pode-se acrescentar, além da nova constituição italiana de 1948, a qual disse pouco, mas com significado, como afirmam Ghezzi e Romagnoli ${ }^{520}$, houve a 
penetração de convenções e tratados internacionais no ordenamento jurídico italiano.

As décadas seguintes foram extremamente produtivas em termos doutrinários. Nos anos sessenta, um dos mais respeitáveis juristas italiano Gino Giugni, desenvolveu a teoria do ordenamento intersindical. Tal questão já havia sido anunciada pelo célebre jurista Carnelutti ${ }^{521}$ quando definiu o contrato coletivo como "híbrido, com corpo de contrato e alma de lei", tal como já referido.

A teoria do ordenamento intersindical buscava explicar tal natureza híbrida e a importância das fontes normativas oriundas da contratação coletiva. Tais normas, no plano do ordenamento jurídico estatal são tratadas como a manifestação de vontade das partes e que as vincula, tal qual um contrato. No entanto, no plano intersindical, a produção normativa encontra grande importância como fonte de obrigações e causa de sanções. A teoria não se opunha à definitiva caracterização das questões sindicais no âmbito do direito privado após cessar a influência do Estado fascista, buscava apenas deixar claro o caráter bivalente das normas coletivas em matéria de direto sindical.

No entanto, a separação definitiva entre sindicato e Estado demandava outros muitos desafios. Dois deles parecem ser mais importantes e difíceis. Aliás, a relutância do Brasil em adotar aplicar as convenções internacionais, tem a ver com a legitimidade da manifestação e da representação para a contratação coletiva. $O$ segundo, com a efetividade da ação sindical e de representações não sindicais.

\subsubsection{O novo modelo italiano}

Em algo podemos concordar, o sistema corporativo é de muito mais fácil entendimento e trato diário. Ao existir um sindicato único reconhecido pelo Estado e que representa toda a categoria profissional ou econômica (empresarial), cessa qualquer dúvida sobre a abrangência de um acordo coletivo ou sobre a extensão da representação do sindicato. Do mesmo modo, a manifestação de vontade, requisito básico da formação de contratos, é tida como suprida pela manifestação sindical, ainda que existam trabalhadores não filiados e que sequer sabem da existência do sindicato. 
De outra banda, a industrialização de finais do século XIX, início do século $\mathrm{XX}$, oferecia maior simplicidade quanto aos métodos de produção, organização do mercado e partes envolvidas. A estrutura fordista da fábrica favorecia a identificação exata dos trabalhadores, os contatos entre estes e a agrupação de obreiros e empresas em grandes grupos, por ofícios/ramos similares. Tal cenário foi se modificando radicalmente, durante o século $X X$, e, de fato, atualmente, é raro encontrar uma fábrica de estilo clássico.

Ao revogar o sistema sindical corporativo, permitir a existência de representações de trabalhadores de caráter não sindical e instaurar um regime de liberdade sindical, muitas soluções necessitaram ser encontradas. Acomodar sociedade e direito nunca é uma tarefa fácil e esta coube principalmente à doutrina e à jurisprudência, conforme foram se apresentando as circunstâncias.

\subsubsection{A liberdade sindical}

Concomitantemente à queda do sistema corporativo e ao advento da nova constituição Italiana, em 1948, surge no mundo, inspirado pela Organização Internacional do Trabalho (OIT), o conceito de Liberdade Sindical. De fato, houve a publicação da Convenção número 87, da Organização Internacional do Trabalho OIT, justamente em 1948, na trigésima primeira reunião da Convenção Internacional do Trabalho.

A Convenção número $87^{522}$ recebe o título: Sobre a Liberdade Sindical e a Proteção do Direito Sindical. O texto é bastante simples e, em linhas gerais, busca estabelecer que as organizações sindicais devem ter liberdade de criação e funcionamento e que os trabalhadores ou empregadores devem ter plena liberdade de se filiar ou não àquelas organizações que desejem. Existem várias recomendações no intuito de evitar que os Estados ou outras instituições públicas ou privadas intervenham na atividade sindical e na organização das entidades sindicais. Exemplo é o artigo $3^{523}$ da mencionada convenção, que assim dispõe:

1. As organizações de trabalhadores e de entidades patronais têm o direito de elaborar os seus estatutos e regulamentos administrativos, de eleger livremente os seus representantes, organizar a sua gestão e a sua atividade e formular o seu programa de ação. 
2. As autoridades públicas devem abster-se de qualquer intervenção suscetível de limitar esse direito ou de entravar o seu exercício legal.

A Constituição Italiana, gestada em resposta ao regime autoritário e corporativo do período anterior, no mesmo ano da Convenção número 87, só poderia consagrar, também ela, a liberdade sindical ampla, plena e sem restrições. À diferença do item 3 da Carta del Lavoro e das legislações brasileiras, a Constituição Italiana de 1948, no seu artigo $39^{524}$, diz "apenas":

Art. 39

L'organizzazione sindacale è libera. Ai sindacati non può essere imposto altro obbligo se non la loro registrazione presso uffici locali o centrali,secondo le norme stabilite dalla legge. É condizione per la registrazione che gli statuti dei sindacati sanciscano un ordinamento interno a base democratica. I sindacati registrati hanno personalità giuridica. Possono, rappresentati unitariamente in proporzione dei loro iscritti, stipulare contratti collettivi di lavoro con efficacia obbligatoria per tutti gli appartenenti alle categorie alle quali il contratto si riferisce.

O "apenas" entre aspas, se refere ao efeito que muitos autores atribuem às disposições da Constituição Italiana de 1948. Segundo muitos, a exemplo de Ghezzi \& Romagnoli ${ }^{525}$, a constituição disse pouco, mas com grande significado. O simples fato de existir a primeira frase (A organização sindical é livre.) seguida de ponto final, já acaba com as discussões sobre até onde chegaria esta liberdade. No ordenamento corporativo e inclusive na Constituição Brasileira de 1988, a mesma frase é seguida de condicionantes que limitam a abrangência da liberdade sindical plena.

A liberdade sindical encontra-se subdividida em outras liberdades menos abrangentes as quais, juntas, compõem o importantíssimo e geral conceito de liberdade sindical. Dell'Ollio e Branca ${ }^{526}$ apontam três subdivisões da liberdade sindical. Seriam elas a liberdade de constituição dos sindicatos, a liberdade de filiação e a liberdade de atuação. Pela liberdade de constituição deve entender-se a total ausência de entraves estatais para a constituição dos sindicatos além dos

524 ITALIA. Costituzione Italiana. Roma, 27 de dezembro de 1947.

525 GHEZZI e ROMAGNOLI, 1982

526 DELL'OLLIO, Matteo e BRANCA, Giorgio. L'organizzazione e l'azione sindale. Padova: CEDAM, 1980 . 
requisitos mínimos para a constituição de uma associação civil, leia-se, requisitos basicamente de forma dos estatutos e dos registros. A liberdade de filiação é a que deve possuir cada trabalhador ou empregador em filiar-se ou desfiliar-se de qualquer organização sem constrangimentos nem prejuízos. Por fim, a liberdade de atuação refere-se a que o sindicato possa livremente exercer sua função sem receber ingerências externas.

Alguns autores brasileiros subdividem a liberdade sindical em mais espécies a exemplo de José Augusto Rodrigues Pinto ${ }^{527}$. Para o citado autor a liberdade sindical subdivide-se em liberdade de trabalhar; liberdade de associar-se; liberdade de organização; liberdade de administração; liberdade de atuação; e, liberdade de filiação. As liberdades apontadas pelo autor são muito similares às apontadas pelo autor italiano já citado. As liberdades de associar-se, no sentido de que aos interessados deve ser permitido compor uma entidade para defesa de seus interesses e a de organização estão ambas englobadas pela liberdade de constituição referidas por Dell'ollio e Branca $^{528}$.

A questão importante é o fato de ter sido garantida a liberdade plena na esfera sindical a partir da Constituição Italiana de 1948. Garantir a liberdade plena é mais difícil do que parece já que torna o ambiente sindical mais difuso, mais plural e torna bastante mais complicada a negociação coletiva e a vigência dos acordos e convenções coletivas. No entanto, a Itália veio enfrentando tais problemas durante a segunda metade do século $X X$ em busca da acomodação da liberdade sindical ao sistema de relações de trabalho pós-industrial.

\subsubsection{Questões sobre a categoria}

A profissão sempre esteve intimamente ligada à formação da identidade, ao papel que cada um desempenha no seu grupo social. Ao extrapolar o grupo familiar, para a sociedade em geral, importa a função que cada um realiza nas relações de trabalho. Seguindo a linha de Durkheim ${ }^{529}$, o trabalho realizado por um aproveita aos demais e contribui para a sobrevivência geral. Por tal motivo, explica-se a constante preocupação em classificar o papel dos indivíduos na sociedade através do ofício 
exercido. Da mesma maneira, ao conhecer o ofício, surgem na imaginação retratos e impressões daquele indivíduo particular. A profissão é, de certa forma, o elo que liga 0 indivíduo à sociedade, onde ele pode contribuir e receber sua contribuição e tomar parte no grupo social que o circunda.

Conhecer as estatísticas com relação às profissões e classificá-las sempre foi uma preocupação dos Estados nacionais. A Itália realiza algum tipo de recenseamento com este objetivo desde 1871, ainda antes da unificação, onde os diversos dialetos são apontados como umas das várias dificuldades do estudo. Desde então foram realizados outros muitos, sendo o último em 2013 seguindo as determinações e classificações de âmbito internacional ${ }^{530}$. A própria OIT possui uma classificação das ocupações a qual é utilizada como ponto de partida para a criação das classificações próprias de cada país ${ }^{531}$.

Como se pode notar, a partir da análise das diversas classificações ao longo da história, mostra-se uma tendência de aumento do número de diferentes profissões com o passar do tempo. Está claro que existem profissões que desaparecem e outras novas que surgem, no entanto, o número de novas profissões parece superar iterativamente o de profissões que somem. Da mesma forma, os critérios de agrupamento das profissões também mudam, de maneira que é difícil encontrar um mesmo critério além do número total de profissões.

O sistema corporativo adotou um critério parecido ao das classificações, ao dividir as profissões e as atividades econômicas seguindo um critério próprio e fixando-as mediante legislação. As profissões e as categorias para associação sindical passaram a ser estabelecidos pelos critérios determinados na legislação corporativa a qual também determinava o sindicato autorizado a representar determinada categoria. Por exemplo, a lei dizia que seriam metalúrgicos todos aqueles trabalhadores empregados em determinadas empresas. Assim, estava criada uma categoria profissional e sua correspondente categoria econômica (formada pelas empresas já descritas).

530 ITÁLIA, Istituto Nazionale di Statistica. Le classificazzione delle professioni. Roma: Stealth, 2013. 531 ORGANIZAÇÃO INTERNACIONAL DO TRABALHO. International Standard Classification of Occupations. Genebra, 2008. 
Tal sistema, de maneira inegável, simplifica as relações sindicais, já que só existe um sindicato de cada categoria e um sindicato com o qual pode estabelecer negociações. Além disso, no início do século $X X$, as relações de trabalho davam-se principalmente no âmbito industrial e não ocorriam mudanças com a velocidade e intensidade da modernidade. Era mais fácil, portanto, estabelecer uma classificação de categorias profissionais. No entanto, o sistema corporativo limita a liberdade sindical.

A categoria, sempre foi uma espécie de fato social que deu fundamento à existência jurídica dos sindicatos. No período corporativo, presume-se a existência de uma categoria em razão de fatos "naturais" ou razoáveis. Ou seja, a partir da existência de um grupo de trabalhadores que executam tarefas similares em empresas similares, presume o Estado corporativo que tais trabalhadores possuem os mesmos interesses, as mesmas dificuldades e parecidas visões de mundo.

Com o advento do reconhecimento da liberdade sindical, já não é mais lícito ao Estado presumir nada. A categoria passa a ser um conceito, já não tão fundamental para a formação dos sindicatos. Em resumo, no sistema corporativo, a categoria é definida antes do sindicato pelo Estado; já em um ambiente de liberdade sindical a categoria não pode existir a priori com relação ao sindicato. Segundo Giugni $^{532}$, somente a partir da auto-organização de um grupo sob um conjunto de normas é que se pode identificar a categoria.

O tema causou inúmeras dúvidas e incertezas a partir do reconhecimento da liberdade sindical. Fundamentalmente, ao retirar-se o Estado como redator do conceito de categoria, cabe aos trabalhadores e empregadores defini-la. Felizmente, estes puderam contar também com a ajuda de doutrinadores, a exemplo de Danilo Guerrieri, quem escreveu uma obra inteira dedicada ao estudo da categoria. Já ao começar seu livro, o autor vaticina: "Esame della nozione di categoria che da antica data affatica la mente dei giuristi senza ancora aver trovato univoca soluzione ${ }^{533, .}$

A categoria, independente do regime a que nos referimos, é um componente importante na individualização do sindicato. Em um regime de liberdade sindical, poderia ser definida como a projeção no espaço e no tempo do sindicato. Além 
disso, é necessário desvincular o conceito de categoria da profissão ou da atividade econômica, a categoria deve passar a ser sindical, antes de econômica ou profissional. Para Guerrieri, a categoria pós-corporativa forma-se em torno a uma série de fatores que adquirem relevância como núcleo da ação do novo grupo. A discussão estabelece-se sobre se a categoria é uma entidade social de fato e existente independentemente do ordenamento jurídico ou se somente a partir da constituição do sindicato esta adquire existência formal e material. Para Guerrieri a categoria não existe como sujeito de interesses senão a partir da constituição de um sindicato. Portanto, a categoria seria uma entidade meramente jurídica, sem existência material, uma abstração, parecida com personalidade jurídica de entidades constituídas de acordo com as exigências legais ${ }^{534}$.

Face a tantas e novas questões, determinar o conceito de categoria no regime pós-corporativo é bastante mais complicado que no regime corporativo. Em teoria, podem ser formados sindicatos com os mais variados escopos de atuação, reunindo trabalhadores de diversas profissões, por isso, a categoria não necessariamente englobará membros possuidores de um mesmo status profissional. No entanto, a categoria é uma entidade jurídica e possui interesses próprios, distintos daqueles dos seus membros.

Muitas outras discussões sobre a questão da categoria seriam pertinentes. No entanto, é impossível abordar todos os matizes de um instituto complexo. A complexidade ocasionou também diversos problemas de adequação dos sindicatos e, principalmente, com relação à negociação coletiva. É postulado da teoria dos contratos a necessária manifestação de vontade para a conclusão do negócio jurídico. O sistema corporativo, a partir do simples pertencimento à determinada categoria, presumia a manifestação de vontade do trabalhador em favor da sua categoria. Em um ambiente de liberdade sindical a manifestação de vontade não pode ser presumida e cria problemas no momento da contratação coletiva. Vejamos como a Itália resolveu tais problemas.

\subsubsection{A abrangência dos contratos coletivos}

Condensar e garantir todos os postulados da liberdade sindical não é tarefa fácil e a legislação, doutrina e jurisprudência italianas vêm desde a metade do 
século $\mathrm{XX}$ tentando encontrar a melhor forma de que possam conviver os diversos postulados da liberdade sindical. Apenas a título de exemplo, imagine-se que determinado sindicato possui acordo coletivo com determinada empresa para o estabelecimento de certas condições aos trabalhadores. O contrato, segundo a doutrina tradicional, gera obrigações apenas entre as partes e seus efeitos não deveriam ser sentidos por terceiros. Neste contexto, a empresa poderia optar então por contratar trabalhadores não vinculados àquele sindicato e assim livrar-se de aplicar as condições mais favoráveis estabelecidas na negociação coletiva. $O$ sindicato de trabalhadores prontamente seria extinto por absoluta falta de trabalhadores.

O contrato coletivo é um tertium genus de contrato e serve como fonte de direitos e obrigações no mundo do trabalho ${ }^{535}$. Bom que se diga, a contratação coletiva é responsável por muito da complexidade e especificidade do direito trabalhista. Para cada relação há uma superposição de normas, lei, contrato coletivo e contrato individual a regular as bases da atividade ${ }^{536}$.

Nesse sentido, como já vimos anteriormente, no sistema corporativo, o Estado garante a correspondência entre categoria profissional/econômica, categoria sindical e categoria contratual entendida esta última como a categoria a quem atinge os efeitos da contratação coletiva. No sistema onde está garantida a liberdade sindical plena nem sempre as categorias se correspondem. Em um esquema simples poder-se-ia definir ambos os sistemas visualmente com o seguinte quadro ${ }^{537}$ : 

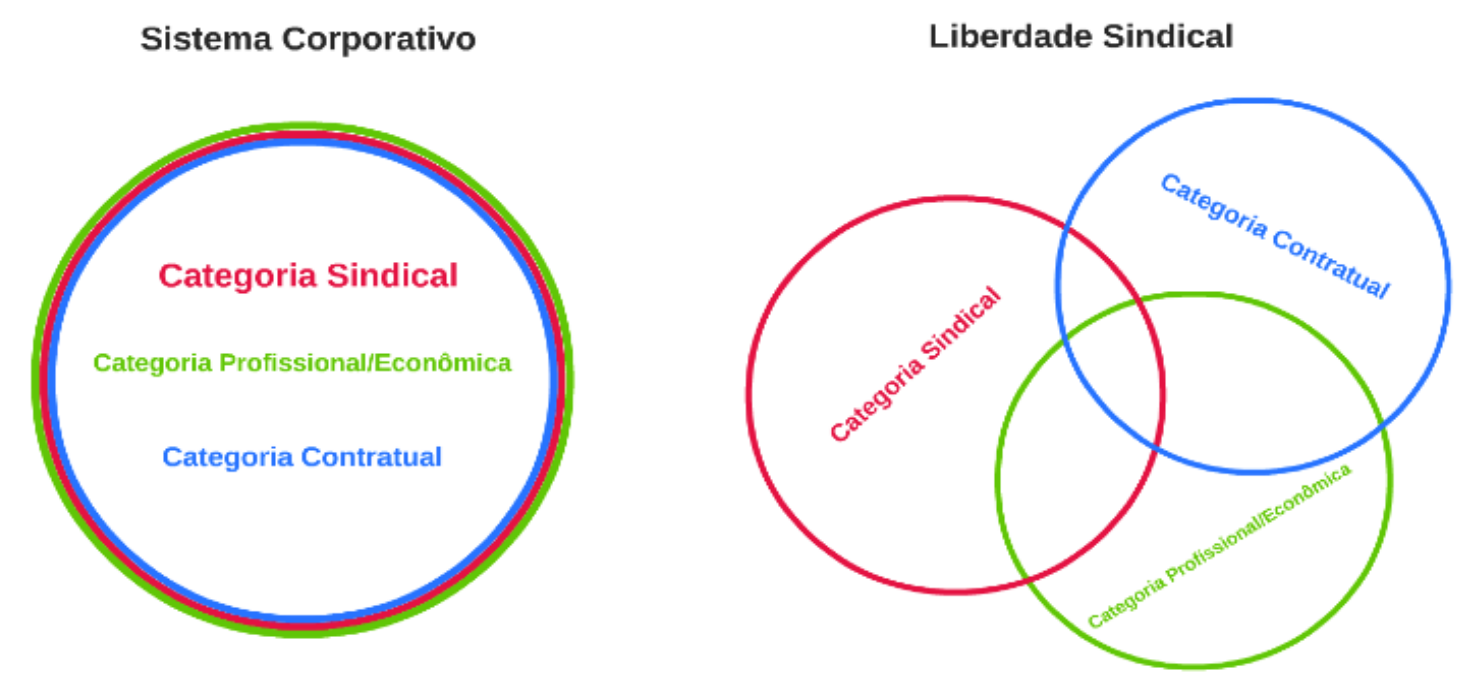

Como se vê acima, a liberdade sindical torna infinitamente mais complexa a contratação coletiva já que esta pode beneficiar/obrigar apenas uma parte da categoria sindical e da categoria profissional/econômica envolvidas. Tal situação poderia ocasionar, por exemplo, que as empresas relutassem em contratar trabalhadores pertencentes a determinada categoria sindical tendo em vista as condições da norma coletiva estabelecida para aquele sindicato.

A solução encontrada pelo sistema sindical italiano para o problema foi a de adotar o critério do sindicato mais representativo ${ }^{538}$. Isto é, quando diversos sindicatos representam a uma categoria profissional/econômica negociará somente o sindicato mais representativo e aquela negociação será válida para toda a categoria profissional/econômica. O sindicato mais representativo pode ser aferido segundo critérios históricos ou técnicos. Com relação a critérios históricos prevalecem as grandes confederações sindicais que negociam contratos coletivos de base regional ou mesmo nacional, os quais abrangem todas as entidades filiadas. 
Os critérios técnicos envolvem a consistência numérica dos membros, presença equilibrada em diversos setores e a participação em atividades públicas e privadas de relevo, audiências públicas, projetos de lei, ações sociais etc. ${ }^{539}$

Segundo muitos autores tal critério já está em decadência pois, além de não garantir a liberdade sindical plena não atende às mutações da base sindical advindas de questões como a terceirização, "pejotização", novas profissões, prevalência do trabalho intelectual sobre o manual e fragmentação social. A solidariedade de classe e os interesses contrapostos presentes no seio das diversas organizações sindicais reclamam uma ação sindical mais plural e complexa. ${ }^{540}$

A Itália entra agora em uma nova de garantia da liberdade sindical e da proibição das condutas antissindicais. No entanto, este novel e difícil estágio da evolução das relações não havia sido possível sem os enfrentamentos e produção doutrinaria e jurisprudencial de mais de 60 anos de liberdade sindical plena.

\subsubsection{Perspectivas}

Segundo o contexto exposto, nota-se que o sistema sindical estabelecido pela Consolidação das Leis do Trabalho, no Brasil, em 1943, tornou-se completamente obsoleto apenas 5 anos depois. Desde então, o Brasil enfrenta as convenções internacionais e não permite a adoção de um sistema de liberdade sindical plena.

As razões são muitas, algumas contextuais e outras apenas de interesse político-econômico. Certamente contribuiu o fato de o Brasil estar ao lado dos aliados ao final da segunda guerra mundial dando a impressão de regime vitorioso, como referido. A pouca coesão social advinda da recente industrialização e de uma massa de trabalhadores principalmente estrangeira também contribuíram para este fato.

Por outro lado, a conveniência do sistema corporativo, para os governantes, é total. Os sindicatos são uma fonte importante de arrecadação através da contribuição sindical e facilmente podem ser utilizados como massa de manobra devido à promíscua relação com o Estado brasileiro. A contribuição sindical compulsória é totalmente incompatível com um regime de liberdade sindical. 
Ademais, com os sindicatos quase como órgãos públicos, o Estado não precisa atuar como parte que é nas relações de trabalho, reservando-se apenas a condição de mediador e coibidor de abusos através do poder judiciário.

Todas estas circunstâncias conduziram o Brasil a um período de mais de 60 anos de atraso no plano sindical em relação à maioria dos países e organizações internacionais. Este fato obsta, inclusive, a participação em acordos internacionais de comércio, os quais exigem, em favor da livre concorrência e regime de preços, a existência de um sistema sindical livre.

É certo que adotar a liberdade sindical plena não será fácil, passará o País por muitas dificuldades, incertezas e um longo período de adaptação. Entretanto, quanto antes o Brasil iniciar sua caminhada, antes poderão a sociedade e as relações de trabalho entender o novo sistema e tomar consciência de suas árduas tarefas institucionais.

\subsection{Sistema sindical espanhol}

O sistema sindical espanhol guarda, por sua vez, semelhanças e diferenças diversas com os sistemas brasileiro e italiano. Cabe recordar que o sistema sindical espanhol passou por uma fase também alinhada com o nazi-fascismo europeu, no período que antecedeu a Segunda Guerra Mundial. A subida ao poder do Generalísimo Francisco Franco deu-se em 1935, época em que Hitler, Mussolini e Getúlio Vargas já se encontravam no poder. Outra circunstância decisiva foi a neutralidade espanhola na Segunda Guerra Mundial, ao final da guerra, não foram vencedores e nem vencidos. Por fim, cabe destacar que, na Espanha, nunca houve um sistema de sindicato único por categoria profissional e, consequentemente, a discussão sobre as categorias profissionais nunca ocupou um lugar central na doutrina e na jurisprudência espanholas.

Ojeda Avilés ${ }^{541}$ pontua o sindicalismo como uma das consequências do sistema de relações industriais em determinado local. Ao conjunto das organizações de trabalhadores o autor chama de movimento obreiro. Reconhece também, o citado 
autor, a centralidade do sindicato dentro do conjunto de manifestações de trabalhadores no sistema de relações industriais.

Por seu turno, Tomás Sala Franco aponta uma extensão dos direitos sindicais, pelo menos a partir do século XX e da Declaração Universal dos Direitos do Homem, de 1948, que proclama o direito de todos a criar sindicatos e a eles filiarse ou desfiliar-se. Desde então, para o mencionado autor, os direitos sindicais passam a ser aplicados não só ao obreiro típico (trabalhador da indústria que labora por conta alheia), mas também aos autônomos, aos funcionários públicos, aos profissionais liberais e outros em situação de passividade laboral, tais como desempregados, aposentados e pensionistas a qualquer título ${ }^{542}$.

O autor Ojeda Avilés explica três teorias que tentam detalhar o papel do sindicato nas relações de produção. A primeira diz que cabe ao sindicato estabelecer regras para regular a competição entre trabalhadores e criar, assim, uma espécie de costume entre trabalhadores. Paulatinamente os Estados, os empregadores e os trabalhadores começam a aceitar a coletivização das relações e a prevalência do papel dos sindicatos na negociação das condições de trabalho ${ }^{543}$.

A segunda teoria aponta o sindicato como gerente (síndico) do descontentamento obreiro. Isto é, o sindicato seria o canal para agregar e levar as pautas dos trabalhadores. A terceira teoria define o sindicato como um contrapoder. Este contrapoder adquire o mesmo sentido dos sistemas de contrapesos constitucional onde é necessário um poder para limitar outros. O sindicato, nesta acepção, exerceria a função de frear a queda dos salários em um contexto desfavorável, por exemplo. O elemento central das relações sindicais é o conflito coletivo e também o direito de greve como sanção ao empregador.

Ojeda Avilés também destaca a existência de diversos modelos de relação entre a lei e a negociação coletiva. A primeira delas é a relação de exclusão onde a negociação coletiva não tem vez e prevalece exclusivamente a lei. A segunda é uma relação de suplementaridade onde a lei normalmente estabelece condições mínimas e a negociação coletiva tende a melhorar tais condições. A terceira forma de relação é a complementaridade, ou seja, a lei marca aspectos fundamentais de determinado 
ponto e a negociação coletiva regula os detalhes. Por fim, a quarta forma é supletória, a lei é dispositiva e deixa o protagonismo à negociação coletiva ${ }^{544}$.

Em um aspecto mais geral, as relações do Estado com a negociação coletiva são definidas em três grandes linhas. A primeira delas é a do Estado Máximo, o qual realiza uma intensa atividade legislativa regulando quase todos os aspectos da vida laboral e assumindo uma postura paternalista com relação ao trabalhador individual. Tal situação é a da maioria dos Estados europeus ainda que em regressão. A lei não proporciona a necessária flexibilidade exigida pela pós-modernidade enquanto a negociação coletiva não oferece a mesma estabilização e segurança jurídica que a lei ${ }^{545}$.

A segunda postura estatal é a do Estado Mediador, aquele que promove a atuação coletiva e a regulação das relações entre as partes. A legislação é apenas adjetiva, propiciando a negociação das condições pelas partes envolvidas e privilegiando a matização das normas segundo as necessidades atuais e momentâneas.

Finalmente, a terceira posição que o Estado pode adotar é a de Estado Mínimo o qual promove a autonomia individual dos trabalhadores na regulação de cada contrato de trabalho. O Estado pode assumir, inclusive, posturas antissindicais no sentido de privilegiar o estabelecimento de condições através do contrato individual $^{546}$.

Ojeda Avilés pontua ser quase impossível dissociar os sindicatos da política. Ainda que não necessariamente vinculados a determinado partido e apoio a este ou àquele candidato os sindicatos detém um poder político enquanto coletividade organizada e capaz de influenciar as decisões políticas. Assim, mesmo que se pretenda um sindicato apartidário, este jamais será apolítico. Neste mesmo sentido, o autor pontua que os interesses econômicos e sociais próprios do sindicalismo também afetam ao Estado ${ }^{547}$. 
O conflito coletivo de trabalho, de certa forma o âmago e a gênese de muitas das questões abordadas pelo direito sindical é aquele conflito expresso e manifesto entre uma coletividade de trabalhadores e um ou mais empregadores. Destaque-se que a menção ao conflito expresso, busca diferenciar este conflito coletivo dos conflitos estruturais presentes na própria estrutura das relações industriais de trabalho $^{548}$.

O sistema constitucional concebe uma visão dialética das relações de trabalho ao reconhecer que trabalhadores e empregadores possuem interesses contrapostos ou impregnados pelo conflito institucional. O ordenamento jurídico laboral e todo o sistema de relações coletivas de trabalho pretende justamente estabelecer canais para resolução dos conflitos estruturais/gerais e expressos/pontuais ${ }^{549}$.

\subsubsection{A evolução do Sindicalismo}

Alguns autores resumem as etapas do sindicalismo associando-as à questão da liberdade sindical. Assim, três seriam as etapas do sindicalismo na Espanha (tendência que acompanha os demais países europeus). Na primeira etapa existiria o Estado liberal em sua mais pura acepção com a proibição do sindicalismo. A segunda etapa seria a de tolerância, onde a proibição seria deixada de lado, principalmente a partir da despenalização de condutas sindicais e os sindicatos tolerados ainda que não permitidos expressamente. Por fim, a terceira etapa é a de reconhecimento, onde começam a existir normativas nacionais e internacionais que reconhecem expressamente os direitos sindicais e a liberdade sindical. É claro que devido às circunstâncias de industrialização e sociais de cada país tais momentos não aconteceram de maneira simultânea. Pode-se apontar o reconhecimento da liberdade sindical na França, em 1884, e na Itália, em $1922^{550}$.

Também na Espanha, o declive do regime absolutista começa a produzir organizações de trabalhadores que começam a se organizar. O eixo mediterrâneo (Catalunha e Andaluzia) é mais radical e se soma ao eixo moderado (Madrid-País Vasco). Esta primeira fase é conhecida como abertura do Estado e florescimento do 
sindicalismo. Oficialmente, as proibições aos grêmios (proibição anteriormente existente por conta dos diversos preconceitos já mencionados) são levantadas pelas Cortes de Cádiz, em $1813^{551}$.

Por volta de 1870, chega a Madrid o genro de Marx, Lafargue, e fomenta tendência socialista. Esta pode ser considerada uma segunda fase do sindicalismo espanhol onde claramente o movimento começa a expandir-se. Em 1874, um decreto proíbe a atuação de entidades que, como a Internacional, atentam contra as bases sociais do Estado, como a família e a propriedade ${ }^{552}$.

A liberdade geral de associação na Espanha foi reconhecida pelo Decreto-Lei 20, de novembro de 1868, logo após a Revolução Setembrina. Tal decreto-lei foi mantido logo pelas constituições de 1869 e 1876 até a Lei de Associações, de 1887, que será o marco legal dentro do qual se organizarão algumas das principais organizações sindicais espanholas como a UGT e $\mathrm{CNT}^{553}$.

No último quartel do século XIX, o eixo radical do mediterrâneo começa a recrudescer e ganha em importância o eixo moderado. Lafargue propaga as teorias marxistas em Madrid criando uma unidade ideológica que culmina com a fundação da União Geral de Trabalhadores (UGT), a primeira central sindical de nível nacional na Espanha. Neste mesmo período, por ocasião da publicação da Encíclica Rerum Novarum, começam a formar-se os primeiros círculos de trabalhadores católicos ${ }^{554}$.

As primeiras décadas do século XX marca o início da configuração do sistema de relações industriais. A UGT anteriormente campeava a quase totalidade do sindicalismo de âmbito nacional e, em apenas doze anos (1888-1900), passou de 3.355 filiados para mais de 30.000. A partir de 1911, aponta-se o embrião de um sistema de relações industriais com regras próprias e, na medida do possível, separado da política.

A primeira guerra mundial supôs uma grande oportunidade para os empresários espanhóis que puderam se expandir e conquistar mercados internacionais. Por outro lado, a notícia da Revolução Russa, de outubro de 1917, 
aliada à falta de informação exata sobre as condições da revolução coloca os trabalhadores em frenesi. Como bem aponta Ojeda Avilés, somente havia chegado a notícia de que, em uma grande nação, o capitalismo havia sido derrotado e os trabalhadores haviam tomado o poder. Em 1918 a CNT (Confederación Nacional del Trabajo) celebra um congresso em Barcelona e pronuncia-se favorável à criação de um sindicato único por ramo de produção por entender que assim possuirá maior capacidade de impregnação e influência em cada setor ${ }^{555}$.

O período seguinte é marcado pela ditadura de Primo de Rivera, onde a CNT retira-se do cenário antes de ser forçosamente fechada e a UGT passa a integrar a estrutura sindical "oficial" da ditadura. Alguns autores apontam essa entrada da UGT no aparato ditatorial como um dos episódios mais obscuros da história do sindicalismo espanhol ${ }^{556}$. No entanto, nos limiares de 1930 , com os presságios da República, as centrais crescem vertiginosamente ${ }^{557}$.

É no período republicano, compreendido entre 1931-1939, onde os primeiros anos produzem uma polarização na ação sindical capitaneada pela UGT e pela CNT. Nesta época também ocorreu o biênio negro, nos anos de 1934 a 1936, no qual praticamente se anula a legislação obreira do período anterior. A crise econômica debilita as condições de trabalho e míngua a ação sindical ${ }^{558}$.

Em 1936, com o início da guerra civil, enfrentam-se uma extrema esquerda dedicada a tentar coletivizar as empresas e também fazendas agrícolas e uma extrema direita financiada pelo nazismo e pelo fascismo. O resultado é a ditadura franquista e o governo baseado no nacional-sindicalismo, período que mais se aproxima do Brasil de Getúlio Vargas.

A organização sindical passa então a ser considerada instrumento do Estado e a integrar a administração estatal. Os sindicatos de esquerda, bem como seus filiados são completamente marginalizados e inclusive perseguidos ${ }^{559}$. Ficam estabelecidos quatro postulados para a organização sindical franquista: a unicidade

555 OJEDA AVILÉS, 1995.

556 MONEREO PÉREZ, José Luis et al. Manual de Derecho Sindical. Granada: Comares, 2015.

557 OJEDA AVILÉS, 1995.

558 OJEDA AVILÉS, 1995.

559 LORENZO SANZ, Eufemio. Represión y Depuración de los Maestros de la província de Palencia en la

Guerra Civil: de los anhelos republicanos a la resignación en el franquismo. Valladolid: IIACyL, 2014. 
sindical, somente poderia existir um sindicato por ramo de atividade e este seria, por óbvio, o "oficial"; totalidade, isto é, todos os trabalhadores de determinado ramo da indústria ou ofício são integrantes do sindicato independentemente de sua vontade e necessariamente terão de recolher contribuição para o sindicato; estrita hierarquia, os cargos superiores são nomeados desde cima e são considerados superiores hierárquicos mais que representantes dos associados ou filiados; verticalidade, todos os integrantes de determinado tipo de atividade econômica, seja aprendiz ou empregador, integram o mesmo sindicato, há apenas a divisão entre as seções social ou econômica para diferenciar o lugar dos empregadores e dos trabalhadores ${ }^{560}$.

Neste tipo de sindicalismo, implantado por um sistema político autoritário, as organizações sindicais não desaparecem e não são tornadas ilegais. O que ocorre é uma absorção das entidades sindicais pelo Estado adquirindo uma dimensão eminentemente pública. A filiação aos sindicatos se dá em caráter automático (obrigatório) com a participação no mercado de trabalho como trabalhador, empregador ou profissional autônomo. Esta filiação e as ações sindicais respondem ao interesse público geral de progresso da economia nacional adotando ações não contratuais, mas predominantemente políticas. Vários países tiveram modelos deste tipo como Itália (talvez o exemplo clássico), Alemanha, França, Portugal, Argentina e Brasil $^{561}$.

Esta primeira fase da ditadura franquista soe ser apontada como os primeiros vinte anos, entre 1936-1956. A partir de então os direitos e liberdades começam a ser paulatinamente devolvidos aos cidadãos espanhóis. Por outro lado, a OIT jamais condenou diretamente o sindicalismo franquista, mesmo em claro desrespeito às convenções e recomendações da entidade.

A transição democrática tem um processo de desarticulação e liquidação do sindicato vertical. Além disso, neste período, o Estado Espanhol passou a ratificar e a integrar no ordenamento jurídico interno diversos pactos internacionais, aí incluídas as Convenções números 87 e 98, da Organização Internacional do 
Trabalho, sobre a liberdade sindical e sobre a negociação coletiva, respectivamente ${ }^{562}$.

A partir da nova constituição em 1978, são reconhecidos os direitos sindicais internacionalmente consagrados como a liberdade sindical, direito de greve, autonomia coletiva, proibição de condutas antissindicais. Contudo, mesmo em um meio livre, o contexto induz tendências de monopólio com o critério do sindicato mais representativo, ou seja, aquele considerado como mais impregnado e com maior atuação recebe o privilégio de negociar em nome da categoria, firmar acordos entre outras. Este critério acaba por prejudicar e retirar quase todo o protagonismo dos sindicatos menores.

A situação produz um crescente desinteresse pela atuação sindical a partir da década de 1980 e o número de afiliados não cessa seu decréscimo. O critério do sindicato mais representativo acaba por produzir diversas dificuldades identificáveis na ação sindical. A primeira dificuldade é organizativa já que há uma cúspide sindical nacional que carece de uma base capilarizada da ação sindical. Ademais, perde-se o viés ideológico e revolucionário e olvidam-se os sindicatos de sua memória histórica. Por fim, está a dificuldade financeira, ao inexistir o financiamento oficial e ao decaírem as taxas de filiação e aumentar as taxas de desemprego os sindicatos passam por dificuldades financeiras.

O Estado, no modelo constitucional posterior a 1978, deve paulatinamente passar a se retirar e procurar intervir cada vez menos na regulação das relações de trabalho. O Estado fica responsável pela definição do sistema geral de relações e pelo fomento dos direitos e liberdades constitucionalmente assegurados. O Estado deve assumir o papel de garantir a autonomia, liberdade e possibilidade para que os sujeitos protagonistas, sindicatos, federações, confederações, grandes centrais, comitês de empresa, possam exercer seu papel de acordo com os postulados constitucionais $^{563}$. 


\subsubsection{Os sujeitos coletivos}

A formação dos sujeitos coletivos obedece, em cada país, a algumas regras próprias. Já na nomenclatura, existe divergência de grande parte da doutrina justamente por este motivo, sobre a nomenclatura da disciplina. Ao existir outros sujeitos da ação coletiva como comitês de empresas ou como uma só empresa isolada. Por isso, muitos dizem que a nomenclatura direito sindical não seria adequada, pois nem todos os sujeitos coletivos são sindicatos.

O sindicato, de outro lado, é um instrumento que caracteriza as sociedades do capitalismo industrial. Os sindicatos não são entidades preocupadas apenas com o aspecto econômico (salários e recompensas pelo trabalho), pode-se dizer que os sindicatos são interlocutores entre poder público, empregadores e trabalhadores ${ }^{564}$.

Sobre o assunto, o autor Ojeda Avilés aponta que

(...) para buena parte de la doctrina la delimitación podría venir de la mano del adjetivo sindical, cuyo significado etimológico - defensor, representante - cuadraría a todos estos sujetos coletivos que serían por ello sujetos sindicales y su actividad se calificaría como acción sindical ${ }^{565}$.

Se privilegiarmos o sentido etimológico da palavra estaria correto entender toda a manifestação coletiva gerida por representantes, em nome de outros, como ação sindical. Cabe ressaltar que o termo também possui outras acepções mais amplas seja no português, seja no espanhol. Síndico pode ser o gestor de um condomínio, o administrador de bens de uma massa falida, o administrador do dinheiro de ordens religiosas entre outros. Somente faltaria, para completar a definição, aclarar que o direito sindical e as manifestações sindicais são aquelas ocorridas no mundo do trabalho, pois o título de sindical tem o poder de conferir ao grupo e seus representantes algumas faculdades e deveres especiais, distintos de outros administradores ou gerentes de interesses alheios.

Para Palomeque López, é necessário distinguir uma dupla acepção da palavra sindicato, a qual irá variar conforme o contexto no qual utilizada. A primeira concepção é mais geral e se refere a representação e defesa coletiva dos 
trabalhadores, quaisquer que sejam os sujeitos coletivos titulares de tal realização. A segunda acepção é a de determinado sindicato como sujeito específico das relações de trabalho ${ }^{566}$.

Os sindicatos, na Espanha, são assim consideradas organizações que possuam certa estabilidade, formada por membros filiados voluntariamente e que atue com independência com relação ao Estado e aos empregadores. Tais organizações são responsáveis por organizar em massa as relações de trabalho. De tal sorte, não pode receber o nome de "sindicato" nenhuma organização que não intervenha diretamente nas relações de trabalho ${ }^{567}$.

Cabe destacar que a constituição espanhola diferencia claramente entre sindicatos e associações profissionais. Ao proibir a sindicalização de magistrados e membros do Ministério Público (Fiscalía), na ativa, a constituição permite a criação de associações profissionais, certamente com menos direitos e menos atribuições que o sindicato ${ }^{568}$.

O sindicato deve ser uma organização constituída e integrada por trabalhadores que ocupem posições similares no plano das relações de trabalho. Devem ser trabalhadores que trabalhem por um salário. Sob este postulado, outras entidades formadas por empregadores, por empregados e trabalhadores, por funcionários públicos ou por trabalhadores autônomos não poderiam ser chamadas de sindicatos. Contudo, o ordenamento jurídico equipara estes tipos de organização aos sindicatos para permitir sua atuação e funcionamento. Os sindicatos são considerados como formações sociais de relevância constitucional e básicas do sistema político ${ }^{569}$.

A sindicalização de empregadores encontra claras distinções com relação à sindicalização dos trabalhadores. É um movimento de associação que nasce como resposta ao movimento obreiro. Por outro lado, enquanto a liberdade sindical dos trabalhadores é coletiva, a dos empregadores é individual, como parte dos 
postulados da livre iniciativa e da ação econômica empresária voltada a um fim determinado ${ }^{570}$.

\subsubsection{Liberdade sindical}

O reconhecimento da liberdade sindical implica, a priori, o reconhecimento da condição sui generis dos sindicatos face a outras organizações dotadas de personalidade jurídica como pode ser uma sociedade empresária ou uma associação civil. Esse caráter sui generis também dificulta afirmar peremptoriamente sobre a natureza jurídica do sindicato. O sindicato é portanto, ao menos na acepção espanhola um grupo de trabalhadores ou empresários com personalidade jurídica e capacidade de obrar que tem por objeto a defesa dos interesses econômicos e sociais de seus membros ${ }^{571}$.

Por organização sindical, em um sentido amplo, também se pode considerar as representações obreiras nas empresas. Faz parte do postulado de liberdade sindical, que todas as manifestações sindicais possam ser exercidas livremente, inclusive no seio da empresa. No caso de grandes empresas, principalmente as gigantes multinacionais, ganha muita relevância, pois existe um grande número de trabalhadores e um amplo rol de especificidades de cada uma das grandes empresas a demandar uma negociação exclusiva ${ }^{572}$.

A liberdade sindical é, na verdade, um complexo de direitos exercitados pelos trabalhadores individual e coletivamente. A liberdade sindical individual consiste principalmente na faculdade de o trabalhador singular filiar-se ou retirar-se dos sindicatos e de exercitar a ação sindical. Já a liberdade sindical coletiva está ligada fundamentalmente aos sindicatos e seus direitos enquanto sujeitos coletivos para se autorregular e exercer a defesa do interesse coletivo ${ }^{573}$.

Cabe destacar que a Espanha passou por quatro décadas de integração obrigatória ao sistema sindical. A simples lembrança deste período fez com que o 
constituinte de 1978 afirmasse textualmente na Constituição a liberdade sindical negativa $^{574}$ no art. 28 , item 1 , que assim versa ${ }^{575}$ :

\begin{abstract}
Artículo 28
1. Todos tienen derecho a sindicarse libremente. La ley podrá limitar o exceptuar el ejercicio de este derecho a las Fuerzas o Institutos armados o a los demás Cuerpos sometidos a disciplina militar y regulará las peculiaridades de su ejercicio para los funcionarios públicos. La libertad sindical comprende el derecho a fundar sindicatos y a afiliarse al de su elección, así como el derecho de los sindicatos a formar confederaciones y a fundar organizaciones sindicales internacionales o a afiliarse a las mismas. Nadie podrá ser obligado a afiliarse a un sindicato. (grifo nosso)
\end{abstract}

A liberdade sindical negativa é também interpretada de modo extensivo. Desta feita, nenhuma obrigação direta ou indireta pode ser estendida ao trabalhador que não deseja integrar o sistema sindical ${ }^{576}$.

\title{
6.5.4 Estrutura das organizações sindicais
}

Na Espanha, o impulso para a formação dos sindicatos, parece vir desde cima, em outras palavras, desde as centrais sindicais que orientam e apoiam a formação e filiação às entidades de base. O embrião de um sindicato costuma surgir em alguma localidade concreta devido a fatos relevantes que põem em contato trabalhadores com interesses afins. Normalmente, este primeiro momento comporta trabalhadores de um mesmo ofício ou de um mesmo ramo da indústria tendo em vista a maior proximidade dos trabalhadores, os quais geralmente são de uma mesma localidade. O próximo passo seria agregar trabalhadores de outros ofícios ou locais para se tornar um sindicato com relevância local e, a seguir, nacional.

Existe ainda, em um regime de liberdade sindical plena, a possibilidade de convergência sindical, coalisões momentâneas entre diversas organizações sindicais em torno de um fim comum. A coordenação ocorre somente em uma atividade concreta, uma negociação, por exemplo, e o estabelecimento de uma norma coletiva que possa abranger todos os filiados dos sindicatos convenentes. $\mathrm{A}$ 
prática de convergências momentâneas é muito comum nos países Escandinavos onde existe inclusive escritórios permanentes de interação entre os sindicatos para a coordenação de interesses comuns.

\subsubsection{Autonomia e negociação coletivas}

Para a resolução dos conflitos coletivos, a Espanha apresenta diversas opções, em um sistema parecido com o Brasileiro. Se a negociação direta entre as partes não é eficaz, o conflito poderá ser judicializado, quando passará necessária e anteriormente por uma fase de mediação administrativa.

Há ainda uma outra possibilidade, elencada no art. 10 do Real-Decreto-Ley, regulador das relações de trabalho (RDLRT). O artigo 10 possui a seguinte redação $^{577}$ :

El Gobierno, a propuesta del Ministerio de Trabajo, teniendo en cuenta la duración o las consecuencias de la huelga, las posiciones de las partes y el perjuicio grave de la economía nacional, podrá acordar la reanudación de la actividad laboral en el plazo que determine, por un período máximo de dos meses o, de modo definitivo, mediante el establecimiento de un arbitraje obligatorio. El incumplimiento de este acuerdo podrá dar lugar a la aplicación de lo dispuesto en los artículos 15 y 16.

Cuando la huelga se declare en empresas encargadas de la prestación de cualquier género de servicios públicos o de reconocida e inaplazable necesidad y concurran circunstancias de especial gravedad, la Autoridad gubernativa podrá acordar las medidas necesarias para asegurar el funcionamiento de los servicios. El Gobierno, asimismo, podrá adoptar a tales fines las medidas de intervención adecuadas.

Segundo o disposto na mencionada lei, o Estado poderá regular a greve quando está for considerada de grave repercussão econômica. Este tipo de interferência estatal ocorre em diversos países. Na maioria dos casos, algumas tipos de atividades são consideradas fundamentais ou essenciais, como acontece com os serviços de saúde, alimentação e de fornecimento de energia.

Tais tipos de atividades sofrem uma clara limitação ao exercício do direito de greve, em prol do interesse público. A OIT, no entanto, já manifestou reservas com relação à ampliação do rol de atividades essenciais e pela limitação do direito de 
greve, principalmente quando o Estado intervém sem ser provocado pelas partes envolvidas no conflito. De fato a OIT define as atividades essenciais, passíveis de sofrerem limitações ao direito de greve, como aquelas que podem representar risco à vida, à saúde ou à segurança do todo ou de uma parte da população. Como exemplos, os princípios da OIT sobre o direito de greve, citam justamente os serviços hospitalares, serviços telefônicos, o fornecimento de água e de eletricidade e o controle de tráfego aéreo. Evidentemente, tal rol não é taxativo e depende das circunstâncias concretas de cada país e de suas vicissitudes. Claramente, a intenção da OIT é alertar para a possível artimanha de utilizar o argumento dos "serviços essenciais" para limitar o direito de greve ${ }^{578}$.

Seja no caso da Espanha, seja no geral, a gênese das associações obreiras normalmente ocorre em torno ao conflito coletivo. Este fenômeno precede o próprio sindicalismo. A autonomia coletiva, sobre a qual descansa o fundamento teórico do direito sindical possui uma dimensão temática plural: como poder de autoorganização do grupo e autorregulação interna; autonomia normativa (poder de determinar as condições de trabalho; autonomia representativa como poder de representação dos interesses do grupo; autotutela e poder de defender os interesses do grupo inclusive através da manifestação do direito de greve ${ }^{579}$.

O convênio coletivo, no caso Espanhol, permanece inteiramente no âmbito privado ainda que esteja no limiar das possibilidades privadas, pois goza de interesse público e substancial apoio da lei. Ademais, os convênios coletivos possuem, por sua própria essência, a dualidade entre contratual e regulamentar. $O$ aspecto contratual prevalece na elaboração do contrato e na negociação. De outro lado, o caráter regulamentar sobressai quando da aplicação do convênio coletivo ${ }^{580}$.

Ojeda Avilés nos oferece um conceito de Convênio Coletivo no direito espanhol. Para o autor os convênios coletivos ${ }^{581}$ :

son instrumentos colectivos adoptados en el curso de una negociación tipificada entre los representantes mayoritarios de empresários y trabajadores, al objeto de regulamentar las relaciones

578 GERNIGON, Bernard; ODERO, Alberto e GUIDO, Horacio. Los principios de la OIT sobre el Derecho de Huelga. Genebra: OIT (Oficina Internacional del Trabajo), 2000.

579 PALOMEQUE LÓPEZ, 2013.

580 OJEDA AVILÉS, 1995.

581 OJEDA AVILÉS. 1995. p. 670 
jurídicas en el ámbito de su autonomia, de conformidade con las normas específicas de la legislación laboral.

Outros conceitos apontam o convênio coletivo como contrato coletivo, negócio jurídico convencional celebrado entre sujeitos coletivos (ao menos da parte dos trabalhadores) e que alcança plenitude institucional a partir do reconhecimento de sua eficácia normativa. $\mathrm{O}$ autor Palomeque López $^{582}$ repete a conhecida frase de Carnelutti ${ }^{583}$ sobre o convênio coletivo que seria "um híbrido, com corpo de contrato e alma de lei".

$\mathrm{Na}$ Espanha, o termo convênio coletivo serve para designar a modalidade clássica de contratação coletiva, entre sindicatos. O termo acordo coletivo, tal qual no Brasil, designa o instrumento coletivo gerado sem a necessária participação de sindicatos em apenas um ou nos dois polos. No Brasil, tendo em vista a ausência de respeito aos postulados internacionais entre eles a unicidade sindical que não permite a liberdade sindical plena, o acordo coletivo somente poderá ser firmado entre sindicato de trabalhadores e empresa ou empresas. No caso espanhol, admite-se a firma de acordos coletivos sem a presença de sindicatos, entre comissão de trabalhadores no âmbito empresarial e empresa ou empresas. Muito se discute, contudo, sobre a eficácia de tal pacto ao conjunto dos trabalhadores representados. Alguns defendem que é necessária a manifestação de vontade individual do trabalhador afetado ainda que de maneira tácita, expressada pela não oposição ao pacto ${ }^{584}$. Já outros autores entendem que o instrumento coletivo firmado pela representação maioritária dos trabalhadores adquire eficácia geral ${ }^{585}$.

A mesma dificuldade sobre abrangência do instrumento coletivo atinge todas as modalidades de contratação coletiva. A opção espanhola parece ser a de privilegiar sempre a manifestação de vontade dos afetados, ainda que seja no sentido de considerar a filiação como a outorga de um mandato que autoriza negociar em nome do filiado. No entanto, a lei contempla a possibilidade de que a administração laboral estenda os efeitos da contratação coletiva erga omnes como forma de prevenir problemas gerados por distintas normas aplicáveis a um mesmo coletivo e mesma base territorial. Estender os efeitos, de outra banda, pode ser 
prejudicial às entidades sindicais, pois acaba por desestimular a filiação e o engajamento sindicais. Os trabalhadores preferirão receber as vantagens dos convênios negociados e estendidos erga omnes sem arcar com os ônus de ser filiado ao sindicato e mobilizar-se. Além disso, cria-se o inevitável problema da extensão a terceiros de efeitos que podem ser considerados negativos, como a redução de jornada, férias coletivas, redução de intervalos. Certamente o terceiro atingido procurará se esquivar de tal extensão dos efeitos ao argumento de que não participou da negociação. A matéria encontra posições antagônicas e está longe de encontrar uma solução pacífica.

Não obstante, o conteúdo dos instrumentos coletivos é dividido basicamente em quatro partes: matérias econômicas; matérias laborais; matérias sindicais; e, matérias assistenciais. Cada uma das partes contempla distintos aspectos da negociação. Na questão econômica está contemplada uma das principais questões empresariais, a política da divisão das riquezas produzidas, salários e outros benefícios. Na matéria laboral incluem-se questões como a organização das atividades, colocação dos trabalhadores, normas de extinção do contrato de trabalho, coeficientes de produtividade, jornada de trabalho, penalidade por faltas cometidas entre outras questões de similar objeto. Nas matérias sindicais normalmente estão regulados os procedimentos para atuação sindical no local de trabalho como a atuação dos representantes dos trabalhadores na rotina da organização empresarial. Por fim, nas matérias assistenciais, são tratadas questões como as benesses sociais oferecidas pelas empresas aos trabalhadores, colônias de férias, clubes, convênios de comércio, creches etc. Bem assim, também são consideradas matérias assistenciais aquelas que melhoram os benefícios da previdência social a exemplo da extensão da licença-maternidade ou paternidade, seguros complementares entre outros ${ }^{586}$.

\subsubsection{Abrangência dos convênios coletivos}

O tema em comento, tal e qual ocorreu na Itália, pede soluções para a abrangência dos convênios coletivos. Uma vez admitido o postulado da liberdade sindical plena é necessário ter um equilíbrio entre a liberdade sindical e as condutas 
antissindicais que poderiam surgir quando o sindicato atuante fosse penalizado ao não ter seus filiados contratados em razão da norma coletiva aplicável ao grupo.

Uma das soluções encontradas pela Espanha foi adotar o sistema do sindicato mais representativo. Neste modelo, em cada negociação coletiva, é avaliado qual o sindicato mais representativo no âmbito da negociação, seja ela de nível local, regional ou nacional. Assim, o sindicato mais representativo segundo os critérios legalmente estabelecidos, recebe o privilégio de negociar em nome de toda a categoria envolvida e cujas normas serão aplicadas com caráter geral aos trabalhadores do âmbito da negociação ${ }^{587}$.

Os critérios para verificação do sindicato mais representativo estão definidos pela Lei Orgânica de Liberdade Sindical (LOLS) ${ }^{588}$. O primeiro critério é sobre o número de eleitores do sindicato, chamado pela lei espanhola de audiência eleitoral, algo similar ao que se conhece no Brasil com a expressão "colégio eleitoral", isto é, o número de eleitores em determinado local ou instituição. Neste caso, o critério da audiência eleitoral é definido pelo número de representantes de empresas ou em instituições públicas obtidos pelo sindicato. Sempre que um sindicato obtenha, em nível nacional, um número igual ou superior ao $10 \%$ do total será considerado mais representativo. Existe, também outro critério de aferição da maior representatividade chamado de "irradiação da representatividade" onde sindicatos ou entidades sindicais filiadas a outra entidade considerada mais representativa poderão ser considerados também como mais representativos ${ }^{589}$.

Também se encaixam nesta hipótese o caso dos convênios de franja, somente aplicáveis a determinada ou a determinadas categorias profissionais. Em tais hipóteses, a categoria profissional contemplada pelo convênio coletivo está repartida em diversos setores da produção e em diversas empresas. Sendo assim, surge o dilema sobre quem teria capacidade e legitimidade para negociar tais convênios para que pudessem ter eficácia geral. A solução encontrada pela legislação espanhola no Estatuto de los Trabajadores (art. 87) foi a de exigir uma assembléia convocada entre os integrantes de um mesmo perfil profissional. $\mathrm{O}$ autor 
Ojeda Avilés traz o exemplo dos Engenheiros de Caminhos. Esta assembléia decidirá por votação direta, livre e secreta qual sindicato ou comissão terá o poder de negociar por toda a categoria ${ }^{590}$.

\subsection{Sobre as diferenças entre os sistemas sindicais}

O sistema de relações industriais que comporta em seu âmago o sistema sindical é definido por Dunlop ${ }^{591}$. Para o mencionado autor, um sistema deve possuir determinados atores, certos contextos, uma ideologia comum e um conjunto de regras que governa tais atores. O conjunto de regras é para o autor um ponto crucial, de fato, o eixo do sistema. Refere a diferença, também, entre as normas que regulam o procedimento e a aplicação das próprias normas ou de outras e daquelas que regulam as condições de trabalho propriamente ditas, chamadas de normas substantivas.

Na Espanha, o Estatuto de los Trabajadores, não permite, tal qual no Brasil, que o os contratos individuais derroguem in peius a convenção/acordo coletivo. Ou seja, o contrato individual, tanto no Brasil quanto na Espanha, podem estabelecer condições mais benéficas que a norma coletiva. Já na Itália, oferecer condições mais benéficas no contrato individual pode ser considerada como atuação antissindical do empregador se tal estipulação não vier expressamente autorizada pela norma coletiva ou pela lei ${ }^{592}$. Tal situação ocorre quando há a pluralidade de sindicatos convenentes e liberdade sindical plena onde a negociação coletiva não se aplica aos trabalhadores e empregadores não filiados aos sindicatos convenentes. Ao oferecer condições mais favoráveis ao trabalhador individual não sindicalizado, o empregador poderia desestimular a filiação aos sindicatos ${ }^{593}$.

Destaque-se a opinião de Ojeda Avilés ${ }^{594}$ de que na maioria dos países, o Estado reconhece a importância dos sindicatos e inclusive estimula a ação obreira. Enquanto isso, em alguns países, como o Brasil, a autonomia segue sendo limitada pela legislação. Tal circunstância impede que o País descumpridor das normas e convenções da OIT possa integrar acordos de livre comércio de grande extensão 
tendo em vista a quase universal exigência de garantia da liberdade sindical para proporcionar uma justa concorrência.

Alguns autores comparam a ação sindical ao cartel de preços que fixa uma tarifa mínima para retribuição, impossibilitando a concorrência. Neste sentido, discordamos da comparação dos sindicatos com cartéis de preços, alinhando-nos com Ojeda Avilés. Os motivos de nossa discordância são vários.

Em primeiro lugar, o estabelecimento do preço mínimo pela mão de obra, (no Brasil consagrou-se a expressão salário normativo) visa a proteger os trabalhadores entre si. Como a mão de obra sempre é mais abundante que a oferta de empregos, a concorrência entre trabalhadores poderia levar a uma redução desenfreada dos salários prejudicando os próprios trabalhadores. Por outro lado, em regimes de liberdade sindical, as organizações possuem liberdade para pactuar os salários. No Brasil, os salários normativos são na maioria das vezes aqueles determinados pelo mercado e que proporcionam apenas uma vida modesta ao trabalhador, recebendo reajustes menores que a inflação. Ademais, o sindicato, em regimes de liberdade sindical, não detém o monopólio da taxação dos preços da mão de obra, ainda que possa existir uma tendência ao monopólio através das grandes negociações e grandes centrais de nível regional e nacional.

Sobre a convergência de ação, nos países estudados, nota-se que é pouco comum tal prática, ainda que na Itália e principalmente na Espanha, a convergência tenha ganho cada vez mais espaço. Este tipo de ação, mesmo no regime de pseudoliberdade brasileira, poderia ser eficaz para ações de interesse comum que congregassem distintos sindicatos com um mesmo interesse. Poder-se-ia, inclusive, estabelecer normas coletivas de caráter mais geral em determinadas regiões, devido às suas peculiaridades.

A prática da convergência de sindicatos em torno a um interesse comum é muito semelhante, como já mencionamos em outro trabalho ${ }^{595}$, às móveis e fugazes associações entre os Nuer, reveladas por Evans-Pritchard ${ }^{596}$. No caso dos Nuer os diversos grupos formam alianças efêmeras para o cumprimento de um objetivo 
comum e somente aquele. Segundo Evans-Pritchard, pode ocorrer que os Nuer tenham em determinado grupo vizinho um aliado na guerra contra um terceiro, mas sejam inimigos ou rivais se a guerra for contra outro. Exatamente a mesma ideia é aplicada aqui à convergência dos sindicatos em torno aos interesses comuns.

No Brasil, a própria estrutural sindical da unicidade cria um intransponível paralelismo entre o sindicato obreiro e o sindicato patronal, tornando mais difícil que outras entidades venham a se somar às reivindicações ou associações. Além disso, como os sindicatos se dão normalmente por ramos de produção (categorias econômicas), já existe uma certa diversificação no próprio sindicato. Por fim, a separação entre as entidades, propiciada pela própria unicidade, torna muito mais difíceis as alianças intersindicais, no caso brasileiro.

Sobre a questão da liberdade sindical, nota-se que a Espanha passou por um processo semelhante ao brasileiro. O período franquista (1936-1976) instituiu, como já dissemos, o modelo fascista de sindicalismo onde o trabalhador era obrigatoriamente inserto no sistema sindical pelo simples fato de trabalhar. Nos mesmos moldes foi o regime brasileiro da unicidade sindical instituído pela CLT, em 1943. Sem embargo, no Brasil o sistema foi mantido após a promulgação de uma constituição moderna e supostamente alinhada com a defesa dos direitos sociais e individuais fundamentais.

Note-se, como referido anteriormente, que as quatro décadas de inserção obrigatória do trabalhador no sistema sindical fizeram com que o constituinte espanhol afirmasse textualmente na Carta Constitucional o direito do trabalhador de ficar fora do sistema sindical e não sofrer nenhuma consequência ou represália em razão de tal decisão. No Brasil, a situação foi diametralmente oposta. Mesmo após 45 anos de regime sindical de origem fascista (1943-1988), a nova Constituição manteve o mesmo sistema sindical que, na Espanha, revolvia o estômago do constituinte uma década antes.

As consequências de tal decisão brasileira são nefastas e principalmente para os integrantes do sistema de relações de trabalho. Os sindicatos chegaram ao ponto de reunir-se e instituir "contribuições" aplicáveis para toda a categoria profissional ou econômica, como se não bastasse, a contribuição sindical de natureza tributária 
devida por todos os trabalhadores e empregadores brasileiros. A situação chegou a tal ponto que o órgão judicial máximo no âmbito da justiça laboral brasileira, o Tribunal Superior do Trabalho possui uma orientação jurisprudencial ${ }^{597}$ sinalizando jurisprudência no sentido de proibir tais cobranças compulsórias:

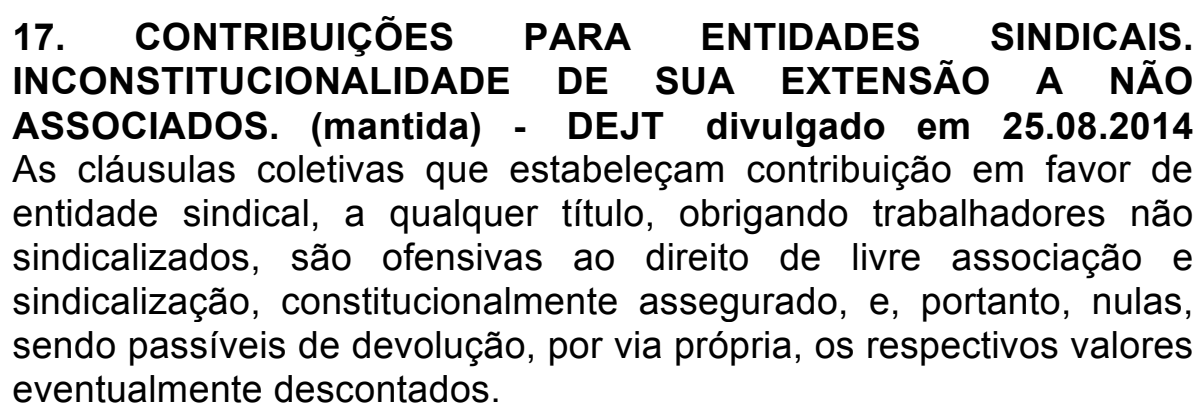

Outro problema que surge do sistema sindical brasileiro é a impossibilidade do reconhecimento dos direitos sindicais como direitos da sociedade e da humanidade em geral. No Brasil, todos aqueles trabalhadores, ex-trabalhadores ou familiares de trabalhadores estão completamente excluídos dos direitos sindicais como a greve, salários normativos e negociação coletiva, por exemplo. Somente os trabalhadores "tradicionais", ou seja, os trabalhadores que possuem um contrato de trabalho regular com um empregador estão incluídos no sistema sindical. Desta forma, fica de fora do sistema um enorme contingente de pessoas como os desempregados, os pensionistas (viúvos e viúvas, acidentados, incapazes temporários ou definitivos), autônomos, trabalhadores informais e muitos profissionais liberais. Tal assunto parece já ter sido resolvido na Espanha e na Itália apenas pelo reconhecimento da liberdade sindical plena onde cada pessoa poderá fundar ou filiar-se ao sindicato de sua escolha.

Como se notou, todos os três sistemas sindicais, apesar de partirem de momentos distintos com relação à industrialização, ao mercado de trabalho e às vicissitudes sociais tiveram um período de convergência na primeira metade do século $X X$, onde predominaram os sistemas corporativos, nazi-fascista e nacionalsindicalista. Após a Segunda Guerra Mundial, a Itália, na sua constituição de 1948, já mudou radicalmente a concepção sobre a liberdade sindical passando a garanti-la de maneira ampla e irrestrita. A Espanha somente veio a reconhecer a mesma situação a partir do final do regime franquista, com a Constituição de 1978. O Brasil 
teve a mesma oportunidade com a transição do regime militar para a democracia, com a Assembléia Nacional Constituinte, em 1988. Incrivelmente, o processo constitucional que culminou com a constituição apelidada de "cidadã" manteve o sistema sindical corporativo que remonta ao nazi-fascismo do início do século $\mathrm{XX}$. Todas estas diferenças e questões enfrentadas por Itália e Espanha, na transição do sistema fascista/nacional-sindicalista, podem servir de ensinamento e apoio ao Brasil, quando finalmente seja realizada tal transição e reconhecida a liberdade sindical plena.

\subsection{Questões sobre a divisão do trabalho}

A divisão do trabalho é um tema extremamente polêmico e controvertido na sociedade atual. Por sua vez, é também um tema central. A maior parte das discussões travadas, atualmente, têm muito mais a ver com a reserva de mercado para determinados estamentos sociais do que com a lógica da divisão social do trabalho e sua importância para a sociedade. Para que se diga a verdade, a divisão do trabalho nunca dependeu de conselhos reguladores, de carreiras estruturadas e de mudanças curriculares dos cursos de graduação.

Atualmente, quanto mais específico é o trabalho, mais complexa é a formação do trabalhador. Nos ofícios especializados, após terminar a formação, o aprendiz adquire o mesmo status do mestre ${ }^{598}$. Esta condição, a de formar concorrentes para o mercado de trabalho, induz a muitas contradições entre a formação e a prática dos novos profissionais.

Durkheim, como referimos anteriormente, foi um dos autores que escreveu especificamente sobre a divisão do trabalho. O mencionado autor seguiu a tendência de outros autores, a exemplo de Comte e Spencer, os quais abordaram também este assunto, um tema bastante controverso e curioso e que rende, até hoje, discussões e debates nas mais diversas sociedades.

No livro "Lecciones de Sociología $599 "$, os três primeiros capítulos tratam da moral profissional. No entanto, o autor assevera ser impossível discorrer sobre a 
moral profissional de cada uma das profissões existentes. Durkheim, pergunta-se sobre outras questões ao começar seu estudo: o primeiro questionamento pretende esclarecer qual o caráter geral da moral profissional com respeito às outras esferas da ética; e, o segundo, indaga sobre quais as condições gerais necessárias para o estabelecimento e funcionamento da moral profissional. A partir destes questionamentos, tentará o autor discorrer sobre as vicissitudes da moral profissional.

O poder coletivo, de onde emana a moral coletiva, é o único, para Durkheim, que pode se sobrepor ao indivíduo e impor o respeito à determinadas normas. Portanto, cada moral profissional é obra de um grupo profissional específico e reúne as características do referido grupo. Assim "podemos decir que la moral profesional estará tanto más desarrollada y poseerá un funcionamiento tanto más avanzado cuanto los grupos profesionales mismos tengan más consistencia y organización ${ }^{600 " . ~}$

Cita o autor, em seguida, o fato de que algumas profissões, principalmente aquelas relacionadas com as atribuições do Estado, formam um corpo definido e bastante coeso, possuindo, inclusive, órgãos encarregados de fazer cumprir as normas do corpo profissional. E, uma profissão apenas, de caráter privado e não público, como as demais, possui uma organização semelhante: a dos advogados.

Durkheim afirma que os indivíduos que exercem o mesmo ofício, pela própria circunstância de exercerem o mesmo ofício, estão obrigatoriamente em contato uns com os outros, ainda que de maneira fortuita e irregular. Por tal motivo, há profissões que somente em razão de tais contatos fortuitos, geram a vaga ideia de moral profissional. É inevitável outra constatação do autor sobre o caminho em direção à formação de sociedades essencialmente industriais onde o trabalho industrial será a forma mais comum de atividade e não pode prescindir de algum tipo de normatividade. Tal necessidade conduz invariavelmente à outra: a de organização dos grupos profissionais. Durkheim reputa como necessárias a existência e manutenção de uma estrutura que recorde ao indivíduo, constantemente, e o faça respeitar os interesses que não são seus, e sim do grupo ao qual pertence. Ao serem tais interesses distintos dos do próprio indivíduo e muitas vezes restritivos destes, é necessária a disciplina de uma moral coletiva que 
o recorde sobre os interesses do grupo. Esta organização e estrutura, receberam o nome histórico de corporação e, associados ao nome, vários preconceitos. Falar em corporação parece ser, por si só, um retorno ao passado e ao velho regime feudal da idade média.

No entanto, é impossível postular a volta das corporações já que, segundo Durkheim, as mesmas estão intimamente ligadas ao regime pré-revolução francesa e não podem sobreviver ao final do mesmo. Em um primeiro momento, as categorias de trabalhadores organizam-se em colégios de natureza privada. Pouco a pouco, tendo em vista o elevado interesse público na manutenção e qualidade dos ofícios, o poder público vai se imiscuindo nas corporações e colégios, tornando-as verdadeiras células da administração.

$\mathrm{Na}$ idade média, a corporação respondia a necessidades diversas e não estritamente ligadas ao trabalho e ao comércio. Eram um local de culto religioso, onde os membros constituíam quase uma segunda família, tornando a vida mais agradável pelo prazer da vida em comum. Ainda que as corporações da idade média guardassem bastantes distinções com relação ao modelo romano, ambas pode ser consideradas como ambientes onde imperava uma moral profissional (coletiva) sobre todos os integrantes. Havia casos, inclusive, de regulamentação e necessidade de aprovação colegiada de despedidas.

Durkheim vê como inevitável, no seio de uma mesma comunidade política, um determinado número de indivíduos, unido por ideias e interesses capazes de diferenciá-los dos demais, constituir uma comunidade associativa. Esta associação buscará fazer valer os interesses em comum, proteger-se dos opositores e, oferecer um local de identificação e sentimento de unidade no meio de conflitos.

O autor não escapa de uma analogia intuída por muitos que se aventuraram no estudo de associações obreiras em geral: tentar comparar família e outras associações, entre elas, a associação obreira. Parece ser uma ideia tentadora, afinal, a sociedade está formada, além de indivíduos, de grupos sociais menores e maiores que se articulam de diversas formas e, nessa relação, constituem o conjunto maior. A própria família não se deve exclusivamente ao fato do parentesco consanguíneo. Durkheim aponta como causas do prestígio da família diversos 
fatores, entre eles, a convivência próxima, a comunidade de cultos e interesses econômicos comuns e um amplo leque de relações capazes de abarcar uma grande parte da existência. A seu turno, a associação "no comprende más que una parte determinada de la existencia: la que concierne a la profesión. ${ }^{601 "}$

Então, embora a associação profissional tenha um importante papel e se relacione diretamente com uma atividade fundamental para a subsistência, não pode substituir a família. Acrescentamos aqui, que a família acompanha-nos desde o nascimento e, muito dificilmente, poderemos mudar de família durante a vida. Já os ofícios e profissões, em muitos casos são circunstanciais e temporários, exigindo, também algo de flexibilidade nas associações profissionais.

Durkheim faz outra consideração importante à qual, também, poderíamos acrescentar outras constatações. O autor afirma a existência de um preconceito histórico contra as corporações. Quando fala em corporações, obviamente se refere às corporações da idade média, as quais exerciam forte regulamentação econômica no campo da oferta de produtos, da fixação de preços e da reserva de mercado. Além disso, as corporações passaram à história como braços do regime feudal da idade média e, portanto, entidades que ajudaram a frear o avanço culturaltecnológico e prolongar a "idade das trevas". Não deixa de ser verdade, quase um século após a morte do autor, que há ainda mais um preconceito contra as associações profissionais, pelo menos, no mundo ocidental. Após a Revolução Socialista, a Guerra Fria e todas as suas consequências, ainda que de maneira inconsciente, sindicatos e associações obreiras alumbram sempre as recordações da revolução, da insurgência e da destruição do sistema estabelecido. Parece ser que ao longo da história é difícil ver as associações profissionais como elementos necessários ao bom andamento da economia e para a estabilização e regulamentação das práticas profissionais. O próprio Durkheim afirma importar-se com o costume e esse costume é definido e sancionado a partir de uma moral comum da associação profissional.

A “moralização da vida econômica" é, para Durkheim, a principal razão de ser das associações obreiras, com mais importância sobre outros aspectos também úteis e pragmáticos. As condições especiais em que inserido o indivíduo no contexto 
do mercado de trabalho, das relações patrão-empregado e entre colegas de ofícios, de concorrência e competição, demandam a moralização e o estabelecimento de algumas regras capazes de "humanizar" as relações.

Já nas suas conclusões, Durkheim toca um problema sobre o qual já se discutia no princípio do século XX. Trata-se de definir como obrigatória ou não a afiliação dos obreiros e empregadores na associação respectiva. Durkheim, a partir de um ponto de vista pragmático vaticina que o interesse em associar-se certamente será geral já que existem só vantagens, a par da impossibilidade de enfrentar o mercado sozinho. O autor defende a obrigatoriedade da filiação e mais, desejava ver as corporações profissionais como novo critério de divisão espacial do país, mais adequado, segundo ele, que a divisão territorial. Ademais, o autor sugere uma série de funções as quais poderiam ser desempenhadas pelas corporações como, por exemplo, a função de editar normas de direito laboral para seu ramo específico de atividade.

É interessante anotar que algumas das ideias de Durkheim foram tornadas realidade e algumas, a exemplo da unicidade sindical e da representação obrigatória, seguem em vigor. Nem por isso se pode concordar com tal nível de controle sobre as "necessidades" do trabalhador, principalmente em uma sociedade pós-industrial do século XXI. Se bem parece ser verdade que o trabalhador associado e atuante possui melhores condições de enfrentar o mercado e a vida, a qualidade de tal associação e com que a estabelecer não poderiam ser determinados a priori, seja pelo Estado, seja pelas próprias Corporações. Neste ponto somos obrigados a discordar de Durkheim, considerando sempre que a obrigatoriedade, talvez naquele momento, fosse necessária para a criação de uma consciência coletiva e um espírito comum ${ }^{602}$.

602 As considerações das páginas precedentes referem-se ao libro Lecciones de Sociologia de Émile Durkheim. Não foram adicionadas repetidas notas de rodapé por questões de estilo e para não importunar o leitor. 


\section{CAPÍTULO VII - AS RELAÇÕES DE TRABALHO NA PRÁTICA}

\subsection{As classificações brasileira e internacionais de ocupações}

Desde 1958, a Organização Internacional do Trabalho publica uma classificação internacional das ocupações (International Standard Classification of Occupations - ISCO-58) como forma de auxiliar nas comparações estatísticas internacionais e guiar a elaboração de classificações no nível de cada país. A Itália, por exemplo, já realiza semelhante classificação desde 1881 e já atualizou sua atual classificação em 2013.

O modelo Italiano atual já foi atualizado segundo a última versão apresentada pela Organização Internacional do Trabalho (ISCO-08). Segundo o Istituto Nazionale de Stadistica, a necessidade de conhecer as profissões dos cidadãos, bem como a necessidade de que existissem padrões mínimos como forma de possibilitar comparações, mostrou-se necessária já na realização do primeiro censo realizado em 1861. Já naquela época, revelava-se o interesse em conhecer a profissão de cada um, principalmente daqueles exercentes de profissões liberais onde os limites, a complexidade e dificuldade de classificação são maiores. Conhecer as profissões de cada um, segundo a entidade oficial Italiana, possibilita ter um retrato da sociedade e da posição que cada um ocupa na hierarquia social. ${ }^{603}$

A Espanha também atualizou a Clasificación Nacional de Ocupaciones (CNO$11)^{604}$ no ano de 2011 e o novo modelo já está de acordo com a ISCO-08. No entanto, a classificação espanhola aumentou o número de categorias de classificação com relação à ISCO-08 e apresenta um total de 10 Grupos, 62 Subgrupos Principais, 170 Subgrupos e 502 Grupos Primários. A classificação traz também alguns conceitos sobre o que seriam trabalho e ocupação:

Se entiende por empleo un conjunto de "tareas y cometidos
desempeñados por una persona, o que se prevé que ésta
desempeñe", en su puesto de trabajo. Se entiende por ocupación "un
conjunto de empleos cuyas principales tareas y cometidos se
caracterizan por un alto grado de similitud". Por ejemplo la ocupación
de periodista podría reunir varios empleos distintos como son:

603 ITÁLIA. Istituto Nazionale Statistica. Classificazione delle Professione. Roma: Stealth, 2013.

604 ESPANHA. Instituto Nacional de Estadística. Clasificación Nacional de Ocupaciones. Madrid: 2012. 
presentador de informativos, reportero o conductor de debates en TV. ${ }^{605}$

As classificações mudaram bastante ao longo do tempo. A primeira classificação internacional (ISCO-58) utilizava critérios de agrupamento distintos da última classificação realizada (ISCO-88). Não é nosso objetivo entrar nos detalhes utilizados para o agrupamento de profissões em cada uma das classificações. No entanto, ainda que com pequenas amostras, podemos ter uma ideia de como evoluíram certos seguimentos de profissões segundo a classificação internacional.

No caso, por exemplo, dos músicos, pode-se notar um aumento no número de atividades listadas desde 1958, em comparação com 2008:

\begin{tabular}{|c|c|}
\hline Músicos ISCO-58 606 & Músicos ISCO-08 ${ }^{607}$ \\
\hline Instrumentalista & Líder de Banda \\
\hline Cantor & Instrumentalista \\
\hline Compositor & Compositor \\
\hline Condutor de Banda e Orquestra & Condutor Musical \\
\hline \multirow[t]{6}{*}{ Orquestrador } & Músico de Night Club \\
\hline & Cantor de Night Club \\
\hline & Orquestrador \\
\hline & Músico de Rua \\
\hline & Cantor de Rua \\
\hline & Cantor \\
\hline
\end{tabular}

605 ESPANHA, 2012. p. 2 606 ORGANIZAÇÃO INTERNACIONAL DO TRABALHO. International Standard Classification of Occupations. Genebra: 1958. 607 ORGANIZAÇÃO INTERNACIONAL DO TRABALHO. International Standard Classification of Occupations. Genebra: 2012. 
Esse pequeno exemplo demostrar como evoluíram as profissões nos últimos 50 anos. Como soe acontecer, algumas profissões fundiram-se e outras foram divididas, criando novas ocupações. A tendência, tal e como afirmava Durkheim ${ }^{608}$, é que a complexidade da sociedade incrementaria o grau de divisão social do trabalho.

Como se pode notar o que antes mostrava como condutor de banda e orquestra agora simplesmente foi transformado em condutor musical já que existem mais possibilidades de atuação do condutor musical além da banda e da orquestra. Por outro lado, a atividade de cantor foi dividida em cantor, cantor de night club e cantor de rua. Certamente, as condições de vida do cantor de rua e do cantor de night club diferem muito das atividades dos demais cantores e, por isso, ganharam uma referência especial no subitem destinado aos músicos. Todas essas circunstâncias também importam desde o ponto de vista sindical para a formação de categorias sindicais entre trabalhadores.

Ainda, o próprio número de categorias e subcategorias aumentou exponencialmente em 50 anos, dando conta da especialização cada vez mais elevada que é a tendência em nossa sociedade. Segue um quadro comparativo dos itens e sub-itens entre a ISCO-58 e a ISCO-08:

\begin{tabular}{|c|c|}
\hline ISCO-58 & ISCO-88 \\
\hline 10 Major Groups & 10 Major Groups \\
\hline------- & 43 Sub-Major Groups \\
\hline 73 Minor Groups & 130 Minor Groups \\
\hline 201 Unit Groups & 436 Unit Groups \\
\hline
\end{tabular}

Os critérios utilizados pela ISCO-58 envolvem a definição do termo "ocupação" definido como o escopo de atividades realizado por determinado trabalhador na maioria dos países. Os próprios realizadores da ISCO-58 
reconhecem que em cada país, o escopo de atividades poderá ser mais restrito ou mais amplo e que um trabalhador considerado muito qualificado em determinado local pode estar na média da qualificação em outro local. Além disso, os realizadores da ISCO-58 também pontuam, com propriedade, sobre a dificuldade de realizar uma classificação como a de ocupações. Segundo os autores, nenhuma classificação é absoluta e, ao final, o julgamento de quem realiza a classificação é que determinará os pontos de inclusão e exclusão para diferenciar uma categoria de outra ${ }^{609}$.

$\mathrm{Na}$ ISCO-08, o objetivo é fornecer um instrumento internacional de referência para a comparação estatística, bem como auxiliar a globalização e crescente mobilidade do mercado de trabalho. Além disso, com a ISCO-08, pretendeu-se ter uma noção do impacto das tecnologias e comunicações no mercado de trabalho e atualizar as definições e conceitos de quase todas as categorias, entre outras utilidades e pontos de partida ${ }^{610}$.

A ISCO-08 também traz os conceitos de job (trabalho) e occupation (ocupação) que são definidos como:

$41 \mathrm{~A}$ job is defined in ISCO-08 as a set of tasks and duties performed, or meant to be performed, by one person, including for an employer or in self employment.

42 Occupation refers to the kind of work performed in a job. The concept of occupation is defined as a set of Jobs whose main tasks and duties are characterized by a high degree of similarity. A person may be associated with an occupation through the main job currently held, a second job, a future job or a job previously held. ${ }^{611}$

Cumpre ressaltar que tais definições são bastante difíceis de encontrar em publicações oficiais o que conduz a inúmeras dúvidas e dificuldades, inclusive na auto-atribuição, pelos cidadãos, da nomenclatura correta. Pela definição apresentada, nota-se que o conceito de ocupação é mais abrangente que o de trabalho e que também as pessoas podem ser associadas com ocupações, inclusive por trabalhos realizados anteriormente e sem vínculo atual. O assunto é importante na medida em que permite algo até a atualidade proibido no Brasil, a sindicalização, por exemplo, dos desempregados de determinado ramo de atividade. Como no Brasil a sindicalização, via de regra, segue o ramo de atividade desempenhada pelo 
empregador, o trabalhador desempregado, assim como o autônomo (na maior parte dos casos) ficam alijados do sistema sindical, não podendo reivindicar melhores condições de trabalho ou de empregabilidade.

No Brasil, a Classificação Brasileira de Ocupações é a versão nacional da classificação de ocupações e foi atualizada pela última vez em 2002, não contemplando as atualizações da ISCO-08. A classificação brasileira também oferece alguns conceitos bastante próximos da classificação internacional:

Ocupação é um conceito sintético não natural, artificialmente
construído pelos analistas ocupacionais. O que existe no mundo
concreto são as atividades exercidas pelo cidadão em um emprego
ou outro tipo de relação de trabalho (autônomo, por exemplo).

Ocupação é a agregação de empregos ou situações de trabalho similares quanto às atividades realizadas. O título ocupacional, em uma classificação, surge da agregação de situações similares de emprego e/ou trabalho. Outros dois conceitos sustentam a construção da nomenclatura da CBO 2002:

Emprego ou situação de trabalho: definido como um conjunto de atividades desempenhadas por uma pessoa, com ou sem vínculo empregatício. Esta é a unidade estatística da CBO. (...) ${ }^{612}$

A Classificação Brasileira de Ocupações traz também conceito do que seria Trabalho e Ocupação. O conceito é bastante parecido com aquele fornecido pela ISCO-08 e também coloca a ocupação como algo mais abrangente que o trabalho. A ocupação é uma soma de atividades similares capazes de formar um grupo conjunto devido à proximidade da tarefa desempenhada. A ocupação reúne, portanto, tipos de trabalhos similares.

Note-se que a CBO utiliza o tipo de trabalho desenvolvido pelo trabalhador para agrupá-lo nesta ou naquela família de ocupações. Por este motivo, é possível encontrar divergências entre as categorias sindicais (onde se considera que as atividades são similares e conexas para formar um sindicato comum) e as famílias ocupacionais relacionadas na CBO. Como exemplo podemos citar os trabalhadores da indústria metalúrgica, divididos em muitas e diferentes ocupações segundo a CBO (técnico em soldagem, técnico em caldeiraria, inspetor de sondagem, técnico 
em estruturas metálicas) entre outras diversas funções que também são enquadradas apenas na Metalurgia para fins de representação sindical.

A estrutura da CBO é similar à da ISCO-08 e baseada principalmente na ISCO-88. São 10 grandes grupos, 48 subgrupos principais, 192 subgrupos e 607 grupos de base ou famílias ocupacionais e um total de 2.511 ocupações com aproximadamente 7.500 títulos sinônimos ${ }^{613}$. Os sinônimos fazem parte da própria nomenclatura de cada ocupação como, por exemplo, o Trabalhador na Manutenção de Edificações que traz consigo nada menos que 10 (dez) sinônimos ${ }^{614}$.

Outro importante ponto no qual toca a CBO é a diferenciação entre a formação acadêmico-profissional/titulação ostentada pelo trabalhador e a função efetivamente desempenhada. A CBO esclarece que a classificação se dá de acordo com a atividade efetivamente desempenhada pelo trabalhador, ou seja, a sua formação não terá total prevalência para a definição do título da ocupação. A própria CBO fornece alguns exemplos: Um engenheiro que trabalha como analista financeiro de um banco
será classificado como analista financeiro e não como engenheiro.
Um médico que trabalha na função de director de um hospital será
classificado como diretor de um hospital e não como médico.
Também será classificado como diretor de hospital o administrador
que ocupar essa posição. Portanto, a relação formação -ocupação
não é necessariamente uma relação biunívoca. ${ }^{615}$

As classificações internacionais nos revelam que existe uma preocupação estatística com o tema das profissões já há muitos anos. Por outro lado, as classificações são sempre subjetivas e sujeitas ao juízo do tempo histórico, das circunstâncias e dos classificadores. No entanto, o critério utilizado, em todas elas, baseia-se nas atividades efetivamente desempenhadas pelo trabalhador singular. $A$ ISCO-08, realiza, inclusive, uma série de questionários e perguntas a integrantes do mercado de trabalho (trabalhadores, empresários, diretores empresariais, funcionários públicos, políticos etc.). Assim, a percepção dos trabalhadores e 
participantes das relações de trabalho também é relevante para o entendimento das funções desempenhadas individualmente.

Portanto, do ponto de vista adotado pelos técnicos que elaboram as classificações de ocupações a distintos níveis, a circunstância verdadeiramente fundamental, é a atividade efetivamente exercida pelo trabalhador. Neste ponto, não são relevantes a formação e tampouco a categoria econômica do empregador para a inserção da ocupação neste ou naquele grupo. Como se pode notar, as classificações das ocupações adotam critérios bastante distintos daqueles utilizados no Brasil para incluir o trabalhador (forçosamente, destaque-se) neste ou naquele sindicato para fins de representação obrigatória. Se a convenção é uma forma de quebrar a rigidez da lei e aproximar a norma da realidade parece um contrassenso que o sindicato precise de lei para formar-se.

\subsection{0 quadro de atividades e profissões da Consolidação das Leis do Trabalho}

A Consolidação das Leis dos Trabalho incorporou ao texto consolidado um decreto de $1939^{616}$ que definia as profissões e atividades econômicas para os fins sindicais. O mencionado decreto trazia as diversas previsões sobre a associação sindical, deveres e direitos dos sindicatos que hoje estão presentes no texto consolidado. Assim, o art. 54 do Decreto 1.402/39 virou o atual art. 577 da atual consolidação. Tal artigo 54 assim versava (e ainda versa, apenas com outro número): “Art. 54. O Ministério do Trabalho, Indústria e Comércio organizará, para os fins da presente lei, o quadro das atividades e profissões. ${ }^{617 "}$

Façamos um parênteses, apenas para referir que o ocorrido acima com as disposições sobre associações sindicais é um dos motivos para que a principal lei trabalhista brasileira receba o nome de "consolidação". O Brasil, ao contrário de outros países, não possui um código do trabalho ou um estatuto especialmente elaborado. Para receber a denominação de "código" a legislação deve guardar um mínimo de sistematicidade e coerência interna capaz de conferir-lhe essa característica especial de induzir a interpretação e aferição do seu espírito e dos seus princípios. A Consolidação, a seu turno, é uma colcha de retalhos de leis e decretos pré-existentes, com alguns acréscimos, não possuindo organicidade, 
coerência interna e sistematicidade necessárias a uma legislação pós-moderna sobre um tema tão relevante como o é a regulamentação das relações de trabalho, fundamento do Estado brasileiro, pela dicção do artigo $1^{\circ}$, inciso IV, da Constituição Federal Brasileira de 1988.

Pois, em 1939, foi dada ao Ministério do Trabalho, Indústria e Comércio a missão de organizar em um quadro todas as atividades econômicas e profissionais existentes, classificando-as hierarquicamente nos três graus de representação sindical (confederação, federação e sindicato) e guardando relação de paridade entre o sindicato obreiro e o sindicato patronal. Desde então, o quadro de atividades e profissões constitui o documento oficial para o enquadramento sindical de trabalhadores e empregadores. Alguns autores, a exemplo de José Carlos Arouca $^{618}$, refere que foram colocados no quadro "inimagináveis agrupamentos de trabalhadores".

O quadro de atividades e profissões também define aquelas que são categorias profissionais diferenciadas e profissões liberais. Uma das poucas distinções existente entre profissão liberal e categoria professional diferenciada, está em uma Nota Técnica da Secretaria de Relações de Trabalho do Ministério do Trabalho ${ }^{619}$. Segundo a mencionada nota, os profissionais liberais são aqueles que exercem suas atividades de forma autônoma ou empregados, mas que estão habilitados legalmente, registrados nos respectivos conselhos profissionais, após o atendimento dos requisitos técnico-científicos e legais necessários ao exercício profissional. A mesma Nota Técnica tratou de conceituar a categoria diferenciada, que seria condição dos trabalhadores que exercem suas funções nas circunstâncias de trabalho previstas em legislação própria, especial ou que, do desempenho das atividade, resulte igualdade de condições de vida.

A confusão entre uma e outra é comum. Ao comentar as exceções à regra da sindicalização, Süssekind conceitua os trabalhadores excepcionados como aqueles que "exerçam profissões ou ofícios diferenciados por estatutos ou regulamentos

618 AROUCA, José Carlos. Dicionários LTR, vol. II - Enquadramento Sindical, jurisprudência. São Paulo: LTr, 1986.

619 BRASIL. MINISTÉRIO DO TRABALHO E EMPREGO. Secretaria das Relações de Trabalho. Nota 11/2006. Disponível em: $<$ http://www.sinfito.org.br/arquivos/contribuicao/MTE_Nota_Tecnica_11.pdf $>$ Acesso em: 05/04/2017. 
especiais ou que irradiam condições de vida peculiares" e nessa categoria inclui a possibilidade de haver profissionais liberais ${ }^{620}$. Para Romita ${ }^{621}$ :

(...) os integrantes do grupo estão unidos por uma rede ou sistema de relações sociais; eles atuam entre si, de acordo com normas ou standards aceitos pelo grupo. Essas relações e essa interação se baseiam em uma série de papéis e de status inter-relacionados, que permitem diferenciar seus membros de quem não seja membro do grupo.

Segundo a opinião dos autores mencionados, o que se pode perceber é que os profissionais liberais são uma espécie dentro do gênero das categorias profissionais diferenciadas. A primeira pode estar inserta na última, mas não o contrário.

Contudo, embora Romita mencione que existe uma rede ou sistema de relações sociais entre os integrantes de um grupo (no caso o grupo de que falamos é uma mesma categoria profissional) a regra-geral da elaboração do quadro de atividades e profissões é privilegiar o enquadramento dos empregados a partir da categoria de atividade do empregador. Ou seja, na classificação criada para fins sindicais, levou-se em consideração a realidade de 1939, bem como os ajustes necessários, de maneira a possibilitar a ordenação das atividades existentes. Partiu aquele legislador da presunção de que a atividade sindical nasce do exercício de atividades em comum. Para o caso das profissões diferenciadas ou liberais, também o legislador assumiu que, por ostentar o mesmo título ou a mesma profissão, os trabalhadores possuem identidade de interesses no plano da ação coletiva.

E foi justamente em tal conjunto de presunções que surgiu o caráter autoritário e retrógrado da legislação brasileira. Em primeiro lugar, e isso parece já ter sido demonstrado pela história, os regimes populistas e fascistas, substituíram a vontade individual e a coletiva pela vontade do Estado na busca do "interesse geral" e do progresso da economia. Portanto, o quadro de atividades e profissões não foi organizado atendendo ao interesse dos trabalhadores e sim como parte do projeto de tutelar e dirigir integralmente as atividades econômicas nacionais. 
Mary Douglas ${ }^{622}$ já referia que as classificações são uma forma de controle. Neste caso, visivelmente, a classificação foi criada para exercer controle sobre a atividade sindical ao realizar o enquadramento automático dos trabalhadores e empregadores em categorias pré-existentes e somente permitir a existência de um sindicato por categoria. Isso sem contar que possuímos uma classificação moderna, derivada de uma sociedade industrial incipiente, aplicada hoje a uma sociedade pósmoderna e pós-industrial, onde as necessidades e realidades são completamente distintas.

Não é preciso dizer que o quadro de atividades e profissões gerou milhares de dúvidas e confusões ao ponto de o Ministério do Trabalho criar uma Comissão de Enquadramento Sindical (CES) para resolver as dúvidas e conflitos com relação ao referido enquadramento sindical. Um exemplo destes conflitos era o enquadramento de uma indústria que produzia e, por óbvio, também vendia seus produtos e, portanto, deveria integrar a categoria da indústria ou do comércio. Ou o caso do enquadramento da indústria que possui filiais que somente comercializam os produtos produzidos pela matriz. A extinta comissão de enquadramento resolvia tais situações determinado para qual categoria se deveria recolher a contribuição sindical e em qual categoria se enquadrava a empresa e, por consequência, seus empregados.

O quadro de atividades e profissões recebeu poucas atualizações com alguns acréscimos, modificações ou eliminação de categorias. A maior destas atualizações, ao que parece, aconteceu em 1970. No entanto, desde a Constituição de 1988, entendemos que o quadro de atividades e profissões perdeu sua eficácia já que a Constituição estendeu maior liberdade no âmbito sindical à exceção da contribuição compulsória e da unicidade sindical.

Portanto, continua vigente a determinação para a existência de somente um sindicato por categoria. No entanto, os trabalhadores, dentro dos ainda estritos limites legais, após a Constituição de 1988, passaram a criar novas categorias como forma de instituição de novos sindicatos. A atividade de criação de categorias a partir de uma nova profissão ou atividade (fato perfeitamente normal e natural, principalmente no caso dos trabalhadores do setor de tecnologia da informação) ou 
o desmembramento de categorias anteriormente existentes é perfeitamente possível. Como já adverte Homero Batista ${ }^{623}$, no Brasil, mesmo com a limitação de apenas um sindicato por categoria e por base territorial, no período posterior à Constituição de 1988, houve um considerável aumento no número de novos sindicatos, principalmente a partir do artifício de criação de categorias.

Mesmo com essa aparente liberdade para a criação de sindicatos, os trabalhadores seguem sofrendo com limitações inexplicáveis no momento da criação de uma entidade sindical. É impossível, em pleno século XXI, que vários trabalhadores de diversos ramos de atividade distintos possam se reunir em um sindicato único em busca de um interesse comum, por exemplo, todos os trabalhadores que laboram no período noturno, sejam porteiros, vigilantes ou trabalhadores de hospitais. Outras profissões multifacetadas e complexas como é o caso da Educação Física ${ }^{624}$, e que possuem profissionais que atuam desde o ensino escolar até a reabilitação física, da recreação ao esporte de alto rendimento constituem somente a categoria profissional diferenciada dos profissionais de educação física o que, quiçá, não atende às expectativas e necessidades de todos os profissionais.

Como bem ressalta Gustavo Barbosa Garcia $^{625}$, a tarefa de definir o que é uma categoria profissional é da sociologia e não do direito, ainda que o fato social adquira importante relevância jurídica. Aqui pensamos que o autor referiu a sociologia como forma de referir-se às ciências sociais e humanas, diferenciado-as do direito. Acrescentamos que o tema da categoria é certamente interdisciplinar e a antropologia, a qual, desde Spencer, já trata sobre o tema da divisão do trabalho, tem muito a contribuir para a definição das categorias. De fato, no atual estado de coisas brasileiro, acreditamos que o profissional mais habilitado para realizar a aferição da relevância social de uma categoria e da representatividade do sindicato seja o antropólogo, a partir de um estudo denso. Situações similares já têm sido resolvidas com o auxílio de laudos antropológicos para verificar a existência ou não de comunidades indígenas ou quilombolas, sua autenticidade e arraigo ao território.

623 SILVA, Homero Batista Mateus da. Curso de Direito do Trabalho Aplicado, vol. 7: Direito Coletivo do Trabalho. Rio de Janeiro: Elsevier, 2010.

624 BONATTO BARCELLOS, Antonio Augusto et al. A sindicalização dos profissionais de Educação Física. in: Revista Conexões, Campinas, v. 13, n. 3, p. 146-174, jul./set. 2015.

625 GARCIA, Gustavo Filipe Barbosa. Curso de Direito do Trabalho. Rio de Janeiro: Forense, 2017. 
O mesmo poderia ser realizado com relação aos sindicatos e categorias profissionais para o que acreditamos a antropologia tem muito a contribuir.

\subsection{Alguns dados estatísticos}

A Organização Internacional do Trabalho mantém um banco de dados estatístico com diversos dados estatísticos relevantes. Infelizmente, a realidade brasileira não consta em diversos destes estudos, talvez pela impossibilidade de comparar os dados de países onde a sindicalização não seja livre. Mesmo assim, aportaremos alguns dos dados da Organização Internacional do Trabalho assim como de outros órgãos como o Ministério do Trabalho e Emprego e o DIEESE, por exemplo.

Um grupo de pesquisa da Universidade de Sheffield (Inglaterra) e da Universidade de Michigan (Estados Unidos) ${ }^{626}$ produziu um mapa mundi ${ }^{627}$ acorde com o número de membros sindicais por habitante. O tamanho dos países varia conforme um maior número de membros sindicais por mil habitantes.

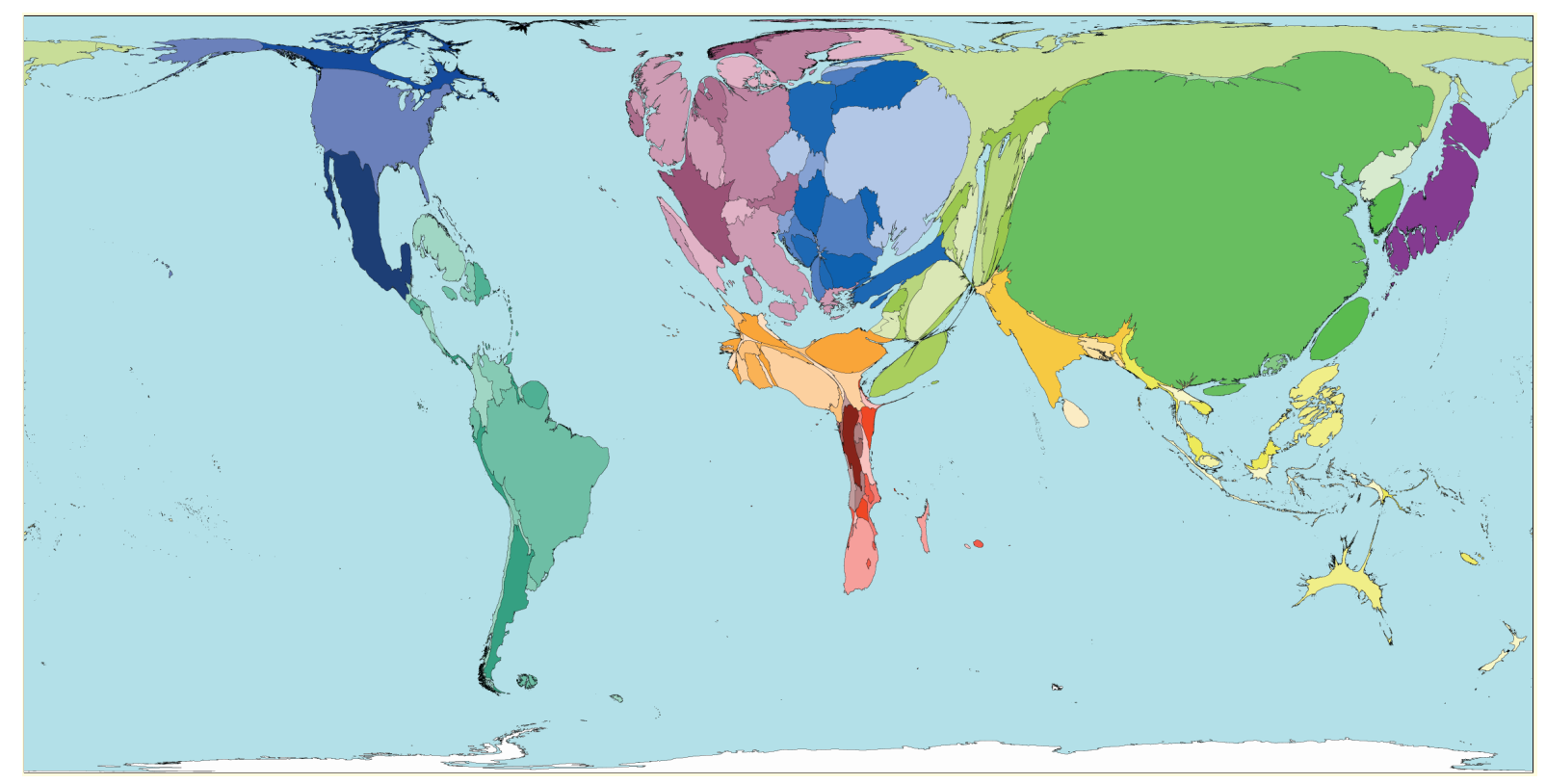

Mapa proporcional ao número de sindicalizados por 1000 habitantes

A recordista de membros sindicais por mil habitantes segundo o mencionado estudo é a Ucrânia, onde 447 trabalhadores são sindicalizados a cada mil 
habitantes. Note-se que o termo habitantes refere-se a toda a população, incluídos aposentados, crianças, jovens e aquelas pessoas que por qualquer motivo não trabalham. Sendo assim, os valores ucranianos revelam que a maior parte dos trabalhadores provavelmente é sindicalizado.

Nos sete primeiros postos, ou seja, onde há mais trabalhadores sindicalizados por habitante, estão a Ucrânia $\left(1^{\circ}\right)$, a Bielorrússia $\left(3^{\circ}\right)$ e os demais cinco postos pertencem aos países Escandinavos, reconhecidamente onde também está presente um dos melhores Índices de Desenvolvimento Humano e os melhores sistemas públicos educativos do mundo. O ranking está assim conformado: Suécia $\left(2^{\circ}\right)$, Finlândia $\left(4^{\circ}\right)$, Islândia $\left(5^{\circ}\right)$, Dinamarca $\left(6^{\circ}\right)$ e Noruega $\left(7^{\circ}\right)$. Os dez primeiros lugares são completados por Rússia $\left(8^{\circ}\right)$, Bélgica $\left(9^{\circ}\right)$ e Cuba $\left(10^{\circ}\right)$.

Como se pode perceber, os dez primeiros postos são todos ocupados ou pelos países escandinavos ou pelos países da antiga tradição (inclusive Cuba evidentemente influenciada por aquela). A única exceção é a Bélgica que figura como um dos dez países onde há maior índice de sindicalização e é um país da Europa Ocidental.

Por sua vez, o estudo refere que um terço dos trabalhadores sindicalizados do mundo está na China apesar de, na proporção, está não figurar entre os primeiros colocados. O Brasil também é referido como local de muitos trabalhadores sindicalizados sem, entretanto, gozar de alta proporção com relação ao total da população.

Na verdade, os dados do Departamento Intersindical de Estatística e Estudos Socioeconômicos (DIEESE) demonstram uma baixíssima taxa de sindicalização entre os trabalhadores brasileiros. É verdade que o número de trabalhadores sindicalizados apresenta um crescimento uniforme ao longo dos anos. No entanto, em proporção similar também aumenta o número de trabalhadores não sindicalizados o que indica existir um crescimento geral do mercado de trabalho e não de uma categoria isoladamente considerada. Os últimos dados apresentados pelo DIEESE ${ }^{628}$ são do ano de 2009 : 


\begin{tabular}{|l|c|}
\hline \multicolumn{2}{|c|}{ BRASIL - 2009 } \\
\hline Trabalhadores Sindicalizados & 16.450 .356 \\
\hline Trabalhadores Não-Sindicalizados & 76.238 .897 \\
\hline
\end{tabular}

De outra banda, é notável o baixo número de trabalhadores sindicalizados em relação total de trabalhadores formais do sistema. O número de trabalhadores não sindicalizados supera em mais de quatro vezes o número de trabalhadores sindicalizados. A evolução de ambos os grupos é bastante similar na série apresentada como se pode notar ${ }^{629}$ :

\begin{tabular}{|l|l|}
\hline \multicolumn{1}{|c|}{ NÃO-SINDICALIZADOS } & \multicolumn{1}{c|}{ SINDICALIZADOS } \\
\hline 199961.546 .540 & 199911.788 .212 \\
\hline $2000----$ & $2000----$ \\
\hline 200163.362 .239 & 200112.733 .350 \\
\hline 200265.659 .075 & 200213.299 .208 \\
\hline 200365.991 .834 & 200314.169 .802 \\
\hline 200467.926 .531 & 200414.889 .996 \\
\hline 200569.727 .017 & 200515.662 .572 \\
\hline 200672.722 .764 & 200616.594 .477 \\
\hline 200774.747 .138 & 200716.038 .881 \\
\hline 200875.624 .450 & 200816.770 .135 \\
\hline 200976.238 .897 & $\underline{200916.450 .356}$ \\
\hline
\end{tabular}

O crescimento é constante em ambos os grupos, a denotar um maior aumento do número de trabalhadores em geral e, consequentemente, do número de sindicalizados e não-sindicalizados. Além disso, no ano de 2009, houve já uma redução do número de trabalhadores sindicalizados em comparação ao ano anterior, fato inédito na série decenal e não verificado com relação ao número de trabalhadores não-sindicalizados. 
O número de sindicatos, a seu turno, apresenta um crescimento constante. A série é irregular, mas podemos notar que o número de sindicatos praticamente dobrou no período de vigência da Constituição de 1988, mesmo esta tendo corroborado o sistema sindical consagrado pela Consolidação das Leis do Trabalho. Em 1987, eram 5.648 sindicatos no Brasil e, em 2001, últimos dados disponíveis, eram 11.354 sindicatos. Em 2015, segundo pesquisa do DIEESE, existiam 11.173 entidades sindicais representativas apenas dos trabalhadores, sem contar as entidades patronais. ${ }^{630}$

No Brasil, a densidade do número de filiados aos sindicatos, sem embargo, vem diminuindo entre 2008 e 2013, conforme dados da Organização Internacional do Trabalho:

\begin{tabular}{|c|c|c|c|c|c|}
\hline \multicolumn{5}{|c|}{ DENSIDADE DE TRABALHADORES SINDICALIZADOS } \\
\hline 2008 & 2009 & 2010 & 2011 & 2012 & 2013 \\
& & & & & \\
\hline $22,2 \%$ & $19,1 \%$ & ------ & $17,8 \%$ & $17,5 \%$ & $16,6 \%$ \\
\hline
\end{tabular}

A mesma tendência não foi verificada em países onde a sindicalização é livre como Espanha e Itália. Na Itália, no mesmo período, verificou-se um aumento da densidade dos sindicalizados e, na Espanha, o número manteve-se constante, com diferenças pouco significativas de um ano para outro.

\begin{tabular}{|c|c|c|c|c|c|}
\hline \multicolumn{5}{|c|}{ DENSIDADE DE TRABALHADORES SINDICALIZADOS } \\
\hline 2008 & 2009 & 2010 & 2011 & 2012 & 2013 \\
& & & & & $17,2 \%$ \\
\hline $17,4 \%$ & $17,8 \%$ & $17,6 \%$ & $17,2 \%$ & $17,5 \%$ & \\
\hline \multicolumn{7}{|c|}{ ENTRE 2008 e 2013 - ESPANHA } \\
\hline 2008 & 2009 & 2010 & 2011 & 2012 & 2013 \\
& & $35,5 \%$ & $35,7 \%$ & $36,3 \%$ & $36,9 \%$ \\
\hline $33,4 \%$ & $34,7 \%$ & & & \\
\end{tabular}


Há de se considerar a forte crise econômica pela qual passou a Europa desde 2008, principalmente os países do eixo mediterrâneo e que, mesmo assim, viram pouco afetada a filiação sindical. Por outro lado, no Brasil, em 2008 ${ }^{631}$, foi promulgada lei que incluiu no sistema sindical as chamadas Centrais Sindicais, entidades sui generis, de abrangência nacional e que não constavam originalmente do sistema sindical concebido pela CLT.

Existem diversos outros dados úteis ao nosso trabalho e sobre os quais é mister refletir. O tempo médio de permanência no emprego aumentou entre 2009 e 2014, ainda que o aumento não tenha sido extremamente significativo. O tempo médio no emprego no Brasil, considerando-se, evidentemente, apenas empregos formais, foi de aproximadamente 60 (sessenta) meses, ou seja, 5 (cinco) anos de trabalho. Segue gráfico de estudo, também do DIEESE ${ }^{632}$ :

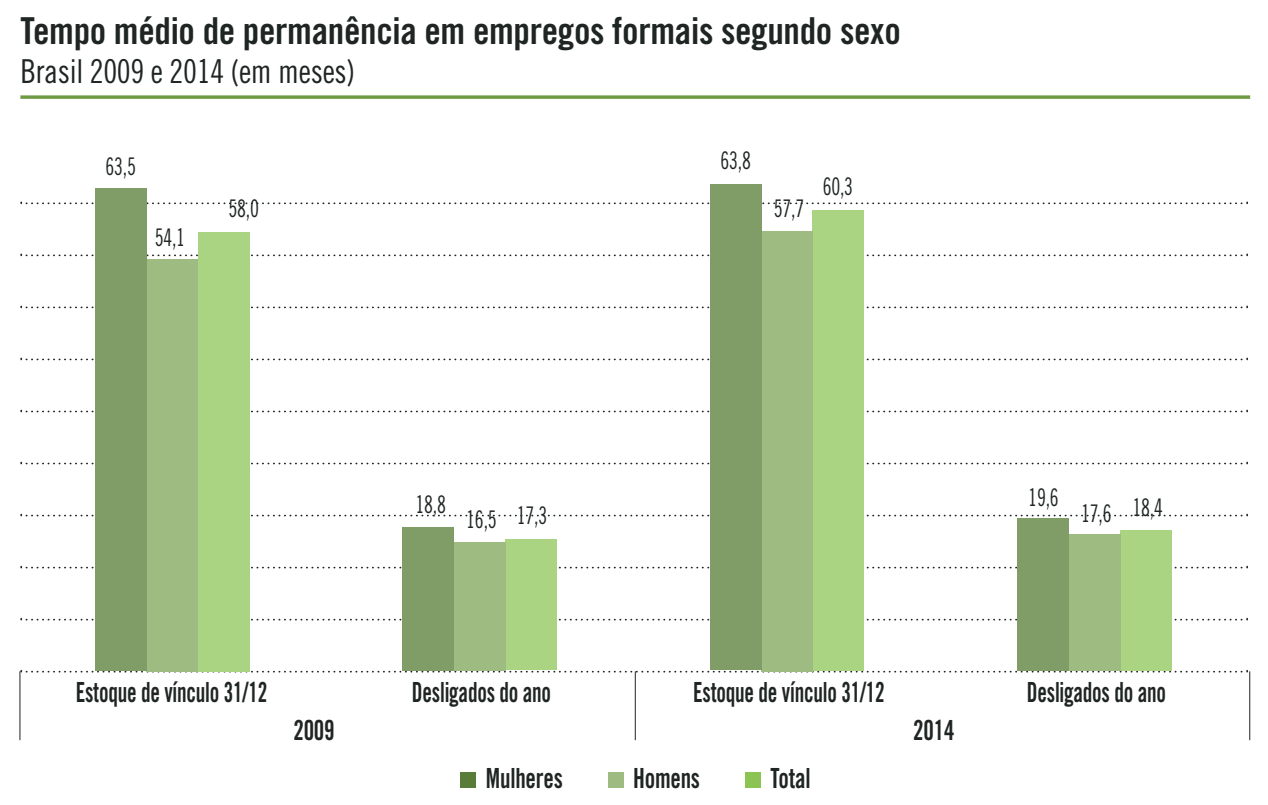

Como se pode notar, ao contrário do imaginário popular, as mulheres possuem maiores tempos médios de permanência no emprego. Além disso, o tempo médio de permanência é bastante considerável levando-se em consideração a cada vez maior taxa de rotatividade da mão de obra (turn over). Este tempo médio de 
permanência no emprego é compatível com a afirmação de Sennet ${ }^{633}$, segundo quem, na pós-modernidade, os indivíduos passam por 5 ou 6 diferentes ocupações ao longo da vida. Levando-se em consideração de o tempo de trabalho necessário para aposentadoria está entre 30 e 35 anos na maioria dos países, parece adequado supor que existe, efetivamente, a possibilidade de que o indivíduo execute 5 ou 6 diferentes ocupações ao longo de sua vida laboral.

Ainda, é mister destacar que, apesar do grande volume de ações judiciais no Brasil, apenas uma pequena parte (no que tange ao mundo laboral) vai parar efetivamente no Poder Judiciário. Com relação ao trabalhador individual, o número de desligamentos (final do contrato de trabalho seja por iniciativa do trabalhador ou do empregador) é imensamente superior ao número de demandas ajuizadas. No ano de 2014 é possível ter uma ideia de tal correlação:

\begin{tabular}{|c|c|}
\hline \multicolumn{2}{|c|}{ BRASIL } \\
\hline $\begin{array}{c}\text { Número total de desligamentos no } \\
\text { Mercado de Trabalho em 2014 }\end{array}$ & $\mathbf{2 6 . 5 3 6 . 0 0 0}$ \\
\hline $\begin{array}{c}\text { Número total de novas ações nas Varas } \\
\text { do Trabalho (1 }{ }^{\mathrm{a}} \text { instância) em 2014 }\end{array}$ & $\mathbf{2 . 3 6 5 . 5 4 7}$ \\
\hline
\end{tabular}

Os dados acima comprovam que nem uma décima parte dos desligamentos do mercado laboral brasileiro acabam por se transformar em ações judiciais para a discussão das questões relativas aos contratos individuais de trabalho. Por certo, o prazo prescricional para o ajuizamento de ações é de dois anos após o final do contrato de trabalho, mas, no entanto, o número de ações do total do ano de 2014 , pode traduzir desligamentos do ano anterior, assim como os desligados do ano de 2014 podem ajuizar ações somente no ano de 2015, assim que as possibilidades provavelmente são compensadas sem maior relevância para o dado central apresentado. Ademais, é importante ressaltar que os principais assuntos veiculados em demandas laborais versam sobre as verbas devidas por ocasião do

633 SENNET, Richard. La corrosión del carácter. Las consecuencias personales del trabajo en el nuevo capitalismo. Barcelona: Anagrama, 2000.

634 DIEESE, 2015. p. 80

635 BRASIL. TRIBUNAL SUPERIOR DO TRABALHO. Coordenadoria de Estatística e Pesquisa. Relatório

Geral da Justiça do Trabalho. Brasília: Cestp, 2015. p.6 
encerramento do contrato de trabalho, sendo que as cinco primeiras posições do ranking de assuntos da justiça do trabalho brasileira apontam justamente para diferentes aspectos das verbas devidas na rescisão do contrato de trabalho ${ }^{636}$.

Seria interessante para o presente estudo, saber o número exato de ações propostas por entidades sindicais e por advogados sindicais em prol da categoria ou de trabalhadores isoladamente considerados. No entanto, após diversos contatos com os centros de estatística do Tribunal Regional do Trabalho da $4^{a}$ Região e do Tribunal Superior do Trabalho, foi-nos dito que tal dado não está mensurado.

Contudo, este dado encontrado no cotejo entre os dados do CAGED e do Relatório Geral da Justiça do Trabalho, desmente uma das ideias pré-concebidas que possuímos sobre as relações de trabalho como fadadas a terminar em uma vara do trabalho e onde o trabalhador sempre vencerá. Neste contexto, no ano de 2014, o último que possuía um relatório detalhado emitido e que utilizamos como exemplo, foram 26.536 .000 (vinte e seis milhões quinhentos e trinta e seis mil) desligamentos em relações de trabalho formais. Aqui, note-se, estão computadas apenas as relações de trabalho devidamente registradas e informadas aos órgãos públicos. No entanto, no mesmo ano, foram apenas 2.365.547 (dois milhões trezentos e sessenta e cinco mil quinhentas e quarenta sete) novas ações trabalhistas ajuizadas.

Em outras palavras, se fosse possível estabelecer uma relação direta, diríamos que menos de $10 \%$ dos desligamentos laborais acaba se tornando uma disputa judicial. É claro que a estatística não é peremptória e apresenta diversos pontos frágeis como por exemplo: a possibilidade do ajuizamento de ações até dois anos após o final do contrato de trabalho; a possibilidade do ajuizamento de ações coletivas que beneficiem dois ou mais trabalhadores; a existência de ações mesmo durante o contrato de trabalho e também a possibilidade de ajuizamento de ações versando sobre relações de trabalho até então não reconhecidas e fora, portanto, das estatísticas oficias. No entanto, mesmo levando-se em consideração todas estas questões, acreditamos que a proporção seja efetivamente próxima aos $10 \%$ de demandas em relação ao total de desligamentos. Em outras palavras, apenas uma 
pequena fração das desavenças entre empregados e empregadores e também seus respectivos sindicatos vai ser decidida pela Justiça do Trabalho.

Todas estas estatísticas, brasileiras e mundiais, bem como os critérios classificatórios adotados pelas organizações internacionais e por diversos países servem para nos dar uma visão panorâmica das relações de trabalho brasileira principalmente com relação às profissões, aos sindicatos e à justiça especializada em questões laborais.

\subsection{O trabalho de campo}

Para ajudar a colher as visões e opiniões dos trabalhadores sobre sua participação no mercado de trabalho e sobre as relações coletivas foi necessário realizar trabalho de campo. No trabalho de campo pudemos realizar observação participante, algumas entrevistas em profundidade e diversos questionários. Registre-se que tentamos realizar entrevistas e observações no âmbito das principais entidades sindicais de trabalhadores da cidade de Porto Alegre. De todos os diversos sindicatos contatados, somente um deles foi receptivo e concedeu entrevistas. Os demais sindicatos sequer retornaram os e-mails enviados e as ligações telefônicas realizadas. Por este motivo, decidimos centrar a investigação nas opiniões de trabalhadores, filiados ou não a sindicatos, mas que buscavam assistência jurídica em pontos de assistência alheios aos seus respectivos sindicatos.

Nosso objetivo era avaliar a percepção dos trabalhadores sobre a sindicalização e o sindicato de sua categoria bem como sobre outros aspectos de sua relação de trabalho. O trabalho foi realizado em dois escritórios de advocacia trabalhista de Porto Alegre, um localizado no Bairro Restinga e outro localizado no Bairro Petrópolis e também em uma associação de moradores do Bairro Restinga que realiza gratuitamente encontros semanais com os associados onde estes podem retirar dúvidas jurídicas com um profissional de cada um dos ramos do direito. Em nosso caso, comparecemos quando havia profissionais ligados ao direito do trabalho e direito previdenciário para acompanhar os atendimentos e, quando possível, realizar entrevistas e questionários. 
Porto Alegre é uma cidade com 1.481.019 habitantes, em 2016, segundo a projeção do IBGE ${ }^{637}$. O município é a capital do Estado do Rio Grande do Sul, o Estado mais meridional do Brasil e, consequentemente, Porto Alegre é a capital estatal mais ao Sul do Brasil. A região metropolitana de Porto Alegre possui aproximadamente 4.064.186 (quatro milhões e sessenta e quatro mil cento e oitenta e seis) ${ }^{638}$ habitantes, é integrada por 31 municípios e ocupa uma área de 9.652,54 $\mathrm{km}^{2}$, o que corresponde a $3,56 \%$ do território do Estado do Rio Grande do Sul ${ }^{639}$. A região metropolitana de Porto Alegre é o principal polo do Estado do Rio Grande do Sul, constituindo-se no centro administrativo, financeiro, cultural e econômico da região. A região concentra quase metade da oferta de empregos do Estado com $40,8 \%$ das ofertas do setor terciário e $37,8 \%$ das ofertas do secundário. É uma área, portanto, de grande densidade populacional e forte concentração econômica ${ }^{640}$.

Neste contexto do município de Porto Alegre e sua Região Metropolitana é que estão insertos o Bairro Restinga e o Bairro Petrópolis que foram locais de realização da pesquisa. Ambos os bairros possuem populações bastante numerosas, embora apresentem perfis distintos de composição demográfica e localização geo-espacial. O Bairro Petrópolis conta com aproximadamente 38.155 moradores e ocupa uma área de 333 hectares $^{641}$ em localização central da cidade de Porto Alegre. É um bairro considerado como de classe média-alta e cuja renda média mensal por domicílio é estimada em 20 salários mínimos. Já o Bairro Restinga está localizado na Zona Sul da cidade, bastante distante do centro da cidade. Em transporte coletivo, o trajeto entre o Bairro Restinga e o centro da cidade pode durar aproximadamente uma hora a depender das condições do trânsito. $O$ Bairro Restinga possui aproximadamente 51.569 moradores e ocupa área de 2.149 hectares. O rendimento mensal médio é de aproximadamente 3 salários mínimos por domicílio ${ }^{642}$.

637 INSTITUTO BRASILEIRO DE GEOGRAFIA E ESTATÍSTICA. Portal Cidades. Disponível em: $<$ http://www.cidades.ibge.gov.br/v3/cidades/municipio/4314902> Acesso em: 17 fev 2017 638 Para estabelecer um termo de comparação, a população da Região Metropolitana de Porto Alegre é próxima da de países como Irlanda ou Croácia.

639 INSTITUTO NACIONAL DE CIÊNCIA E TECNOLOGIA. Observatório das Metrópoles. Rio de Janeiro: FAPERJ, 2010.

640 HAMESTER, Paulo Rudolfo et al. A Região Metropolitana de Porto Alegre. in: Metrópolis em Revista.

Vol. 03, $\mathrm{n}^{\mathrm{o}}$ 1, Curitiba, 2001. pp. 33-40

6411 Hectare equivale a $10.000 \mathrm{~m}^{2}$.

642 Dados da Prefeitura Municipal de Porto Alegre. Disponível em:

http://www2.portoalegre.rs.gov.br/spm/default.php?reg=54\&p_secao=131 Acesso em: 23 jan 2017. 
Como se pode notar, ambos os bairros parecem ser antitéticos com relação à localização, área, rendimento médio e densidade populacional. Ambos os bairros são bastante populosos e o Bairro Restinga conta com mais de 50.000 habitantes, uma quantidade superior à população de muitos municípios. Segundo alguns autores, os municípios com população entre 50.000 e 100.000 habitantes estão em um estamento médio com relação ao porte ${ }^{643}$. Em nosso caso, com a realização do trabalho de campo em ambos os locais, buscou-se justamente abarcar um maior número de probabilidades e estamentos sociais.

No sistema brasileiro, como já explicitado anteriormente, todos os trabalhadores são necessariamente representados por algum sindicato e por isso pagam uma "contribuição sindical" com natureza tributária (imposto) para financiar o sistema sindical. Tal contribuição tem o valor equivalente a um (1) dia de trabalho anual, correspondente à remuneração de um (1) dia de trabalho do mês de março. Por sua vez, os sindicatos, como entidades que recebem a maior parte dos valores pagos pelos trabalhadores $(60 \%$ do total é destinado ao Sindicato da Categoria que pertence o trabalhador pagante, $15 \%$ é destinado à Federação à qual é filiado o Sindicato, 5\% para a Confederação à qual é filiada a Federação, 10\% para a Central Sindical à qual é filiado o sindicato e $10 \%$ para um fundo governamental chamado de Conta Emprego e Salário), têm obrigação de prestar assistência jurídica aos seus representados. Isto é, todo trabalhador tem direito a requerer assistência jurídica gratuita no Sindicato de sua categoria. Entretanto, impressiona o número de trabalhadores que preferem ajuizar demandas na justiça laboral utilizando-se de advogados particulares ou de associações privadas. Por certo que esses profissionais recebem pelo seu trabalho, valor que diminuirá os ganhos do trabalhador. Mesmo assim, existem cada vez mais trabalhadores que optam por se valer de advogados particulares, ao invés de procurar a assistência jurídica sindical.

É certo que o sistema sindical brasileiro, ao impor a representação, não estimula a participação, a filiação e o engajamento dos trabalhadores na sua entidade de classe. O trabalhador é obrigado a custear o sistema e também é 
obrigado a ser representado pelo sindicato de sua categoria. Isso pode conduzir a um total descaso com relação ao sindicato de sua categoria e ao sistema sindical de maneira geral. Mesmo assim, todas as rescisões contratuais de empregados com mais de um ano de serviço na mesma empresa necessitam, obrigatoriamente, passar pelo crivo do sindicato da categoria. Ou seja, todos os trabalhadores despedidos ou que pediram demissão após um ano de trabalho na mesma empresa, estiveram pelo menos uma vez na sede do sindicato e passaram a conhecer o sindicato que obrigatoriamente os representa.

Diante de todo este contexto, a amostra utilizada foi incidental. Esperava-se os trabalhadores que procuravam algum dos três pontos da realização do trabalho de campo para que, com a concordância destes, fosse possível a realização de entrevistas e/ou a resposta aos questionários durante o período em que o pesquisador lá se encontrava.

Tal trabalho resultou na realização de 14 (quatorze) entrevistas em profundidade, 53 (questionários) preenchidos e mais de 80 (oitenta) atendimentos observados no total. Ressalte-se que sendo o programa de doutorado na Espanha e o trabalho de campo realizado no Brasil, não dispusemos de todo o tempo e/ou financiamento necessário para uma estadia mais prolongada de maneira a possibilitar um maior tempo de observação participante. A realização do trabalho de campo durou um total de 6 (seis) meses divididos em distintos períodos ao longo da realização da tese doutoral.

\subsection{0 que pensam os trabalhadores}

A primeira pergunta que certamente pairava no ar era acerca do motivo pelo qual determinado trabalhador, por lei vinculado a um sindicato para representá-lo, buscava assistência jurídica privada, em um contexto onde necessitará abrir mão de parte de suas verbas para remunerar o advogado contratado. Para que fique claro, há ainda uma discussão presente em boa parte da doutrina e jurisprudência brasileiras sobre a possibilidade de honorários sucumbenciais/assistenciais na justiça do trabalho. O sindicato e, consequentemente, o advogado que atua em nome do sindicato na defesa dos trabalhadores sindicalizados possuem 0 
direito/dever de representar juridicamente os trabalhadores auferindo verbas sucumbenciais/assistenciais pagas pela contraparte em caso de êxito na ação.

Por outro lado, os advogados privados (aqueles que não atuam como assistentes jurídicos de sindicatos) precisam cobrar pelos seus serviços e o fazem na forma de porcentagem dos ganhos dos trabalhadores. Em outras palavras, o trabalhador abre mão de parte de seus possíveis ganhos para contratar um advogado privado. Normalmente num contrato de risco, isto é, somente da hipótese de procedência da reclamatória, o advogado ou a sociedade de advogados terá direito aos honorários contratuais. Intuitivo que o trabalhador, ao buscar a justiça, já não conta com o salário, sendo difícil contratar patrocínio privado antecipando honorários.

Questionados sobre tal aspecto, os trabalhadores deram diferentes respostas, para a questão, mas, ainda que diferentes, todas as respostas induzem a um mesmo tipo de conclusão: há confiança ou ao menos um início de confiança com relação ao causídico escolhido e desconfiança em relação ao sindicato da categoria respectiva. Como já dito, todos os trabalhadores com mais de um ano de contrato de trabalho necessariamente conhecem a localização e o próprio sindicato de sua categoria, pois lá aconteceu o ato da rescisão contratual entre empregado e empregador.

Podemos resumir em três as principais respostas para esclarecer os motivos que levaram o trabalhador a procurar assistência jurídica privada e não aquela oferecida pelo sindicato da categoria. A primeira delas, a levar inserta outra expressão também dita pelos trabalhadores, é: "um amigo indicou". Esta resposta também leva implícito outro tipo de resposta também bastante repetida, a de que "confiava no doutor". Por certo, a confiança nasce de uma indicação, proximidade ou experiência prévia de maneira que ambas as expressões estão a sugerir algum tipo de vínculo entre o trabalhador e o causídico escolhido. Este vínculo de confiança, por mais tênue que seja, na maior parte das vezes logra ser maior que qualquer vínculo existente entre o trabalhador e o sindicato obreiro, fazendo com que este último seja preterido na escolha do assistente jurídico. 
Outra afirmação recorrente é a de que "os diretores não trabalham". Neste caso, os trabalhadores desejavam se referir aos dirigentes sindicais, que, na concepção daqueles, não eram trabalhadores como os demais. Efetivamente, existe a possibilidade de que o dirigente sindical seja dispensado de suas funções no emprego e seja remunerado pelo sindicato, em salário idêntico ao que receberia na empresa, apenas para exercer as funções de dirigente sindical. Além disso, mesmo aqueles não dispensados, possuem significativa redução da carga de trabalho "normal" em prol do labor sindical. Tais circunstâncias fazem com que muitos dos próprios companheiros de categoria já os vejam como outro tipo de trabalhador. Essa visão do dirigente sindical como "outro" leva à desconfiança e à sensação de que os problemas dos dirigentes sindicais são distintos dos problemas do trabalhador comum.

Algo similar também foi dito por diversos trabalhadores do Bairro Restinga, para justificar o porquê de buscar assistência jurídica na associação de moradores do bairro ou em escritórios de advocacia particulares também do próprio bairro. A justificativa apresentada por diversos trabalhadores foi bastante similar: "Os problemas do Centro (da Cidade) não são os mesmos nossos". Com isso queriam dizer que a condição de trabalhador de determinada categoria profissional e de morador do Bairro Restinga, principalmente esta segunda, eram fundamentais na determinação da visão de mundo experimentada pelo trabalhador.

Por fim, cabe destacar uma desconfiança com relação aos sindicatos que provém da própria gênese do sistema sindical brasileiro, isto é, o problema dos sindicatos "pelegos". Como já aqui ressaltado, a gênese do sistema sindical brasileiro foi no sentido de criar organismos que pudessem controlar a massa de trabalhadores que surgia nos grandes centros urbanos brasileiros. A criação de sindicatos por lei, sua obrigatoriedade, a representação forçada, o sistema piramidal e o paralelismo entre sindicato obreiro e sindicato patronal foram formas encontradas para organizar e canalizar as revindicações da massa de trabalhadores. Os sindicatos brasileiros têm em sua origem o propósito de contribuir com o Estado e com a economia gerida por Getúlio Vargas.

Durante as várias décadas que o sistema está em vigor, proliferaram diversos sindicatos apenas formais, mas que, na verdade, visavam atender aos interesses 
estatais e empresariais, deixando em último plano os interesses dos trabalhadores. Criou-se no imaginário dos trabalhadores esta figura do sindicato "pelego", alcunha recebida pelos sindicatos que não velam pelos interesses obreiros, mas pelos seus próprios interesses, enquanto na administração da entidade, e pelos interesses empresariais do empregador. Por tal motivo, e quiçá, por desconhecimento da atuação sindical os trabalhadores já possuem uma desconfiança inata com relação ao sindicato da sua categoria. Lado outro, a própria situação de paralelismo sindical entre sindicato obreiro e sindicato patronal cria um paradoxo dificilmente superável. O sindicato obreiro existe em função da categoria econômica na qual laboram os trabalhadores representados por ele. Se a categoria econômica deixa de existir ou perde importância ou número de funcionários, o próprio sindicato obreira deixa de existir ou perde boa parte de seu financiamento. Portanto, a reinvindição obreira deve sempre andar com cuidado ante a ameaça constante dos prejuízos da categoria e, consequentemente, os prejuízos que ele próprio enfrentará. Note-se que o financiamento sindical se dá pelo desconto nos vencimentos dos trabalhadores que por ele são representados. Se já não existem trabalhadores ou estes são extremamente reduzidos em número o próprio sindicato obreiro perderá em importância e fonte de custeio.

\subsection{1 "Meter no Pau" versus Adicionais}

A imensa maioria dos trabalhadores entrevistados e que buscava consultoria jurídica, seja na Associação de Moradores do Bairro Restinga, seja no Escritório de advocacia do Bairro Petrópolis, utilizavam a expressão "meter no pau" ou sua variante "colocar no pau" para demonstrar que desejavam ajuizar uma ação trabalhista contra seu ex ou atual empregador. Poucos trabalhadores utilizavam a expressão "quero buscar meus direitos" e somente dois daqueles observados ou entrevistados já traziam uma ideia pré-concebida da nomenclatura do direito que desejava reclamar, em um caso, férias e, em outro, horas extraordinárias.

A expressão "meter no pau" utilizada pelo trabalhador, a quem chamaremos de J., revela que os trabalhadores buscam, em geral, reaver algo que lhes foi tomado pelo empregador. Este algo surge primeiro como um sentimento de injustiça, a sensação de algo está errado até que culmina com a procura de alguém de confiança para liderar a luta contra o empregador representada pela expressão 
"meter no pau". Por óbvio, a possibilidade e a viabilidade de uma ação jurídica (neste caso particular chamada de reclamatória trabalhista no contexto brasileiro) não surge da simples vontade do trabalhador em demandar, mas de fatos concretos que evidenciem ao menos uma causa provável para o ajuizamento de uma ação com razoáveis expectativas de êxito.

A própria origem da expressão é controversa e não está catalogada em dicionários de expressões idiomáticas à exceção de algumas páginas de perguntas e respostas na internet. O pau aqui referido pode ser associado ao "pau-de-comer" em referência ao pau que era atravessado à boca dos escravos que, nos navios negreiros, negavam-se a comer. Por outro lado, a expressão também pode ser associada a colocar o escravo infrator no tronco ou no "pau-de-arara" para receber o merecido castigo. Independente da origem, ambas remetem ao passado escravagista e trazem a ideia de algo imposto, forçado e também de punição. $O$ "meter no pau" também representa um momento do ritual de inversão de papéis referido por Turner e já neste trabalho comentado. A hora de "meter no pau" é o momento em que o trabalhador assume o protagonismo, coloca seu patrão no "pau" (representação simbólica do banco dos réus), onde o ex-empregador pagará por todos os seus excessos cometidos durante a relação de trabalho.

Quando o trabalhador se apresenta perante o causídico que se encarregará do seu caso, sua ideia, é a de que deseja demandar contra o ex-empregador (na maioria dos casos é o ex-empregador e em casos bastante mais raros é contra o empregador atual, cujo contrato segue em vigor - o que leva ao problema da despedida arbitrária e sem justa causa) e ponto final. A partir de então, o causídico inicia uma espécie de entrevista em profundidade, quase na condição de antropólogo, objetivando desvendar as condições de trabalho daquele trabalhador em particular, de modo a aferir os direitos laborais eventualmente não atendidos pelo empregador e que serão o objeto da reclamatória trabalhista a ser proposta.

O "meter no pau" será transformado, aos poucos, em pedidos bastante específicos, constantes principalmente de posições jurisprudenciais que atualizaram ou desvirtuaram a normativa trabalhista brasileira existente. Os pedidos serão sobre o adicional de horas extraordinárias; adicional pelo trabalho noturno; responsabilidade do tomador de serviços; diferenças de recolhimentos fundiários e 
junto a seguridade social etc. No entanto, o trabalhador J., do nosso exemplo, não chega a se dar conta daquilo que está acontecendo. $\mathrm{O}$ trabalhador conta sua história no intuito de convencer o causídico de várias questões, nenhuma delas associada aos efetivos pedidos que serão posteriormente postulados em seu nome. $O$ trabalhador tenta convencer o causídico de que ele, o trabalhador, é um sujeito honrado e esforçado, que jamais fez "corpo mole" e que, sem embargo, foi injustiçado ao ter recebido pouco, ter trabalhado demais, nunca ter gozado férias ou domingos de descanso etc.

A insatisfação dos trabalhadores que foram observados, ressalvados alguns casos pontuais, é bastante geral e envolve sua condição de vida como um todo. A insatisfação diz com o salário; com o pouco tempo de descanso; com as funções desempenhadas; e, com a dificuldade que é (ou foi) a sua vida durante aquele período. Há aqui uma ideia geral de injustiça que parece pairar sobre as cabeças brasileiras, bem como uma contradição na alma de cada um destes trabalhadores. A escravidão, que produziu feridas ainda abertas no Brasil, tornou a ideia do exercício do trabalho como algo sujo, impuro e injusto de per se. Além disso, há a noção de que o empregador, tal e qual o antigo dono de escravos, aproveita-se dos seus funcionários, utiliza-os e não os remunera nunca de maneira justa e suficiente.

Por outro lado, o posto de trabalho e a fidúcia, ainda que mínima, depositada no trabalhador que logra ser contratado, são bens muito valorizados. Ainda, há uma relação de amizade, proximidade, que pessoaliza as relações de trabalho no Brasil. Não basta que alguém seja um bom profissional, bom empresário, deve-se também primar pela simpatia, pela cordialidade e pelo bom trato nas relações interpessoais. Assim, há também a ideia de algo contra a moral quando o trabalhador volta-se para aquele que o acolheu, deu-lhe um posto de trabalho e confiou-lhe parte de seu patrimônio.

Assim, parece estar presente no subconsciente dos trabalhadores, principalmente daqueles que procuram a assistência jurídica, um paradoxo moral entre a injustiça e a ingratidão, por um lado desejando obter ou reaver valores que Ihe seriam devidos e, por outro, com o sentimento de que estaria sendo mesquinho e ingrato para com seu ex-empregador. A situação é só mais um exemplo de como é 
difícil, ao menos no Brasil ${ }^{644}$, haver a separação entre as relações pessoais e profissionais, algo que acaba por trazer um toque de vingança pessoal ao ato de ingressar com uma ação judicial trabalhista. O "meter no pau" lembra-nos, no século $\mathrm{XXI}$, sobre os pecados cometidos nos séculos anteriores e se faz presente nas relações laborais brasileiras.

\subsubsection{O problema da despedida arbitrária}

É inegável que as relações de trabalho, principalmente após a primeira metade do século $X X$, passaram por muitas transformações. Talvez a mais fundamental tenha sido o reconhecimento do trabalho como elemento de dignidade da pessoa humana, para usar a expressão utilizada pelo legislador constituinte de 1988, no artigo $1^{\circ}$, inciso III, da Carta Republicana, e sua inserção no rol de direitos humanos fundamentais, aliás, fundamento do próprio Estado brasileiro.

Partindo de tal pressuposto, o instituto da despedida deixa de ser apenas uma decisão do empregador para tomar contornos de interesse geral em prol da dignidade do trabalhador. Como se diria no século passado a cena laboral deveria conjugar os interesses do capital e do trabalho, ou, hodiernamente, interesses sociais e econômicos, dois elementos interconectados e dependentes um do outro.

Por isso, na imensa maioria dos países ocidentais, de tradição de direito romano-germânico, a despedida, de um funcionário singular ou de vários, já não se admite sem uma causa que a justifique. Em outras palavras, a Constituição brasileira, a exemplo de outros países, veda a dispensa arbitrária ou sem justa causa. A vedação já está presente no sistema brasileiro há mais de um quarto de século sem haver cobrado um patamar mínimo de efetividade. Aliás, a baixa multa/compensação para o caso de uma despedida sem justa causa traz consigo a impressão de que esta é permitida, bastando depositar algumas migalhas para o trabalhador. Mutatis mutandis, seria como acreditar ser permitido trafegar em excesso de velocidade, bastando, para isso, o depósito de uma multa em favor do Estado.

A dispensa arbitrária, isto é, sem qualquer razão além da arbitrariedade do empregador, ou a sem justa causa, aquela fundada na discricionariedade de uma 
causa, mas não justa o suficiente para embasar o despedimento, são ambas vedadas pela Constituição brasileira. Se a sanção posta é inexistente, insuficiente ou não atende minimamente os requisitos de um sancionamento eficiente, a ponto de coibir a prática da conduta vedada, a norma carece de efetividade. Afinal, é o que se passa em nosso sistema, ao ponto de muitos acreditarem ser permitida a dispensa sem justa causa, fato arraigado, inclusive, no próprio ideário dos trabalhadores. Diversos trabalhadores (exatamente seis daqueles observados em entrevistas) referiram ter feito acordos com seus empregadores para compor de alguma forma as verbas da despedida. Segundo eles, era melhor deixar de receber uma parte das verbas rescisórias, mas que lhes fosse permitido realizar o saque dos depósitos do FGTS (Fundo de Garantia por Tempo de Serviço) e receber as parcelas do segurodesemprego. A despedida sem justa causa é a única que traz tais possibilidades. $O$ pedido de demissão e a despedida motivada por uma justa causa impedem que o trabalhador possa acessar as verbas fundiárias ou receber o seguro-desemprego. Assim, tais acordos são bastante comuns no dia-a-dia das relações de trabalho e versam sobre prestações sociais contributivas, o que parece surreal. Ou seja, empregado e empregador, acordam uma burla ao sistema de prestações sociais contributivas, neste caso, o seguro-desemprego e ao sistema do Fundo de Garantia, tudo "autorizado" ou tornado possível, graças à possibilidade de despedida sem uma justa causa que a embase. Somadas, estas circunstâncias induzem a incrível rotatividade dos postos de trabalho brasileiros e os pesados gastos com subvenções aos desempregados.

Então, ao falarmos de despedida é necessário que tenhamos clara a questão da justa causa, vista a partir de uma interpretação sistemática e constitucional, ela é necessária para qualquer despedida, seja em uma despedida individual, seja na coletiva. O sistema português, a partir da constatação de tal necessidade, divide a justa causa em duas subespécies: justa causa disciplinar e justa causa objetiva.

A justa causa disciplinar é a mesma que, no Brasil, conhecemos como justa causa. É a motivação advinda de uma falta disciplinar grave praticada pelo trabalhador e que torna insustentável a continuação da relação de trabalho. Uma das peculiaridades da justa causa disciplinar é ser ela decorrente de um ato específico (ou reiteração de atos após a progressão de punições). 
Já a justa causa objetiva, traz motivação ligada à empresa. Aqui, a continuação da relação de trabalho também deverá se revelar impossível, mas por outros motivos. A motivação será assentada em questões econômicas ou de mercado, tecnológicas ou estruturais. A maneira de elencar os motivos justificadores da despedida veio, claramente, do sistema concebido para o despedimento coletivo. A causa da despedida é normalmente alheia ao trabalhador.

A possibilidade de que um trabalhador seja despedido a qualquer momento pela simples vontade do empregador, sem justa causa disciplinar ou objetiva, torna as relações de trabalho ainda mais complexas. Primeiro, porque os resquícios da escravidão, como bem refere DaMatta, ainda estão presentes nas relações de trabalho que muitas vezes pessoalizam as relações entre empregado e empregador, a ponto de que ganhar a "simpatia" do empregador, em um contexto onde a despedida arbitrária segue sendo possível, pode ser um atributo fundamental para o sucesso nas relações de trabalho. Segundo, porque se o trabalho é necessidade para a sobrevivência (existência digna), o trabalhador pode ser compelido a assinar documentos, realizar tarefas (como horas extraordinárias excessivas por exemplo) ou sujeitar-se às diversas situações desagradáveis, apenas para que possa seguir mantendo seu posto de trabalho.

Há ainda um terceiro fator a considerar, seja, como a justa causa, no Brasil, restringe-se à justa causa por razões disciplinares, ao ser despedido por justa causa os trabalhadores acreditam que seu histórico laboral fica "manchado", fato referido por, pelo menos, três trabalhadores ouvidos e cujo principal motivo para buscar o ajuizamento de uma demanda na justiça especializada laboral foi o de reverter a "despedida justa". Por óbvio que o recebimento das verbas rescisórias também é um fator que seduz os obreiros a buscar a justiça laboral, mas, pelo relato de tais trabalhadores ao causídico que lhes atendia, pareceu-nos que a questão da mácula causada pela justa causa era o ponto central.

Houvesse a necessidade e possibilidade da despedida por justa causa devido à razões objetivas, a despedida por justa causa deixaria, com o passar do tempo, de representar uma mácula no histórico funcional do trabalhador. A justa causa por razões objetivas envolve diversos fatores alheios à participação do trabalhador, tais 
como crises econômicas; perda de mercado; crescimento da concorrência; preços dos insumos; flutuação bursátil; novas tecnologias etc.

\subsubsection{Desvio de Função versus Poder Diretivo}

Este é um exemplo clássico de como a lei e, neste caso, a interpretação jurisprudencial não se fundem com o horizonte do destinatário da lei, o trabalhador. Foi frequente entre os trabalhadores entrevistados e também nos atendimentos observados a queixa dos trabalhadores por terem sido compelidos, durante o contrato de trabalho, a realizar outras funções, distintas daquela para a qual foram contratados.

Ou seja, no entendimento de diversos trabalhadores, estes deveriam realizar somente as funções para as quais foram contratados e não outras. No imaginário coletivo dos trabalhadores, a função que consta em sua carteira de trabalho, bem como aquelas constantes de seus contratos de trabalho são vinculantes e exigem respeito por parte dos empregadores. Na verdade, a fala de um dos trabalhadores, a quem nos referiremos apenas como P., foi reveladora da injustiça da situação: "Se eu soubesse, não teria aceitado."

Claro, transportássemos a mesma situação para um contrato de natureza civil e as consequências seriam absurdas. Imagine-se que alguém contrata um mecânico para realizar determinado reparo em um automóvel, no entanto, quando já terminado o conserto, pretende que o mecânico também exerça algumas atividades de motorista e recolha os filhos do contratante no colégio. Está bastante claro que, neste último caso, muito provavelmente o mecânico negar-se-ia a realizar a tarefa como diria não ter sido ajustado entre as partes a realização de tal tarefa e que o valor acordado seria suficiente para remunerar apenas o conserto do veículo. A realização da outra tarefa demandaria um novo ajuste.

$\mathrm{Na}$ opinião dos trabalhadores acontece exatamente o mesmo. Ao firmar um contrato de trabalho, entendem que se obrigaram a realizar determinadas tarefas por um determinado salário e não qualquer tarefa ideada pelo empregador durante sua jornada de trabalho. Parece certo que um contrato, qualquer que seja, deve sempre ser lido em seu todo e não somente em seu núcleo. Evidente que a parte central do contrato de trabalho é que alguém se obriga a prestar trabalho por determinado 
salário. No entanto, não podemos esquecer que outras condições provavelmente influem para que o contrato seja firmado como as horas de trabalho, o turno, a descrição das funções, tipos de benefícios oferecidos pelo empregador (plano de saúde, planos de previdência, participação nos lucros etc.). Todas estas circunstâncias podem induzir a que um trabalhador prefira receber um salário nominal mais baixo em troca de outros benefícios como vale-alimentação e plano de saúde. Além disso, a função desempenhada joga também uma parte importante na formação do convencimento do trabalhador para firmar o contrato de trabalho.

É obvio que a função de descarregar cargas ao sol não é parecida, nem equivalente, com a de servir cafés em um ambiente climatizado. Quando há uma oferta de emprego e o trabalhador decide candidatar-se, por certo, leva em consideração tais circunstâncias e, mentalmente, aqui traduzindo de uma linguagem etic para emic, chega à conclusão de que lhe interessa realizar determinadas funções por um determinado salário, e não outras por igual ou diferente salário.

Quando, durante o contrato de trabalho, o empregador passa a exigir outras funções do empregado este último sente-se enganado e entende que sua manifestação de vontade, seu consentimento foi viciado, ao aceitar vincular-se àquele determinado emprego. Sem embargo, ao menos no Brasil, está pacificado entendimento jurisprudencial no sentido de que o empregado deve realizar toda e qualquer função "compatível com suas possibilidades" durante a jornada de trabalho. Há aqui, claramente um descompasso entre o que pensam os trabalhadores e o entendimento jurisprudencial, porque a lei representa coisas distintas a ambos os segmentos.

Cabe destacar, e por certo que este não é o caso, a Organização Internacional do Trabalho ${ }^{645}$, coloca o consentimento do trabalhador como elemento central nas suas classificações de trabalhos forçados. Para a OIT o conceito de trabalhos envolve três elementos centrais que são: a realização de um trabalho ou serviço; a ameaça de penalidade; e, a ausência de voluntariedade. No último requisito, a ausência de voluntariedade pode se dar também pela obtenção de um consentimento favorável através de artifícios, como o engano, o erro, a fraude. 
Assim, o trabalho deixa de ser voluntário, para a Organização Internacional do Trabalho, se o consentimento foi obtido mediante fraude ou ameaça. Não trataremos aqui de trabalhos forçados, mas uma simples analogia poderia ser feita principalmente na questão do consentimento expressado ante informações incompletas ou que não condizem com a verdade.

Por fim, neste tópico, importante deixar clara a opinião dos diversos trabalhadores observados sobre o assunto. A maioria deles acredita ser uma injustiça o fato de que seu empregador lhe contrate para uma determinada função e mande-o realizar outra. São diversos os pedidos de reparação dos trabalhadores por fatos como este, denotando que, ao menos para os trabalhadores, a lei tem distinto significado.

\subsubsection{A lista negra}

É importante destacar um temor que assola a quase totalidade dos trabalhadores observados: o de restar prejudicado em sua vida laboral por ajuizar uma ação trabalhista. $O$ temor era expressado quase sempre no momento em que se concluía pela existência de direitos que levariam ao ajuizamento de uma ação judicial. Neste momento, o trabalhador normalmente realizava uma pausa para perguntar quais seriam as consequências do ajuizamento de uma ação trabalhista para sua vida laboral futura. Quase todos os trabalhadores demonstravam preocupação com as represálias do seu ex-empregador no sentido de fornecer más referências e dificultar as futuras contratações do trabalhador no mercado.

O contexto narrado também nos remete ao período da escravidão e do predomínio de um Estado extremamente alinhado com o modus operandi fascista. Nestes sistemas, o trabalhador deveria apenas trabalhar e jamais reinvidicar seus direitos, sendo severamente punido aquele que o fizesse. Também são dessa época outras legislações que buscavam impor o trabalho (no sentido moderno da palavra), sob pena de prisão ou detenção, a exemplo dos tipos contravencionais penais que proibiam e proíbem até hoje a vadiagem ${ }^{646}$.

646 BRASIL. Lei das Contravenções Penais. Decreto-Lei No 3.688, de 3 de outubro de 1941.

Art. 59. Entregar-se alguem habitualmente à ociosidade, sendo válido para o trabalho, sem ter renda que lhe assegure meios bastantes de subsistência, ou prover à própria subsistência mediante ocupação ilícita:

Pena - prisão simples, de quinze dias a três meses. 
Sendo assim, quase sempre, o trabalho do causídico também consistia em convencer o trabalhador de que tais retaliações já não são mais tão frequentes e são consideradas atos discriminatórios, de maneira que poderiam ensejar novas ações. Ainda, a justiça obreira tem tomado muitas precauções neste sentido e torna-se cada vez mais difícil descobrir a quantidade e/ou qualidade dos processos ajuizados por determinado trabalhador.

A denominada lista negra, contudo, permanece viva no imaginário dos trabalhadores como resquício de outros períodos. Ainda que a prática apresente atualmente poucas consequências práticas, existem diversos trabalhadores que deixam de ajuizar ações em razão do temor de represálias por parte de seu exempregador.

\subsubsection{Das $08 \mathrm{~h}$ às $17 \mathrm{~h}$ com uma hora de intervalo}

A resposta acima, busca representar a síntese das respostas dos trabalhadores ao serem indagados sobre sua jornada de trabalho, declinavam a jornada de trabalho que constava em seu contrato de trabalho. Então, normalmente, o advogado que atendia o trabalhador, começava a questionar sobre os horários de entrada e saída, os tempos de intervalo para descanso. Em seguida, então, o trabalhador começa a declinar seus horários efetivos de entrada e de saída e os tempos de intervalo para descanso. Cabe ressaltar, em diversas oportunidades, a jornada efetivamente praticada estava muito distante daquela jornada contratual.

No entanto, a situação revela, por um lado, a importância que os trabalhadores em geral dão para o contrato de trabalho firmado com o empregador e por outro, a diferente compreensão das perguntas feitas pelos operadores jurídicos. Note-se que o causídico, ao perguntar sobre a jornada de trabalho dos obreiros, perguntava sobre a real jornada, a praticada efetivamente, justamente no intuito de avaliar as possíveis consequências jurídicas da jornada praticada em relação àquela constante do contrato de trabalho. No entanto, os trabalhadores, de forma quase unânime e uníssona, respondiam, invariavelmente, citando a jornada contratual.

Se a mesma resposta dada ao causídico fosse dada em uma audiência, todos entenderiam que a jornada contratual era cumprida à risca e, portanto, não haveria fundamento fático, jurídico, legal ou contratual para o pedido de horas 
extraordinárias. Este fato, considerado no contexto, demonstra, mais uma vez, que a linguagem utilizada pelos operadores do direito é bastante distinta daquela utilizada pelos trabalhadores. Por outro lado, os trabalhadores atribuem suma importância ao contrato de trabalho, em seus diversos itens e aspectos, ainda que o não compreendam perfeitamente. Devemos levar em consideração, que o trabalhador ordinário não está habituado com avançadas técnicas de interpretação do texto contratual ou legal e tampouco com as diversas orientações jurisprudenciais que constantemente são construídas e desconstruídas nos tribunais.

Além da observação participante e das entrevistas em profundidade, também foram respondidos alguns questionários por aqueles trabalhadores que com isso concordaram e dispuseram alguns minutos para a realização da pesquisa. Os questionários recolhiam perguntas bastante simples, possibilitando o entendimento da maior parte dos trabalhadores ainda que, em alguns casos, fosse necessário auxílio do pesquisador para a correta compreensão das perguntas.

\subsection{Sobre os questionários}

Como já mencionado, foram aplicados 47 questionários nos sujeitos que voluntária e anonimamente acederam a respondê-los. Os questionários foram respondidos por trabalhadores que buscavam atendimento jurídico no Bairro Restinga e também no Bairro Petrópolis.

O objetivo dos questionários foi o de oferecer um panorâma geral dos trabalhadores, bem como o de fornecer alguns dados para análise com relação ao mercado de trabalho, a categoria profissional e o sindicato da categoria. Foram aplicados questionários diretos seguindo as recomendações de Nogueira ${ }^{647}$. Levamos em consideração a necessidade de que os questionários pudessem ser respondidos de maneira rápida e por trabalhadores com muito distintos níveis de escolaridade. Aliás, em alguns casos, houve o preenchimento do questionário com a assistência de um leitor, especialmente quando o trabalhador apresentava pouca familiaridade com a leitura e a compreensão de texto. Comentaremos alguns dos dados gerais e, a seguir, procuraremos estabelecer correlações entre as respostas em cada categoria. 
O perfil predominante são de mulheres entre 31 e 45 anos. A diferença entre homens e mulheres não pode ser considerada significativa para o caso e também pode ter a ver com as condições de voluntariado para o preenchimento dos questionários. Já a faixa etária com mais pessoas dobra a segunda mais prevalente conforme se nota nos gráficos ${ }^{648}$ abaixo:

\section{Gráfico 1 IDADES}

$\varpi$ Entre 18 e 30 anos $₫$ Entre 31 e 45 anos - Entre 46 e 60 anos $₫$ Mais de 60 anos

$9 \%$

$21 \%$

$23 \%$

$47 \%$

\section{Gráfico 2}

SEXO

Masculino Feminino

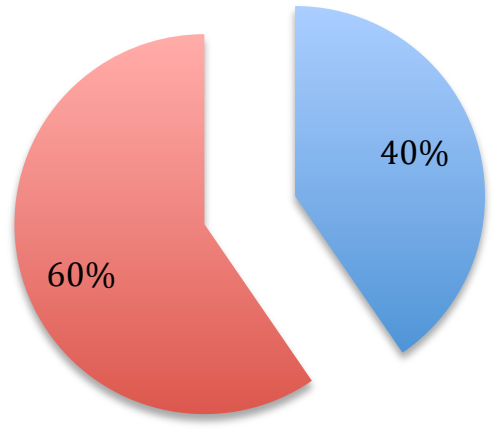

648 Todos os gráficos foram elaborados pelo próprio autor com base com nos questionários respondidos pelos informantes. 
O questionário possuía algumas instruções complementares para o preenchimento, de maneira que não houvesse dúvidas no momento de colocar as informações. É o caso das duas perguntas seguintes que buscavam averiguar, por um lado, quantos anos, dos últimos dez, o sujeito esteve trabalhando em alguma atividade, formal ou informal. A pergunta seguinte buscava averiguar, no mesmo período (últimos dez anos), se o sujeito esteve trabalhando no mercado formal. No Brasil, popularmente, estar no mercado formal quer dizer trabalhar com a carteira de trabalho assinada pelo empregador. A condição de autônomo, mesmo que registrada e dentro do mercado formal, foi considerada para os nossos fins como pertencente ao mercado informal já que a sindicalização de trabalhadores autônomos está em um limbo no Brasil dada a estrutura sindical já explicitada.

Poder-se-ia dizer, preservando uma visão quase medieval, que os autônomos não se poderiam sindicalizar simplesmente porque não possuem o polo oposto com o qual contender e apresentar exigências. Ou seja, não estaria formada a dicotomia capital-trabalho "necessária" à prática sindical. É quase o argumento lançado por alguns autores, a exemplo de Orlando Gomes e Elson Gottschalk ${ }^{649}$ que estabelecem a diferença entre sindicatos e corporações de ofício justamente pela ausência, no caso destes últimos, de um polo oposto com o qual contender.

De qualquer forma, os dois gráficos seguintes revelam as condições de trabalho formal e informal do universo estudado:

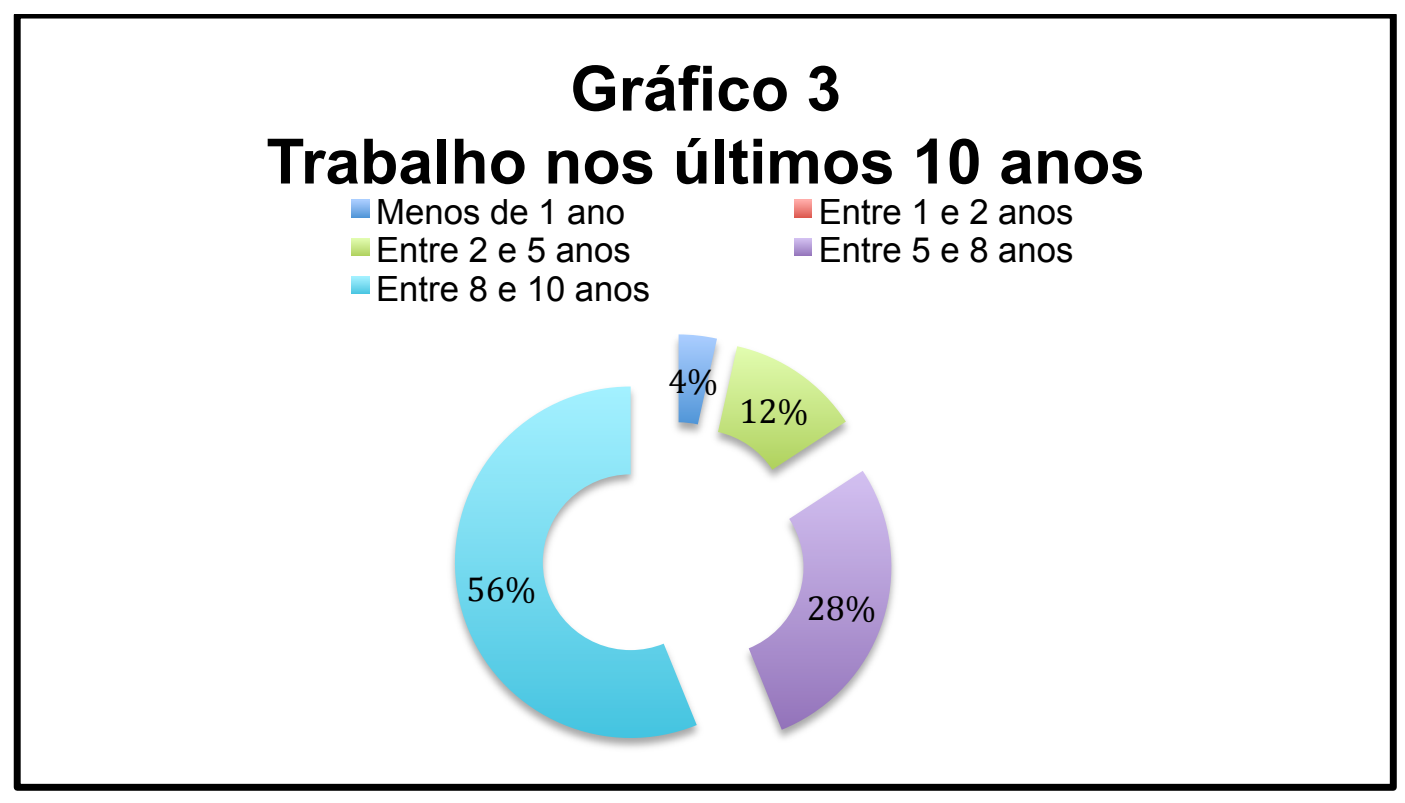

649 GOMES e GOTTSCHALK, 2002. 


\section{Gráfico 4 \\ Trabalho com carteira assinada nos últimos 10 anos}

Menos de 1 ano

Entre 5 e 8 anos
Entre 1 e 2 anos

Entre 8 e 10 anos

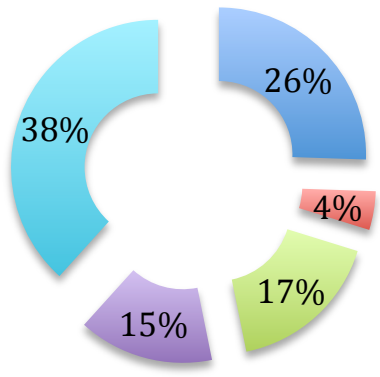

Entre 2 e 5 anos

Como se pode notar, a maioria dos trabalhadores laborou na maior parte ou na integralidade dos dez últimos anos, considerando-se qualquer trabalho. Quando partimos para análise do trabalho formal, a proporção daqueles que trabalharam entre 8 e 10 anos reduz-se de $58 \%$ para $38 \%$. No que toca ao trabalho formal e informal, nota-se que a maior parte dos trabalhadores laborou mais de 5 anos nos últimos dez. No trabalho em geral os maiores percentuais são os de maior tempo que significam o trabalho entre 5 e 10 anos nos últimos 10 anos. Já ao passar-se à análise do trabalho formal há uma inversão de percentuais onde o trabalho com menos de um ano assume a segunda posição no lugar do trabalho entre 5 e 8 anos.

Tal contexto corrobora estudos no âmbito do $\mathrm{IBGE}^{650}$, onde o tempo de permanência no trabalho é normalmente superior a 2 anos em todas as regiões metropolitanas estudadas. Na região metropolitana de Porto Alegre, em dezembro de 2015, 69,9\% dos trabalhadores permanecem mais de dois anos no mesmo emprego. O segundo maior percentual, também corroborando o presente estudo, é de vínculos de menos de um ano, o que soma um total de $18 \%$.

A circunstância provavelmente reflete a realidade dos contratos de experiência ou temporários onde é contratada mão de obra por tempo determinado de no máximo 90 dias, no caso dos contratos de experiência e, de no máximo 6 
meses, no caso dos contratos a prazo determinado. Superados os umbrais relativos à contratação temporária ou ao contrato de experiência, normalmente há a permanência no emprego por mais de dois anos, chegando a longos períodos como 8 ou 10 anos, tal como evidenciado no presente estudo.

Além disso, é importante destacar, não há, ou existe em pouca quantidade e qualidade, diálogo entre empregados e empregadores em relação às condições de trabalho. As reclamações dirigidas aos advogados normalmente são referidas à totalidade do contrato de trabalho demonstrando que as situações perduram anos sem resolução e sua discussão é postergada para após a rescisão do contrato.

Nos gráficos seguintes também se pode notar a circunstância de que a duração média no emprego no Brasil, de aproximadamente três anos, segundo os mesmos dados do IBGE, corrobora a quantidade de empregos distintos em dez anos apresentada pelos questionários com predominância de três empregos em dez anos conforme os gráficos abaixo:

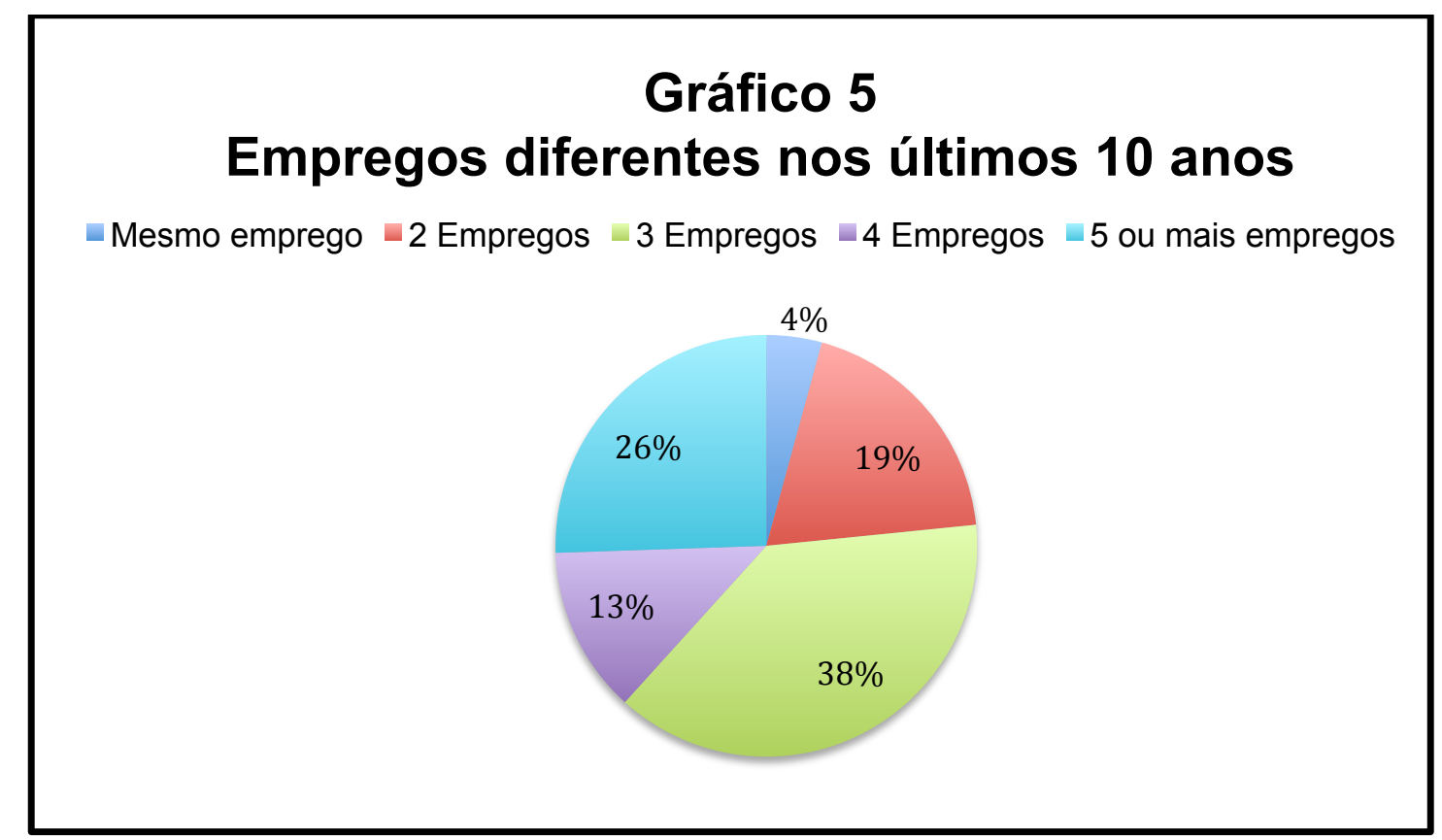

Como se pode notar, o maior percentual é daqueles trabalhadores com três empregos distintos em dez anos (38\%) dos questionados. O segundo maior percentual é daqueles que ostentaram um mesmo emprego nos últimos dez anos, o qual, contudo, é superado pela soma dos trabalhadores que tiveram 2, 4 ou mais de 5 empregos nos últimos dez anos. Portanto, parece que a média apontada pelo 
IBGE também é corroborada no presente estudo com um tempo médio de três anos de permanência no emprego ou 3 trabalhos em dez anos.

Este contexto também foi adiantado por Richard Sennet ${ }^{651}$ em sua obra sobre as consequências pessoais do trabalho no novo esquema capitalista. $O$ autor destaca existir atualmente uma maior necessidade de mudança e adaptação dos trabalhadores e que o trabalhador médio do século XXI necessita ser flexível e estar sempre em movimento, já que as rotinas e previsibilidade não mais atributos do mercado de trabalho. A questão proposta por Sennet é também evidenciada no seguinte gráfico:

\section{Gráfico 6 Ramo de atividade nos últimos empregos}

$\square$ Mesmo ramo $\quad$ Ramos diferentes

$47 \%$

$53 \%$

Daqueles trabalhadores que tiveram vários empregos ao longo dos últimos dez anos, mais da metade (53\%) o fez em distintos ramos de atividades. Note-se que não se trata de atividades distintas em um mesmo ramo de indústria ou serviço, como por exemplo o comerciário que, de vendedor, passa a caixa, mas de mudanças completas de atividade, como é o caso do vendedor que passa a exercer a atividade de motorista ou vigilante.

O seguinte gráfico também corrobora os demais, já que trata sobre a atividade efetivamente desempenhada e onde, novamente, o percentual 
prevalecente foi 0 daqueles trabalhadores que tiveram ao menos 3 atividades distintas nos últimos dez anos, com um total de $41 \%$ dos questionados.

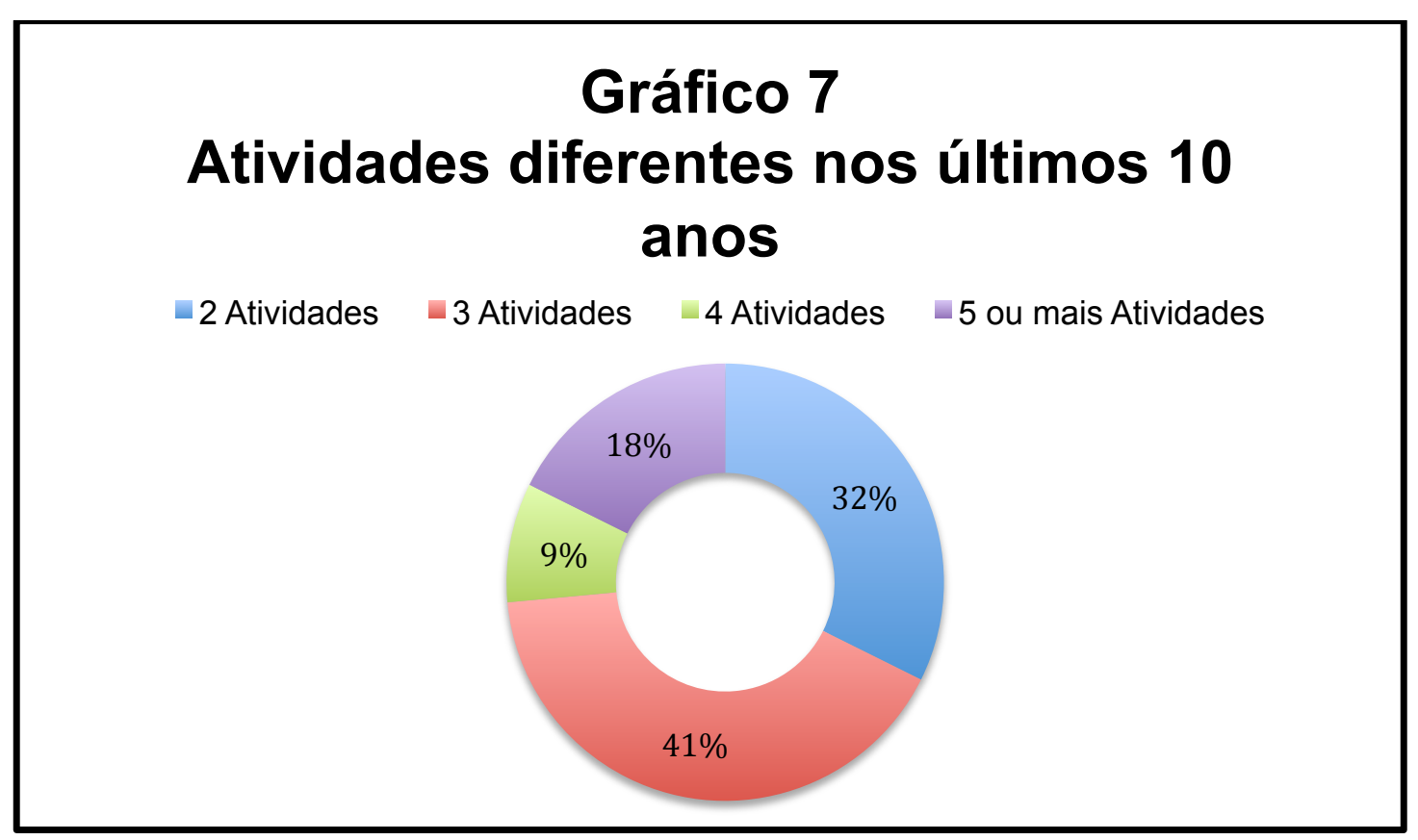

A rotatividade e flexibilidade de funções, no entanto, parecem não ter relação direta com a formação para determinada profissão. É importante destacar que, por formação, entendemos, no âmbito do presente estudo, como qualquer nível de conhecimentos técnico-acadêmico-profissionais necessários ao desempenho de determinada função, ainda que esta não esteja reconhecida como uma profissão diferenciada e não possua um status jurídico próprio. Assim, sem embargo de que aproximadamente a metade dos questionados possuísse formação para o exercício de determinada profissão, foram obtidas as médias anteriormente citadas com relação ao número de diferentes trabalhos nos últimos dez anos, bem como os distintos ramos de atividades. Certamente, o percentual daqueles que mudaram de ramo de atividade deve ser composto por trabalhadores sem uma formação específica, o que torna mais fácil e menos custosa a adaptação em um novo setor. 


\section{Gráfico 8 \\ Formação específica para alguma profissão}

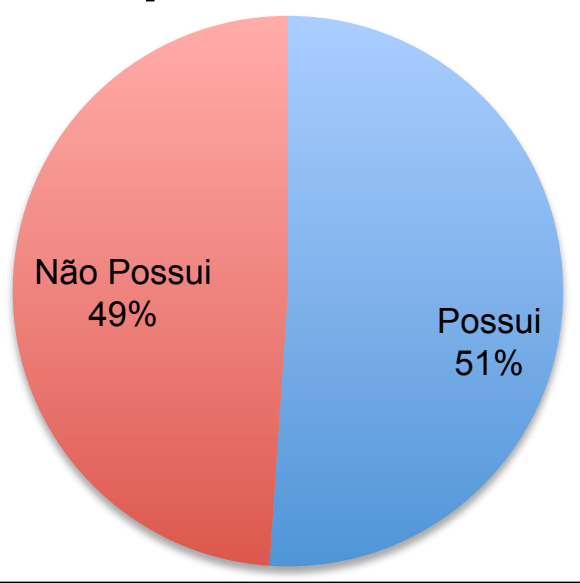

O seguinte gráfico corrobora a hipótese lançada acima, demonstrando que os trabalhadores que possuem formação, em sua maioria, trabalharam a quase integralidade dos últimos dez anos na atividade para a qual possuem formação $(41 \%)$. Entretanto, a soma daqueles que trabalharam menos de um ano (umbrais do contrato de experiência e trabalho temporário) e daqueles que trabalharam entre $2 \mathrm{e}$ 5 anos (onde está inserto o tempo médio de permanência no emprego) supera o percentual dos trabalhadores que se mantiveram firmes na atividade de formação, com um total de $42 \%$. Os dados permitem inferir a existência de uma grande rotatividade no mercado de trabalho e que a mesma não se restringe ao emprego formalmente considerado, mas também ao ramo de atividade e às funções desempenhadas.

Tal contexto, aliado às atuais normas sindicais brasileiras, também faz com que, em cada troca de emprego o trabalhador tenha de obrigatoriamente mudar de sindicato já que a regra-geral se dá pela atividade econômica do empregador. Ao mudar de representação a cada três ou quatro anos, impede-se a formação de vínculos duradouros entre os trabalhadores da mesma categoria bem como para que os trabalhadores possam angariar a confiança e apoios necessários para o caso de desejar concorrer aos cargos de direção sindical. 


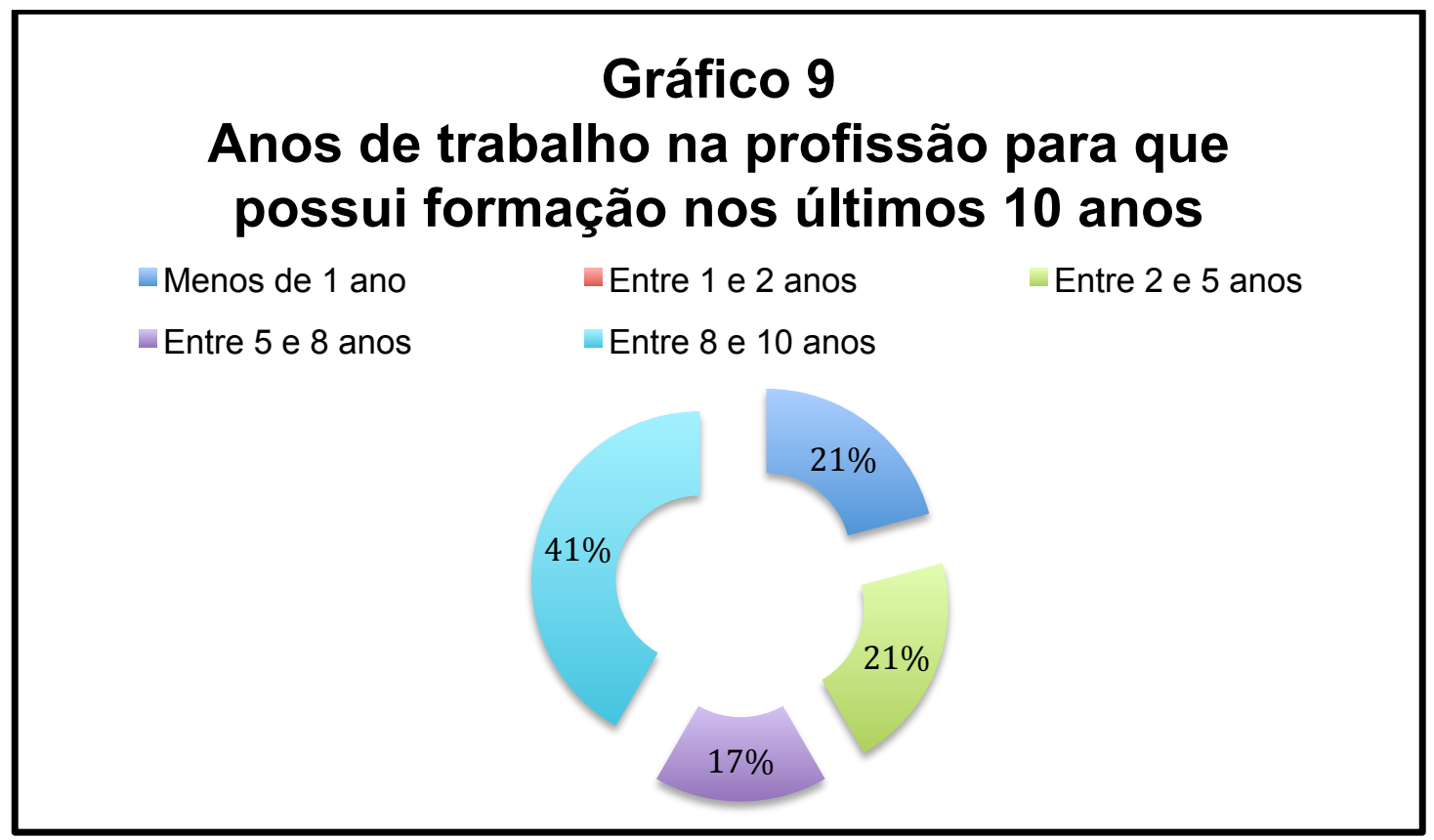

Os gráficos a seguir passam a demonstrar o grau de conhecimento e de proximidade dos trabalhadores questionados com $\mathrm{O}$ sindicato $\mathrm{e}$ com os trabalhadores da mesma categoria. A maioria dos trabalhadores, como seria previsível, declara conhecer o sindicato que representa ou representava a sua categoria.

Como já mencionamos anteriormente, em todos os contratos de trabalho formais com mais de um ano de duração, a rescisão contratual deve ser realizada obrigatoriamente com a assistência sindical para a rescisão contratual. Portanto, muito provavelmente, entre os trabalhadores que sequer conhecem ou conheceram o sindicato de sua categoria estarão aqueles que laboraram no mercado informal ou que laboraram no mercado formal, mas por período inferior a um ano.

Entre aqueles que declararam conhecer o sindicato da categoria, não significa participação nas atividades sindicais ou mesmo sentimento de representação por aquela agremiação. Aliás, $70 \%$ dos questionados, mesmo declarando conhecer o sindicato de sua categoria, procuraram assistência jurídica em outro local e não no sindicato de sua categoria. Note-se que a assistência jurídica aos representados (não há necessidade de filiação para que o trabalhador possa usufruir da maioria dos serviços que são deveres dos sindicatos). 
Neste sentido, duas hipóteses são possíveis, ou há um completo desconhecimento dos seus direitos enquanto trabalhador e sujeito que recolhe obrigatoriamente a contribuição sindical ou o trabalhador conhece seus direitos, mas não confia no sindicato de sua categoria preferindo aconselhar-se e contar com a assistência jurídica de outros profissionais. A contratação de advogados para demandar na justiça laboral invariavelmente ocasionará uma perda de direitos por parte do trabalhador, já que uma porcentagem de seus ganhos será destinada ao pagamento de seus procuradores. Há, na prática, o pagamento em dobro, de serviços sindicais não utilizados, os quais são custeados, principalmente, pela contribuição sindical de cunho obrigatório e o pagamento de advogados privados quando há a necessidade de aconselhamento ou demandas judiciais.

\section{Gráfico 10 \\ Conhece ou conheceu o sindicato da sua categoria?}

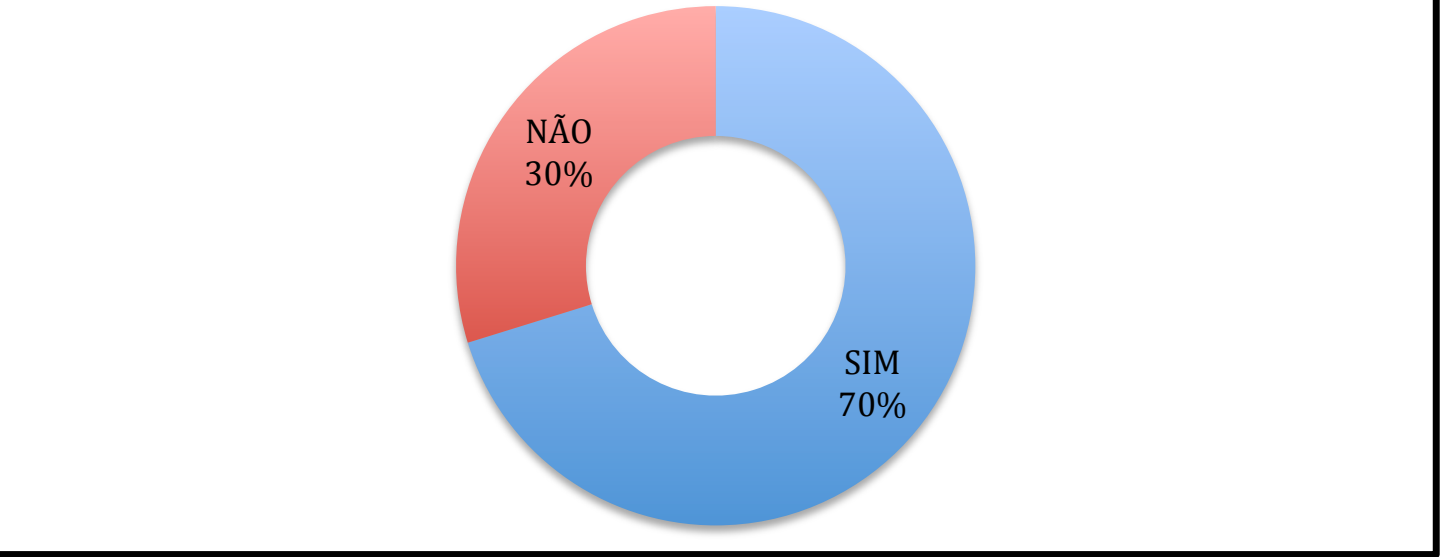

Para os próximos resultados, consubstanciados no gráfico 11 , o resultado praticamente é invertido. Dos questionados, um total de $60 \%$ afirma que nunca foi filiado a nenhum sindicato e apenas $40 \%$ já foram, em algum momento de sua vida laboral, filiados a algum sindicato. Note-se que na pergunta havia a ressalva de que, para que o trabalhador seja considerado filiado ao sindicato, haveria a necessidade de algum tipo de cadastro ou termo de adesão/filiação, bem como o pagamento de mensalidade.

É importante destacar que muitos sindicatos estabelecem a imposição de outras contribuições via negociação coletiva, as quais são impostas aos 
trabalhadores da categoria mesmo que estes não sejam filiados ao sindicato. Não se pode excluir, embora as explicações fornecidas para o preenchimento do questionário, que alguns trabalhadores tenham confundido a "contribuição assistencial" descontada em seus pagamentos, com a mensalidade sindical devida somente pelos trabalhadores afiliados.

\section{Gráfico 11 Já foi filiado a algum sindicato?}

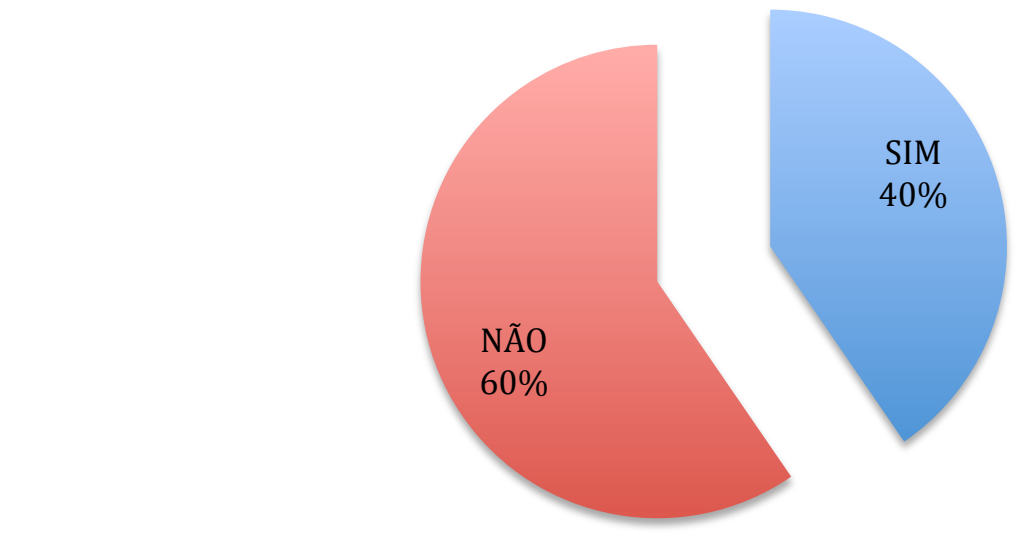

No gráfico de número 12, a maioria dos trabalhadores alega conhecer as funções do sindicato que defende a sua categoria profissional. Mesmo conhecendo tais funções, todos os trabalhadores questionados estavam buscando orientações jurídicas fora dos sindicatos da sua categoria. Isso nos permite concluir que muitos trabalhadores, mesmo conhecendo a obrigação de que o sindicato preste assessoria jurídica aos representados, prefere buscar auxílio em outros locais e não no sindicato. Este fato significa que a representação e atribuição "automática" de um sindicato ao trabalhador não tem o condão de inspirar neste último sentimentos de representatividade e confiança suficientes para que conte com a entidade sindical no momento de necessidade. 


\section{Gráfico 12 \\ Conhece as funções do Sindicato da sua categoria?}

No gráfico de número 13, a imensa maioria dos trabalhadores questionados afirma saber quais são os trabalhadores que compõem a sua categoria profissional. Embora a maioria dos questionados, segundo os dados dos gráficos 10, 12 e 13, afirme ter conhecimento do sindicato de sua categoria, das funções e dos trabalhadores que o compõem, tais dados não se coadunam com as estatísticas gerais que mostram o Brasil como um País com baixos níveis de participação sindical e com apenas uma ínfima parte dos trabalhadores como militantes sindicais (apenas 16 milhões em um universo de mais de 90 milhões de trabalhadores).

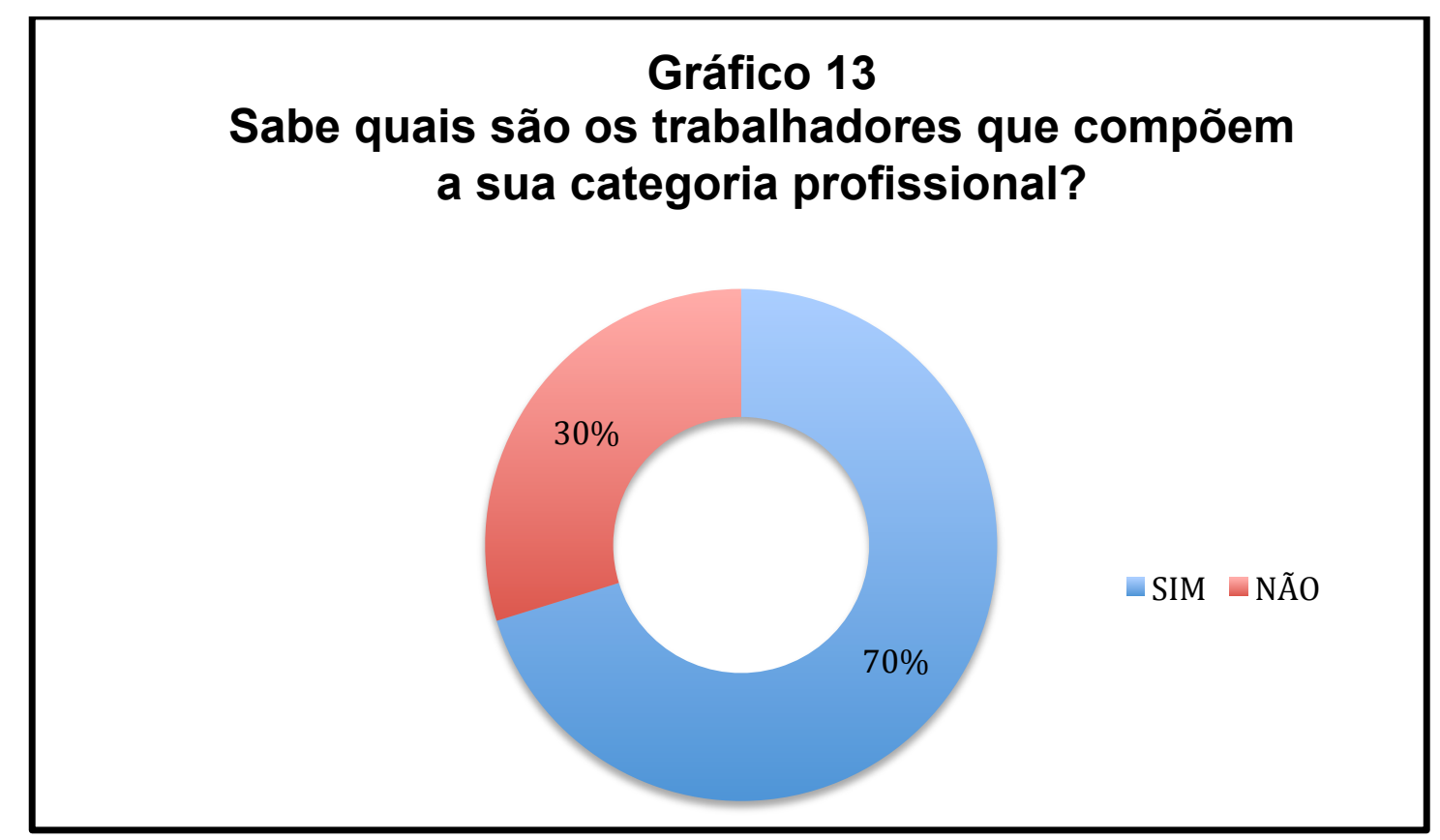


No gráfico de número 14 revela-se a impressão dos trabalhadores sobre sua categoria profissional, assim como, de maneira intuitiva, muitos acreditam que a categoria profissional constitui-se de maneira distinta das determinações legais. A regra-geral é de que a categoria profissional seja formada de acordo com a atividade econômica do empregador. Assim, na maior parte das vezes, todos os trabalhadores de uma mesma empresa, excetuados aqueles que compõem categorias profissionais diferenciadas, pertencerão a uma mesma categoria profissional. Por exemplo, se a empresa é da área do comércio, seus funcionários pertencerão à categoria dos comerciários.

Neste sentido, pouco mais da metade dos trabalhadores afirmou que os trabalhadores que considera mais próximos (no sentido de vivenciar os mesmos problemas, ter a mesma visão de mundo, explicação fornecida para o preenchimento do questionário) são os colegas de trabalho na mesma empresa. Um dado interessante, já adentrando em correlações entre as respostas fornecidas é que, tanto aqueles trabalhadores que afirmaram conhecer sua categoria profissional, como aqueles que afirmaram não a conhecer, responderam de maneira distinta e extremamente dividida a pergunta do gráfico de número 14. Ou seja, a categoria é constituída pelos demais trabalhadores da mesma função para alguns e para os companheiros da mesma empresa para outros. Ainda, alguns trabalhadores consideram que o componente territorial é importante e serve para aproximação das visões de mundo e embrião de associativismo. 


\section{Gráfico 14 \\ Quais os trabalhadores que considera mais próximos a você?}

Colegas da mesma empresa

Vizinhos do mesmo bairro
- Todos que exercem a mesma função

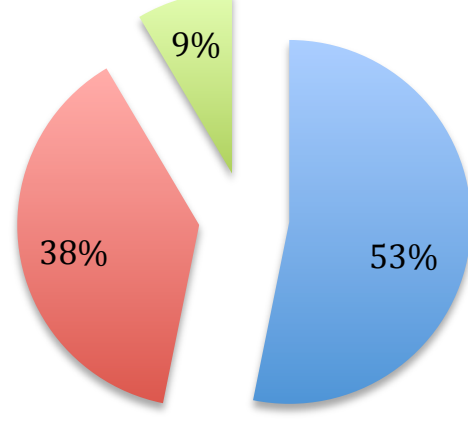

Os questionários e os dados obtidos a partir da contabilização das respostas, servem para trazer um panorama dos trabalhadores que buscam assistência jurídica em Porto Alegre por razões laborais. Como se pode notar, buscou-se avaliar o perfil dos questionados, bem como alguns de seus interesses, ideias e opiniões de forma a complementar o trabalho de campo e servir como elemento de apoio às demais estatísticas, impressões e teorias já expostas durante o trabalho. 


\section{CAPÍTULO VIII - CONCLUSÕES}

Em uma tese doutoral e sobre um assunto tão amplo, diverso e polêmico como o que aqui tratamos, não temos a pretensão de encerrar o debate. Utilizamos o termo conclusão apenas para indicar o fechamento do presente estudo e também por sua equivalência aos termos "conclusiones" do espanhol e "conclusions" do inglês. As três línguas (inglês, espanhol e português) são as usuais em comunicações de trabalhos científicos no contexto ibero-americano e, ainda que em português muitos venham optando pela expressão "considerações finais ${ }^{652 ",}$ preferimos utilizar o termo conclusões pela correspondência com os demais idiomas e pela praxe da linguagem utilizada no meio acadêmico. Por certo que não pretendemos indicar o esgotamento do assunto tratado. Talvez toda uma vida de estudos não seja suficiente para esgotar apenas e cada um dos tópicos principais por nós tratados no presente trabalho.

Por outro lado, o trabalho de selecionar assuntos e bibliografia também implica a escolha de autores e de obras, em detrimento de outras. Com o desenvolvimento a passos largos da ciência torna-se impossível dentro do tempo de realização de uma tese doutoral, conhecer e manejar todas as obras relevantes sobre cada tema. Neste estudo fizemos nossas opções, principalmente pelo manejo de autores clássicos e já consagrados sobre os assuntos tratados. As inovações ficaram por conta do trabalho de campo etnográfico que colheu as opiniões e considerações dos trabalhadores e da interpretação dada, seja a artigos de lei, seja às teorias apresentadas ou mesmo para os resultados da observação participante.

O presente estudo contou com algumas dificuldades, não sendo possível realizar o trabalho de campo pelo tempo considerado como ideal, segundo a literatura especializada. Fizeram parte das dificuldades a distância entre Porto Alegre, no extremo Sul do Brasil, e Salamanca, na Espanha, o calendário de atividades acadêmicas, bem como a exigência de outras diversas tarefas ao longo da tese doutoral das quais somente a publicação de artigos em revistas de reconhecido prestígio, revelou-se uma tarefa hercúlea a demandar muito do tempo

652 A expressão "considerações finais" tem sido utilizada para indicar o fechamento de trabalhos acadêmicos principalmente por parecer menos pretenciosa que o termo conclusões que, na visão de alguns, suporia o esgotamento do assunto. 
disponível. Sem embargo, acreditamos também ter existido uma série de circunstâncias que possibilitaram um melhor andamento do trabalho, tais como o apoio incondicional e constante de parte dos orientadores, a bolsa de estudos recebida por parte do Banco Santander e, por fim, o amparo constante de amigos e familiares.

\subsection{A Antropologia no Século XXI:}

A antropologia é uma ciência nova e versátil, foi-se adaptando aos novos tempos tal e qual a teoria da adaptação evolutiva, primeiro adiantada por Spencer e depois desenvolvida por Darwin. Nestes pouco mais de 150 anos de antropologia (consideraremos, para este fim, a escola evolucionista e da antropologia marxista, ambas com início em meados do século XIX) foram muitas orientações teóricas e obras de relevo, que ajudaram não só a compreender nossa sociedade, mas também a modificá-la. Procuramos dar a conhecer a antropologia, principalmente para aqueles profissionais que são somente afeitos ao estudo do direito e podem ganhar muito a partir da compreensão sócio-cultural do fenômeno jurídico.

A antropologia encontra-se atualmente em um estágio de estagnação enquanto às grandes correntes teóricas e grandes debates mundiais. Está dividida em focos de atuação especializados e aplicados que tendem a apropriar-se das discussões sobre determinado aspecto social, vide o exemplo das vicissitudes indígenas, dos imigrantes ou de outras minorias. A antropologia urbana, de algum modo, tem-se tornado a nova antropologia e busca respostas para a maior parte das questões que afligem a humanidade, já que mais da metade da população mundial vive em áreas urbanas e a tendência é de incremento neste número. Mesmo no caso da antropologia urbana, existem muitos focos de atuação e não há uma unidade de conceitos e de assuntos de pesquisa.

O valor da antropologia, em nosso entender, principalmente em tempos onde tudo deve ser rápido e resumido (em no máximo 140 caracteres como é o caso do aplicativo Twitter) é oferecer respostas para as situações simples. São aquelas situações que todos conhecemos, repetimos e, na maior da parte das vezes, o fazemos de maneira inconsciente, apenas seguindo a traditio. 
Porquê nos casamos? Porquê realizamos rituais funerários? Porquê brindamos com bebidas? Porquê fazemos de almoços, happy-hours e jantares ocasiões sociais onde nos aproximamos de pessoas às vezes desconhecidas? A maior parte de tais perguntas já foi respondida pela antropologia em pouco mais de 150 anos. Muitos podem dizer que de nada serve saber essa resposta ou que saber a origem não mudará os hábitos das pessoas. O mesmo se pode dizer da lei da gravidade, por acaso não sabiam todos que os objetos caiam quando soltos no espaço (aqui o espaço não se refere, por óbvio, ao espaço sideral onde a gravidade é ínfima)? No entanto, a descoberta de Newton foi aclamada como revolucionária e capaz de mudar todos os paradigmas. Estamos de acordo, e assim foram os achados antropológicos deste século e meio de descobertas, polêmicas e etnografias.

Nossa tarefa atual é utilizar a antropologia para tentar responder outras perguntas que, em nosso entender, à ela cabe responder. O autor Filipe Barbosa Garcia, já citado neste estudo, reconhece em seu excelente livro sobre direito do trabalho que a formação de categorias e os grupos profissionais são problemas mais afeitos às ciências sociais que ao direito. E, efetivamente, dentro das ciências sociais, a antropologia parece ser a que mais pode contribuir para o estudo das formações e dos grupos profissionais. Muitos autores, ao longo da história, autores do relevo de Spencer e de Durkheim, preocuparam-se sobre a origem das profissões, caso de Spencer, ou sobre a divisão do trabalho, caso de Durkheim. E essa parece ser uma questão afeita ao método antropológico que, combinado aos conhecimentos do direito, pode auxiliar no deslinde do tema.

Não é demais dizer, o estudo da antropologia marxista também pode auxiliar na derrubada de velhos mitos relacionados às relações de trabalho. Em primeiro lugar, não é demais recordar, a obra-prima de Marx "O capital" completa, no ano de redação das presentes conclusões (2017), seus 150 anos de publicação. Por outro lado, a teoria marxista apoia-se em grande parte no esquema evolucionista. No entanto, enquanto este último foi coberto de críticas e foi superado por diversas outras perspectivas ao longo destes últimos 150 anos, a ponto de que todos, ao menos na área de antropologia, referirem o esquema evolucionista apenas por seu valor histórico e teórico para o desenvolvimento do estudo da cultura. Ninguém se 
atreveria, em pleno 2017, a respaldar o esquema de Morgan sobre os estágios da humanidade ou seguir acreditando na evolução unilinear e por etapas. Aliás, o esquema evolucionista, como já referimos, foi um dos grandes responsáveis por conferir, ao vocábulo evolução, um sentido associado ao de avanço em uma direção determinada, quando, na verdade, disso nunca se tratou. Sem embargo, as teorias marxistas seguem vivas e ganhando adeptos que às vezes as utilizam de maneira ortodoxa, sem respeitar seus matizes e, principalmente, sem superar a dimensão histórico-cultural que nos separa, hoje, da realidade na qual escreveu Marx.

Bem assim, parece que já superamos a perspectiva de que todas as ações humanas possuem um fim exclusivamente material. A antropologia desdobrou-se em exemplos, sendo alguns clássicos como o Potlach e o Kula de que nem todas as ações humanas visam a um fim exclusiva ou primordialmente material. Nos movemos, muitas vezes, imbuídos de outros sentimentos, como a vontade do reconhecimento, crescimento do prestígio, honra, pena, empatia etc. O próprio Marx reconhecia, no seu livro "formações econômicas pré-capitalistas" que, em Roma, durante um bom período, o sistema social era destinado a criar melhores cidadãos e não a maximizar lucros.

Entendemos que algo similar passa atualmente, o sistema capitalista não tem por objetivo maximizar os lucros deste ou aquele e sim tornar melhores as condições de vida gerais. Por óbvio que existem diversas aberrações quando, principalmente, começam a mesclar-se os interesses estatais e empresariais e o Estado deixa de atuar em nome da totalidade a que deveria representar. Existem, contudo, outros bons exemplos, que souberam conjugar as virtudes de uma posição intermediária entre a utopia Marxista e o capitalismo desenfreado, como é o caso dos Estados escandinavos que (como indicado anteriormente) também possuem índices altíssimos de filiação e participação de trabalhadores em sindicatos e ótimos índices de qualidade de vida em geral.

Com relação ainda à teoria marxista, quiséramos acrescentar a necessidade de superação do maniqueísmo existente entre trabalho e capital ou entre trabalhadores e empregadores. Em primeiro lugar, nem sempre os interesses serão contrapostos e, muitos dos problemas enfrentados por ambos são, na verdade, problemas de responsabilidade do Estado que, ao menos no Brasil, 
convenientemente, aparta-se das discussões sindicais como se fosse um ente alheio aos conflitos laborais. Em segundo lugar, é óbvio que existirão, invariavelmente, interesses contrapostos entre empregados e empregadores assim como existem em diversas outras esferas da sociedade onde existem lítigios e estes são resolvidos, judicialmente ou extrajudicialmente através da negociação e composição. Aliás, cabe destacar, existem interesses contrapostos inclusive entre categorias profissionais, na busca da reserva de espaços de mercado e designação de tarefas exclusivas à esta ou àquela categoria. A luta de classes foi uma hipérbole para designar o redirecionamento dos conflitos entre grupos humanos de uma esfera para a outra. É evidente que em um sistema capitalista os conflitos entre trabalhadores e empregadores adquirem um papel central nas discussões em razão da própria forma como estruturado o sistema, mas, daí a dizer que a finalidade da luta de classes é a própria extinção do sistema a partir da vitória dos trabalhadores parece um exagero inaceitável atualmente. Não é demais dizer que o valor das empresas e das commodities, na era da sociedade da informação está muito mais associado a valores, ideias e demanda do que efetivamente ao custo do produto e às horas de trabalho que se investiu para produzi-lo. As bolsas de valores sobem ou descem por questões, na maioria das vezes, alheias aos trabalhadores de determinadas companhias, embora a felicidade dos trabalhadores e boa valoração da empresa por parte destes possa contribuir com o aumento do seu valor de mercado. Pode-se concluir, por isso, que nem todos os interesses de empregadores e trabalhadores são contrapostos e é possível aproximar-se de soluções intermediárias que sejam vantajosas para a maioria.

Assim, como os limites entre as ciências são artificiais e destinados a organizar e facilitar a ação e o pensamento humanos, o homem também é indiviso e suas facetas biológica, psíquica, social e cultural são utilizadas apenas para explicações. Na verdade, sempre que se estuda o homem, em qualquer dos seus aspectos, estamos a estudar um fato integral e o veremos sob a lente daquela ciência que escolhemos e que ressaltará determinados aspectos da condição humana. Ou seja, com isso queremos dizer que os fatos para estudo são os mesmos e são indivisíveis, o que podemos, apenas, também devido às nossas limitações, é realizar um recorte e analisá-los segundo o filtro de teorias e saberes que nos são mais próximos. É praticamente impossível conceber um fenômeno 
envolvendo o homem que não seja ao mesmo tempo importante nos aspectos biológico, social, psicológico e cultural. Assim são por exemplo, as regras de parentesco e entre elas a proibição do incesto, os rituais funerários e sucessórios, as atividades esportivas, as guerras, o Kula, o potlach e uma infinidade de exemplos mais.

De outro lado, tentamos deixar clara a importância que a cultura tem para o homem e, tal como fez Geertz, tentar derrubar o mito de que a cultura seja privilégio do Homo sapiens. Aqui concordamos com o mencionado autor no sentido de que as espécies anteriores do gênero homo e inclusive outras espécies de hominídeos foram desenvolvendo a cultura ao longo de milhares de anos, de maneira lenta e gradual e com isso moldando a própria evolução biológica (prova disso são, por exemplo, os jacimentos de Atapuerca, na Provincía de Burgos, a revelar restos da espécie Homo heidelbergensis com algo de tecnologia e ritos funerários). Contudo, até pouco tempo atrás, aproximadamente 20.000 anos, a evolução cultural não tinha dado seu salto o que a fez ficar muito adiante da evolução biológica. A diferença das velocidades é tão grande que nos fez pensar, ou intuir, que a evolução biológica estancou quando do surgimento do Homo sapiens, preparando a espécie e abrindo passo à evolução cultural. Não foi o que aconteceu. As espécies de hominídeos e do gênero homo moldaram a evolução biológica a partir de uma lenta e gradual evolução cultural e, portanto, somos de algum modo o resultado daquilo que fizeram nossos antepassados.

Ainda, é importante destacar que somos a espécie do planeta mais dependente de um sistema cultural complexo. Possuímos pouquíssima informação gravada em nosso sistema genético e, à diferença da maioria dos animais, não poderíamos sobreviver sem um longo período de criação com auxílio de outros e não saberíamos como atuar se não aprendermos as regras de um sistema cultural que possa guiar nossa existência. A cultura, neste sentido, não é um capricho, mas uma necessidade e, independente do sistema cultural e de seus costumes, ele é necessário e tão válido como os demais.

Aqui já adentramos na discussão entre etnocentrismo e relativismo cultural, os conceitos, opostos à primeira vista, na verdade são complementares e imprescindíveis. Na sociedade ocidental, imediatamente após a Segunda Guerra 
Mundial e todos os seus abusos e horrores estabelecemos um núcleo de direitos ou o núcleo de sistemas culturais que deve(riam)m ser comuns a todas as sociedades ocidentais (referi-mo-nos à Declaração Universal dos Direitos do Homem e aos países europeus e americanos principalmente). Tal estabelecimento de um núcleo cultural expresso em direitos individuais e coletivos, é profundamente etnocêntrico, ao entender que todas as sociedades devem agir de tal forma. A seu turno, o relativismo cultural revela que as diferenças são válidas e que cada pauta cultural deve ser analisada dentro do seu contexto.

$\mathrm{Na}$ verdade, o relativismo cultural nos demonstra que a importância está na existência de um sistema que sirva de guia às condutas dos indivíduos e não no próprio conteúdo do sistema em si. A depender do indicador que utilizemos para medir as sociedades chegar-se-á à conclusão (do ponto de vista daquele que analisa) sobre a maior ou menor eficiência deste ou daquele sistema.

Outro ponto por nós trabalhado foi acerca dos conceitos de emic e etic, ambos já próximos de uma perspectiva pós-estruturalista da antropologia que reconhece a importância da linguagem como sistema simbólico. No caso, a forma de comunicar os fatos pode mudar radicalmente a impressão que deles se tem. Ainda que os conceitos sejam oriundos da perspectiva estruturalista de Kenneth Pike e dos conceitos linguísticos de fonêmica e fonética, o uso que deles fazem os antropólogos, a exemplo de Marvin Harris, pretende realçar a importância da linguagem para a interpretação dos fatos culturais. Malinowski já possuía, décadas antes, a mesma preocupação quando se havia dado conta de que certas expressões eram impossíveis de ser traduzidas ao inglês e que, se assim o fossem, induziriam o leitor em erro ou alterariam seu significado.

$\mathrm{Na}$ verdade, a antropologia, com a orientação teórica hermenêutica/simbólica, precedida pelo estruturalismo, participou do "linguistic turn" (giro linguístico, em português e em espanhol) das ciências sociais. A influência do giro linguístico atingiu os autores pós-estruturalistas e principalmente aqueles que integraram a linha da antropologia simbólica/hermenêutica e que atribuíram maior importância à linguagem na análise dos fatos. Em nosso entender, as consequências do giro linguístico são as de reconhecer (e isso de fato ocorreu no campo antropológico) que os significados das comunicações pela linguagem não se 
encerram no sentido literal das palavras, como se os símbolos (neste caso palavras escritas ou faladas) possuíssem uma etiqueta que lhes desse o significado à moda de dicionário. Ocorre que o ato de se comunicar encerra como que uma "atmosfera" à sua volta e cada comunicação traz com ela uma intenção e é por si mesma um ato capaz de influenciar o mundo à sua volta. É, ao que nos parece, o que quis ensinar Geertz com o exemplo da piscadela e seu fascínio com a descrição densa. A descrição densa é aquela capaz de transmitir não somente o que foi dito ou realizado, mas o contexto e essa "atmosfera" que possa revelar as intenções do agente e os efeitos do ato, seja ele de escrever, falar ou simbolizar de qualquer forma.

Sob este paradigma a Antropologia tem sido utilizada nos mais variados estudos, voltados, principalmente, para a compreensão de fenômenos urbanos e pós-modernos. A antropologia, portanto, é uma preciosa aliada de outras ciências e principalmente do direito, onde muito pode contribuir para a compreensão dos fatos jurídicos.

\subsection{Direito e Antropologia}

Ao iniciarmos este estudo, parecia difícil explicar aos curiosos em geral qual a relação entre direito e antropologia. Aqueles mais conservadores, não conseguem vislumbrar como a antropologia poderia contribuir à ciência jurídica. Seja por desconhecimento, ortodoxia ou mesmo reserva de mercado, existem muitos profissionais que são contrários a visões multidisciplinares e inovações nos campos de saber. No entanto, acreditamos que a Antropologia pode contribuir enormemente para o direito, para o ensino jurídico e para a prática jurídica cotidiana.

Como já havíamos detalhado, mesmo nas mais conservadoras escolas de direito, os estudos de introdução ao estudo do direito, direito romano e história do direito invariavelmente buscam caracterizar as sociedades e o contexto histórico onde surgidas as primeiras leis (normalmente o Código de Hamurabi e a Lei das XII Tábuas). O mesmo ocorre com o direito romano onde, para explicar as normas de direito (aquelas posteriores à Lei das XII Tábuas) era necessário contextualizar a sociedade romana, seus costumes, suas tradições e suas regras de cidadania e parentesco. Do contrário, algumas normas romanas jamais fariam sentido. $\mathrm{O}$ direito 
comparado, até hoje, é uma forma de efetuar uma comparação entre duas culturas, limitada a um grande aspecto cultural que é o sistema jurídico. Comparar sistemas jurídicos, normas, organização judiciária etc., entre dois ou mais países, também é uma forma de fazer antropologia, restringindo-se a uma pauta cultural específica.

Desde a metade do século XIX, autores como Maine já se davam conta da correlação existente entre o costume (o que poderíamos ampliar para cultura) local e as leis existentes em cada sociedade. O mencionado autor também foi um dos pioneiros a ampliar o conceito de direito também para as sociedades que ostentavam um conjunto de normas não escritas, mas com características que extrapolavam as simples sanções sobrenaturais ou sociais, partindo para uma sanção conjunta da coletividade. A ideia de Maine, que acabou por ficar famosa, "do status ao contrato", representa justamente a passagem de uma sociedade pequena ou reduzida, onde o papel social do indivíduo era atribuído de acordo com seu status, principalmente de parentesco, para as sociedades onde o papel dos indivíduos é atribuído por contratos (seja de trabalho, seja de matrimônio/divórcio, societário etc.).

Essa mudança também representa a evolução e a passagem do direito à condição de protagonista no controle social e na proteção do núcleo duro da cultura. Também comentamos que o direito é parte da cultura, é uma criação humana destinada a possibilitar e facilitar a convivência, oferecendo uma maior previsibilidade e segurança nas ações dos demais. Ou seja, o direito, originalmente foi concebido como um sistema que visava a tornar mais previsível e segura a vida em sociedade, principalmente em grandes grupos. Todas essas situações induzem a pensar que o direito tem múltiplas valências em nosso sistema social. É claro que o direito serve, como nas definições clássicas, de instrumento de justiça (com todas as abstrações e nuances inerentes ao termo), mas também como um sistema que organiza a resolução de conflitos. Atualmente, parece que a função do direito como resolução oficial do conflito adquiriu um papel mais relevante e, verdadeiramente, o que tem importado é que haja uma decisão oficial estatal que ponha termo ao conflito institucionalizado.

O direito, neste aspecto, parece que assumiu o papel desempenhado pela religião até pouco tempo, tornando-se algo cheio de dogmas, regras e, inclusive, 
superstições. O ensino jurídico tornou-se uma nova versão de iniciação religiosa onde se aprende o vocabulário jurídico, alguns brocardos e a lei vigente, e só. Temos perdido, ao menos no Brasil, muito da capacidade crítica e das condições para olhar as normas desde o ponto de vista de destinatários e responsáveis pela mesma. Toda norma possui uma justificação sócio-cultural que a precede e a maior ou menor adequação da norma à realidade faz com que esta seja mais eficaz e mais justa. O costume, fazendo-se uma analogia com o materialismo cultural, é a infraestrutura das normas jurídicas, principalmente nos sistemas de direito vinculados à tradição anglo-saxônica da common law.

No sistema romano-germânico e nas línguas românicas, possuímos duas palavras para designar lei e direito demonstrando, claramente, que a lei e o direito nem sempre estarão de acordo e seguem pela mesma senda. Tal abstração ocorre como consequência dos sistemas democráticos representativos onde a atividade legislativa cada vez se distancia mais das vidas do cidadão médio e assume outros contornos, por vezes recebendo influências externas alheias ao processo legislativo e que acabam moldando-o. O Estado, por sua vez, assume a condição de porta-voz da vontade geral e do interesse público quando, sabidamente, nem sempre os interesses do povo, detentor do poder, são convergentes com o do Estado e de seus legítimos representantes.

Assim é a contradição entre a produção legislativa e sua linguagem técnica ou simples. Tal oposição entre estilos legislativos sempre esteve presente nos sistemas democráticos: redigir a lei em linguagem técnica e o mais precisa possível ou usar uma linguagem acessível à maior parte da população. Este o desafio. Não é demais lembrar que a lei é feita por representantes do povo e para o conjunto da população. A lei não é destinada somente aos juristas e, portanto, deveria fazer-se entender pelo maior número possível de pessoas. O contexto da má qualidade na produção legislativa e a existência de leis permeadas por interesses alheios ao processo legislativo e ao interesse popular têm cada vez mais, ao menos no Brasil, induzido à que o Poder Judiciário exerça atividade criadora do direito sob o pretexto de interpretação das normas e, dentro desta, da revelação da verdadeira vontade do legislador. 
Parece-nos evidente que a lei necessita uma fundamentação histórica, social e cultural. Essa fundamentação faz parte dos requisitos de validade da legislação (ao menos no plano material) e também é necessário que recuperemos a base de cada norma na hora de interpretá-la para que não sejam cometidos absurdos, tais como justificar uma conduta com base em uma norma que foi concebida justamente para impedir tal conduta. Essa fundamentação histórico-sócio-cultural da norma jurídica poderá auxiliar também em uma maior segurança jurídica para a população, que entenderá a lei e saberá exatamente o bem jurídico por ela tutelado e as condutas que ela pretende vedar, permitir ou institucionalizar.

A hermenêutica, a partir do giro linguístico já aqui referido, aproxima o direito das demais ciências humanas. A interpretação de um discurso/relato/situação produzido em um trabalho de campo etnográfico é substancialmente similar à interpretação de uma norma jurídica. Ambos possuem uma realidade cultural como pano de fundo, um momento histórico, um interlocutor e um contexto que ajudam a conferir sentido ao texto. A descrição densa busca trazer essa fundamentação que envolve os discursos para o campo da interpretação.

A ausência de conhecimentos dessa fundamentação cultural das normas têm esvaziado cada vez mais as discussões jurídicas, ao menos no Brasil. Os debates nacionais, inclusive naquelas questões de relevo decididas pela suprema corte brasileira, derivam invariavelmente para questões procedimentais (prazos, legitimidade, adequação) ou aspectos pragmáticos sobre a estrutura necessária de fiscalização caso seja permitida ou proibida determinada conduta. $\mathrm{Na}$ verdade, o debate deveria ser da questão central, ou seja, aferir se nós, enquanto sociedade, desejamos permitir/vedar/restringir certas práticas e condutas ou não. O direito, ao menos no Brasil, está somente tangenciando as grandes discussões nacionais e o mesmo acaba por se repetir nos pequenos litígios.

Provavelmente os maiores pontos de contato atuais entre a antropologia e o direito sejam justamente no sentido de oferecer uma fundamentação sócio-cultural à norma jurídica e oferecer o método de interpretação simbólico que, para nós, é perfeitamente aplicável ao estudo das normas e também dos casos concretos postos à apreciação do poder judiciário. Realizar a interpretação a partir de uma minuciosa explicação de todo o contexto da lei ou do caso em liça, são 
circunstâncias essenciais para submeter tal interpretação ao crivo dos demais e justificar dita interpretação. O exemplo da piscadela de Geertz é perfeito. Se o observador não detalhar o contexto em que o autor da piscadela executa a piscadela nunca poderíamos averiguar se tratava-se de uma piscadela conspiratória ou um simples tique nervoso.

Além disso, aproveitando os conceitos de emic e etic já explicados no presente trabalho defendemos uma aproximação cada vez maior da linguagem jurídica à simplicidade. Chega-se ao ponto, no direito, de que o próprio emissor de uma norma (em teoria o povo, detentor de capacidade legislativa que a delega a representantes) não a entende. A mitigação deste tipo de absurdo passa por uma linguagem jurídica cada vez mais emic. Não que as expressões e princípios expressos em latim não sejam úteis, o são, principalmente na formação jurídica que, em parte, é fazer com o sujeito aproprie-se de um arcabouço de conhecimentos próprios da ciência jurídica. Mas a regra não pode ser o embate entre brocardos originados do direito romano em pleno século XXI, esquecendo-nos de tudo o que aconteceu com a humanidade desde então. A linguagem da prática jurídica, da lei e do rito processo deve ser acessível ao maior número possível de pessoas.

\subsection{Perspectivas para o sindicalismo}

Segundo o que tratamos no presente estudo, os sindicatos são a resposta social ao sistema econômico da industrialização e da urbanização. Os sindicatos são, em nosso entender, em parte herdeiros da tradição das corporações e grêmios de ofícios da idade média. O sindicalismo é, portanto, a culminação de um processo histórico onde influíram mudanças econômicas, sociais e culturais, muitas delas tratadas nas páginas precedentes. Ao longo dos anos, o sindicalismo passou por distintas fases de proibição, tolerância e reconhecimento, principalmente pelas legislações europeias.

Ao menos desde o final da Segunda Guerra Mundial, passou-se a reconhecer o direito à associação em sindicatos como um elemento básico de cidadania, o qual deveria ser garantido a todos. Neste sentido, os convênios internacionais e maioria das constituições que romperam com regimes autoritários anteriores reconheceram a plena liberdade de associação civil e de associação em sindicatos. 
A realidade sindical brasileira, embora originada em contexto muito similar ao das realidades, à época, da Itália e Espanha, possui suas próprias vicissitudes que delineiam um contexto sui generis até a presente data. Na primeira metade do século $\mathrm{XX}$, os três tiveram a subida ao poder de regimes autoritários alinhados com o fascismo. Mussolini, Franco e Getúlio tiveram muito em comum em diversos aspectos, dentre os quais está a imposição de um modelo de organização sindical pensado para controlar os trabalhadores e colocar o movimento sindical a serviço do Estado. Já comentamos que as similitudes entre o sindicalismo brasileiro atual e os sindicalismos espanhol e italiano das décadas de 20, 30 e 40 (com seus matizes) são muitas.

A realidade brasileira da década de 1930 era a de um País que, até poucas décadas atrás, ainda tinha institucionalizado o sistema escravocrata. A abolição da escravatura no Brasil, que também significou, em grande parte, o rompimento com a Monarquia e a posterior proclamação da República, ocorreu apenas em 1888. Logo após essa abolição formal é óbvio que as pautas sociais e alguns comportamentos introjetados ao longo de séculos de convivência com a escravidão não sumiram de uma hora à outra. Entre a abolição da escravidão e a publicação da atual legislação trabalhista brasileira transcorreu apenas pouco mais de meio século (1888-1943) e um período marcado pela chegada de milhões de trabalhadores estrangeiros que foram insertos em um regime de trabalho semifeudal e que acabaram por inchar algumas das principais cidades brasileiras criando as condições para industrialização e os conflitos obreiros.

Foi nesse contexto, de incipientes descontentamentos obreiros capitaneados por um grande número de imigrantes de primeira ou segunda geração e escravos libertos e seus descendentes que surgiu a normativa sindical de Getúlio Vargas. Pelas próprias condições apontadas, não havia coesão social e tampouco um movimento sindical organizado. Assim, Getúlio não só criou e impôs categorias, sindicatos e contribuições (talvez um movimento acertado para o contexto) como também inventou o Brasil, criando elementos identitários que passaram a fazer parte do ideário nacional e puderam congregar essa grande massa de pessoas de diferentes origens que se reunia no território brasileiro. 
Os sindicatos brasileiros apresentam uma mácula de origem, tal qual a federação brasileira. Tanto um como outro foram criados "de cima para baixo". Isto é, no Brasil foi criado, desde sempre, um poder central que resolveu, em determinado momento, ceder uma pequena parte do poder aos entes federados que agora agonizam ante a impossibilidade de arcar com todas as suas responsabilidades. O mesmo se pode dizer com relação aos sindicatos, foram criados por um governo central como forma de controle dos trabalhadores e direção, pelo Estado brasileiro, da economia nacional. Não surgiram de movimentos obreiros organizados.

A legislação sindical Brasileira plasmada da Consolidação das Leis do Trabalho é, como demonstramos aqui, muito similar à legislação Italiana do período de Mussolini e também bastante similar à legislação espanhola da época franquista. A Itália, logo após a Segunda Guerra Mundial, evento que abalou significativamente a realidade italiana causou um rompimento total com o regime anterior e, desde 1948, a Itália reconhece a liberdade sindical plena de acordo com os acordos internacionais da qual é firmatária. No caso Espanhol, o mesmo ocorreu a partir da derrocada do regime franquista e da nova constituição de 1978 que rompeu com o regime anterior consagrando a liberdade sindical plena. O Brasil teve a mesma oportunidade em 1988 e a unicidade sindical foi um dos grandes pontos de atrito nos debates constitucionais. Note-se que diversos constituintes representavam interesses sindicais, bem como empresariais, e, para a imensa maioria, vencidos alguns poucos, era mais conveniente a manutenção da unicidade sindical e, consequentemente, a cobrança da contribuição sindical.

A contribuição sindical compulsória é, sem sombra de dúvidas, o maior obstáculo a que se alcance, no Brasil, o direito à liberdade sindical plena. O imposto dedicado aos sindicatos tem sua cobrança facilitada pela existência de um sindicato por categoria em cada base territorial e, definidas as categorias, é bastante simples determinar quem deve pagar a quem. Além disso, a cobrança de um imposto para o financiamento da atividade sindical já contraria por si mesma a liberdade de escolher entre participar ou não do movimento sindical.

A questão da categoria, que foi uma preocupação na Itália até o fim do sistema corporativo, inclusive com a publicação de obras inteiras e específicas 
tratando do assunto, parece nunca ter sido uma preocupação séria no Brasil. Ora, em um sistema sindical estruturado a partir de categorias econômicas e profissionais, parece lógico que a questão da categoria, seus limites, sua formação seja a pauta central nos estudos sindicais. A categoria, já nos ensinava Danilo Guerrieri, pode adotar diversas formas, pode existir uma categoria profissional ou econômica, outra categoria contratual (a de abrangência dos acordos e convenções coletivas) e, por fim, a categoria sindical formalmente organizada em sindicatos. $O$ sistema corporativo unifica todas as categorias anteriores em apenas uma, tornando obrigatória a correspondência entre categorias profissional-econômica, sindical e contratual. Como já aprendemos da experiência italiana, não necessariamente existirá essa correspondência em um regime de liberdade sindical plena, o que torna as relações muito mais complexas e laboriosas.

Contrario sensu, entenderam, jurisprudência e doutrina que, a partir da Constituição de 1988, o quadro de atividades e profissões da Consolidação das Leis do Trabalho não é mais vinculante e, assim, podem ser criadas novas categorias profissionais distintas daquelas previstas no mencionado quadro. Tal situação provocou um grande aumento do número de sindicatos no Brasil, desde 1988, embora persista a regra de apenas um sindicato por categoria e por base territorial. A lógica é a do desmembramento infinito de categorias para a criação de novos sindicatos e a consequente legitimação para recebimento da contribuição sindical devida pelos "representados" embora estes últimos estejam distantes ou sequer saibam que possuem um novo sindicato que os representa.

A conjugação da ausência de mudança legislativa, bem como a falta de preocupação com a questão da categoria, conduziram o Brasil ao cenário atual onde, na prática, tem-se o pior de ambos os mundos. Como não se pode fundar um novo sindicato sem que "nasça" uma nova categoria, a criação de categorias virou um negócio que "redistribui" a renda obtida com a contribuição sindical compulsória. As categorias são criadas com base em interesses, na maior parte das vezes, distintos daqueles dos trabalhadores, apenas para abocanhar uma fatia da contribuição sindical compulsória, sem importar a combatividade sindical e os serviços assistenciais oferecidos aos representados. 
Outra consideração merecedora de atenção é a forma como tem sido decididos os conflitos sobre enquadramento sindical. O enquadramento sindical, em razão das normas atuais para a sindicalização brasileira deve levar em consideração dois fatores primordiais: base territorial e atividade profissional-econômica. No entanto, somente com relação à base territorial, em não raros casos, acontece de a empresa ter sede em determinado município, contratar os trabalhadores em outro para prestar serviços em um terceiro. Ademais, esse trabalhador contratado, por vezes reside em um quarto local, distinto dos três anteriores. Nestas hipóteses, fica a pergunta: Qual a base territorial que deveria prevalecer (Ponto de interrogaçao). A resposta depende da análise de diversos fatores, entre eles importa saber onde o trabalhador gasta seu salário, por exemplo, já que as remunerações são ajustadas de acordo com a realidade local dos gastos. O mesmo ocorre com relação às questões de categoria profissional ou econômica com trabalhadores que executam diversas funções e trabalham para várias empresas do grupo econômico. $E$ o problema é sério, já que dessa decisão, do enquadramento sindical, dependerá o recebimento ou não de diversos direitos por parte do obreiro, inclusive seguros de vida e pensionamento aos herdeiros. Essa nova complexidade, reclama a atuação especifica de profissionais auxiliares do juízo, que, em nosso entender, poderiam colaborar na aferição do efetivo enquadramento sindical, representatividade de sindicatos e outras demandas relacionadas a aplicabilidade de acordos ou convenções coletivas. Este profissional, o antropólogo, poderia auxiliar o juízo com base em laudos específicos sobre as questões sindicais, trazendo para o processo, uma visão mais próxima da realidade social e laboral do contexto em liça.

No momento de redação das presentes conclusões houve a aprovação pelo parlamento brasileiro da Lei $n^{\circ} 13.429$ de 2017 que permitiu a terceirização, inclusive das chamadas "atividades fim" ou seja, uma empresa de produção de calçados, por exemplo, poderá terceirizar a própria produção dos calçados, no todo ou em parte. Muitas discussões surgiram em torno ao projeto e quase todos os sindicatos obreiros colocaram-se ferrenhamente contra a nova lei. Curiosamente, um dos argumentos utilizados pelas entidades era justamente que a terceirização "enfraqueceria" o movimento sindical. Na verdade, os sindicatos estão preocupados com a diminuição do número de trabalhadores da sua categoria oficial e com a consequente perda de receitas oriundas do imposto sindical. Uma empresa que 
anteriormente possuísse 100 empregados próprios, ao reduzir a quantidade de contratos de trabalho, optando por terceirizar parte das atividades, irá ocasionar a diminuição do número de trabalhadores representados pelo sindicato obreiro vinculado ao sindicato patronal. Com isso, os sindicatos vinculados às atividades de terceirização irão crescer, em detrimento dos demais.

Segundo o que pudemos apurar com as estatísticas apresentadas e os resultados obtidos com o trabalho de campo, a imensa maioria dos trabalhadores brasileiros não é filiada ao sindicato de sua categoria e uma grande parte nunca o foi durante sua vida laboral. Os sindicatos seguem atuando à revelia da participação da maior parte da categoria que formalmente representam. E mais, os sindicatos têm instituído, mediante acordo ou convenção coletiva, outras contribuições que vinculam todos os trabalhadores da categoria, independente de sua anuência ou, na maior parte das vezes, do seu conhecimento.

Também pudemos concluir que a maior parte dos trabalhadores desconhece amplamente seus direitos nos plano das relações individuais e coletivas de direito. A maioria acaba por procurar profissionais de sua confiança (indicações de amigos, de vizinhos ou de colegas de trabalho) a despeito de saber da existência do sindicato de sua categoria. O sindicato, por todas as circunstâncias já mencionadas, é visto por muitos com desconfiança, como um órgão, de alguma maneira, mais vinculado ao empregador ou a administração pública, do que preocupado com a defesa dos interesses de seus afiliados. Como não há uma participação ativa da maior parte das categorias, em muitos sindicatos algumas cúpulas dirigentes acabam por se eternizar no poder e eliminar ainda mais a participação de outros trabalhadores na gestão sindical.

Além disso, pudemos observar que a maioria dos trabalhadores troca de emprego e, inclusive, de ramo de atividade em média três vezes a cada dez anos. No atual sistema sindical, a simples troca de empregador (ainda que a atividade executada pelo trabalhador seja similar), pode ocasionar a troca de sindicato tendo em vista que a regra-geral se dá pela atividade econômica preponderante do empregador. As trocas constantes de sindicato representativo impedem ou dificultam que o trabalhador forme vínculos sólidos com o seu sindicato, que participe da 
administração sindical, que tome parte nas atividades e discussões sobre interesses comuns da classe.

Aqui também, vem à luz o problema da despedida arbitrária e sem justa causa, ainda permitida no Brasil e que também têm o condão de afastar o trabalhador do sindicato a que pertencer tendo em vista que a atribuição "automática" do sindicato representativo se dá pela condição em determinado ramo de atividade. Existem alguns elementos que protegem o trabalhador que concorre à direção sindical por períodos curtos de tempo e que, ainda assim, passado aquele período, permitem as despedidas sem fundamento, como forma de alijar da atividade sindical algum membro da direção particularmente combativo, por exemplo. Importante destacar, também, que, tal como está posto, a própria existência do sindicato obreiro está ligada à existência da atividade econômica do empregador. Por exemplo, se um sindicato obreiro vinculado à determinada atividade econômica em algum município for especialmente combativo e causar diminuição dos lucros daquela unidade e esta vier a cessar suas atividades, o próprio sindicato obreiro também deverá encerrar suas atividades, já que não mais existirá aquela atividade econômica naquela base territorial. Isto quer dizer que muitos dos sindicatos obreiros devem optar por efetivamente reivindicar aquilo que pretendem ou preservar os interesses do empregador que tem em suas mãos a existência ou a extinção do sindicato obreiro.

O atual sistema sindical brasileiro também exclui da atividade sindical diversas categorias que participam ativamente no mercado como, para citar alguns exemplos, os empregados domésticos, os autônomos e os desempregados. Todas essas pessoas são trabalhadores ou potenciais trabalhadores que tem todo o direito de exercitar seu direito às reivindicações sindicais pela melhora das condições de trabalho, por maior oferta de empregos, por insatisfações com os tributos, por melhora nas prestações sociais oferecidas pelo Estado. Seria perfeitamente justo que tais classes de trabalhadores também pudessem participar da atividade sindical, o que, pela atual legislação Ihes é vedado, embora existam algumas instituições ditas "sindicatos", que se utilizam de tal nomenclatura apesar de, efetivamente, não o serem, de acordo com a legislação. 
Observando a evolução histórica dos problemas surgidos com o reconhecimento da liberdade sindical, pode-se notar que o principal deles reside na abrangência dos contratos coletivos e na legitimidade para negociar em nome de alguma categoria. Na Itália, entendeu-se como necessário que o trabalhador tenha manifestado seu consentimento ao menos no primeiro nível, ou seja, o trabalhador filia-se ao sindicato $X$ que, por sua vez, filia-se à confederação $Y$ que negocia um acordo de nível nacional e que portanto afetará também o trabalhador daquele sindicato $X$. Já na Espanha optou-se pela regra do sindicato mais representativo de cada categoria a quem incumbirá negociar em nome daquela categoria e suas decisões vincularão aos demais sindicatos e trabalhadores. Na Itália, portanto, o problema da definição exata de categorias deixou de ser um óbice ao estabelecimento de contratos coletivos e da definição da abrangência destes.

O problema da categoria, a bem da verdade, parece ser uma herança medieval, mais precisamente das corporações de ofício. Houve uma época em que, segundo Durkheim, os próprios trajes profissionais (indumentárias próprias de cada profissão) buscavam ressaltar ou esconder características morfológicas derivadas do exercício de cada profissão. Além de características morfológicas próprias, cada profissão também continha um amplo leque de características identitárias próprias, além das vestimentas, como festas próprias e divindades associadas àquela profissão determinada, um longo ciclo formativo com rituais de iniciação e passagem, uma linguagem própria e até mesmo a residência em locais previamente determinados. Todas estas circunstâncias fizeram com que a humanidade se acostumasse a classificar os humanos de acordo com a profissão que exercem tal e qual ocorre com as nacionalidades. A pós-modernidade e a globalização (achatamento do mundo segundo Friedman) vêm reduzindo sensivelmente as diferenças entre ambos e cada vez mais há uma homogeneização de condutas, costumes e práticas, embora a humanidade necessite de tais classificações como forma de prever a conduta do outro, em razão dos rótulos que lhe são possíveis de atribuir.

Atualmente, ao que deduzimos, a grande maioria das profissões deixou de apresentar grandes diferenças com relação às demais e os trabalhos tornaram-se, em muito, apoiados na tecnologia, reduzindo drasticamente as distinções 
morfológicas e identitárias de cada profissão. A categoria do século XXI deveria ser formada de acordo com interesses comuns manifestados pelos trabalhadores que decidem fundar um sindicato. Como já expusemos anteriormente, diversos trabalhadores de distintos ramos de atividade podem apresentar interesses em comum e desejar unir-se para reivindicar melhores condições neste sentido. Por outro lado, mesmo ao trocar de atividade, pode ser que determinado trabalhador deseje manter-se filiado ao sindicato de sua confiança o que também deveria ser possível.

As perspectivas de futuro são justamente essas. Uma eliminação cada vez maior das diferenças entre cada atividade e uma aproximação, inclusive, das ciências entre si tendo em vista que todas fazem partes do conhecimento humano. Nesse contexto, entendemos que a categoria num futuro onde haja liberdade sindical plena será aquela decidida de acordo com os interesses comuns e a vontade dos trabalhadores que precisarão, finalmente, tomar as rédeas da atividade sindical brasileira após mais de 60 anos. 


\section{IX - REFERÊNCIAS}

AGUIRRE BAZTÁN, Silvio Ángel e OLIVEIRA MARTINS, José Clérton. A pesquisa qualitativa de enfoque etnográfico. Coimbra: Grácio, 2014.

AGUIRRE BAZTÁN, Silvio Ángel. La Cultura de las Organizaciones. Barcelona: Ariel, 2004.

ALONSO OLEA, Manuel e CASAS BAAMONDE, Maria Emília. Derecho del Trabajo. Madrid: Publicaciones Universidad de Madrid, 1995.

ALONSO OLEA, Manuel. Introdução ao direito do trabalho. Trad. C. A. Barata Silva. Livraria Sulina Editora, Porto Alegre, 1969.

ALONSO OLEA, Manuel. Variaciones sobre Hegel. Madrid: Civitas, 1987.

APILLUELLO MARTÍN, Margarita. La intervención de la comisión paritaria del convenio colectivo supraempresarial en la solución del conflicto de trabajo. Barcelona: Cedecs, 1997.

ARAÚJO, José Carlos E. Transformações no conceito de trabalho e sociedade pós-industrial. in: VIDOTTI, Tárcio José et al. Direito Coletivo do Trabalho em uma sociedade pós-industrial. São Paulo: LTr, 2003.

ARISTÓTELES. Ética a Nicómaco. Introducción, traducción y notas de José Luis Calvo Martínez. Madrid: Alianza, 2001.

ASSIS, Olney Queiroz e KUMPEL, Vitor Frederico. Manual de Antropologia Jurídica. São Paulo: Saraiva, 2011.

BARFIELD, Thomas. (Ed.) Diccionário de Antropología. Barcelona: Bellaterra: 2000.

BENEDICT, Ruth. El hombre y la cultura. Barcelona: Edhasa, 1989.

BERNSTEIN, Basil. Clases, códigos y control. Estudios teóricos para una sociología del lenguaje. Torrejon de Ardóz: Akal, 1989.

BOAS, Franz. Cuestiones Fundamentales de Antropología Cultural. Madrid: Solar, 1964.

BOAS, Franz. The Limitations of the Comparative Method of Anthropology. in: Science, New Series, Vol. 4, No. 103 (Dec. 18, 1896), pp. 901-908

BOAS, Franz. The methods of ethnology. in: American Anthropologist, New Series, Vol. 22, № 4, (Oct-Dic, 1920) pp. 311-321.

BOBBIO, Norberto. Giusnaturalismo e positivismo giuridico. Lecce: Laterza, 2011. 
BONATTO BARCELLOS, Antonio Augusto e LEAL DA SILVA, Elizabet. A despedida coletiva no Brasil: uma análise da possível aplicação da experiencia europeia. in: Revista de Processo do Trabalho e Sindicalismo, $n^{\circ} 7$, Porto Alegre, 2016.

BONATTO BARCELLOS, Antonio Augusto e STURMER, Gilberto.

Multiculturalismo, Identidade Coletiva e Espaços de Atuação Sindical no

Brasil. in: SÁNCHEZ BRAVO, Álvaro e CERVI, Jacson Roberto. Multiculturalismo, Tecnología y Medio Ambiente. Sevilla: Punto Rojo, 2015.

BONATTO BARCELLOS, Antonio Augusto; MONTEIRO, Alberto de Oliveira; PADILLA, Luiz Roberto Nunes. A sindicalização dos profissionais de Educação Física. in: Revista Conexões, Campinas, v. 13, n. 3, p. 146-174, jul./set. 2015.

BOYD, R. \& RICHERSON, P.J. Culture and evolutionary Process. University of Chicago Press (1985).

BRASIL. Lei das Contravenções Penais. Decreto-Lei Nº 3.688, de 3 de outubro de 1941.

BRASIL. Ministério do Trabalho e Emprego. Classificação Brasileira de Ocupações. Brasília: 2010.

BRASIL. Presidência da República. Consolidação das Leis do Trabalho, DecretoLei $n^{\circ} 5.4252$ de $1^{\circ}$ de maio de 1943.

BRASIL. Presidência da República. Constituição Federal de 05 de outubro de 1988.

BRASIL. Presidência da República. Lei nº 7.783 de 28 de junho 1989.

BRASIL. Presidência da República. Lei nº 11.648 de 31 de março de 2008.

BRASIL. TRIBUNAL SUPERIOR DO TRABALHO. Coordenadoria de Estatística e Pesquisa. Casos novos por assunto - varas do trabalho. Brasília: Cestp, 2016.

BRASIL. TRIBUNAL SUPERIOR DO TRABALHO. Coordenadoria de Estatística e Pesquisa. Relatório Geral da Justiça do Trabalho. Brasília: Cestp, 2015.

BRASIL. Tribunal Superior do Trabalho. Orientação Jurisprudencial número 17 da Seção de Dissídios Coletivos. Brasília: DEJT, 2014.

BRITO PEREIRA, João Batista. O sindicalismo no Brasil. Uma proposta para o seu fortalecimento. in: VIDOTTI, T. J. E GIORDANI, F.A. (Coord.) Direito Coletivo do Trabalho em uma sociedade pós-industrial. São Paulo: LTr, 2003.

BUARQUE DE HOLANDA, Sérgio. Raízes do Brasil. São Paulo: Companhia das Letras, 1995.

BUENO, Eduardo. A viagem do descobrimento. Rio de Janeiro: Objetiva, 1998. 
BUENO, Eduardo. Brasil: uma história. São Paulo: Ática, 2003.

CALVO BUEZAS, Tomás y BARBOLLA CAMARERO, Domingo. Antropología:

Teorías de la Cultura, métodos y técnicas. Badajoz: Abecedario, 2006.

CAMPOS BATALHA, Wilson de Souza. Sindicatos, sindicalismo. São Paulo: LTr, 1992.

CARDOSO, Fernando Henrique. Capitalismo e Escravidão no Brasil Meridional: o negro na sociedade escravocrata do Rio Grande do Sul. Rio de Janeiro: Paz e Terra, 1997.

CARNELUTTI, Francesco. Teoria del Regolamento Collettivo dei Rapporti di Lavoro. Padova: CEDAM, 1936.

CARRARA, Angelo Alves. A população do Brasil, 1570-1700: uma revisão historiográfica. in: Revista Tempo, Niterói, vol 20, 2014.

CARRION, Valentin. Comentários à Consolidação das Leis do Trabalho. São Paulo: LTr, 2009.

CARVALHO, José Murilo de. Nación Imaginada: memoria, mitos y héroes. in: GONZÁLEZ, E., MORENO, A. e SEVILLA, R. Reflexiones en torno a 500 años de historia de Brasil. Madrid: Catriel, 2000.

CASSAR, Vólia Bomfim. Direito do Trabalho. Niterói: Impetus, 2009.

CASTELLS, Manuel. La era de la información, vol. 1: La sociedad red. Madrid: Alianza, 2001.

CASTILLA URBANO, Francisco. Los derechos humanos y el pensamiento de Francisco de Vitoria. in: Revista de Filosofía, Maracaibo, n 33, vol. 3, 2000.

COMTE, Auguste. Curso de Filosofía Positiva. Madrid: Aguilar, 1973.

CHILDE, Vere Gordon. La evolución social. Madrid: Alianza, 1984.

COMTE, Auguste. Curso de Filosofía Positiva. Madrid: Aguilar, 1973.

DAMATTA, Roberto. O que faz do brasil, Brasil? Rio de Janeiro: Rocco, 2000.

DAMATTA, Roberto. Relativizando [recurso eletrônico]: uma introdução à Antropologia Social. Rio de Janeiro: Rocco Digital, 2011.

DAVID, René. Los grandes sistemas jurídicos contemporáneos. Madrid: Aguilar, 1968.

DELGADO, Maurício Delgado. Curso de Direito do Trabalho. São Paulo: LTr, 2009. 
DELL'OLLIO, Matteo e BRANCA, Giorgio. L'organizzazione e l'azione sindale. Padova: CEDAM, 1980.

DEPARTAMENTO INTERSINDICAL DE ESTATÍSTICA E ESTUDOS SOCIOECONÔMICOS. Anuário do Sistema Público de Emprego, Trabalho e Renda 2015: Livro 1, Mercado de Trabalho. São Paulo: DIEESE, 2015.

DOUGLAS, Mary. Natural Symbols. Explorations in Cosmology. Londres: Routledge, 2004.

DUNLOP, John T. Sistema de Relaciones Industriales. Barcelona: Península, 1978.

DURHAM, W.H. Co-evolution: Genes, Culture and Human Diversity. Stanford University Press. (1991).

DURKHEIM, Émile. La divisón del trabajo social. Madrid: Akal, 1982.

DURKHEIM, Emile. Lecciones de Sociología: Física de las costumbres y del derecho. Buenos Aires: Schapire, 1966.

ELTIS, David e RICHARDSON, David. Atlas of the transatlatic slave trade. New Heaven \& London: Yale University Press, 2010.

ENGELS, Friedrich. Introducción a la dialectica de la naturaleza. El papel del trabajo em la transformación del mono em hombre. Introducción de Daniel Lacalle. Madrid: Ayuso, 1974.

ESPANHA. Cortes Generales. Constituição Espanhola de 29 de dezembro de 1978. Madrid: Boletim Oficial do Estado, 1978.

ESPANHA. Instituto Nacional de Estadística. Clasificación Nacional de Ocupaciones. Madrid: 2012.

ESPANHA. Lei Orgânica de Liberdade Sindical de 2 de agosto de 1985. Madrid: Boletim Oficial do Estado, 1985.

ESPANHA. Real-Decreto-Lei $\mathbf{1 7}$ de 04 de março. Madrid: Boletim Oficial do Estado, 1977.

ESPINA BARRIO, Ángel Baldomero. Freud y Lévi-Strauss: Influencias, aportaciones y deficiencias de las antropologías dinâmica y estructural. Salamanca: Universidad Pontificia de Salamanca, 1997.

ESPINA BARRIO, Ángel Baldomero. Lévi-Strauss: ¿El último moderno y el primer postmoderno? In: ESPINA BARRIO, Ángel Baldomero; DE LA FUENTE, Iñigo González. Antropología de lberoamérica: Estudios Socioculturales en Brasil, España, México y Portugal. Recife: Massangana, 2010. pp. 23-40

ESPINA BARRIO, Ángel Baldomero. Manual de Antropologia Cultural. Tradução de Mário Hélio Gomes de Lima. Recife: Massangana, 2005. 
ESTEVA FABREGAT, Claudio. Antropología Industrial. Barcelona: Anthropos, 1984.

EVANS-PRITCHARD, Edward Evan. La mujer en las sociedades primitivas. Barcelona: Península, 1971.

EVANS-PRITCHARD, Edward Evan. Los Nuer. Barcelona: Anagrama, 1977.

FAUSTO, Boris. A revolução de 30: historiografia e história. São Paulo: Companhia das Letras, 1997.

FAUSTO, Boris. História do Brasil. São Paulo: Editora da Universidade de São Paulo, 1995.

FAUSTO, Boris. Historiografia da Imigração para São Paulo. São Paulo: Ed. Sumaré-FAPESP, 1991.

FENELON, Dea Ribeiro. 50 textos de história do Brasil. São Paulo: Hucitec, 1986.

FERNÁNDEZ ÁLVAREZ, Óscar. Bronislaw Malinowski: La antropología y el Funcionalismo. León: Universidad, Secretariado de Publicaciones y Medios Audiovisuales, 2004.

FIGUEROLA, Francisco José. Sindicalismo: síntesis histórica. Buenos Aires: Perrot, 1958.

FIRTH, Raymond. Elementos de Antropología Social. Buenos Aires: Amorrortu, 1971.

FRANÇA. Lei Le Chapelier de 14 de junho de 1791. Disponível em: www.viepublique.fr/documents-vp/loiChapelier.pdf Acesso em: 21 jun 2016.

FRAZER, James George. La rama dorada: Magia y Religión. México, D.F.: Fondo de Cultura Economica, 1956.

FREYRE, Gilberto. Casa Grande \& Senzala: formação da família brasileira sob o regime da economia patriarcal. São Paulo: Global 2003.

FRIEDMAN, Thomas L. O mundo é Plano: o mundo globalizado do século XXI. Rio de Janeiro: Objetiva, 2009.

FUSTEL DE COULANGES, Numa Denis. La ciudad antigua. Madrid: Peninsula, 1984.

GADAMER, Hans Georg. Verdad y método. Vol. I, Fundamentos de una hermenéutica filosófica. Salamanca: Sígueme, 1996.

GALANTINO, Luisa. Diritto Sindicale. Torino: Giapichelli, 2003. 
GARCIA, Gustavo Filipe Barbosa. Curso de Direito do Trabalho. Rio de Janeiro: Forense, 2017.

GARCÍA-PERROTE ESCARTÍN, Ignacio. Manual de Derecho del Trabajo. Valencia: Tirant lo Blanch, 2012.

GEERTZ, Clifford. A interpretação das Culturas. Rio de Janeiro: LTC, 2012.

GEERTZ, Clifford. Nova luz sobre a Antropologia. Rio de Janeiro: Zahar, 2001.

GERNIGON, Bernard; ODERO, Alberto e GUIDO, Horacio. Los principios de la OIT sobre el Derecho de Huelga. Genebra: OIT (Oficina Internacional del Trabajo), 2000.

GHEZZI, Giorgio e ROMAGNOLI, Umberto. II diritto sindacale. Bologna: Zanichelli, 1987.

GIGLIO, Walter D. Direito Processual do Trabalho. São Paulo: Saraiva, 2005.

GIUGNI, Gino. Diritto Sindacale. Bari: Cacucci, 2002.

GLUCKMAN, Max. Política, derecho y ritual en la sociedad tribal. Madrid: Akal, 1978.

GODELIER, Maurice. Economía, Fetichismo y Religión en las Sociedades

Primitivas. Madrid: Siglo XXI, 1978.

GONZÁLEZ DÍEZ, Emiliano. De la naturalización y extranjería en Indias. in: ESPINA BARRIO, Ángel Baldomero (Ed.) Antropología en Castilla y León e Iberoamérica, V: Emigración e integración cultural. Salamanca: Ediciones Universidad de Salamanca, 2003. pp. 53-63

GONZÁLEZ DÍEZ, Emiliano. Reflexiones en torno a la integración de Indias de Juan Ginés de Sepúlveda. in: ESPINA BARRIO, Ángel Baldomero (Ed.) Antropología en Castilla y León e Iberoamérica, IV: Cronistas de Indias. Salamanca: Ediciones Universidad de Salamanca, 2002. pp. 31-37

GUASP, Jaime. La pretensión procesal, II. Madrid: Civitas, 1981.

GUERRIERI, Danilo. La categoria nell'ordinamento giuridico del lavoro. Milano: A. Giuffré, 1963.

HABERMAS, Jurgen. Direito e Democracia: entre facticidade e validade. Rio de Janeiro: Tempo Brasileiro, 2003.

HABERMAS, Jurgen. Teoría de la acción comunicativa, tomo I: Racionalidad de la acción y racionalización social. Madrid: Taurus, 1999.

HAMESTER, Paulo Rudolfo; VOLPI, Julio César; JOBIM, Gilda Franco. A Região Metropolitana de Porto Alegre. in: Metrópolis em Revista. Vol. 03, n 1, Curitiba, 2001. 
HAMMERSLEY, Martyn e ATKINSON, Paul. Etnografía, métodos de investigación. Barcelona: Paidós, 1994.

HARRIS, Marvin. El desarrollo de la teoría antropologica. Historia de las teorias de la cultura. Madrid: Siglo XXI, 2003.

HARRIS, Marvin. Materialismo Cultural. Madrid: Alianza, 1985.

HEGEL, Georg Wilhelm Friedrich. Fenomenología del Espíritu. Valencia: Pretextos, 2006.

HEGEL, Georg Wilhelm Friedrich. Lecciones sobre la filosofía de la historia universal. Madrid: Alianza, 1982.

HEGEL, Georg Wilhelm Friedrich. Principios de la Filosofia del Derecho. Buenos Aires: Sudamericana, 1975.

HOBSBAWN, Eric. En torno a los orígenes de la revolución industrial. Madrid, Siglo XXI, 1988.

HORKHEIMER, Max. Crítica de la razón instrumental. Trad. H. A. Murena y D. J. Vogelmann. Buenos Aires: Sur, 1973.

INSTITUTO BRASILEIRO DE GEOGRAFIA E ESTATÍSTICA. Centro de Documentação e Disseminação de Informações. Brasil: $\mathbf{5 0 0}$ anos de povoamento. Rio de Janeiro: IBGE, 2007.

INSTITUTO BRASILEIRO DE GEOGRAFIA E ESTATÍSTICA. Portal Cidades. Disponível em: <http://www.cidades.ibge.gov.br/v3/cidades/municipio/4314902> Acesso em: $17 \mathrm{fev} 2017$

INSTITUTO NACIONAL DE CIÊNCIA E TECNOLOGIA. Observatório das Metrópoles. Rio de Janeiro: FAPERJ, 2010.

ITÁLIA. Carta del Lavoro. 21 de abril de 1927. Disponível em: $<$ http://www.historia.unimi.it/sezione/fonti/codificazione/cartalavoro.pdf> Acesso em: 27 de novembro de 2015.

ITÁLIA. Costituzione Italiana. Roma, 27 de dezembro de 1947.

ITÁLIA. Istituto Nazionale Statistica. Classificazione delle Professione. Roma: Stealth, 2013.

IZQUIETA ETULAIN, Jose Luis. Materialismo, culturas y modos de producción. Alcance y límites de la nueva antropología marxista. Salamanca: Editorial San Esteban, 1990.

JHERING, Rudolf Von. El espíritu del derecho romano en las diversas fases de su desarrollo. Granada: Comares, 1998. 
JHERING, Rudof Von. El fin en el derecho. Buenos Aires: Heliasta, 1978.

JOHNSTON, William B. Global labor force 2000: the new world labor market. in: Harvard Business Review, march/april, 1991. Disponível em: <

https://hbr.org/1991/03/global-work-force-2000-the-new-world-labor-market> Acesso em: 17 fev 2016.

JORGE NETO, Francisco Ferreira e PESSOA CAVALCANTE, Jouberto de Quadros. Estudos dirigidos: direito do trabalho: com questões selecionadas dos concursos da magistratura, Ministério Público do Trabalho e exame da Ordem dos Advogados. São Paulo: LTr, 2009.

KARDINER, Abram. El individuo y su sociedad : la psicodinámica de la organización social primitiva. México: Fondo de Cultura Economica, 1945.

KELSEN, Hans. Teoría general del derecho y del Estado. México: Universidad Nacional Autónoma de México, 1958

KELSEN, Hans. Teoría Pura del Derecho. México: Porrúa, 2005.

KLERING, Luis Roque; KRUEL, Alexandra Jochim; STRANZ, Eduardo. Os pequenos municípios do Brasil - uma análise segundo índices de gestão. in: Revista Análise, v. 23, n. 1, p. 31-44, jan./abr. 2012, Porto Alegre.

KORSBAEK, Leif. Raymond Firth: La Organización social y el cambio social. Iberóforum. Revista de Ciencias Sociales de la Universidad Iberoamericana [en linea] 2010, V (Enero-Junio) : [Fecha de consulta: 6 de junio de 2016] Disponible en:<http://www.redalyc.org/articulo.oa?id=211014857008> pp.149-183

KOTTAK, Conrad Philip. Antropología Cultural. México, D.F.: McGraw-Hill, 2011.

KOTTAK, Conrad Phillip. Antropología. Una exploración de la diversidad humana con temas de cultura hispana. Madrid: Mcgraw-Hill, 1995.

KROEBER, Alfred Louis. Anthropology. New York: H.B.C., 1948.

LAKATOS, Eva Maria; MARCONI, Marina de Andrade. Fundamentos da metodologia científica. São Paulo: Atlas, 1991.

LASK, Emil. Filosofía Jurídica. Buenos Aires: Depalma, 1946.

LÉVI-STRAUSS, Claude. Antropología Estructural. Buenos Aires: Eudeba, 1968.

LÉVI-STRAUSS, Claude. Antropología Estructural: mito, sociedad y humanidades. Madrid: Siglo XXI, 2009.

LÉVI-STRAUSS, Claude. Las Estructuras Elementales de Parentesco. Barcelona: Paidós, 1988. 
LÉVI-STRAUSS, Claude. Mitológicas I: El crudo y el cocido. México: Fondo de Cultura Económica, 1972-A.

LÉVI-STRAUSS, Claude. Mitológicas II: De la miel a las cenizas. México: Fondo de Cultura Económica, 1972-B.

LÉVI-STRAUSS, Claude. Tristes Trópicos. Barcelona: Paidós, 2002.

LEVINE, Robert M. Pai dos Pobres? O Brasil e a era Vargas. São Paulo: Companhia das Letras, 2001.

LIEBERMAN, Daniel E. La historia del cuerpo humano. Evolución, salud y enfermedad. Barcelona: Pasado\&Presente, 2013.

LIMA, Luiz Tenório de. Movimento Sindical e Luta de Classes. São Paulo: Oliveira Mendes, 1998.

LINTON, Ralph. Estudio del Hombre. México: Fondo de Cultura Económica

LISÓN TOLOSANA, Carmelo. Antropología social y hermenéutica. Madrid: FCE, 1983.

LORENZO SANZ, Eufemio. Represión y Depuración de los Maestros de la província de Palencia en la Guerra Civil: de los anhelos republicanos a la resignación en el franquismo. Valladolid: IIACyL, 2014.

MAESTRE ALFONSO, Juan. Introducción a la Antropología Social. Madrid: Akal, 1974.

MAGNANI, Mariella. Diritto Sindacale. Torino: Giappichelli, 2013.

MAINE, Henry Summer. El antiguo derecho y la costumbre primitiva. Madrid: España Moderna, [1900?].

MAIR, Lucy. Introducción a la Antropología Social. Madrid: Alianza, 1980.

MALINOWSKI, Bronislaw. Crimen y Costumbre en la sociedad salvaje. Barcelona: Ariel, 1971

MALINOWSKI, Bronislaw. Los argonautas del Pacífico Occidental. Barcelona: Península, 1973.

MALINOWSKI, Bronislaw. The Family Among the Australian Aborigenes. Londres: University of London Press, 1913.

MANSILLA, Hugo Celso Felipe. Crítica a las filosofías de la historia de Hegel y Marx a partir de sus consecuencias práctico-políticas. in: Signos Filosóficos, vol. IX, nº 18, México D.F., jul-dez/2007. p. 82-103 
MARX, Karl. Contribución a la crítica de la economía política. Madrid: Alberto Corazón, 1978.

MARX, Karl. El Capital. Buenos Aires: Maceda, 2014.

MARX, Karl. El capital: critica de la economia política. México: Fondo de Cultura Económica, 1984.

MARX, Karl e ENGELS, Friedrich. La ideología Alemana: crítica de la novísima filosofía alemana en las personas de sus representantes Feuerbach, B. Bauer y Stirner y del socialismo alemán en las de sus diferentes profetas. Barcelona: Grijalbo, 1972.

MARX, Karl e HOBSBAWN, Eric J. Formaciones Económicas Precapitalistas. México, D.F.: Siglo XXI, 2011.

MASON, Otis. Similarities in culture. in: American Anthropologist. N. 8, 1895. pp. 101-117

MAUSS, Marcel. Antropología y Sociología. Madrid: Tecnos, 1971.

MEAD, Margaret. Adolescencia, sexo y cultura en Samoa. Barcelona: PlanetaAgostini, 1985.

MEAD, Margaret. Sexo y temperamento en las sociedades primitivas. Barcelona: Laia, 1973.

MESSINA, Giuseppe. Le nuove forma de intervento dello Stato nei conflitti collettivi di lavoro. in: Rivista di Diritto Pubblico, 1911.

MISHEL, L. e BERNSTEIN, J. The state of working America 1994-1995. Washington: Economy Policy Institute, 1994.

MONEREO PÉREZ, José Luis; MOLINA NAVARETE, Cristóbal; MORENO VIDA, María Nieves. Manual de Derecho Sindical. Granada: Comares, 2015.

MORAES, Antonio Carlos Robert de. Bases da Formação Territorial do Brasil. in: Revista Geografares, Vitória, $\mathrm{n}^{\circ} 2$, jun/2001.

MORGAN, Lewis Henry. La Sociedad Primitiva. Madrid: Endymión, 1987.

MOTA, Carlos Guilherme e LOPEZ, Adriana. Historia de Brasil: una interpretación. Traducción de José Manuel Santos Pérez. Salamanca: Ediciones Universidad de Salamanca, 2009.

NASCIMENTO, Amauri Mascaro. Compêndio de Direito Sindical. São Paulo: LTr, 2008.

NASCIMENTO, Amauri Mascaro. Direito Sindical. São Paulo: Saraiva, 1991. 
NOGUEIRA, Roberto. Elaboração e análise de questionários: uma revisão da literatura básica e a aplicação dos conceitos a um caso real. Rio de Janeiro : UFRJ/COPPEAD, 2002.

NUNES DA COSTA, Marta. O que Marx nos pode ensinar sobre a nova "classe perigosa" - crítica, neoliberalismo e o futuro da emancipação humana. in: Revista Novos Estudos, n 101, São Paulo, mar/2015, pp. 97-114.

OJEDA AVILÉS, Antonio. Derecho Sindical. Madrid: Tecnos, 1995.

OLIVEIRA, Lucia Lippi. O Brasil dos Imigrantes. Rio de Janeiro: Jorge Zahar Editor, 2002.

OLIVEIRA VIANNA, Francisco José de. Problemas de direito sindical. Rio de Janeiro: M. Limonad, 1943.

ORGANIZAÇÃO INTERNACIONAL DO TRABALHO. Convenção n 87. San Francisco, 1948.

ORGANIZAÇÃO INTERNACIONAL DO TRABALHO. International Standard Classification of Occupations. Genebra: 1958.

ORGANIZAÇÃO INTERNACIONAL DO TRABALHO. International Standard Classification of Occupations. Genebra: 2012.

ORGANIZAÇÃO INTERNACIONAL DO TRABALHO. Standards on Forced Labour - The new Protocol and Recommendation at a Glance. International Labour Office, Fundamental Principles and Rights at Work Branch (FUNDAMENTALS) Geneva: ILO, 2016.

ORTEGA Y GASSET, José. La Rebelión de las Masas. Madrid: Tecnos, 2003.

OSUNA FERNÁNDEZ-LARGO, Antonio. La hermenéutica jurídica de Hans Georg Gadamer. Valladolid: Publicaciones Universidad de Valladolid, 1992.

PAES DE ANDRADE, Paulo Bonavides. História Constitucional do Brasil. Brasília: OAB Editora, 2002.

PALOMEQUE LÓPEZ, Manoel Carlos. Derecho del Trabajo e Ideología. Madrid: Tecnos, 2011.

PALOMEQUE LÓPEZ, Manoel Carlos. Derecho del Trabajo. Madrid: Tecnos, 1994.

PALOMEQUE LÓPEZ, Manuel Carlos. Derecho Sindical. Madrid: CEF, 2013.

PAPA LEÃO XIII. Encíclica Rerum Novarum: sobre a condição dos operários.

Disponível em: <

http://www.vatican.va/holy_father/leo_xiii/encyclicals/documents/hf_Ixiii_enc_15051891_rerum-novarum_po.html > Acesso em: 04/06/2014. 
PAULO, Vicente e ALEXANDRINO, Marcelo. Direito do Trabalho. Rio de Janeiro: Impetus, 2005.

PERSIANI, Mattia. Diritto Sindacale. Padova: Cedam, 2012.

PIKE, Kenneth. Language in relation to a unified theory of the structure of human behavior. volumen I, Glendale: Summer Institute of Lingustics, 1954.

PINTO, José Augusto Rodrigues. Direito Sindical e Coletivo do Trabalho. São Paulo: LTr, 1998.

POLANYI, Karl. Primitive, archaic and modern economies: essays of Karl Polanyi. New York: Doubleday, 1968.

PRADO JÚNIOR, Caio. A evolução política do Brasil e outros estudos. SãoPaulo: Companhia das Letras, 2012.

PRADO JÚNIOR, Caio. A formação do Brasil contemporâneo: colônia. São Paulo: Companhia das Letras, 2011.

RADCLIFFE-BROWN, Alfred Reginald. El método de la antropología social. Traducción de Carlos Manzano. Barcelona: Anagrama, 1975.

RADCLIFFE-BROWN, Alfred Reginald. Estructura y función en la sociedad primitiva. Barcelona: Península, 1974.

REALE, Miguel. Lições preliminares de direito. São Paulo: Saraiva, 2001.

RIBEIRO, Darcy. O povo brasileiro: a formação e o sentido do Brasil. São Paulo: Companhia das Letras, 1995.

RIBEIRO, Darcy. O processo civilizatório: estudos de antropologia da civilização; etapas da evolução sócio-cultural. Petrópolis: Vozes, 1979.

RODRÍGUEZ, César. La decisión judicial: el debate Hart-Dworkin. Santafé de Bogotá: Universidad de los Andes, 1997.

ROMITA, Arion Sayão. Direito Sindical Brasileiro. Rio de Janeiro: Editora Brasília, 1976.

ROMITA, Arion Sayão. Organização sindical, justiça do trabalho, direito à greve na constituição. Rio de Janeiro: Ed. Trabalhistas, 1987.

ROUSSEAU, Jean Jacques. Discurso sobre el origen de la desigualdad entre los hombres. Barcelona: Península, 1970.

RUSSOMANO, Mozart Victor. Comentários à Consolidação das Leis do Trabalho. Rio de Janeiro: Forense, 1997.

SAHLINS, Marshall. Sociedades Tribais. Rio de Janeiro: Zahar, 1983. 
SALA FRANCO, Tomás. Derecho Sindical. Valencia: Tirant lo Blanch, 2013.

SANMARTÍN BARROS, Israel. El fin de la historia en Hegel y Marx. in: História da Historiografia, Ouro Preto, n 12, ago/2013.

SANTORO-PASSARELLI, Giuseppe. Diritto Sindacale. Bari: Laterza, 2009.

SANTOS, Boaventura de Sousa. Sociología jurídica crítica : para un nuevo sentido común en el derecho. Madrid: Trotta, 2009.

SANTOS, Luiz Alberto Matos dos. A liberdade sindical como direito fundamental. São Paulo: LTr, 2009.

SAUSSURE, Ferdinand de. Curso de linguística general. Tres Cantos (Madrid): Akal, 2006.

SCHAPERA, Isaac. Malinowski y la teoría de la ley. in: Hombre y Cultura: La obra de Bronislaw Malinowski. Madrid: Siglo XXI, 1974

SCHWARZ, Rodrigo Garcia. Direito do Trabalho. Rio de Janeiro: Elsevier, 2009.

SENNET, Richard. A cultura do novo capitalismo. Tradução de Clóvis Marques. Rio de Janeiro: Record, 2006.

SENNET, Richard. La corrosión del carácter: las consecuencias personales del trabajo en el nuevo capitalismo. Barcelona: Anagrama, 2005.

SIERRA, María Teresa e CHENAUT, Victoria. Los debates recientes y actuales en la antropología jurídica: las corrientes anglosajonas. in: Antropología Jurídica:

Perspectivas Socioculturales en el Estudio del Derecho. KROTZ, Esteban. Barcelona: Anthropos, 2014. pp. 113-170

SILVA, Homero Batista Mateus da. Curso de Direito do Trabalho Aplicado, vol. 07: Direito Coletivo do Trabalho. Rio de Janeiro, Elsevier, 2010.

SPENCER, Herbert. El progreso, su ley y su causa. Tradução de Miguel de Unamuno. Madrid: La España Moderna, 1895.

SPENCER, Herbert. Fundamentos de la Moral. Sevilla: Administración de la Biblioteca Científico-Literaria, 1881.

SPENCER, Herbert. Orígen de las Profesiones. Barcelona: Ediciones populares Iberia, 1932.

SPENCER, Herbert. The Principles of Sociology. Berlim: Heptagon, 2013.

STEWARD, Julian $\mathrm{H}$. Theory of culture change: the methodology of cultural evolution. Champaign, IL: University of Illinois Press, 1990. 
STRECK, Lênio Luiz. Hermenêutica jurídica $\mathbf{e}(\mathbf{m})$ crise: uma exploração hermenêutica da construção do direito. Porto Alegre: Livraria do Advogado, 2000.

STURMER, Gilberto. A efetividade dos direitos sociais constitucionais e a liberdade sindical. in: Revista Sequência, n 58 , p. 9-22, Florianópolis: julho de 2009.

SUSSEKIND, Arnaldo. Direito Constitucional do Trabalho. Rio de Janeiro: Renovar, 2004.

THOMPSON, Edward Palmer. La formación de la classe obrera en Inglaterra. Tomo I. Barcelona: Editorial Crítica, 1989.

THOMPSON, Edward Palmer. La formación de la classe obrera en Inglaterra. Tomo II. Barcelona: Editorial Crítica, 1989.

TROTTA, Wellington. O pensamento político de Hegel à luz de sua filosofia do direito. in: Revista de Sociologia e Política, v. 17, n 32, Curitiba, fev/2009, pp. 9-31

TURNER, Victor. El proceso ritual. Madrid: Taurus, 1988.

TYLOR, Edward Burnett. Antropología: introducción al estudio del hombre y de la civilización. Barcelona: Editorial Alta Fulla, 1987.

TYLOR, Edward Burnett. Cultura Primitiva, I. Los Orígenes de la Cultura. Madrid: Ayuso, 1977.

VALLS PLANA, Ramón. Del Yo al Nosotros. Lectura de la Fenomenología del Espíritu de Hegel. Barcelona: Estela, 1971.

VAN GENNEP, Arnold. Los ritos de paso: estudio sistematico de las ceremonias de la puerta y del umbral. Madrid: Taurus, 1986.

VASQUEZ, Eduardo. Dialectica y Derecho en Hegel. Caracas: Monte Avila, 1968.

VELASCO, Honorio. e DÍAZ DE RADA, Ángel. La lógica de la investigación etnográfica. Madrid: Trotta, 1997.

VERDIER, Jean-Maurice. Syndicats et droit syndical. Vol. I, Liberté, structures, action. Paris: Dalloz, 1987.

VIANNA, Luiz Werneck. Liberalismo e sindicato no Brasil. Rio de Janeiro: Paz e Terra, 1976.

WARMINSKI, Andrzej. Hegel/Marx: Consciousness and life. in: Yale French Studies, n 88, New Haven, 1995.

WEBB, Sidney e WEBB, Beatrice. Historia del Sindicalismo: 1666-1920. Madrid: Ministerio de Trabajo y Seguridad Social, 1990. 
WHITE, Leslie Alvin. La ciencia de la cultura: un estudio sobre el hombre y la civilzación. Buenos Aires: Paidós, 1964.

WISSLER, Clark. The relation of nature to man in aboriginal America. New York: Oxford University Press, 1926.

XIMENES, Cristiana Ferreira Lírio. Bahia e Angola: redes comerciais e o tráfico de escravos (1750-1808). Tese (Doutorado) - Universidade Federal Fluminense, Instituto de Ciências Humanas e Filosofia, Departamento de História, 2012.

ZWEIG, Stefan. Brasil: País del Futuro. Buenos Aires: Espasa-Calpe, 1950. 


\section{APÊNDICE "A"- MODELO DE QUESTIONÁRIO APLICADO}

\section{QUESTIONÁRIO}

(A resposta ao presente questionário é voluntária e anônima. O mesmo está destinado a contribuir com a realização de tese doutoral no Programa de Doutorado em Ciências Sociais da Universidad de Salamanca/Espanha e não tem fins lucrativos)

Idade: ( ) entre 18 e $30 \operatorname{anos}$ ( ) entre 31 e 45 anos ( ) entre 46 e 60 anos ( ) mais de 60 anos

Sexo: ( ) Masculino ( ) Feminino

1 - Nos últimos 10 (dez) anos, quantos anos trabalhou regularmente (não quer dizer com a carteira assinada)?

( ) menos de 1 ano ( )entre 1 e 2 anos ( ) entre 2 e 5 anos ( ) entre 5 e 8 anos ( ) entre 8 e 10 anos

2 - Nos últimos 10 (dez) anos, quantos anos trabalhou com carteira assinada?

( ) menos de 1 ano ( )entre 1 e 2 anos ( ) entre 2 e 5 anos ( ) entre 5 e 8 anos ( ) entre 8 e 10 anos

3 - Nos últimos 10 (dez) anos quantos empregos diferentes você teve?
( ) 2
( ) 3
( ) 4
( ) 5 ou mais

4 - No caso de haver exercido diferentes empregos, você considera que as atividades eram de um mesmo ramo (exemplo: portaria e vigilância) ou de ramos distintos (exemplo: vendedor e motorista):

( ) mesmo ramo $\quad$ ( ) ramos diferentes

5 - No caso de serem de ramos distintos, nos últimos 10 (dez) anos, quantas atividades diferentes você exerceu?
( ) 2
( ) 3
( ) 4
( ) 5 ou mais

6 - Você possui alguma formação específica para exercer alguma profissão (exemplo: curso de soldador)?

( ) $\operatorname{sim}($ ) não

7 - Nos últimos 10 (dez) anos, quantos anos você trabalhou na profissão em que possui formação?

( ) menos de 1 ano ( )entre 1 e $2 \operatorname{anos}($ ) entre 2 e 5 anos ( ) entre 5 e 8 anos ( ) entre 8 e 10 anos

8 - Você conhece ou conheceu o sindicato que defendia seus interesses?

( ) $\operatorname{sim}($ ) não

9 - Você já foi filiado a algum sindicato (para isso seria necessário preencher um termo de adesão e pagar uma mensalidade)?

( ) $\operatorname{sim}$ ( ) não

10 - Você sabe quais as funções do sindicato de sua categoria profissional?

( ) $\operatorname{sim}($ ) não

11 - Você sabe quem são os trabalhadores que compõem a sua categoria profissional?

( ) $\operatorname{sim}($ ) não

12 - Quais são os trabalhadores que você considera mais próximos (mesmos problemas, mesmas visões)?

( ) colegas da mesma empresa ( ) todos que exercem a mesma atividade [exemplo: todos os porteiros]

( ) vizinhos do bairro 


\section{APÊNDICE "B" - EXTRATO DO CADERNO FOTOGRÁFICO}

Foram suprimidas todas as imagens que continham traços ou perfis de pessoas por questões éticas e legais de preservação da imagem e identidade dos informantes e de outras pessoas presentes. As fotos que seguem buscam apenas situar e oferecer um panorama geral aos leitores sobre os locais onde realizada a pesquisa. Todas as imagens são de autoria própria.
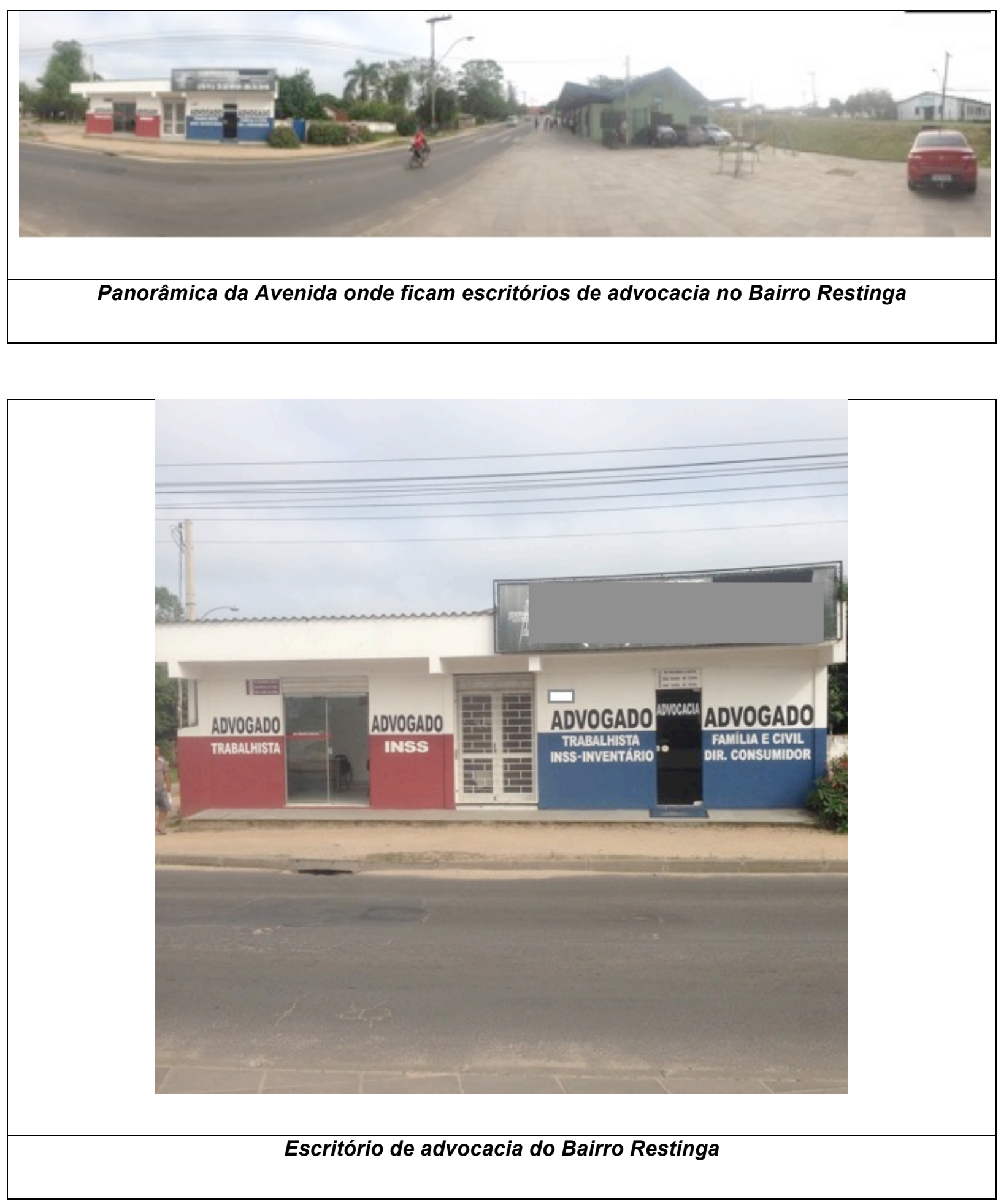


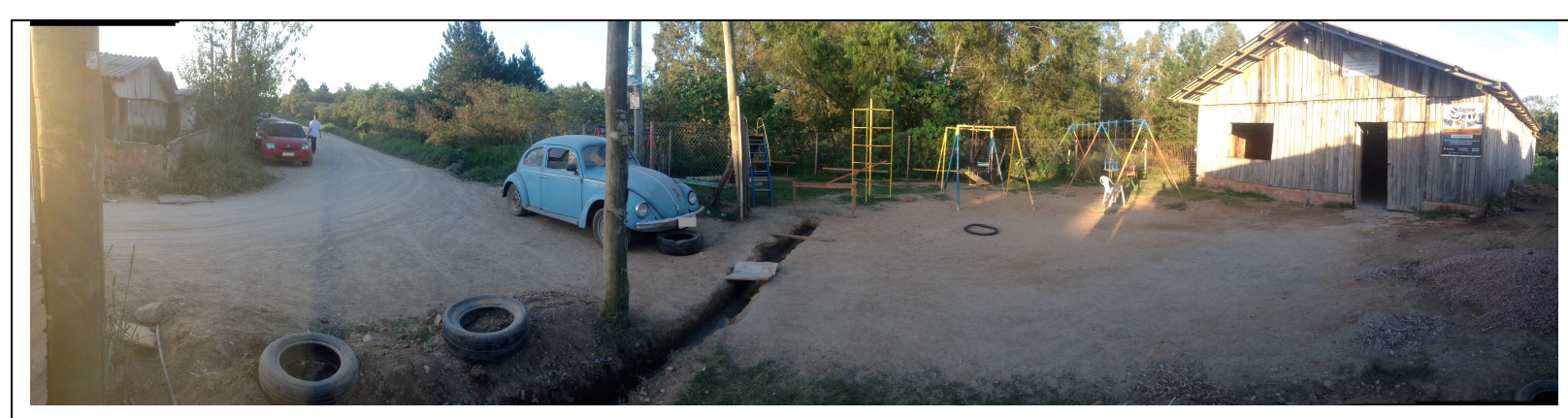

Panorâmica da Associação de Moradores do Bairro Restinga

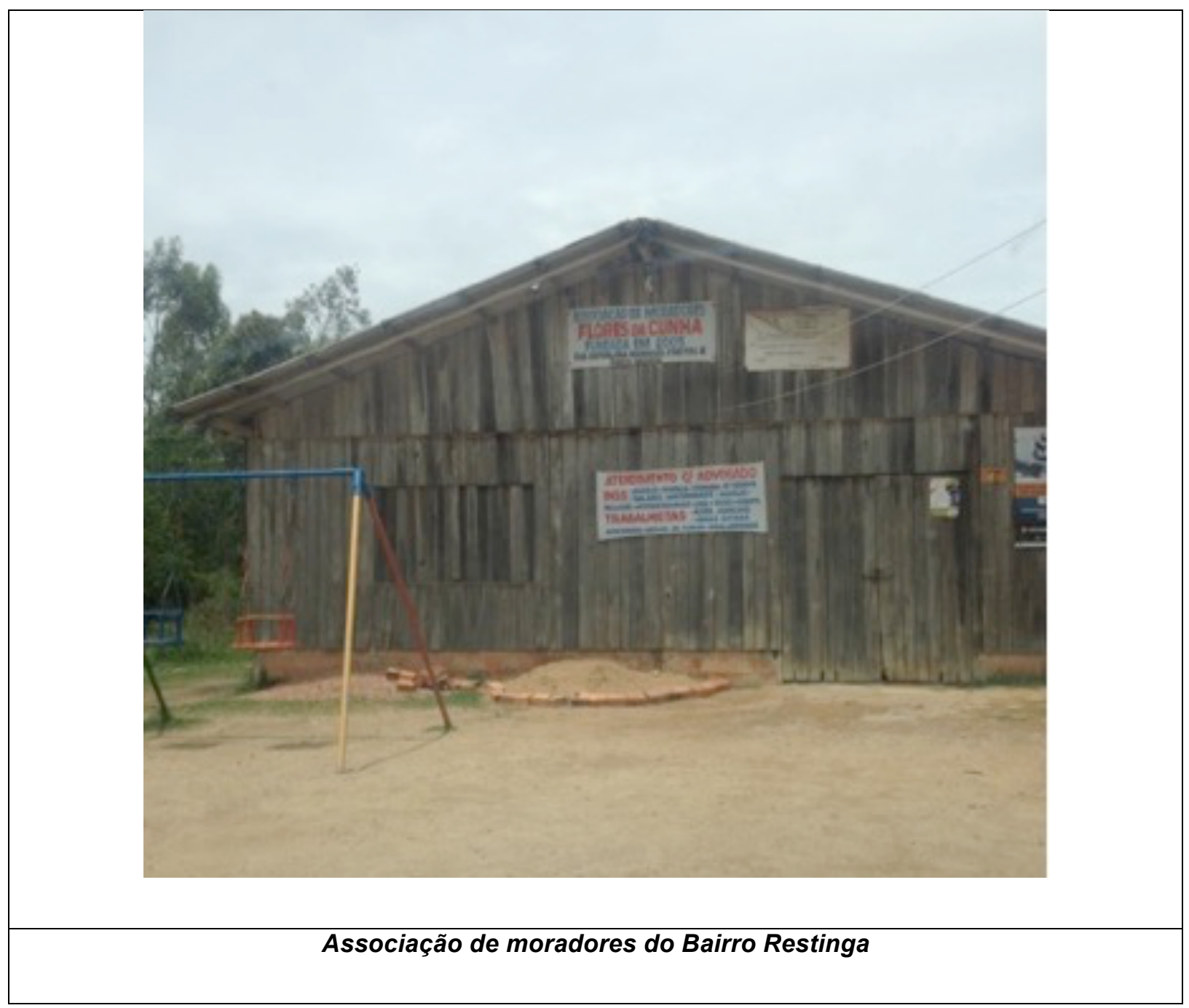




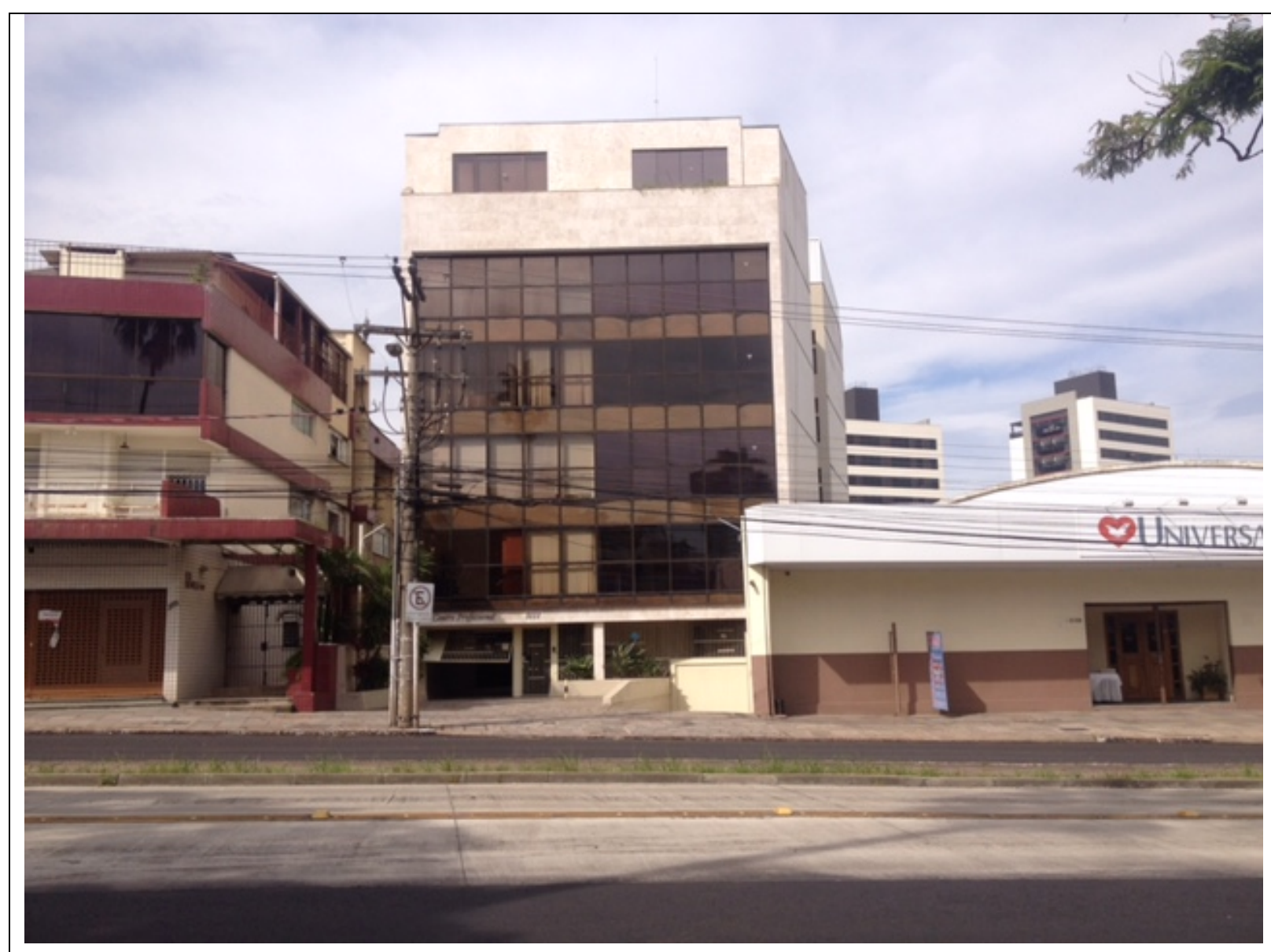

Fachada e vista das adjacências do escritório do Bairro Petrópolis 


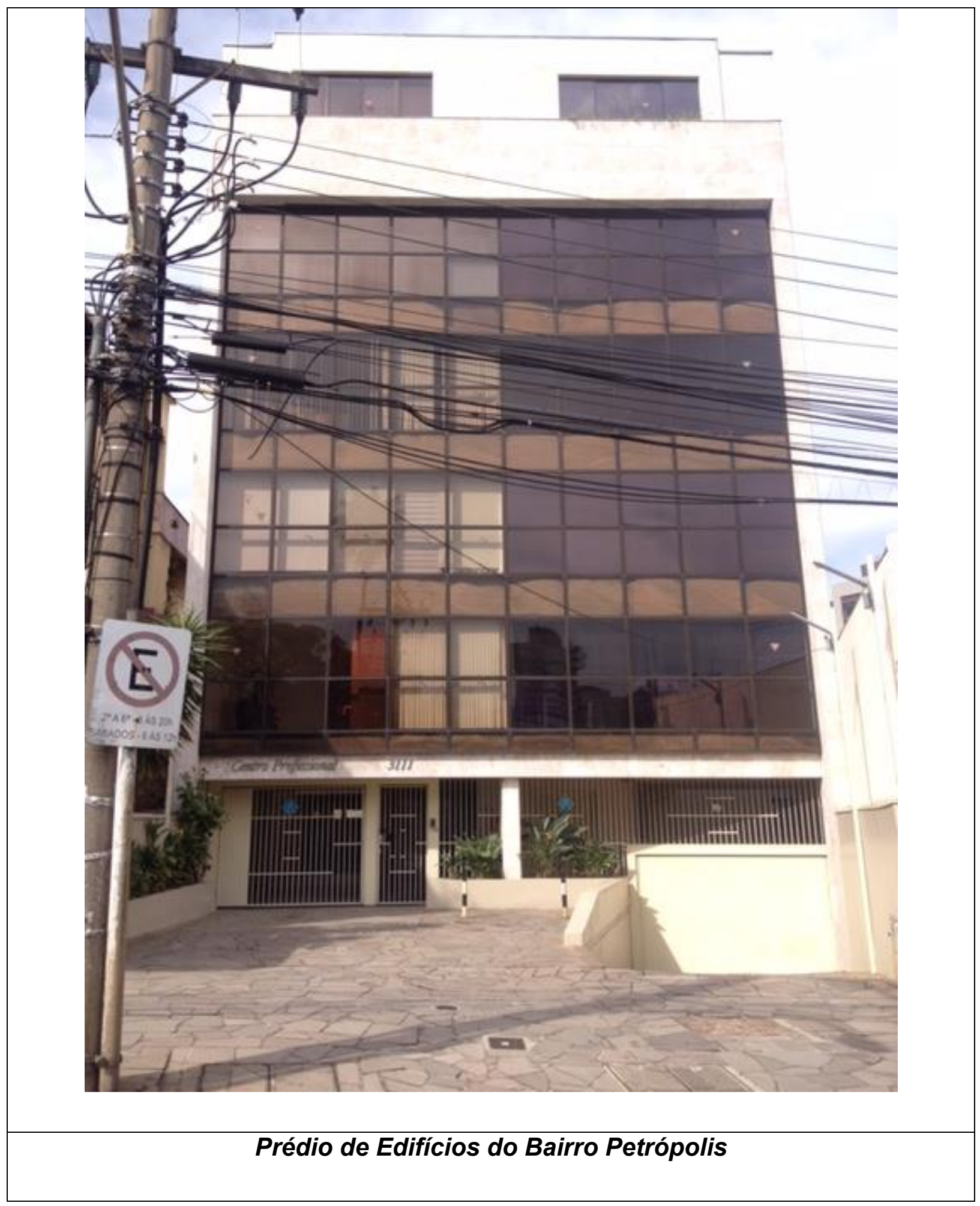




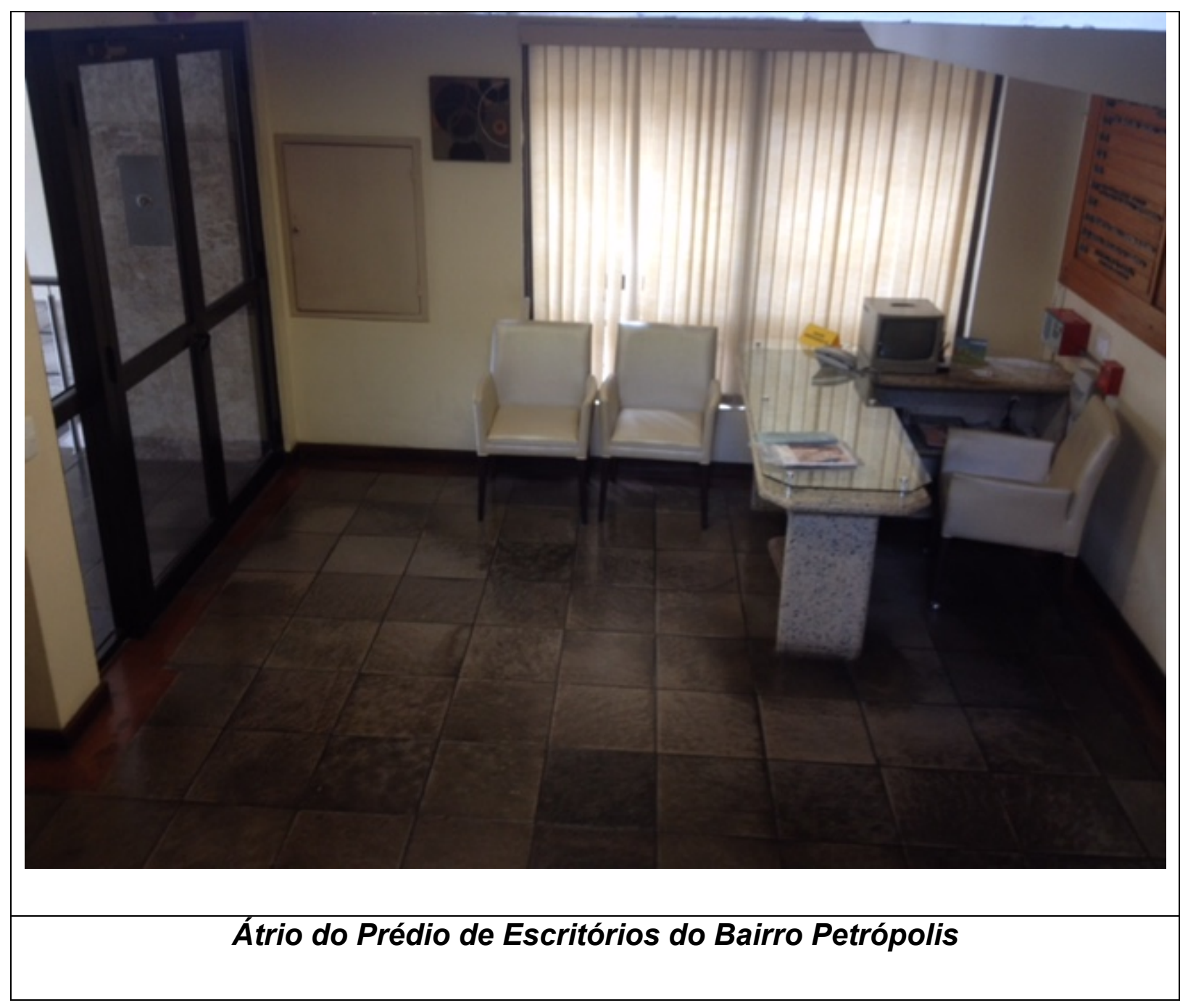




\title{
APÊNDICE "C" - MODELO DE TERMO DE CONSENTIMENTO LIVRE E ESCLARECIDO FIRMADO PELOS PARTICIPANTES DA PESQUISA
}

\author{
TERMO DE CONSENTIMENTO LIVRE E ESCLARECIDO (TCLE)
}

\author{
PROGRAMA DE DOUTORADO EM CIÊNCIAS SOCIAIS: TESE SOBRE AS \\ RELAÇÕES COLETIVAS DE TRABALHO NO BRASIL
}

Você está sendo convidado(a) a participar da pesquisa acima, cujo objetivo principal é entender como se formam as categorias profissionais dentro do sistema sindical brasileiro. $\mathrm{O}$ estudo apresenta um risco considerado mínimo pelo constrangimento eventual que o entrevistado possa ter pelo roteiro de entrevista a ser seguido. Você, ao participar da pesquisa, não sofrerá nenhum prejuízo no local de trabalho. Este estudo se justifica por contribuir para formulação de estratégias que possam melhorar a relação entre os trabalhadores e a efetividade da ação sindical. Ou seja, poderá trazer benefícios tanto aos trabalhadores como aos empregadores.

A entrevista deve durar em torno de 30 minutos. Os seus dados serão sempre tratados confidencialmente, você não será identificado (a) por nome, e os resultados deste estudo serão usados para fins científicos. Seus dados ficarão arquivados por 5 anos sob guarda da instituição de vinculação do investigador responsável (Universidad de Salamanca). Sua participação no estudo é voluntária, de forma que, caso você decida não participar, nenhum comprometimento você terá por esta decisão. Você não terá custo nem receberá por participar. Sua participação não é obrigatória e, a qualquer momento, você poderá desistir e retirar seu consentimento.

Caso você tenha dúvidas ou deseje solicitar esclarecimento, entrar em contato com o pesquisador responsável Antonio Augusto Bonatto Barcellos (fone +34603476502; antonio.barcellos@usal.es) ou com os professores e diretores da pesquisa, Dr. Ángel Baldomero Espina Barrio, da Universidade de Salamanca(+34923294400/espina@usal.es) ou Dr. Emiliano González Díez, da Universidade de Burgos, (+34-947258736/egonzalez@ubu.es).

Assinatura do participante da pesquisa:

Assinatura do pesquisador responsável:

Local e Data:

Observação: O presente documento baseado nas Diretrizes Éticas para Pesquisadores Brasileiros e será assinado em duas vias, de igual teor, ficando uma via em poder do sujeito ou de seu representante legal e outra com o pesquisador responsável. 


\title{
ANEXO “A” - EXTRATO DA CONSTITUIÇÃO DA REPÚBLICA BRASILEIRA
}

\author{
CONSTITUIÇÃO DA REPÚBLICA FEDERATIVA DO BRASIL DE 1988
}

\section{PREÂMBULO}

Nós, representantes do povo brasileiro, reunidos em Assembléia Nacional Constituinte para instituir um Estado Democrático, destinado a assegurar o exercício dos direitos sociais e individuais, a liberdade, a segurança, o bem-estar, o desenvolvimento, a igualdade e a justiça como valores supremos de uma sociedade fraterna, pluralista e sem preconceitos, fundada na harmonia social e comprometida, na ordem interna e internacional, com a solução pacífica das controvérsias, promulgamos, sob a proteção de Deus, a seguinte CONSTITUIÇÃO DA REPÚBLICA FEDERATIVA DO BRASIL.

\section{TÍTULO I DOS PRINCÍPIOS FUNDAMENTAIS}

Art. $1^{\circ}$ A República Federativa do Brasil, formada pela união indissolúvel dos Estados e Municípios e do Distrito Federal, constitui-se em Estado Democrático de Direito e tem como fundamentos:

I - a soberania;

II - a cidadania;

III - a dignidade da pessoa humana;

IV - os valores sociais do trabalho e da livre iniciativa;

$\mathrm{V}$ - o pluralismo político.

Parágrafo único. Todo o poder emana do povo, que o exerce por meio de representantes eleitos ou diretamente, nos termos desta Constituição.

Art. $2^{\circ}$ São Poderes da União, independentes e harmônicos entre si, o Legislativo, o Executivo e o Judiciário.

Art. $3^{\circ}$ Constituem objetivos fundamentais da República Federativa do Brasil:

I - construir uma sociedade livre, justa e solidária;

II - garantir o desenvolvimento nacional;

III - erradicar a pobreza e a marginalização e reduzir as desigualdades sociais e regionais;

IV - promover o bem de todos, sem preconceitos de origem, raça, sexo, cor, idade e quaisquer outras formas de discriminação.

Art. $4^{\circ} \mathrm{A}$ República Federativa do Brasil rege-se nas suas relações internacionais pelos seguintes princípios:

I - independência nacional;

II - prevalência dos direitos humanos;

III - autodeterminação dos povos;

IV - não-intervenção;

$V$ - igualdade entre os Estados;

VI - defesa da paz;

VII - solução pacífica dos conflitos;

VIII - repúdio ao terrorismo e ao racismo;

IX - cooperação entre os povos para o progresso da humanidade;

$X$ - concessão de asilo político.

Parágrafo único. A República Federativa do Brasil buscará a integração econômica, política, social e cultural dos povos da América Latina, visando à formação de uma comunidade latino-americana de nações. 


\section{TÍTULO II DOS DIREITOS E GARANTIAS FUNDAMENTAIS CAPÍTULO I DOS DIREITOS E DEVERES INDIVIDUAIS E COLETIVOS}

Art. $5^{\circ}$ Todos são iguais perante a lei, sem distinção de qualquer natureza, garantindo-se aos brasileiros e aos estrangeiros residentes no País a inviolabilidade do direito à vida, à liberdade, à igualdade, à segurança e à propriedade, nos termos seguintes:

I - homens e mulheres são iguais em direitos e obrigações, nos termos desta Constituição;

II - ninguém será obrigado a fazer ou deixar de fazer alguma coisa senão em virtude de lei;

III - ninguém será submetido a tortura nem a tratamento desumano ou degradante;

IV - é livre a manifestação do pensamento, sendo vedado o anonimato;

$\mathrm{V}$ - é assegurado o direito de resposta, proporcional ao agravo, além da indenização por dano material, moral ou à imagem;

VI - é inviolável a liberdade de consciência e de crença, sendo assegurado o livre exercício dos cultos religiosos e garantida, na forma da lei, a proteção aos locais de culto e a suas liturgias;

VII - é assegurada, nos termos da lei, a prestação de assistência religiosa nas entidades civis e militares de internação coletiva;

VIII - ninguém será privado de direitos por motivo de crença religiosa ou de convicção filosófica ou política, salvo se as invocar para eximir-se de obrigação legal a todos imposta e recusar-se a cumprir prestação alternativa, fixada em lei;

IX - é livre a expressão da atividade intelectual, artística, científica e de comunicação, independentemente de censura ou licença;

X - são invioláveis a intimidade, a vida privada, a honra e a imagem das pessoas, assegurado o direito a indenização pelo dano material ou moral decorrente de sua violação;

XI - a casa é asilo inviolável do indivíduo, ninguém nela podendo penetrar sem consentimento do morador, salvo em caso de flagrante delito ou desastre, ou para prestar socorro, ou, durante o dia, por determinação judicial; $\quad$ (Vide Lei $n^{\circ}$ 13.105, de 2015) (Vigência)

XII - é inviolável o sigilo da correspondência e das comunicações telegráficas, de dados e das comunicações telefônicas, salvo, no último caso, por ordem judicial, nas hipóteses e na forma que a lei estabelecer para fins de investigação criminal ou instrução processual penal; $\quad$ (Vide Lei n 9.296, de 1996)

XIII - é livre o exercício de qualquer trabalho, ofício ou profissão, atendidas as qualificações profissionais que a lei estabelecer;

XIV - é assegurado a todos o acesso à informação e resguardado o sigilo da fonte, quando necessário ao exercício profissional;

$X V$ - é livre a locomoção no território nacional em tempo de paz, podendo qualquer pessoa, nos termos da lei, nele entrar, permanecer ou dele sair com seus bens;

$\mathrm{XVI}$ - todos podem reunir-se pacificamente, sem armas, em locais abertos ao público, independentemente de autorização, desde que não frustrem outra reunião anteriormente convocada para o mesmo local, sendo apenas exigido prévio aviso à autoridade competente;

XVII - é plena a liberdade de associação para fins lícitos, vedada a de caráter paramilitar;

XVIII - a criação de associações e, na forma da lei, a de cooperativas independem de autorização, sendo vedada a interferência estatal em seu funcionamento; 
XIX - as associações só poderão ser compulsoriamente dissolvidas ou ter suas atividades suspensas por decisão judicial, exigindo-se, no primeiro caso, o trânsito em julgado;

$X X$ - ninguém poderá ser compelido a associar-se ou a permanecer associado;

$\mathrm{XXI}$ - as entidades associativas, quando expressamente autorizadas, têm legitimidade para representar seus filiados judicial ou extrajudicialmente;

XXII - é garantido o direito de propriedade;

XXIII - a propriedade atenderá a sua função social;

XXIV - a lei estabelecerá o procedimento para desapropriação por necessidade ou utilidade pública, ou por interesse social, mediante justa e prévia indenização em dinheiro, ressalvados os casos previstos nesta Constituição;

XXV - no caso de iminente perigo público, a autoridade competente poderá usar de propriedade particular, assegurada ao proprietário indenização ulterior, se houver dano;

XXVI - a pequena propriedade rural, assim definida em lei, desde que trabalhada pela família, não será objeto de penhora para pagamento de débitos decorrentes de sua atividade produtiva, dispondo a lei sobre os meios de financiar o seu desenvolvimento;

XXVII - aos autores pertence o direito exclusivo de utilização, publicação ou reprodução de suas obras, transmissível aos herdeiros pelo tempo que a lei fixar;

XXVIII - são assegurados, nos termos da lei:

a) a proteção às participações individuais em obras coletivas e à reprodução da imagem e voz humanas, inclusive nas atividades desportivas;

b) o direito de fiscalização do aproveitamento econômico das obras que criarem ou de que participarem aos criadores, aos intérpretes e às respectivas representações sindicais e associativas;

XXIX - a lei assegurará aos autores de inventos industriais privilégio temporário para sua utilização, bem como proteção às criações industriais, à propriedade das marcas, aos nomes de empresas e a outros signos distintivos, tendo em vista o interesse social e o desenvolvimento tecnológico e econômico do País;

$X X X$ - é garantido o direito de herança;

XXXI - a sucessão de bens de estrangeiros situados no País será regulada pela lei brasileira em benefício do cônjuge ou dos filhos brasileiros, sempre que não lhes seja mais favorável a lei pessoal do "de cujus";

XXXII - o Estado promoverá, na forma da lei, a defesa do consumidor;

XXXIII - todos têm direito a receber dos órgãos públicos informações de seu interesse particular, ou de interesse coletivo ou geral, que serão prestadas no prazo da lei, sob pena de responsabilidade, ressalvadas aquelas cujo sigilo seja imprescindível à segurança da sociedade e do Estado; (Regulamento) (Vide Lei $\mathrm{n}^{\circ} 12.527$, de 2011)

XXXIV - são a todos assegurados, independentemente do pagamento de taxas:

a) o direito de petição aos Poderes Públicos em defesa de direitos ou contra ilegalidade ou abuso de poder;

b) a obtenção de certidões em repartições públicas, para defesa de direitos e esclarecimento de situações de interesse pessoal;

XXXV - a lei não excluirá da apreciação do Poder Judiciário lesão ou ameaça a direito;

XXXVI - a lei não prejudicará o direito adquirido, o ato jurídico perfeito e a coisa julgada;

XXXVII - não haverá juízo ou tribunal de exceção; 
XXXVIII - é reconhecida a instituição do júri, com a organização que lhe der a lei, assegurados:

a) a plenitude de defesa;

b) o sigilo das votações;

c) a soberania dos veredictos;

d) a competência para o julgamento dos crimes dolosos contra a vida;

XXXIX - não há crime sem lei anterior que o defina, nem pena sem prévia cominação legal;

XL - a lei penal não retroagirá, salvo para beneficiar o réu;

XLI - a lei punirá qualquer discriminação atentatória dos direitos e liberdades fundamentais;

XLII - a prática do racismo constitui crime inafiançável e imprescritível, sujeito à pena de reclusão, nos termos da lei;

XLIII - a lei considerará crimes inafiançáveis e insuscetíveis de graça ou anistia a prática da tortura , o tráfico ilícito de entorpecentes e drogas afins, o terrorismo e os definidos como crimes hediondos, por eles respondendo os mandantes, os executores e os que, podendo evitá-los, se omitirem; (Regulamento)

XLIV - constitui crime inafiançável e imprescritível a ação de grupos armados, civis ou militares, contra a ordem constitucional e o Estado Democrático;

XLV - nenhuma pena passará da pessoa do condenado, podendo a obrigação de reparar o dano e a decretação do perdimento de bens ser, nos termos da lei, estendidas aos sucessores e contra eles executadas, até o limite do valor do patrimônio transferido;

XLVI - a lei regulará a individualização da pena e adotará, entre outras, as seguintes:

a) privação ou restrição da liberdade;

b) perda de bens;

c) multa;

d) prestação social alternativa;

e) suspensão ou interdição de direitos;

XLVII - não haverá penas:

a) de morte, salvo em caso de guerra declarada, nos termos do art. 84, XIX;

b) de caráter perpétuo;

c) de trabalhos forçados;

d) de banimento;

e) cruéis;

XLVIII - a pena será cumprida em estabelecimentos distintos, de acordo com a natureza do delito, a idade e o sexo do apenado;

XLIX - é assegurado aos presos o respeito à integridade física e moral;

$L$ - às presidiárias serão asseguradas condições para que possam permanecer com seus filhos durante o período de amamentação;

LI - nenhum brasileiro será extraditado, salvo o naturalizado, em caso de crime comum, praticado antes da naturalização, ou de comprovado envolvimento em tráfico ilícito de entorpecentes e drogas afins, na forma da lei;

LII - não será concedida extradição de estrangeiro por crime político ou de opinião;

LIII - ninguém será processado nem sentenciado senão pela autoridade competente;

LIV - ninguém será privado da liberdade ou de seus bens sem o devido processo legal; 
LV - aos litigantes, em processo judicial ou administrativo, e aos acusados em geral são assegurados o contraditório e ampla defesa, com os meios e recursos a ela inerentes;

LVI - são inadmissíveis, no processo, as provas obtidas por meios ilícitos;

LVII - ninguém será considerado culpado até o trânsito em julgado de sentença penal condenatória;

LVIII - o civilmente identificado não será submetido a identificação criminal, salvo nas hipóteses previstas em lei; (Regulamento).

LIX - será admitida ação privada nos crimes de ação pública, se esta não for intentada no prazo legal;

LX - a lei só poderá restringir a publicidade dos atos processuais quando a defesa da intimidade ou o interesse social o exigirem;

LXI - ninguém será preso senão em flagrante delito ou por ordem escrita e fundamentada de autoridade judiciária competente, salvo nos casos de transgressão militar ou crime propriamente militar, definidos em lei;

LXII - a prisão de qualquer pessoa e o local onde se encontre serão comunicados imediatamente ao juiz competente e à família do preso ou à pessoa por ele indicada; LXIII - o preso será informado de seus direitos, entre os quais o de permanecer calado, sendo-lhe assegurada a assistência da família e de advogado;

LXIV - o preso tem direito à identificação dos responsáveis por sua prisão ou por seu interrogatório policial;

LXV - a prisão ilegal será imediatamente relaxada pela autoridade judiciária;

LXVI - ninguém será levado à prisão ou nela mantido, quando a lei admitir a liberdade provisória, com ou sem fiança;

LXVII - não haverá prisão civil por dívida, salvo a do responsável pelo inadimplemento voluntário e inescusável de obrigação alimentícia e a do depositário infiel;

LXVIII - conceder-se-á habeas corpus sempre que alguém sofrer ou se achar ameaçado de sofrer violência ou coação em sua liberdade de locomoção, por ilegalidade ou abuso de poder;

LXIX - conceder-se-á mandado de segurança para proteger direito líquido e certo, não amparado por habeas corpus ou habeas data, quando o responsável pela ilegalidade ou abuso de poder for autoridade pública ou agente de pessoa jurídica no exercício de atribuições do Poder Público;

LXX - o mandado de segurança coletivo pode ser impetrado por:

a) partido político com representação no Congresso Nacional;

b) organização sindical, entidade de classe ou associação legalmente constituída e em funcionamento há pelo menos um ano, em defesa dos interesses de seus membros ou associados;

LXXI - conceder-se-á mandado de injunção sempre que a falta de norma regulamentadora torne inviável o exercício dos direitos e liberdades constitucionais e das prerrogativas inerentes à nacionalidade, à soberania e à cidadania;

LXXII - conceder-se-á habeas data:

a) para assegurar o conhecimento de informações relativas à pessoa do impetrante, constantes de registros ou bancos de dados de entidades governamentais ou de caráter público;

b) para a retificação de dados, quando não se prefira fazê-lo por processo sigiloso, judicial ou administrativo;

LXXIII - qualquer cidadão é parte legítima para propor ação popular que vise a anular ato lesivo ao patrimônio público ou de entidade de que o Estado participe, à 
moralidade administrativa, ao meio ambiente e ao patrimônio histórico e cultural, ficando o autor, salvo comprovada má-fé, isento de custas judiciais e do ônus da sucumbência;

LXXIV - o Estado prestará assistência jurídica integral e gratuita aos que comprovarem insuficiência de recursos;

LXXV - o Estado indenizará o condenado por erro judiciário, assim como o que ficar preso além do tempo fixado na sentença;

LXXVI - são gratuitos para os reconhecidamente pobres, na forma da lei: (Vide Lei $n^{\circ} 7.844$, de 1989)

a) o registro civil de nascimento;

b) a certidão de óbito;

LXXVII - são gratuitas as ações de habeas corpus e habeas data, e, na forma da lei, os atos necessários ao exercício da cidadania. (Regulamento)

LXXVIII - a todos, no âmbito judicial e administrativo, são assegurados a razoável duração do processo e os meios que garantam a celeridade de sua tramitação. (Incluído pela Emenda Constitucional $n^{\circ} 45$, de 2004)

$\S 1^{\circ}$ As normas definidoras dos direitos e garantias fundamentais têm aplicação imediata.

$\S 2^{\circ}$ Os direitos e garantias expressos nesta Constituição não excluem outros decorrentes do regime e dos princípios por ela adotados, ou dos tratados internacionais em que a República Federativa do Brasil seja parte.

$\S 3^{\circ}$ Os tratados e convenções internacionais sobre direitos humanos que forem aprovados, em cada Casa do Congresso Nacional, em dois turnos, por três quintos dos votos dos respectivos membros, serão equivalentes às emendas constitucionais. (Incluído pela Emenda Constitucional $n^{\circ} 45$, de 2004) (Atos aprovados na forma deste parágrafo)

$\S 4^{\circ} \mathrm{O}$ Brasil se submete à jurisdição de Tribunal Penal Internacional a cuja criação tenha manifestado adesão. (Incluído pela Emenda Constitucional $n^{\circ} 45$, de 2004)

\section{CAPÍTULO II DOS DIREITOS SOCIAIS}

Art. $6^{\circ}$ São direitos sociais a educação, a saúde, a alimentação, o trabalho, a moradia, o transporte, o lazer, a segurança, a previdência social, a proteção à maternidade e à infância, a assistência aos desamparados, na forma desta Constituição. (Redação dada pela Emenda Constitucional nº 90, de 2015)

Art. $7^{\circ}$ São direitos dos trabalhadores urbanos e rurais, além de outros que visem à melhoria de sua condição social:

I - relação de emprego protegida contra despedida arbitrária ou sem justa causa, nos termos de lei complementar, que preverá indenização compensatória, dentre outros direitos;

II - seguro-desemprego, em caso de desemprego involuntário;

III - fundo de garantia do tempo de serviço;

IV - salário mínimo, fixado em lei, nacionalmente unificado, capaz de atender a suas necessidades vitais básicas e às de sua família com moradia, alimentação, educação, saúde, lazer, vestuário, higiene, transporte e previdência social, com reajustes periódicos que lhe preservem o poder aquisitivo, sendo vedada sua vinculação para qualquer fim;

$\mathrm{V}$ - piso salarial proporcional à extensão e à complexidade do trabalho;

VI - irredutibilidade do salário, salvo o disposto em convenção ou acordo coletivo;

VII - garantia de salário, nunca inferior ao mínimo, para os que percebem remuneração variável; 
VIII - décimo terceiro salário com base na remuneração integral ou no valor da aposentadoria;

IX - remuneração do trabalho noturno superior à do diurno;

X - proteção do salário na forma da lei, constituindo crime sua retenção dolosa;

XI - participação nos lucros, ou resultados, desvinculada da remuneração, e, excepcionalmente, participação na gestão da empresa, conforme definido em lei;

XII - salário-família pago em razão do dependente do trabalhador de baixa renda nos termos da lei; (Redação dada pela Emenda Constitucional $n^{\circ} 20$, de 1998)

XIII - duração do trabalho normal não superior a oito horas diárias e quarenta e quatro semanais, facultada a compensação de horários e a redução da jornada, mediante acordo ou convenção coletiva de trabalho; (vide Decreto-Lei $n^{\circ} 5.452$, de 1943)

XIV - jornada de seis horas para o trabalho realizado em turnos ininterruptos de revezamento, salvo negociação coletiva;

$\mathrm{XV}$ - repouso semanal remunerado, preferencialmente aos domingos;

$\mathrm{XVI}$ - remuneração do serviço extraordinário superior, no mínimo, em cinqüenta por cento à do normal; (Vide Del 5.452, art. $59 \S 1^{\circ}$ )

XVII - gozo de férias anuais remuneradas com, pelo menos, um terço a mais do que o salário normal;

XVIII - licença à gestante, sem prejuízo do emprego e do salário, com a duração de cento e vinte dias;

XIX - licença-paternidade, nos termos fixados em lei;

XX - proteção do mercado de trabalho da mulher, mediante incentivos específicos, nos termos da lei;

$\mathrm{XXI}$ - aviso prévio proporcional ao tempo de serviço, sendo no mínimo de trinta dias, nos termos da lei;

XXII - redução dos riscos inerentes ao trabalho, por meio de normas de saúde, higiene e segurança;

XXIII - adicional de remuneração para as atividades penosas, insalubres ou perigosas, na forma da lei;

XXIV - aposentadoria;

XXV - assistência gratuita aos filhos e dependentes desde o nascimento até 5 (cinco) anos de idade em creches e pré-escolas; (Redação dada pela Emenda Constitucional $n^{\circ} 53$, de 2006)

XXVI - reconhecimento das convenções e acordos coletivos de trabalho;

XXVII - proteção em face da automação, na forma da lei;

XXVIII - seguro contra acidentes de trabalho, a cargo do empregador, sem excluir a indenização a que este está obrigado, quando incorrer em dolo ou culpa;

XXIX - ação, quanto aos créditos resultantes das relações de trabalho, com prazo prescricional de cinco anos para os trabalhadores urbanos e rurais, até o limite de dois anos após a extinção do contrato de trabalho; (Redação dada pela Emenda Constitucional $n^{\circ} 28$, de 25/05/2000)

XXX - proibição de diferença de salários, de exercício de funções e de critério de admissão por motivo de sexo, idade, cor ou estado civil;

XXXI - proibição de qualquer discriminação no tocante a salário e critérios de admissão do trabalhador portador de deficiência;

XXXII - proibição de distinção entre trabalho manual, técnico e intelectual ou entre os profissionais respectivos;

XXXIII - proibição de trabalho noturno, perigoso ou insalubre a menores de dezoito e de qualquer trabalho a menores de dezesseis anos, salvo na condição de aprendiz, 
a partir de quatorze anos;

(Redação dada pela Emenda Constitucional $n^{\circ} 20$, de 1998)

XXXIV - igualdade de direitos entre o trabalhador com vínculo empregatício permanente e o trabalhador avulso

Parágrafo único. São assegurados à categoria dos trabalhadores domésticos os direitos previstos nos incisos IV, VI, VII, VIII, X, XIII, XV, XVI, XVII, XVIII, XIX, XXI, XXII, XXIV, XXVI, XXX, XXXI e XXXIII e, atendidas as condições estabelecidas em lei e observada a simplificação do cumprimento das obrigações tributárias, principais e acessórias, decorrentes da relação de trabalho e suas peculiaridades, os previstos nos incisos I, II, III, IX, XII, XXV e XXVIII, bem como a sua integração à previdência social. $\quad$ (Redação dada pela Emenda Constitucional $n^{\circ} 72$, de 2013)

Art. $8^{\circ}$ É livre a associação profissional ou sindical, observado o seguinte:

I - a lei não poderá exigir autorização do Estado para a fundação de sindicato, ressalvado o registro no órgão competente, vedadas ao Poder Público a interferência e a intervenção na organização sindical;

II - é vedada a criação de mais de uma organização sindical, em qualquer grau, representativa de categoria profissional ou econômica, na mesma base territorial, que será definida pelos trabalhadores ou empregadores interessados, não podendo ser inferior à área de um Município;

III - ao sindicato cabe a defesa dos direitos e interesses coletivos ou individuais da categoria, inclusive em questões judiciais ou administrativas;

IV - a assembléia geral fixará a contribuição que, em se tratando de categoria profissional, será descontada em folha, para custeio do sistema confederativo da representação sindical respectiva, independentemente da contribuição prevista em lei;

$\mathrm{V}$ - ninguém será obrigado a filiar-se ou a manter-se filiado a sindicato;

VI - é obrigatória a participação dos sindicatos nas negociações coletivas de trabalho;

VII - o aposentado filiado tem direito a votar e ser votado nas organizações sindicais;

VIII - é vedada a dispensa do empregado sindicalizado a partir do registro da candidatura a cargo de direção ou representação sindical e, se eleito, ainda que suplente, até um ano após o final do mandato, salvo se cometer falta grave nos termos da lei.

Parágrafo único. As disposições deste artigo aplicam-se à organização de sindicatos rurais e de colônias de pescadores, atendidas as condições que a lei estabelecer.

Art. $9^{\circ} \dot{E}$ assegurado o direito de greve, competindo aos trabalhadores decidir sobre a oportunidade de exercê-lo e sobre os interesses que devam por meio dele defender.

$\S 1^{\circ}$ A lei definirá os serviços ou atividades essenciais e disporá sobre o atendimento das necessidades inadiáveis da comunidade.

$\S 2^{\circ}$ Os abusos cometidos sujeitam os responsáveis às penas da lei.

Art. 10. É assegurada a participação dos trabalhadores e empregadores nos colegiados dos órgãos públicos em que seus interesses profissionais ou previdenciários sejam objeto de discussão e deliberação.

Art. 11. Nas empresas de mais de duzentos empregados, é assegurada a eleição de um representante destes com a finalidade exclusiva de promover-lhes o entendimento direto com os empregadores. 


\section{ANEXO "B" - EXTRATO DA CONSTITUIÇÃO DO REINO DE ESPANHA}

DON JUAN CARLOS I, REY DE ESPAÑA, A TODOS LOS QUE LA PRESENTE VIEREN Y ENTENDIEREN, SABED: QUE LAS CORTES HAN APROBADO Y EL PUEBLO ESPAÑOL RATIFICADO LA SIGUIENTE CONSTITUCIÓN:

\section{PREÁMBULO}

La Nación española, deseando establecer la justicia, la libertad y la seguridad y promover el bien de cuantos la integran, en uso de su soberanía, proclama su voluntad de:

Garantizar la convivencia democrática dentro de la Constitución y de las leyes conforme a un orden económico y social justo.

Consolidar un Estado de Derecho que asegure el imperio de la ley como expresión de la voluntad popular.

Proteger a todos los españoles y pueblos de España en el ejercicio de los derechos humanos, sus culturas y tradiciones, lenguas e instituciones.

Promover el progreso de la cultura y de la economía para asegurar a todos una digna calidad de vida.

Establecer una sociedad democrática avanzada, y

Colaborar en el fortalecimiento de unas relaciones pacíficas y de eficaz cooperación entre todos los pueblos de la Tierra.

En consecuencia, las Cortes aprueban y el pueblo español ratifica la siguiente

\section{CONSTITUCIÓN}

\section{Artículo 7}

Los sindicatos de trabajadores y las asociaciones empresariales contribuyen a la defensa y promoción de los intereses económicos y sociales que les son propios. Su creación y el ejercicio de su actividad son libres dentro del respeto a la Constitución y a la ley. Su estructura interna y funcionamiento deberán ser democráticos.

\section{Artículo 21}

1. Se reconoce el derecho de reunión pacífica y sin armas. El ejercicio de este derecho no necesitará autorización previa.

2. En los casos de reuniones en lugares de tránsito público y manifestaciones se dará comunicación previa a la autoridad, que sólo podrá prohibirlas cuando existan razones fundadas de alteración del orden público, con peligro para personas o bienes.

\section{Artículo 22}


1. Se reconoce el derecho de asociación.

2. Las asociaciones que persigan fines o utilicen medios tipificados como delito son ilegales.

3. Las asociaciones constituidas al amparo de este artículo deberán inscribirse en un registro a los solos efectos de publicidad.

4. Las asociaciones sólo podrán ser disueltas o suspendidas en sus actividades en virtud de resolución judicial motivada.

5. Se prohíben las asociaciones secretas y las de carácter paramilitar.

\section{Artículo 23}

1. Los ciudadanos tienen el derecho a participar en los asuntos públicos, directamente o por medio de representantes, libremente elegidos en elecciones periódicas por sufragio universal.

2. Asimismo, tienen derecho a acceder en condiciones de igualdad a las funciones y cargos públicos, con los requisitos que señalen las leyes.

\section{Artículo 28}

1. Todos tienen derecho a sindicarse libremente. La ley podrá limitar o exceptuar el ejercicio de este derecho a las Fuerzas o Institutos armados o a los demás Cuerpos sometidos a disciplina militar y regulará las peculiaridades de su ejercicio para los funcionarios públicos. La libertad sindical comprende el derecho a fundar sindicatos y a afiliarse al de su elección, así como el derecho de los sindicatos a formar confederaciones y a fundar organizaciones sindicales internacionales o a afiliarse a las mismas. Nadie podrá ser obligado a afiliarse a un sindicato.

2. Se reconoce el derecho a la huelga de los trabajadores para la defensa de sus intereses. La ley que regule el ejercicio de este derecho establecerá las garantías precisas para asegurar el mantenimiento de los servicios esenciales de la comunidad.

\section{Artículo 35}

1. Todos los españoles tienen el deber de trabajar y el derecho al trabajo, a la libre elección de profesión u oficio, a la promoción a través del trabajo y a una remuneración suficiente para satisfacer sus necesidades y las de su familia, sin que en ningún caso pueda hacerse discriminación por razón de sexo.

2. La ley regulará un estatuto de los trabajadores.

\section{Artículo 37}

1. La ley garantizará el derecho a la negociación colectiva laboral entre los representantes de los trabajadores y empresarios, así como la fuerza vinculante de los convenios. 
2. Se reconoce el derecho de los trabajadores y empresarios a adoptar medidas de conflicto colectivo. La ley que regule el ejercicio de este derecho, sin perjuicio de las limitaciones que puedan establecer, incluirá las garantías precisas para asegurar el funcionamiento de los servicios esenciales de la comunidad.

\section{Artículo 38}

Se reconoce la libertad de empresa en el marco de la economía de mercado. Los poderes públicos garantizan y protegen su ejercicio y la defensa de la productividad, de acuerdo con las exigencias de la economía general y, en su caso, de la planificación. 


\section{ANEXO “C” - EXTRATO DA CONSTITUIÇÃO DA REPÚBLICA ITALIANA}

\section{Principi fondamentali}

\section{Art. 1}

L'Italia è una Repubblica democratica, fondata sul lavoro.

La sovranità appartiene al popolo, che la esercita nelle forme e nei limiti della Costituzione.

\section{Art. 2}

La Repubblica riconosce e garantisce i diritti inviolabili dell'uomo, sia come singolo sia nelle formazioni sociali ove si svolge la sua personalità, e richiede l'adempimento dei doveri inderogabili di solidarietà politica, economica e sociale.

\section{Art. 3}

Tutti i cittadini hanno pari dignità sociale e sono eguali davanti alla legge, senza distinzione di sesso, di razza, di lingua, di religione, di opinioni politiche, di condizioni personali e sociali.

È compito della Repubblica rimuovere gli ostacoli di ordine economico e sociale, che, limitando di fatto la libertà e l'eguaglianza dei cittadini, impediscono il pieno sviluppo della persona umana e l'effettiva partecipazione di tutti i lavoratori all'organizzazione politica, economica e sociale del Paese.

\section{Art. 4}

La Repubblica riconosce a tutti i cittadini il diritto al lavoro e promuove le condizioni che rendano effettivo questo diritto.

Ogni cittadino ha il dovere di svolgere, secondo le proprie possibilità e la propria scelta, un'attività o una funzione che concorra al progresso materiale o spirituale della società.

\section{Titolo III - Rapporti economici}

\section{Art. 35.}

La Repubblica tutela il lavoro in tutte le sue forme ed applicazioni.

Cura la formazione e l'elevazione professionale dei lavoratori.

Promuove e favorisce gli accordi e le organizzazioni internazionali intesi ad affermare e regolare i diritti del lavoro.

Riconosce la libertà di emigrazione, salvo gli obblighi stabiliti dalla legge nell'interesse generale, e tutela il lavoro italiano all'estero.

Art. 36. 
II lavoratore ha diritto ad una retribuzione proporzionata alla quantità e qualità del suo lavoro e in ogni caso sufficiente ad assicurare a sé e alla famiglia un'esistenza libera e dignitosa.

La durata massima della giornata lavorativa è stabilita dalla legge.

II lavoratore ha diritto al riposo settimanale e a ferie annuali retribuite, e non può rinunziarvi.

\section{Art. 37.}

La donna lavoratrice ha gli stessi diritti e, a parità di lavoro, le stesse retribuzioni che spettano al lavoratore.

Le condizioni di lavoro devono consentire l'adempimento della sua essenziale funzione familiare e assicurare alla madre e al bambino una speciale adeguata protezione.

La legge stabilisce il limite minimo di età per il lavoro salariato.

La Repubblica tutela il lavoro dei minori con speciali norme e garantisce ad essi, a parità di lavoro, il diritto alla parità di retribuzione.

\section{Art. 38.}

Ogni cittadino inabile al lavoro e sprovvisto dei mezzi necessari per vivere ha diritto al mantenimento e all'assistenza sociale.

I lavoratori hanno diritto che siano preveduti ed assicurati mezzi adeguati alle loro esigenze di vita in caso di infortunio, malattia, invalidità e vecchiaia, disoccupazione involontaria.

Gli inabili ed i minorati hanno diritto all'educazione e all'avviamento professionale.

Ai compiti previsti in questo articolo provvedono organi ed istituti predisposti o integrati dallo Stato.

L'assistenza privata è libera.

\section{Art. 39.}

L'organizzazione sindacale è libera.

Ai sindacati non può essere imposto altro obbligo se non la loro registrazione presso uffici locali o centrali, secondo le norme di legge.

È condizione per la registrazione che gli statuti dei sindacati sanciscano un ordinamento interno a base democratica.

I sindacati registrati hanno personalità giuridica. Possono, rappresentati unitariamente in proporzione dei loro iscritti, stipulare contratti collettivi di lavoro con efficacia obbligatoria per tutti gli appartenenti alle categorie alle quali il contratto si riferisce. 
Art. 40.

II diritto di sciopero si esercita nell'ambito delle leggi che lo regolano. [6]

Art. 41.

L'iniziativa economica privata è libera.

Non può svolgersi in contrasto con l'utilità sociale o in modo da recare danno alla sicurezza, alla libertà, alla dignità umana.

La legge determina i programmi e i controlli opportuni perché l'attività economica pubblica e privata possa essere indirizzata e coordinata a fini sociali.

\section{Art. 42.}

La proprietà è pubblica o privata. I beni economici appartengono allo Stato, ad enti o a privati.

La proprietà privata è riconosciuta e garantita dalla legge, che ne determina i modi di acquisto, di godimento e i limiti allo scopo di assicurarne la funzione sociale e di renderla accessibile a tutti.

La proprietà privata può essere, nei casi preveduti dalla legge, e salvo indennizzo, espropriata per motivi d'interesse generale.

La legge stabilisce le norme ed i limiti della successione legittima e testamentaria e i diritti dello Stato sulle eredità.

Art. 43.

A fini di utilità generale la legge può riservare originariamente o trasferire, mediante espropriazione e salvo indennizzo, allo Stato, ad enti pubblici o a comunità di lavoratori o di utenti determinate imprese o categorie di imprese, che si riferiscano a servizi pubblici essenziali o a fonti di energia o a situazioni di monopolio ed abbiano carattere di preminente interesse generale.

Art. 44.

Al fine di conseguire il razionale sfruttamento del suolo e di stabilire equi rapporti sociali, la legge impone obblighi e vincoli alla proprietà terriera privata, fissa limiti alla sua estensione secondo le regioni e le zone agrarie, promuove ed impone la bonifica delle terre, la trasformazione del latifondo e la ricostituzione delle unità produttive; aiuta la piccola e la media proprietà. La legge dispone provvedimenti a favore delle zone montane.

Art. 45.

La Repubblica riconosce la funzione sociale della cooperazione a carattere di mutualità e senza fini di speculazione privata. 
La legge ne promuove e favorisce l'incremento con i mezzi più idonei e ne assicura, con gli opportuni controlli, il carattere e le finalità.

La legge provvede alla tutela e allo sviluppo dell'artigianato.

Art. 46.

Ai fini della elevazione economica e sociale del lavoro in armonia con le esigenze della produzione, la Repubblica riconosce il diritto dei lavoratori a collaborare, nei modi e nei limiti stabiliti dalle leggi, alla gestione delle aziende.

Art. 47.

La Repubblica incoraggia e tutela il risparmio in tutte le sue forme; disciplina, coordina e controlla l'esercizio del credito.

Favorisce l'accesso del risparmio popolare alla proprietà dell'abitazione, alla proprietà diretta coltivatrice e al diretto e indiretto investimento azionario nei grandi complessi produttivi del Paese. 


\title{
ANEXO “D” - EXTRATO DA CONSOLIDAÇÃO DAS LEIS DO TRABALHO
}

\author{
TÍTULO V - DA ORGANIZAÇÃO SINDICAL \\ CAPÍTULO I - DA INSTITUIÇÃO SINDICAL \\ SEÇÃO I - DA ASSOCIAÇÃO EM SINDICATO
}

Art. 511. É lícita a associação para fins de estudo, defesa e coordenação dos seus interesses econômicos ou profissionais de todos os que, como empregadores, empregados, agentes ou trabalhadores autônomos ou profissionais liberais exerçam, respectivamente, a mesma atividade ou profissão ou atividades ou profissões similares ou conexas.

$\S 1^{\circ} \mathrm{A}$ solidariedade de interesses econômicos dos que empreendem atividades idênticas, similares ou conexas, constitue o vínculo social básico que se denomina categoria econômica.

$\S 2^{\circ} \mathrm{A}$ similitude de condições de vida oriunda da profissão ou trabalho em comum, em situação de emprego na mesma atividade econômica ou em atividades econômicas similares ou conexas, compõe a expressão social elementar compreendida como categoria profissional.

$\S 3^{\circ}$ Categoria profissional diferenciada é a que se forma dos empregados que exerçam profissões ou funções diferenciadas por força de estatuto profissional especial ou em consequência de condições de vida singulares.

$\S 4^{\circ}$ Os limites de identidade, similaridade ou conexidade fixam as dimensões dentro das quais a categoria econômica ou profissional é homogênea e a associação é natural .

Art. 512 - Somente as associações profissionais constituídas para os fins e na forma do artigo anterior e registradas de acordo com o art. 558 poderão ser reconhecidas como Sindicatos e investidas nas prerrogativas definidas nesta Lei.

Art. 513. São prerrogativas dos sindicatos :

a) representar, perante as autoridades administrativas e judiciárias os interesses gerais da respectiva categoria ou profissão liberal ou interesses individuais dos associados relativos á atividade ou profissão exercida;

b) celebrar contratos coletivos de trabalho;

c) eleger ou designar os representantes da respectiva categoria ou profissão liberal;

d) colaborar com o Estado, como orgãos técnicos e consultivos, na estudo e solução dos problemas que se relacionam com a respectiva categoria ou profissão liberal; 
e) impor contribuições a todos aqueles que participam das categorias econômicas ou profissionais ou das profissões liberais representadas.

Parágrafo Único. Os sindicatos de empregados terão, outrossim, a prerrogativa de fundar e manter agências de colocação.

Art. 514. São deveres dos sindicatos :

a) colaborar com os poderes públicos no desenvolvimento da solidariedade social;

b) manter serviços de assistência judiciária para os associados;

c) promover a conciliação nos dissídios de trabalho.

d) sempre que possível, e de acordo com as suas possibilidades, manter no seu quadro de pessoal, em convênio com entidades assistenciais ou por conta própria, um assistente social com as atribuições específicas de promover a cooperação operacional na empresa e a integração profissional na Classe. (Incluída pela Lei $n^{\circ}$ 6.200, de 16.4.1975)

Parágrafo único. Os sindicatos de empregados terão, outrossim, o dever de :

a) promover a fundação de cooperativas de consumo e de crédito;

b) fundar e manter escolas do alfabetização e prevocacionais.

\section{SEÇÃO II - DO RECONHECIMENTO E INVESTIDURA SINDICAL}

Art. 515. As associações profissionais deverão satisfazer os seguintes requisitos para serem reconhecidas como sindicatos :

a) reunião de um terço, no mínimo, de empresas legalmente constituidas, sob a forma individual ou de sociedade, se se tratar de associação de empregadores; ou de um terço dos que integrem a mesma categoria ou exerçam a mesma profissão liberal se se tratar de associação de empregados ou de trabalhadores ou agentes autônomos ou de profissão liberal;

b) duração de 3 (três) anos para o mandato da diretoria; (Redação dada pelo Decreto-lei $n^{\circ} 771$, de 19.8.1969)

c) exercício do cargo de presidente por brasileiro nato, e dos demais cargos de administração e representação por brasileiros.

Parágrafo único. O ministro do Trabalho, Indústria, e Comércio poderá, excepcionalmente, reconhecer como sindicato a associação cujo número de associados seja inferior ao terço a que se refere a alínea a.

Art. 516 - Não será reconhecido mais de um Sindicato representativo da mesma categoria econômica ou profissional, ou profissão liberal, em uma dada base territorial. 
Art. 517. Os sindicatos poderão ser distritais, municipais, intermunicipais, estaduais e interestaduais. Excepcionalmente, e atendendo às peculiaridades de determinadas categorias ou profissões, o ministro do Trabalho, Indústria e Comércio poderá autorizar o reconhecimento de sindicatos nacionais.

$\S 1^{\circ} \mathrm{O}$ ministro do Trabalho, Indústria e Comércio, outorgará e delimitará a base territorial do sindicato.

$\S 2^{\circ}$ Dentro da base territorial que Ihe for determinada é facultado ao sindicato instituir delegacias ou secções para melhor proteção dos associados e da categoria econômica ou profissional ou profissão liberal representada.

Art. 518. O pedido de reconhecimento será dirigido ao ministro do Trabalho, Indústria e Comércio, instruido com exemplar ou cópia autenticada dos estatutos da associação.

$\S 1^{\circ}$ Os estatutos deverão conter :

a) a denominação e a sede da associação;

b) a categoria econômica ou profissional ou a profissão liberal cuja representação é requerida;

c) a afirmação de que a associação agirá como orgão de colaboração com os poderes públicos e as demais associações no sentido da solidariedade social e da subordinação dos interesses econômicos ou profissionais ao interesse nacional;

d) as atribuições, o processo eleitoral e das votações, os casos de perda de mandato e de substituição dos administradores;

e) o modo de constituição e administração do patrimônio social e o destino que lhe será dado no caso de dissolução;

f) as condições em que se dissolverá associação.

$\S 2^{\circ} \mathrm{O}$ processo de reconhecimento será regulado em instruções baixadas pelo ministro do Trabalho, Indústria e Comércio.

Art. 519 - A investidura sindical será conferida sempre à associação profissional mais representativa, a juízo do Ministro do Trabalho, constituindo elementos para essa apreciação, entre outros:

a) o número de associados;

b) os serviços sociais fundados e mantidos;

c) o valor do patrimônio.

Art. 520. Reconhecida como sindicato a associação profissional, ser-lhe-á expedida carta de reconhecimento, assinada pelo ministro do Trabalho, Indústria e Comércio, 
na qual será especificada a representação econômica ou profissional conferida e mencionada a base territorial outorgada.

Parágrafo único. O reconhecimento investe a associação nas prerrogativas do art. 513 e a obriga aos deveres do art. 514, cujo inadimplemento a sujeitará às sanções desta lei.

Art. 521 - São condições para o funcionamento do Sindicato:

a) proibição de qualquer propaganda de doutrinas incompatíveis com as instituições e os interêsses da Nação, bem como de candidaturas a cargos eletivos estranhos ao sindicato. (Redação dada pelo Decreto-lei n 9.502, de 23.7.1946)

b) proibição de exercício de cargo eletivo cumulativamente com o de emprego remunerado pelo sindicato ou por entidade sindical de grau superior;

c) gratuidade do exercício dos cargos eletivos.

d) proibição de quaisquer atividades não compreendidas nas finalidades mencionadas no art. 511, inclusive as de caráter político-partidário; (Incluída pelo Decreto-lei n 9.502, de 23.7.1946)

e) proibição de cessão gratuita ou remunerada da respectiva sede a entidade de índole político-partidária. (Incluída pelo Decreto-lei nº 9.502, de 23.7.1946

Parágrafo único. Quando, para o exercício de mandato, tiver o associado de sindicato de empregados, de trabalhadores autônomos ou de profissionais liberais de se afastar do seu trabalho, poderá ser-Ihe arbitrada pela assembléia geral uma gratificação nunca excedente da importância de sua remuneração na profissão respectiva.

\section{SEÇÃO III - DA ADMINISTRAÇÃO DO SINDICATO}

Art. 522. A administração do sindicato será exercida por uma diretoria constituída no máximo de sete e no mínimo de três membros e de um Conselho Fiscal composto de três membros, eleitos esses órgãos pela Assembléia Geral.

$\S 1^{\circ}$ A diretoria elegerá, dentre os seus membros, o presidente do sindicato.

$\S 2^{\circ} \mathrm{A}$ competência do Conselho Fiscal é limitada à fiscalização da gestão financeira do sindicato.

$\S 3^{\circ}$ - Constituirão atribuição exclusiva da Diretoria do Sindicato e dos Delegados Sindicais, a que se refere o art. 523, a representação e a defesa dos interesses da entidade perante os poderes públicos e as empresas, salvo mandatário com poderes outorgados por procuração da Diretoria, ou associado investido em representação prevista em lei. (Incluído pelo Decreto-lei $n^{\circ}$ 9.502, de 23.7.1946) 
Art. 523 - Os Delegados Sindicais destinados à direção das delegacias ou seções instituídas na forma estabelecida no $\S 2^{\circ}$ do art. 517 serão designados pela diretoria dentre os associados radicados no território da correspondente delegacia.

Art. 524 - Serão sempre tomadas por escrutínio secreto, na forma estatutária, as deliberações da Assembléia Geral concernentes aos seguintes assuntos: (Redação dada pela Lei $n^{\circ} 2.693$, de 23.12.1955)

a) eleição de associado para representação da respectiva categoria prevista em lei; (Redação dada pelo Decreto-lei nº 9.502, de 23.7.1946)

b) tomada e aprovação de contas da diretoria;(Redação dada pelo Decreto-lei $n^{\circ}$ 9.502, de 23.7.1946)

c) aplicação do patrimônio; (Redação dada pelo Decreto-lei nº 9.502, de 23.7.1946)

d) julgamento dos atos da Diretoria, relativos a penalidades impostas a associados; (Redação dada pelo Decreto-lei nº 9.502, de 23.7.1946)

e) pronunciamento sobre relações ou dissídio de trabalho. Neste caso, as deliberações da Assembléia Geral só serão consideradas válidas quando ela tiver sido especialmente convocada para esse fim, de acordo com as disposições dos estatutos da entidade sindical. O quorum para validade da Assembléia será de metade mais um dos associados quites; não obtido esse quorum em primeira convocação, reunir-se-á a Assembléia em segunda convocação com os presentes, considerando-se aprovadas as deliberações que obtiverem 2/3 (dois terços) dos votos. (Incluída pela Lei $n^{\circ} 2.693$, de 23.12.1955)

$\S 1^{\circ}$ - A eleição para cargos de diretoria e conselho fiscal será realizada por escrutínio secreto, durante 6 (seis) horas contínuas, pelo menos, na sede do Sindicato, na de suas delegacias e seções e nos principais locais de trabalho, onde funcionarão as mesas coletoras designadas pelos Delegados Regionais do Trabalho. (Incluído pelo Decreto-lei n 9.502, de 23.7.1946)

$\S 2^{\circ}$ - Concomitantemente ao término do prazo estipulado para a votação, instalarse-á, em Assembléia Eleitoral pública e permanente, na sede do Sindicato, a mesa apuradora, para a qual serão enviadas, imediatamente, pelos presidentes das mesas coletoras, as urnas receptoras e as atas respectivas. Será facultada a designação de mesa apuradora supletiva sempre que as peculiaridades ou conveniências do pleito a exigirem. (Incluído pelo Decreto-lei $n^{\circ}$ 9.502, de 23.7.1946)

$\S 3^{\circ}$ - A mesa apuradora será presidida por membro do Ministério Público do Trabalho ou pessoa de notória idoneidade, designado pelo Procurador-Geral da Justiça do Trabalho ou Procuradores Regionais. (Incluído pelo Decreto-lei $n^{\circ}$ 9.502, de 23.7.1946)

$\S 4^{\circ}$ - O pleito só será válido na hipótese de participarem da votação mais de $2 / 3$ (dois terços) dos associados com capacidade para votar. Não obtido esse coeficiente, será realizada nova eleição dentro de 15 (quinze) dias, a qual terá validade se nela tomarem parte mais de $50 \%$ (cinqüenta por cento) dos referidos 
associados. Na hipótese de não ter sido alcançado, na segunda votação, o coeficiente exigido, será realizado o terceiro e último pleito, cuja validade dependerá do voto de mais de $40 \%$ (quarenta por cento) dos aludidos associados, proclamando o Presidente da mesa apuradora em qualquer dessas hipóteses os eleitos, os quais serão empossados automaticamente na data do término do mandato expirante, não tendo efeito suspensivo os protestos ou recursos oferecidos na conformidade da lei. (Redação dada pela Lei $n^{\circ} 2.693$, de 23.12.1955)

$\S 5^{\circ}$ - Não sendo atingido o coeficiente legal para eleição, o Ministério do Trabalho, Industria e Comercio declarará a vacância da administração, a partir do término do mandato dos membros em exercício, e designará administrador para o Sindicato, realizando-se novas eleições dentro de 6 (seis) meses. (Incluído pelo Decreto-lei $n^{\circ}$ 9.502, de 23.7.1946)

Art. 525 - É vedada a pessoas físicas ou jurídicas, estranhas ao Sindicato, qualquer interferência na sua administração ou nos seus serviços. (Redação dada pelo Decreto-lei $n^{\circ}$ 9.502, de 23.7.1946),

Parágrafo único - Estão excluídos dessa proibição:

a) os delegados do Ministério do Trabalho, Indústria e Comércio, especialmente designados pelo ministro ou por quem o represente;

b) os que, como empregados, exerçam cargos no Sindicato mediante autorização da Assembléia Geral.

Art. 526 - Os empregados do Sindicato serão nomeados pela diretoria respectiva ad referendum, da Assembléia Geral, não podendo recair tal nomeação nos que estiverem nas condições previstas nos itens II, IV, V, VI, VII e VIII do art. 530 e, na hipótese de o nomeador haver sido dirigente sindical, também nas do item I do mesmo artigo. (Redação dada pelo Decreto-lei $n^{\circ} 925$, de 10.10.1969)

Parágrafo único. (Revogado pela Lei $n^{\circ} 11.295$, de 2006)

$\S 2^{\circ}$ Aplicam-se ao empregado de entidade sindical os preceitos das leis de proteção do trabalho e de previdência social, inclusive o direito de associação em sindicato. (Incluído pela Lei $n^{\circ} 11.295$, de 2006)

Art. 527. Na sede de cada sindicato haverá um livro de registro, autenticado pelo funcionário competente do Ministério do Trabalho, Indústria e Comércio, e do qual deverão constar:

a) tratando-se de sindicato de empregadores; a firma, individual ou coletiva, ou a denominação das empresas e sua sede, o nome, idade, estado civil, nacionalidade e residência dos respectivos sócios ou, em se tratando de sociedade por ações, dos diretores, bem como a indicação desses dados quanto ao sócio ou diretor que representar a empresa no sindicato;

b) tratando-se de sindicato de empregados ou de agentes ou trabalhadores autônomos ou de profissionais liberais, alem do nome, idade, estado civil, 
nacionalidade, profissão ou função e residência de cada associado, o estabelecimento ou lugar onde exerce a sua profissão ou função, o número e a série da respectiva carteira profissional e o número da inscrição na instituição de previdência a que pertencer.

Art. 528 -Ocorrendo dissídio ou circunstâncias que perturbem o funcionamento de entidade sindical ou motivos relevantes de segurança nacional, o Ministro do Trabalho e Previdência Social poderá nela intervir, por intermédio de Delegado ou de Junta Interventora, com atribuições para administrá-la e executar ou propor as medidas necessárias para normalizar-Ihe o funcionamento. (Redação dada pelo Decreto-lei $n^{\circ}$ 3, de 27.1.1966)

\section{SEÇÃO IV - DAS ELEIÇÕES SINDICAIS}

Art. 529 - São condições para o exercício do direito do voto como para a investidura em cargo de administração ou representação econômica ou profissional:

a) ter o associado mais de seis meses de inscrição no Quadro Social e mais de 2 (dois) anos de exercício da atividade ou da profissão; (Redação dada pelo Decretolei $\left.\mathrm{n}^{\circ} 8.080,11.10 .1945\right)$

b) ser maior de 18 (dezoito) anos;

c) estar no gozo dos direitos sindicais.

Parágrafo único - É obrigatório aos associados o voto nas eleições sindicais. (Incluído pelo Decreto-lei n²29, de 28.2.1967)

Art. 530 - Não podem ser eleitos para cargos administrativos ou de representação econômica ou profissional, nem permanecer no exercício dêsses cargos: (Redação dada pelo Decreto-lei $n^{\circ} 229$, de 28.2.1967)

I - os que não tiverem definitivamente aprovadas as suas contas de exercício em cargos de administração; (Incluído pelo Decreto-lei nº 229, de 28.2.1967)

II - os que houverem lesado o patrimônio de qualquer entidade sindical; (Incluído pelo Decreto-lei n 229, de 28.2.1967)

III - os que não estiverem, desde dois (2) anos antes, pelo menos, no exercício efetivo da atividade ou da profissão dentro da base territorial do sindicato, ou no desempenho de representação econômica ou profissional; (Incluído pelo Decreto-lei $\mathrm{n}^{\circ} 229$, de 28.2.1967)

IV - os que tiverem sido condenados por crime doloso enquanto persistirem os efeitos da pena; (Incluído pelo Decreto-lei n² 229, de 28.2.1967)

V - os que não estiverem no gôzo de seus direitos políticos; (Incluído pelo Decretolei $n^{\circ} 229$, de 28.2.1967)

VI - (Revogado pela Lei nº 8.865, de 29.3.1994) 
VII - má conduta, devidamente comprovada; (Incluído pelo Decreto-lei $\mathrm{n}^{\circ} 507$, de 18.3.1969)

VIII - (Revogado pela Lei nº 8.865, de 29.3.1994)

Parágrafo único: (Revogado pela Lei $n^{\circ} 2.693$, de 23.12.1955)

Art. 531. Nas eleições para cargos de diretoria e do conselho fiscal serão considerados eleitos os candidatos que obtiverem maioria absoluta de votos em relação ao total dos associados eleitores.

$\S 1^{\circ}$ Não concorrendo à primeira convocação maioria absoluta de eleitores, ou não obtendo nenhum dos candidatos essa maioria, proceder-se-á à nova convocação para dia posterior, sendo então considerados eleitos os candidatos que obtiverem maioria dos eleitores presentes.

$\S 2^{\circ}$ Havendo somente uma chapa registada para as eleições, poderá a assembléia em última convocação ser realizada duas horas após à primeira convocação desde que do edital respectivo conste essa advertência.

$\S 3^{\circ}$ Concorrendo mais de uma chapa poderá o Ministério do Trabalho, Indústria e Comércio designar o presidente da sessão eleitoral, desde que o requeiram os associados que encabeçarem as respectivas chapas. (Redação dada pelo Decretolei $\left.n^{\circ} 8.080,11.10 .1945\right)$

$\S 4^{\circ} \mathrm{O}$ ministro do Trabalho, Indústria e Comércio expedirá instruções regulando o processo das eleições.

Art. 532 - As eleições para a renovação da Diretoria e do Conselho Fiscal deverão ser procedidas dentro do prazo máximo de 60 (sessenta) dias e mínimo de 30 (trinta) dias, antes do término do mandato dos dirigentes em exercício. (Redação dada pelo Decreto-lei $\left.n^{\circ} 8.080,11.10 .1945\right)$

$\S 1^{\circ}$ Não havendo protesto na ata da assembléia eleitoral ou recurso interposto por algum dos candidatos, dentro de 15 dias a contar da data das eleições, a posse da diretoria eleita independerá, da aprovação das, eleições pelo Ministério do Trabalho, Indústria e Comercio. (Incluído pelo Decreto-lei nº 8.080, 11.10.1945)

$\S 2^{\circ}$ Competirá, à diretoria em exercício, dentro de 30 dias da realização das eleições" e não tendo havido recurso, dar publicidade ao resultado do pleito, fazendo comunicação ao órgão local do Ministério do Trabalho, Indústria e Comércio, da relação dos eleitos, com os dados pessoais de cada um e a designação da função que vai exercer. (Incluído pelo Decreto-lei $\mathrm{n}^{\circ}$ 8.080, 11.10.1945)

$\S 3^{\circ}$ Havendo protesto na ata da assembléia eleitoral ou recurso interposto dentro de 15 dias da realização das eleições, competirá a diretoria em exercício encaminhar, devidamente instruído, o processo eleitoral ao órgão local do Ministério do Trabalho, Indústria e Comércio, que o encaminhará para decisão do Ministro de Estado. Nesta hipótese, permanecerão na administração até despacho final do processo a diretoria 
e o conselho fiscal que se encontrarem em exercício. (Incluído pelo Decreto-lei $\mathrm{n}^{\circ}$ $8.080,11.10 .1945)$

$\S 4^{\circ} \mathrm{Não}$ se verificando as hipóteses previstas no parágrafo anterior, a posse da nova diretoria deverá se verificar dentro de 30 dias subsequentes ao término do mandato da anterior. (Incluído pelo Decreto-lei $n^{\circ} 8.080,11.10 .1945$ )

$\S 5^{\circ}$ - Ao assumir o cargo, o eleito prestará, por escrito e solenemente, o compromisso de respeitar, no exercício do mandato, a Constituição, as leis vigentes e os estatutos da entidade. (Incluído pelo Decreto-lei nº 229, de 28.2.1967)

\section{SEÇÃO V - DAS ASSOCIAÇÕES SINDICAIS DE GRAU SUPERIOR}

Art. 533 - Constituem associações sindicais de grau superior as federações e confederações organizadas nos termos desta Lei.

Art. 534 - É facultado aos Sindicatos, quando em número não inferior a 5 (cinco), desde que representem a maioria absoluta de um grupo de atividades ou profissões idênticas, similares ou conexas, organizarem-se em federação. (Redação dada pela Lei $n^{\circ} 3.265$, de 22.9.1957)

$\S 1^{\circ}$ - Se já existir federação no grupo de atividades ou profissões em que deva ser constituída a nova entidade, a criação desta não poderá reduzir a menos de 5 (cinco) o número de Sindicatos que àquela devam continuar filiados. (Incluído pela Lei $n^{\circ} 3.265$, de 22.9.1957)

$\S 2^{\circ}$ - As federações serão constituídas por Estados, podendo o Ministro do Trabalho, Industria e Comercio autorizar a constituição de Federações interestaduais ou nacionais. (Parágrafo $1^{\circ}$ renumerado pela Lei $n^{\circ} 3.265$, de 22.9.1957)

$\S 3^{\circ}$ - É permitido a qualquer federação, para o fim de lhes coordenar os interesses, agrupar os Sindicatos de determinado município ou região a ela filiados; mas a união não terá direito de representação das atividades ou profissões agrupadas. (Parágrafo $2^{\circ}$ renumerado pela Lei $n^{\circ} 3.265$, de 22.9.1957)

Art. 535 - As Confederações organizar-se-ão com o mínimo de 3 (três) federações e terão sede na Capital da República.

$\S 1^{\circ}$ - As confederações formadas por federações de Sindicatos de empregadores denominar-se-ão: Confederação Nacional da Indústria, Confederação Nacional do Comércio, Confederação Nacional de Transportes Marítimos, Fluviais e Aéreos, Confederação Nacional de Transportes Terrestres, Confederação Nacional de Comunicações e Publicidade, Confederação Nacional das Empresas de Crédito e Confederação Nacional de Educação e Cultura.

$\S 2^{\circ}$ - As confederações formadas por federações de Sindicatos de empregados terão a denominação de: Confederação Nacional dos Trabalhadores na Indústria, Confederação Nacional dos Trabalhadores no Comércio, Confederação Nacional dos Trabalhadores em Transportes Marítimos, Fluviais e Aéreos, Confederação Nacional dos Trabalhadores em Transportes Terrestres, Confederação Nacional dos 
Trabalhadores em Comunicações e Publicidade, Confederação Nacional dos Trabalhadores nas Empresas de Crédito e Confederação Nacional dos Trabalhadores em Estabelecimentos de Educação e Cultura.

$\S 3^{\circ}$ - Denominar-se-á Confederação Nacional das Profissões Liberais a reunião das respectivas federações.

$\S 4^{\circ}$ - As associações sindicais de grau superior da Agricultura e Pecuária serão organizadas na conformidade do que dispuser a lei que regular a sindicalização dessas atividades ou profissões.

Art. 536 - C (Revogado pelo Decreto-Lei n²229, de 28.2.1967)

Parágrafo único - (Revogado pelo Decreto-Lei n²29, de 28.2.1967)

Art. 537. O pedido de reconhecimento de uma federação será dirigido ao ministro do Trabalho, Indústria e Comércio, acompanhado de um exemplar dos respectivos estatutos e das cópias autenticadas das atas da assembléia de cada sindicato ou federação que autorizar a filiação.

$\S 1^{\circ}$ A organização das federações e confederações obedecerá às exigências contidas nas alíneas b e c do art. 515.

$\S 2^{\circ}$ A carta de reconhecimento das federações será expedida pelo ministro do Trabalho, Indústria e Comércio, na qual será especificada a coordenação econômica ou profissional conferida e mencionada a base territorial outorgada.

$\S 3^{\circ} \mathrm{O}$ reconhecimento das confederações será feito por decreto do Presidente da República.

Art. 538 - A administração das federações e confederações será exercida pelos seguintes órgãos: (Redação dada pela Lei n² 2.693, de 23.12.1955)

a) Diretoria; (Redação dada pela Lei n² 2.693, de 23.12.1955)

b) Conselho de Representantes;(Redação dada pela Lei nº 2.693, de 23.12.1955)

c) Conselho Fiscal. (Redação dada pela Lei nº 2.693, de 23.12.1955)

$\S 1^{\circ}$ - A Diretoria será constituída no mínimo de 3 (três) membros e de 3 (três) membros se comporá o Conselho Fiscal, os quais serão eleitos pelo Conselho de Representantes com mandato por 3 (três) anos. (Redação dada pelo Decreto-lei $n^{\circ}$ 771, de 19.8.1969)

$\S 2^{\circ}$ - Só poderão ser eleitos os integrantes dos grupos das federações ou dos planos das confederações, respectivamente. (Parágrafo incluído pela Lei $n^{\circ} 2.693$, de 23.12.1955) 
$\S 3^{\circ}$ - O Presidente da federação ou confederação será escolhido dentre os seus membros, pela Diretoria. (Parágrafo $2^{\circ}$ renumerado pela Lei $\mathrm{n}^{\circ} 2.693$, de 23.12.1955)

$\S 4^{\circ}$ - O Conselho de Representantes será formado pelas delegações dos Sindicatos ou das Federações filiadas, constituída cada delegação de 2 (dois) membros, com mandato por 3 (três) anos, cabendo 1 (um) voto a cada delegação. (Parágrafo $3^{\circ}$ renumerado e alterado dada pelo Decreto-lei $n^{\circ} 771$, de 19.8.1969)

$\S 5^{\circ}$ - A competência do Conselho Fiscal é limitada à fiscalização da gestão financeira. (Incluído pela Lei ${ }^{\circ} 2.693$, de 23.12.1955)

Art. 539 - Para a constituição e administração das Federações serão observadas, no que for aplicável, as disposições das Seções II e III do presente Capítulo.

\section{SEÇÃO VI - DOS DIREITOS DOS EXERCENTES DE ATIVIDADES OU PROFISSÕES E DOS SINDICALIZADOS}

Art. 540. A tôda emprêsa, ou indivíduo que exerçam respectivamente atividade ou profissão, desde que satisfaçam as exigências desta lei, assiste o direito de ser admitido no sindicato da respectiva categoria.

$\S 1^{\circ}$ - Perderá os direitos de associado o sindicalizado que, por qualquer motivo, deixar o exercício de atividade ou de profissão.

$\S 2^{\circ}$ - Os associados de Sindicatos de empregados, de agentes ou trabalhadores autônomos e de profissões liberais que forem aposentados, estiverem em desemprego ou falta de trabalho ou tiverem sido convocados para prestação de serviço militar não perderão os respectivos direitos sindicais e ficarão isentos de qualquer contribuição, não podendo, entretanto, exercer cargo de administração sindical ou de representação econômica ou profissional.

Art. 541 - Os que exercerem determinada atividade ou profissão onde não haja Sindicato da respectiva categoria, ou de atividade ou profissão similar ou conexa, poderão filiar-se a Sindicato de profissão idêntica, similar ou conexa, existente na localidade mais próxima.

Parágrafo único - O disposto neste artigo se aplica aos Sindicatos em relação às respectivas federações, na conformidade do Quadro de Atividades e Profissões a que se refere o art. 577.

Art. 542. De todo o ato lesivo de direitos ou contrário a esta lei, emanado da Diretoria, do Conselho ou da Assembléia Geral da entidade sindical, poderá qualquer exercente de atividade ou profissão recorrer, dentro de 30 dias, para a autoridade competente do Ministério do Trabalho, Indústria e Comércio.

Art. 543 - O empregado eleito para cargo de administração sindical ou representação profissional, inclusive junto a órgão de deliberação coletiva, não poderá ser impedido do exercício de suas funções, nem transferido para lugar ou 
mister que lhe dificulte ou torne impossível o desempenho das suas atribuições sindicais. (Redação dada pelo Decreto-lei n² 229, de 28.2.1967)

$\S 1^{\circ}$ - O empregado perderá o mandato se a transferência fôr por êle solicitada ou voluntàriamente aceita. (Redação dada pelo Decreto-lei nº 229, de 28.2.1967)

$\S 2^{\circ}$ - Considera-se de licença não remunerada, salvo assentimento da emprêsa ou cláusula contratual, o tempo em que o empregado se ausentar do trabalho no desempenho das funções a que se refere êste artigo. (Redação dada pelo Decretolei $\mathrm{n}^{\circ} 229$, de 28.2.1967)

$\S 3^{\circ}$ - Fica vedada a dispensa do empregado sindicalizado ou associado, a partir do momento do registro de sua candidatura a cargo de direção ou representação de entidade sindical ou de associação profissional, até 1 (um) ano após o final do seu mandato, caso seja eleito inclusive como suplente, salvo se cometer falta grave devidamente apurada nos termos desta Consolidação. (Redação dada pela Lei $n^{\circ}$ 7.543, de 2.10.1986)

$\S 4^{\circ}$ - Considera-se cargo de direção ou de representação sindical aquele cujo exercício ou indicação decorre de eleição prevista em lei. (Redação dada pela Lei $n^{\circ}$ 7.223, de 2.10.1984)

$\S 5^{\circ}$ - Para os fins dêste artigo, a entidade sindical comunicará por escrito à emprêsa, dentro de 24 (vinte e quatro) horas, o dia e a hora do registro da candidatura do seu empregado e, em igual prazo, sua eleição e posse, fornecendo, outrossim, a êste, comprovante no mesmo sentido. O Ministério do Trabalho e Previdência Social fará no mesmo prazo a comunicação no caso da designação referida no final do $\S 4^{\circ}$. (Incluído pelo Decreto-lei $n^{\circ} 229$, de 28.2.1967)

$\S 6^{\circ}$ - A emprêsa que, por qualquer modo, procurar impedi que o empregado se associe a sindicato, organize associação profissional ou sindical ou exerça os direitos inerentes à condição de sindicalizado fica sujeita à penalidade prevista na letra a do art. 553, sem prejuízo da reparação a que tiver direito o empregado. (Incluído pelo Decreto-lei $n^{\circ} 229$, de 28.2.1967)

Art. 544 - É livre a associação profissional ou sindical, mas ao empregado sindicalizado é assegurada, em igualdade de condições, preferência: (Redação dada pelo Decreto-lei $n^{\circ} 229$, de 28.2.1967)

I - para a admissão nos trabalhos de emprêsa que explore serviços públicos ou mantenha contrato com os podêres públicos; (Incluído pelo Decreto-lei $n^{\circ} 229$, de 28.2.1967)

II - para ingresso em funções públicas ou assemelhadas, em caso de cessação coletiva de trabalho, por motivo de fechamento de estabelecimento; (Incluído pelo Decreto-lei $n^{\circ} 229$, de 28.2.1967)

III - nas concorrências para aquisição de casa própria, pelo Plano Nacional de Habitação ou por intermédio de quaisquer instituições públicas; (Incluído pelo Decreto-lei $n^{\circ} 229$, de 28.2.1967) 
IV - nos loteamentos urbanos ou rurais, promovidos pela União, por seus órgãos de administração direta ou indireta ou sociedades de economia mista; (Incluído pelo Decreto-lei n² 229, de 28.2.1967))

V - na locação ou compra de imóveis, de propriedade de pessoa de direito público ou sociedade de economia mista, quando sob ação de despêjo em tramitação judicial; (Incluído pelo Decreto-lei n² 229, de 28.2.1967)

VI - na concessão de empréstimos simples concedidos pelas agências financeiras do Govêrno ou a êle vinculadas; (Incluído pelo Decreto-lei ${ }^{\circ} 229$, de 28.2.1967)

VII - na aquisição de automóveis, outros veículos e instrumentos relativos ao exercício da profissão, quando financiados pelas autarquias sociedades de economia mista ou agências financeiras do Govêrno;(Incluído pelo Decreto-lei $\mathrm{n}^{\circ}$ 229, de 28.2.1967)

VIII - (Revogado pela Lei $n^{\circ} 8.630$, de 25.2.1993)

IX - na concessão de bolsas de estudo para si ou para seus filhos, obedecida a legislação que regule a matéria. (Incluído pelo Decreto-lei nº 229, de 28.2.1967)

Art. 545 - Os empregadores ficam obrigados a descontar na folha de pagamento dos seus empregados, desde que por eles devidamente autorizados, as contribuições devidas ao Sindicato, quando por este notificados, salvo quanto à contribuição sindical, cujo desconto independe dessas formalidades. (Redação dada pelo Decreto-lei nº 925, de 10.10.1969)

Parágrafo único - O recolhimento à entidade sindical beneficiária do importe descontado deverá ser feito até o décimo dia subseqüente ao do desconto, sob pena de juros de mora no valor de $10 \%$ (dez por cento) sobre o montante retido, sem prejuízo da multa prevista no art. 553 e das cominações penais relativas à apropriação indébita. (Incluído pelo Decreto-lei nº 925, de 10.10.1969)

Art. 546 - Às empresas sindicalizadas é assegurada preferência, em igualdade de condições, nas concorrências para exploração de serviços públicos, bem como nas concorrências para fornecimento às repartições federais, estaduais e municipais e às entidades paraestatais.

Art. 547 - É exigida a qualidade de sindicalizado para o exercício de qualquer função representativa de categoria econômica ou profissional, em órgão oficial de deliberação coletiva, bem como para o gozo de favores ou isenções tributárias, salvo em se tratando de atividades não econômicas.

Parágrafo único. Antes da posse ou exercício das funções a que alude o artigo anterior ou de concessão dos favores será indispensavel comprovar a sindicalização, ou oferecer prova, mediante certidão negativa no Departamento Nacional do Trabalho, no Distrito Federal, ou da autoridade regional do Ministério do Trabalho, Indústria e Comércio, nos Estados e no Território do Acre, de que não existe sindicato no local onde o interessado exerce a respectiva atividade ou profissão. 


\section{SEÇÃO VII - DA GESTÃO FINANCEIRA DO SINDICATO E SUA FISCALIZAÇÃO}

Art. 548 - Constituem o patrimônio das associações sindicais:

a) as contribuições devidas aos Sindicatos pelos que participem das categorias econômicas ou profissionais ou das profissões liberais representadas pelas referidas entidades, sob a denominação de imposto sindical, pagas e arrecadadas na forma do Capítulo III deste Título;

b) as contribuições dos associados, na forma estabelecida nos estatutos ou pelas Assembléias Gerais;

c) os bens e valores adquiridos e as rendas produzidas pelos mesmos;

d) as doações e legados;

e) as multas e outras rendas eventuais.

Art. 549 - A receita dos sindicatos, federações e confederações só poderá ter aplicação na forma prevista nos respectivos orçamentos anuais, obedecidas as disposições estabelecidas na lei e nos seus estatutos. (Redação dada pela Lei $n^{\circ}$ 6.386, de 9.12.1976)

$\S 1^{\circ}$ Para alienação, locação ou aquisição de bens imóveis, ficam as entidades sindicais obrigadas a realizar avaliação prévia pela Caixa Econômica Federal ou pele Banco Nacional da Habitação ou, ainda, por qualquer outra organização legalmente habilitada a tal fim. (Incluído pela Lei $n^{\circ} 6.386$, de 9.12.1976)

$\S 2^{\circ}$ Os bens imóveis das entidades sindicais não serão alienados sem a prévia autorização das respectivas assembléias gerais, reunidas com a presença da maioria absoluta dos associados com direito a voto ou dos Conselhos de Representantes com a maioria absoluta dos seus membros. (Incluído pela Lei $n^{\circ}$ 6.386, de 9.12.1976)

$\S 3^{\circ}$ Caso não seja obtido o quorum estabelecido no parágrafo anterior, a matéria poderá ser decidida em nova assembléia geral, reunida com qualquer número de associados com direito a voto, após o transcurso de 10 (dez) dias da primeira convocação.(Incluído pela Lei n 6.386, de 9.12.1976)

$\S 4^{\circ}$ Nas hipóteses previstas no $\S 2^{\circ}$ e $3^{\circ}$ a decisão somente terá validade se adotada pelo mínimo de $2 / 3$ (dois terços) dos presentes, em escrutínio secreto.(Incluído pela Lei n ${ }^{\circ} 6.386$, de 9.12.1976)

$\S 5^{\circ}$ Da deliberação da assembléia geral, concernente à alienação de bens imóveis, caberá recurso voluntário, dentro do prazo de 15 (quinze) dias, ao Ministro do Trabalho, com efeito suspensivo.(Incluído pela Lei n 6.386 , de 9.12.1976)

$\S 6^{\circ} \mathrm{A}$ venda do imóvel será efetuada pela diretoria da entidade, após a decisão da Assembléia Geral ou do Conselho de Representantes, mediante concorrência 
pública, com edital publicado no Diário oficial da União e na imprensa diária, com antecedência mínima de 30 (trinta) dias da data de sua realização. (Incluído pela Lei $n^{\circ}$ 6.386, de 9.12.1976)

$\S 7^{\circ}$ Os recursos destinados ao pagamento total ou parcelado dos bens imóveis adquiridos serão consignados, obrigatoriamente, nos orçamentos anuais das entidades sindicais. (Incluído pela Lei ${ }^{\circ} 6.386$, de 9.12.1976)

Art. 550. Os orçamentos das entidades sindicais serão aprovados, em escrutínio secreto, pelas respectivas Assembléias Gerais ou Conselho de Representantes, até 30 (trinta) dias antes do início do exercício financeiro a que se referem, e conterão a discriminação da receita e da despesa, na forma das instruções e modelos expedidos pelo Ministério do Trabalho. (Redação dada pela Lei $n^{\circ} 6.386$, de 9.12.1976)

$\S 1^{\circ}$ Os orçamentos, após a aprovação prevista no presente artigo, serão publicados, em resumo, no prazo de 30 (trinta) dias, contados da data da realização da respectiva Assembléia Geral ou da reunião do Conselho de Representantes, que os aprovou, observada a seguinte sistemática:(Redação dada pela Lei $n^{\circ} 6.386$, de 9.12.1976)

a) no Diário oficial da União - Seção I - Parte II, os orçamentos das confederações, federações e sindicatos de base interestadual ou nacional;

b) no órgão de imprensa oficial do Estado ou Território ou jornal de grande circulação local, os orçamentos das federações estaduais e sindicatos distritais municipais, intermunicipais e estaduais.

$\S 2^{\circ}$ As dotações orçamentárias que se apresentarem insuficientes para 0 atendimento das despesas, ou não incluídas nos orçamentos correntes, poderão ser ajustadas ao fluxo dos gastos, mediante a abertura de créditos adicionais solicitados pela Diretoria da entidade às respectivas Assembléias Gerais ou Conselhos de Representantes, cujos atos concessórios serão publicados até o último dia do exercício correspondente, obedecida a mesma sistemática prevista no parágrafo anterior.(Redação dada pela Lei $n^{\circ}$ 6.386, de 9.12.1976)

$\S 3^{\circ}$ Os créditos adicionais classificam-se em: (Redação dada pela Lei $n^{\circ} 6.386$, de 9.12.1976)

a) suplementares, os destinados a reforçar dotações alocadas no orçamento; e (Incluída pela Lei n 6.386, de 9.12.1976)

b) especiais, os destinados a incluir dotações no orçamento, a fim de fazer face às despesas para as quais não se tenha cosignado crédito específico. (Incluída pela Lei $n^{\circ}$ 6.386, de 9.12.1976)

$\S 4^{\circ} \mathrm{A}$ abertura dos créditos adicionais depende da existência de receita para sua compensação, considerando-se, para esse efeito, desde que não comprometidos: (Parágrafo incluído pela Lei $n^{\circ} 6.386$, de 9.12.1976) 
a) o superavit financeiro apurado em balanço do exercício anterior; (Incluída pela Lei $\mathrm{n}^{\circ}$ 6.386, de 9.12.1976)

b) o excesso de arrecadação, assim entendido o saldo positivo da diferença entre a renda prevista e a realizada, tendo-se em conta, ainda, a tendência do exercício; e (Incluída pela Lei n 6.386, de 9.12.1976)

c) a resultante da anulação parcial ou total de dotações alocadas no orçamento ou de créditos adicionais abertos no exercício. (Incluída pela Lei $n^{\circ} 6.386$, de 9.12.1976)

$\S 5^{\circ}$ Para efeito orçamentário e contábil sindical, o exercício financeiro coincidirá com o ano civil, a ele pertencendo todas as receitas arrecadadas e as despesas compromissadas. (Incluído pela Lei $n^{\circ} 6.386$, de 9.12.1976)

Art. 551. Todas as operações de ordem financeira e patrimonial serão evidenciadas pelos registros contábeis das entidades sindicais, executados sob a responsabilidade de contabilista legalmente habilitado, em conformidade com o plano de contas e as instruções baixadas pelo Ministério do Trabalho. (Redação dada pela Lei $n^{\circ} 6.386$, de 9.12.1976)

$\S 1^{\circ} \mathrm{A}$ escrituração contábil a que se refere este artigo será baseada em documentos de receita e despesa, que ficarão arquivados nos serviços de contabilidade, à disposição dos órgãos responsáveis pelo acompanhamento administrativo e da fiscalização financeira da própria entidade, ou do controle que poderá ser exercido pelos órgãos da União, em face da legislação específica. (Redação dada pela Lei n 6.386, de 9.12.1976)

$\S 2^{\circ}$ Os documentos comprobatórios dos atos de receita e despesa, a que se refere o parágrafo anterior, poderão ser incinerados, após decorridos 5 (cinco) anos da data de quitação das contas pelo órgão competente.(Redação dada pela Lei $n^{\circ}$ 6.386, de 9.12.1976)

$\S 3^{\circ}$ É obrigatório o uso do livro Diário, encadernado, como folhas seguida e tipograficamente numeradas, para a escrituração, pelo método das partidas dobradas, diretamente ou por reprodução, dos atos ou operações que modifiquem ou venham a modificar a situação patrimonial da entidade, o qual conterá, respectivamente, na primeira e na última páginas, os termos de abertura e de encerramento.(Redação dada pela Lei $n^{\circ}$ 6.386, de 9.12.1976)

$\S 4^{\circ} \mathrm{A}$ entidade sindical que se utilizar de sistema mecânico ou eletrônico para sua escrituração contábil, poderá substituir o Diário e os livros facultativos ou auxiliares por fichas ou formulários contínuos, cujos lançamentos deverão satisfazer a todos os requisitos e normas de escrituração exigidos com relação aos livros mercantis, inclusive no que respeita a termos de abertura e de encerramento e numeração sequencial e tipográfica.(Redação dada pela Lei nº 6.386, de 9.12.1976)

$\S 5^{\circ} \mathrm{Na}$ escrituração por processos de fichas ou formulários contínuos, a entidade adotará livro próprio para inscrição do balanço patrimonial e da demonstração do 
resultado do exercício, o qual conterá os mesmos requisitos exigidos para os livros de escrituração. (Redação dada pela Lei $n^{\circ}$ 6.386, de 9.12.1976)

$\S 6^{\circ}$ Os livros e fichas ou formulários contínuos serão obrigatoriamente submetidos a registro e autenticação das Delegacias Regionais do Trabalho localizadas na base territorial da entidade.(Redação dada pela Lei $n^{\circ} 6.386$, de 9.12.1976)

$\S 7^{\circ}$ As entidades sindicais manterão registro específico dos bens de qualquer natureza, de sua propriedade, em livros ou fichas próprias, que atenderão às mesmas formalidades exigidas para a livro Diário, inclusive no que se refere ao registro e autenticação da Delegacia Regional do Trabalho local. (Parágrafo incluído pela Lei $n^{\circ} 6.386$, de 9.12.1976)

$\S 8^{\circ}$ As contas dos administradores das entidades sindicais serão aprovadas, em escrutínio secreto, pelas respectivas Assembléias Gerais ou Conselhos de Representantes, com prévio parecer do Conselho Fiscal, cabendo ao Ministro do Trabalho estabelecer prazos e procedimentos para a sua elaboração e destinação.(Parágrafo incluído pela Lei $n^{\circ} 6.386$, de 9.12.1976)

Art. 552 - Os atos que importem em malversação ou dilapidação do patrimônio das associações ou entidades sindicais ficam equiparados ao crime de peculato julgado e punido na conformidade da legislação penal. (Redação dada pelo Decreto-lei $n^{\circ}$ 925, de 10.10.1969)

\section{SEÇÃO VIII - DAS PENALIDADES}

Art. 553 - As infrações ao disposto neste Capítulo serão punidas, segundo o seu caráter e a sua gravidade, com as seguintes penalidades:

a) multa de Cr\$ 100 (cem cruzeiros) e 5.000 (cinco mil cruzeiros), dobrada na reincidência;

b) suspensão de diretores por prazo não superior a 30 (trinta) dias;

c) destituição de diretores ou de membros de conselho;

d) fechamento de Sindicato, Federação ou Confederação por prazo nunca superior a 6 (seis) meses;

e) cassação da carta de reconhecimento.

f) multa de 1/30 (um trinta avos) do salário mínimo regional, aplicável ao associado que deixar de cumprir sem causa justificada, o disposto no parágrafo único do artigo 529. (Incluída pelo Decreto-lei $n^{\circ} 229$, de 28.2.1967)

$\S 1^{\circ}$ - A imposição de penalidades aos administradores não exclui a aplicação das que este artigo prevê para a associação. (Parágrafo único renumerado pelo Decretolei $n^{\circ} 925$, de 10.10.1969) 
$\S 2^{\circ}$ - Poderá o Ministro do Trabalho e Previdência Social determinar o afastamento preventivo de cargo ou representação sindicais de seus exercentes, com fundamento em elementos constantes de denúncia formalizada que constituam indício veemente ou início de prova bastante do fato e da autoria denunciados. (Incluído pelo Decreto-lei n 925, de 10.10.1969)

Art 554. Destituida a administração na hipótese da alínea c do artigo anterior, o ministro do Trabalho, Indústria e Comércio nomeará um delegado para dirigir a associação e proceder, dentro do prazo de 90 dias, em assembléia geral por ele convocada e presidida; à eleição dos novos diretores e membros do Conselho Fiscal.

Art 555. A pena de cassação da carta de reconhecimento será imposta à entidade sindical:

a) que deixar de satisfazer as condições de constituição e funcionamento estabelecidas nesta Lei;

b) que se recusar ao cumprimento de ato do Presidente da República, no uso da faculdade conferida pelo art. 536; (Vide Decreto $n^{\circ} 229$, de 1967)

c) que criar obstáculos à execução da política econômica adotada pelo Governo. (Redação dada pelo Decreto-lei n 8.080, 11.10.1945)

Art. 556. A cassação da carta de reconhecimento da entidade sindical não importará no cancelamento de seu registo, nem, consequentemente, a sua dissolução, que se processará de acordo com as disposições da lei que regulam a dissolução das associações civís.

Parágrafo único - No caso de dissolução, por se achar a associação incursa nas leis que definem crimes contra a personalidade internacional, a estrutura e a segurança do Estado e a ordem política e social, os seus bens, pagas as dívidas decorrentes das suas responsabilidades, serão incorporados ao patrimônio da União e aplicados em obras de assistência social.

Art. 557 - As penalidades de que trata o art. 553 serão impostas:

a) as das alíneas a e b, pelo diretor geral do Departamento Nacional do Trabalho, com recurso para o ministro de Estado;

b) as demais, pelo ministro de Estado.

$\S 1^{\circ}$ Quando se trata de associações de grau superior, as penalidades serão impostas pelo ministro de Estado, salvo se a pena for da cassação da carta de reconhecimento de confederação, caso em que a pena será imposta pelo Presidente da República.

$\S 2^{\circ}$ Nenhuma pena será imposta sem que seja assegurada defesa ao acusado. 


\section{SEÇÃO IX - DISPOSIÇÕES GERAIS}

Art. 558 - São obrigadas ao registro todas as associações profissionais constituídas por atividades ou profissões idênticas, similares ou conexas, de acordo com o art. 511 e na conformidade do Quadro de Atividades e Profissões a que alude o Capítulo II deste Título. As associações profissionais registradas nos termos deste artigo poderão representar, perante as autoridades administrativas e judiciárias, os interesses individuais dos associados relativos à sua atividade ou profissão, sendoIhes também extensivas as prerrogativas contidas na alínea "d" e no parágrafo único do art. 513.

$\S 1^{\circ} \mathrm{O}$ registro a que se refere o presente artigo competirá às Delegacias Regionais do Ministério do Trabalho e Previdência Social ou às repartições autorizadas em virtude da lei. (Redação dada pelo Decreto-lei no 925, de 10.10.1969)

$\S 2^{\circ}$ - O registro das associações far-se-á mediante requerimento, acompanhado da cópia autêntica dos estatutos e da declaração do número de associados, do patrimônio e dos serviços sociais organizados.

$\S 3^{\circ}$ - As alterações dos estatutos das associações profissionais não entrarão em vigor sem aprovação da autoridade que houver concedido o respectivo registro.

Art. 559 -O Presidente da República, excepcionalmente e mediante proposta do Ministro do Trabalho, fundada em razões de utilidade pública, poderá conceder, por decreto, às associações civis constituídas para a defesa e coordenação de interesses econômicos e profissionais e não obrigadas ao registro previsto no artigo anterior, a prerrogativa da alínea "d" do art. 513 deste Capítulo.

Art. 560 -Não se reputará transmissão de bens, para efeitos fiscais, a incorporação do patrimônio de uma associação profissional ao da entidade sindical, ou das entidades aludidas entre si.

Art. 561 - A denominação "sindicato" é privativa das associações profissionais de primeiro grau, reconhecidas na forma desta Lei.

Art. 562 - As expressões "federação" e "confederação", seguidas da designaç̧ão de uma atividade econômica ou profissional, constituem denominações privativas das entidades sindicais de grau superior.

Art. 563 - (Revogado pelo Decreto-lei no 925, de 10.10.1969)

Art. 564 - Às entidades sindicais, sendo-Ihes peculiar e essencial a atribuição representativa e coordenadora das correspondentes categorias ou profissões, é vedado, direta ou indiretamente, o exercício de atividade econômica.

Art. 565 - As entidades sindicais reconhecidas nos termos desta Lei não poderão filiar-se a organizações internacionais, nem com elas manter relações, sem prévia licença concedida por decreto do Presidente da República. (Redação dada pela Lei $\mathrm{n}^{\circ}$ 2.802, de 18.6.1956) 
Art. 566 - Não podem sindicalizar-se os servidores do Estado e os das instituições paraestatais.

Parágrafo único - Excluem-se da proibição constante deste artigo os empregados das sociedades de economia mista, da Caixa Econômica Federal e das fundações criadas ou mantidas pelo Poder Público da União, dos Estados e Municípios. (Redação dada pela Lei $n^{\circ} 7.449$, de 20.12.1985)

\section{CAPÍTULO II - DO ENQUADRAMENTO SINDICAL}

Art. 570. Os sindicatos constituir-se-ão, normalmente, por categorias econômicas ou profissionais, eepecíficas, na conformidade da discriminação do quadro das atividades e profissões a que se refere o art. 577 ou segundo ae subdivisões que, sob proposta da Comissão do Enquadramento Sindical, de que trata o art. 576, forem criadas pelo ministro do Trabalho, Indústria e Comércio.

Parágrafo único - Quando os exercentes de quaisquer atividades ou profissões se constituírem, seja pelo número reduzido, seja pela natureza mesma dessas atividades ou profissões, seja pelas afinidades existentes entre elas, em condições tais que não se possam sindicalizar eficientemente pelo critério de especificidade de categoria, é-lhes permitido sindicalizar-se pelo critério de categorias similares ou conexas, entendendo-se como tais as que se acham compreendidas nos limites de cada grupo constante do Quadro de Atividades e Profissões.

Art 571. Qualquer das atividades ou profissões concentradas na forma do parágrafo único do artigo anterior poderá dissociar-se do sindicato principal, formando um sindicato específico, desde que o novo sindicato, a juizo da Comissão do Enquadramento Sindical, ofereça possibilidade de vida associativa regular e de ação sindical eficiente.

Art 572. Os sindicatos que se constituirem por categorias similares ou conexas, nos termos do parágrafo único do art. 570, adotarão denominação em que fiquem, tanto como possivel, explicitamente mencionadas as atividades ou profissões concentradas, de conformidade com o quadro das atividades e profissões, ou se se tratar de subdivisões, de acordo com o que determinar a Comissão do Enquadramento Sindical.

Parágrafo único - Ocorrendo a hipótese do artigo anterior, o Sindicato principal terá a denominação alterada, eliminando-se-lhe a designação relativa à atividade ou profissão dissociada.

Art. 573 - O agrupamento dos Sindicatos em Federações obedecerá às mesmas regras que as estabelecidas neste Capítulo para o agrupamento das atividades e profissões em Sindicatos.

$\S 1^{\circ}$ (Revogado pelo Decreto-Lei $n^{\circ} 229$, de 28.2.1967)

$\S 2^{\circ}$ (Revogado pelo Decreto-Lei $n^{\circ} 229$, de 28.2.1967) 
Parágrafo único - As Federações de Sindicatos de profissões liberais poderão ser organizadas independentemente do grupo básico da Confederação, sempre que as respectivas profissões se acharem submetidas, por disposições de lei, a um único regulamento. (Parágrafo $1^{\circ}$ renumerado pelo Decreto-lei $n^{\circ} 229$, de 28.2.1967)

Art. 574 - Dentro da mesma base territorial, as empresas industriais do tipo artesanal poderão constituir entidades sindicais, de primeiro e segundo graus, distintas das associações sindicais das empresas congêneres, de tipo diferente.

Parágrafo único. Compete à Comissão de Enquadramento Sindical definir, de modo genérico, com a aprovação do ministro do Trabalho, Indústria e Comércio, a dimensão e os demais característicos das empresas industriais de tipo artesanal.

Art 575. O quadro de atividades e profissões será revisto de dois em dois anos, por proposta da Comissão do Enquadramento Sindical, para o fim de ajustá-lo às condições da estrutura econômica e profissional do país.

$\S 1^{\circ}$ - Antes de proceder à revisão do Quadro, a Comissão deverá solicitar sugestões às entidades sindicais e às associações profissionais.

$\S 2^{\circ}$ - A proposta de revisão será submetida à aprovação do Ministro do Trabalho, Industria e Comercio.

Art. 576 - A Comissão do Enquadramento Sindical será constituída pelo DiretorGeral do Departamento Nacional do Trabalho, que a presidirá, e pelos seguintes membros: (Redação dada pela Lei $n^{\circ} 5.819$, de 6.11.1972)

I - 2 (dois) representantes do Departamento Nacional do Trabalho; (Redação dada pela Lei $n^{\circ} 5.819$, de 6.11.1972)

II - 1 (um) representante do Departamento Nacional de Mão-de-Obra; (Redação dada pela Lei $n^{\circ} 5.819$, de 6.11.1972)

III - 1 (um) representante do Instituto Nacional de Tecnologia, do Ministério da Indústria e do Comércio; (Redação dada pela Lei $n^{\circ} 5.819$, de 6.11.1972)

IV - 1 (um) representante do Instituto Nacional de Colonização e Reforma Agrária, do Ministério da Agricultura; (Redação dada pela Lei $n^{\circ} 5.819$, de 6.11.1972)

V - 1 (um) representante do Ministério dos Transportes; (Redação dada pela Lei $n^{\circ}$ 5.819, de 6.11.1972)

VI - 2 (dois) representantes das categorias econômicas; e (Redação dada pela Lei $\mathrm{n}^{\circ} 5.819$, de 6.11.1972)

VII - 2 (dois) representantes das categorias profissionais. (Redação dada pela Lei $n^{\circ}$ 5.819, de 6.11.1972)

$\S 1^{\circ}$ - Os membros da CES serão designados pelo Ministro do Trabalho e Previdência Social, mediante. (Incluído pelo Decreto-lei nº 229, de 28.2.1967) 
a) indicação dos titulares das Pastas, quanto aos representantes dos outros Ministérios; (Incluído pelo Decreto-lei n²29, de 28.2.1967)

b) indicação do respectivo Diretor Geral, quanto ao do DNMO; (Incluído pelo Decreto-lei $n^{\circ} 229$, de 28.2.1967)

c) eleição pelas respectivas Confederações, em conjunto, quanto aos representantes das categorias econômicas e profissionais, de acôrdo com as instruções que forem expedidas pelo Ministro do Trabalho e Previdência Social. (Incluído pelo Decreto-lei $n^{\circ} 229$, de 28.2.1967)

$\S 2^{\circ}$ - Cada Membro terá um suplente designado juntamente com o titular. (Incluído pelo Decreto-lei $n^{\circ} 229$, de 28.2.1967)

$\S 3^{\circ}$ - Será de 3 (três) anos o mandato dos representantes das categorias econômica e profissional. (Redação dada pelo Decreto-lei $n^{\circ}$ 925, de 10.10.1969)

$\S 4^{\circ}$ - Os integrantes da Comissão perceberão a gratificação de presença que for estabelecida por decreto executivo.(Incluído pelo Decreto-lei $n^{\circ} 229$, de 28.2.1967)

$\S 5^{\circ}$ - Em suas faltas ou impedimentos o Diretor-Geral do DNT será substituído na presidência pelo Diretor substituto do Departamento ou pelo representante deste na Comissão, nesta ordem. (Redação dada Decreto-lei nº 506, de 18.3.1969)

$\S 6^{\circ}$ - Além das atribuições fixadas no presente Capítulo e concernentes ao enquadramento sindical, individual ou coletivo, e à classificação das atividades e profissões, competirá também à CES resolver, com recurso para o Ministro do Trabalho e Previdência Social, tôdas as dúvidas e controvérsias concernentes à organização sindical. (Incluído pelo Decreto-lei n²229, de 28.2.1967)

Art. 577 - O Quadro de Atividades e Profissões em vigor fixará o plano básico do enquadramento sindical.

\section{CAPÍTULO III - DA CONTRIBUIÇÃO SINDICAL}

\section{SEÇÃO I - DA FIXAÇÃO E DO RECOLHIMENTO DO IMPOSTO SINDICAL}

Art. 578 - As contribuições devidas aos Sindicatos pelos que participem das categorias econômicas ou profissionais ou das profissões liberais representadas pelas referidas entidades serão, sob a denominação do "imposto sindical", pagas, recolhidas e aplicadas na forma estabelecida neste Capítulo. (Vide Decreto-Lei $\mathrm{n}^{\circ}$ 229, de 1967) (Vide Lei $n^{\circ} 11.648$, de 2008)

Art. 579 - A contribuição sindical é devida por todos aquêles que participarem de uma determinada categoria econômica ou profissional, ou de uma profissão liberal, em favor do sindicato representativo da mesma categoria ou profissão ou, inexistindo êste, na conformidade do disposto no art. 591. (Redação dada pelo Decreto-lei $n^{\circ} 229$, de 28.2.1967) (Vide Lei $n^{\circ} 11.648$, de 2008) 
Art. 580. A contribuição sindical será recolhida, de uma só vez, anualmente, e consistirá: (Redação dada pela Lei nº 6.386, de 9.12.1976) (Vide Lei $n^{\circ}$ 11.648, de 2008)

I - Na importância correspondente à remuneração de um dia de trabalho, para os empregados, qualquer que seja a forma da referida remuneração; (Redação dada pela Lei $n^{\circ} 6.386$, de 9.12.1976)

II - para os agentes ou trabalhadores autônomos e para os profissionais liberais, numa importância correspondente a 30\% (trinta por cento) do maior valor-dereferência fixado pelo Poder Executivo, vigente à época em que é devida a contribuição sindical, arredondada para $\mathrm{Cr} \$ 1,00$ (um cruzeiro) a fração porventura existente; (Redação dada pela Lei n 7.047 , de $1^{\circ} .12 .1982$ )

III - para os empregadores, numa importância proporcional ao capital social da firma ou empresa, registrado nas respectivas Juntas Comerciais ou órgãos equivalentes, mediante a aplicação de alíquotas, conforme a seguinte tabela progressiva: (Redação dada pela Lei $n^{\circ} 7.047$, de $1^{\circ} .12 .1982$ )

\begin{tabular}{|c|c|c|c|}
\hline & lasse de Capital & Alíquota & \\
\hline 1. & até 150 vezes o maior valor-de-referência & & $0,8 \%$ \\
\hline 2. & acima de 150 até 1.500 vezes o maior & valor-de-referência & $0,2 \%$ \\
\hline 3. & $\begin{array}{l}\text { acima de } 1.500 \text { até } 150.000 \text { vezes o maior } \\
\ldots \ldots \ldots \ldots . . . . .\end{array}$ & valor-de-referência & $0,1 \%$ \\
\hline & $\begin{array}{l}\text { acima de } 150.000 \text { até } 800.000 \text { vezes o maior } \\
\ldots \ldots . . . . .\end{array}$ & valor-de-referência & $0,02 \%$ \\
\hline
\end{tabular}

$\S 1^{\circ} \mathrm{A}$ contribuição sindical prevista na tabela constante do item III deste artigo corresponderá à soma da aplicação das alíquotas sobre a porção do capital distribuído em cada classe, observados os respectivos limites. (Redação dada pela Lei $n^{\circ}$ 6.386, de 9.12.1976)

$\S 2^{\circ}$ Para efeito do cálculo de que trata a tabela progressiva inserta no item III deste artigo, considerar-se-á o valor de referência fixado pelo Poder Executivo, vigente à data de competência da contribuição, arredondando-se para $\operatorname{Cr} \$ 1,00$ (um cruzeiro) a fração porventura existente. (Redação dada pela Lei nº 6.386, de 9.12.1976) 
$\S 3^{\circ}$ - É fixada em $60 \%$ (sessenta por cento) do maior valor-de-referência, a que alude o parágrafo anterior, a contribuição mínima devida pelos empregadores, independentemente do capital social da firma ou empresa, ficando, do mesmo modo, estabelecido o capital equivalente a 800.000 (oitocentas mil) vezes o maior valor-dereferência, para efeito do cálculo da contribuição máxima, respeitada a Tabela progressiva constante do item III. (Redação dada pela Lei $n^{\circ} 7.047$, de $1^{\circ} .12 .1982$ )

$\S 4^{\circ}$ Os agentes ou trabalhadores autônomos e os profissionais liberais, organizados em firma ou empresa, com capital social registrado, recolherão a contribuição sindical de acordo com a tabela progressiva a que se refere o item III. (Incluído pela Lei $n^{\circ}$ 6.386, de 9.12.1976)

$\S 5^{\circ}$ As entidades ou instituições que não estejam obrigadas ao registro de capital social, consideração, como capital, para efeito do cálculo de que trata a tabela progressiva constante do item III deste artigo, o valor resultante da aplicação do percentual de $40 \%$ (quarenta por cento) sobre o movimento econômico registrado no exercício imediatamente anterior, do que darão conhecimento à respectiva entidade sindical ou à Delegacia Regional do Trabalho, observados os limites estabelecidos no $\S 3^{\circ}$ deste artigo. (Incluído pela Lei $n^{\circ} 6.386$, de 9.12.1976)

$\S 6^{\circ}$ Excluem-se da regra do $\S 5^{\circ}$ as entidades ou instituições que comprovarem, através de requerimento dirigido ao Ministério do Trabalho, que não exercem atividade econômica com fins lucrativos. (Incluído pela Lei $n^{\circ} 6.386$, de 9.12.1976)

Art. 581. Para os fins do item III do artigo anterior, as empresas atribuirão parte do respectivo capital às suas sucursais, filiais ou agências, desde que localizadas fora da base territorial da entidade sindical representativa da atividade econômica do estabelecimento principal, na proporção das correspondentes operações econômicas, fazendo a devid a comunicação às Delegacias Regionais do Trabalho, conforme localidade da sede da empresa, sucursais, filiais ou agências. (Redação dada pela Lei $n^{\circ} 6.386$, de 9.12.1976) (Vide Lei $n^{\circ} 11.648$, de 2008)

$\S 1^{\circ}$ Quando a empresa realizar diversas atividades econômicas, sem que nenhuma delas seja preponderante, cada uma dessas atividades será incorporada à respectiva categoria econômica, sendo a contribuição sindical devida à entidade sindical representativa da mesma categoria, procedendo-se, em relação às correspondentes sucursais, agências ou filiais, na forma do presente artigo. (Redação dada pela Lei ${ }^{\circ}$ 6.386, de 9.12.1976)

$\S 2^{\circ}$ Entende-se por atividade preponderante a que caracterizar a unidade de produto, operação ou objetivo final, para cuja obtenção todas as demais atividades convirjam, exclusivamente em regime de conexão funcional. (Redação dada pela Lei $n^{\circ}$ 6.386, de 9.12.1976)

Art. 582. Os empregadores são obrigados a descontar, da folha de pagamento de seus empregados relativa ao mês de março de cada ano, a contribuição sindical por estes devida aos respectivos sindicatos. (Redação dada pela Lei $n^{\circ} 6.386$, de 9.12.1976) (Vide Lei $n^{\circ} 11.648$, de 2008) 
$\S 1^{\circ}$ Considera-se um dia de trabalho, para efeito de determinação da importância a que alude o item I do Art. 580, o equivalente: (Redação dada pela Lei $n^{\circ} 6.386$, de 9.12.1976)

a) a uma jornada normal de trabalho, se o pagamento ao empregado for feito por unidade de tempo; (Redação dada pela Lei $n^{\circ} 6.386$, de 9.12.1976)

b) a 1/30 (um trinta avos) da quantia percebida no mês anterior, se a remuneração for paga por tarefa, empreitada ou comissão. (Redação dada pela Lei $n^{\circ} 6.386$, de 9.12.1976)

$\S 2^{\circ}$ Quando o salário for pago em utilidades, ou nos casos em que o empregado receba, habitualmente, gorjetas, a contribuição sindical corresponderá a 1/30 (um trinta avos) da importância que tiver servido de base, no mês de janeiro, para a contribuição do empregado à Previdência Social. (Redação dada pela Lei $n^{\circ} 6.386$, de 9.12.1976)

Art. 583 - O recolhimento da contribuição sindical referente aos empregados e trabalhadores avulsos será efetuado no mês de abril de cada ano, e o relativo aos agentes ou trabalhadores autônomos e profissionais liberais realizar-se-á no mês de fevereiro. (Redação dada pela Lei $n^{\circ}$ 6.386, de 9.12.1976) (Vide Lei $n^{\circ} 11.648$, de 2008)

$\S 1^{\circ}$ - O recolhimento obedecerá ao sistema de guias, de acordo com as instruções expedidas pelo Ministro do Trabalho.(Incluído pela Lei $n^{\circ} 6.386$, de 9.12.1976)

$\S 2^{\circ}$ - O comprovante de depósito da contribuição sindical será remetido ao respectivo Sindicato; na falta deste, à correspondente entidade sindical de grau superior, e, se for o caso, ao Ministério do Trabalho. (Incluído pela Lei $n^{\circ} 6.386$, de 9.12.1976)

Art. 584. Servirá de base para o pagamento da contribuição sindical, pelos agentes ou trabalhadores autônomos e profissionais liberais, a lista de contribuintes organizada pelos respectivos sindicatos e, na falta destes, pelas federações ou confederações coordenadoras da categoria. (Redação dada pela Lei $n^{\circ} 6.386$, de 9.12.1976) (Vide Lei nº 11.648, de 2008)

Art. 585. Os profissionais liberais poderão optar pelo pagamento da contribuição sindical unicamente à entidade sindical representativa da respectiva profissão, desde que a exerça, efetivamente, na firma ou empresa e como tal sejam nelas registrados. (Redação dada pela Lei $n^{\circ}$ 6.386, de 9.12.1976) (Vide Lei $n^{\circ}$ 11.648, de 2008)

Parágrafo único. Na hipótese referida neste artigo, à vista da manifestação do contribuinte e da exibição da prova de quitação da contribuição, dada por sindicato de profissionais liberais, o empregador deixará de efetuar, no salário do contribuinte, o desconto a que se refere o Art. 582. (Redação dada pela Lei $n^{\circ} 6.386$, de 9.12.1976) 
Art. 586. A contribuição sindical será recolhida, nos meses fixados no presente Capítulo, à Caixa Econômica Federal ao Banco do Brasil S. A. ou aos estabelecimentos bancários nacionais integrantes do sistema de arrecadação dos tributos federais, os quais, de acordo com instruções expedidas pelo Conselho Monetário Nacional, repassarão à Caixa Econômica Federal as importâncias arrecadadas. (Redação dada pela Lei $n^{\circ}$ 6.386, de 9.12.1976) (Vide Lei $n^{\circ} 11.648$, de 2008)

$\S 1^{0}$ Integrarão a rede arrecadadora as Caixas Econômicas Estaduais, nas localidades onde inexistam os estabelecimentos previstos no caput deste artigo. (Redação dada pela Lei $n^{\circ} 6.386$, de 9.12.1976)

$\S 2^{\circ}$ Tratando-se de empregador, agentes ou trabalhadores autônomos ou profissionais liberais o recolhimento será efetuado pelos próprios, diretamente ao estabelecimento arrecadador. (Redação dada pela Lei nº 6.386, de 9.12.1976)

$\S 3^{\circ} \mathrm{A}$ contribuição sindical devida pelos empregados e trabalhadores avulsos será recolhida pelo empregador e pelo sindicato, respectivamente. (Redação dada pela Lei $n^{\circ}$ 6.386, de 9.12.1976)

Art. 587. O recolhimento da contribuição sindical dos empregadores efetuar-se-á no mês de janeiro de cada ano, ou, para os que venham a estabelecer-se após aquele mês, na ocasião em que requeiram às repartições o registro ou a licença para o exercício da respectiva atividade. (Redação dada pela Lei $n^{\circ} 6.386$, de 9.12.1976) (Vide Lei no 11.648, de 2008)

Art. 588. A Caixa Econômica Federal manterá conta corrente intitulada "Depósitos da Arrecadação da Contribuição Sindical", em nome de cada uma das entidades sindicais beneficiadas, cabendo ao Ministério do Trabalho cientificá-la das ocorrências pertinentes à vida administrativa dessas entidades. (Redação dada pela Lei $n^{\circ}$ 6.386, de 9.12.1976) (Vide Lei $n^{\circ} 11.648$, de 2008)

$\S 1^{\circ}$ Os saques na conta corrente referida no caput deste artigo far-se-ão mediante ordem bancária ou cheque com as assinaturas conjuntas do presidente e do tesoureiro da entidade sindical. (Redação dada pela Lei $n^{\circ} 6.386$, de 9.12.1976)

$\S 2^{\circ}$ A Caixa Econômica Federal remeterá, mensalmente, a cada entidade sindical, um extrato da respectiva conta corrente, e, quando solicitado, aos órgãos do Ministério do Trabalho. (Redação dada pela Lei $n^{\circ} 6.386$, de 9.12.1976)

Art. 589. Da importância da arrecadação da contribuição sindical serão feitos os seguintes créditos pela Caixa Econômica Federal, na forma das instruções que forem expedidas pelo Ministro do Trabalho: (Redação dada pela Lei $n^{\circ} 6.386$, de 9.12.1976) (Vide Lei no 11.648, de 2008)

I - para os empregadores: (Redação dada pela Lei nº 11.648, de 2008)

a) $5 \%$ (cinco por cento) para a confederação correspondente; (Incluída pela Lei $n^{\circ}$ 11.648, de 2008) 
b) $15 \%$ (quinze por cento) para a federação; (Incluída pela Lei $n^{\circ} 11.648$, de 2008)

c) $60 \%$ (sessenta por cento) para o sindicato respectivo; e (Incluída pela Lei $\mathrm{n}^{\circ}$ 11.648, de 2008)

d) $20 \%$ (vinte por cento) para a 'Conta Especial Emprego e Salário'; (Incluída pela Lei $n^{\circ} 11.648$, de 2008)

II - para os trabalhadores: (Redação dada pela Lei n²11.648, de 2008)

a) $5 \%$ (cinco por cento) para a confederação correspondente; (Incluída pela Lei $n^{\circ}$ 11.648, de 2008)

b) $10 \%$ (dez por cento) para a central sindical; (Incluída pela Lei $n^{\circ} 11.648$, de 2008 )

c) $15 \%$ (quinze por cento) para a federação; (Incluída pela Lei $n^{\circ} 11.648$, de 2008)

d) $60 \%$ (sessenta por cento) para o sindicato respectivo; e (Incluída pela Lei $n^{\circ}$ 11.648, de 2008)

e) $10 \%$ (dez por cento) para a 'Conta Especial Emprego e Salário'; (Incluída pela Lei $n^{\circ} 11.648$, de 2008)

III - (revogado); (Redação dada pela Lei no 11.648, de 2008)

IV - (revogado). (Redação dada pela Lei nº 11.648, de 2008)

$\S 1^{\circ}$ O sindicato de trabalhadores indicará ao Ministério do Trabalho e Emprego a central sindical a que estiver filiado como beneficiária da respectiva contribuição sindical, para fins de destinação dos créditos previstos neste artigo. (Incluído pela Lei n 11.648, de 2008)

$\S 2^{\circ}$ A central sindical a que se refere a alínea $b$ do inciso II do caput deste artigo deverá atender aos requisitos de representatividade previstos na legislação específica sobre a matéria. (Incluído pela Lei $n^{\circ} 11.648$, de 2008)

Art. 590. Inexistindo confederação, o percentual previsto no art. 589 desta Consolidação caberá à federação representativa do grupo. (Redação dada pela Lei $n^{\circ} 11.648$, de 2008) (Vide Lei n 11.648, de 2008)

$\S 1^{\circ}$ (Revogado). (Redação dada pela Lei nº 11.648, de 2008)

$\S 2^{\circ}$ (Revogado). (Redação dada pela Lei nº 11.648, de 2008)

$\S 3^{\circ}$ Não havendo sindicato, nem entidade sindical de grau superior ou central sindical, a contribuição sindical será creditada, integralmente, à 'Conta Especial Emprego e Salário'. (Redação dada pela Lei n 11.648, de 2008) 
$\S 4^{\circ}$ Não havendo indicação de central sindical, na forma do $\S 1^{\circ}$ do art. 589 desta Consolidação, os percentuais que Ihe caberiam serão destinados à 'Conta Especial Emprego e Salário' (Incluído pela Lei n 11.648, de 2008)

Art. 591. Inexistindo sindicato, os percentuais previstos na alínea $c$ do inciso I e na alínea $d$ do inciso II do caput do art. 589 desta Consolidação serão creditados à federação correspondente à mesma categoria econômica ou profissional. (Redação dada pela Lei $n^{\circ} 11.648$, de 2008) (Vide Lei $n^{\circ} 11.648$, de 2008)

Parágrafo único. Na hipótese do caput deste artigo, os percentuais previstos nas alíneas a e $b$ do inciso I e nas alíneas a e $c$ do inciso II do caput do art. 589 desta Consolidação caberão à confederação. (Redação dada pela Lei $n^{\circ} 11.648$, de 2008)

\section{SEÇÃO II - DA APLICAÇÃO DO IMPOSTO SINDICAL}

Art. 592 - A contribuição sindical, além das despesas vinculadas à sua arrecadação, recolhimento e controle, será aplicada pelos sindicatos, na conformidade dos respectivos estatutos, usando aos seguintes objetivos: (Redação dada pela Lei $\mathrm{n}^{\circ}$ 6.386, de 9.12.1976) (Vide Lei $n^{\circ} 11.648$, de 2008)

I - Sindicatos de empregadores e de agentes autônomos: (Redação dada pela Lei $n^{\circ}$ 6.386, de 9.12.1976)

a) assistência técnica e jurídica; (Redação dada pela Lei nº 6.386, de 9.12.1976)

b) assistência médica, dentária, hospitalar e farmacêutica; (Redação dada pela Lei $n^{\circ} 6.386$, de 9.12.1976)

c) realização de estudos econômicos e financeiros; (Redação dada pela Lei $\mathrm{n}^{\circ}$ 6.386, de 9.12.1976)

d) agências de colocação; (Redação dada pela Lei n 6.386, de 9.12.1976)

e) cooperativas; (Redação dada pela Lei nº 6.386, de 9.12.1976)

f) bibliotecas; (Incluída pela Lei n 6.386, de 9.12.1976)

g) creches; (Incluída pela Lei nº 6.386, de 9.12.1976)

h) congressos e conferências; (Incluída pela Lei nº.386, de 9.12.1976)

i) medidas de divulgação comercial e industrial no País, e no estrangeiro, bem como em outras tendentes a incentivar e aperfeiçoar a produção nacional. (Incluída pela Lei $n^{\circ} 6.386$, de 9.12.1976)

j) feiras e exposições; (Incluída pela Lei nº 6.386, de 9.12.1976)

I) prevenção de acidentes do trabalho; (Incluída pela Lei $n^{\circ} 6.386$, de 9.12.1976)

m) finalidades desportivas. (Incluída pela Lei $n^{\circ} 6.386$, de 9.12.1976) 
II - Sindicatos de empregados: (Redação dada pela Lei nº 6.386, de 9.12.1976)

a) assistência jurídica; (Redação dada pela Lei nº 6.386, de 9.12.1976)

b) assistência médica, dentária, hospitalar e farmacêutica; (Redação dada pela Lei $\mathrm{n}^{\circ}$ 6.386, de 9.12.1976)

c) assistência à maternidade; (Redação dada pela Lei nº 6.386, de 9.12.1976)

d) agências de colocação; (Redação dada pela Lei $n^{\circ}$ 6.386, de 9.12.1976)

e) cooperativas; (Redação dada pela Lei $n^{\circ} 6.386$, de 9.12.1976)

f) bibliotecas; (Redação dada pela Lei nº 6.386, de 9.12.1976)

g) creches; (Redação dada pela Lei nº 6.386, de 9.12.1976)

h) congressos e conferências; (Redação dada pela Lei $n^{\circ} 6.386$, de 9.12.1976)

i) auxilio-funeral; (Redação dada pela Lei nº 6.386, de 9.12.1976)

j) colônias de férias e centros de recreação; (Redação dada pela Lei $n^{\circ} 6.386$, de 9.12.1976)

I) prevenção de acidentes do trabalho; (Incluída pela Lei nº 6.386, de 9.12.1976)

m) finalidades deportivas e sociais; (Incluída pela Lei $n^{\circ} 6.386$, de 9.12.1976)

n) educação e formação profissicinal. (Incluída pela Lei nº 6.386, de 9.12.1976)

o) bolsas de estudo. (Incluída pela Lei nº 6.386, de 9.12.1976)

III - Sindicatos de profissionais liberais:(Redação dada pela Lei $n^{\circ} 6.386$, de 9.12.1976)

a) assistência jurídica; (Redação dada pela Lei n 6.386, de 9.12.1976)

b) assistência médica, dentária, hospitalar e farmacêutica; (Redação dada pela Lei no 6.386, de 9.12.1976)

c) assistência à maternidade; (Redação dada pela Lei $n^{\circ} 6.386$, de 9.12.1976)

d) bolsas de estudo; (Redação dada pela Lei nº 6.386, de 9.12.1976)

e) cooperativas; (Redação dada pela Lei nº 6.386, de 9.12.1976)

f) bibiotecas; (Redação dada pela Lei n 6.386, de 9.12.1976)

g) creches; (Redação dada pela Lei nº 6.386, de 9.12.1976) 
h) congressos e conferências; (Redação dada pela Lei nº 6.386, de 9.12.1976)

i) auxílio-funeral; (Redação dada pela Lei $n^{\circ} 6.386$, de 9.12.1976)

j) colônias de férias e centros de recreação; (Redação dada pela Lei $n^{\circ} 6.386$, de 9.12.1976)

I) estudos técnicos e científicos; (Incluída pela Lei no 6.386, de 9.12.1976)

m) finalidades desportivas e sociais; (Incluída pela Lei $n^{\circ} 6.386$, de 9.12.1976)

n) educação e formação profissional; (Incluída pela Lei nº 6.386, de 9.12.1976)

o) prêmios por trabalhos técnicos e científicos. (Incluída pela Lei $n^{\circ} 6.386$, de 9.12.1976)

IV - Sindicatos de trabalhadores autônomos: (Redação dada pela Lei $n^{\circ} 6.386$, de 9.12.1976)

a) auisténcia técnica e jurídica; (Redação dada pela Lei $n^{\circ}$ 6.386, de 9.12.1976)

b) assistência médica, dentária, hospitalar e farmacêutica; (Redação dada pela Lei $\mathrm{n}^{\circ}$ 6.386, de 9.12.1976)

c) assistência à maternidade; (Redação dada pela Lei $n^{\circ} 6.386$, de 9.12.1976)

d) bolsas de estudo; (Redação dada pela Lei $n^{\circ} 6.386$, de 9.12.1976)

e) cooperativas; (Redação dada pela Lei no 6.386, de 9.12.1976)

f) bibliotecas; (Redação dada pela Lei $n^{\circ} 6.386$, de 9.12.1976)

g) creches; (Redação dada pela Lei no 6.386, de 9.12.1976)

h) congressos e conferências; (Redação dada pela Lei nº 6.386, de 9.12.1976)

i) auxílio-funeral; (Redação dada pela Lei n 6.386, de 9.12.1976)

j) colônias de férias e centros de recreação; (Incluída pela Lei $n^{\circ} 6.386$, de 9.12.1976)

I) educação e formação profissional; (Incluída pela Lei no 6.386, de 9.12.1976)

m) finalidades desportivas e sociais; (Incluída pela Lei nº 6.386, de 9.12.1976)

$\S 1^{\circ} \mathrm{A}$ aplicação prevista neste artigo ficará a critério de cada entidade, que, para tal fim, obedecerá, sempre, às peculiaridades do respectivo grupo ou categoria, facultado ao Ministro do Trabalho permitir a inclusão de novos programas, desde que assegurados os serviços assistenciais fundamentais da entidade. (Redação dada pela Lei $n^{\circ} 6.386$, de 9.12.1976) 
$\S 2^{\circ}$ Os sindicatos poderão destacar, em seus orçamentos anuais, até $20 \%$ (vinco por cento) dos recursos da contribuição sindical para o custeio das suas atividades administrativas, independentemente de autorização ministerial. (Incluído pela Lei $n^{\circ}$ 6.386, de 9.12.1976)

$\S 3^{\circ} \mathrm{O}$ uso da contribuição sindical prevista no $\S 2^{\circ}$ não poderá exceder do valor total das mensalidades sociais consignadas nos orçamentos dos sindicatos, salvo autorização expressa do Ministro do Trabalho. (Incluído pela Lei $\mathrm{n}^{\circ}$ 6.386, de 9.12.1976)

Art. 593. As percentagens atribuídas às entidades sindicais de grau superior e às centrais sindicais serão aplicadas de conformidade com o que dispuserem os respectivos conselhos de representantes ou estatutos. (Redação dada pela Lei $\mathrm{n}^{\circ}$ 11.648, de 2008) (Vide Lei $n^{\circ} 11.648$, de 2008)

Parágrafo único. Os recursos destinados às centrais sindicais deverão ser utilizados no custeio das atividades de representação geral dos trabalhadores decorrentes de suas atribuições legais. (Incluído pela Lei nº 11.648, de 2008)

Art. 594 - O "Fundo Social Sindical" será gerido e aplicado pela Comissão do Imposto Sindical em objetivos que atendam aos interesses gerais da organização sindical nacional ou à assistência social aos trabalhadores. (Redação dada pelo Decreto-lei $n^{\circ}$ 9.615, de 20.8.1946) (Vide Lei $n^{\circ} 4.589$, de 1964) (Vide Lei $n^{\circ}$ 11.648, de 2008)

\section{SEÇÃO V - DISPOSIÇÕES GERAIS}

Art. 601 - No ato da admissão de qualquer empregado, dele exigirá o empregador a apresentação da prova de quitação do imposto sindical. (Vide Lei $n^{\circ}$ 11.648, de 2008)

Art. 602 - Os empregados que não estiverem trabalhando no mês destinado ao desconto da imposto sindical serão descontados no primeiro mês subseqüente ao do reinício do trabalho. (Vide Lei nº 11.648, de 2008)

Parágrafo único - De igual forma se procederá com os empregados que forem admitidos depois daquela data e que não tenham trabalhado anteriormente nem apresentado a respectiva quitação.

Art. 603 - Os empregadores são obrigados a prestar aos encarregados da fiscalização os esclarecimentos necessários ao desempenho de sua missão e a exibir-Ihes, quando exigidos, na parte relativa ao pagamento de empregados, os seus livros, folhas de pagamento e outros documentos comprobatórios desses pagamentos, sob pena da multa cabível. (Vide Lei $n^{0} 11.648$, de 2008)

Art. 604 - Os agentes ou trabalhadores autônomos ou profissionais liberais são obrigados a prestar aos encarregados da fiscalização os esclarecimentos que lhes forem solicitados, inclusive exibição de quitação do imposto sindical. (Vide Lei $\mathrm{n}^{\circ}$ 11.648, de 2008) 
Art. 605 - As entidades sindicais são obrigadas a promover a publicação de editais concernentes ao recolhimento do imposto sindical, durante 3 (três) dias, nos jornais de maior circulação local e até 10 (dez) dias da data fixada para depósito bancário. (Vide Lei $n^{\circ} 11.648$, de 2008)

Art. 606 - Às entidades sindicais cabe, em caso de falta de pagamento da contribuição sindical, promover a respectiva cobrança judicial, mediante ação executiva, valendo como título de dívida a certidão expedida pelas autoridades regionais do Ministério do Trabalho e Previdência Social. (Redação dada pelo Decreto-lei $n^{\circ}$ 925, de 10.10.1969) (Vide Lei $n^{\circ} 11.648$, de 2008)

$\S 1^{\circ} \mathrm{O}$ Ministro do Trabalho, Indústria e Comércio baixará as instruções regulando a expedição das certidões a que se refere o presente artigo das quais deverá constar a individualização de contribuinte, a indicação do débito e a designação da entidade a favor da qual será recolhida a importância de imposto, de acordo com o respectivo enquadramento sindical.

$\S 2^{\circ}$ - Para os fins da cobrança judicial do imposto sindical, são extensivos às entidades sindicais, com exceção do foro especial, os privilégios da Fazenda Pública, para cobrança da dívida ativa.

Art. 607 - É considerado como documento essencial ao comparecimento às concorrências públicas ou administrativas e para o fornecimento às repartições paraestatais ou autárquicas a prova da quitação do respectivo imposto sindical e a de recolhimento do imposto sindical, descontado dos respectivos empregados. (Vide Lei $n^{\circ} 11.648$, de 2008)

Art. 608 - As repartições federais, estaduais ou municipais não concederão registro ou licenças para funcionamento ou renovação de atividades aos estabelecimentos de empregadores e aos escritórios ou congêneres dos agentes ou trabalhadores autônomos e profissionais liberais, nem concederão alvarás de licença ou localização, sem que sejam exibidas as provas de quitação do imposto sindical, na forma do artigo anterior. (Vide Lei $n^{\circ} 11.648$, de 2008)

Parágrafo único - A não observância do disposto neste artigo acarretará, de pleno direito, a nulidade dos atos nele referidos, bem como dos mencionados no artigo 607. (Parágrafo incluído pela Lei $n^{\circ} 6.386$, de 9.12.1976)

Art. 609 - O recolhimento da contribuição sindical e todos os lançamentos e movimentos nas contas respectivas são isentos de selos e taxas federais, estaduais ou municipais. (Vide Lei $n^{\circ} 11.648$, de 2008)

Art. 610 - As dúvidas no cumprimento deste Capítulo serão resolvidas pelo DiretorGeral do Departamento Nacional do Trabalho, que expedirá as instruções que se tornarem necessárias à sua execução. (Redação dada pela Lei $n^{\circ} 4.589$, de 11.12.1964) (Vide Lei $n^{\circ} 11.648$, de 2008)

TíTULO VI - CONVENÇÕES COLETIVAS DE TRABALHO 
Art. 611 - Convenção Coletiva de Trabalho é o acôrdo de caráter normativo, pelo qual dois ou mais Sindicatos representativos de categorias econômicas e profissionais estipulam condições de trabalho aplicáveis, no âmbito das respectivas representações, às relações individuais de trabalho. (Redação dada pelo Decreto-lei $\mathrm{n}^{\circ} 229$, de 28.2.1967)

$\S 1^{\circ}$ É facultado aos Sindicatos representativos de categorias profissionais celebrar Acordos Coletivos com uma ou mais emprêsas da correspondente categoria econômica, que estipulem condições de trabalho, aplicáveis no âmbito da emprêsa ou das acordantes respectivas relações de trabalho. (Redação dada pelo Decretolei $n^{\circ} 229$, de 28.2.1967)

$\S 2^{\circ}$ As Federações e, na falta desta, as Confederações representativas de categorias econômicas ou profissionais poderão celebrar convenções coletivas de trabalho para reger as relações das categorias a elas vinculadas, inorganizadas em Sindicatos, no âmbito de suas representações. (Redação dada pelo Decreto-lei ${ }^{\circ}$ 229, de 28.2.1967)

Art. 612 - Os Sindicatos só poderão celebrar Convenções ou Acordos Coletivos de Trabalho, por deliberação de Assembléia Geral especialmente convocada para êsse fim, consoante o disposto nos respectivos Estatutos, dependendo a validade da mesma do comparecimento e votação, em primeira convocação, de 2/3 (dois terços) dos associados da entidade, se se tratar de Convenção, e dos interessados, no caso de Acôrdo, e, em segunda, de 1/3 (um têrço) dos mesmos. (Redação dada pelo Decreto-lei $n^{\circ} 229$, de 28.2.1967)

Parágrafo único. O "quorum" de comparecimento e votação será de 1/8 (um oitavo) dos associados em segunda convocação, nas entidades sindicais que tenham mais de 5.000 (cinco mil) associados. (Incluído pelo Decreto-lei $n^{\circ} 229$, de 28.2.1967)

Art. 613 - As Convenções e os Acordos deverão conter obrigatòriamente: (Redação dada pelo Decreto-lei $n^{\circ} 229$, de 28.2.1967)

I - Designação dos Sindicatos convenentes ou dos Sindicatos e emprêsas acordantes; (Incluído pelo Decreto-lei n²229, de 28.2.1967)

II - Prazo de vigência; (Incluído pelo Decreto-lei n²229, de 28.2.1967)

III - Categorias ou classes de trabalhadores abrangidas pelos respectivos dispositivos; (Incluído pelo Decreto-lei n²29, de 28.2.1967)

IV - Condições ajustadas para reger as relações individuais de trabalho durante sua vigência; (Incluído pelo Decreto-lei n²229, de 28.2.1967)

V - Normas para a conciliação das divergências sugeridas entre os convenentes por motivos da aplicação de seus dispositivos; (Incluído pelo Decretolei $n^{\circ} 229$, de 28.2.1967) 
VI - Disposições sôbre o processo de sua prorrogação e de revisão total ou parcial de seus dispositivos; (Incluído pelo Decreto-lei $n^{\circ} 229$, de 28.2.1967)

VII - Direitos e deveres dos empregados e emprêsas; (Incluído pelo Decreto-lei $n^{\circ} 229$, de 28.2.1967)

VIII - Penalidades para os Sindicatos convenentes, os empregados e as emprêsas em caso de violação de seus dispositivos. (Incluído pelo Decreto-lei $n^{\circ}$ 229, de 28.2.1967)

Parágrafo único. As convenções e os Acordos serão celebrados por escrito, sem emendas nem rasuras, em tantas vias quantos forem os Sindicatos convenentes ou as emprêsas acordantes, além de uma destinada a registro. (Incluído pelo Decreto-lei n²29, de 28.2.1967)

Art. 614 - Os Sindicatos convenentes ou as emprêsas acordantes promoverão, conjunta ou separadamente, dentro de 8 (oito) dias da assinatura da Convenção ou Acôrdo, o depósito de uma via do mesmo, para fins de registro e arquivo, no Departamento Nacional do Trabalho, em se tratando de instrumento de caráter nacional ou interestadual, ou nos órgãos regionais do Ministério do Trabalho e Previdência Social, nos demais casos. (Redação dada pelo Decreto-lei $n^{\circ} 229$, de 28.2.1967)

$\S 1^{\circ}$ As Convenções e os Acôrdos entrarão em vigor 3 (três) dias após a data da entrega dos mesmos no órgão referido neste artigo.(Redação dada pelo Decretolei $n^{\circ} 229$, de 28.2.1967)

$\S 2^{\circ}$ Cópias autênticas das Convenções e dos Acordos deverão ser afixados de modo visível, pelos Sindicatos convenentes, nas respectivas sedes e nos estabelecimentos das emprêsas compreendidas no seu campo de aplicação, dentro de 5 (cinco) dias da data do depósito previsto neste artigo. (Redação dada pelo Decreto-lei $n^{\circ} 229$, de 28.2.1967)

$\S 3^{\circ}$ Não será permitido estipular duração de Convenção ou Acôrdo superior a 2 (dois) anos. (Redação dada pelo Decreto-lei $n^{\circ} 229$, de 28.2.1967)

Art. 615 - O processo de prorrogação, revisão, denúncia ou revogação total ou parcial de Convenção ou Acôrdo ficará subordinado, em qualquer caso, à aprovação de Assembléia Geral dos Sindicatos convenentes ou partes acordantes, com observância do disposto no art. 612. (Redação dada pelo Decreto-lei $n^{\circ} 229$, de 28.2.1967)

$\S 1^{\circ} \mathrm{O}$ instrumento de prorrogação, revisão, denúncia ou revogação de Convenção ou Acôrdo será depositado para fins de registro e arquivamento, na repartição em que o mesmo originariamente foi depositado observado o disposto no art. 614. (Incluído pelo Decreto-lei $n^{\circ} 229$, de 28.2.1967)

$\S 2^{\circ}$ As modificações introduzidos em Convenção ou Acôrdo, por fôrça de revisão ou de revogação parcial de suas claúsulas passarão a vigorar 3 (três) dias 
após a realização de depósito previsto no $\S 1^{\circ}$. (Incluído pelo Decreto-lei $n^{\circ} 229$, de 28.2.1967)

Art. 616 - Os Sindicatos representativos de categorias econômicas ou profissionais e as emprêsas, inclusive as que não tenham representação sindical, quando provocados, não podem recusar-se à negociação coletiva. (Redação dada pelo Decreto-lei $n^{\circ} 229$, de 28.2.1967)

$\S 1^{\circ}$ Verificando-se recusa à negociação coletiva, cabe aos Sindicatos ou emprêsas interessadas dar ciência do fato, conforme o caso, ao Departamento Nacional do Trabalho ou aos órgãos regionais do Ministério do Trabalho e Previdência Social, para convocação compulsória dos Sindicatos ou emprêsas recalcitrantes. (Incluído pelo Decreto-lei ${ }^{\circ} 229$, de 28.2.1967)

$\S 2^{\circ}$ No caso de persistir a recusa à negociação coletiva, pelo desatendimento às convocações feitas pelo Departamento Nacional do Trabalho ou órgãos regionais do Ministério de Trabalho e Previdência Social, ou se malograr a negociação entabolada, é facultada aos Sindicatos ou emprêsas interessadas a instauração de dissídio coletivo. (Incluído pelo Decreto-lei n² 229, de 28.2.1967)

$\S 3^{\circ}$ - Havendo convenção, acordo ou sentença normativa em vigor, o dissídio coletivo deverá ser instaurado dentro dos 60 (sessenta) dias anteriores ao respectivo termo final, para que o novo instrumento possa ter vigência no dia imediato a esse termo. (Redação dada pelo Decreto-lei n 424, de 21.1.1969)

$\S 4^{\circ}$ - Nenhum processo de dissídio coletivo de natureza econômica será admitido sem antes se esgotarem as medidas relativas à formalização da Convenção ou Acordo correspondente. (Incluído pelo Decreto-lei $n^{\circ} 229$, de 28.2.1967)

Art. 617 - Os empregados de uma ou mais emprêsas que decidirem celebrar Acôrdo Coletivo de Trabalho com as respectivas emprêsas darão ciência de sua resolução, por escrito, ao Sindicato representativo da categoria profissional, que terá o prazo de 8 (oito) dias para assumir a direção dos entendimentos entre os interessados, devendo igual procedimento ser observado pelas emprêsas interessadas com relação ao Sindicato da respectiva categoria econômica. (Redação dada pelo Decreto-lei $n^{\circ} 229$, de 28.2.1967)

$\S 1^{\circ}$ Expirado o prazo de 8 (oito) dias sem que o Sindicato tenha se desincumbido do encargo recebido, poderão os interessados dar conhecimento do fato à Federação a que estiver vinculado o Sindicato e, em falta dessa, à correspondente Confederação, para que, no mesmo prazo, assuma a direção dos entendimentos. Esgotado êsse prazo, poderão os interessados prosseguir diretamente na negociação coletiva até final. (Incluído pelo Decreto-lei $\mathrm{n}^{\circ} 229$, de 28.2.1967)

$\S 2^{\circ}$ Para o fim de deliberar sôbre o Acôrdo, a entidade sindical convocará assembléia geral dos diretamente interessados, sindicalizados ou não, nos têrmos do art. 612. (Incluído pelo Decreto-lei $n^{\circ} 229$, de 28.2.1967) 
Art. 618 - As emprêsas e instituições que não estiverem incluídas no enquadramento sindical a que se refere o art. 577 desta Consolidação poderão celebrar Acôrdos Coletivos de Trabalho com os Sindicatos representativos dos respectivos empregados, nos têrmos dêste Título. (Redação dada pelo Decreto-lei $\mathrm{n}^{\circ} 229$, de 28.2.1967)

Art. 619. Nenhuma disposição de contrato individual de trabalho que contrarie normas de Convenção ou Acôrdo Coletivo de Trabalho poderá prevalecer na execução do mesmo, sendo considerada nula de pleno direito. (Redação dada pelo Decreto-lei $n^{\circ} 229$, de 28.2.1967)

Art. 620. As condições estabelecidas em Convenção quando mais favoráveis, prevalecerão sôbre as estipuladas em Acôrdo. (Redação dada pelo Decreto-lei $\mathrm{n}^{\circ}$ 229, de 28.2.1967)

Art. 621. As Convenções e os Acordos poderão incluir entre suas cláusulas disposição sôbre a constituição e funcionamento de comissões mistas de consulta e colaboração, no plano da emprêsa e sôbre participação, nos lucros. Estas disposições mencionarão a forma de constituição, o modo de funcionamento e as atribuições das comissões, assim como o plano de participação, quando fôr o caso. (Redação dada pelo Decreto-lei $n^{\circ} 229$, de 28.2.1967)

Art. 622. Os empregados e as emprêsas que celebrarem contratos individuais de trabalho, estabelecendo condições contrárias ao que tiver sido ajustado em Convenção ou Acôrdo que lhes fôr aplicável, serão passíveis da multa nêles fixada. (Redação dada pelo Decreto-lei n² 229, de 28.2.1967)

Parágrafo único. A multa a ser imposta ao empregado não poderá exceder da metade daquela que, nas mesmas condições seja estipulada para a emprêsa. (Redação dada pelo Decreto-lei n² 229, de 28.2.1967)

Art. 623. Será nula de pleno direito disposição de Convenção ou Acôrdo que, direta ou indiretamente, contrarie proibição ou norma disciplinadora da política econômicofinanceira do Govêrno ou concernente à política salarial vigente, não produzindo quaisquer efeitos perante autoridades e repartições públicas, inclusive para fins de revisão de preços e tarifas de mercadorias e serviços. (Redação dada pelo Decretolei $n^{\circ} 229$, de 28.2.1967)

Parágrafo único. Na hipótese dêste artigo, a nulidade será declarada, de ofício ou mediante representação, pelo Ministro do Trabalho e Previdência Social, ou pela Justiça do Trabalho em processo submetido ao seu julgamento. (Incluído pelo Decreto-lei $n^{\circ} 229$, de 28.2.1967)

Art. 624. A vigência de cláusula de aumento ou reajuste salarial, que implique elevação de tarifas ou de preços sujeitos à fixação por autoridade pública ou repartição governamental, dependerá de prévia audiência dessa autoridade ou repartição e sua expressa declaração no tocante à possibilidade de elevação da tarifa ou do preço e quanto ao valor dessa elevação. (Redação dada pelo Decretolei $n^{\circ} 229$, de 28.2.1967) 
Art. 625. As controvérsias resultantes da aplicação de Convenção ou de Acôrdo celebrado nos têrmos dêste Título serão dirimidas pela Justiça do Trabalho. (Redação dada pelo Decreto-lei n 229, de 28.2.1967) 


\title{
ANEXO "E" - EXTRATO DA CARTA DEL LAVORO
}

\author{
LA CARTA DEL LAVORO
}

21 aprile 1927

\section{DELLO STATO CORPORATIVO E DELLA SUA ORGANIZZAZIONE}

I. La Nazione italiana è un organismo avente fini, vita, mezzi di azione superiori per potenza e durata a quelli degli individui divisi o raggruppati che la compongono. $\mathrm{E}$ una unità morale, politica ed economica, che si realizza integralmente nello Stato fascista.

II. II lavoro, sotto tutte le sue forme organizzativi ed esecutive, intellettuali, tecniche, manuali è un dovere sociale. A questo titolo, e solo a questo titolo, è tutelato dallo Stato.

Il complesso della produzione è unitario dal punto di vista nazionale; i suoi obiettivi sono unitari e si riassumono nel benessere dei singoli e nello sviluppo della potenza nazionale.

III. L'organizzazione sindacale o professionale è libera. Ma solo il sindacato legalmente riconosciuto e sottoposto al controllo dello Stato, ha il diritto di rappresentate legalmente tutta la categoria di datori di lavoro o di lavoratori, per cui è costituito: di tutelarne, di fronte allo Stato e alle altre associazioni professionali, gli interessi; di stipulare contratti collettivi di lavoro obbligatori per tutti gli appartenenti alla categoria, di imporre loro contributi e di esercitare, rispetto ad essi, funzioni delegate di interesse pubblico.

IV. Nel contratto collettivo di lavoro trova la sua espressione concreta la solidarietà tra i vari fattori della produzione, mediante la conciliazione degli opposti interessi dei datori di lavoro e dei lavoratori, e la loro subordinazione agli interessi superiori della produzione.

V La Magistratura del lavoro è l'organo con cui lo Stato interviene a regolare le controversie del lavoro, sia che vertano sulla osservanza dei patti e delle altre norme esistenti, sia che vertano sulla determinazione di nuove condizioni di lavoro.

VI. Le associazioni professionali legalmente riconosciute assicurano l'uguaglianza giuridica tra i datori di lavoro e i lavoratori, mantengono la disciplina della produzione e del lavoro e ne promuovono il perfezionamento.

Le corporazioni costituiscono l'organizzazione unitaria delle forze della produzione e ne rappresentano integralmente gli interessi.

In virtù di questa integrale rappresentanza, essendo gli interessi della produzione interessi nazionali, le corporazioni sono riconosciute come organi di Stato.

Quali rappresentanti degli interessi unitari della produzione le corporazioni possono dettare norme obbligatorie sulla disciplina dei rapporti di lavoro e anche sul 
coordinamento della produzione tutte le volte che ne abbiano avuto i necessari poteri dalle associazioni collegate.

VII. Lo Stato corporativo considera l'iniziativa privata nel campo della produzione come lo strumento più efficace e più utile nell'interesse della Nazione.

L'organizzazione privata della produzione essendo una funzione di interesse nazionale, l'organizzatore dell'impresa è responsabile dell'indirizzo della produzione di fronte allo Stato. Dalla collaborazione delle forze produttive deriva fra esse reciprocità di diritti e di doveri. II prestatore d'opera, tecnico, impiegato od operaio, è un collaboratore attivo dell'impresa economica la direzione della quale spetta al datore di lavoro che ne ha la responsabilità.

VIII. Le associazioni professionali di datori di lavoro hanno l'obbligo di promuovere in tutti i modi l'aumento, il perfezionamento della produzione e la riduzione dei costi. Le rappresentanze di coloro che esercitano una libera professione o un'arte e le associazioni di pubblici dipendenti concorrono alla tutela degli interessi dell'arte, della scienza e delle lettere, al perfezionamento della produzione e al conseguimento dei fini morali dell'ordinamento corporativo.

IX. L'intervento dello Stato nella produzione economica ha luogo soltanto quando manchi o sia insufficiente l'iniziativa privata o quando siano in gioco interessi politici dello Stato. Tale intervento può assumere la forma del controllo, dell'incoraggiamento e della gestione diretta.

X. Nelle controversie collettive dei lavoro l'azione giudiziaria non può essere intentata se l'organo corporativo non ha prima esperito il tentativo di conciliazione.

Nelle controversie individuali concernenti l'interpretazione e l'applicazione dei contratti collettivi di lavoro, le associazioni professionali hanno facoltà di interporre i loro uffici per la conciliazione. La competenza per tali controversie è devoluta alla magistratura ordinaria, con l'aggiunta di assessori designati dalle associazioni professionali interessate.

\section{DEL CONTRATTO COLLETTIVO DI LAVORO E DELLE GARANZIE DEL LAVORO.}

XI. Le associazioni professionali hanno l'obbligo di regolare, mediante contratti collettivi, i rapporti di lavoro fra le categorie di datori di lavoro e di lavoratori, che rappresentano.

II contratto collettivo di lavoro si stipula fra associazioni di primo grado, sotto la guida e il controllo delle organizzazioni centrali, salva la facoltà di sostituzione da parte dell'associazione di grado superiore, nei casi previsti dalla legge e dagli statuti.

Ogni contratto collettivo di lavoro, sotto pena di nullità, deve contenere norme precise sui rapporti disciplinari, sul periodo di prova, sulla misura e, sul pagamento della retribuzione, sull'orario di lavoro.

XII. L'azione del Sindacato, l'opera conciliativa degli organi corporativi e la sentenza della Magistratura del lavoro, garantiscono la corrispondenza del salario alle esigenze normali di vita, alle possibilità della produzione e al rendimento dei lavoro. 
La determinazione dei salario è sottratta a qualsiasi norma generale e affidata all'accordo delle parti nei contratti collettivi.

XIII. I dati rilevati dalle pubbliche Amministrazioni, dall'Istituto centrale di statistica e dalle associazioni professionali legalmente riconosciute, circa le condizioni della produzione e del lavoro e la situazione del mercato monetario, e le variazioni del tenore di vita dei prestatori d'opera, coordinati ed elaborati dal Ministero delle corporazioni, daranno il criterio per contemperare gli interessi delle varie categorie e delle classi fra di loro e di queste con l'interesse superiore della produzione.

XIV. La retribuzione deve essere corrisposta nella forma più consentanea alle esigenze del lavoratore e dell'impresa.

Quando la retribuzione sia stabilita a cottimo, e la liquidazione dei cottimi sia fatta a periodi superiori alla quindicina, sono dovuti adeguati acconti quindicinali o settimanali.

II lavoro notturno, non compreso in regolari turni periodici, viene retribuito con una percentuale in più, rispetto al lavoro diurno.

Quando il lavoro sia retribuito a cottimo, le tariffe di cottimo debbono essere determinate in modo che all'operaio laborioso, di normale capacità lavorativa, sia consentito di conseguire un guadagno minimo oltre la paga base.

$\mathrm{XV}$. II prestatore di lavoro ha diritto al riposo settimanale in coincidenza con le domeniche.

I contratti collettivi applicheranno il principio tenendo conto delle norme di legge esistenti, delle esigenze tecniche delle imprese, e nei limiti di tali esigenze procureranno altresì che siano rispettate le festività civili e religiose secondo le tradizioni locali. L'orario di lavoro dovrà essere scrupolosamente e intensamente osservato dal prestatore d'opera.

$\mathrm{XVI}$. Dopo un anno di ininterrotto servizio il prestatore d'opera, nelle imprese a lavoro continuo, ha diritto ad un periodo annuo di riposo feriale retribuito.

XVII. Nelle imprese a lavoro continuo il lavoratore ha diritto, in caso di cessazione dei rapporti di lavoro per licenziamento senza sua colpa, ad una indennità proporzionata agli anni di servizio. Tale indennità è dovuta anche in caso di morte del lavoratore.

XVIII. Nelle imprese a lavoro continuo, il trapasso dell'azienda non risolve il contratto di lavoro, e il personale ad essa addetto conserva i suoi diritti nei confronti del nuovo titolare. Ugualmente la malattia del lavoratore, che non ecceda una determinata durata, non risolve il contratto di lavoro. II richiamo alle armi o in servizio della M.V.S.N. non è causa di licenziamento.

XIX. Le infrazioni alla disciplina e gli atti che perturbino il normale andamento dell'azienda commessi dai prenditori di lavoro, sono puniti secondo la gravità della mancanza, con la multa, con la sospensione dal lavoro e, per i casi più gravi, col licenziamento immediato senza indennità. 
XX. II prestatore di opera di nuova assunzione è soggetto ad un periodo di prova, durante il quale è reciproco il diritto alla risoluzione del contratto, col solo pagamento della retribuzione per il tempo in cui il lavoro è stato effettivamente prestato.

XXI. II contratto collettivo di lavoro estende i suoi benefici e la sua disciplina anche ai lavoratori a domicilio. Speciali norme saranno dettate dallo Stato per assicurare la pulizia e l'igiene del lavoro a domicilio.

\section{DEGLI UFFICI DI COLLOCAMENTO}

XXII. Lo Stato accerta e controlla il fenomeno della occupazione e della disoccupazione dei lavoratori, indice complessivo delle condizioni della produzione e del lavoro.

XXIII. Gli uffici di collocamento sono costituiti a base paritetica sotto il controllo degli organi corporativi dello Stato. I datori di lavoro hanno l'obbligo di assumere i prestatori d'opera pel tramite di detti uffici. Ad essi è data facoltà di scelta nell'ambito degli iscritti negli elenchi con preferenza a coloro che appartengono al Partito e al Sindacato fascisti, secondo la anzianità di iscrizione.

XXIV. Le associazioni professionali di lavoratori hanno l'obbligo di esercitare un'azione selettiva fra i lavoratori, diretta ad elevarne sempre di più la capacità tecnica e il valore morale.

XXV Gli organi corporativi sorvegliano perché siano osservate le leggi sulla prevenzione degli infortuni e sulla pulizia del lavoro da parte dei singoli soggetti alle associazioni collegate.

\section{DELLA PREVIDENZA, DELL'ASSISTENZA,}

\section{DELL'EDUCAZIONE E DELL'ISTRUZIONE}

XXVI. La previdenza è un'alta manifestazione del principio di collaborazione. II datore di lavoro e il prestatore d'opera devono concorrere proporzionalmente agli oneri di essa. Lo Stato, mediante gli organi corporativi e le associazioni professionali, procurerà di coordinare e di unificare, quanto è più possibile, il sistema e gli istituti di previdenza.

XXVII. Lo Stato fascista si propone:

1) il perfezionamento dell'assicurazione infortuni;

2) il miglioramento e l'estensione dell'assicurazione maternità;

3) l'assicurazione delle malattie professionali e della tubercolosi come

avviamento all'assicurazione generale contro tutte le malattie;

4) il perfezionamento dell'assicurazione contro la disoccupazione involontaria;

5) l'adozione di forme speciali assicurative dotalizie per i giovani lavoratori. 
XXVIII. E' compito delle associazioni di lavoratori la tutela dei loro rappresentanti nelle pratiche amministrative e giudiziarie, relative all'assicurazione infortuni e alle assicurazioni sociali.

Nei contratti collettivi di lavoro sarà stabilita, quando sia tecnicamente possibile, la costituzione di casse mutue per malattia col contributo dei datori di lavoro e dei prestatori di opera, da amministrarsi da rappresentanti degli uni e degli altri, sotto la vigilanza degli organi corporativi.

XXIX. L'assistenza ai propri rappresentati, soci e non soci, è un diritto e un dovere delle associazioni professionali. Queste debbono esercitare direttamente le loro funzioni di assistenza, né possono delegarle ad altri enti od istituti, se non per obiettivi d'indole generale, eccedenti gli interessi delle singole categorie.

XXX. L'educazione e l'istruzione, specie l'istruzione professionale, dei loro rappresentati, soci e non soci, è uno dei principali doveri delle associazioni professionali. Esse devono affiancare l'azione delle Opere nazionali relative al dopolavoro e alle altre iniziative di educazione. 